\title{
Scenario-analyse economische aspecten coronaire hartziekten
}

Citation for published version (APA):

Boas, G. (1994). Scenario-analyse economische aspecten coronaire hartziekten. [Doctoral Thesis, Maastricht University]. Rijksuniversiteit Limburg. https://doi.org/10.26481/dis.19940407gb

Document status and date:

Published: 01/01/1994

DOI:

10.26481/dis.19940407gb

Document Version:

Publisher's PDF, also known as Version of record

\section{Please check the document version of this publication:}

- A submitted manuscript is the version of the article upon submission and before peer-review. There can be important differences between the submitted version and the official published version of record.

People interested in the research are advised to contact the author for the final version of the publication, or visit the DOI to the publisher's website.

- The final author version and the galley proof are versions of the publication after peer review.

- The final published version features the final layout of the paper including the volume, issue and page numbers.

Link to publication

\footnotetext{
General rights rights.

- You may freely distribute the URL identifying the publication in the public portal. please follow below link for the End User Agreement:

www.umlib.nl/taverne-license

Take down policy

If you believe that this document breaches copyright please contact us at:

repository@maastrichtuniversity.nl

providing details and we will investigate your claim.
}

Copyright and moral rights for the publications made accessible in the public portal are retained by the authors and/or other copyright owners and it is a condition of accessing publications that users recognise and abide by the legal requirements associated with these

- Users may download and print one copy of any publication from the public portal for the purpose of private study or research.

- You may not further distribute the material or use it for any profit-making activity or commercial gain

If the publication is distributed under the terms of Article $25 \mathrm{fa}$ of the Dutch Copyright Act, indicated by the "Taverne" license above, 
Scenario-analyse Economische Aspecten Coronaire Hartziekten 
Aan Ingrid en Sonja 


\section{Scenario-analyse Economische Aspecten}

\section{Coronaire Hartziekten}

\section{PROEFSCHRIFT}

ter verkrijging van de graad van doctor

aan de Rijksuniversiteit Limburg te Maastricht, op gezag van de Rector Magnificus, Prof.Dr. H. Philipsen, volgens het besluit van het College van Dekanen, in het openbaar te verdedigen op donderdag 7 april 1994 om 16.00 uur

door

\section{Gijsbert Michiel Boas}

geboren te Djakarta op 17 maart 1952 


\section{Promotor:}

Prof.dr.ir.drs. O.J. Vrieze

\section{Co-promotor:}

Dr. R.T.J.M. Janssen (GGD, Gemeente Arnhem)

\section{Beoordelingscommissie:}

Prof.dr. L.L.G. Soete (voorzitter)

Prof.dr. E.K.A. van Doorslaer (EUR)

Dr. J.C. Jager (RIVM, Bilthoven)

Prof.dr. P.G. Knipschild

Prof.dr. R.M. Leidl 


\section{Voorwoord}

'Bij God en Curaçao is alles mogelijk" is een bekend gezegde in Curaçao. Als lit een waarheid is, dan is dit gezegde ook van toepassing op mij met betrekking ot dit proefschrift. Er heeft bij mij nooit bewust het "instinct" bestaan om te romoveren. Tot het ene moment dat ik door Prof. Koos Vrieze (Wiskunde/RL) sevraagd werd hoe ik stond tegenover het idee om op mijn onderzoek te promoveren. Dit moment moet omstreeks 1990 zijn geweest. Daarna ben ik mijn tijdsJesteding zo gaan invullen dat ik hoe langer hoe meer het punt ging naderen van 'en nu is er geen weg meer terug".

Mijn twee beste vrienden uit mijn vorige werkkring Siegfried Victorina, Msc., van de Dienst Ambulante Geestelijke Volksgezondheid (AGV) uit Curaçao en Guno Codfried, arts, van het academisch ziekenhuis Paramaribo (azP) uit Suriname moeten vast paragnostische gaven gehad hebben. $\mathrm{Zij}$ waren er altijd van overtuigd dat ik ooit zou gaan promoveren. Hierbij moet ik direct een woord van dank uitspreken aan Prof. Bob Logan van de London School of Tropical Medicine and Hygiene, die ons drieën destijds in Curaçao begeleidde en mij het advies gaf: "they (de universiteit in Nederland) will recognise you". Wijlen Prof. Lou Groot en Prof. Frans Rutten, beiden voormalig voorzitter van de vakgroep Economie van de Gezondheidszorg (EGZ/RL), hebben het aangedurfd mij na mijn terugkomst uit Curaçao aan te trekken als onderzoeker.

Koos Vrieze en dr. Richard Janssen, oud-collega (EGZ/RL) zijn het in de persoonlijke sfeer geweest die mij keer op keer de stimulans hebben gegeven om tc groeien naar het moment dat "je aan je proefschrift gaat schrijven". Het zal ongeveer twee jaar geleden zijn geweest dat ik voor mezelf heb besloten: "en nu ga ik het afmaken".

Op de eerste plaats ben ik erg veel dank verschuldigd aan mijn promotor Koos Vrieze. Hij heeft zich naast begeleider ook altijd ingezet als onderzoeker. Deze inzet van hem is voor mij van onschatbare waarde geweest. In $1986 \mathrm{kwam}$ ik werken bij de vakgroep Economie van de Gezondheidszorg aan de Rijksuniversiteit Limburg. Daarvoor had ik 8 jaar bij de overheid in Curaçao gewerkt als beleidsmedewerker. Het is Koos Vrieze geweest die mij tot onderzoeker gevormd heeft.

Een tweede woord van dank wil ik uitspreken aan Richard Janssen. Als co-promotor en directe oud-collega van mij kwam hij vaak met de aanwijzingen hoe een ogenschijnlijk complexe materie op een heldere manier aangepakt kon worden. Ik ben hem zeer erkentelijk voor zijn bereidheid om altijd maar weer com- 
mentaar te geven op de teksten van mijn proefschrift. Wij hebben in $1990 \mathrm{sa}$ een cursus gezondheidseconomie in Curaçao gedoceerd. Het was een voom voor mij om van een geboren docent als Richard Janssen de "kneepjes van onderwijs" als op een presenteerblaadje voorgeschoteld te krijgen.

Op de derde plaats wil ik een woord van dank richten aan Marijke Verheij de vakgroep Wiskunde (RL). Marijke verzorgde niet alleen de technische re over de vormgeving, maar heeft in zekere zin samen met Ruth Schrijen ( $\mathrm{H}$ kunde/RL) het proefschrift tot twee keer toe "gered" door met alle inzet, "zh en tranen" de gestelde deadlines te halen. Annelies Derks (Wiskunde/RL) Maria Kalivas (EGZ/RL) hebben hen hierbij bekwaam ondersteund.

Ir. Jeroen Kuipers en dr. Jean Derks, beiden van de vakgroep Wiskunde ( $R$ hebben het computer-simulatieprogramma ontworpen en geïmplementeerd. hebben mij met hun inzicht in het computerprogramma geweldig bijgestaan in verklaring van tal van epidemiologisch-wiskundige relaties in het model. Ik hen voor deze vakbekwame adviezen danken en tevens voor hun voortduren bereidheid klaar te staan als ik een scenario weer verkeerd "ingesteld" had. E extra woord van dank aan Jeroen voor zijn bereidheid paranymph te willen $z$ tijdens de verdediging van mijn proefschrift.

Jan van Emmerik, Ing. van de vakgroep EGZ (RL) wil ik danken voor het inz ten van zijn onnavolgbare talent computerprogramma's met elkaar te lat "praten". Zo heeft hij mij geweldig geholpen toen op het moment "surprêm dat ik de scenario's voor de beoordelingscommissie moest aanleveren, alles $f$ ging in het computerprogramma, terwijl Jean Derks op dienstreis was naar V.S..

Drs. Ron van der Wal van Tarma Software Research heeft op verzoek van K Vrieze de userinterface ontworpen en geïmplementeerd. De aanwezigheid v een userinface heeft dit onderzoek ongekende mogelijkheden gegeven.

Drs. Joan van Aalst van het Centraal Orgaan tarieven Gezondheidszorg (COT heeft mij veel gegevens verstrekt met betrekking tot de kostprijzen van medis behandelingen. Met dr. Johan Janssen, cardioloog, voorheen werkzaam bij vakgroep Cardiologie (RL/azM) heb ik jarenlang gewerkt aan het in kaart br gen van de gegevens over het ziekteproces van coronaire hartziekten en het bruik van medische voorzieningen in deze. Beiden ben ik zeer erkentelijk vo hun bijdragen.

In dit kader wil ik mw. L. Relik-van Wely, cardioloog (Diaconessenhuis Eir hoven) danken voor haar bereidheid om altijd maar weer de zo essentiële ge vens van de Commissie Coronair Angiografie te verschaffen. Hierbij past 0 een woord van dank aan mw. L. Groot, arts, van de Stichting Informatiecentr 
Gezondheidszorg (SIG) die mij in lange telefonische gesprekken inhoudelijk te woord heeft willen staan op allerlei vragen die ik had over de door haar verstrekte gegevens.

Aan Prof. J. van Ree van de vakgroep Huisartsgeneeskunde (RL) ben ik een woord van dank verschuldigd voor de moeite die hij heeft gedaan mij gegevens over preventieprogramma's te verstrekken en mij te wijzen op de plaats die de huisarts in deze inneemt. Dezelfde woorden van dank wil ik richten aan de cardiologen van St. Jozef Ziekenhuis te Kerkrade die mij vanuit hun ervaringen inzicht gaven in de medische consumptie met betrekking tot $\mathrm{CHZ}$ in een algemeen ziekenhuis.

Diverse leden van de vakgroep Cardiologie (azM/RL) zijn bereid geweest met hun expertkennis bij te dragen in een utiliteitsonderzoek met betrekking tot coronaire hartziekten, waarvoor nogmaals een woord van dank. Deze lijst van personen is niet volledig. Ik wil graag een ieder bedanken die mij direct of op een andere manier heeft bijgestaan in het verkrijgen van de benodigde empirische gegevens op het betreffende terrein van onderzoek.

Graag wil ik de leden van het secretariaat van de Stuurgroep Toekomstscenario's Gezondheidszorg (STG) danken voor hun persoonlijk enthousiasme waarmee ze aandacht gegeven hebben aan het welslagen van mijn onderzoek dat ten grondslag ligt van dit proefschrift.

Verder dank ik Prof.dr. L.L.G. Soete (MERIT/RL), Prof.dr. E.K.A. van Doorslaer EUR/UIA, Dr. J.C. Jager (RIVM), Prof.dr. P.G. Knipschild (Epidcmiologie/RL), en Prof.dr. R.M. Leidl (EGZ/RL) voor hun bereidwilligheid lid te zijn van de beoordelingscommissie. Een bijzonder woord van dank wil ik richten aan Eddy van Doorslaer als vroegere collega die in zijn commentaar mij van uitvoerig inhoudelijk kritisch en waardevol advies heeft bezorgd. Ik ben hem hiervoor zeer erkentelijk. Hetzelfde geldt voor de adviezen die ik van de overige leden van de beoordelingscommissie heb gekregen. Volgens mij heeft de definitieve versie van het proefschrift die nu op tafel ligt hierdoor een veel grotere diepgang gekregen. Het is mede door het commentaar van de beoordelingscommissie dat het proefschrift nog meer in volume is gegroeid dan het oorspronkelijk al had. Het is mijn hoop dat de kwantiteit ook de kwaliteit verder ten goede is gekomen.

Mijn vakgroep Economie van de Gezondheidszorg (EGZ) van de Rijksuniversiteit Limburg ( $R L$ ) wil ik danken voor hun steun en warme belangstelling die ik altijd gekregen heb tijdens het schrijven van het proefschrift. Ik wil hierbij drs. Frits Harmsze (EGZ/RL), drs. Jan Winter (oud-collega EGZ/RL), en Richard Janssen noemen die waar mogelijk mij ontlast hebben van mijn onderwijsactivi- 
teiten om mij de gelegenheid te geven aan mijn proefschrift te schrijven. In verband wil ik ook Reiner Leidl danken, die mij als de nieuwe vakgroepvool ter van EGZ de ruimte heeft gegeven om dit werk te voltooien.

Een algemeen woord van dank wil ik richten aan de gehele vakgroep Wisku van de Rijksuniversiteit Limburg. De geweldige gastvrijheid en vriendschap ik van deze vakgroep heb gekregen en nog steeds krijg hebben een diepe inc op mij gemaakt.

Het toeval heeft gewild dat Mieke Zemmelink in dezelfde periode dat ik n proefschrift heb geschreven student-assistent is geweest bij de vakgroep El Graag wil ik Mieke danken voor haar betrokkenheid en voor haar bereidheid ook paranymph te willen zijn bij de verdediging van mijn proefschrift.

De morele kracht voor het afronden van het proefschrift heb ik gevonden mijn kinderen Ingrid en Sonja, aan wie ik mijn proefschrift dan ook wil opc gen. 
Inleiding

Scenario-methode

6.1 Inleiding

6.2 Bevolkingsstudie CHZ Preventiescenario's

6.3 Cohortstudie CHZ Preventiescenario's

6.5 Cohortstudie CHZ Medische scenario's

ALGEMENE BESCHOUWING

Inleiding

Sensitiviteitsanalyses . . . . . . . . . . . . . . . . . . 189

3 Vervangende ziekten en - sterften $\ldots \ldots \ldots \ldots \ldots \ldots \ldots \ldots 20 \ldots$

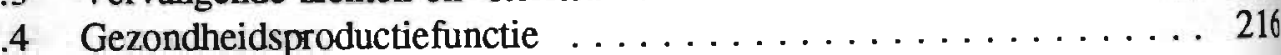

.6 Programmabudgettering $\ldots \ldots \ldots \ldots \ldots \ldots \ldots \ldots \ldots \ldots \ldots \ldots \ldots \ldots \ldots$

\section{BIJLAGEN}

I.2 CHZ-Risicofactoren Gezonde Bevolking $\ldots \ldots \ldots \ldots \ldots \ldots \ldots$

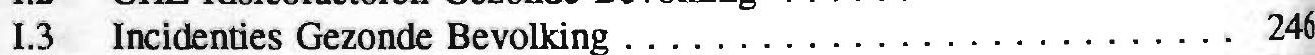

I.4 Incidenties CHZ-Bevolking $\ldots \ldots \ldots \ldots \ldots \ldots \ldots \ldots \ldots$

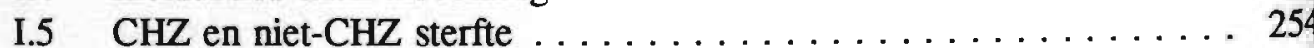

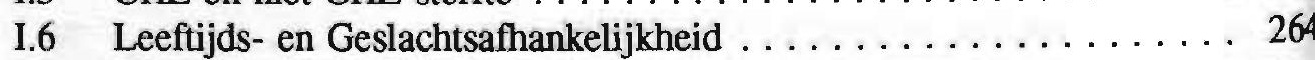

II ONDERDELEN CHZ-MODEL $\ldots \ldots \ldots \ldots \ldots \ldots \ldots \ldots .26$

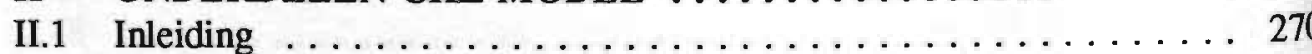

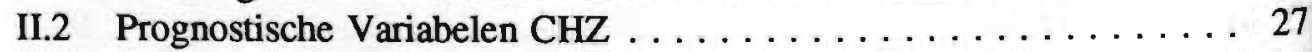

II.3 Stratificatie Bevolking naar Risicogroepen $\ldots \ldots \ldots \ldots \ldots \ldots 27$

II.4 Behandelingstrajecten $\ldots \ldots \ldots \ldots \ldots \ldots \ldots \ldots \ldots \ldots . \ldots \ldots$

II.5 Indicatiestelling Therapeutische Behandelingen . . . . . . . 29

II.6 Verdeling CHZ-gebeurtenissen over Therapeutische Behandelingen . 29 
KOSTPRIJZEN CHZ ... . . . . . . . . . . 305

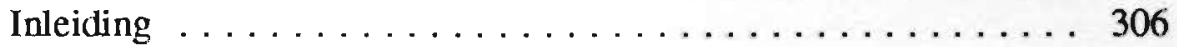

Kostprijzen Preventieprogramma's . . . . . . . . . . . . . 307

Kostprijzen Medische Behandelingen . . . . . . . . . . 319

EEN VOORBEELD VAN TOEKENNING UTILITEITEN . . 341

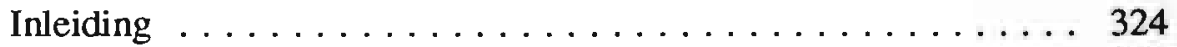

Meettechnieken . . . . . . . . . . . . . . . . . 343

Functieclassificatie voor CHZ-Patiënten . . . . . . . . . . 344

Enkele Studies naar QALY's . . . . . . . . . . . . . . . . 348

Beschrijving Utiliteitsonderzoek CHZ-Ziektetoestanden . . . . . . 352

Utiliteitswaarden . . . . . . . . . . . . . . . 361

piloog ................................ 365

iteratuurlijst $\ldots \ldots \ldots \ldots \ldots \ldots \ldots \ldots \ldots \ldots \ldots \ldots \ldots \ldots \ldots \ldots$

amenvatting $\ldots \ldots \ldots \ldots \ldots \ldots \ldots \ldots \ldots \ldots \ldots \ldots \ldots \ldots \ldots$

ummary $\ldots \ldots \ldots \ldots \ldots \ldots \ldots \ldots \ldots \ldots \ldots \ldots \ldots \ldots \ldots \ldots \ldots$ 



\section{INLEIDING}

\subsection{Inleiding}

1.2 Maatschappelijke betekenis $\mathrm{CHZ}$

1.3 Probleemstelling, Vraagstelling, en Methodiek

1.4 Kengetallen

1.5 Opzet van de dissertatie 


\section{$1.1 \quad$ Inleiding}

Deze dissertatie is voor een belangrijk deel gebaseerd op de eindrapportage twee projecten die verricht zijn onder auspiciën van de Stuurgroep Toekomsts nario's Gezondheidszorg (Vrieze e.a., 1993). De twee projecten zijn de volgen (i) "Operationalisering van een model Hart- en Vaatziekten" toegekend aan vakgroep Wiskunde van de Rijksuniversiteit Limburg.

(ii) Economische aspecten van het scenario Hart- en Vaatziekten", toegeke aan de vakgroep Economie van de Gezondheidszorg van de Rijksunive teit Limburg.

Beide projecten zijn onder gezamenlijke verantwoordelijkheid als én geïn greerd project uitgevoerd.

In maart 1983 installeerde de toenmalige Minister van WVC de Stuurgro Toekomstscenario's Gezondheidszorg (STG). De belangrijkste taak van de S? betreft het exploreren van mogelijke toekomstige ontwikkelingen op het terre van de volksgezondheid en de gezondheidszorg, gericht op de beleidsonderste ning met betrekking tot lange termijn planning. De werkwijze van de STG he: zich geconcentreerd op de samenstelling van onderzoeksteams, elk bestaande experts met betrekking tot een deelterrein van de gezondheidszorg (vgl. ST 1987). In tabel 1.1 is een overzicht opgenomen van de diverse deelterrein waarop toekomstanalyses in opdracht van de STG zijn uitgevoerd. Deze lijst niet volledig maar is meer bedoeld om een indruk te geven over het werkterr van de STG (vgl. Schreuder, 1987, en STG, 1993).

\begin{tabular}{|c|c|}
\hline A. ZIEKTE/ZIEKTEPROCESSEN & $\begin{array}{l}\text { HART- EN VAATZIEKTEN } \\
\text { KANKER } \\
\text { CHRONISCHE ZIEKTEN } \\
\text { ADS }\end{array}$ \\
\hline B. DETERMINANTEN VAN ZIEKTE & $\begin{array}{l}\text { ONGEVALLEN } \\
\text { LEEFWIJZEN } \\
\text { ARBEID EN GEZONDHEID } \\
\text { MILIEU EN GEZONDHEID }\end{array}$ \\
\hline $\begin{array}{l}\text { C. VOORZIENINGEN / STRUCTUUR / } \\
\text { ORGANISATIE }\end{array}$ & $\begin{array}{l}\text { EERSTELIJNS GEZONDHEISZORG } \\
\text { BASISGEZONDHEIDSZORG } \\
\text { ZIEKENHUIS 21E EEUW } \\
\text { GEESTELIJE GEZONDHEIDSZORG }\end{array}$ \\
\hline $\begin{array}{l}\text { D. MAATSCHAPPELIJKE } \\
\text { ONTWIKKELINGEN }\end{array}$ & $\begin{array}{l}\text { VERGRIJZING } \\
\text { MEDISCHE TECHNOLOGIE } \\
\text { VERGRIJZING IN AMSTERDAM }\end{array}$ \\
\hline
\end{tabular}

Tabel 1.1 Deelterreinen STG-studies 
In beide bovengenoemde projecten is de nadruk gelegd op methodologische aspecten ten einde inzicht te verwerven in de toepasbaarheid van de ontwikkelde methodieken op niet alleen het terrein van Hart- en Vaatziekten maar evenzeer op andere ziekteterreinen binnen de gezondheidszorg. In deze studies is het onderzoeksterrein afgebakend tot het thema coronaire hartziekten (CHZ).

De keuze om de methodologie te benadrukken is terug te vinden in de opbouw van deze dissertatie. Per hoofdstuk komt in het algemeen een afgerond onderdeel van de methodologie aan de orde.

Het is vooral hierom dat de onderhavige scenariostudie op een essentieel punt afwijkt van andere scenariostudies die onder auspiciën van de STG zijn uitgevoerd (vgl. Van Genugten e.a., 1991). In onze studie hebben we namelijk niet een poging gedaan om op basis van "expert" meningen een aantal waarschijnlijke toekomstscenario's te ontwikkelen (vgl. Bijl, 1991). In plaats daarvan hebben we een "framework" ontwikkeld dat kan dienen als doorrekenmodel voor een groot aantal scenario's met betrekking tot $\mathrm{CHZ}$.

In paragraaf $1.3 \mathrm{zal}$ het begrip scenario verder uitgewerkt worden (zie ook hoofdstuk 5). Op deze plaats volstaat de omschrijving dat een scenario een mogelijke toekomstige ontwikkeling weergeeft.

Het genoemde doorrekenmodel heeft de vorm van een computerprogramma, genaamd CHZ-simulator. De gebruiker heeft de mogelijkheid zelf scenario's te ontwikkelen en te testen via dit computerprogramma. Het computerprogramma is dus een instrument om scenario's te bouwen.

Er wordt bij de formulering van scenario's in deze studie gebruik gemaakt van een ontwikkelde database die onderdelen van scenario's bevat. De structuur van deze database is op twee doelen afgestemd:

(i) De doorrekening van geformuleerde scenario's moet de lezer (of de gebruiker) een adequate indruk verschaffen omtrent de diverse mogelijke toekomstverkenningen die met het computerprogramma uit te testen zijn.

(ii) De mogelijk te vormen scenario's hebben een zeker realisme zodat de voorbeeldberekeningen die we in deze dissertatie presenteren, een eigen intrinsieke waarde verkrijgen.

Aldus vormt dit computerprogramma een structuur dat ons in staat stelt toekomstbeelden te genereren en te analyseren. Inhoudelijk is deze structuur gebaseerd op de huidige relevante medische kennis voor de ziektecategorie coronaire hartziekten. De basisstructuur is dusdanig flexibel ingericht dat nieuwe medische inzichten of reductie van onzekerheden eenvoudig aangebracht kunnen worden. In de uiteindelijke vorm is het computerprogramma toegerust met een gebruikers 
interface of userinterface. Deze interface maakt het mogelijk op een hoog agg gatieniveau te "communiceren" met het computerprogramma.

Het computerprogramma is in feite de vertaling van een model. Het model is et weergave van de relevante aspecten van het thema coronaire hartziekten. Hiert is het computerprogramma een getrouwe weergave van het model. De woorde "model" en "computerprogramma" hebben we in dit verband met elkaar geïden ficeerd. In het vervolg worden deze woorden als elkaars synoniem beschouwd.

De essentie van het model is dat het een verbindende schakel vormt tussen a pecten op patiëntniveau (het zogenaamde microniveau) en aspecten op landelij, of bevolkingsniveau (het zogenaamde macroniveau). Deze verbinding is in beic richtingen uitgewerkt.

Jaarlijks worden via het model de lotgevallen van standaardpersonen gesimuleer: en geaggregeerd tot landelijke cijfers. De standaardpersonen maken ziekte me! en ondergaan medische behandelingen, alles met bepaalde kansen. De geaggrt geerde cijfers geven een beeld van het vórkomen en de gevolgen van coronair: hartziekten en van het jaarlijkse beslag op de operatiecapaciteit van de gezon heidszorg. Dergelijke informatie op bevolkingsniveau vormt voor de beleidsvo mende instanties het uitgangspunt bij de ontwikkeling van lange termijn strat: gieën.

Anderzijds kunnen beleidsstrategieën geformuleerd worden en in de vorm va scenario's in het model worden gebracht. Het computerprogramma berekent ver volgens de effecten van deze beleidsstrategieën op de standaardpersonen. In d sectie "Effecten van Gezondheidszorg" uit Van der Maas e.a. (1989) wordt ee soortgelijke wisselwerking besproken tussen populatie epidemiologie en klinisch epidemiologie. Deze wisselwerking heeft betrekking op respectievelijk het onder zoek naar omgevingsfactoren als oorzaken van ziekte en op klinische besliskur de.

In het model worden dus de interacties tussen beleidsstrategieën en de lotgeval len van standaardindividuen geanalyseerd. We verwachten dat het model in di zin een direct ondersteunende rol kan spelen bij het planningsproces van beleid: vormende instanties.

Dit hoofdstuk is als volgt opgebouwd. In paragraaf 1.2 bespreken we de maat schappelijke betekenis van coronaire hartziekten. In samenhang hiermee wordt it paragraaf 1.3 de probleemstelling, de vraagstelling, en de methodiek van $d$ dissertatie uitgewerkt. $\mathrm{Er}$ wordt in paragraaf 1.4 een aantal kengetallen gegever met betrekking tot hart- en vaatziekten en $\mathrm{CHZ}$ in het bijzonder. Deze kengetal len dienen voor een verdere toelichting op de maatschappelijke betekenis val coronaire hartziekten. Tot slot geven we in paragraaf 1.5 een toelichting over opzet van de dissertatie. 


\subsection{Maatschappelijke betekenis $\mathrm{CHZ}$}

De sterfte aan hart- en vaatziekten vormt in Nederland de belangrijkste doodsoorzaak. Deze sterfte bedraagt ca. $41 \%$ van de totale sterfte in 1988 (CBS,1991). De coronaire hartziekten (CHZ) veroorzaken in 1988 ca. $45 \%$ van de sterfte aan hart- en vaatziekten en ongeveer $19 \%$ van de totale sterfte (CBS, 1991). In paragraaf 1.4 van dit hoofdstuk zijn tabellen opgenomen die een overzicht geven van de kosten en het aantal overledenen aan hart- en vaatziekten. We hebben ter vergelijking in die paragraaf een aantal kengetallen gegeven met betrekking tot de kosten en de sterfte van de vijf belangrijkste diagnosegroepen.

De CHZ kunnen getypeerd worden als de ziekten van de kransslagaders. Er is sprake van CHZ wanneer het lumen van de (middel)grote arteriën rondom de hartspier zich te veel gaan vernauwen en onvoldoende aanvoer van zuurstof en voedingsstoffen naar de hartspier plaatsvindt. Veelal zal de oorzaak atherosclerose van de arterie zijn. De typisch angineuze pijnklachten zijn een direct en kenmerkend gevolg van een tekort aan zuurstof van de hartspier.

Er is sprake van een hartinfarct wanneer een kransslagader geheel is afgesloten. Men spreekt van plotse hartdood of "sudden death" wanneer er een plotse stilstand van de bloedcirculatie optreedt die bijna steeds het gevolg is van een hartinfarct.

De drie belangrijkste risicofactoren met betrekking tot $\mathrm{CHZ}$ zijn verhoogd cholesterolniveau, hypertensie, en roken. Steeds meer onderzoekers raken er van overtuigd dat cholesterol, met name in vorm van visceraal vet (buikholtevet) de grootste risicofactor voor CHZ vormt (Jongkind, 1993). Te veel visceraal vet leidt tot een verhoogde produktie van de zogenaamde "very low density lipoproteins" (VLDL). De VLDL zouden de enige onafhankelijke risicofactor zijn met betrekking tot het ontstaan van atherosclerose (vgl. bijlage I).

Het relatieve risico voor $\mathrm{CHZ}$ wordt multiplicatief verhoogd wanneer er een combinatie is van verhoogd serumcholesterolgehalte, hypertensie en roken. We illustreren in figuur 1.1 de relatieve CHZ-risico's van de betreffende risicofactoren voor mensen waarbij zich nog geen $\mathrm{CHZ}$ heeft ontwikkeld (de zogenaamde "gezonde" bevolking) met behulp van de drie elkaar overlappende cirkels van Mancia (1988). 


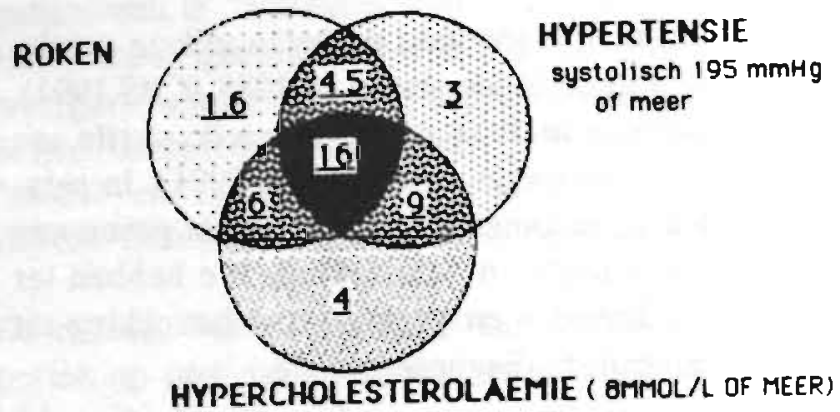

Figuur 1.1 Relatieve risico's van risicofactoren voor $\mathrm{CHZ}$ bron: Mancia (1988)

De CHZ worden als een chronische ziekte getypeerd omdat het atherosclerotis ziekteproces nauwelijks omkeerbaar is. De angineuze pijnklachten kunnen emstig zijn en frequent vo6rkomen, dat de patiënt als geïnvalideerd beschou kan worden. De hartinfarct-patiënt (oud-myocardinfarct) kan zich minder vit voelen, heeft een vergrote kans op nieuwe angineuze klachten en een vergi kans op een recurrent infarct.

Een klinisch syndroom dat voor een belangrijk deel door $\mathrm{CHZ}$ wordt veroorza of daarmee samenhangt is hartinsufficiëntie (ook wel aangeduid als decompen tio cordis) of congestive heart failure (CHF). De CHF staat voor circulatiesto nis van het bloed, veroorzaakt door een chronisch falende pompwerking van hart. Het is een typische verouderingsziekte waarbij verbetering niet te verwa ten valt en harttransplantatie uiteindelijk de enig aangewezen therapievorm Verder tast CHF ook andere orgaansystemen in het lichaam aan, zoals het fun oneren van de nieren. Vanwege het eigen ziektebeeld, de afwijkende therap vorm en het probleem van de herkenbaarheid in de praktijk, is ervoor geko dit ziektestadium in deze fase van de modelontwikkeling slechts zijdelings $n$ te nemen. De CHF gaat gepaard met symptomen die intensieve en langdur verpleegkundige zorg behoeven, waardoor er veel kosten binnen de gezondhei zorg gegenereerd worden.

De bevolkingsontwikkeling in Nederland zal als gevolg van de naoorlogse boortegolf gedomineerd worden door een verdergaande vergrijzing (vgl. Van Maas, 1982). Het aandeel van het aantal personen van 65 jaar en ouder in totale bevolking zal naar verwachting stijgen van ca. $12 \%$ in 1988 naar ca. 2 in 2.035 (Van der Maas, 1989). 
Je CHZ-sterfte wordt hoe langer hoe meer uitgesteld (langere CHZ-vrije levensseriode of langere CHZ-ziekteduur) door preventie en door betere medische berandeling (vgl. Goldman e.a., 1984, en Hoogendoorn, 1987, 1990). De trend in le mortaliteitscijfers en de klinische morbiditeitscijfers met betrekking tot $\mathrm{CHZ}$ ;uggereert dat er een verschuiving plaatsvindt van het acute naar het chronisch ijden (STG, 1989, Dunning, 1993).

De gesignaleerde vergrijzing van de Nederlandse bevolking en de mogelijk lanzere levensverwachting van de CHZ-patiënt zal in de toekomst een toename van ZHZ-incidenties en een grotere CHZ-prevalentie genereren. De geschetste CHZmorbiditeitscyclus zal zich verder versterken, waardoor er een stijging ontstaat van het aantal infarct-overlevenden met matige tot ernstige pompfunctiestoomissen (slechte ejectie fractie). Ook de reductie en behandelingsmogelijkheden van andere ziekten dan coronaire hartziekten, bijvoorbeeld die van kanker, dragen bij aan de vergrijzing van de bevolking. Dit gegeven en het geschetste toegenomen aantal hartpatiënten met een slechte ejectie fractie zullen verder bijdragen aan zen toename van het aantal CHZ-patiënten en het aantal CHF-patiënten. Het aantal acute sterften zal als gevolg van het toegenomen aantal hartpatiënten met een slechte ejectie fractie naar verwachting op den duur weer gaan stijgen.

De CHZ generen veel kosten. De totale medische kosten van CHZ, zoals berekend in het model, bedragen in $1988 \mathrm{ca} . f 1,2$ miljard. In hoofdstuk 4 lichten we toe dat hieronder verstaan worden de kosten van preventie en medische behandelingen met betrekking tot $\mathrm{CHZ}$. Een grote financiële betekenis hebben de inkomensvervangende uitkeringen. Deze bedragen in 1988 voor hart- en vaatziekten ca. $f$ 2,4 miljard (zie hoofdstuk 4).

De verwachting is dat het kostenniveau verder zal toenemen als gevolg van technologische ontwikkelingen, de vergrijzing, en een verschuiving van de acute naar de chronische zorg.

Wat in de toekomst voor de kosten van gezondheidszorg mogelijk nog belangrijker zal worden is de relatie van het gezondheidszorgsysteem met andere maatschappelijke systemen op vooral sociaal en economisch terrein, de zogenaamde intersectorale relaties (vgl. het facetbeleid uit Nota 2000, 1986). De zogenaamde intersectorale kosten staan sterk onder de invloed van veranderende gezondheidsthema's en macro-economische doelstellingen, zoals volledige werkgelegenheid en economische groei. Wat voor macro-economische consequenties brengen veranderende leef- en voedingsgewoonten geïnitieerd door de sector gezondheidszorg met zich mee voor bijvoorbeeld de industriële sector en de sector landbouw en veeteelt en omgekeerd?

In maatschappelijk brede scenario-studies zou de invloed op de collectieve lastendruk, de werkgelegenheid binnen de gezondheidszorg, en de gevolgen voor de 
economische groei bestudeerd kunnen worden. Er zal een nadere discussie ten worden gevoerd over de rol en de betekenis van de gezondheidszorg huidige verworven systeem ten opzichte van andere maatschappelijke verws heden.

De toekomstanalyse van de economische aspecten van $\mathrm{CHZ}$ vindt plaats I het maatschappelijk perspectief. Hiermee wordt bedoeld dat alle voordel het vervolg aangeduid als opbrengsten of effecten, en alle kosten van inspa gen die een maatschappij levert zoveel mogelijk in de analyse worden betrol Deze inspanningen zijn binnen de gezondheidszorg gericht op de volgend zondheidsdoelen (vgl. Nota 2000, 1986):

(i) verlaging van de voor leeftijd gestandaardiseerde totale sterfte,

(ii) verhoging van de gezonde levensverwachting in de bevolking,

(iii) het op een doelmatige en doeltreffende manier bereiken van (i) en (ii).

De bestrijding van ziekten brengt bepaalde economische consequenties met mee. Deze economische consequenties beperken zich niet alleen tot de betre de ziekte, maar zullen zich ook uitstrekken naar andere ziekten als gevolg verschuivingen die in de totale mortaliteit en totale morbiditeit gaan optreden Tijdens onze simulatie experimenten is gebleken dat het effect van $\mathrm{CHZ}$-inci tie reducerende scenario's voor een gedeelte weer teniet wordt gedaan door vangende ziekten en -sterften (zie hoofdstuk 6). Dit leidt tot onverwachte ne effecten. Een voorbeeld is de noodzakelijke verschuiving in het type zorg aangeboden wordt. De totale kosten binnen de gezondheidszorg zouden als volg van deze verschuiving kunnen stijgen indien de vervangende ziekte duurdere is dan de oorspronkelijke ziekte (bijv. kanker versus $\mathrm{CHZ}$ ). Het is tuurlijk niet zo dat in zo'n geval een dergelijk scenario als ontoelaatbaar worden beschouwd. Echter het signaleren van dergelijke onverwachte neve fecten lijkt ons uitermate belangrijk.

Overigens is het geen eenvoudige zaak de precieze mechanismen van dit neveneffecten vast te stellen. Dit is bijvoorbeeld gebleken bij een aantal t waarbij daling van het serumcholesterolgehalte weliswaar leidde tot een d van de CHZ-sterfte in het cohort, maar niet tot een stijging van de totale le verwachting (vgl. McCormick e.a., 1988 en MacMahon e.a., 1986). De st die de sterfte aan $\mathrm{CHZ}$ meten zijn vaak niet opgezet om alle sterfteoorzak registreren. Het onderzoek naar de totale sterfte vereist een grote en langd onderzoeksopzet. Een beperking van het proefschrift is dan ook dat we de danks żijn uitgegaan van een onafhankelijkheid van doodsoorzaken (zie ho stukken 3,6 , en 7 ). 
Zoals reeds in de inleiding genoemd, analyseert het door ons ontwikkelde model de wisselwerking tussen het microniveau (patiëntniveau) en het macroniveau (bevolkingsniveau) (zie hoofdstuk 7). Het zijn de epidemiologie en de beschrijvende statistiek die een belangrijke rol spelen in het verzamelen en analyseren van de macrogegevens. De beleidsvormende instanties (op overheidsniveau) baseren hun beleidskeuzen vooral op de macrogegevens. Zo zal het waargenomen aantal jaarlijkse hartinfarcten een beslissingsondersteunende variabele zijn bij de bepaling van het aantal en de capaciteiten van de intensive care unit's. Evenzo is de bovengrens van het aantal toegestane open hartoperaties mede gebaseerd op de epidemiologische gegevens betreffende coronaire hartziekten, alhoewel hier ook andere overwegingen mede een rol spelen. De keuzen zelf echter grijpen vaak rechtstreeks aan op het microniveau. Bijvoorbeeld verruiming van capaciteiten en financiële middelen zullen artsen aanzetten tot het kiezen van andere behandelingen voor de verschillende soorten patiënten (zie bijlage II). Scenariostudies passen in de geschetste wisselwerking. In scenariostudies wordt informatie verzameld en geanalyseerd. Er worden consistente, mogelijke toekomstbeelden geschetst die mee kunnen tellen bij het uitzetten van het beleid voor de toekomst (het zogenaamde anticiperend beleid) (vlg. Hulshof, 1993).

\subsection{Probleemstelling, Vraagstelling en Methodiek}

Een belangrijk probleem waar onderzoekers vaak mee te maken krijgen is dat het heden en het verleden de nodige onzekerheid in zich hebben, en dat de toekomst onbekend is. Het is een filosofische discussie of de toekomst uniek bepaald kan worden op basis van de kenmerken van het heden en het verleden. De onzekerheden uit het verleden kunnen voor een aanzienlijk gedeelte gereduceerd worden indien de diverse registraties systematischer en betrouwbaarder zouden plaatsvinden (vgl. sectie "De gegevensbronnen over de Volksgezondheid" uit Van der Maas e.a., 1989).

Wat we wel weten is dat we onvoldoende inzicht hebben in de causale samenhang van sociale, culturele, economische en natuurwetenschappelijke patronen, om met zekerheid te kunnen voorspellen hoe de volksgezondheid en de gezondheidszorg zich in de toekomst zullen gaan ontwikkelen (vlg. Lalonde, 1974).

Er is echter op nogal wat deelaspecten concrete informatie voorhanden. Aanwezigheid van risicofactoren voor coronaire hartziekten bij een persoon kan een verhoogde kans op CHZ-incidentie geven in vergelijking tot afwezigheid. Met behulp van epidemiologisch onderzoek kan er een statistische kwantificering worden gegeven van deze relatie (vgl. Gunning-Schepers, 1989).

Onzeker is welke factoren nu precies, in causale zin, het atherosclerotisch proces in gang zetten en met welke snelheid of hoever dit proces gevorderd moet zijn 
om zich als "ziekte" te presenteren. Zo zou het mannelijke geslachtshormoon tosteron verantwoordelijk zijn voor het bekende verschijnsel dat mannen groter risico voor $\mathrm{CHZ}$ hebben dan vrouwen. Dit geslachtshormoon heeft actief effect op endotheline met een sterk vaatvernauwende werking als gevol Veel moeilijker wordt het als we inzicht zouden willen hebben in het toekon rookgedrag van de Nederlandse bevolking. Ook al zouden we van de afgelc 10 jaar precies geregistreerd hebben voor de Nederlandse bevolking wie hoe rookt en wie niet, dan nog is het niet mogelijk voor de komende jaren het is gedrag uit de geregistreerde trend te bepalen. Altijd kunnen er onverwachte buigingen plaatsvinden die sociaal-cultureel geïndiceerd zijn. Achteraf overi worden er vaak aanvaardbare "verklaringen" voor dergelijke ombuigingen ge muleerd.

De wijze waarop met het aspect onzekerheid kan worden omgegaan is via formuleren van scenario's. We zien een scenario als een "realistisch" toekom traject dat alle relevante informatie bevat met betrekking tot het onderwerp studie. Er is in hoofdstuk 5, met betrekking tot het formuleren van scenari een aantal randvoorwaarden genoemd. Hierin gaan we dieper in op de betek die wij aan het begrip realistisch toekennen.

De informatie in de beschouwde periode betreft aspecten als niveau van het zondheidszorgsysteem (populatieniveau of macroniveau versus individueel niv of microniveau), trajecten voor de risicoprofielen (verdeling risicofactoren er te signaleren trends), ontwikkelingen op medisch technologisch terrein (verar ringen in indicatiestellingen), populatie dynamica (demografische ontwikke gen), en in het algemeen de invloeden van de voorgaande determinanten prognoses van ziekte(n) met betrekking tot de sterfte, kwaliteit van leven en ten.

Scenario-onderzoek levert geen zekerheden op over de toekomst, maar heef doel op mogelijke toekomstige ontwikkelingen te anticiperen waardoor deze ïnvloed kunnen worden. Het bieden van informatie en van visies waar beleic gebaseerd kan worden en waarmee de stuurbaarheid van de ontwikkelingen groot kan worden, staat hierbij voorop. Hieruit volgt dat scenario-onderzoel maatschappelijke relevantie van de effecten en de kosten moet omvatten. He kaart brengen van deze maatschappelijke relevantie is een belangrijk element het dissertatie-onderzoek.

Het onzekerheidsaspect over de toekomst kan toegespitst worden op de v wat de verwachte problemen zijn met betrekking tot de gezondheidszorg in algemeen en $\mathrm{CHZ}$ in het bijzonder. De problemen met betrekking tot $\mathrm{CHZ}$ 
tin de vorige paragraaf impliciet besproken aan de hand van de verwachte ontfwikkelingen over de sterfte, kwaliteit van leven, en kosten.

EEr zijn verscheidene ontwikkelingen te signaleren die verwijzen naar de te ver\&wachten problemen binnen de gezondheidszorg. Deze ontwikkelingen zijn dat (i) ade grenzen van de besteedbare middelen steeds scherper in zicht komen en (ii) pde technologische mogelijkheden nagenoeg onbegrensd zijn (vgl. Commissie van Zorg, 1991). Er ontstaat hoe langer hoe meer een druk tot het stellen van priorikteiten en het maken van keuzen. Dit blijkt ondermeer uit het bestaan van wachtlijsten (open hartchirurgie en dotteren), achterblijvende zorg voor zwakzinnigen een voor geestelijk gehandicapte bejaarden, tekorten aan verpleegkundigen en andere beroepsgroepen.

De vraag komt op hoe de aanwezige capaciteiten en de beschikbare middelen het best aangewend kunnen worden. De huidige indeling van de gezondheidszorg is gebaseerd op een indeling naar voorzieningen. De Nota 2000 (1986) pleit ervoor om ook een indeling van de gezondheidszorg naar ziektecategorieën in te voeren. Het gevolg is dat middelenverdelingen hoe langer hoe meer beargumenteerd worden op basis van een vermeende bijbehorende gezondheidsopbrengst. In het extreme geval is de middelenbeheerder uit op een maximalisatie van de gezondheidsopbrengst gegeven een te verdelen budget.

Het doel van de dissertatie is te beschrijven op welke wijze scenario-analyse gebruikt kan worden als een voor het beleid geschikt economisch analyse instrument, zodanig dat daarmee inzicht verkregen kan worden in de mogelijke toekomstige ontwikkeling van de kosten en effecten van $\mathrm{CHZ}$ volgens verschillende toekomsttrajecten.

De vraagstellingen van deze studie zijn de volgende:

(i) wat zijn bij reductie van $\mathrm{CHZ}$ de gevolgen voor de totale mortaliteit, de CHZ-mortaliteit, en de CHZ-morbiditeit van de Nederlandse bevolking?

(ii) hoe verhouden de verschillende CHZ-scenario's zich tot elkaar in termen van kosten-effectiviteit?

(iii) wat is de bijdrage van de scenariomethode aan de doelmatigheid en doeltreffendheid van de gezondheidszorg met betrekking tot $\mathrm{CHZ}$ ?

We hebben de scenariomethode gebruikt bij de uitwerking van ons onderzoek. De scenariomethode richt zich op alternatieve toekomstbeelden, aangeduid als scenario's. Analyse van de toekomst bezit steeds een zekere fictie. Om deze fictie zo veel mogelijk te reduceren is kennis van de huidige situatie en de onderlinge verbanden tussen de deelaspecten van het object van studie een onmis- 
baar startpunt. Anderzijds is medische kennis altijd maar een momentopn; Medische kennis evolueert voortdurend al dan niet op geleide van technologi ontwikkelingen.

Er worden bij scenario's die van elkaar verschillen op verschillende mani inspanningen verricht (gezondheidszorgprogramma's), waardoor er uiteenlopt effecten worden gegenereerd. De scenario's representeren de toekomstige pi die door het gebruik van deze gezondheidsprogramma's gecreëerd worden. economische analyse van een scenariostudie houdt in dat op een systemati wijze alle inspanningen en effecten van de gezondheidszorgprogramma's wo: geïdentificeerd, gekwantificeerd, en gewaardeerd op een zodanige wijze, dat zinvolle vergelijking tussen de verschillende scenario's mogelijk wordt. He een noodzakelijke randvoorwaarde dat een uniforme methode voor kwanti ring en waardering hierbij wordt gehanteerd (vgl. Van Hout e.a., 1992, en Ineveld e.a., 1990). De toelichting over de gehanteerde meet- en waarderings thoden is opgenomen in bijlage I, II en III.

De gegevens die nodig zijn voor de vorming van de scenario's hebben we zo mogelijk gebaseerd op de resultaten van empirisch onderzoek en privé-comm caties. We hebben voor het genereren van de alternatieve toekomstbeelden simulatie model geconstrueerd. Met behulp van dit model kunnen de toekoms trajecten op dynamische wijze worden ontwikkeld en op hun economische co quenties worden doorgerekend. Er is bij de vorming van de scenario's de $z$ naamde inductieve scenariomethode toegepast. Met deze methode worden schillende toekomstbeelden tot stand gebracht door steeds verschillende vari in de sturende variabelen aan te brengen.

De door ons uitgewerkte scenario's kunnen worden weergegeven met behulp de volgende bestanddelen:

(i) met betrekking tot preventieprogramma's:

- cholesterolreductie,

- anti-rookcampagnes.

(ii) met betrekking tot medische programma's:

- capaciteitsbeperking of uitbreiding van operaties,

- uitbreiding indicatiestelling voor operaties,

- opvoeren hartrevalidatie ter terugdringing van nieuwe $\mathrm{CHZ}$-incidenties

- reductie van opname "delay",

- het vaker en effectiever toepassen van thrombolytica,

- CAG-screening voor vroegtijdige opsporing van verhoogde CHZ-risico groepen,

- reanimatiecursussen ter voorkoming van plotse hartdood. 
In de volgende hoofdstukken worden deze gezondheidszorgprogramma's uitgewerkt en de betreffende begrippen nader gedefinieerd. Het is in deze scenario's niet zozeer de vraag of de beschreven toekomstpaden werkelijkheid worden, maar of de aan de scenario's ten grondslag liggende vooronderstellingen en aannames wel voldoende geldigheid hebben met betrekking tot het te voeren anticiperend beleid. De volgende twee hoofddoelstellingen van ons scenario onderzoek zijn hieruit afgeleid.

1. Het ontwerpen en ontwikkelen van een model dat geschikt is om toekomstige en mogelijke trajecten (te formuleren als scenario's) voor de Nederlandse bevolking met betrekking tot coronaire hartziekten te analyseren.

2. Het uitvoeren van een economische analyse van alle kosten en effecten van $\mathrm{CHZ}$ met behulp van het model.

Uit deze twee hoofddoelen zijn nog twee afgeleide doelen te formuleren die in hoge mate samenhangen met de beide hoofddoelen.

3. Het zo goed en zo volledig mogelijk operationaliseren van het model met de huidige (en historische) kennis op het terrein van coronaire hartziekten, inclusief het aspect van de oorzakelijke factoren.

Het zo goed en zo volledig mogelijk toevoegen van kosten aan medische programma's en preventie programma's.

\subsection{Kengetallen}

De hart- en vaatziekten kunnen worden veroorzaakt door aangeboren hartgebreken en dergelijke en met name door de atherosclerotische aandoeningen met betrekking tot vernauwing en afsluiting van de middelgrote slagaderen in hart-, hersen-, buik-, en beenvaten.

De verzameling hart- en vaatziekten wordt volgens de "International Classification of Diseases" (ICD) onderscheiden in de volgende diagnosegroepen (tussen haakjes staan de codes aangegeven volgens de negende revisie van de ICD:

ischaemische hartziekten (IHZ) (ICD-nummers 410-414).

In de literatuur spreekt men liever van coronaire hartziekten (CHZ). Men wil hiermee aanduiden dat het gaat om alleen de ischeamische klachten die veroorzaakt worden door het atherosclerotisch vernauwingsproces rondom de kransslagaders (CHZ is IHZ, maar niet alle IHZ is $\mathrm{CHZ}$ ). In hoofdstuk 2 volgt een verdere toelichting.

celebro vasculaire aandoeningen (CVA) (ICD-nummers 430-438). 
3. decompensatio cordis of congestive heart failure (CHF) (ICD-nummers 429).

4. hypertensie (ICD-nummers 401-405).

5. overige hart- en vaatziekten, waaronder de aangeboren hartgebreken, il matische hartziekten en klepgebreken, veneuze perifere vaatziekten en in tueuze hartziekten (ICD-nummers tussen 390 en 459).

Hieronder geven we de onderverdeling van de categorie ischaemische hartziel die in de negende revisie wordt gehanteerd (ontleend aan STG, 1993):

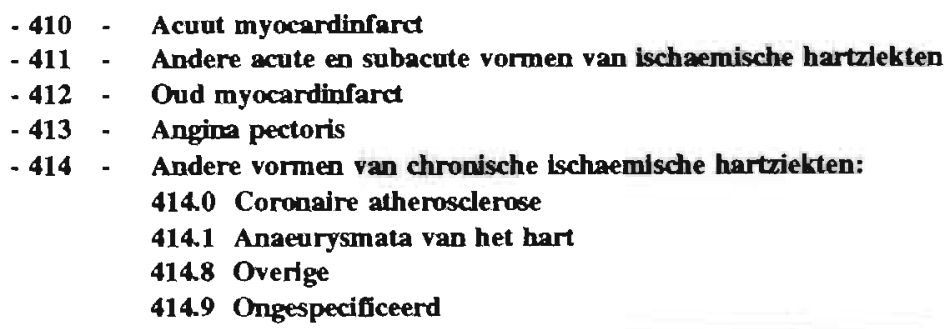

In de tabellen 1.2 en 1.3 worden respectievelijk de kosten (Koopmanschap e 1991) en de sterfte (CBS, 1991) van hart- en vaatziekten verdeeld naar de hierboven genoemde diagnosegroepen. Uit de vergelijking van de tabellen 1.2 1.3 blijkt duidelijk dat de $\mathrm{CHZ}$ getypeerd kunnen worden als een "lethal disea (vgl. Hartunian e.a., 1981).

We hebben in tabel 1.2 de CHZ-kosten die door Koopmanschap e.a. (1991) 2 berekend ongecorrigeerd overgenomen. De CHZ-kosten die we met het mo berekenen bedragen ca. $f$ 1,2 miljard. Een verklaring voor het verschil tus! Koopmanschap en ons model wordt in hoofdstuk 4 gegeven.

$\begin{array}{lll}\begin{array}{l}\text { HART- EN VAATZIEKTEN (1988) } \\ \text { waarvan : }\end{array} & \\ \text { CHZ } & \text { f } 0,8 \text { miljand } & (24 \%) \\ \text { CVA } & \text { f } 1,2 \text { miljard } & (35 \%) \\ \text { CHF } & \text { f } 0,4 \text { miljard } & (12 \%) \\ \text { HYPERTENSIE } & \text { f } 0,1 \text { miljand } & (3 \%) \\ \text { OVERIG } & f 0,9 \text { miljard } & (26 \%)\end{array}$

Tabel 1.2 Kosten hart- en vaatziekten in 1988 bron: Koopmanschap e.a. (1991) 
waarvan :

CHZ

CVA

CHZ

OVERIG
$45 \%$

$23 \%$

9\%

$22 \%$

Tabel 1.3 Sterfte hart- en vaatziekten in 1988

bron: CBS (1991)

In tabel 1.4 wordt een overzicht gegeven van het aantal overledenen aan hart- en vaatziekten naar leeftijd en geslacht in 1988 (CBS, 1991). Het aantal sterften aan hart- en vaatziekten ouder dan 65 jaar is in $1988 \mathrm{ca}$. $85,5 \%$. Van de totale sterfte bedraagt het aantal overledenen ouder dan 65 jaar in $1988 \mathrm{ca} .78 \%$. Het aantal CHZ-overledenen ouder dan 65 jaar in 1988 ligt op ca. 80,5\%. Het zijn de CVA's en de CHF's die gemeten naar mortaliteit een relatief oudere groep van de bevolking treffen.

\begin{tabular}{|l|r|r|r|r|}
\cline { 2 - 5 } \multicolumn{1}{c|}{} & \multicolumn{2}{c|}{ MANNEN } & \multicolumn{2}{c|}{ VROUWEN } \\
\hline LEEFTLJD & $<65 \mathrm{Jr}$ & $265 \mathrm{Jr}$ & $<65 \mathrm{Jr}$ & $265 \mathrm{Jr}$ \\
CHZ & 3.675 & 10.079 & 903 & 8.797 \\
HART- EN VAATZIEKTEN & 5.559 & 20.585 & 1.827 & 23.582 \\
TOTALE DOODSOORZAAK & 17.495 & 47.906 & 9.488 & 49.274 \\
\hline
\end{tabular}

Tabel 1.4

Overledenen naar doodsoorzaak, leeftijd en geslacht in 1988 bron: CBS (1991)

In de tabellen 1.5 en 1.6 zijn de totale kosten en de totale sterfte van de vijf belangrijkste diagnosegroepen weergegeven. De totale kosten van de zorgsectoren in Nederland bedragen in $1990 \mathrm{ca}$. 9,5\% van het Bruto Nationaal Produkt. Dit komt overeen met ca.

$f$ 48,4 miljard (FOZ, 1991). In 1988 zijn de totale kosten f 44,3 miljard. Hiervan wordt $f 4,5$ miljard door de bejaardenzorg en maatschappelijke zorg veroorzaakt. De zogenaamde zorgkosten bedragen per saldo $f 39,8$ miljard. De totale sterfte in 1988 bestaat uit 124.163 personen (CBS, 1991).

\section{ZORGKOSTEN}

waarvan :

1. PSYCHISCHE ZIEKTEN

2. HART - EN VAATZIEKTEN

3. SPIJSVERTERINGSZIEKTEN

4. BEWEGINGSAPPARAAT

5. NIEUWVORMINGEN f 39,8 miljard

$22,0 \%$

$8,7 \%$

$7,6 \%$

$7,0 \%$

$4,6 \%$ 
ZORGKOSTEN

waarvan :

1. PSYCHISCHE ZIEKTEN

2. HART- EN VAATZIEKTEN

3. SPLJSVERTERINGSZIEKTEN

4. BEWEGINGSAPPARAAT

5. NIEUWVORMINGEN

Tabel 1.5 Kosten Top 5 Diagnosegroepen in 1988

bron: Koopmanschap e.a. (1991)

\section{STERFTEN}

maarvan :

1. BLOEDSOMLOOPORGANEN

2. NIEUWVORMINGEN

3. ADEMHALINGSWEGEN

4. LETSEL/VERGIFTIGINGSWEGEN

5. SPIJSVERTERINGSORGANEN
$22,0 \%$

$8,7 \%$

$7,6 \%$

$7,0 \%$

$4,6 \%$

Tabel 1.6 Sterfte Top 5 Diagnosegroepen in 1988 bron: CBS (1991)

We hebben in de tabellen 1.5 en 1.6 een top vijf samengesteld van de diagn groepen die respectievelijk de meeste kosten en sterfte genereren. De concli die uit de vergelijking van deze twee tabellen getrokken kan worden is dat $h$ en vaatziekten als belangrijkste doodsoorzaak na de psychische ziekten de me te kosten veroorzaken. De nieuwvormingen vormen de tweede belangrijk doodsoorzaak maar staan wat betreft kosten op de vijfde plaats. De zorgkos van $\mathrm{CHZ}$ bedragen ca. $3 \%$ van de totale zorgkosten ( $f 1,2$ miljard ten opzic van $f 39,8$ miljard), terwijl de $\mathrm{CHZ}$-sterfte ca. $19 \%$ uitmaakt van de totale ster van alle diagnosegroepen (23.418 personen ten opzichte van 124.163 persone Hieruit blijkt duidelijk de kwalificatie van $\mathrm{CHZ}$ als "lethal disease".

De gegeven vergelijking uit de tabellen 1.5 en 1.6 kan leiden tot een ongenv. ceerd beeld. In tabel 1.7 hebben we de kosten van kanker en $\mathrm{CHZ}$ uitgedruk het aantal nieuw bijgekomen ziektegevallen. Het blijkt dat bij een nagenoeg? lijke incidentie de kosten per incidentie in het geval van kanker ca. 1,5 keer ger zijn dan die van $\mathrm{CHZ}$. 


\begin{tabular}{|l|r|r|r|}
\hline Ziekten & Totaal aantal nleuwe gevallen & Totale kosten & Kosten per incldentle \\
\hline Kanker & $48.000^{1)}$ & $f 1,8$ mlljard $^{2)}$ & $f 37.500,-$ \\
\hline CHZ & 52000 & $f 1,2$ miljard & f 23,000,-- \\
\hline
\end{tabular}

Tabel 1.7 Kosten kanker en CHZ per incidentiegeval in 1988

1) bron: Stiggelbout e.a. (1990)

2) bron: Koopmanschap e.a. (1991)

In tabel 1.8 hebben we een vergelijking gemaakt tussen de kosten per prevalentie van een tweetal psychische ziekten enerzijds en CHZ anderzijds. De kosten per prevalentie van schizofrenie zijn hier drie keer zo hoog als die van CHZ.

\begin{tabular}{|l|r|r|r|}
\hline Zlekten & Prevalentie per 100 inwoners & Totale kosten & Kosten per prevalentie \\
\hline Schizofrenie $^{1)}$ & 0,6 & $f 778 \mathrm{mln}$ & $f \quad 1300.000$ \\
\hline Dyspepsie $^{2)}$ & 1,5 & $f 506 \mathrm{~mm}$ & $f \quad 34000$ \\
\hline CHZ & 2,7 & $f 1,2 \mathrm{mlljard}$ & $f \quad 44.000$ \\
\hline
\end{tabular}

Tabel 1.8 Kosten schizofrenie, dyspepsie en CHZ per prevalentiegeval in 1988

1) bron: Evers e.a. (1992)

2) bron: Warndorff e.a. (1992)

Er worden in tabel 1.9 de belangrijkste CHZ-kengetallen met betrekking tot 1988 weergegeven, zoals deze in het model gebruikt zijn. 
waarvan:

1. ICD-CODE

410 (AMI)

BUITEN HET ZIEKENHUIS (SD+FMI)

$13.343^{21)} \quad(73 \%)$

BINNEN HET ZIEKENHUIS (FMI2+AMI operatie mortaliteit)

2. ICD-CODE

411-415

OVERIG W.O. OPERATIEMORTALITEIT

3. OPERATIEMORTALITEIT (O.M.)

waarvan :

$\begin{array}{ll}\text { ICD-410 (AMI) } & 414 \\ \text { ICD-411-415 (overig) } & 540\end{array}$

4. FMI2+O.M.

MEDISCHE KOSTEN CHZ

waarvan:

VOORTRAJECT

OPNAMETRAJECT

f $86.1 \mathrm{~mm}$.

FOLLOW-UP TRAJECT

f $261.0 \mathrm{mln}$.

1. CHZ STERFTE ALS \% TOTALE STERFTE ${ }^{* 1)}$

2. CHZ KOSTEN ALS \% TOTALE ZORGKOSTEN ${ }^{-3]}$

3. CHZ OPNAMES ALS \% TOTALE OPNAMES ${ }^{-4)}$

-1) CBS, 1991

-2) Hoogendoorn, 1990

-3) Koopmanschap e.a., 1991

•4) Stichting Informatiecentrum Gezondheidszorg (1992)

Tabel 1.9 CHZ-Kengetallen in 1988, zoals in het model gebruikt. 


\begin{tabular}{|l|r|r|r|r|r|r|r|r|}
\hline OMSCHRUJVING & 1980 & 1982 & 1984 & 1988 & 1990 & 1990 & 1991 & 1992 \\
\hline OPNAMES & 51.566 & 59.103 & 67.944 & 72.658 & 72.265 & 81.569 & 1.569 & 86.075 \\
\hline OPERATIES & 3.063 & 4.939 & 8.037 & 9.966 & 12.200 & 14.404 & 14.404 & 18.702 \\
\hline FM12 / OM & 5.418 & 5.425 & 5.616 & 5.703 & 5.471 & 4.953 & 4.757 & 4.157 \\
\hline
\end{tabular}

Tabel 1.10 CHZ-kengetallen 1980-1990

bron: Stichting Informatiecentrum Gezondheidszorg (1992)

In tabel 1.10 wordt een aantal CHZ-kengetallen over de periode 1980-1990 weergegeven.

Uit tabel 1.10 blijkt over de periode 1980-1990 het volgende. Het aantal operaties is in 1990 ten opzichte van 1980 vervijfvoudigd. De opnames zijn ten opzichte van 1980 in 1990 met $55 \%$ gestegen. De totale sterfte binnen het ziekenhuis vertoont een dalende tendens van $9 \%$ over de periode 1980-1990. De dalende tendens van de totale ziekenhuissterfte is vooral interessant wanneer we het plaatsen tegen de achtergrond van de bevolkingsontwikkeling. De bevolking in de leeftijdsgroep 40 jaar en ouder is toegenomen met $18 \%$ van ca. $5,2 \mathrm{mln}$. personen in 1980 tot ca. 6,2 mln. personen in 1990 (CBS, 1991). De dalende trend in de totale ziekenhuissterfte en de stijgende trend in het aantal opnames bevestigt het in paragraaf 1.2 geschetste beeld van een verschuiving in het acute lijden naar het chronisch lijden.

Wij hebben het CHZ-model geijkt op gegevens uit 1988. De in het model gebruikte gegevens met betrekking tot 1988 uit tabel 1.9 wijken op sommige punten af in vergelijking met de aantallen die in tabel 1.10 zijn opgenomen (zie toelichting in Bijlage I, II en III). We hebben de gegevens uit tabel 1.10 geactualiseerd voor de periode 1990-1992. Deze laatste jaren konden echter niet meer als ijkpunten in het model opgenomen worden. We verwijzen voor een verdere toelichting hierover naar Hoofdstuk 7.

\subsection{Opzet van de dissertatie}

De voorliggende dissertatie bestaat in feite uit twee delen. Het eerste gedeelte is conceptueel, methodologisch en resultaatgericht van aard. Het tweede gedeelte concentreert zich op de meer technische en empirische informatie. Dit gedeelte legt zich meer toe op de beschrijving van $\mathrm{CHZ}$, zowel vanuit medisch-epidemiologisch, modelmatig, en kostprijstechnisch oogpunt. De lezer kan het tweede deel gebruiken als een soort "naslagwerk" met betrekking tot de CHZ-aspecten die in 
het eerste deel genoemd worden. De opzet hierbij is dat het eerste deel onaff kelijk van het tweede deel gelezen kan worden. Op deze manier kunnen de m methodologische aspecten met betrekking tot scenario-analyse en economis analyse meer "los" van CHZ gelezen worden. Het eerste gedeelte wordt daar aangeduid als zijnde "het proefschrift". We hebben het tweede gedeelte in vorm van een "bijlage bij het proefschrift" weergegeven.

Hoofdstuk 1 betrof de inleiding van het proefschrift. We zijn hierbij ingegaan de maatschappelijke betekenis van $\mathrm{CHZ}$. De maatschappelijke betekenis heb we gerelateerd aan de sterfte en aan de kosten die $\mathrm{CHZ}$ met zich meebreng Deze zijn geillustreerd aan de hand van een aantal kengetallen. Er wordt aantal veranderingen gesignaleerd die van vergaande invloed kunnen zijn deze maatschappelijke betekenis van $\mathrm{CHZ}$. De genoemde veranderingen betref een verdergaande vergrijzing van de bevolking, veranderde leefgewoonten, technologische ontwikkelingen binnen de gezondheidszorg. Vervolgens heb: we een uiteenzetting gegeven van de probleemstelling, vraagstelling en met diek van het proefschrift. Er wordt in het proefschrift beschreven op welke wi scenario-analyse gebruikt kan worden als een voor het beleid geschikt eco: misch analyse-instrument, waarbij het aandachtsgebied beperkt is gebleven $\mathrm{CHZ}$.

In Hoofstuk 2 worden de huidige (medische) inzichten met betrekking tot $\mathrm{C}$ beschreven. Er wordt eerste ingegaan op het ziekteverloop van CHZ. De centr aspecten hierbij met betrekking tot het model zijn het atherosclerotisch proc de doorbloeding van de hartspier bij plaquevorming in de kransslagaders, we selversterf van de hartspier bij totale afsluiting van éen of meer kransslagad. en het restniveau van de ejectiefractie. Het ziekteverloop "uit zich" in de $w$ van manifestatievormen: angina pectoris (AP), instabiele angina pectoris (UA acuut myocard infarct (AMI), en plotse hartdood (SD). Er is in de groep ! hart- en vaatziekten een ziektegroep die in nauwe relatie staat tot $\mathrm{CHZ}$. D: ziektegroep is hartinsufficiëntie of congestive heart failure (CHF). De behan lingsgang van de CHF-patiënt wordt in het model, vanwege het eigen ziek beeld en de afwijkende therapievorm, in vergelijk met $\mathrm{CHZ}$ niet verder gevol Het hoofdstuk wordt afgesloten met de bespreking van preventieprogramma's medische behandelingen. In Hoofdstuk 1 is al genoemd dat er met betrekking de preventieprogramma's worden onderscheiden: cholesterolreducerende p gramma's en anti-rookcampagnes. We motiveren in Hoofdstuk 2 dat er in model geen bloeddrukverlagende programma's zijn opgenomen. In het mo worden de kosten van $\mathrm{CHZ}$ berekend door het aantal medische behandelinget vermenigvuldigen met een kostprijs (zie Hoofdstuk 4 en Bijlage III). We heb daartoe de medische behandelingen onderscheiden naar zogenaamde therape 
sche behandelingen, onderhoudsbehandelingen, en de behandeling van chronische ziekten.

Hoofdstuk 3 gaat over de opbouw van het CHZ-model. In het model worden mogelijke toekomstige ontwikkelingen van incidenties, prevalenties, mortaliteit, en kosten van coronaire hartziekten op bevolkingsniveau beschreven en geanalyseerd. Het uitzetten van toekomstpaden op bevolkingsniveau vereist een bepaalde modelmatige benadering van de bevolkingsopbouw (zie ook Bijlage II). Vervolgens wordt ingegaan op de kenmerken en eigenschappen van het model. Het model wordt gekenmerkt als een dynamisch simulatiemodel, dat de Nederlandse bevolking eens per jaar, op 1 januari, verdeeld over homogene doelgroepen, volgens een stochastisch proces. Het $\mathrm{CHZ}$-model kan hierbij gekarakteriseerd worden als een Markov-model. De belangrijkste eigenschap van het model is dat het kengetallen voor scenario's produceert. Deze kengetallen betreffen enerzijds de kosten en anderzijds de effecten met betrekking tot de relatie coronaire hartziekten en volksgezondheid (zie ook hoofdstuk 6). Hierop volgend vindt de bespreking van de modelopbouw plaats. Het model is opgebouwd uit vier compartimenten, te weten:

1) de gezonde bevolking, bestaande uit personen "zonder CHZ"

2) de groep van personen die in het betreffende jaar zijn getroffen door een CHZ-manifestatievorm

3) de groep van personen die in een meer stabiele (of latente) fase van $\mathrm{CHZ}$ verkeren

4) de sterfte, zowel aan $\mathrm{CHZ}$ als aan niet-CHZ.

We hebben het gedeelte van het model dat de overlevenden van een $\mathrm{CHZ}$-manifestatie doorsluist naar de latente CHZ-fase in het volgende jaar aangeduid als het brugmodel. De latente fase van het ziekteproces speelt zich af in het morbiditeitsmodel. Hierbij is de latente CHZ-fase weergegeven als de CHZ-bevolking (zie ook Bijlage II). Er wordt in het model rekening gehouden met de instroom van CHF-patiënten "met CHZ" en de uitstroom van CHZ-patiënten naar de populatie "met CHF" (zie Hoofdstuk 3). We laten de omvang van het aantal personen "met CHF" ook afhankelijk zijn van de instroom uit de bevolking "zonder CHZ" en "zonder CHF".

In Hoofdstuk 4 wordt ingegaan op de economische aspecten van het $\mathrm{CHZ}$-model. Aan de orde komen de verschillende vormen van economische evaluatie. In het proefschrift worden de kosten en effecten van een scenario vanuit het maatschappelijk perspectief in vergelijking met elkaar betrokken. We gebruikten de kosteneffectiviteitsanalyse hierbij als de evaluatievorm. De belangrijkste overwe- 
ging hiervoor is dat in de scenariostudie geen utiliteiten zijn opgenomen, door er geen gebruik gemaakt kon worden van de kostenutiliteitsanalyse evaluatievorm. We zijn van mening dat bij de toepassing van economische luatie op scenario's er een onderscheid gemaakt moet worden tussen ener cohortstudies van scenario's en anderzijds bevolkingsstudies van scenario's. I mening wordt ingegeven omdat bij het verrichten van kosteneffectiviteitsanaly met betrekking tot bevolkingsstudies van scenario's een zekere terughoudend in acht genomen moet worden. In de paragraaf Kostenindelingen wordt overzicht gegeven van de in de literatuur gangbare indelingen. We motiv hierbij dat het eerder aangehaalde maatschappelijk perspectief in het proefset "beperkt" is tot de kosten en effecten die binnen de gezondheidszorg direct de gezondheidszorgprogramma's zijn verbonden (de zogenaamde directe m sche kosten). Vervolgens worden de CHZ-kosten in 1988 besproken die aar hand van het model zijn berekend. We hebben voor de bepaling van het ax medische behandelingen behandelingstrajecten ontwikkeld. De behandelings jecten komen in Bijlage II uitgebreid aan de orde. De laatste paragraaf han over het concept kostendeterminant. We komen hierbij tot de conclusie die pompfunctie van het hart (ejectiefractie) als een krachtige kostendetermir beschouwd kan worden.

Hoofdstuk 5 gaat over de scenario's CHZ. Hierbij komen aan de orde scenario-methode, het CHZ-basisscenario, en de beschrijving van de scenari De scenario's worden gecreëerd met behulp van gezondheidszorgprogramm De beschrijving van de scenario's bestaat dus uit de beschrijving van de gezi heidszorgprogramma's. Het begrip scenario is een aanduiding voor het betrefi. de toekomstige pad. Dit aspect komt in Hoofdstuk 6 verder aan de orde. De nario's worden vergeleken met een referentiescenario, zijnde het basisscent We willen aan het basisscenario uitdrukkelijk geen voorspellende betekenis $\mathrm{k}$. ten. De scenariomethode is niets anders dan een techniek die de bestaande feil kennis over de huidige werkelkijkheid combineert met onzekere aspecten i betrekking tot de mogelijke toekomstige ontwikkelingen.

In Hoofdstuk 6 vindt de scenario-analyse plaats. De scenario-analyse houd een analyse van het toekomstbeeld dat door de scenario's met behulp van de: zondheidszorgprogramma's tot stand is gekomen. We maken voor deze scenz analyse gebruik van een aantal kengetallen. Het gaat hierbij met name ofi verschillen, de relatieve betekenis, tussen de kengetallen van deze scenario's vinden scenario-analyses plaats met betrekking tot:

1) Bevolkingsstudie CHZ-preventiescenario's,

2) Cohortstudie CHZ-preventiescenario's,

3) Bevolkingsstudie CHZ medische scenario's, 
4) Cohortstudie CHZ medische scenario's.

In Hoofdstuk 7 wordt een algemene beschouwing gegeven. De algemene beschouwing. De algemene beschouwing richt zich op vier aspecten:

\section{1) Sensitiviteitsanalyse}

We bestuderen hierbij de invloed van variaties in een aantal modelparameters op de modeluitkomsten. Er is hierbij een onderscheid gemaakt tussen sensitiviteitsanalyse van bevolkingsstudies en sensitiviteitsanalyse van cohortstudies. We bespreken bij de sensitiviteitsanalyse van cohortstudies tevens de kritiek die er bestaat op het gebruik van de zogenaamde "QALY-league" tabellen.

2) Vervangende ziekten en -sterften

Er wordt ingegaan op het begrip vervangende ziekten en -sterften. We illustreren aan de hand van een voorbeeld wat de gevolgen in termen van kosten en effecten voor $\mathrm{CHZ}$ zijn wanneer er met vervangende ziekten en -sterften rekening wordt gehouden. In Hoofstuk I is reeds aangehaald dat in het model uitgegaan wordt van onafhankelijkheid van doodsoorzaken.

\section{3) Gezondheidsproduktiefunktie}

De gezondheidsproduktiefunktie geeft inzicht in de gevolgen van de verdeling van de schaarse middelen voor de volksgezondheid op microniveau. Er is in het proefschrift geen empirisch of theoretisch onderzoek gedaan naar de operationalisering van dit instrument.

4) Programmabudgettering

We willen programmabudgettering omschrijven als een planningsmodel dat gericht is op het budgetteren van gezondheidszorgprogramma's. Programmabudgettering biedt ons inziens een structuur aan voor de prioriteringsproblematiek op overheidsniveau wanneer deze gebaseerd wordt op doelmatigheidsoverwegingen.

We sluiten het proefschrift af met een Epiloog. Hierin komen de volgende punten aan de orde.

(i) Validiteit van het model en scenario's

(ii) Tekortkonmingen van het model

(iii) Bruikbaarheid model en scenariostudie voor het beleid

(iv) Aanbevelingen nieuw onderzoek

De bijlagen bij het proefschrift geven de achtergronden van het $\mathrm{CHZ}$-model weer. Dit gedeelte kan worden beschouwd als de technische rapportage waarin 
De bijlagen bij het proefschrift geven de achtergronden van hei CHZ-mo: weer. Dit gedeelte kan worden beschouwd als de technische rapportage waa de belangrijkste gegevens worden verantwoord die in het model ijn gebri De technische rapportage is verspreid over drie bijlagen. Deze bijligen zijn vo de overzichtelijkheid doorlopend genummerd met romeinse cijfers. We gaan Bijlage I in op de epidemiologie van CHZ. In Bijlage II wordt inicht gege in de onderdelen van het CHZ-model. De gebruikte berekeningsmthodiek de in het model gehanteerde kostprijzen wordt in Bijlage III behanceld. In Bi ge IV is een voorbeeld van toekenning utiliteiten opgenomen. 


\section{CORONAIRE HARTZIEKTEN}

2.1 Inleiding

2.2 Ziekteverloop CHZ

2.3 CHZ-manifestatievormen

2.4 Preventie Programma's

2.5 Medische Behandelingen 


\subsection{Inleiding}

Coronaire hartziekten (CHZ) zijn ziekten van de coronaire arterièn of krans aders. De kransslagaders zijn (middel)grote arteriën die de bloectoevoer nat hartspier verzorgen. In de kransslagaders kunnen vernauwingen ontstaan die bloedtoevoer afremmen. Hierdoor krijgt de hartspier minder voedingsstoffer minder zuurstof. Zodra de hartspier meer zuurstof nodig heeft, treden er klad op. Deze klachten kunnen zijn een beklemmende en drukkende pijn op de 1 (aangeduid als het pijnsyndroom angina pectoris of AP). Er sterft een "st van de hartspier wanneer de bloedtoevoer in én of meerdere kransslagaders ledig is afgesneden. Men spreekt van een (acuut) hartinfarct (AMI).

De drie belangrijkste medische of therapeutische behandelingen die met bet king tot $\mathrm{CHZ}$ worden onderscheiden zijn:

1) klinische behandeling met geneesmiddelen (MED),

2) bypass- of omleidingsoperatie (CABGs of kortweg $C A B G$ ), en

3) de dotterbehandeling (PTCA).

Kort samengevat bestaat de CABG uit het aanbrengen van een nieuw stu (slag)ader tot voorbij de plaats van de vernauwing. De PTCA geschiedt met "slangetje" met aan het uiteinde een ballonnetje. Het slangetje wordt in de $\mathrm{km}$ slagader tot in de vernauwing geschoven. Door het opblazen van het ballon wordt de vernauwing weggedrukt.

Het is in de literatuur bekend dat het CHZ-risico toeneemt bij het roken vas garetten, bij een hoge bloeddruk, of een serumcholesterolgehalte boven een paald niveau.

Vaak wordt voor een verhoogde bloeddruk en/of verhoogd serum cholesteri halte boven een bepaalde waarde een dieet voorgeschreven, dat na nader on zoek zo mogelijk wordt aangevuld met medicamenten.

Wij zullen in dit hoofdstuk vier preventie programma's beschrijven, te weten:

1) een cholesterolverlagend dieet-programma,

2) een cholesterolverlagend medicamenteus programma,

3) een hypertensieverlagend medicamenteus programma, en

4) een anti-rookcampagne.

Het blijkt dat er veel aspecten en gegevens over het anatomisch-fysiologisch ces van $\mathrm{CHZ}$ en de invloed van interventies daarop, ontbreken of (nog) 0 
kend zijn. Wij hebben met betrekking tot deze gegevens een aantal keuzen gemakt. Deze keuzen worden gemotiveerd in de verschillende paragrafen.

Het hoofdstuk is als volgt ingedeeld. In paragraaf 2.2 bespreken we het riekteverloop van coronaire hartziekten. Hiermee samenhangend worden in paragraaf 2.3 de CHZ-manifestatievormen beschreven. De preventieprogramma's en de medische behandelingen worden in paragraaf 2.4 respectievelijk paragraaf 2.5 besproken.

\subsection{Ziekteverloop CHZ}

Algemeen wordt aangenomen dat de belangrijkste oorzaak van $\mathrm{CHZ}$ atherosclerose is. Atherosclerose is een langzaam verlopend proces van plaque vorming op de binnenwand van de kransslagaders. Het proces van atherosclerose wordt ook wel aangeduid als aderverkalking.

Het is in causale zin niet precies bekend door welke factoren en met welke snelheid het atherosclerotisch proces in werking wordt gezet. Het vórkomen van bepaalde lipiden in de bloedbaan, proliferatie van gladde spiercellen en lokale thrombusvorming spelen naar algemeen wordt aangenomen hierbij een belangrijke rol. Tegenwoordig wordt gedacht dat vele kleine stoornissen op erfelijke basis samen een oorzakelijke rol kunnen spelen met betrekking tot het ontstaan van atherosclerose. De oorzaak hiervan moet worden gezocht in een defect van een specifiek gen. Van de verdere ontwikkeling van de DNA-diagnostiek in de komende jaren verwacht men ook op dit terrein nieuwe inzichten te krijgen.

Er bestaan veel onduidelijkheden over de vraag of regressie van atherosclerose door verandering van voedingsgewoonten (de zogenaamde hygiënische maatregelen) mogelijk is. De Coronary Intervention Study (Levy, 1986), de Leidse Interventie Studie (Barth, 1986, Arntzenius, 1985), en Regress (uit: Arntzenius, 1990) suggereren in dit verband dat cholesterolverlaging kan leiden tot een regressie van de atherosclerose vorming.

De kransslagaders gaan door de plaques en eventueel ander weefsel (thrombusmateriaal) dichtslibben. Bij toenemende plaque vorming wordt het stadium van de vernauwing of stenose bereikt: een gedeeltelijke (of zelfs gehele) afsluiting van de kransslagader. Dergelijke afsluitingen kunnen zich in meerdere kransslagaders tegelijkertijd en ook in de hoofdstam voordoen.

In eerste instantie vindt ter compensatie van de doorstroombelemmeringen vasodilatatie achter de stenose plaats, terwijl ook collaterale verbindingen zich kunnen gaan ontwikkelen. Zo kan het vórkomen dat patiënten met een ernstige 
stenose nauwelijks waarneembare klachten hebben en vice versa, of dat $\mathrm{ma}$ handeling de angineuze pijnklachten niet verdwijnen. De meting van de $d$ bloeding van de hartspier verkeert nog in een experimenteel stadium, zodin kransslagader die is dichtgeslibd het belangrijkste aangrijpingspunt bij een me sche of therapeutische behandeling blijft.

Op het moment dat de compensatie niet meer toereikend is vindt te weinig do bloeding met betrekking tot de aanvoer van zuurstof en voedingsstoffen in stroomgebied van de kransslagader plaats. Het gevolg is dat de zuurstofvraag zuurstofaanbod overtreft.

De onvoldoende doorbloeding van een weefselgebied wordt ischemie genoe: waarmee het nog steeds reversibele stadium van het ziekteproces wordt aar. duid. Myocardiale ischemie hoeft niet altijd veroorzaakt te worden door slechte doorgankelijkheid van atherosclerotische vaten. Andere oorzaken zijn voorbeeld vernauwde klep (aorta stenose) en spierziekten. Men spreekt daar liever van coronaire hartziekten dan van ischemische hartziekten (Dawber, 198

Het zuurstofgebrek hoeft niet direct tot weefselsterfte te leiden. De typisch a neuze pijnen die bij ischemie van de hartspier optreden dwingen tot rust, wh door het zuurstofgebruik van het myocard vermindert. Het betreffende weef gebied krijgt hiermee de kans niet aangetast te worden tijdens de ischemis periode.

Wanneer de hartspiercellen het verschil tussen zuurstofaanbod en zuurstofvi niet langer meer kunnen verwerken treedt necrose of weefselversterf op. Het $p$ ces van necrose is irreversibel. De dode hartspiercellen dragen niet meer bij de contractiliteit van het hart. Men spreekt van een hartinfarct wanneer weef versterf plaatsvindt in een bepaald regionaal gebied van de hartspier. De plo van het hartinfarct komt meestal overeen met het verzorgingsgebied van kransslagader waarin de stenose aanwezig is.

Er kunnen levensbedreigende ritmestoornissen ontstaan met als gevolg hart stand (het kamerfibrilleren).

Een verlaagde contractiliteit van het hart uit zich in een verlaagde pompfun van met name de linkerkamer (linkerventrikel of LV) van het hart. De glot maat van de pompfunctie wordt weergegeven door de ejectie fractie (EF). pompfunctie van het hart is met name voor de kwaliteit van leven en de ove ving op de lange duur van belang.

In figuur 2.1 is een schematische weergave van het beschreven ziekteverloop $\mathrm{CHZ}$ opgenomen. 


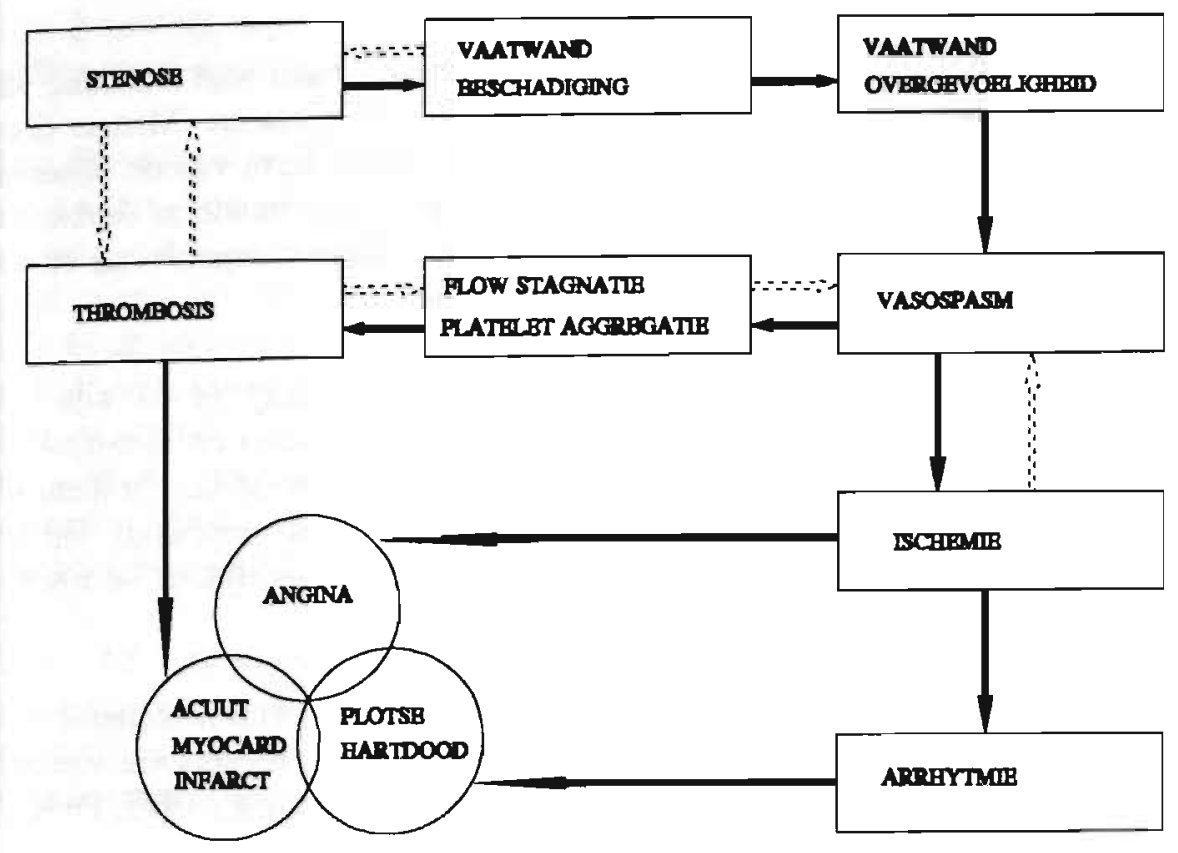

Figuur 2.1

Schematische weergave ziekteverloop $\mathrm{CHZ}$

Vervolgens kan een nieuwe ischemie in een ander gedeelte van het weefselgebied rondom het hart ontstaan dan waar de oorspronkelijke weefselsterfte plaatsvond. Ook kan door de reductie in de pompcapaciteit van het hart een groter beroep op de resterende hartspiercellen worden gedaan, met als gevolg een nieuwe discrepantie tussen zuurstofaanvoer en zuurstofgebruik. Er ontwikkelt zich een vicieuze cirkel, waardoor de eerste $\mathrm{CHZ}$-incidentie gevolgd wordt door eén of meerdere nieuwe $\mathrm{CHZ}$-incidenties. Een $\mathrm{CHZ}$-patiënt kan aldus door verdere progressie van het atherosclerotisch lijden na een eerste $\mathrm{CHZ}$-manifestatievorm opnieuw dezelfde of ên van de andere $\mathrm{CHZ}$-manifestatievormen krijgen.

\subsection{CHZ-manifestatievormen}

Er worden ten aanzien van de incidentie van $\mathrm{CHZ}$ in de literatuur doorgaans vier manifestatievormen onderscheiden, namelijk angina pectoris (AP), instabiele angina pectoris (UAP), acuut myocard infarct (AMI) en plotse hartdood (SD). 


\section{Angina Pectoris (AP)}

Angina pectoris (AP) is een symptomencomplex dat op basis van ischemie de hartspier zich met wisselende verschijningsvormen manifesteert (Manger C 1989). Het ziektebeeld wordt in de regel aangeduid met de term van de bijho: de pijnklacht AP. De pijnklachten kenmerken zich door snoerende of drukke pijn op het borstbeen, die optreden bij een bepaald inspanningsniveau en meestal verdwijnen na rust (Klootwijk e.a., 1987).

De gebruikelijke diagnostische onderzoekingen met betrekking tot AP zijn termonitoring, nucleair inspanningsonderzoek (Thallium Scale) en niet-nucle inspanningsonderzoek (of inspanningstest). De inspanningstest kan bestaan fietsergometrie (soort home-trainer) of tredmolen-test (soort loopband). op ECG (electrocardiogram of hartfilmpje) wordt afgelezen of er tijdens de insp ning afwijkingen met betrekking tot het cardiogram ontstaan.

De AP-klachten worden veelal geclassificeerd volgens het classificatiesche van de New York Heart Association (NYHA). Dit classificatieschema verd de ernst van AP-klachten in vier AP-klassen, te weten (Selzer e.a., 1972, Ped e.a., 1979):

AP1 geen klachten (of a-symptomatisch),

AP2 milde klachten,

AP3 minder emstige klachten,

AP4 ernstige klachten (invaliderend).

Een APl kan ontdekt worden bij inspanningstesten. Er kan namelijk sprake van én of zelfs meerdere vemauwde kransslagaders, zonder dat de bijbehore angineuze klachten zich voordoen (zie paragraaf 2.2 met betrekking tot de van doorbloeding van de hartspier als de oorzaak van AP-klachten). De behan ling van AP1 genereert kosten die zonder opsporing niet gemaakt zouden $z$ Dergelijke vormen van (vermoede) AP kunnen geïndiceerd worden voor inva diagnostisch onderzoek. Deze onderzoekingen vinden plaats met behulp van coronair angiogram (CAG). Een AP3 en een AP4 zijn altijd geïndiceerd een klinische opname (zie Bijlage II).

In de doodsoorzakenstatistieken is het aantal personen dat aan AP als zie overlijdt nihil (STG, 1989). Het is niet aan AP maar aan een AMI (of een ano ziekte) waaraan AP-patiënten in de regel overlijden.

In Bijlage II wordt besproken dat wegens gebrek aan voldoende gegevens 0 het vo6rkomen van de vier typen AP, wij deze vier AP-typen hebben samen voegd tot twee typen: 


\section{Instabiele Angina Pectoris of Unstable Angina Pectoris (UAP)}

De instabiele angina pectoris (UAP) is een bijzondere vorm van AP. Men spreekt van UAP wanneer er sprake is van een verergering in de ernst van de pijnklachten in een korte tijdsperiode (meestal binnen enkele dagen of nog korter). In de literatuur wordt UAP wel omschreven met de term dreigend infarct. In veel UAP-gevallen is er sprake van thrombusvorming (privé-communicatie, Janssen, 1991).

Er heeft zich in geval van een UAP nog geen onherstelbare schade in het weefselgebied van de hartspier voorgedaan (het irreversibele proces van necrose). De klachten bij UAP liggen op overwegend AP3 tot AP4 niveau (McCormick e.a., 1985).

Een UAP waarbij de kransslagader zich (volledig) afsluit resulteert in weefselversterf rondom de hartspier (het hartinfarct). Een behandelde UAP zal in de meeste gevallen een ongecompliceerd verloop behouden. In $10-14 \%$ van de gevallen ontwikkelt een UAP zich tijdens de opname tot een AMI of SD (De Feyter e.a., 1986, Kaiser e.a., 1989, Ambrose e.a., 1989).

\section{Acuut Myocard Infarct (AMI)}

Het hartinfarct ontstaat door een volledige afsluiting (100\% stenose) van eén of meerdere kransslagaders. Een thrombus-afsluiting is bij een AMI in 75-90\% van de gevallen angiografisch aangetoond (Vermeer 1987, Yusuf e.a., 1988/1).

Het versterf van een stuk hartspier is een direct gevolg van een AMI. Het belangrijkste gevolg van een hartinfarct voor de lange termijn is de verlaagde pompfunctie.

Een AMI wordt klinisch veelal vastgesteld op basis van twee criteria: een hartfilmpje, waarop het cardiogram bepaalde afwijkingen van het hartritme weergeeft (positieve ECG) en een verhoging van de hartenzymen in het bloed (Fracheboud,1987).

De infarctgrootte hangt vooral samen met het afstervingsproces van het hartweefsel. Dit afstervingsproces wordt in 4-8 uur voltooid (Marder e.a., 1988/2). De AMI-behandeling start daarom in een zo'n vroeg mogelijk stadium van de infarctontwikkeling.

Het hartinfarct kan gelokaliseerd worden afhankelijk van de plaats in het genoemde verzorgingsgebied van de afgesloten kransslagaders. In de literatuur zijn niet veel gegevens over AMI-lokaties te verkrijgen. Daarbij komt dat de verschillende typen AMI-lokaties niet goed objectief meetbaar zijn (privé-communicatie, Janssen, 1992). De plaats van het AMI is daarom in het model niet opgenomen. 
Wij hebben de AMI-sterfte gedefinieerd als de sterfte ten gevolge van sudi death (SD) en de sterfte ten gevolge van fataal MI (FMI). De beide sterfter zaken zijn aangegeven als dood direct na SD (DSD) en dood in samenhang. AMI (DMI). De FMI betreft patiënten die binnen 30 dagen na de eerste symp men van het AMI komen te overlijden. We maken hierbij een onderscheid to FMI1 en FMI2. De FMI1 is de sterfte binnen 24-uur vo6rdat opname op de pleegafdeling of de coranary care unit (CCU) heeft plaatsgevonden. De FML de sterfte die in het ziekenhuis na opname plaatsvindt. Een fataal MI die bim 24 uur, maar na opname plaatsvindt, wordt aldus beschouwd als FML2. De F binnen 24 uur, maar op de EHBO, is geclassificeerd als FMI1 (privé comme catie AZM, 1992, en STG, 1989).

Er bestaat in de literatuur een onderscheid tussen herkend MI en niet-herkend! (Kannel e.a., 1984). Een niet-herkend MI wordt per definitie niet opgespor omdat het infarct a-typisch is, of omdat er geen symptomen (zogenaands infarct) aanwezig zijn (STG, 1989). De eventuele herkenning vindt soms achte plaats bij een routine-onderzoek, screeningsprogramma, of obductie. We nerz aan dat ten gevolge van technologische ontwikkelingen tegenwoordig meer AV gevallen in een al dan niet eerder stadium als zodanig herkend worden. Er $i$ weinig gegevens bekend met betrekking tot de incidentie en prognose van niet-herkend MI, zodat we ons uitsluitend op een herkend MI hebben gecone treerd.

\section{Plotse hartdood of Sudden Death (SD)}

Een plotse stilstand van de bloedcirculatie wordt aangeduid met plotse harto of "sudden death" (SD). Deze wordt gekenmerkt door het plotseling wegvall van de pompfunctie van het hart als gevolg van abnormale hartritmen. De langrijkste oorzaken van aritmiën zijn plotselinge ischemie van het hart en glk dingsstoomissen.

In sommige gevallen zijn de geleidingsstoornissen niet terug te voeren op $w$ narialijden. Een SD wordt door ons alleen als een CHZ-manifestatievorm schouwd in geval van onderliggend coronarialijden (CHZ). Het criterium bi voor is het AMI. Er is in ca. 50\% van de SD-gevallen sprake van een AM aan de SD voorafgaat (Schatzkin e.a., 1984). De SD ten gevolge van CHZ wor vaak geregistreerd als AMI, zodat een overlap bestaat in de classificatie o dood ten gevolge van een AMI.

In de literatuur worden verschillende SD-definities gebruikt. Wij hanteren w de definiëring van SD de sterfte binnen 1 uur na een AMI, geclassificeerd! DSD. De sterfte ten gevolge van AMI later dan 1 uur wordt door ons geclass ceerd als dood door fataal MI (FMI1 of FMI2). De FMI1-sterfte en FMI2-ster worden in het model beiden als DMI geclassificeerd. 
Indien niet binnen 1 tot 4 minuten reanimatie plaatsvindt, zal de patiënt zeker overlijden. Hoewel patiënten SD dus kunnen overleven, is de groep SD-overlevenden klein. Er bestaat een verhoogde kans op een herhaald (of recurrent) SDrisico van 25\% per jaar (Kremers e.a., 1989). De SD-overlevenden zullen in de meeste gevallen een slechte pompfunctie (EF) hebben $(\mathrm{EF}<40 \%)$.

In figuur 2.2 hebben we de samenhang tussen de CHZ-manifestatievormen op een vereenvoudigde manier weergegeven.

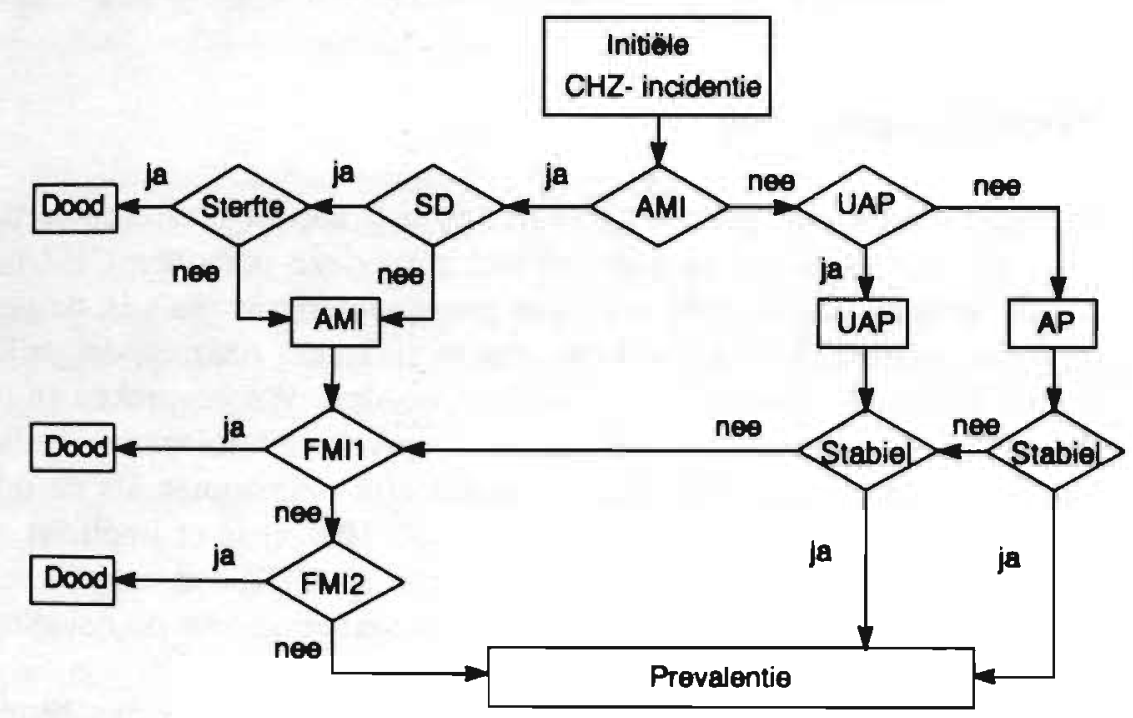

Figuur 2.2

Schematische weergave samenhang $\mathrm{CHZ}$-manifestatievormen bron: bewerkt naar Hartunian e.a. (1981)

\section{Congestive Heart Failure (CHF)}

Een aparte ziektegroep vormt de hartinsufficiëntie, ook wel decompensatio cordis of congestive heart failure (CHF) genoemd. Het is een typische verouderingsziekte. Deze ziekte kenmerkt zich door een chronisch falende pompwerking van het hart (Erdman e.a., 1990).

De prognose is zeer slecht met een sterftekans van ca. 60\% in 3 jaar (Franciosa, 1986, Mancini e.a., 1986). Het optreden van CHF wordt in $40 \%-60 \%$ van de gevallen veroorzaakt door coronarialijden (Kannel, 1987, Yancy e.a., 1988). Hierbij is er veelal sprake van een latente vorm van $\mathrm{CHZ}$, waarbij zich een zodanig 
chrunisch sterk verminderde EF openbaart, dat therapie geen daadwerkelijke vensverlengende kansen meer biedt.

De betekenis van CHF voor de coronaire hartziekten (CHZ) wordt nog eens o derstreept doordat 50\%-60\% sterft aan een AMI of een SD (Packer, 1985). In het model hebben we "chronische AP3-4" beschouwd als CHF. Er is spred van chronische AP3-4 wanneer na intensieve medicatie ook een operatie n meer tot de mogelijkheden behoort.

Zoals eerder aangegeven wordt het aantal personen met CHF in het mot slechts zijdelings meegenomen. De behandelingsgang, de daaraan verbonden kn ten, en de levensverwachting van deze personen worden niet verder gevolgd.

\subsection{Preventieprogramma's}

Preventieprogramma's zijn gericht op personen met én of meerdere verhoogi CHZ-risicofactoren en waarvan niet bekend is of deze personen $\mathrm{CHZ}$ hebt: (kransslagaderstenose $>50 \%$ ). Het doel van preventieprogramma's in de gezon bevolking is het verhoogde risicofactorniveau te verlagen, zodanig, dat de kane op CHZ en CHZ-sterfte daarmee verminderd worden. We bespreken in hoo. stuk 3 dat verhoogd serumcholesterolgehalte (hypercholesterolaemie), verhoo: bloeddruk (hypertensie), en roken in het model zijn opgenomen als de drie t langrijkste risicofactoren met betrekking tot $\mathrm{CHZ}$. Hierbij is er impliciet ane nomen dat er tussen deze drie $\mathrm{CHZ}$-risicofactoren en $\mathrm{CHZ}$ een causaal verba bestaat (zie ook Hoofdstuk 1). In Bijlage I is de verdeling van de risicofactor over de Nederlandse bevolking opgenomen.

In figuur 2.3 is het interventieproces van preventieprogramma's met betreklit tot $\mathrm{CHZ}$ op een schematische wijze weergegeven.

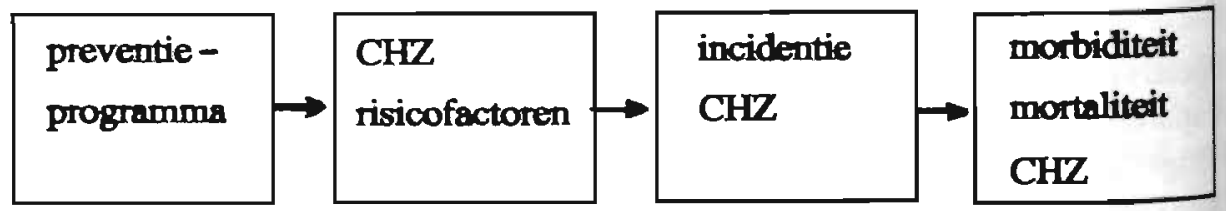

Figuur 2.3 Schematische weergave interventieproces preventieprogramma's 
Er kunnen met betrekking tot $\mathrm{CHZ}$ vier typen preventieprogramma's geformuleerd worden, te weten:

1) een cholesterolverlagend dieet-programma,

2) een cholesterolverlagend medicamenteus programma,

3) een hypertensieverlagend medicamenteus programma,

4) anti-rook campagne.

De vier verschillende typen preventieprogramma's worden hieronder kort toegelicht. De beschrijving van de effecten vindt plaats in hoofdstuk 5 bij de bespreking van de gezondheidszorgprogramma's waar de scenario's uit worden samengesteld.

\section{Cholesterolverlagend Dieet-programma}

Een dieetprogramma kan een uitwerking hebben op zowel het serumcholesterolgehalte als het bloeddrukniveau. Wij hebben gekozen voor een cholesterolverlagend dieet-programma omdat cholesterol meer dan hypertensie een krachtige prognostische betekenis voor het CHZ-risico heeft. Dit aspect wordt onder punt 3 verderop in deze paragraaf uitgewerkt.

Het dieetprogramma wordt in de regel toegepast bij een waargenomen serumcholesterolgehalte $\geq 6,5 \mathrm{mmol} / \mathrm{h}$. Wij zijn op basis van gegevens uit de literatuur er van uitgegaan dat bij een dieetprogramma, uitgaande van een goede therapietrouw, een $10 \%$ daling van het totale serumcholesterol bereikt kan worden (vgl. Mensink e.a., 1989, Katan, 1989, Lovastatin Study Group III, 1988). Het aspect therapietrouw wordt verder besproken onder het volgende punt 2 . We hebben in Bijlage III bij de kostprijsberekening aangegeven hoe het dieet-programma is opgebouwd.

Het dieet kan worden aangevuld met een medicamenteuze behandeling wanneer het serumcholesterolgehalte $>8,0 \mathrm{mmol} / \mathrm{l}$ blijft (Gezondheidsraad, 1990). De wijze waarop dit plaats kan vinden wordt onder het volgende punt 2 besproken.

Zonder (effectieve) begeleiding worden de dieetvoorschriften na een aantal jaren of maanden vaak niet meer nageleefd. Wij veronderstellen daarom dat de begeleiding dusdanig georganiseerd is, dat het dieetvoorschrift blijvend wordt opgevolgd. (vergelijk Van Ree, 1981, 1985/1 en 1985/2, betreffende het Nijmeegs Interventie Project).

\section{Cholesterolverlagend medicamenteus programma}

De toediening van geneesmiddelen is een in belang toenemende methode om het serumcholesterolgehalte te reduceren. Een medicamenteuze behandeling zonder 
de combinatie met een dieet schijnt een aanzienlijk mindere cholesteroldaling te leveren (Hunninghake, uit: Arntzenius, 1990/1, Barth, privé communicar 1991). Een medicamenteuze cholesterolverlaging kan dan ook niet gezien wo den als substituut voor dieet (Erkelens, 1988). We hebben daarom aangenoms dat in de medicamenteus verlaagde cholesterolwaarden de effecten van cholest rolverlagend-dieet begrepen zijn.

Cholestyramine was het eerste cholesterolverlagende geneesmiddel dat in trials een significante daling van het (relatieve) $\mathrm{CHZ}$-risico heeft laten zien. $\mathrm{D}$ medicamenteuze behandeling van hypercholesterolaemie is echter met de ontwi keling van cholesterol-produktieremmende middelen een nieuwe fase ingegae Deze HMG-CoA-reductaseremmers (HMG-blockers) werken in op de leve waardoor ze de eigen lichaamsproduktie van het cholesterol in dit orgaan ster afremmen (Van Zwieten, 1988). De meest bekende preparaten zijn Simvastain en Lovastatine. Deze geneesmiddelen hebben geringe bijwerkingen en een me kelijke manier van inname. Uit de literatuur blijkt verder dat de cholesterolren mers het totale cholesterol verlagen bij doseringen van $1 \times 20 \mathrm{mg}$. per dag $b$ volledige therapietrouw met 25\% (Lovastatin Study Group III, 1988, Rept 1987).

Volgens Martens (1989) zijn bij een vergelijkbare groep van mannen de koste per gewonnen levensjaar van Simvastatine ca. vier keer lager dan die van $\mathrm{Ch}$ lestyramine. Hierbij is er nog geen rekening gehouden met het verschil in bi werkingen, die bij Cholestyramine ongunstiger uitvallen. De medicatie die in ev cholesterolverlagende therapie wordt voorgeschreven bestaat in het model dax om alleen uit de HMG-blockers. De voorgeschreven medicatiedosis is in Bijlag III bij de kostprijsberekening van het cholesterolprogramma opgenomen.

De Gezondheidsraad (1990) vindt dat een cholesterolverlagende medicatie aller geïndiceerd mag worden wanneer na een cholesterolverlagend dieet van 6 max den de cholesterolwaarde $>8,0 \mathrm{mmol} / \mathrm{l}$ blijft en minstens én extra risicofact aanwezig is. Wij schatten in dat ca. $10 \%$ van het aantal mensen met een chole terolgehalte $>8,0 \mathrm{mmol} / \mathrm{l}$ op dit moment medicamenteus behandeld wordt. $\mathrm{Dt}$ schatting kunnen we niet met (gepubliceerde) onderzoeksresultaten onderbouwe Het geschatte aantal van $10 \%$ is mede gebaseerd op een gepubliceerd intervir in een editie van de NRC uit 1989 met de woordvoerder van het concern dat Nederland de HMG-blockers distribueert.

Volgens Levy (1986) en Garber e.a. (1989) duurt het 3 jaar voordat een chole terolverlagende behandeling tot een daling van het relatieve CHZ-risico leidt. zijn in de literatuur geen gegevens beschikbaar over het aantal non-responder 
We veronderstellen daarom dat het cholesterolniveau in alle gevallen op de behandeling reageert.

Op de daling van het relatieve CHZ-risico is de therapietrouw van grote invloed. De patiënten met familiaire hyperlipidemie (erfelijke aanleg) zullen naar verwachting wel een hoge therapietrouw hebben. Het probleem ligt dan ook meer bij patiënten met verhoogde cholesterolwaarden die hiervan geen merkbare gevolgen ondervinden. Er treedt geen signaal op die de patiënt motiveert zijn medicatie in te nemen. In het algemeen daalt de therapietrouw naarmate de medicatieen dieetbegeleiding te wensen overlaat. Om de gevoeligheid van het aspect therapietrouw te meten hebben we daarom in het model de mogelijkheid ingebouwd te variëren met verschillende percentages therapietrouw (zie ook Hoofdstuk 5).

De behandeling kan ook vroegtijdig beëindigd worden. De literatuur geeft hier geen gegevens over, zodat we in het model geen rekening houden met (individuele) vroegtijdige beëindiging van een cholesterolverlagende medicamenteuze behandeling. Om dezelfde reden is het niet bekend of de cholesterolverlagende effecten zich onderscheiden naar leeftijd en geslacht. We nemen daarom aan dat de cholesterolverlagende effecten leeftijds- en geslachtsonafhankelijk zijn. Het spreekt voor zich dat de grove benadering met betrekking tot de non-responders, vroegtijdige beëindiging, en leeftijds - en geslachtsveronderstelde onafhankelijkheid van de therapie in een meer gedetailleerde studie voor verfijning in aanmerking komt.

\section{Hypertensieverlagend medicamenteus programma}

Een behandeling met anti-hypertensiva is in de regel geïndiceerd bij een diastolische bloeddruk $\geq 100 \mathrm{mmHg}$ nadat een niet-medicamenteuze behandeling onvoldoende effect heeft geressorteerd. De medicamenteus bereikte bloeddrukdalingen zijn inclusief de effecten van hypertensie-verlagend dieet. In de literatuur is niet bekend hoeveel mensen met verhoogde bloeddruk medicamenteus worden behandeld. In hoofdstuk 4 is bij de berekening van de CHZ-kosten in 1988 aangenomen dat het aantal met anti-hypertensiva behandelde personen $10 \%$ bedraagt van het aantal mensen met hypertensie. Wij hebben dit aantal gelijk gesteld aan het aantal mensen dat medicamenteus voor hypercholesterolaemie wordt behandeld (zie vorig punt 2 ).

Er is in Hoofdstuk 5 geen hypertensieverlagend medicamenteus programma als preventieprogramma in het model opgenomen. In de eerste plaats zijn er weinig gegevens bekend over de effecten van bloeddrukverlaging met betrekking tot $\mathrm{CHZ}$ waarbij er wel of geen andere verhoogde risicofactorniveau's danwezig zijn. In de tweede plaats bestaat de algemene opvatting dat hypertensie voor andere risicofactoren met betrekking tot $\mathrm{CHZ}$ een meer potentiërende positie in- 
neemt (zie Bijlage I). In figuur 2.4 wordt uitgebeeld dat hypertensie een diree oorzaak vormt van CHF (hartfalen) en van CVA (hersenbloeding), en dat hype tensie (alleen) bijdraagt tot $\mathrm{CHZ}$ (hartinfarct) als er sprake is van een verhoog serumcholesterolgehalte.

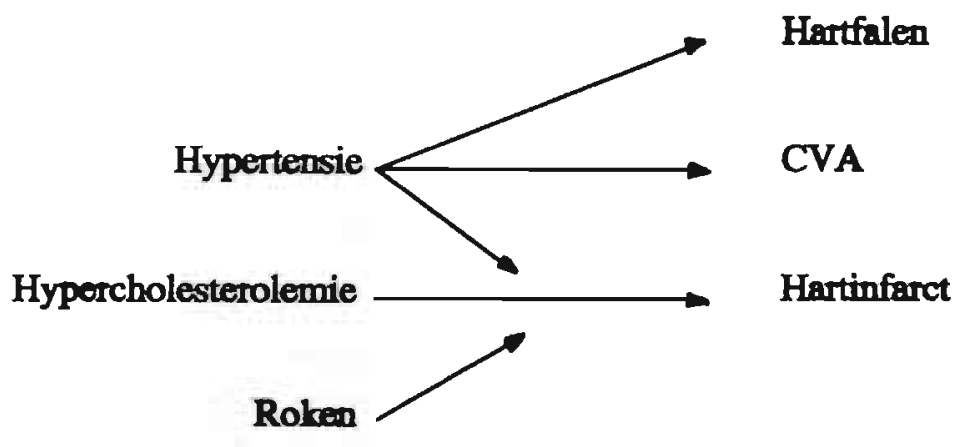

Figuur 2.A

Schematische voorstelling oorzakelijke samenhang risicofactoren en hart-6 vaatziekten

bron: redactioneel commentaar in Hart Bulletin (1988)

Er zijn voor de berekening van de totale kosten van anti-hypertensiva in Hoofi stuk 4 gegevens nodig over de geneesmiddelen die in een hypertensie progran ma gebruikt worden. We geven hieronder een voorbeeld dat model heeft gester voor de kostprijsberekening van het hypertensie programma in Bijlage III. In de praktijk wordt vaak een stapsgewijze ("stepped-care") medicamentewi therapie met anti-hypertensiva toegepast. We hebben ons bij deze therapievon gebaseerd op het behandelingsprotocol van de Hypertensiedienst Groninge (Schuurman e.a., 1987). De voorgeschreven dosis bestaat in $75 \%$ van de gevalle uit $100 \mathrm{mg}$ Atenolol en $50 \mathrm{mg}$ Hydrochloorthiazide en in $25 \%$ van de gevalle uit $200 \mathrm{mg}$ Atenolol, $100 \mathrm{mg}$ Hydrochloorthiazide en $5 \mathrm{mg}$ Prazosin. Atenold Hydrochloorthiazide en Prazosin behoren respectievelijk tot de geneesmiddeler groepen $\beta$-blockers, diuretica en $\alpha$-blockers. Bij de $\beta$-blockers daalt het harti nuutvolume door een verlaging van de hartfrequentie. Een diureticum (urine-dif? vend middel) leidt tot een vermindering van het plasmavolume. De $\alpha$-blocker leiden tot een vaatverwijding zonder dat er een toename van het hartminut volume plaatsvindt.

Het gebruik van diuretica en $\beta$-blockers kan een stijging van het serumcholest rolniveau met $+5 \%$ tot gevolg hebben (Koopmans e.a., 1987). De $\alpha$-blocké hebben een serumcholesterolverlagende werking met 5\%. (Repka e.a., 1987). 
de stepped-care therapie zal dit cholesterolverlagend effect geneutraliseerd worden.

\section{Anti-rook campagne}

Het roken van sigaretten versterkt het risicoverhogend effect van andere risicofactoren met betrekking tot $\mathrm{CHZ}$ (zie Hoofdstuk 1). Evenals het geval bij hypertensie wordt er aangenomen dat roken een minder verhogend effect heeft op het CHZ-risico in bevolkingen met zeer lage serumcholesterolwaarden (vgl. Rose, 1982). Enigszins populair gezegd zou men bij wijze van spreken een verhoogd cholesterolgehalte moeten hebben om van roken een hartinfarct te krijgen (vgl. Leaf, 1989, Rose, 1981, en Roubenoff e.a., 1986).

We hebben het terugdringen van het rookgedrag wel in het model als preventieprogramma opgenomen omdat het gezondheidsrisico van roken voor $\mathrm{CHZ}$ een maatschappelijk actueel thema vormt, te weten:

(i) Het roken is een sterk cultuurgebonden gedragsverschijnsel. Een anti-rook campagne is een preventieprogramma dat zich in dit verband bij uitstek leent voor het beïnvloeden van levensstijlrisico's.

(ii) Het populatie-attributief risico (PAR) is voor roken hoog, gegeven het feit dat 33\% (nog steeds) van de Nederlandse bevolking rookt. Het PAR geeft bij benadering aan welk percentage van de incidentie van een ziekte tnegeschreven kan worden aan de prevalentie van een bepaalde risicofactor.

(iii) De heersende opvatting bestaat dat $25 \%$ van de sterfte aan hart- en vaatziekten, $90 \%$ van de longkankersterfte, en $75 \%$ van de bronchitis- en CARA sterfte aan roken toegeschreven kan worden.

Er zijn in het model twee anti-rook campagnes als preventieprogramma opgenomen, te weten: 1) een anti-rook campagne algemeen (lees: huisarts), en een antirook campagne scholen.

We hebben de anti-rook campagne huisarts gebaseerd op het "vijfstappenplan in de huisartsenpraktijk" van Mudde e.a. (1989). Het vijfstappenplan komt overeen met Van Ree's (1989) strategie die een ontmoedigingsbeleid voor rokers in de huisartsenpraktijk een noodzaak vindt. Het vijfstappenplan wordt in Bijlage III bij de kostprijsberekening van de anti-rook campagne huisarts verder uitgewerkt. De anti-rook campagne scholen richt zich op scholieren in de leeftijd 10-19 jaar. We hebben als voorbeeld de voorlichtingscampagne van De Vries (1989) gebruikt. De toelichting op deze campagne volgt in Bijlage III bij de kostprijsberekening van de anti-rook campagne scholen. 
De relatieve CHZ-kans zal niet direct na het stoppen-met-roken dalen. Deze ve tragingstijd bedraagt bij mannen $\mathrm{ca} .5$ jaar en bij vrouwen ca. 3 jaar. Hiert hebben wij ons gebaseerd op de resultaten van Rosenberg e.a. (1990).

\subsection{Medische behandelingen}

De medische behandelingen kunnen worden onderscheiden naar behandelinge die een therapeutisch effect beogen, onderhoudsbehandelingen en behandelinger van chronische zieken (zie Bijlage III).

De therapeutische behandelingen worden uitgevoerd om angineuze klachten verminderen, CHZ-sterften en (nieuwe) CHZ-manifestaties te voorkómen danwe zolang mogelijk uit te stellen. De ambulance is hierbij beschouwd als een speci le therapeutische behandelingsvorm (zie Bijlage II).

Een bijzondere plaats nemen de medische behandelingen in die verricht word: wanneer al dan niet vermoede initiële AP-klachten zich uiten. Deze behandeli: gen hebben een therapeutische betekenis, in die zin dat gestreefd wordt ei klinische opname zolang mogelijk uit te stellen.

Wij hebben de onderhoudsbehandelingen in het model aangeduid als followbehandelingen. De follow-up behandelingen betreffen ontslagmedicatie en med catie tijdens de verdere follow-up fase, poliklinische consulten en diagnostiel thrombosedienst, en de controle CAG's. De hartrevalidatie en reanimatie $z$ : ingedeeld bij de follow-up behandelingen (zie bijlage II). Evenwel zouden hartrevalidatie en de reanimatie vanwege het therapeutische doel dat ze in $z$ hebben ook tot de therapeutisch behandelingen gerekend kunnen worden.

De behandelingen van chronische zieken zijn gericht op patiënten waarbij de th: rapie geen daadwerkelijke levensverlenging meer biedt. Deze behandelinge stellen zich tot doel de kwaliteit van leven zoveel mogelijk te verbeteren dan zolang mogelijk te behouden. Voorbeelden van dit behandelingstype zijn behs delingen voor FMI- en CHF-patiënten.

De therapeutische behandelingen die in het model als zodanig worden ondre scheiden zijn de volgende:

coronair angiogram (CAG), kransslagaderomleidingsoperatie (CABG), hartcatth terisatie of dotteren (PTCA), klinische behandeling met medicatie, zoals f blockers (MED), thrombolytica ( $T$ ), reanimatie, ambulance, en hartrevalidatie.

We hebben in figuur 2.5 een schematische weergave van de medische behanks lingen opgenomen. 


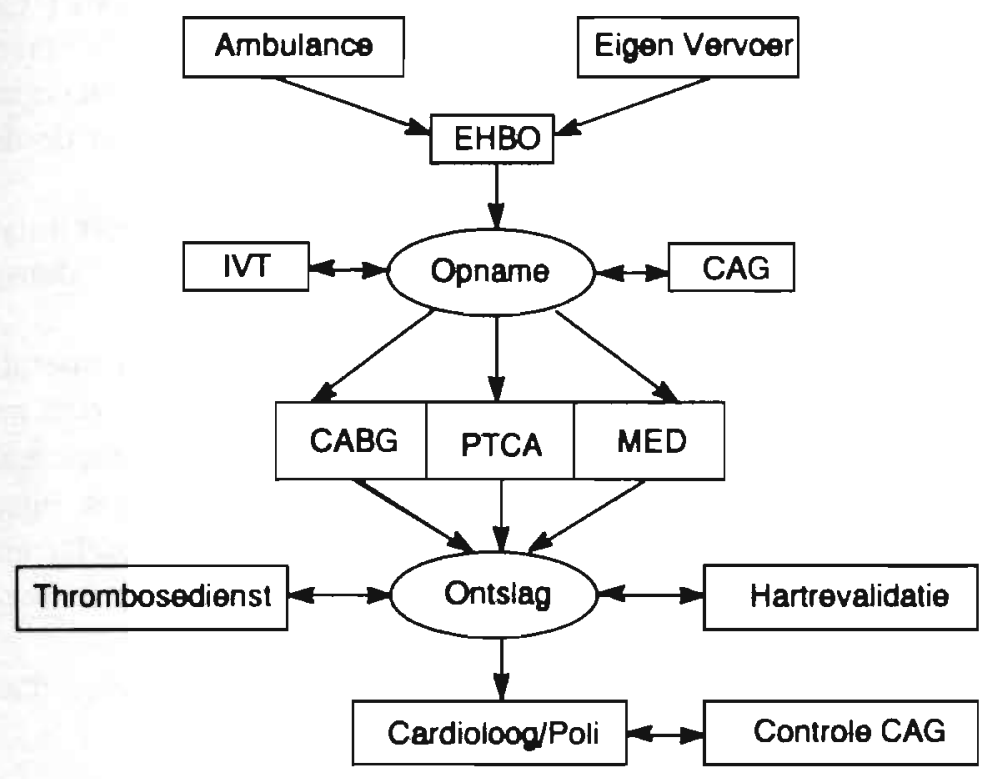

Figur 2.5 Verkorte schematische weergave medische behandelingen

Vervolgens geven we van elke therapeutische behandeling een korte beschrijving. In de bijlagen II en III wordt de samenhang besproken die er bestaat tussen enerzijds de therapiekeuze en anderzijds de patiëntkenmerken en (eventuele) andere overwegingen van meer strategische aard. Bijvoorbeeld, verruiming van capaciteiten en financiële middelen kunnen artsen (als beslissingsnemer) aanzetten tot het kiezen van andere behandelingen voor hun patiënten (vgl. "target income hypoyhesis" uit Admiraal e.a., 1988).

CAG

De CAG (coronair angiografie) is de enige diagnosemethodiek waarmee het aantal vernauwde kransslagaders, de plaats en de mate van de kransslagaderstenose vastgesteld kunnen worden. Wij hebben op basis van de literatuur vier functies aan de CAG toegekend, te weten:

1) de CAG met als hulpmiddel bij de bepaling van de therapiekeuze. Dit type CAG heeft meer een diagnostische functie. In het algemeen is een CAG geïndiceerd als de medicamenteuze behandeling (in of buiten het ziekenhuis) niet tot een verlichting van de klachten leidt of wanneer de ernst van de symptomen een (plotselinge) progressie vertonen. Een operatieve ingreep is dan veelal geboden. 
2) de CAG die wordt gebruikt vlak vóor en tijdens hartoperaties ("CAG vót operatie" respectievelijk "CAG tijdens operatie"). De CAG verschaft (d meest up-to-date) informatie over de plaats en de toestand van de kransslag. aderstenose. De "CAG voor operatie" vormt onderdeel van de deelgroef "diagnostische CAG's".

3) de CAG die tijdens opname na de behandeling met thrombolytica (T plaatsvindt ter beoordeling van de reperfusiegraad ("CAG tijdens opnam: na T").

4) de CAG die verricht wordt na de hartoperatie ("CAG na operatie"). D: CAG heeft dan een preventieve functie. Een herstenose kan zich manifeste ren zonder dat deze gepaard gaat met angineuze klachten (Black e.a., 1988, De CAG na operatie hangt sterk af van de mening van de arts, bijvoorbeel met betrekking tot de mogelijkheid om een herstenose zonder angineuz: klachten te ontdekken. In de meeste gevallen zal een herstenose zich ken. merken door aanhoudende angineuze klachten.

In Bijlage II is een verdere toelichting met betrekking tot de verschillend? functies van een CAG opgenomen.

\section{Hartoperaties}

De hartoperaties zijn de volgende:

1) Coronary Artery Bypass Graft surgery (CABGs of kortweg CABG),

2) Percutane Transluminale Coronair Angioplastiek (PTCA).

De CABG is een open-hartoperatie. Hierbij worden kransslagadervernauwingen overbrugd door een omleiding ("bypass") aan te leggen. De bypass bestaat ut een stukje ader dat meestal afkomstig is van de ader uit het been. Dit type CABG wordt in de literatuur aangeduid als saphenous-veneuze bypass-operati (SV-CABG). Ook kan een implantatie van de borstader worden toegepast. Deze interne mammarie arterie bypass-operatie (IMA-CABG) heeft betere overlevingkansen en minder kansen op een herhaalde CHZ-gebeurtenis. In de praktijk bestaat meestal een combinatie van IMA-CABG en een SV-CABG. Een dergelijk onderscheid is voor ons model te gedetailleerd omdat de patiëntenstromen darvoor op een te hoog aggregatieniveau worden onderscheiden. Dit onderscheid is meer van belang wanneer de twee CABG-typen in een CABG-kosteneffectivteitsstudie worden betrokken.

De PTCA heft de vernauwing in de kransslagader op door middel van dilatatie met een balloncatheter. Het stolsel wordt als het ware weggeduwd of de plaque wordt geplet. 
Er bestaan twee verschillende behandelingsprocedures, te weten spoed- en electieve procedures. Een spoed-procedure (of acute opname) is een procedure die niet is uitgevoerd op chronologische volgorde vanuit de wachtlijst. Dit is het geval wanneer acuut ingrijpen (overname patiënten) of snel ingrijpen (spoedlijst) binnen én week respectievelijk zes weken vereist is. De spoed-procedure is met name gericht op de overleving, terwijl de electieve-procedure meer gericht is op de verbetering van de kwaliteit van leven.

We maken een onderscheid tussen een spoed- en een electieve procedure om verschillende redenen:

1) Een spoed-procedure heeft een hoger risico op operatiemortaliteit. Dit hogere operatiesterfterisico wordt waarschijnlijk veroorzaakt door de kritieke situatie waarin de patiënten verkeren (Gezondheidsraad, 1984/18).

2) Een spoed- en een electieve procedure zijn inherent aan het onderscheid tussen een spoed- (of acute) opname en een gewone (of electieve) opname. Wij beschouwen de AMI en de UAP als acute manifestatievormen en de AP als een electieve manifestatievorm. Een acute manifestatievorm wordt meestal gekenmerkt door een verhoogd $\mathrm{CHZ}$-sterfterisico (inclusief een verhoogd operatiesterfterisico) en een verhoogde kans op een nieuwe $\mathrm{CHZ}$ manifestatic.

3) Er bestaat een verschil in kosten tussen een spoed-procedure en een electieve procedure. Een spoed-procedure (of acute opname) brengt meer kosten met zich mee afhankelijk van de ernst van de manifestatievorm, de ernst van de ejectie fractie (EF), en het aantal vernauwde kransslagaders.

Aan de andere kant kent een electieve procedure meer diagnostische onderzoekingen die aan de feitelijke operatie voorafgaan. Zo zijn er aan een electieve PTCA twee CAG's verbonden, de "CAG vór operatie" en de "CAG tijdens operatie" (de CAG waarmee de PTCA wordt uitgevoerd). De electieve CABG gaat eveneens gepaard met twee CAG's. We gaan ervan uit dat wanneer de electieve CABG wordt uitgevoerd, er na de eerste CAG ("CAG vór operatie") een tweede CAG nodig is ter bepaling van de actuele toestand ("CAG tijdens operatie").

De parameters die naast de type behandelingsprocedure het operatiesterfterisico beïnloeden, zijn de EF, het aantal vernauwde kransslagaders, de leeftijd en het geslacht. Het spoedeisende karakter van een operatieve ingreep hangt nauw samen met de EF en de snelheid waarmee de angineuze klachten zich verergeren. Het operatiesterfterisico wordt groter naarmate meerdere kransslagaders tegelijk vernauwd zijn.

De gemiddelde operatiesterfte stijgt met de leeftijd. In de meeste studies vertonen vrouwen een hoger operatiesterfterisico dan mannen. De kransslagaders zijn 
bij vrouwen kleiner van diameter. Dit bemoeilijkt de operatieve ingreep (Bam veld e.a., 1985).

In de literatuur wordt een operatieve procedure niet succesvol beschouwd wa neer er sprake is van operatiesterfte, post-operatieve sterfte, of een her-ingres die tijdens dezelfde klinische opname wordt uitgevoerd. Een voorbeeld van e. her-ingreep is wanneer een PTCA-procedure gevolgd wordt door een spoet CABG. De operatie-sterfte en de post-operatieve sterfte worden samen wel een aangeduid als de proceduresterfte. De post-operatieve sterfte wordt veelal ver oorzaakt door een nieuw infarct (peri-MI), die rondom de operatie optreedt. 1 de literatuur wordt de peri-MI niet duidelijk gedefinieerd. Wij beschouwen peri-MI als de verzamelnaam voor SD, ritmestoornissen en AMI. Een peri-M kan overleefd worden, evenwel veelal met een $\mathrm{EF}<40 \%$. De overlevenden va een peri-MI hebben een verhoogde kans op een herhaald AMI en op $\mathrm{CH}$. sterfte.

\section{Medicamenteuze Behandeling}

Een medicamenteuze behandeling (MED) heeft tot doel het hart minder zuursti te laten gebruiken. Hierbij bestaan verschillende geneesmiddelengroepen, weten: 1) de $\beta$-blokkerende stoffen, 2) de nitraten en 3) de calciumantagonisten $\mathrm{Ze}$ verschillen echter in hun aangrijpingspunten. Het nut van MED bij een AV is controversieel (Berreklouw, 1988/2). De klinische medicatie (MED) is in he algemeen agressiever van aard dan de medicamenteuze behandeling die als on derhoudsdosis in de follow-up situatie wordt toegediend.

\section{Thrombolytica (T)}

De thrombolytica (T) is erop gericht stolsels in de kransslagaders zo snel moge lijk op te lossen en nieuwe stolsels te voorkomen. De snelle toediening van Ti zinvol wanneer thrombusvorming in de kransslagaders de oorzaak is van he AMI. Hoe eerder de behandeling begint, hoe groter de kans op overleving hoe groter de kans op herstel dan wel het behoud van de hartfunctie zal zijn. De thrombolytische behandeling bij een UAP verkeert in een experimenter stadium. Er zijn weinig prognostische gegevens in de literatuur hierover beschil: baar. In het model wordt daarom geen rekening gehouden met de toepassing ve T bij UAP.

De behandeling met thrombolytica kan intraveneus en intracoronair worden to gediend. De intracoronaire toediening van thrombolytica (ICT) komt in de prak tijk weinig meer voor. De belangrijkste redenen hiervoor zijn dat door technolv gische ontwikkelingen de effectiviteit van intraveneuze thrombolytica (IVT) vergelijken is met die van ICT, terwijl de toepassing van ICT tijdverlies en br: 
gere kosten met zich meebrengt (Marder e.a., 1988/1, Janssen, privé-communicatie, 1991). Vanaf nu spreken we daarom alleen nog van IVT.

Er bestaan zo'n zes verschillende typen thrombolytica. Het meest bekend is de Streptokinase (SK). De SK is verreweg het goedkoopst, terwijl de effectiviteit met betrekking tot de CHZ-sterfte vergelijkbaar is met de andere thrombolytische geneesmiddelen (White e.a., 1989, ISIS-3, uit: Nieuwsbrief, 1991). In het model wordt uitgegaan van SK die intraveneus wordt toegediend.

De behandeling van een vers AMI met IVT start in de regel direct bij aankomst van de patiënt in het ziekenhuis (of in de ambulance indien de vereiste faciliteiten en bemanning aanwezig zijn). In het model wordt geen rekening gehouden met de mogelijkheid om IVT buiten het ziekenhuis toe te passen. Wij gaan er van uit dat een gemiddelde ambulancerit 15-20 minuten duurt, waardoor de behaalde tijdwinst van een vroegtijdige behandeling met IVT minimaal is (vgl. DGD-Maastricht, 1990).

\section{Reanimatie}

Reanimatie wordt toegepast op personen die getroffen worden door plotse hartdood (SD). De behandeling is erop gericht de stilstand van de bloedsomloop binnen 4 minuten te herstellen. In de gevallen dat geen defibrillator aanwezig is bestaat de reanimatie uit hartmassage en mond op mond beademing. Hierdoor wordt tijdwinst voor het ambulance-team bereikt. Al een kleine hoeveelheid rondgepompt bloed geeft voor enige tijd bescherming tegen onherstelbare beschadiging van de hartspier (en tegen hersenletsel).

Een succesvolle reanimatie hangt af van de mogelijkheid om een adequate diagnosestelling te verrichten, de snelle beschikbaarheid van een ambulance, en de aanwezigheid van getrainde omstanders in hartreanimatie.

\section{Ambulance}

Een ambulance heeft tot doel een patiënt zo snel mogelijk na de eerste symptomen van een al dan niet vermoed infarct op te laten nemen in het ziekenhuis. In de huidige situatie wordt binnen 30 minuten na de eerste AMI-symptomen vaak eerst de huisarts gewaarschuwd. Het kan daarna ca. 2 uur duren voordat de huisarts de AMI-patiënt met spoed in het ziekenhuis laat opnemen (Bleeker e.a., 1990). De te realiseren tijdwinst bij het tijdig inroepen is ca. 2,5 uur, waardoor er een groter aantal AMI-patiënten met IVT behandeld kan worden.

\section{Hartrevalidatie}

Hartrevalidatie wordt toegepast op infarct- en operatiepatiënten die uit het ziekenhuis zijn ontslagen. De klinische hartrevalidatie (in een hartrevalidatiecentrum) kan een positief effect hebben op de CHZ-sterfte en op de kwaliteit van 
leven. De EF wordt door hartrevalidatie verder gestabiliseerd, terwijl er een $p$ ventief effect optreedt met betrekking tot nieuwe CHZ-gebeurtenissen.

In de huidige situatie wordt $50 \%$ van de patiënten die voor revalidatie in aa merking komen, daadwerkelijk gerevalideerd (Revalidatie Commissie, 1990). H hangt namelijk sterk af van de lokale omstandigheden of een infarct- of operati patiënt gerevalideerd wordt.

Van het aantal hartrevalidatiepatiënten heeft $60 \%$ een AMI gehad, $30 \%$ el CABG, en $10 \%$ een UAP of PTCA (Revalidatie Commissie, 1990). Hiervan he ben we de volgende verdeling ruwweg afgeleid:

1) $33 \%$ van alle infarctpatiënten die medicamenteus zijn behandeld, krijgt hartrevalidatie,

2) $50 \%$ van alle patiënten die een operatie hebben ondergaan (zowel $C A B$ als PTCA) krijgen na ontslag hartrevalidatie.

\section{Lasertechnologie}

Wij geven tot slot een korte beschouwing over de lasertechnologie met betrel king tot CHZ. Het gebruik van lasers in de kransslagaders is nog experimenteel. In Nederland wordt momenteel met twee typen coronaire lasers geëxperimer teerd: de "ND-YAG laser balloon angioplasty system" (LBA) en de "Al excimer laser angioplasty system". Een derde lasersysteem dat buiten Nederlan bestaat is de "GV medical Argon laser assisted angioplasty system" (LASTAC De coronaire lasers zouden al dan niet gecombineerd met CABG dan wel PTC. atherosclerotische vernauwingen en thrombosen in de kransslagaderen kunne opheffen.

De laserangioplastiek kan een alternatief zijn voor de al reeds traditioneel gewo den behandelingsprocedures als CABG en PTCA omdat de laser in staat (acute) kransslagaderafsluitingen te rekanaliseren. Onzeker is of de laser herst nose vermindert. Er kunnen ook complicaties optreden. Inmiddels is bekend laserbehandeling met betrekking tot CHZ hooguit van waarde is bij enkele spec fieke kransslagadervernauwingen, waarvoor PTCA niet in aanmerking komt. Voor het verkrijgen van een volledig overzicht over de laserontwikkeling $\mathrm{e}$ andere ontwikkelingen met betrekking tot CHZ-behandelingen verwijzen we ne de Gezondheidsraad (1992) die hierover een achtergrondstudie heeft uitgebrach Omdat er geen of nauwelijks gegevens zijn over levensverwachting, operati sterfterisico, en kost(prijzen) hebben we de lasertechnologie niet als medisct behandeling opgenomen. 
3 HET CHZ-MODEL

3.1 Inleiding

3.2 De Bevolkingsopbouw

3.3 Kenmerken en Eigenschappen model

3.4 De Modelopbouw

3.5 Het Brugmodel

3.6 Het Morbiditeitsmodel 
Het doel van het $\mathrm{CHZ}$-model betreft het construeren en analyseren van (toe komst)scenario's over mogelijke toekomstige ontwikkeling van incidenties, pre valenties, mortaliteit en kosten van de coronaire hartziekten (CHZ) in de Neder landse bevolking.

Het CHZ-model is geïmplementeerd in de vorm van een computerprogramma De variaties in visies op toekomstige ontwikkelingen kunnen in het computerpro gramma worden verwerkt als variaties in de diverse parameters. Het computer programma simuleert de toekomstige ontwikkelingen rondom CHZ vanaf 198: tot 2010. We bedoelen met de simulatie van een scenario in dit verband ener. zijds de aanpassing van de parameters op het gewenste niveau en anderzijds de doorrekening van het aangepaste computerprogramma.

De constructie van scenario's vindt plaats door het maken van bepaalde (strategi: sche) keuzen ten aanzien van een aantal gezondheidszorgprogramma's. Een ge. zondheidszorgprogramma kan worden omschreven als een activiteit (in de vorm van eén of meerdere interventies) die tot doel heeft de gezondheidstoestand te verbeteren en/of de levensverwachting te laten toenemen. Een onderling consistent geheel van gezondheidszorgprogramma's vormt een scenario. Wij makes een onderscheid tussen reeds bestaande gezondheidszorgprogramma's en zogenaamde additionele gezondheidszorgprogramma's. De additionele gezondheids. zorgprogramma's kunnen worden geïnterpreteerd als variaties en/of aanvullinger op het gangbare. De kosten en effecten (opbrengsten) die deze gezondheidszorg. programma's met betrekking tot een bepaald toekomstig pad generen, vormen het resultaat van de doorrekening van scenario's (zie Hoofdstuk 6). In het algemeen brengen de additionele gezondheidszorgprogramma's "onbedoelde" never effecten met zich mee met betrekking tot het aantal behandelingen van ander (reeds) bestaande gezondheidszorgprogramma's en het optreden van CHZ-inidenties. Deze neveneffecten leiden tot veranderingen in de prognose (de levens verwachting) en in de kosten (secundaire kosteneffecten). In paragraaf 3.3 wort het onderscheid tussen primaire en secundaire kosteneffecten behandeld.

Een model is een benaderende beschrijving van de werkelijkheid in symbolen met behulp waarvan de samenhang tussen een aantal relevant geachte variabelen kan worden beschreven (Vrieze, 1993). De beschrijving van de werkelijkheid is een complex proces. Er zijn veel onzekerheden met betrekking tot data omtrert toekomst, heden en verleden (zie Hoofdstuk 1). Veel medische en epidemiologische studies hebben betrekking op niet-representatieve deelgroepen van de bevolking. Zodoende zullen er tekortkomingen blijven met betrekking tot de kwali- 
teit, betrouwbaarheid, en representativiteit van de databestanden die in het model gebruikt zijn. Zo zijn er bijvoorbeeld geen (betrouwbare) gegevens over nevendivendiagnosen beschikbaar. Eén van de oorzaken hiervan is dat in de CBS-doodsoorzaakstatistieken de sterfte als gevolg van een nevendiagnose in het algemeen geregistreerd wordt als de sterfte ten gevolge van het onderliggend lijden van de andere ziekte (hoofddiagnose).

Het CHZ-model is opgebouwd uit twee deelmodellen, modules genaamd. Deze modules zijn verwerkt in een computerprogramma.

De eerste module heeft betrekking op het "niet-CHZ" gedeelte van de Nederlandse bevolking en de aanwezigheid en verspreiding van risicofactoren hierin (de demografische module). De uitgangen van deze module geven de jaarlijkse incidenties voor de diverse vormen van coronaire hartziekten voor de Nederlandse bevolking.

De tweede module betreft de analyse van het ziekteproces bij personen met coronaire hartziekten. Jaarlijks wordt het totaal aan medische behandelingen geïnventariseerd alsmede de consequenties hiervan voor de personen die lijden aan CHZ (de ziekte module).

Het model is globaal gesproken standaard gevuld met de huidige kennis op het terrein van coronaire hartziekten, en met de huidige trends. Dit betekent dat een simulatie op basis hiervan voor de komende jaren geïnterpreteerd kan worden als de verrassingsvrije voortzetting van het heden. Dit wordt door ons het basisscenario genoemd (zie verder Hoofdstuk 5).

In de beide modules van het model zijn diverse aangrijpingspunten voor scenariovorming ingebouwd. De scenario's kunnen vervolgens onderling met elkaar worden vergeleken door ze af te zetten tegen het basisscenario.

De model-opzet is adaptief, zodat wijzigingen of aanvullingen in het databestand kunnen worden aangebracht. Er zijn een 30-tal parameterwaarden in het model opgenomen die door de gebruiker naar eigen keuze kunnen worden ingesteld (zie Hoofdstuk 5). Het CHZ-model is zodanig gemodelleerd dat het model uitgebreid kan worden met vervangende ziekte- en sterfterisico's en met leeftijdsspecifieke sterfterisico's. Deze laatsten worden vaak aangeduid als comorbiditeit (zie Hoofdstuk 7).

Het model heeft uiteindelijk een gebruikersvriendelijke vorm gekregen. Met behulp van een userinterface kan een gebruiker zijn eigen scenario bouwen en laten inwerken op het basisskelet van het computerprogramma. Na afloop van de simulatie kunnen de verkregen resultaten via de userinterface vergeleken worden met het basisscenario. 
Dit hoofdstuk is als volgt ingedeeld. In paragraaf 3.2 wordt behandeld hoe bevolkingsopbouw in het model benaderd wordt. De kenmerken en eigenscha pen van het model worden in paragraaf 3.3 besproken. In paragraaf 3.4 staat modelopbouw beschreven. Wij gaan hierbij in op het onderscheid van een br model en een morbiditeitsmodel. Het brugmodel en het morbiditeitsmodel wo den respectievelijk toegelicht in de paragrafen 3.5 en 3.6.

De Bevolkingsopbouw

De bevolkingsopbouw geeft de omvang en samenstelling van de bevolking wet De bevolkingsprognose doet een voorspelling over de toekomstige omvang samenstelling van de bevolking. Deze voorspelling is het resultaat van (aannem lijke) veronderstellingen ten aanzien van geboorte, sterfte en migratie.

In het model is een bevolkingsopbouw en een bevolkingsprognose verwerk. $\mathrm{B}$ wordt onderzocht wat de invloed is van de bevolkingsontwikkeling op de 00 wikkeling van $\mathrm{CHZ}$. We gaan in het model hierbij uit van de werkelijk aanwe ge bevolking in 1988. Het verwachte geboortepatroon en de verwachte leeftijd en geslachtsspecifieke niet CHZ-sterfte komen overeen met de middenvaria van de CBS-bevolkingsprognose 1990 (CBS,1986). De verwachte CHZ-sterf wordt in het model gezien als een te beïnvloeden variabele als gevolg van pr ventieprogramma's, technologische verbeteringen en dergelijke. De verwach totale sterfte wordt gecorrigeerd voor de verwachte $\mathrm{CHZ}$-sterfte. We zijn hiet uitgegaan van onafhankelijkheid van doodsoorzaken (zie paragraaf vervangen ziekten en -sterften uit Hoofdstuk 7).

Voor zowel de gestandaardiseerde CHZ-sterfte als de gestandaardiseerde nie CHZ-sterfte geldt dat ze de afgelopen jaren gedaald zijn. In het model gaan uit van een autonome daling van $1 / 2$ a $1 \%$ per jaar van de algemene sterfte de totale bevolking vanaf de geboorte. Dit levert in 2010 een toename van levensverwachting bij geboorte op van 1,5 jaar (zie Bijlage I). Er kan dan vo de CHZ-sterfte een extra beïnvloeding plaatsvinden via scenariokeuzen.

De bevolkingsopbouw in het model bestaat uit 1 jaars-categorieën voor alle let tijden vanaf 30 jaar. Elk jaar wordt in het model een aantal ex-29 jarigen geg nereerd. De ondergrens van 30 jaar is aangehouden, omdat bij de leeftijd < jaar de CHZ-incidentie nauwelijks optreedt. Er zijn vanaf de leeftijd $100 \mathrm{ja}$ geen personen meer in het model.

De demografische structuur is in het model dusdanig verwerkt dat er twee so ten studies verricht kunnen worden (zie ook Hoofdstuk 5): 
(i) Een bevolkingsstudie

Hier doet de gehele bevolking (0-100 jaar) mee. Voor iedere leeftijd wordt er elk jaar bepaald hoeveel CHZ-incidentie er optreedt. De betreffende personen worden onttrokken aan de gezonde bevolking en na behandeling overgeheveld naar de zieke bevolking. De relevante resultaten op geaggregeerd niveau (bevolkingsniveau) worden bijgehouden.

\section{(ii) Een cohortstudie}

Voor een cohortstudie doet een bepaalde groep personen mee van een bepaalde leeftijd, geslacht, en andere risicokenmerken met betrekking tot CHZ. Tijdens de simulatie wordt dit vervolgd, zonder dat hier additionele personen aan toegevoegd worden. Via sterfte vallen er personen af. Er bestaat de mogelijkheid de simulatie uit te voeren met dat gedeelte van de Nederlandse bevolking overeenkomstig de specificaties of met een hypothetisch cohort bestaande uit 1 miljoen personen. In alle gevallen hebben de relevante resultaten betrekking op het cohort. Bijvoorbeeld, bestaat het cohort bij aanvang uit 40-jarige vrouwen, niet-rokend met een verhoogd cholesterol en normale hypertensie dan heeft de levensverwachting betrekking op zo'n persoon gegeven dat deze op 40-jarige leeftijd nog leefde.

Het demografisch gedeelte van het model is geijkt op de CBS gegevens. In figuur 3.1 zijn de CBS voorspellingen (CBS, 1989) en de modeluitkomsten met elkaar te vergelijken. 

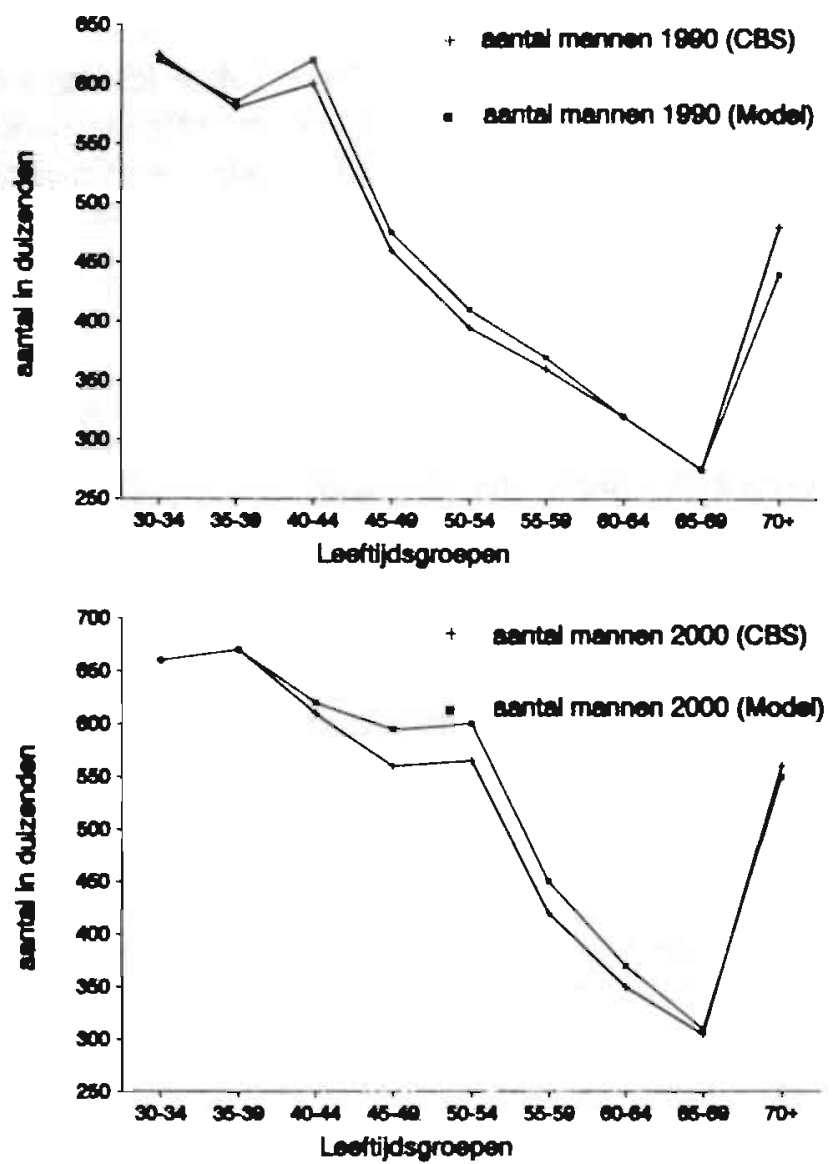

Figuur 3.1

Vergelijking van de modeluitkomsten voor de mannelijke bevolking met gemeten en CBS voorspelde aantallen

We hebben in het model aangenomen dat iets minder dan de helft van jaarlijks aantal geboorten uit jongens bestaat en iets meer dan de helft meisjes. Er wordt geen rekening gehouden met emigratie of met immigra Hoewel dit eenvoudig gerealiseerd kan worden, is het achterwege gelaten om lange termijn voorspellingen in dit opzicht erg onbetrouwbaar zijn. De verscl len in "fit" tussen de CBS-uitkomsten en model-uitkomsten in figuur 3.1 wort hierdoor grotendeels verklaard. Zo zijn de meer recente CBS-bevolkingsprog ses alweer bijgesteld, doordat er meer migranten bijkomen dan was voorzien.

In het model wordt de beschouwde bevolkingsgroep steeds opgedeeld in th deelgroepen: de "gezonde" bevolking en de "zieke" bevolking. Met "gezor wordt hier bedoeld niet aan coronaire hartziekten lijdend. De "zieke" bevolk 
verwijst in dit verband naar dat gedeelte van de bevolking dat ooit in het verleden een vorm van coronaire hartziekten heeft gehad. Ieder van deze twee groepen heeft zijn eigen verdere opdeling waarin groepen worden gevormd bestaande uit personen die als identiek kunnen worden beschouwd met betrekking tot hun kenmerken ten aanzien van $\mathrm{CHZ}$ (zie Bijlage II). Iedere deelgroep wordt als het ware door een standaardindividu gerepresenteerd. De individualisering is op deze wijze in het model gebracht. In de volgende paragraaf 3.3 gaan we verder in op de betekenis dat het aspect individualisering in dit verband heeft voor de modelopbouw.

Voor de "gezonde" bevolking is de opdeling in deelgroepen verricht op basis van risicoprofielen. Een risicoprofiel is een unieke combinatie van leeftijdsgroep, geslacht, rookgewoonte, serumcholesterolgehalte en diastolische bloeddruk. Voor de verdere uitwerking van risicoprofielen verwijzen we naar bijlage II. De gekozen drempelwaarden (afkappunten) van de verschillende risicofactoren zijn in Bijlage I uitgewerkt.

Er is voor de "zieke" bevolking een verdere opdeling gemaakt op basis van de ernst van de ziekte. De belangrijkste determinerende factoren hierbij zijn de resterende ejectiefractie (EF) van het hart en de globale kwaliteit (K) van het kransslagadersysteem (zie bijlagen I en II). In de paragrafen 3.5 en 3.6 komen we terug op beide aspecten.

$\mathrm{Er}$ is voor ieder van de gedefinieerde groepen personen in de gezonde bevolking jaarlijks een risicogroepsafhankelijke kans gespecificeerd dat zich een bepaalde manifestatievorm van coronaire hartziekten voordoet. Deze kans is geschat met behulp van logistische regressies gebaseerd op de Framingham Heart Study (Kannel e.a., 1987).

In het geval dat een persoon getroffen wordt door een manifestatievorm dan verhuist hij of zij naar de zieke bevolking. Aldus wordt er jaarlijks een aantal zieken gegenereerd en onttrokken aan de gezonde bevolking. Ook onder de "zieke" bevolking kan zich een nieuwe manifestatievorm van coronaire hartziekten voordoen. Hiervoor zijn zogenaamde jaarlijkse kansen op een nieuwe incidentie ingevoerd.

\subsection{Kenmerken en Eigenschappen model}

Het CHZ-model is een dynamisch simulatiemodel dat gekarakteriseerd kan worden als een Markov model. De term Markov heeft betrekking op het feit dat ieder jaar alle relevante variabelen aangepast worden aan de nieuwe situatie op basis van de huidige gezondheidszorgprogramma's en de situatie in het voorafgaande jaar. In een Markov model wordt de historie aldus steeds in de huidige 
toestand verwerkt. De historie kan dan vergeten worden daar alle informatie i de huidige toestand opgenomen is.

Een dynamisch model is een model waarbij de variabelen in de tijd veranderen op geleide van onderlinge relaties die al of niet tijdsafhankelijk zijn. Dynamisch modellen verhogen het realiteitsgehalte van scenariostudies. Immers met behuly hiervan is het mogelijk rekening te houden met bijvoorbeeld demografische ver anderingen in de tijd, en met de constructie van in de tijd samenhangende toe komstige gezondheidszorgtracés (zie Hoofdstuk 5).

Een systeem is een verzameling van elementen en relaties tussen de elementen Een element (of een component) vertegenwoordigt bijvoorbeeld een deelgroef uit de bevolking die homogeen is ten aanzien van bepaalde eigenschappen (0) kenmerken). Deze kenmerken zijn leeftijd, geslacht, risicogedrag en gezondheidstoestand (toestand gezond, toestand ziek).

In het model wordt iedere deelgroep door een standaardindividu gerepresenteer en volgen alle personen uit de groep de procesgang van $z 0^{\prime} n$ standaardindividv De rechtvaardiging van de opdeling van de bevolking in zogenaamde homogen. groepen "identieke" personen zit in de uit de kansrekening bekende wet der grole aantallen. Indien dergelijke groepen voldoende groot zijn dan kan het statistisch gedrag van de gehele groep weergegeven worden door het verwachte gedrag val êtr individu.

De procesgang van ieder van de boven gedefinieerde standaardindividuen is nit: gedefinieerd als een deterministisch gebeuren, in de zin dat precies na een wiomschreven tijdsperiode er een overgang naar een volgend stadium plaatsvinth De procesgang is gedefinieerd als een zogenaamd stochastisch proces, hetgen hier betekent dat ieder jaar de voortzetting van het ziekteproces van het stardaardindividu afhangt van een kansproces. Dus met een bepaalde kans overlijt het standaardindividu, en met een bepaalde kans bliff de ziekte stabiel.

Op groepsniveau betekent dit dat een deel van de groep, gelijk aan de kans, $z$ sterven. Deze kansen op mogelijke voortzettingen kunnen vertaald worden als overeenkomstige fractie personen uit de desbetreffende groep die jaarlijks dez: voortzetting volgen. Dit mechanisme stelt ons in staat om ieder jaar na te gan hoeveel personen naar verwachting hun groep verlaten en naar welke groep $z$ verhuizen.

In feite is hiemede bereikt dat een groot aantal verschillende procesgangen dor het model nagebootst worden, die allen met een zekere kans optreden.

Een toestand geeft de waarde van de kenmerken weer die aan de componenlet zijn verbonden. De warden van de toestandskenmerken zijn bijvoorbeeld mat nelijk geslacht, leeftijdsgroep $40-45$ jaar, aantal rokers, en de ziektefase of ziet tetoestand. Met toestand bedoelen we hier de verdeling van de bevolking over 
risicogroepen van de gezonde bevolking en over de deelgroepen van de zieke (CHZ) bevolking.

Er is sprake van een gebeurtenis wanneer de toestand van een homogene deelgroep (of de waarde van het kenmerk met betrekking tot de deelgroep) verandert. Een incidentie is synoniem voor een gebeurtenis die betrekking heeft op de verandering van een bepaalde gezondheidstoestand (vgl. Van Genugten e.a., 1992).

In figuur 3.2 wordt het verband tussen twee opeenvolgende toestanden schematisch weergegeven. Een gebeurtenis wordt beschouwd als een overgangsfase op weg naar hetzij een (nieuwe) ziektefase, hetzij sterfte, en gaat hierbij gepaard met een therapeutische behandeling (zie hoofdstuk 2). De patiënten worden vanuit de vorige toestand verdeeld over de nieuwe toestand. De therapeutische behandelingen beïnvloeden hierbij het verdelingsproces.

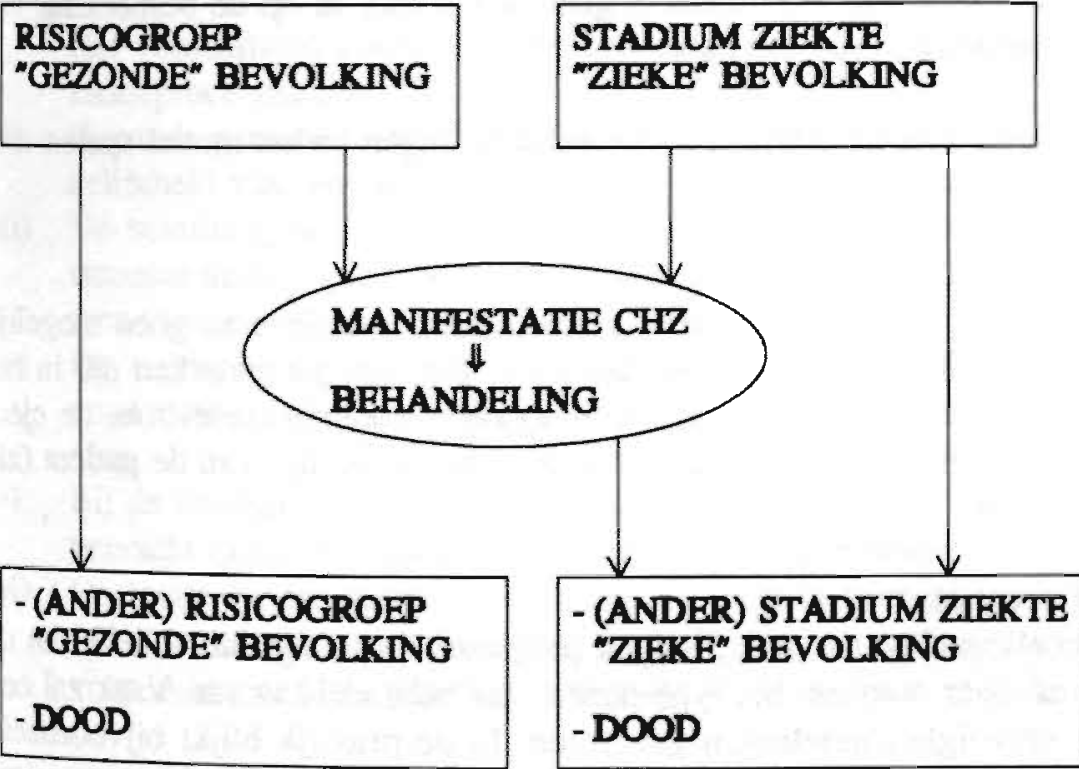

jaar $t$

jasr $t+1$

Figuur 3.2

De jaarlijkse toestandsovergangen scbematisch weergegeven 
Het optreden van een gebeurtenis kan worden beïnvloed door een gezondheids zorgprogramma. Wij onderscheiden twee typen gezondheidszorgprogramma's medische programma's en preventieprogramma's.

Een medisch programma kan worden beschouwd als een geheel van tén of mee therapeutische behandelingen (of interventies) dat aangrijpt op de overgang vai een gebeurtenis naar de nieuwe ziektetoestand dan wel naar de toestand dood. De preventieprogramma's veranderen de verdeling van de Nederlandse bevolking over de risicogroepen. Personen die een ander risico-profiel krijgen ten gevolg van een preventieprogramma, worden geacht het relatieve risico ten aanzien var $\mathrm{CHZ}$ te hebben dat hoort bij het nieuwe risico-profiel.

De verdeling van de risicogroepen over de Nederlandse bevolking werkt via de in het model gelegde verbanden door op de CHZ-incidenties en de CHZ-sterften De effecten van preventieprogramma's kunnen in de werkelijkheid voor een gedeelte steeds weer teniet worden gedaan door het optreden van vervangende ziekten en sterften. In de fase van levensverlenging krijgen de niet-CHZ ziekteen sterfteoorzaken de kans een vervangende rol te spelen. Zoals eerder genoemi veronderstellen we dat er in het model geen veranderingen optreden in de inc: denties van deze vervangende ziekten en -sterften. In Hoofdstuk 7 komen wij dit laatste aspect terug. In Hoofdstuk 5 gaan wij verder in op de bespreking ve preventie- en medische programma's.

Bij de verwerking van de therapeutische behandelingen in het model spelen di: aspecten een cruciale rol.

\section{1) Aspect indicatiestelling}

We hebben getracht voor de diverse typen behandelingen deze zo goed mogelii] te identificeren op basis van patiëntkenmerken. De patiëntkenmerken die in he model een rol spelen voor de indicatiestelling zijn de manifestatievorm, de ejer tiefractie, het vaatlijden, de ernst van de stenose en de leeftijd van de patiënt $(z:$ Bijlage II).

\section{2) Aspect prognose}

Iedere behandelingswijze heeft zijn eigen prognose. Dit hangt niet alleen van behandeling af maar ook van het type patiënt dat behandeld wordt. Vaak zal et behandeling vervolgbehandelingen genereren. In de praktijk blijkt bijvoorbell dat van personen die een PTCA-behandeling ondergaan reeds in het eerste jas ca. 30\% opnieuw in aanmerking komt voor een PTCA-behandeling (David 1988 , Berreklouw e.a., 1989).

Bij de prognose is niet alleen van belang wat de te verwachten toekomstige be handelingen zijn, maar ook wat de kwaliteit van leven van de patiënt is en ho. 
groot de jaarlijkse sterftekans is. Verderop in deze paragraaf bespreken we dat het aspect kwaliteit van leven niet in het model is opgenomen.

\section{3) Aspect kosten}

Behandelingen en behandelingstrajecten brengen kosten met zich mee. Voor de doorrekening is het van belang te weten hoe vaak jaarlijks iedere behandeling verricht wordt. Hiertoe behoren ook de verstrekte medicijnen en de ziekenhuisverpleegkosten (zie Bijlage III). Aan ieder type patiënt is daartoe een bepaalde kans toegekend dat hij een bepaalde behandeling jaarlijks zal ondergaan.

Het aspect kosten heeft ons genoopt de medische behandelingen zo gedetailleerd mogelijk uiteen te rafelen. De uitwerking hiervan wordt weergegeven in Bijlage II onder de paragraaf behandelingstrajecten. Het zo gedetailleerd mogelijk onderbouwen van de kosten is vooral zinvol, omdat het om bijzonder grote groepen patiënten gaat. Het gevolg is dat kleine wijzigingen in behandelingspatronen een grote invloed kunnen hebben op de totale kosten.

Samenvattend kan het model geïnterpreteerd worden als een patiëntenstroommodel dat gekenmerkt wordt door de volgende karakteristieken:

(i) Het verschijnsel coronaire hartziekten wordt getraceerd aan de hand van ziekteprocesgangen.

(ii) Gezonde personen verkrijgen een vorm van coronaire hartziekten in afhankelijkheid van risicoprofielen.

(iii) De bevolking wordt teruggebracht tot een hanteerbaar aantal zogenaamde standaardindividuen, die representatief zijn voor groepen personen ten aanzien van het verschijnsel coronaire hartziekten.

(iv) De ziekteprocesgangen worden bepaald door behandelingsprofielen. Deze zouden zowel van invloed zijn op de kwaliteit van leven als op de overleving.

(v) Bij de behandelingsprofielen is een verregaande vorm van detaillering aangebracht om de bijbehorende kosten te kunnen bepalen.

(vi) De totale kosten worden berekend als de som over alle handelingen van volume (aantal handelingen) $\mathrm{x}$ kostprijs (prijs per handeling). Er wordt voor iedere behandelingsactiviteit jaarlijks het volume bijgehouden.

De voornaamste functie van het model is te dienen als analyse instrument voor mogelijke toekomstige ontwikkelingen op het terrein van de coronaire hartziekten. Dit betekent dat het model in staat moet zijn zekere kengetallen te genereren voor toekomstige trajecten. Er kunnen twee groepen van kengetallen worden onderscheiden, te weten: 


\section{(i) De kosten}

De belangrijkste kengetallen hierbij zijn de volgende:

a) de interventie- of programmakosten die direct verband houden met de interventie of programma (bijvoorbeeld de kosten van preventie), aangeduid al primaire kosteneffecten.

b) de veranderingen in de medische kosten die indirect met het programma samenhangen (bijvoorbeeld stijging van het aantal operaties als gevolg var een thrombolytische behandeling van AMI-patiënten), aangeduid als secundal. re kosteneffecten.

(ii) De relatie coronaire hartziekten en volksgezondheid

Deze relatie valt niet in én getal of variabele uit te drukken. Kengetallen in di verband zijn:

a) levensverwachting geherwaardeerd naar kwaliteit van leven,

b) levensperiode vrij van coronaire hartziekten,

c) levensverwachting vanaf de eerste CHZ-manifestatie (ziekteduur),

d) kwaliteit van leven gedurende de ziekte in relatie tot therapieën,

e) invloed toekomstige trajecten op aantallen opnames, operaties, incidenties en sterften.

De eerste vier kengetallen zijn niet onafhankelijk van elkaar. In kanstheoretische termen is a) in principe samengesteld uit de andere drie $(a=b+c * d)$. Het computerprogramma is zo ingericht dat de kengetallen b) en c) eenvoudig te berekenen zijn. Na definiëring en toekenning van de utiliteiten kunnen daarna de beide andere onderdelen worden bepaald.

De genoemde items kunnen rechtstreeks met het model bepaald worden. Alleen met de items a) en d) ligt dit iets moeilijker. Aan iedere ziektetoestand, en ook aan de behandelingen tijdens het brugjaar kunnen utiliteiten gekoppeld worden Deze utiliteiten drukken uit hoe de patiënt zijn huidige toestand waardeert als fractie van de optimale toestand (overeenkomend met gezond). De verwerking van dergelijke utiliteiten in het model verkeert nog in een experimenteel stadiuri zodat we de resultaten van een op kleine schaal uitgevoerd utiliteitsonderzoek niet in het model hebben opgenomen (zie Hoofdstuk 4). In Bijlage IV zijn de resultaten van deze voorstudie ter illustratie opgenomen. We geven in Hoofdsuls 4 een uitgebreide verantwoording voor het weglaten van de utiliteiten in (dert fase) van ons model. 


\subsection{De Modelopbouw}

Indien een persoon getroffen wordt door een manifestatievorm van coronaire hartziekten dan kan het eerste ziektejaar worden beschouwd als een overgangsfase op weg naar een meer stabiele fase (of latente fase) van de ziekte. De modelmatige analyse van een gebeurtenis geschiedt in het zogenaamde brugmodel. Het brugmodel sluist de overlevenden aan het eind van het eerste jaar door naar het morbiditeitsmodel. Dit doorgeleiden bestaat uit behandelingen met betrekking tot de diagnosefase, ziekenhuisopname, operatie, medicamenteuze therapie, FMI2, CHF en operatiemortaliteit (OM).

In het morbiditeitsmodel speelt zich de latente fase van het ziekteproces af. De personen in het morbiditeitsmodel doorlopen aan het begin van ieder jaar de kans op een nieuwe CHZ-incidentie, de kans op niet-CHZ-sterfte en per saldo de kans om in de latente CHZ-toestand te blijven. Personen uit het morbiditeitsmodel die gedurende een bepaald jaar niet getroffen worden door een nieuwe CHZmanifestatie krijgen gedurende zo'n jaar een zogenaamde follow-up behandeling. Hun gezondheidstoestand kan eventueel verslechteren. De follow-up behandeling wordt na verloop van 1-4 jaren afgebouwd. In geval van een nieuwe CHZ-manifestatie keert de betreffende persoon opnieuw terug in het brugmodel.

Aldus bestaat het behandelen van patiënten in het model uit twee gedeelten. Ten eerste een intensieve behandeling tijdens het brugmodel en ten tweede een follow-up behandeling in de latente fase van het ziekteproces in het morbiditeitsmodel. Uit de Bijlagen II en III zal blijken dat de follow-up behandeling nog weer in twee stukken onderverdeeld is. Dit betreft enerzijds het eerste jaar na de manifestatie, het follow-up traject $<1$ jaar geheten, en anderzijds de periode na dit eerste jaar tot aan een volgende gebeurtenis, aangeduid als het follow-up traject $\geq 1$ jaar. In de Bijlagen I en II geven we een toelichting op de gekozen tijdsperioden.

In feite is er nog een derde behandelingsfase en deze betreft het zogenaamde voortraject (zie Bijlage II). Het gaat hier met name om personen bij wie de ziektegeschiedenis voor de eerste keer start met angina pectoris klachten. Met het voortraject bedoelen we de medische behandeling van initiële AP3-4, totdat een eventuele ziekenhuisopname volgt.

In tabel 3.1 is aangegeven welke toestandsovergangen er jaarlijks vanuit een bepaalde deelgroep plaats kunnen vinden. Een persoon kan in de volgende toestand dus tot een andere deelgroep behoren. 


\begin{tabular}{|l|l|l|}
\hline Van Deelgroep: & Naar: & Oorzaak: \\
\hline \multirow{2}{*}{ In Gezonde Bevolking } & $\begin{array}{l}\text { Zelfde deelgroep } \\
\text { in Gezonde bevolking }\end{array}$ & Geen verandering \\
\cline { 2 - 3 } & $\begin{array}{l}\text { Andere deelgroep } \\
\text { in Gezonde Bevolking }\end{array}$ & $\begin{array}{l}\text { a) Ouder worden } \\
\text { b) Veranderd risicogedrag }\end{array}$ \\
\cline { 2 - 4 } & $\begin{array}{l}\text { Deelgroep in } \\
\text { Zleke Bevolking }\end{array}$ & CHZ-oorzank \\
\cline { 2 - 4 } & \begin{tabular}{l} 
Deelgroep Dood \\
\cline { 2 - 4 }
\end{tabular} & $\begin{array}{l}\text { a) CHZ-oorzaak } \\
\text { b) Niet CHZ-oorcalk }\end{array}$ \\
\hline
\end{tabular}

\begin{tabular}{|l|l|l|}
\hline Van Deelgroep: & Naar: & Oorcaak: \\
\hline In Zieke Bevolking & $\begin{array}{l}\text { Zelfde deelgroep } \\
\text { in Zleke Bevolling }\end{array}$ & Geen verandering \\
\cline { 2 - 3 } & $\begin{array}{l}\text { Andere deelgroep } \\
\text { in Zieke Bevolking }\end{array}$ & $\begin{array}{l}\text { a) Geleidelijke verslechtering } \\
\text { gezondheldstoestand } \\
\text { b) nieuwe incidentie volgt } \\
\text { ander diektestadtum }\end{array}$ \\
\cline { 2 - 4 } & Deelgroep Dood & $\begin{array}{l}\text { a) CHZ-oorcaak } \\
\text { b) Niet CHZ-oorcalk }\end{array}$ \\
\hline
\end{tabular}

Tabel 3.1 Toestandsovergangen CHZ-deelgroepen

De deelgroep in de gezonde bevolking vertegenwoordigt een bepaalde risicogroep. Deelgroepen van de zieke bevolking worden geassocieerd met ziektestadia van het CHZ-proces (zie ook de eerdere toelichting in paragraaf 3.2).

In het model zijn voor iedere vaste risicogroep de overgangskansen met betrekking tot de diverse manifestatievormen van $\mathrm{CHZ}$ constant genomen in de tijd. (Overigens kan de gebruiker deze kans wel tijdsafhankelijk maken via een beirivloedbare modelparameter.) Het Markov gedrag van dit gedeelte van het model is dus stationair. Dit geldt niet voor de CHZ-bevolking en met name niet vor het brugmodel. We nemen bijvoorbeeld aan dat voor de operaties $C A B G$ et PTCA de operatiesterfte jaarlijks met een bepaalde fractie daalt als gevolg var de technologische vooruitgang en de betere diagnostische technieken. Ook 20Uden we zekere veronderstellingen kunnen maken over verbetering van de prog. nose. Het model bezit wel de optie om zo'n prognoseverbetering te implementeren, maar is door ons in onze scenario-berekeningen niet gebruikt. De prognose 
bij een bepaald type operatie is namelijk niet alleen afhankelijk van de kwaliteit van de operatie maar ook van welke type patiënten geopereerd worden, kortom van de indicatiestelling. Aangezien de indicatiestellingen voor operaties in de praktijk van vandaag de neiging hebben op te schuiven naar de "moeilijkere" gevallen is het zeer de vraag of de prognose in algemene zin na operaties gunstiger wordt.

In figuur 3.3 is het CHZ-model opgenomen. In het CHZ-model zijn de posities weergegeven waar de preventieprogramma's en de therapeutische behandelingen op het ziekteverloop aangrijpen.

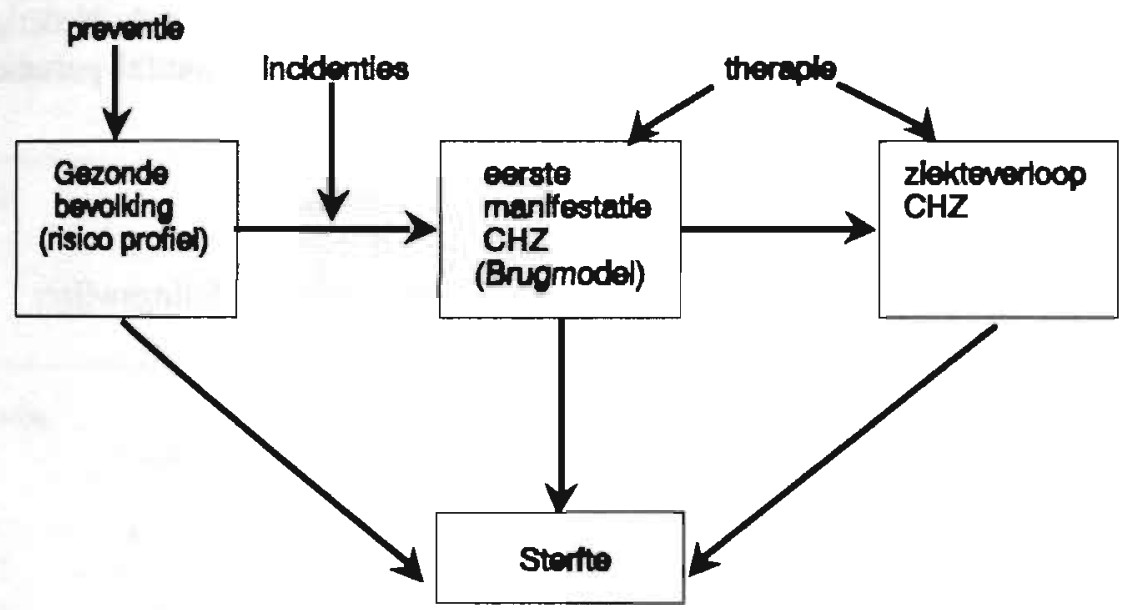

Figuur 3.3 Het Model Coronaire Hartziekten

Aldus kunnen wij nu aangeven welke methodologische uitgangspunten er met betrekking tot het CHZ-model zijn gemaakt:

(i)

$\mathrm{Er}$ is een gezonde bevolking van waaruit jaarlijks op basis van risicoprofielen coronaire hartziekten gegenereerd worden. Ieder risicoprofiel heeft een risicospecifieke kans waaruit een bepaalde CHZ-manifestatie zich voordoet. De preventieprogramma's grijpen aan op de verdeling van de risicofactoren over de gezonde bevolking.

(ii) De personen die getroffen worden door een CHZ-manifestatie verhuizen naar de CHZ-bevolking. 
(ii) De personen die getroffen worden door een CHZ-manifestatie verhui. zen naar de CHZ-bevolking.

(iii) Het brugmodel vervult een dubbelfunctie. Het beschrijft de medische behandelingen en het fungeert als overgangsfase naar het morbiditeitsmodel.

(iv) In het morbiditeitsmodel verkeren de zieke personen in een latente CHZ-fase. Er vinden follow-up behandelingen plaats. De tijdsduur var de follow-up behandelingen bedraagt 1-4 jaar. In geval van een nieuwe CHZ-incidentie gaan de betreffende personen opnieuw het brugmodel in.

(v) Sterfte, zowel aan $\mathrm{CHZ}$ als aan andere oorzaken (de niet-CHZ-sterfte), treedt op onder de gezonde bevolking en de zieke bevolking.

(vi) De invloed en betekenis van coronaire hartziekten voor de Nederlandse bevolking wordt bijgehouden middels een groot aantal parameters, zoals:
a) Jaarlijkse incidentie uit de gezonde bevolking;
b) Jaarlijkse incidentie uit de zieke bevolking;
c) Aantal opnames uitgesplitst naar soort en behandelingswijze;
d) Verwachte leeftijd eerste CHZ-incidentie;
e) Levensverwachting vanaf eerste CHZ-manifestatie;
f) Kosten van opnames en follow-up behandelingen;
g) Totale kosten CHZ.

\subsection{Het Brugmodel}

Zoals eerder genoemd kenmerkt het eerste ziektejaar zich door een overgangsfase naar een latent stadium van de ziekte. Als latent ziekte stadium onderscheiden we de ziektetoestand "wel" of "geen" oud myocard infarct. In beide gevallen gaan we ervan uit dat er een sluimerende vorm van angina pectoris aanwezig is. De eindpunten van het eerste jaar worden voor een groot gedeelte bepaald door de voorafgaande manifestatievorm. Voor een ander gedeelte worden ze bepald door de behandelingstrajecten. In bijlage II zijn voor ieder van de manifestatiex behandelingstrajecten beschreven die op basis van klinische patiëntkenmerken medische behandelingen toevoegen aan patiënten. De eindpunten en de medische acties tijdens het brugjaar zijn in onderstaande tabel 3.2 te vinden. 


\begin{tabular}{|c|c|c|}
\hline Manifestatie & Brugactie & Elndpunt \\
\hline SD & $\begin{array}{l}\text { ambulance } \\
\text { reanimatie } \\
\text { defbrillatie }\end{array}$ & $\begin{array}{l}\text { Intent CHZ } \\
\text { DSD, genoteerd als DMO }\end{array}$ \\
\hline AP1-2 & $\begin{array}{l}\text { huisarts consult } \\
\text { cordiologlsch consult } \\
\text { electleve operatle } \\
\text { medicamenteuze therapie }\end{array}$ & $\begin{array}{l}\text { Iotent CHZ } \\
\text { DMI }\end{array}$ \\
\hline AP3-4 & $\begin{array}{l}\text { cardiologisch consult } \\
\text { ziekenhuisopname } \\
\text { spoed/electieve operatie } \\
\text { medicamenteuze theraple }\end{array}$ & $\begin{array}{l}\text { Irtent CHZ } \\
\text { DMI }\end{array}$ \\
\hline AMI & $\begin{array}{l}\text { ambulance } \\
\text { zielcenhuisopname } \\
\text { spoed/electleve operatle } \\
\text { medicamenteuze therapie }\end{array}$ & $\begin{array}{l}\text { Iatent CHZ } \\
\text { DMI }\end{array}$ \\
\hline UAP & $\begin{array}{l}\text { ambulance } \\
\text { cardiologisch consuht } \\
\text { zielrenhuisopname } \\
\text { spoed/electieve operatie } \\
\text { medicamenteuze theraple }\end{array}$ & $\begin{array}{l}\text { Istent CHZ } \\
\text { DMI }\end{array}$ \\
\hline
\end{tabular}

Legenda:

SD Plotse hartdood (sudden death); hieronder wordt dood ten gevolge van AMI binnen 1 uur verstaan

DSD Dood door Sudden Death

AP1-2 Angina Pectoris klachten NYHA niveau 1 à 2

AP3-4 Angina Pectoris klachten NYHA niveau 3 à 4

AMI Acuut Myocard Infarct

DMI Dood ten gevolge van AMI, later dan 1 uur na optreden van AMI (FMI1 of FML2)

UAP Instabiele Angina Pectoris (unstable AP)

latent $\mathrm{CHZ}$ sluimerende coronaire bartziekten

Tabel 3.2 Relaties tussen manifestatievormen, brugacties en stabiel stadium van de ziekte

Na elke manifestatie wordt slechts eén van de eindpunten bereikt. Uiteraard worden niet op alle patiënten alle mogelijke behandelingen uit de "brugfase" toegepast.

In dit overzicht is buiten beschouwing gelaten dat patiënten in éen jaar getroffen kunnen worden door meerdere manifestatievormen van coronaire hartziekten. In het model nemen we aan dat een patiënt per jaar hoogstens twee manifestaties van CHZ kan krijgen. 
Modelmatig betekent bovenstaande presentatie dat ieder jaar vanuit iedere risi. cogroep (of deelgroep) er een bepaald aantal personen overgeheveld wordt nara het morbiditeitsmodel. De precieze aantallen naar ieder van deze deelgroepen hangen af van de succeskansen en prognoses van de behandelingstrajecten. Hierbij zijn er twee verfijningen aangebracht. De eerste verfijning betreft het aspect vaatlijden dat een maat beoogt te zijn voor het aantal aangedane krans. slagaders bij AP-klachten. Meer aangedane kransslagaders geven een hogere kans op recurrente manifestaties. De tweede verfijning betreft het aspect ejectiefractie. Zowel met betrekking tot de indicatiestellingen voor de klinische therspiekeuze als voor de intensiteit van de follow-up behandeling is een ejectiefracie van meer of minder dan $40 \%$ van doorslaggevende betekenis. Het betreft hier een maat voor de resterende functionaliteit van de linker ventrikel na een hariin. farct.

Er is dus in het model expliciet verondersteld dat de stadia AP3-4 en UAP steeds overgangsstadia zijn die in principe niet kunnen persisteren door hun levensbedreigend karakter. Óf deze mensen overlijden (met als intermediaire gebeurtenis meestal een acuut myocard infarct), of ze komen in een meer stabielk fase. Eén uitzondering is gemaakt voor de AP3-4 mensen waarbij geen operatieve behandeling meer mogelijk is (ejectiefractie $\leq 20 \%$ ). Uit paragraaf $3.6 \mathrm{zl}$ blijken dat deze chronische AP3-4 mensen worden ingedeeld bij de personen me hartinsufficiëntie (CHF).

In Bijlage II zijn meer details te vinden betreffende de opbouw van het model en de verantwoording van de door ons gemaakte keuzen.

We beëindigen deze paragraaf met het stroomschema voor het brugmodel dat in figuur 3.4 wordt afgebeeld. Dit stroomschema laat de overgang van patiëntenstromen van de huidige toestand $t$ naar een nieuwe toestand $t+1$ zien. Hierbij worden bepaalde kansen doorlopen op CHZ-sterfte, CHF, en bepaalde type behandelingen. Op ieder knooppunt zijn de betreffende vertakkingskansen afhankelijk van de persoonskenmerken en de ernst van het ziektestadium. 


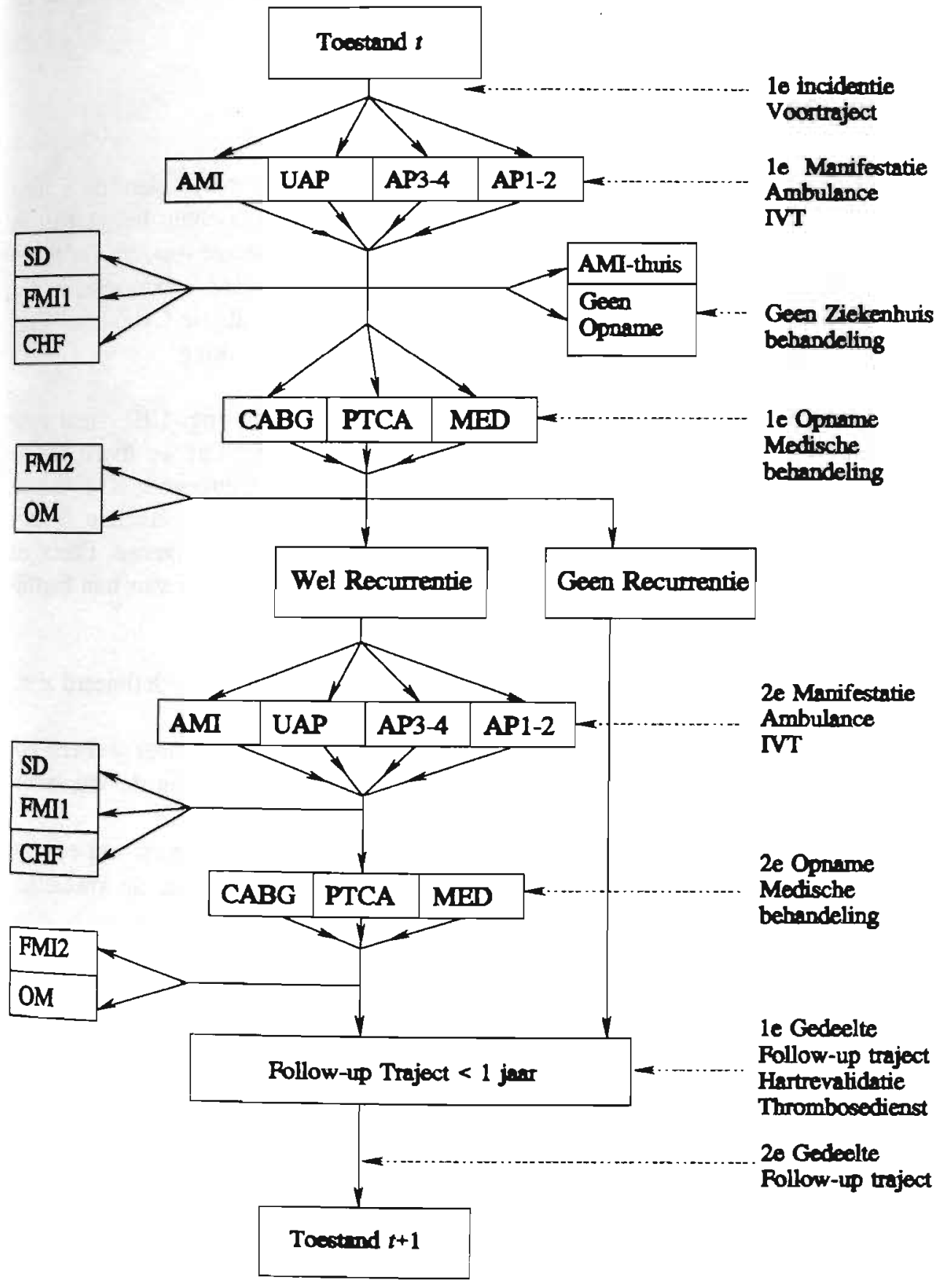

Figuur 3.4 Het stroomschema van het brugmode] 
De patiëntenstromen in figuur 3.4 kunnen zowel uit de gezonde bevolking als wi de zieke $(\mathrm{CHZ})$ bevolking gegenereerd worden.

\subsection{Het Morbiditeitsmodel}

De ziektetoestanden worden in het model opgedeeld in twee tijdfasen: de tijdar $<1$ jaar en de tijdfase $\geq 1$ jaar. De tijdfasen duiden aan hoelang het geleden is dat bij een CHZ-patiënt een CHZ-manifestatie heeft plaatsgevonden. De groep van patiënten die in het eerstvelgende jaar na de laatste CHZ-gebeurtenis in een latente $\mathrm{CHZ}$-toestand verkeert, wordt door ons aangeduid als de CHZ-bevolking Vanaf nu zullen we deze groep aanduiden als de CHZ-bevolking.

Naast de CHZ-bevolking hanteren we nog de CHF-bevolking. CHF staat vort congestive heart failure en in Hoofdstuk 2 is uiteengezet dat we hiermede de personen met chronische hartinsufficiëntie bedoelen. Voor ongeveer $60 \%$ van d: CHF-personen is coronaire hartziekten de basis van de hartinsufficiëntie (Yang e.a., 1988). Personen uit de CHF-fractie hebben een slechte prognose. Enerzij omdat hun leeftijd gemiddeld hoog is, anderzijds door de ernst van hun harlij; den.

De CHZ-bevolking is onderverdeeld in 5 groepen die als volgt gedefinieerd zjjr

$\mathrm{K}^{+} \quad$ Personen die (nog) geen hartinfarct gehad hebben, maar wel een of name ten gevolge van AP. De globale kwaliteit van de kransslag: aders is nog behoorlijk.

$\mathrm{K}^{-} \quad$ Personen die (nog) geen hartinfarct gehad hebben, maar wel een of name ten gevolge van AP. De globale kwaliteit van de kransslag: aders is matig tot slecht.

$\mathrm{EF}^{+} / \mathrm{K}^{+} \quad$ Personen die minstens 1 keer een hartinfarct gehad hebben. De harrfunctie is nog redelijk: ejectiefractie $\geq 40 \%$. De globale kwalitil van de kransslagaders is nog behoorlijk.

$\mathrm{EF}^{+} / \mathrm{K}^{-} \quad$ Personen die minstens 1 keer een hartinfarct gehad hebben. De hart functie is nog redelijk: ejectiefractie $\geq 40 \%$. De globale kwalitel van de kransslagaders is matig tot slecht.

EF Personen die minstens 1 keer een hartinfarct gehad hebben. De hart functie is matig tot slecht: ejectiefractie $<40 \%$.

De personen uit de EF deelgroep hebben een slechte prognose. Binnen 1 jaz stroomt $2 / 3$ door naar de CHF-bevolking terwijl $1 / 3$ een nieuwe $\mathrm{CHZ}$-manifesta 
tie krijgt (zie figuur 3.7 verderop in deze paragraaf en de daarbij horende toelichting).

In het model zijn diverse leeftijds- en geslachtsafhankelijke variabelen verwerkt die als morbiditeitsindicator gebruikt kunnen worden. De presentatie hiervan is opgenomen in Bijlage I. De verantwoording komt voomamelijk via Stichting Informatiecentrum Gezondheidszorg (SIG) en CBS gegevens. Daarnaast is de nodige (inter-)nationale literatuur gebnuikt. Enige leeftijds- en geslachtsafhankelijke variabelen zijn plotse hartdood, fataal myocard infarct, operatiemortaliteit, kans op CHF bij AMI, kans op recurrentie voor CHZ-bevolking, en niet-CHZsterfte.

De aldus gedefinieerde bevolkingsgroepen groeien of verkleinen jaarlijks op basis van de patiëntenstromen. In figuur 3.5 worden deze patiëntenstromen voor 1988 op het hoogste aggregatieniveau weergegeven. 


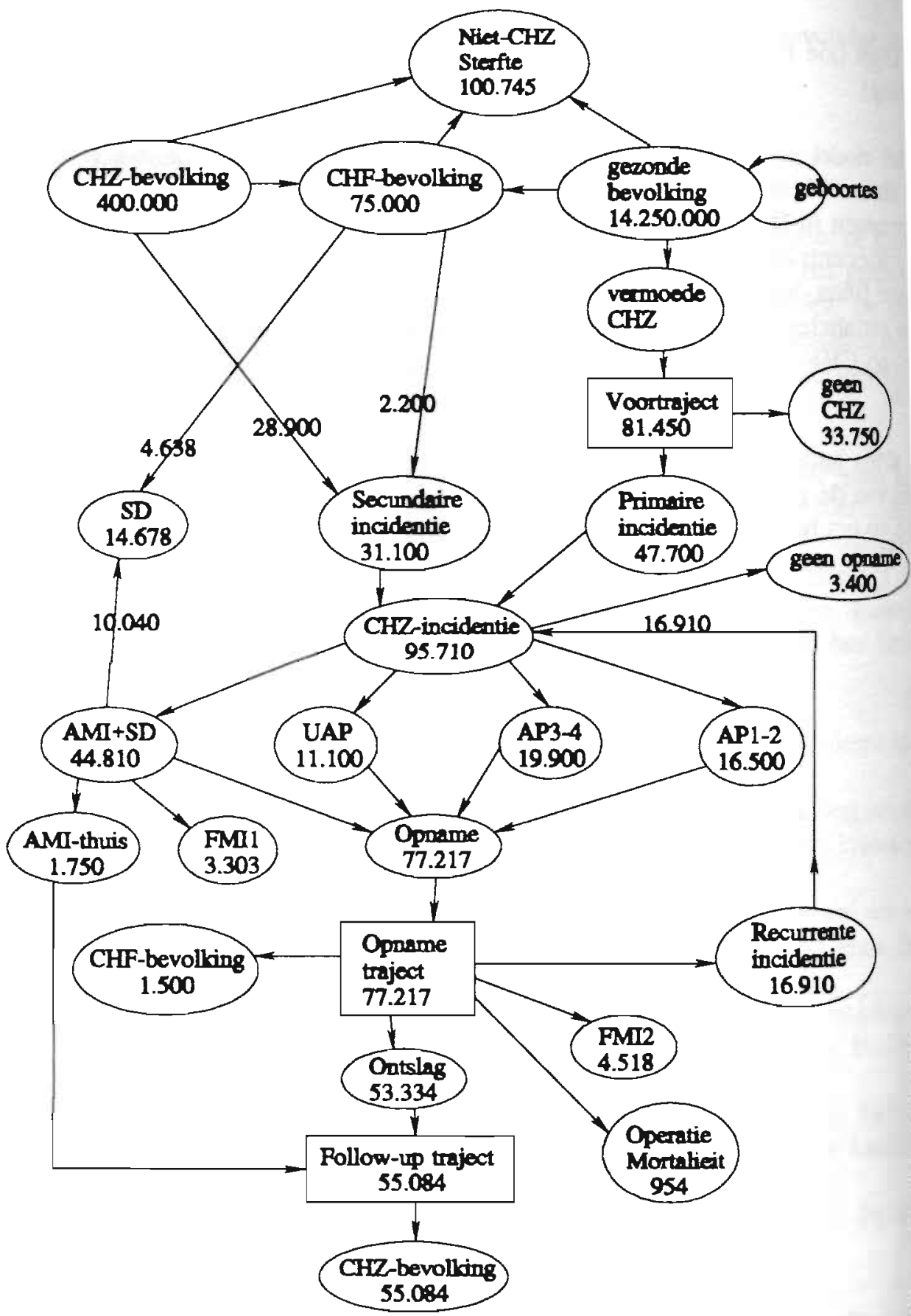

Figuur 3.5 De patiëntenstromen voor 1988 
De CHZ-patiënten waarbij zich CHF ontwikkelt stromen naar de CHF-bevolking. Er kan zich in de CHF-groep elk jaar SD en AMI ontwikkelen. De CHZ-patiëntenstroom die uit de CHF-bevolking komt heeft een slechte prognose en sterft in de meeste gevallen tengevolge van SD (DSD) of een AMI (DMI). In figuur 3.5 komen onder meer de volgende patiëntenstromen voor:

1) de totale instroom van vermoede CHZ-patiènten uit de gezonde bevolking ( 81.450 personen);

2) de incidentie uit de gezonde bevolking (47.700 personen);

3) de 1ste incidentie uit de CHZ-bevolking en CHF-bevolking (28.900 resp. 2.200 personen);

4) de 2de incidentie in hetzelfde jaar van ontslag (of recurrente incidentie) na de 1ste opname (16.910 personen);

5) de ontslagen na de 1ste opname die in hetzelfde jaar geen tweede incidentie hebben gekregen en de ontslagen na de 2de opname (53.334 personen);

6) de totale instroom van de CHZ-bevolking (55.084 personen);

7) de CHZ-sterfte bestaande uit SD (14.678 personen), FMI 1 (3.303 personen), FMI2 (4.518 personen), en operatiemortaliteit (954 personen).

Om de verschillende momenten van incidentie in de tijd te onderscheiden zijn er in figuur 3.5 drie incidentietypen geïntroduceerd, te weten:

1) primaire incidentie (incidentie uit de gezonde bevolking),

2) secundaire incidentie (eerste incidentie uit de CHZ-bevolking), en

3) recurrente incidentie (tweede incidentie in hetzelfde jaar van ontslag na de eerste opname).

In Bijlage I worden deze incidentietypen verder toegelicht.

Het aantal personen in 1988 uit figuur 3.5 waarbij $\mathrm{CHZ}$ voor de eerste keer wordt vermoed bedraagt 81.450 . Hiervan hebben 33.750 personen geen $\mathrm{CHZ}$ (zie Bijlage II). In Bijlage II zullen we specificeren dat de personen met een al dan niet vermoed AMI of UAP rechtstreeks worden opgenomen en niet lopen via het voortraject. We hebben aangenomen dat alle opnames in 1988 "terechte" opnames waren. We komen in hoofdstuk 6 terug op dit fenomeen van terechte en onterechte opnames. In het voortraject worden de initiële AP1-2 en AP3-4 gestationeerd totdat een opname volgt.

Uit figuur 3.5 blijkt dat er in het aantal primaire incidenties 3.400 personen zijn begrepen die uiteindelijk niet opgenomen worden (zie bijlage II). Het aantal primaire incidenties dat tot een daadwerkelijke opname leidt bestaat zodoende uit 
44.300 personen. In het vervolg wordt dit aantal van 44.300 personen bedet wanneer we spreken over het aantal primaire incidenties (zie bijlage II).

Er is ieder jaar een bepaald aantal patiënten dat in én jaar twee manifestadie meemaakt. Op basis van de analyse van de ons ter beschikking staande gegeven betreft dit in 1988 ongeveer 16.910 patiënten. Hierbij is aangenomen dat all patiënten met een tweede manifestatie binnen hetzelfde jaar worden opgenomen We veronderstellen dat iedere patiënt per jaar hoogstens 2 keer in Cén jaar ke worden opgenomen. Daarnaast zijn er 60.307 personen die gedurende 1988 t eenmalige opname wegens $\mathrm{CHZ}$ meegemaakt hebben. Het totaal aantal patiënter dat in 1988 minstens én keer wegens CHZ zijn opgenomen bedraagt 77.217. $\mathrm{Er}$ is de mogelijkheid opengehouden een beperkt aantal AMI's thuis te laten be. handelen (bestaande uit 1.750 personen). We veronderstellen dat de AMI-thuir verpleging betrekking heeft op personen die op oudere leeftijd een eerste AM meemaken en die een goede EF na het AMI behouden. De personen met tet AMI-thuis behandeling gaan via het brugmodel aan het eind van het jaar ore naar de CHZ-bevolking en komen in het follow-up traject terecht.

Het aggregatieniveau van de patiëntenstromen is in de figuren 3.6 tot en met 31 verder uitgesplitst.

In de figuren 3.6 en 3.7 worden respectievelijk de uitstromen als gevolg va CHZ-manifestaties uit de Gezonde bevolking in 1988 en de uitstromen als ge volg van CHZ-manifestaties uit de CHZ-bevolking in 1988 weergegeven.

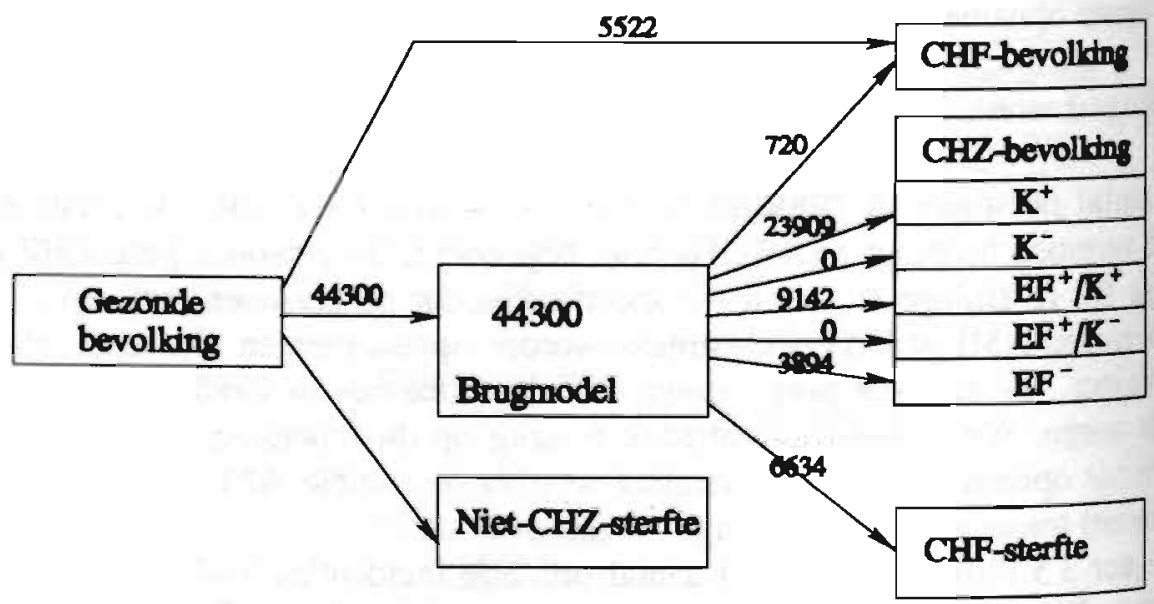

Figuur 3.6 Uitstroom uit de Gezonde bevolking in 1988 


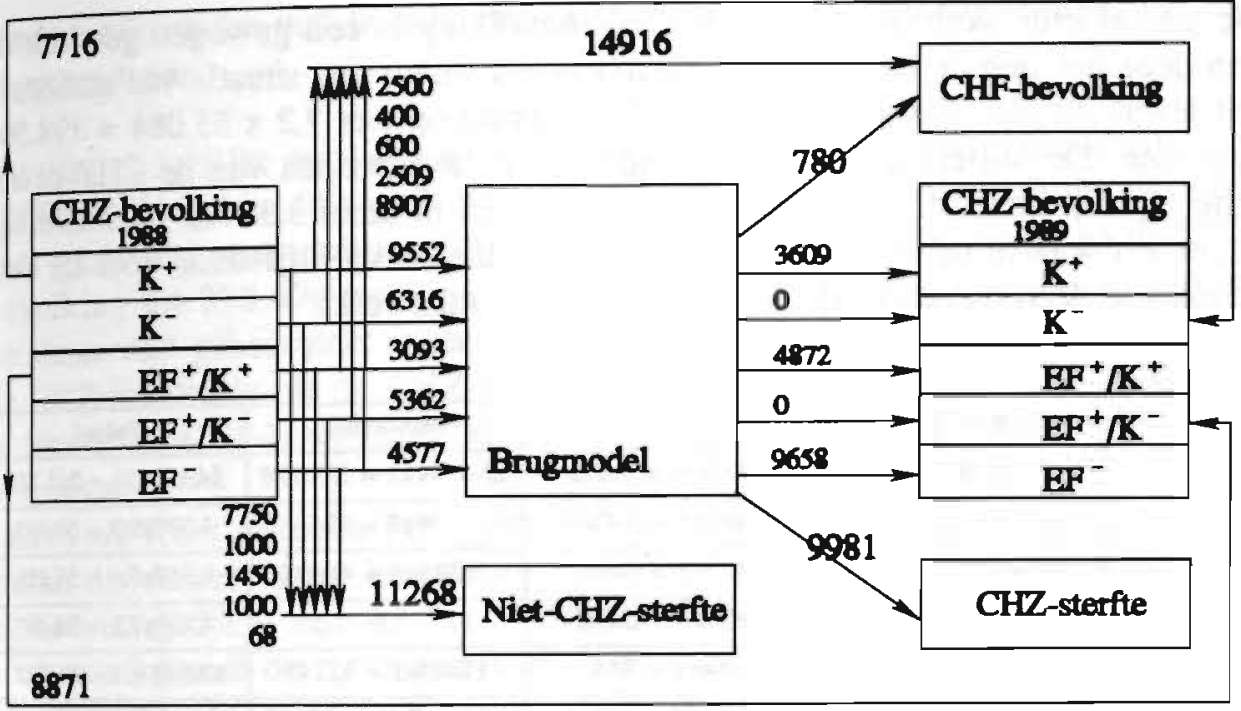

Figuur 3.7 Uitstroom uit de CHZ-bevolking in 1988

Wat bij een eerste blik op de figuren 3.6 en 3.7 niet opvalt is dat de som van de uitgaande stromen voor ieder van de groepen $\mathrm{K}^{+}, \mathrm{K}^{-}, \mathrm{EF}^{+} / \mathrm{K}^{+}, \mathrm{EF}^{+} / \mathrm{K}^{-}, \mathrm{EF}^{-}$en CHF gelijk is aan de som van de binnenkomende stromen. Deze groepen zijn dus stationair voor 1988 gekozen. Indien de ingang in het $\mathrm{CHZ}$-systeem, zijnde de jaarlijkse incidenties uit de gezonde bevolking niet zou veranderen, zou dit ook het geval zijn voor deze jaarlijkse stromen. Echter als gevolg van de komende veroudering van de bevolking verandert het ingangssignaal van het systeem jaarlijks. Een tweede oorzaak van wijziging betreft gezondheidsprogramma's die hetzij op incidenties aangrijpen, hetzij op het brugmodel, met een wijziging van de uitstroom van het brugmodel tot gevolg.

De omvang van de CHZ-bevolking in 1988 is geschat op basis van de verwachte verblijfsduur tot de eerstvolgende gebeurtenis en de gevonden uitstroom in 1988 . Hierbij is de verblijfsduur gebaseerd op de jaarlijkse kans die iedere persoon heeft om in één van de vier uitstromen terecht te komen (AMI, UAP, AP3-4, niet-CHZ-sterfte). De verwachte verblijfsduur is afhankelijk van de laatste therapeutische behandeling. Deze bedraagt:

$\begin{array}{ll}\text { - Oud-CABG } & : 8,6 \text { jaar } \\ \text { - Oud-PTCA } & : \text { 5,9 jaar } \\ \text { - Oud-MED } & : \text { 7,1 jaar }\end{array}$ 
De gemiddelde verblijfsduur in de CHZ-bevolking is een gewogen gemiddelit van deze getallen en bedraagt 7,2 . Geredeneerd vanuit een situatie van stationar teit levert dit een omvang van de CHZ-bevolking op van $7,2 \times 55.084=398.50$ personen. De initiële aantallen personen uit de deelgroepen van de CHZ-bevo. king zijn op dezelfde wijze bepaald. We hebben in tabel 3.3. een overzicht of genomen waarin de berekening van de gemiddelde verblijfsduur voor de ver schillende deelgroepen in de CHZ-bevolking is uitgewerkt.

\begin{tabular}{|c|c|c|c|c|}
\hline Toestand & oud-CABG & oud-PTCA & ond-MED & Totend \\
\hline SVD & $129 \times 18=2.322$ & $902 \times 10=9.020$ & $23.090 \times 11=253.990$ & $24.121 \times 11=265.3$ \\
\hline MVD & $2.497 \times 12=29.964$ & $869 \times 4=3.476$ & $31 \times 3=93$ & $3.397 \times 9,9=33.53$ \\
\hline $\mathrm{EF}^{*} / \mathrm{SVD}$ & $24 \times 12=288$ & $120 \times 8=9.608$ & $8.332 \times 5=41.660$ & $9.557 \times 5,4 \approx 51.556$ \\
\hline $\mathrm{EF}^{*} / \mathrm{MVD}$ & $3.521 \times 9=31.689$ & $936 \times 3=2808$ & $\mathbf{0}$ & $4.457 \times 7,7 \approx 34.47$ \\
\hline EF & $1455 \times 1=1455$ & $354 \times 1=354$ & $11743 \times 1=11743$ & $13.552 \times 1=13.55 ?$ \\
\hline Totaal & $7626 \times 8,6=65718$ & $4262 \times 5,9=25266$ & $43196 \times 7,1=307486$ & $55.084 \times 7,2 \approx 398.47$ \\
\hline
\end{tabular}

Tabel 3.3 Berekening van de verblijfsduur tot de eerstvolgende gebeurtenis voor de $\mathrm{CH}$ bevolking.

Iedere cel bevat: Aantal personen x Aantal verblijfsjaren. Voor de laatste kolon geldt dat de verblijfsduur hier berekend is als het quotiènt van de totale persoos verblijfsjaren en het totaal aantal personen uit de betreffende rij.

$\mathrm{Er}$ is voor de bepaling van de verblijfjaren gebruik gemaakt van de volgent. literatuur: Barner e.a. (1985), Kamp e.a. (1989), Laird-Meeter e.a. (1983), vor de CABG; Berreklouw e.a. (1989), voor de PTCA; Ament (e.a., 1986), voor k MED. Zo nemen de incidenties van recurrente AP-klachten na het eerste jar geleidelijk aan toe. De hoogte van deze incidenties is afhankelijk van het aanti en de ernst van de kransslagadervernauwingen voór de ingreep, de hoogte val EF en de type therapeutische behandeling (Laird-Meeter e.a., 1983, 1988, Geni e.a., 1989). In de literatuur worden de volgende secundaire AP3-4 incidentielar sen gegeven:

$30 \%$ recurrentie na oud-CABG binnen 6 jaar (Kamp e.a., 1989), $30 \%$ recurrentie na oud-PTCA binnen 3 jaar (Berreklouw e.a., 1989), $30 \%$ recurrentie na oud-MED binnen 2 jaar (Ament e.a., 1986).

Er zijn weinig gegevens beschikbaar over recurrente incidenties met betrekking tot AMI en UAP. Centraal in tabel 3.3 staat de verblijfsduur van 1 jaar voor alli EF-personen en de verblijfsduur van 18 jaar voor de SVD/CABG. De ander jaren mocten vooral gezien worden als schattingen relatief ten aanzien van del? 
twee verblijfsduren met in acht neming van de elkaar soms tegensprekende literatuurresultaten.

Uit tabel 3.3 blijkt dat het cohort van 55.084 personen dat binnenkomt in de CHZ-bevolking hier in totaal 398.470 persoonsverblijfsjaren verblijft. Dit betekent dat indien we aannemen dat het systeem in evenwicht is, dat de totale CHZbevolking uit 398.470 personen bestaat. De gemiddelde verblijfsduur tot de eerstkomende gebeurtenis is daarmede $398.470 / 55.084 \approx 7,2$ jaren. In 1988 is de CHZ-incidentie uit de CHZ-bevolking gelijk aan 28.900 (exclusief de 2200 incidentie uit $\mathrm{CHF}$-bevolking). Hiervan keren 18.139 personen terug in de $\mathrm{CHZ}$ bevolking.

Indien we ieder persoon het "gemiddelde traject" zouden laten volgen, volgt hieruit dat de verwachte levensduur na binnenkomst in de CHZ-bevolking (lees: ziekteduur) gelijk is aan 7,2 / $(1-(18.139 / 55.084))=10,7$ jaar. Dit is in overeenstemming met de resultaten van de door ons uitgevoerde simulatie van het basisscenario.

De totale CHZ-bevolking in 1988 kan beschouwd worden als een maatgetal dat in grote lijnen overeenkomt met de gemiddelde $\mathrm{CHZ}$-prevalentie in dat jaar. De gemiddelde prevalentie is gelijk aan de gemiddelde incidentie vermenigvuldigd met de gemiddelde ziekteduur (vgl. Sturmans, 1986). Zoals eerder besproken bestaat de gemiddelde CHZ-incidentie in 1988 uit 44.300 personen. Vanwege het chronische karakter van $\mathrm{CHZ}$ gaan we ervan uit dat de $\mathrm{CHZ}$-incidentie gestandaardiseerd voor leeftijd in de tijd gezien constant is. Wanneer we de gemiddelde $\mathrm{CHZ}$-incidentie van 44.300 personen vermenigvuldigen met de gemiddelde ziekteduur van 10,7 jaar, komt de gemiddelde CHZ-prevalentie uit op 474.000 personen. Het verschil van 74.000 personen tussen de gemiddelde prevalentie en de CHZ-bevolking wordt verklaard uit het aantal personen dat na de secundaire incidentie uit de CHZ-bevolking niet terugkeert.

In figuur 3.8 is de uitstroom uit de CHF-bevolking in 1988 opgenomen. Ook deze groepen zijn voor 1988 stationair gekozen. Een optelsom van de CHF-uitstromen uit de figuren 3.6 en 3.7 laat zien dat deze overeenkomt met de in figuur 3.8 weergegeven uitstroom uit de CHF-bevolking. 


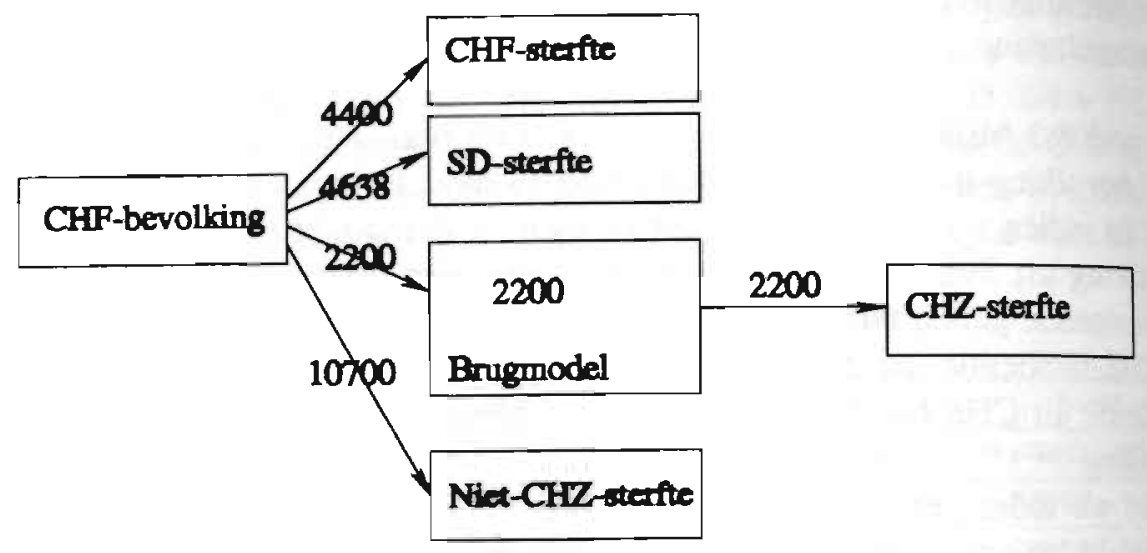

Figuur 3.8 Uitstroom uit de CHF-bevolking in 1988

Personen met coronaire hartinsufficiëntie worden geacht een dermate slechte hartfunctie te hebben dat therapie hoogstens enige "kwaliteit van leven" verbelering kan aanbrengen (zie Hoofdstuk 2). De jaarlijkse sterftekans is geschat of $33 \%$, zodat deze personen gemiddeld 3 jaar in de CHF-bevolking verblijve (vgl. Kulbertus, 1983).

De sterfte in de CHF-bevolking treedt op door 4 oorzaken op (zie Bijlage 1): AMI uit CHF, SD uit CHF, CHF/CHZ en niet-CHZ-sterfte.

Met $\mathrm{CHF} / \mathrm{CHZ}$ duiden we sterfte aan met CHF als hoofddiagnose, maar mel $\mathrm{CHZ}$ als onderliggende doodsoorzaak. De CHF/CHZ-sterfte is geijkt op de CHFsterfte in 1988 (CBS, 1991). Volgens een publicatie van Packer (1985) is de totale $\mathrm{CHZ}$-gerelateerde CHF-sterfte over de verschillende diagnosegroepen te verdelen, als

$\mathrm{AMU} / \mathrm{CHF}: \mathrm{SD} / \mathrm{CHF}: \mathrm{CHF} / \mathrm{CHZ}=2: 2: 1$.

De niet-CHZ-sterfte uit de CHF-bevolking is geschat op 10.700 personen. Hieri wordt de grootste groep gevormd door de CHF-gerelateerde sterfte en de res door de niet-CHZ/niet-CHF sterfte die geschat is op basis van sterftecijfers var personen van 75 en ouder (CBS, 1991). 


\section{ECONOMISCHE ASPECTEN CHZ-MODEL}

\subsection{Inleiding}

4.2 Economische Evaluatie

4.3 Kosteneffectiviteitsanalyse

4.4 Gezondheidseffecten

4.5 Kostenindelingen

4.6 Kosten CHZ-model

4.7 Kostendeterminanten 


\subsection{Inleiding}

In het scenariorapport Hart- en vaatziekten (STG, 1986) wordt een beschouving gegeven over de kosten die door de hart- en vaatziekten worden gegenereerd. in 1976 bedroegen de behandelingskosten van hart- en vaatziekten ca. $f 1.728 \mathrm{mln}$ Dit was ca. $8,9 \%$ van de totale kosten van gezondheidszorg. Naaborg (uit: STC, 1986) geeft op basis van een trendmatige berekening voor 1984 een kostenom vang van $f 2.700 \mathrm{mln}$. voor hart- en vaatziekten. Volgens een recente publikatie van Koopmanschap e.a. (1991) bedragen de kosten van hart- en vaatziekten in $1988 f 3.458 \mathrm{mln}$., waarvan $f 815 \mathrm{mln}$. voor coronaire hartziekten (door $g$. noemde auteurs aangeduid als ischaemische hartziekten). De verdubbeling van de kosten van hart- en vaatziekten in 1988 ten opzichte van 1976 komt enigrins overeen met de stijging van de totale kosten in de gezondheidszorg tussen 1976 en 1988.

Er zijn naast medische kosten ook produktiviteitsverliezen verbonden aan harten vaatziekten. Schaapveld e.a. (1990) hebben geschatte produktiviteitsverliezell over 1985 gepubliceerd die gebaseerd zijn op de uitgaven voor ziekteverzuim an arbeidsongeschiktheid. Op basis van deze benadering hebben Schaapveld e.a (1990) de productiviteitsverliezen voor hart- en vaatziekten over 1985 geraam op $f 2.397 \mathrm{mln}$.

De steeds voortdurende ontwikkeling van nieuwe medische technieken en ge neesmiddelen zal in de komende jaren van grote invloed zijn op de kostenont. wikkeling en de prognoses van ziekten. Het is niet altijd even duidelijk dat in. vesteringen van nieuwe medische technieken leiden tot een efficiënter gebnuik van de aanwezig beschikbare middelen. De levenscyclus van een nieuwe technologie (het zogenaamde diffusiesieproces) bestaat eerst uit een ontwikkelingsfax waarin de selectie van ideeën en dergelijke plaatsvindt, vervolgens de fase waarin het produkt ter beschikking komt van de markt (groei- en verzadigingsfase), en de eindfase waarin een nieuw en beter alternatief wordt ontwikkeld (Ament e.a., 1988). Er bestaat de tendens dat nieuwe medische technologieën in de groei- en verzadigingsfase beschikbaar komen voor een wijd gebruik, zonder di de gevolgen van dit gebruik voor de gezondheid en gezondheidszorg onderworpen zijn geweest aan (economische) evaluatiestudies (vgl. Banta, 1984, en Bell, 1986). In dit verband kan er voor het beleid op macroniveau scenariostudies ir gezet worden om de maatschappelijke gevolgen van het mogelijk toekomstig gebruik van nieuwe medische voorzieningen in kaart te brengen. Het is hierbij arn te bevelen dat scenariostudies mede expliciet aandacht besteden aan de volgent: aspecten: 


\section{(i) het perspectief van de probleemstelling}

In een scenariostudie worden er zoveel mogelijk alle kosten en effecten (of opbrengsten) in beschouwing genomen. Kosten en effecten kunnen hier ruim geïnterpreteerd worden, wat vraagt om een afbakening van het gezichtsveld. Er kunnen mensen ten gevolge van een preventie - of medisch programma bij een bepaalde ziektecategorie langer leven en vervolgens sterven aan een andere doodsoorzaak, zoals de zogenaamde vervangende ziekten en -sterften (zie Hoofdstuk 7). De vraag is dan of de kosten en effecten die bij de behandeling voor de laatste ziekte gemaakt zijn wel of niet toegerekend moeten worden aan het oorspronkelijk programma? De invalshoek van de belanghebbende speelt hier een belangrijke rol. Bijvoorbeeld, vanuit het perspectief van de zorgaanbieder of een zorgverzekeraar zijn uitsluitend de kosten en effecten van belang die een budgettaire betekenis hebben (het zogenaamde financieel perspectief). In onze scenariostudie wordt de probleemstelling vanuit het maatschappelijk perspectief beschouwd (zie paragraaf 4.2 voor een verdere toelichting op deze begrippen). We hebben hierbij het perspectief beperkt tot de kosten en effecten die binnen de gezondheidszorg direct aan de gezondheidszorgprogramma's met betrekking tot $\mathrm{CHZ}$ zijn verbonden. In Hoofdstuk 7 zijn in een voorbeeld de kosten en effecten van gezondheidszorgprogramma's met betrekking tot $\mathrm{CHZ}$ uitgewerkt wanneer wel met het optreden van vervangende ziekten en -sterften rekening wordt gehouden.

\section{(ii) de ontwikkelingen in de tijd}

In scenariostudies worden beschrijvingen gepresenteerd van mogelijke toekomstige ontwikkelingen. Hierbij staan drie deelaspecten centraal. Het eerste aspect betreft de onzekerheid over het beslag dat in de tijd gezien op de produktiemiddelen wordt gelegd. Dit beslag kan zich in de eerste plaats wijzigen als gevolg van efficiëntie verhogende maatregelen. Deze onzekerheid zal zich in geval van een scenario nog sterker manifesteren. Een doorrekening van een gewijzigd beslag op de produktiemiddelen vereist een vergaand inzicht in de kostprijsopbouw. In Bijlage III wordt toegelicht dat wij zijn uitgegaan van een gemiddelde kostprijsberekening. Voor de doelstelling van onderhavig project voldoet deze benadering. Voor scenariostudies of kosteneffectiviteitstudies waarbij het de bedoeling is dat efficiëntiepatronen leiden tot andere kostprijzen is een meer gedetailleerde kostprijsberekening vereist. We hebben dit aspect ondervangen dat iedere gebruiker zijn eigen kostprijs als parameter kan aangeven (zie Hoofdstuk 5).

Het tweede aspect heeft betrekking op de veranderende vraag naar zorg in de tijd. Welke effecten treden er op in geval van een verandering van het risicoprofiel van de bevolking, de verwachte "dubbele" vergrijzing, en gewijzigde indicatiestellingen als gevolg van technologische ontwikkelingen? Bij een vergrijzing van de patiëntenopbouw stijgen de kostprijzen door (a) een toename van de gemiddelde ligduur, (b) frequentere controle in de polikliniek en (c) meer CAG's. 
Deze verwachte kostprijsontwikkeling presenteert zich autonoom wanneer de be. volkingsontwikkeling in de scenario's wordt doorgerekend.

Het derde aspect richt zich op de vraag in hoeverre een betrouwbare inschatting gemaakt kan worden over de ontwikkeling in de tijd met betrekking tot verbeleringen van de levensverwachting en de kwaliteit van leven. Zo kunnen er groes verschillen bestaan tussen de te verwachten effecitiviteit die in de "clinical trials" (efficacy) en de te verwachten effectiviteit die in de praktijk bereikt worden. $\mathrm{W}_{2}$ zal de invloed zijn op de scenarioresultaten wanneer door technologische ontwikkelingen de behandelingskosten en prognoses in de tijd gaan variëren?

\section{(iii) het aspect onzekerheid}

Het aspect onzekerheid hangt voor een belangrijk deel samen met het onder (ii) genoemde aspect betreffende de ontwikkelingen in de tijd. Er kunnen in de sanariostudies ook onzekerheden ontstaan wanneer empirische gegevens toegepas worden (zie Hoofdstuk 1). Welke onzekerheden in relatie tot de betrouwbaarheil van de huidige empirische gegevens liggen hieraan ten grondslag? Voor het verkrijgen van informatie over de gevoeligheid van deze en de eerder genoembe onzekere factoren hebben we in Hoofdstuk 7 gevoeligheidsanalyses uitgevoerd Een bepaalde variabele waarvan men onvoldoende zeker is doorloopt een interval van mogelijke waarden, waarbij er gekeken wordt in welke mate de resultsten hierdoor beïnvloed worden.

\section{(iv) het aspect tijdsvoorkeur}

De tijdsvoorkeur heeft betrekking op kosten en effecten die over lange tijdsperioden gegenereerd worden. Dit begrip speelt een belangrijke rol in scenariostudies. In de scenariostudies is deze differentiatie met behulp van verdiscontering van toekomstige kosten én effecten bereikt.

Wanneer kosten en effecten niet op hetzelfde tijdstip optreden, zijn deze niel zonder meer met elkaar vergelijkbaar. Het belangrijkste argument hiervoor is dis vanwege tijdsvoorkeur ("social rate of time preference") een ongelijke waardering ontstaat. In principe wordt de voorkeur gegeven aan de beschikking over een consumptiegoed of een som geld nu dan in de toekomst. De tijdsvoorkeur zou dan gelijkgesteld kunnen worden aan de rente die men ontvangt als vergoe. ding voor het uitstellen van consumptie. Dit ter onderscheid van rentevergoedingen die betrekking hebben op risico en inflatie. De hoogte van de discontover: kan gezien worden als het netto-resultaat van tijdsvoorkeur, risico en inflati (vgl. Drummond e.a., 1987). Het terugrekenen van de kosten en effecten nar hetzelfde tijdstip heet verdisconteren. De disconteringsformule om de contante waarde te berekenen is: 


$$
C=\frac{F_{1}}{(1+r)^{r}}
$$

waarbij:

$\mathrm{C} \quad=$ contante waarde

$\mathrm{F}(\mathrm{t}) \quad=$ toekomstige kosten of effecten in jaar $\mathrm{t}$

$1 /(1+r)=$ disconteringsfactor

$=$ disconteringsvoet

In de literatuur met betrekking tot verdiscontering bestaat een discussie over het al of niet verdisconteren van verwachte gewonnen levensjaren en over een acceptabele hoogte van de disconteringsvoet. Keeler e.a. (1983) beargumenteren dat niet alleen kosten maar ook effecten bij een eindig lopend programma verdisconteerd moeten worden. Bij het verdisconteren van alleen de kosten is uitstel van een programma altijd superieur aan het onmiddellijk uitvoeren van dat programma. Later gedane kosten worden, gelet op de contante waarde nu, steeds goedkoper (vgl. Van Doorslaer e.a., 1988).

Wij spreken geen voorkeur in dit verband uit. Het model en het bijbehorende computerprogramma heeft de mogelijkheid om ook de effecten te verdisconteren. Denkbaar is om bij effecten van preventieprogramma's die in een later stadium optreden een lagere disconteringsvoet te hanteren dan de aan de tijdsvoorkeur ontleende disconteringsvoet. Op basis van een Ministersraadbesluit in 1986 is het in Nederland gebruikelijk een disconteringsvoet van 5\% te hanteren (Van Doorslaer e.a., 1988). Om te beoordelen wat de invloed van de hoogte van de disconteringsvoet is op de uitkomsten van de scenario's kunnen de berekeningen in het model herhaald worden voor verschillende disconteringsvoeten.

In het vervolg van dit hoofdstuk maken we cuidelijk dat de verdisconteringsproblematiek alleen speelt voorzover er in het model sprake is van een cohortstudie (zie ook Hoofdstuk 7).

Dit hoofdstuk heeft de volgende paragraafindeling. De paragrafen 4.2 tot en met 4.5 hebben een conceptueel karakter. In paragraaf 4.2 wordt er een beschouwing gegeven over de aspecten betreffende de economische evaluatie van scenario's. De economische evaluatie is in paragraaf 4.3 toegespitst op de kosteneffectiviteitsanalyse van scenario's. De gezondheidseffecten worden in paragraaf 4.4 beschreven. In aansluiting hierop geven we in paragraaf 4.5 diverse kostenindelingen en hun relevantie voor scenariostudies. De kosten van $\mathrm{CHZ}$ zoals berekend in ons model komen in paragraaf 4.6 aan de orde. In paragraaf 4.7 wordt het begrip kostendeterminant en onze $\operatorname{keuze}(\mathrm{n})$ daaromtrent met betrekking tot $\mathrm{CHZ}$ besproken. 


\subsection{Economische Evaluatie}

Economische evaluaties zijn een hulpmiddel bij het doen van keuzen in een reld van schaarste, waarbij alternatieven steeds moeilijker overzienbaar worden Bezien vanuit de optiek van scenarioanalyses op bevolkingsniveau beoogt de conomische evaluatie een hulpmiddel te zijn bij de planning van gezondheids zorgprogramma's en de introductie van nieuwe technologieën (zie ook Hoofdstul 7).

In tabel 4.1 volgt een globaal overzicht van de verschillende economische evalu atievormen.

\begin{tabular}{|c|c|c|c|c|}
\hline \multirow{6}{*}{$\begin{array}{l}\text { Vergelijking } \\
\text { tussen twee } \\
\text { of meer } \\
\text { scenario's }\end{array}$} & \multirow{4}{*}{$\begin{array}{l}\mathbf{N} \\
\mathbf{E} \\
\mathbf{E} \\
\mathbf{N}\end{array}$} & \multicolumn{2}{|c|}{ NEEN } & JA \\
\hline & & $\begin{array}{l}\text { Alleen } \\
\text { effecten }\end{array}$ & $\begin{array}{l}\text { Alleen } \\
\text { kosten }\end{array}$ & $\begin{array}{l}\text { Entecten } \\
\text { en kosten }\end{array}$ \\
\hline & & \multicolumn{2}{|c|}{ 1a. Partiële evaluatie } & 2. Partiële evaluatle \\
\hline & & $\begin{array}{l}\text { Beschrijving } \\
\text { effecten }\end{array}$ & $\begin{array}{l}\text { Beschrijuing } \\
\text { kosten }\end{array}$ & Beschrijving effecten en kotete \\
\hline & \multirow{2}{*}{$\begin{array}{l}\mathbf{J} \\
\mathbf{A}\end{array}$} & \multicolumn{2}{|c|}{ 3a. Partiēle evaluatie $3 \mathrm{~b}$. } & $\begin{array}{l}\text { 4. Volledige economische ent } \\
\text { luatie }\end{array}$ \\
\hline & & $\begin{array}{l}\text { Evaluatie } \\
\text { effectiviteit }\end{array}$ & $\begin{array}{l}\text { Evaluatie } \\
\text { kosten }\end{array}$ & $\begin{array}{l}\text { Kosten-Baten analyse } \\
\text { Kosten-efrectiviteits andyse }\end{array}$ \\
\hline
\end{tabular}

Tabel 4.1 Economische evaluatievormen

bron: adaptatie van Drummond e.a. (1987)

Het bovenste gedeelte van de matrix uit tabel 4.1 betreft een beschrijving vi kosten en effecten zonder dat er nog sprake is van een vergelijking. In het : derste gedeelte worden de verschillende vormen van economische evaluatie at gegeven, waarbij alleen in cel 4 er sprake is van volledige economische evalis tie.

Keuzen maken op basis van economische evaluatie impliceert dat er sprake mx zijn van een vergelijking tussen scenario's. In de terminologie van Drummon e.a. (1987) kan er zowel van een partiële als van een volledige economist evaluatie sprake zijn. Voor de onderhavige scenariostudie is de vorm van wolk dige economische evaluatie relevant, omdat hierbij zowel de kosten als de effir ten tussen twee of meer scenario's vergeleken worden. 
Er worden door Drummond e.a. (1987) vier vormen van volledige economische evaluatie onderscheiden:

kosten-minimalisatie-analyse,

kosteneffectiviteitsanalyse,

kostenutiliteitsanalyse,

kosten-baten-analyse.

De verschillende vormen van volledige economische evaluatie die met betrekking tot de verdelingsmethoden in de gezondheidszorg gehanteerd worden zijn gebaseerd op de kosten-baten-benadering ("cost-benefit approach", ook wel aangeduid als "economic appraisal" ). Deze benadering belichaamt een manier van denken met betrekking tot het expliciet maken van (alle) winsten en verliezen die uit een bepaalde inspanning of activiteit voortvloeien (vgl. Drummond, 1980, en Mooney, 1992).

Van Doorslaer e.a. (1990) nemen als criterium voor de indeling in cel 4 uit tabel 4.1 de wijze waarop de effecten van de te evalueren alternatieven in bepaalde gekwantificeerde eenheden uitgedrukt worden.

Bij de kosten-minimalisatie-analyse wordt er vanuit gegaan dat alle strategieën tot hetzelfde doel leiden. De effecten zijn steeds identiek, waardoor met een vergelijking van alleen de kosten volstaan kan worden.

De kosteneffectiviteitsanalyse kan worden gebruikt om gezondheidszorgprogramma's te vergelijken die in principe hetzelfde doel nastreven. De kosten worden daarbij in een "intermediaire" eenheid uitgedrukt, zoals de extra kosten per voorkómen ziektegeval. Het nadeel is dat op deze wijze programma's met ongelijke effectmaten moeilijk met elkaar vergeleken kunnen worden. Daarvoor biedt de kostenutiliteitsanalyse een oplossing.

De kostenutiliteitsanalyse heeft als effectmaat de Quality Adjusted Life Years (QALY). Hierbij wordt in de effectmaat de levensverwachting gecorrigeerd of geherwaardeerd voor de kwaliteit van leven. De correctiefactoren zijn gewichten tussen 0 en 1 die afkomstig zijn van utiliteitsmetingen. Utiliteiten zijn waarderingen die patiënten (of derden) toekennen aan een bepaalde gezondheidstoestand. Er bestaan in de literatuur uitgebreide overzichten van de verschillende methoden van utiliteitsmetingen, waar wij gemakshalve naar verwijzen (vgl. Torrance, 1987, Drummond, 1991). In paragraaf 4.4 gaan we verder in op het begrip QALY.

Voor een scenario-onderzoek is het van belang dat de gehanteerde effectmaat relatie heeft met termen van gezondheid zoals levenswinst en kwaliteit van leven. De kostenutiliteitsanalyse komt dan naar voren als het meest geschikte analyseconcept voor de koppeling van evaluatiecriteria aan de scenario's. Zoals reeds 
aangegeven in Hoofdstuk 3 hebben we in onze scenariostudie geen utiliteiten genomen. Voor het model geldt "de niet voor kwaliteit van leven gecorrigerd levenswinst" dan als de belangrijkste effectmaat waarin de kosten worden uitg drukt.

Verwarrend is dat de literatuur vaak spreekt over kosteneffectiviteitsanalyse, a een kostenutiliteitsanalyse bedoeld wordt. Dit komt omdat kostenutiliteitsanalys in wezen alleen maar een bijzondere vorm van kosteneffectiviteitsanalyses (Van Doorslaer e.a., 1988). Teneinde zoveel mogelijk aan te sluiten bij de gang bare terminologie zal in dit onderzoek ook alleen van kosteneffectiviteitsanaly gesproken worden.

De kosten-baten-analyse heeft als kenmerkt dat de effecten in geld uitgedni worden. Het voordeel van deze evaluatievorm is dat de kosten en de effecte hiermee in dezelfde eenheid zijn uitgedrukt en daardoor met elkaar vergelek kunnen worden. Een belangrijk nadeel van deze laatste evaluatievorm is het pro bleem van de monetaire waardering van het menselijk leven. De kosten-bate analyses werden vooral gebruikt ten tijde van de eerste toepassingen van ecom mische evaluatieonderzoek. Hierbij waren de monetaire waarderingen gebaser op de human-capital-benadering. De mens vertegenwoordigt als het ware een geld uitgedrukte produktiefactor. In dit verband bespreken we in paragraaf 4.50 frictiekostenbenadering die de betekenis van de human-capital-benadering hei doen verminderen. Een meer fundamentele kritiek is dat op basis van de hume capital-benadering de gezondheidszorg alleen optimaal zou kunnen worden ing richt, wanneer de geleverde diensten zoveel mogelijk aan mensen met een hos arbeidsproductiviteit ten goede zou komen (Van Doorslaer e.a., 1988).

Nauw verwant aan het concept van economische evaluatie staat het concept ve "medical technology assessment" (MTA). Het MTA-concept beoogt informat aan te dragen voor de beoordeling van medische technologieën op effectivite kosten, sociale, organisatorische, juridische en ethische aspecten. Bij MTA gi het veel meer om het procesmatige karakter van de introductie van nieuwe tet nologieën in een brede maatschappelijke zin dan om de analytische toepassing: van de evaluatietechnieken (Mulder, 1989).

Economische evaluatie is erop gericht (extra) beslissingsondersteunende infomi tie aan te leveren. De beslisser zal de argumenten verkregen uit de economisch evaluatie veelal afwegen met andere overwegingen, zoals "equity" (een gelij) heidscriterium). Het gaat hier om de relatie tussen de efficiënte verdeling van beschikbare middelen (allocatieve efficiëntie) en gelijkheid.

Er wordt in de economische literatuur een onderscheid gemaakt tussen tech sche efficiëntie en allocatieve efficiëntie (vgl. NIVRA-geschrift, 1986). De ted nische efficiëntie beoogt met een gegeven hoeveelheid middelen een maxims resultaat te bereiken. De allocatieve efficiëntie verwijst naar het Pareto-optimur 
In een Pareto-optimum is een aanvaardbaar nut voor de gemeenschap als geheel bereikt, wanneer geen enkel individu erop vooruit kan gaan zonder dat anderen erop achteruit gaan (vgl. Veenbergen e.a., 1988). De "invisible hand" van de marktwerking zou ervoor zorg dragen dat steeds een Pareto-optimum tot stand komt. Er moet hierbij sprake zijn van een perfecte marktvorm. De gezondheidszorgmarkt voldoet niet aan de voorwaarden van een perfecte marktvorm (vgl. Wamer e.a., 1982). Het marktmechanisme wordt in de gezondheidszorg voor een deel vervangen door zogenaamde niet-markt georiënteerde verdelingsmethoden (zie ook Hoofdstuk 7).

Gelijkheid is een relatief begrip. Er bestaan verschillende definities van gelijkheid met betrekking tot de rechten op gezondheidszorg (vgl. Mooney, 1992). Er wordt bijvoorbeeld in het begrip QALY geen onderscheid gemaakt tussen individuen (of groepen van individuen), waardoor iedere QALY even zwaar meetelt in de berekeningen (vgl. Wagstaff, 1991). Impliciet wordt er in de QALY-benadering op deze manier toch een gelijkheidscriterium gehanteerd.

De twee meest toegepaste verdelingsprincipes in de economische theorie zijn het utilitaristische - en het egalitaire principe (vgl. Sturmans, 1989).

In het utilitaristische verdelingsprincipe staat het maximaliseren van sociaal welzijn (of het nut) centraal, gegeven een bepaalde hoeveelheid geldmiddelen (budget). Een voorbeeld is de aanwezige middelen aan te wenden voor (alleen) die behandelingen waarmee de grootste gezondheidswinst te bereiken valt. Een nadeel van het utiliteitsprincipe (of het nuttigheidsprincipe) in dit verband is dat er geen onderscheid wordt gemaakt tussen de verschillende behoeften aan zorg en het daaruit voortvloeiende recht op zorg.

Het egalitaire principe gaat uit van het recht op gelijkheid in welzijn. Er wordt in dit principe bijvoorbeeld de meeste aandacht geschonken aan voorzieningen ten behoeve van de langdurig zieken. De aanwending van middelen voor dergelijke voorzieningen zal op gespannen voet staan met het doelmatigheidsprincipe. De kosten-baten-benadering, waar de eerder genoemde vormen van volledige economische evaluatie onder vallen, kan beschouwd worden als een uitvloeisel van de Paretiaanse inzichten (Veenbergen e.a., 1988). Er wordt in deze benadering geen rekening gehouden met verdelingsaspecten binnen die gemeenschap (Van Doorslaer e.a., 1988). De kosten-baten-benadering is een utilitaire benadering die botst met het egalitaire verdelingsprincipe.

Er zal in de praktijk een compromis tot stand komen tussen het doelmatigheidscriterium van het utilitaristiche verdelingsprincipe enerzijds en het rechtvaardigheidscriterium van het egalitaire verdelingsprincipe anderzijds. We kunnen een voorbeeld van een dergelijk compromis illustreren met behulp van de sociale welvaartsfunctie. Het optimale verdelingspunt in deze functie wordt gevonden door te bepalen hoeveel "eenheden" doelmatigheid de maatschappij bereid is in 
te leveren om een extra "eenheid" gelijkheid te verkrijgen. In deze situatie is voorbeeld de totale som van QALY's minder dan wanneer er een maximale deling van de welvaart (allocatieve efficiëntie) was nagestreefd (vgl. Wagst 1991).

Het zijn Drummond e.a. (1987) die met betrekking tot deze spanning tussen allocatieve efficiënte en het gelijkheidscriterium de volgende pragmatische of sing hebben gekozen:

"de toepassing van de Pareto-benadering met betrekking tot de verdeling van middelen in de gezondheidszorg geeft economen de mogelijkheid een zo'n ef ciënt mogelijk optimum te bereiken, en laat anderen zich concentreren op: equity-vraagstukken".

Economische evaluatie wordt wel eens verward met een financiële evaluatie. een economische evaluatie worden naast kosten ook effecten gezet, deze lasic gekwantificeerd in gezondheids(zorg)termen. De financiële evaluatie beperkt gezichtsveld tot financiële resultaten met betrekking tot veranderingen in ink sten en uitgaven.

In een economische evaluatie kunnen de kosten vanuit verschillende invalsi ken beschouwd worden (vgl. Van Hout e.a., 1992, en Winter, 1993), te weter

(i) het maatschappelijk perspectief, waarbij het kostenconcept wordt onswit ven als de tegenwaarde van alle inspanningen die binnen de maatschn? worden geleverd (Van Hout, 1990). Wij duiden het maatschappelijk p spectief aan als het macro-economisch perspectief, of kortweg economi perspectief.

(ii) het financieel perspectief dat georiënteerd is op de stroom van geldmii len die is aangewend voor het gebruik van produktiefactoren of vor: verrichten van diensten.

(iii) het bedrijfseconomisch perspectief dat zich richt op de marginale vere ringen in het gebruik van de produktiefactoren.

In scenariostudies op bevolkingsniveau gaat het vooral om het maatschappe perspectief. Wanneer scenariostudies worden gebruikt als basis voor de beil vorming zullen immers zowel alle kosten als effecten van een scenario in vergelijking met elkaar betrokken moeten worden. Afhankelijk van de vraass ling kunnen de twee andere perspectieven ook als uitgangspunt genomen " den. 


\subsection{Kosteneffectiviteitsanalyse}

In een scenariostudie worden verschillende scenario's geformuleerd. De vraag is hoe deze scenario's zich tot elkaar verhouden in termen van kosteneffectiviteit.

Er spelen bij de economische evaluatie op basis van kosten-effectiviteit twee criteria een essentiële rol. Deze criteria worden aan de ene kant gevormd door de extra kosten en aan de andere kant door de extra effecten die een scenario ten opzichte van het basisscenario genereert. In de kosten-effectiviteitsanalyse worden de twee criteria aan elkaar gekoppeld. Dit multicriterium of kosteneffectiviteitsratio (KER) is gedefinieerd als:

$$
\mathrm{KER}=\frac{\text { extra kosten }}{\text { extra QALY's }}
$$

warbij:

extra kosten $=$ het verschil tussen de (directe) kosten en besparingen dat een scenario genereert in vergelijking met het basisscenario (stilzwijgend wordt er vanuit gegaan dat de kosten groter zijn dan de besparingen);

extra QALY's = de extra levensverwachting of levenswinst, geherwaardeerd voor de kwaliteit van leven verbonden aan het scenario in vergelijking met het basisscenario.

Bij de methode van de kosteneffectiviteitsanalyse worden de diverse scenario's eerst ieder voor zich vergeleken met het referentiescenario of basisscenario. Deze vergelijking wordt uitgedrukt in een getal, de kosteneffectiviteitsratio (KER) geheten. De scenario's worden vervolgens onderling vergeleken op basis van hun KER. Met scenario's bedoelen we alternatieve toekomstbeelden die wij gebaseerd hebben op empirische gegevens, literatuurkennis en "privé communicaties". Voor het basisscenario wordt meestal de verrassingsvrije voortzetting van de huidige demografische, epidemiologische, medisch-technologische en financieel-economische trends gekozen (zie Hoofdstuk 5).

In Hoofdstuk 6 is de toepassing van de kosteneffectiviteitsanalyse uitgewerkt met betrekking tot cohortstudies van scenario's.

Het door ons ontwikkelde model geeft aan de uitkomstenkant per scenario zowel de jaarlijkse kosten voor coronaire hartziekten als de jaarlijkse sterfte per leeftijdsgroep en geslacht. In principe is het dus mogelijk op basis van dit model een kosteneffectiviteitsanalyse uit te voeren. Als simulatiegroep kan in het model een keus worden gemaakt tussen een homogene groep van én leeftijd en geslacht 
(een zogenaamde cohortstudie) of de gehele Nederlandse bevolking eventued i geperkt door risicokenmerken (een bevolkingsstudie) (zie Hoofdstuk 5).

De eisen die aan de kosten-effectiviteitsanalyse met betrekking tot cohorstuve van scenario's gesteld worden, zijn de volgende (zie ook Hoofdstuk 6):

(i) er is sprake van een cohort dat op basis van $\mathrm{CHZ}$-incidenties in de tijd volgd wordt (de zgn. incidentie-benadering;

(ii) het cohort wordt niet aangevuld met nieuwe personen;

(iii) het cohort bestaat uit homogene personen die vergelijkbare risicokeme ken hebben met betrekking tot $\mathrm{CHZ}$;

(iv) alle personen in het cohort doorlopen ieder jaar een bepaalde incideriti kans en de kans op sterfte;

(v) de toekomstige extra kosten en levenswinst worden geaggregeerd en al th niet verdisconteerd teruggebracht naar het aanvangsjaar van de simulaie.

We nemen een zekere terughoudendheid in acht met het verrichten van kostert fectiviteitsanalyses met betrekking tot bevolkingsstudies van scenario's, en $\mathrm{k}$ om de volgende redenen:

(1) Kosteneffectiviteitsanalyse wordt gewoonlijk toegepast op zogenaani homogene cohorten, groepen personen die allen min of meer gelijksortis kenmerken hebben ten aanzien van de beschouwde ziekte. Toegepas ry deze wijze wordt dit criterium als zinvol beschouwd. Daar wij in een k volkingsstudie de gehele Nederlandse bevolking beschouwen die pers. nario kan variëren ten aanzien van het aspect coronaire hartziekten, get zulks niet in dat geval. De verschillende onderdelen van de scenario'sf pen op verschillende groepen personen binnen de bevolking aan. Het: niet duidelijk wat dan de betekenis van kosteneffectiviteit voor de beri king als geheel zal zijn.

(2) Een tweede reden betreft het feit dat in de bepaling van met name det fectiviteit van scenario's een extra levensjaar voor een op dit moment ? jarige op dezelfde wijze gewaardeerd wordt als een extra levensjarr in een nu 80-jarige. Hier spelen ethische problemen een rol. Duidelijk is er op dit vlak geen consensus aanwezig is (vgl. ook Commissie Kewent de Zorg, 1991).

(3) De derde reden betreft het aspect van de allocatie van middelen over of lijksoortige gezondheidszorgprogramma's. In hoeverre mag een rekenty uitmondend in een kosteneffectiviteitsratio een belangrijke rol spelen th de herverdeling van middelen over bijvoorbeeld serumcholesterolverlage de programma's, of intensivering ambulancediensten, of uitbreiden bx 
revalidatie, of uitbreiding PTCA behandelingen. Voor ieder van deze medische programma-faciliteiten is een minimumniveau vereist, maar of kosteneffectiviteitsanalyse de precieze verhoudingen mag (kan) bepalen is een open vraag.

Het een en ander wil niet zeggen dat er met betrekking tot de bevolkingsstudies geen evaluatie in economische zin kan plaatsvinden. Er worden in het model verschillende kengetallen van scenario's over kosten en effecten geproduceerd. In Hoofdstuk 6 worden deze kosten en effecten van de verschillende scenario's in vergelijking met die van het basisscenario geanalyseerd en op hun economische consequenties geëvalueerd. Desgewenst zouden deze vergelijkingen in ratio's uitgedrukt kunnen worden. Wij pleiten ervoor de kosteneffectiviteitsanalyse met betrekking tot cohortstudies te interpreteren als de "klassieke" kosteneffectiviteitsanalyse, en de kosteneffectiviteitsanalyse met betrekking tot bevolkingsstudies aan te duiden als "ratioananalyse van de kosten en effecten van scenario's".

\subsection{Gezondheidseffecten}

De term gezondheidseffect van een scenario wil een verschil in gezondheidstoestand aanduiden tussen het betreffende scenario en het basisscenario. In Hoofdstuk 3 zijn we ingegaan op de modelmatige omschrijving van een gezondheidstoestand.

Een gezondheidstoestand kan worden gemeten met behulp van gezondheidsindicatoren. Hiervoor verwijzen wij naar Hoogeveen e.a. (1989) en Van Genugten e.a. (1992), die een overzicht geven van de gezondheidsindicatoren die in scenariostudies gebruikt kunnen worden.

De gezondheidseffecten worden bereikt met behulp van gezondheidszorgprogramma's. De verandering in de gezondheidstoestand brengt een aantal economische consequenties met zich mee, zoals weergegeven in figuur 4.1. (vgl. Drummond, 1980, en Luce e.a., 1990). 


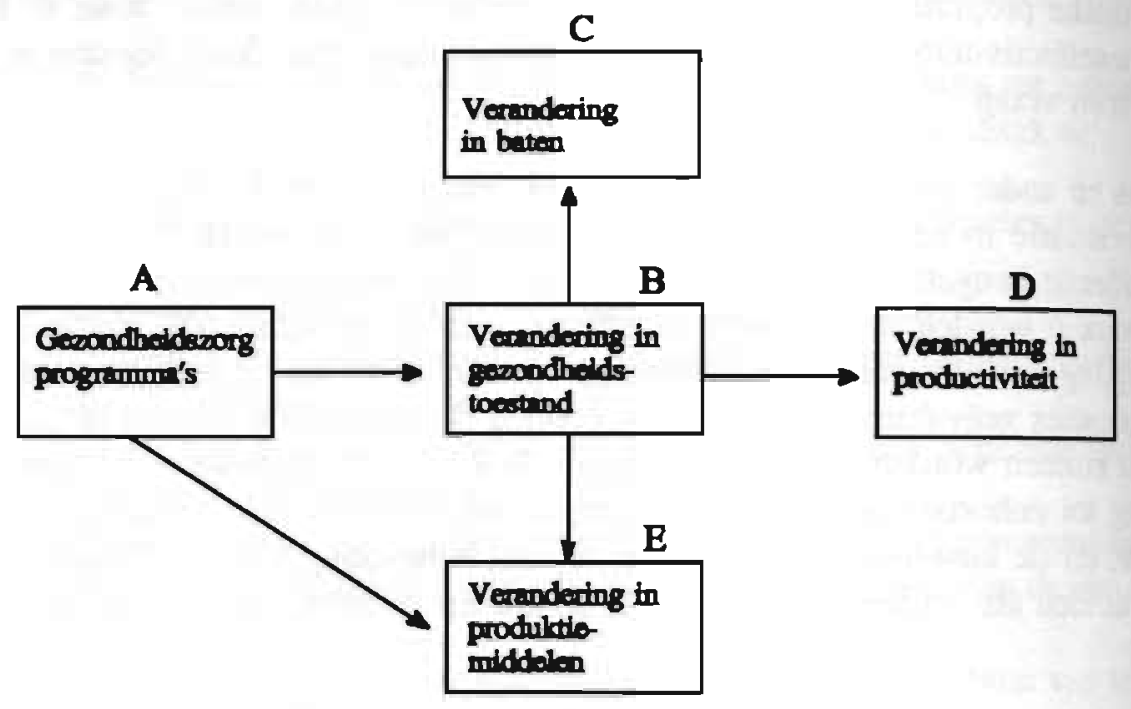

Figuur 4.1 Effecten van gezondheidsprogramma's bron: adaptatie van Luce e.a. (1990)

In figuur 4.1 genereert het gezondheidsprogramma (veld $A$ ) bepaalde veranderingen in zowel het gebruik van de produktiemiddelen (veld E) als in de gezon heidstoestand (veld B). De economische consequenties die als gevolg van de ve randeringen in de gezondheidstoestand kunnen optreden zijn de volgende:

(i) de baten van de veranderde gezondheidstoestand, uitgedrukt in monetair eenheden of in utilitaire maten (veld $\mathrm{C}$ );

(ii) de verandering in arbeidsproductiviteit (veld D);

(iii) de besparingen (of extra kosten tijdens de levensverlenging) in het gebrui van de produktiemiddelen (veld E).

Een gezondheidseffect kan in economische zin worden beschouwd als een pto dukt (zie Hoofdstuk 7). De produktiefactoren worden ingezet voor het produie ren van het produkt gezondheidszorg, zoals verpleegdagen, geneesmiddelen operaties. De gezondheidszorg vormt niet het eindpunt van dit produktieprowi maar een tussenprodukt. Deze tussen - of intermediaire produkten vormen ? hun beurt de input voor een ander produktieproces, met het produkt gezoridhil als eindprodukt (vgl. Hagen, 1985, en Admiraal e.a., 1988). 
In scenariostudies op bevolkingsniveau is men met name geïnteresseerd in het eindprodukt gezondheid. De meting van de gezondheidseffecten die door de scenario's gegenereerd worden zou moeten geschieden in de vorm van QALY's. Zoals eerder vermeld wordt met het begrip QALY beoogd gewonnen levensjaren te herwaarderen met behulp van een variabele, de utiliteit, die de "levenskwaliteit" van de betreffende levensjaren aangeeft. De utiliteit geeft een waardering van een bepaalde gezondheidstoestand weer en wordt uitgedrukt in een getal tussen 0 en 1 , waarbij 1 voor de toestand volledig gezond en 0 voor de toestand dood staat. Er bestaat een behoefte om de kwaliteit van de ziektetoestanden van bijvorbeeld verschillende diagnosegroepen, al dan niet na een therapeutische behandeling, met elkaar te vergelijken. De kwaliteit die aan de verschillende ziektetoestanden wordt toegekend duiden wij aan als de utiliteitswaarde.

Een QALY zelf is dus geen utiliteit, maar een relatieve maat. Het begrip QALY wil ongelijksoortige effecten vergelijkbaar maken door deze uit te drukken in profielen van verwachte levensverwachting die geherwaardeerd zijn voor de kwaliteit van leven. Hiermede wordt er rekening gehouden met zowel de levensduur als met de kwaliteit van leven. QALY's zijn met name geschikt om verbonden te worden aan behandelingsstrategieën voor chronische ziekten, waarmee weinig levenswinst geboekt kan worden. Ze richten zich vooral op wegnemen van de klachten en de verbetering van de kwaliteit van het leven. Bijvoorbeeld, een angineuze behandeling is primair gericht op verlichting van de AP-klachten, terwijl de behandeling van een vernauwde kransslagader meer op overleving is georiënteerd. De AP is een klinische maat waarmee de pijn wordt aangegeven (zie Hoofdstuk 2).

In Hoofdstuk 3 is opgemerkt dat we een voorstudie met betrekking tot het verkrijgen van empirische waarden voor utiliteiten hebben uitgevoerd. Hierbij hebben we afgezien van een gebruik ten behoeve van deze studie. Zoals eerder besproken zijn wij van mening dat bij scenariostudies op bevolkingsniveau alle kosten en effecten van een scenario in een vergelijking met elkaar moeten worden betrokken (zie Hoofdstukken 1, 3, en 4). De belangrijkste reden dat er desondanks geen utiliteiten in het model gebruikt zijn, is dat wij binnen de gegeven doelstellingen van ons scenario-onderzoek dit aspect een lagere prioriteit gegeven hebben. Hiervoor hebben we een aantal overwegingen, te weten:

(i) In Bijlage I bespreken we dat er bij alle $\mathrm{CHZ}$-manifestatievormen sprake is van een gemeenschappelijke etiologie. Dit komt tot uitdrukking in een overeenkomstige initiële acute verandering van het endotheel van de kransslagaders. In dit verband kunnen ernstige angineuze klachten in principe beschouwd worden als een signaal voor een vergrote kans op een acute $\mathrm{CHZ}$-manifestatievorm (zie Bijlage II). Wij hebben de behandeling van 
AP3-4 daarom in eerste instantie geïnterpreteerd als een behandeling van een vernauwde kransslagader die op de overleving is gericht. Op deze manier hebben alle gezondheidszorgprogramma's in onze scenariostudie de. zelfde effectmaat als doel, namelijk de levenswinst, waardoor ze met el. kaar vergelijkbaar worden. Wij zijn dan ook van mening dat de scenariouitkomsten, die in Hoofdstuk 6 worden behandeld, vanuit dit perspectief gezien niet veel van hun waarde verliezen.

(ii) In het model is in modelmatige termen wel degelijk rekening gehouden met aspecten betreffende kwaliteit van leven. De patiënten verkeren, al dan niet na een geslaagde medische behandeling van een CHZ-manifestatie, in een bepaalde latente CHZ-toestand (zie Hoofdstuk 3 en Bijlage II). Dit latent ziektestadium vertegenwoordigt in wezen de type AP1-2, waarbij er een onderscheid gemaakt wordt naar de toestand "wel" of "geen" oud myocard infarct. We hebben aan dit laatste onderscheid het restniveau van de EF gekoppeld (zie Bijlage II). Het restniveau van de EF is de meest belangrijke prognostische variabele met betrekking tot de CHZ-levensverwachting. Tegelijkertijd uit een slechte EF zich in de vorm van klachten. In de vragenlijst van ons experimenteel utiliteitsonderzoek (opgenomen in Bijlage IV) hebben we een onderscheid aangebracht in de ziektetoestand met $\mathrm{EF} \geq 40 \%$ en $\mathrm{EF}<40 \%$. Het zou programmatisch gezien daarom een kleine moeite zijn de gevonden utiliteiten in het model te gebruiken.

(iii) $\mathrm{Er}$ is een aantal methodologische redenen te noemen waarom wij de gevonden utiliteiten niet in het model opgenomen hebben (zie ook Bijlage IV):

a) er is door ons gebruik gemaakt van een waarderingsstudie die ontworpen was om de utiliteiten van harttransplantatie te meten (Bonsel e.a., 1988). Er zou moeten worden onderzocht in hoeverre de gebruikle kwaliteit van leven-items uit die studie toegepast kunnen worden voor CHZ. Onze ervaringen met het proefpanel zijn in dit opzicht gunstig.

b) het is onduidelijk hoe in de studie van Bonsel e.a. (1988) de gewichten die aan elk item toegekend worden tot stand zijn gekomen. Het was voor ons zodoende niet mogelijk te beoordelen wat de betekenis van deze gewichten vormt voor $\mathrm{CHZ}$ en in hoeverre de gewichten bijgesteld moesten worden.

c) er bestaan in de literatuur bezwaren tegen de "visual analogue scale" die door Bonsel e.a. (1988) in hun studie is toegepast. Het grote voordeel van deze meettechniek is de praktische toepasbaarheid. De betrouwbaarheid van de standard gamble, zijnde een veel moeilijker meettechniek, staat echter ook ter discussie.

d) ons proefpanel bestond uit een 7-tal cardiologen. In de eerste plaats staat er al ter discussie in hoeverre een arts uitspraken kan doen over 
de waardering van kwaliteit-van-leven items aangaande hun patiënten. In de tweede plaats was ons panel te klein om de uitkomsten in statistische zin als voldoende betrouwbaar te beschouwen. Wel bestond er een grote mate van énstemmigheid onder de respondenten over hun inschatting van de verschillende ziektebelevingen (Bijlage IV).

(iv) Er bestaan in de literatuur vraagtekens over de bruikbaarheid van de zogenaamde "QALY-league" tabellen. In deze tabellen worden de resultaten van economische evaluatiestudies gepresenteerd in de vorm van "incrementele kosten per QALY's". De programma's in de top van genoemde tabellen hebben de laagste KER en worden als de beste beschouwd. Wij komen hierop terug in Hoofdstuk 7. Er zijn bij ons echter grote twijfels over de zin van dit soort tabellen bij (scenario) studies op bevolkingsniveau, ook al ondervangen wij een gedeelte van onze bezwaren door uit te gaan van de zogenaamde cohortstudies. Verder bestaat er in het geval van scenariostudies grote onzekerheid over de consistentie in de tijd met betrekking tot de waardering van kwaliteit van leven.

\subsection{Kostenindelingen}

Het kostenconcept in onze scenariostudie wordt gebruikt vanuit het maatschappelijk perspectief, kortweg aangeduid als "maatschappelijke kosten".

We omschrijven de maatschappelijke kosten als alle in geld te waarderen inzet van middelen, te weten:

(i) inzet van middelen die zowel binnen als buiten de sector gezondheidszorg direct aan gezondheidsprogramma's zijn verbonden;

(ii) inzet van middelen die impliciet door gezondheidszorgprogramma's zijn gegenereerd, maar niet specifiek aan de gezondheidszorgprogramma's kunnen worden toegekend. Een voorbeeld van de laatste kosten zijn de medische kosten van andere ziekten die in het verleden zonder een sterftereducerend gezondheidszorgprogramma niet gemaakt zouden zijn wegens (voortijdig) sterfte.

In de omschrijving van de maatschappelijke kosten is een aantal kostenbegrippen besloten, zoals de begrippen directe en indirecte kosten.

Directe en indirecte kosten hebben op macroniveau een andere dimensie dan op instellingsniveau (microniveau). Op microniveau gaat het om de vraag of de kosten direct oorzakelijk samenhangen met het produktieproces. Directe kosten hebben een duidelijk aanwijsbare oorzakelijke relatie met dit proces, veelal gebaseerd op technische specificaties. Bij indirecte kosten is het verband met het pro- 
dukt mueilijker te leggen. Bekende voorbeelden zijn de kosten van stafafdelingen en directie.

Op macroniveau gaat het om de vraag in hoeverre kosten die door gezondheids. zorgprogramma's worden gegenereerd, al dan niet specifiek aan het betreffende programma kunnen worden toegerekend. Een gezondheidszorgprogramma op macroniveau zou in bedrijfseconomische zin vergeleken kunnen worden met het produktieproces op microniveau.

In tabel 4.2 hebben we de kosten binnen en buiten de sector gezondheidszorg ingedeeld naar directe kosten en indirecte kosten.

\begin{tabular}{|l|l|l|}
\hline kostencategorieèn & directe kosten & indirecte kosten \\
\hline $\begin{array}{l}\text { kosten binnen gezondhejdszorg } \\
\text { kosten buiten gezondheidszorg }\end{array}$ & $\begin{array}{l}\text { programmakosten (A) } \\
\text { tijd- en sociale prijzen (C) }\end{array}$ & $\begin{array}{l}\text { kosten in periode levensverienging (B) } \\
\text { productiviteitsvertiezen (D) }\end{array}$ \\
\hline
\end{tabular}

Tabel 4.2 Kostencategorieën vanuit perspectief overbeid

Het is mogelijk de kosten te verdelen naar vaste en variabele kosten. De vaste kosten blijven constant onafhankelijk van het aantal verrichtingen (of het aantal behandelde patiënten), terwijl de variabele kosten zich wel wijzigingen.

Van Hout e.a. (1988) maken onderscheid in patiëntgebonden en niet-patiëntgebonden kosten. De patiëntgebonden kosten kunnen aan de behandeling van een patiënt toegewezen worden. De niet-patiëntgebonden kosten hangen samen met de organisatie van het programma. Op microniveau zijn dat bijvoorbeeld de kosten van een afdelingshoofd of de kosten van administratie, terwijl op macroniveau dat de kosten zijn van voorlichting, onderzoek, screening en dergelijke.

Wij hebben de indeling in patiëntgebonden en niet-patiëntgebonden kosten niet gebruikt. Een dergelijke indeling leent zich meer voor de beoordeling van de kosten vanuit een bedrijfseconomisch perspectief (vgl. Van Hout e.a., 1992), in ieder geval voor een meer gedetailleerde benadering dan ons model biedt. Onze benadering richt zich op het volgen van patiëntenstromen, zodat wij meer geinteresseerd zijn in de gemiddelde programmakosten per eenheid produkt die aan de patiëntenstromen toegerekend kunnen worden (zie Bijlage III).

Luce et al (1990) en Drummond (1990) maken geen expliciet onderscheid tussen kosten binnen en buiten de gezondheidszorg. $\mathrm{Zij}$ verdelen de kosten eerst naar directe en indirecte kosten, waarna de kosten worden ingedeeld naar medische kosten (kosten binnen gezondheidszorg) en niet-medische kosten (kosten buiten gezondheidszorg). Verder onderscheiden Luce et al en Drummond de niet in geld meetbare kosten of "intangible" kosten. Voorbeelden van intangible kosten 
zijn de indirecte kosten die door pijn, dood, en verlies van kwaliteit van leven worden veroorzaakt. Dit kostentype is impliciet verwerkt in het eerder genoemde QALY-concept, zodat om dubbeltellingen te vermijden, deze kostentypen niet aan de kostenzijde meegerekend moeten worden. Het voorbeeld van intangible kosten leent zich meer voor de kosten-baten analyse, waar alle effecten in geld worden uitgedrukt. Er wordt dan een correctiefactor op de uitkomsten toegepast.

Zoals weergegeven in tabel 4.2 zijn er vier kostencategorieën onderscheiden, te weten:

\section{(i) directe medische kosten (veld A)}

De directe medische kosten bestaan uit de kosten binnen de gezondheidszorg die samenhangen met het betreffende gezondheidszorgprogramma. Deze kosten betreffen de middelen die worden aangewend met betrekking tot preventie, diagnostiek, verpleging, medicatie, operatieve ingrepen, en (hart)revalidatie. De kosten van administratie en organisatie (op instellingsniveau) zijn hierbij (impliciet) inbegrepen. Vanaf nu verstaan we onder medische kosten de kosten van preventie en medische behandelingen met betrekking tot $\mathrm{CHZ}$.

De directe medische kosten kunnen worden geïnterpreteerd als de tegenwaarde van de produktiefactoren (menskracht en middelen) die ingezet worden om een bepaald gezondheidszorgprogramma uit te voeren. In economische zin is hierbij alleen sprake van kosten als de opgeofferde produktiefactoren geschikt zijn voor een "betere" alternatieve aanwending, de zogenaamde "benefit forgone elswhere" dan wel "lost opportunities". In de literatuur is hier de term "opportuniteitskosten" van afgeleid. Intuïtief gaat het om de waarde van de gemiste effecten (uitgedrukt in geld) in plaats van de waarde van de opgeofferde middelen.

Het begrip opportuniteitskosten vormt een theoretisch concept waarmee de werkelijke baten van een inspanning of een activiteit expliciet worden gemaakt. De toepassing van dit begrip speelt een belangrijke rol bij het maken van keuzen met betrekking tot de verdeling van schaarse beschikbare middelen (zie ook Hoofdstuk 7).

In de praktijk blijkt dat er aan het gebruik van COTG- en ziekenfondstarieven grote bezwaren verbonden zijn (Van Ineveld e.a., 1990, De Charro e.a., 1989). Tariefsvergoedingen lopen veelal niet parallel met de daadwerkelijke inzet van personeel en middelen. Het gevolg is dat niet meer het werkelijke beslag op de produktiefactoren wordt weergegeven. In onze scenariostudie is daarom zoveel mogelijk uitgegaan van de werkelijke kosten (kostprijzen) van de behandelingen. Wanneer deze niet bekend zijn is noodzakelijkerwijs teruggevallen op gepubliceerde tarieven (zie verder Bijlage II). 
(ii) indirecte medische kosten (veld B)

Het uitbannen of terugdringen van $\mathrm{CHZ}$ brengt welhaast automatisch een verschuiving in prevalenties van andere ziekten met zich mee (het aspect van vervangende ziekten en - sterften). Zoals eerder beschreven zal door de technologische ontwikkelingen en de langere levensduur van de CHZ-patiënten het aantal mensen dat in de CHZ-bevolking verblijft gaan stijgen. Hierdoor nemen de kansen op het krijgen van andere ziekten in de CHZ-bevolking toe. De indirecte medische kosten zijn dan de extra medische kosten die in de langere levensfase als gevolg van het optreden van andere ziekten ontstaan.

Deze kosten worden ook wel getypeerd als "spillovers". Spillovers hebben betrekking op de reikwijdte van het gezondheidszorgprogramma die zodanig is dal de extra kosten en baten niet meer aan het programma zelf kunnen worden toegekend (Van Doorslaer e.a., 1988). In de literatuur staat het daarom ter discussie of de indirecte medische kosten al dan niet aan de oorspronkelijke ziekte toegerekend moeten worden (vgl. Drummond et al, 1987). Het zou buiten de competentie van dit scenario-onderzoek gaan, als de effecten van de CHZ-programma's op de incidenties en daarmee op de kosten van andere ziekten in deze contexl berekend zouden worden.

\section{(iii) directe niet-medische kosten (veld C)}

De tijdprijzen en de sociale prijzen (of sociale kosten) worden gerekend tot de directe niet-medische kosten. De tijdprijzen bestaan uit reis- en tijdkosten die gemaakt worden bij het bezoeken van de hulpverlener. De sociale prijzen worden gemaakt door familieleden die behulpzaam zijn bij de lichamelijke en gees. telijke verzorging van de zieke.

Het begrip directe niet-medische kosten wordt door Gerard e.a. (1993) in eer brede maatschappelijke context geplaatst. Hun redenering hierbij is dat er alleer kosten worden gemaakt wanneer betere alternatieve aanwendingen verloren zjir gegaan. Deze betere alternatieve aanwendingen kunnen in andere maatschappelijke sectoren dan de sector gezondheidszorg liggen. Mede vanwege het feit dal de tijd - en sociale prijzen moeilijk te kwantificeren zijn, hebben we deze kos. tencategorie niet in onze benadering opgenomen (vgl. Janssen, 1989).

\section{(iv) indirecte niet-medische kosten (veld D)}

De indirecte niet-medische kosten worden gevormd door de produktiviteitsverlie. zen, veroorzaakt door ziekte, arbeidsongeschiktheid of vroegtijdige sterfte. Dool preventie van ziekte en/of vroegtijdige sterfte kan produktiviteitswinst worder behaald. In zekere zin kunnen de productiviteitswinsten beschouwd worden al: de eerder genoemde spillovers van een gezondheidszorgprogramma. Volgen: Van Doorslaer e.a. (1988) worden deze kosten vanuit het maatschappelijk perspectief doorgaans wel in ogenschouw genomen. In andere literatuurbronner 
daarentegen wordt de vookeur uitgesproken de indirecte niet-medische kosten niet in de economische evaluatiestudies te betrekken (vgl. Drummond e.a., 1987).

De verloren gegane produktie wordt meestal gewaardeerd op basis van de "human capital" benadering. De mens vertegenwoordigt als het ware een bepaalde waarde in geld uitgedrukt, die inzetbaar is in het produktieproces. Er wordt voor de waarde van de produktie die verloren is gegaan meestal de bruto loonkosten genomen. In paragraaf 4.2 hebben we bij de bespreking van de kosten-baten-analyse reeds aangegeven welke bezwaren aan de monetaire waardering van het menselijk leven zijn verbonden.

Door een groeiende reserve aan arbeidskrachten en een steeds grotere mate van arbeidsmobiliteit kunnen door ziekte ontstane vacatures in samenlevingen als Europa 1992 na verloop van tijd worden opgevuld. De kosten blijven in deze benadering dan beperkt tot de periode waarin de potentiële produktie daadwerkelijk verloren is gegaan. In dit verband wordt wel van frictiekosten gesproken. Volgens deze benadering zouden de produktiviteitsverliezen nog maar een fractie van het bedrag aan inkomensvervangende verliezen bedragen (vgl. Haselen, 1987).

Bij economisch evaluatieonderzoek worden inkomensvervangende uitkeringen niet als kosten maar als "transfers" beschouwd omdat er geen verbruikte middelen tegenover dit soort uitgaven staan. Paradoxaal echter dreigen de inkomensvervangende uitkeringen onbetaalbaar te worden, terwijl het begrip produktiviteitsverlies in economische zin als zodanig een beduidend minder grote betekenis krijgt. Verder behoren de coronaire hartziekten tot de groep degeneratieve ziekten, zodat een geringer deel van de levensjaren die met een gezondheidszorgprogramma gewonnen worden betrekking hebben op de produktieve levensjaren (Verkooijen e.a., 1989). We hebben om deze redenen ervan afgezien de indirecte niet-medische kosten in ons kostenonderzoek op te nemen.

Resumerend hebben we de niet-medische kosten in onze scenariostudie buiten beschouwing gelaten om de volgende redenen:

(i) voor zowel de tijd - en sociale prijzen als de produktiviteitsverliezen en produktiviteitswinsten geldt dat ze moeilijk te kwantificeren zijn in monetaire termen;

(ii) het verminderde belang dat aan produktiviteitsverliezen gehecht kan worden vanwege:

a) het relatief gering aantal produktieve levensjaren met betrekking tot $\mathrm{CHZ}$, en

b) de waardering van de verloren gegane produktie op basis van de frictiekosten benadering; 
(iii) het feit dat in de literatuur meestal de keuze gemaakt wordt om alleen directe kosten binnen de gezondheidszorg in de economische evaluatie dies te betrekken (vgl. Drummond e.a., 1987, en Gerard e.a., 1993);

(iv) de bezwaren die verbonden zijn aan de monetaire waardering van het $m$ selijk leven.

De exercitie die we hebben uitgevoerd om de CHZ-kosten te berekenen kan w den getypeerd als een "cost-of-illness" studie (ook wel aangeduid als "dise costing") (vgl. Van den Boom e.a., 1992). Zoals hierboven besproken hebben ons beperkt tot de meting en waardering van de directe medische kosten CHZ. De cost-of-illness studies vormen in scenariostudies de basis voor econ misch evaluatieonderzoek. In dit soort studies wordt de ziektelast aangegeven met de incidentie en/of prevalentie van een bepaalde ziekte samenhangen. Der lijke studies geven inzicht in de kostenopbouw, morbiditeit en mortaliteit van ziekte en kunnen daarmee een bijdrage geven aan een prioriteitsstelling in onderzoeksbeleid (Van Doorslaer e.a., 1990). De tabel 1.9 uit Hoofdstuk 1 ge enig inzicht in de morbiditeit en mortaliteit van CHZ. De tabel 4.5, verderop dit hoofdstuk, geeft een overzicht van de kosten van medische behandeling $\mathrm{CHZ}$.

\subsection{Kosten CHZ-model}

We hebben de CHZ-kosten berekend aan de hand van de formule volume (a tal)*gemiddelde (kost)prijs. Deze formule duidt erop dat iedere behandelin gang zijn eigen kosten creëert. Het volume wordt door het model aangeleve De data ten behoeve van het volume worden in de Bijlagen I en II behande De kosten van CHZ bestaan uit de kosten van preventie en de kosten van me sche behandelingen. De kostprijzen komen in Bijlage III aan de orde.

Er zijn in 1988 in de gezonde bevolking preventie kosten gemaakt voor chole: rolverlagende medicatie en anti-hypertensiva. In Bijlage I wordt de veronders ling gemotiveerd dat er in de CHZ-bevolking geen kosten voor de bestrijo van deze risicofactoren worden gemaakt.

De kosten van cholesterolverlagende medicatie hebben we als volgt berekend. De Nederlandse bevolking bestaat in 1988 uit ca. $14.7 \mathrm{mln}$. personen (CF 1991). De CHZ-bevolking in ons model bevat ca. 400.000 personen. Er 2 $(14.7-0.4=) 14.3 \mathrm{mln}$. personen in de gezonde bevolking. Het aantal men: met een cholesterolwaarde $>8,0 \mathrm{mmol} / \mathrm{l}$ in de gezonde bevolking bedragt $4 \%$ (zie Bijlage I). In Hoofdstuk 2 is beschreven dat ca. $10 \%$ van dit an medicamenteus wordt behandeld, zodat er $(14.3 \mathrm{mln} . * .04 * .10 \Rightarrow 60.000 \mathrm{p}$ 
sonen zijn die cholesterolverlagende medicatie toegediend krijgen. Uitgaande van een stationaire situatie kunnen we aannemen dat nagenoeg al deze personen reeds langer dan 1 jaar cholesterolverlagende medicatie krijgen. Dit onderscheid is van belang omdat de kostprijs voor de behandeling van initiële hypercholesterolaemie (ca. $f 2.100,--$ per jaar) hoger is dan die van de follow-up behandeling (ca. $f 1.600,--)$. Voor een toelichting op de berekening van deze kostprijzen verwijzen we naar Bijlage III. We veronderstellen dat de helft van de doelgroep in 1988 de geneesmiddelen daadwerkelijk inneemt. Deze veronderstelling is gebaseerd op gegevens uit de literatuur met betrekking tot de therapietrouw bij hypertensie, zoals verderop in deze paragraaf wordt toegelicht. De kostprijs in geval onvolledige therapietrouw is evenredig aan de kostprijs in geval van volledige therapietrouw. In ons voorbeeld bedraagt de kostprijs cholesterolverlagende medicatie $(50 \% * f 1.600,--=) f 800,--$.

In de praktijk zullen de geneesmiddelen vaak wel gekocht worden terwijl de medicatie niet of niet volledig wordt ingenomen. Onze kostprijsbenadering zal dan ook eerder tot een onderschatting dan tot een overschatting van de kostprijs leiden. In Hoofdstuk 6 worden de scenarioresultaten getoond van een preventieprogramma waarin wordt uitgegaan van onvolledige therapietrouw.

De berekening van de kosten van anti-hypertensiva in de gezonde bevolking in 1988 is analoog aan die van de cholesterolverlagende medicatie uitgevoerd. Het aantal mensen met een bloeddrukniveau $\geq 95 \mathrm{mmHg}$ in de gezonde bevolking is ca. $4 \%$. We schatten in dat hiervan $10 \%$ medicamenteus wordt behandeld. Er krijgen dan $(14.3 \mathrm{mln} . * .04 * .10=) 60.000$ personen medicatie. De therapietrouw is op 50\% gesteld. De Gezondheidsraad (1983/2) rapporteert in dit verband dat er in de V.S. een therapietrouw was van minder dan 50\%. (vgl. Russell, 1985, en Weinstein e.a., 1985). De kostprijs anti-hypertensiva bedraagt (50\%* $f$ 981,-- $=f 490,--$.

In tabel 4.3 worden de door ons berekende kosten van cholesterolverlagende medicatie en van anti-hypertensiva in de gezonde bevolking in 1988 weergegeven.

\begin{tabular}{|l|l|r|}
\hline $\begin{array}{l}\text { cholesterolverlagende medicatie } \\
\text { ant-hypertensiva }\end{array}$ & $\begin{array}{l}60.000 \text { personen } * f 803,- \\
60.000 \text { personen } * f 490,--\end{array}$ & $\begin{array}{l}f 48 \mathrm{mbm} \\
\text { f } 29 \mathrm{~mm}\end{array}$ \\
\hline
\end{tabular}

Tabel 4.3 Kosten cholesterolverlagende medicatie en anti-hypertensiva in 1988, zoals in het model gebruikt. 
We hebben de kosten van medische behandeling afgeleid uit de behandeling: gang die een patiënt door de verschillende behandelingstrajecten kan doorloper (zie Bijlage II). Een behandelingstraject geeft voor elke CHZ-manifestatievom de verschillende typen medische behandelingen aan. Gegeven het aantal patiên ten dat een bepaald behandelingstraject doorloopt, kan op deze wijze het jaarlijk se aantal medische behandelingen in het model berekend worden.

Er wordt met betrekking tot de behandelingstrajecten een driedeling onderschei den:

a) het voortraject,

b) het opnametraject,

c) het follow-up traject.

Het follow-up traject wordt onderverdeeld in de follow-up gedurende het lste jaar $(<1$ jaar) en de follow-up met betrekking op de periode daarna ( $\geq 1$ jarr) In tabel 4.4 is een overzicht gegeven van de medische behandelingen waar de behandelingstrajecten uit bestaan.

\begin{tabular}{|ll|}
\hline Voortraject & - huisarts \\
& - cardioloog \\
& - medicatie \\
& - diagnostiek \\
\hline Opnametraject & \\
& - ambulance \\
& - verpleging \\
& - intensive care \\
& - medicatie \\
& - diagnostiek \\
& - cartioloog \\
& - operaties \\
\hline Follow-up traject & \\
\hline & - hartrevalidatie \\
& - thrombosedienst \\
& - medicatie \\
& - diagnostiek \\
- cardioloog/huisarts
\end{tabular}

Tabel 4.4 Medische behandelingen behandelingstrajecten

De meeste kosten worden gegenereerd in het opnametraject. We hebben daarniti in figuur 4.3 de behandelingsgangen van de patiëntenstromen uit het opnamertat ject beknopt afgebeeld (zie verder Bijlage II). 


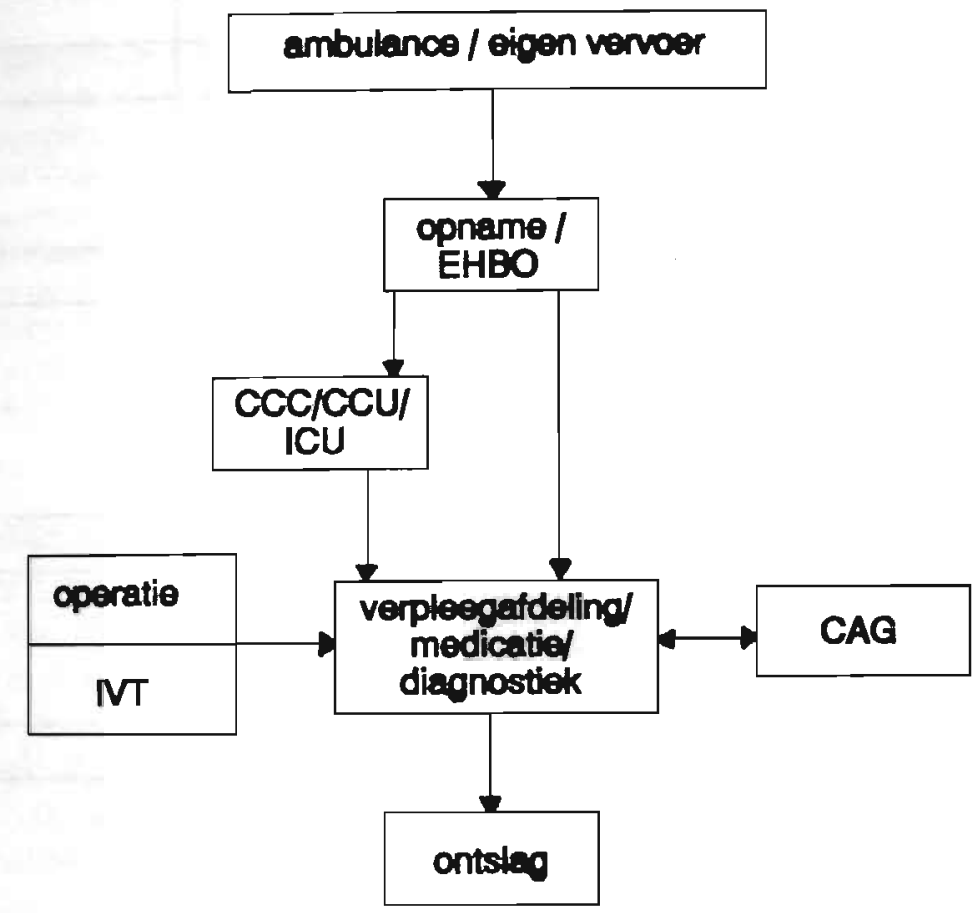

Figur $\mathbf{4 . 2}$ Behandelingsgangen opnametraject

De instroom van het opnametraject gaat via opname ziekenhuis (EHBO), waarbij de ambulance tot het opnametraject is gerekend. Ter vergelijking merken we op dat in het Financieel Overzicht Zorg (FOZ) de ambulance-diensten tot de functie van de basisgezondheidszorg behoren. Modelmatig is door ons deze functie gekoppeld aan het aantal acute myocard infarcten (AMI) en het aantal instabiele angina pectoris patiënten (UAP). Vanwege het startpunt in het ziekenhuis maken deze twee manifestatievormen geen voortrajectkosten (zie Bijlage III).

We hebben in tabel 4.5 een schatting opgenomen van de totale kosten van medische behandeling van $\mathrm{CHZ}$ die in 1988 in Nederland zijn gemaakt.

De kostenanalyse is gebaseerd op het jaar 1988, omdat dit het meest recente jaar was waarvan we de meest volledige gegevens konden verkrijgen. Sommige kostengegevens waren alleen met betrekking tot andere jaren beschikbaar. Deze kosten zijn zoveel mogelijk uitgedrukt in het prijsniveau van het jaar 1988 .

In het kostenoverzicht uit tabel 4.5 zijn de kosten van hypertensie- en cholesterolverlagende medicatie niet opgenomen. 


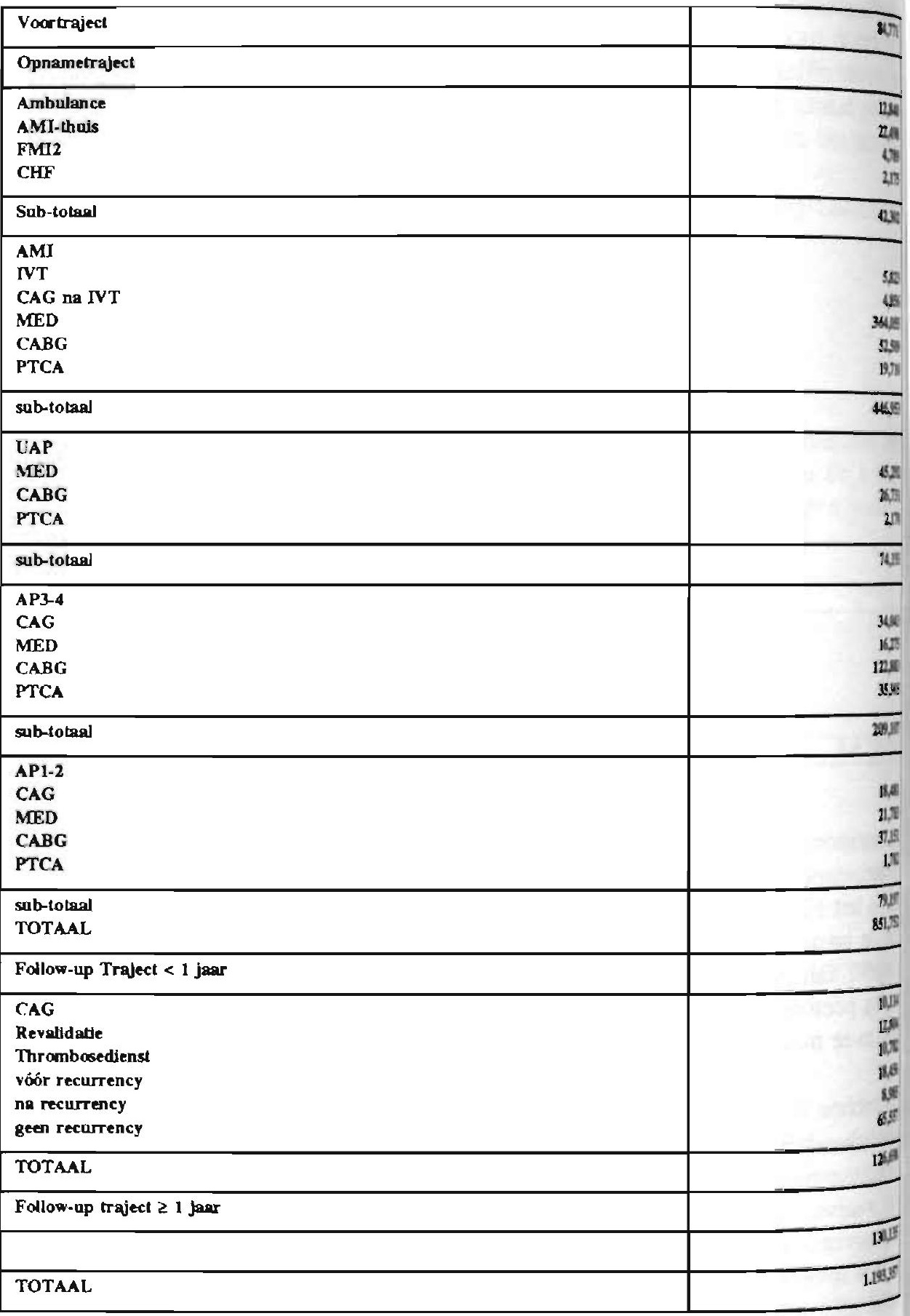

Tabel 4.5 Totale CHZ-kosten van Voortraject, Opnametraject, Follow-up traject $<1$ jara th Follow-up traject $\geq 1$ jaar NB: De genoemde bedragen zijn in miljoenen gube 
legenda

$\begin{array}{ll}\text { AMI } & \text { - acuut myocard infarct } \\ \text { FMI2 } & \text { - fataal myocard infarct (binnen het ziekenhuis) } \\ \text { CHF } & \text { - congestive heart failure } \\ \text { IVT } & \text { - intraveneuze thrombolytica } \\ \text { CAG } & \text { - coronair angiogram } \\ \text { MED } & \text { - klinische medicatie } \\ \text { CABG } & \text { - by-pass operatie } \\ \text { PTCA } & \text { - dotteren } \\ \text { UAP } & \text { - instabiele angina pectoris } \\ \text { AP }_{3-} & \text { - angina pectoris, WYHA-classificatie } \mathrm{AP}_{3} \text { en } \mathrm{AP}_{4}\end{array}$

De totale CHZ-kosten in tabel 4.5 bedragen ca. $f$ 1,2 miljard. Er zijn in Nederland weinig gegevens bekend over de kosten die voor $\mathrm{CHZ}$ gemaakt worden. Het enige vergelijkingsmateriaal waarmee een kostenvalidering van ons model uitgevoerd kan worden betreft de eerder genoemde publicatie van Koopmanschap e.a. (1991). Hun schatting bedroeg $f 815 \mathrm{mln}$. voor de totale kosten van $\mathrm{CHZ}$ in 1988, waarbij zij als basis voor hun berekeningen het Financieel Overzicht Zorg (1990) gebruikt hebben.

Het is onduidelijk in hoeverre in het bedrag van $f 815 \mathrm{mln}$. de kosten van antihypertensiva en cholesterolverlagende medicatie zijn opgenomen. Omdat deze kosten naar onze schatting een relatief gering bedrag betreffen, gaan we er vanuit dat het bedrag van $f 815 \mathrm{mln}$. vergelijkbaar is met het door ons berekende bedrag van $f 1,2$ miljard. Daar 1988 voor ons het ijkjaar is en alle modeluitkomsten qua patiëntenaantallen goed overeenkomen met bekende gegevens uit de literatuur, lijkt het erop dat genoemde auteurs een onderschatting hebben gemakt in hun berekening over de CHZ-kosten in 1988.

Hiervoor hebben we drie verklaringen. In de eerste plaats bestaat er de sterke indruk dat door Koopmanschap e.a. (1991) geen rekening is gehouden met de kosten die in de door ons aangeduide voor- en follow-up trajecten gemaakt worden. Zoals blijkt uit tabel 4.5 verklaren deze kosten voor het grootste deel het verschil van ca. $f 400 \mathrm{mln}$. ( $f$ 1,2 miljard - $f 815 \mathrm{mln}$.). De auteurs vermelden zelf dat ca. $25 \%$ van de totale kosten van gezondheidszorg als gevolg van de door hun gevolgde methodiek niet aan de verschillende diagnosegroepen toewijsbaar zijn. Een tweede verschil is dat Koopmanschap e.a. (1991) conform de FOZ-methodiek de kosten van beleid en beheer en de kosten van collectief preventieve zorg en beheer in hun berekeningen opgenomen hebben. Deze kosten vormen samen ca. $8 \%$ van de totale kosten van gezondheidszorg. In onze schatting van de CHZ-kosten zijn de kosten van beleid en beheer en de kosten van collectief preventieve zorg en beheer niet verwerkt. Wanneer wij wel rekening houden met 
deze kosten zou het eerder genoemde verschil van $f 400 \mathrm{mln}$. alleen maar groter worden.

Een mogelijk derde verklaring is dat wij in onze benadering zoveel mogelijk zjo uitgegaan van de werkelijke kosten van $\mathrm{CHZ}$, terwijl het $\mathrm{FOZ}$ gebaseerd is op de betaalde declaraties van de zorgverzekeraars aan de zorgaanbieders. Deze declaraties zijn gebaseerd op tarieven. In Bijlage III motiveren we dat tarieven door. gaans geen goede afspiegeling vormen van de werkelijke kostprijzen.

\subsection{Kostendeterminanten}

Een kostendeterminant wordt door ons omschreven als een factor die een bepalende invloed heeft op de kostenontwikkeling van een ziektecategorie.

Wij hebben in relatie tot $\mathrm{CHZ}$ de volgende kostendeterminanten aangeduid:

(i) het aantal vernauwde kransslagaders,

(ii) de mate van angina pectoris,

(iii) de plaats van het myocardinfarct,

(iv) de pompfunctie van het hart (ejectie fractie).

Er is in Bijlage II een uitgebreide toelichting over deze variabelen opgenomen. De belangrijkste aandachtspunten zijn samengevat de volgende.

Een vernauwing (stenose) op basis van atherosclerose kan zich in eén of meer kransslagaders voordoen. Het spreekt voor zich dat hoe meer kransslagaders vernauwd zijn, de prognose slechter wordt. Een belangrijke variabele hierbij is de mate van vernauwing (stenose vorming). In de meeste gevallen zal het proces van stenose vorming gepaard gaan met angineuze pijnklachten.

De plaats van het infarct wordt grofweg aangeduid met een voorwandinfarct en een onderwandinfarct. Het voorwandinfarct heeft de slechtste prognose.

De ejectiefractie (EF) is een globale maat voor de hoeveelheid bloed die per hartslag wordt uitgepompt. Een slechte EF ontstaat door een aanzienlijke beschadiging van de hartspier tengevolge van een acuut myocardinfarct (AMI). Hoe groter of hoe vollediger het hartinfarct, hoe groter de kans wordt op een verminderde pompfunctie van de hartspier. Het afkappunt voor een goede of slechte EF hebben we op $40 \%$ gesteld.

Uit klinische waarnemingen blijkt dat patiënten die met een slechte ejectiefracti $(\mathrm{EF}<40 \%)$ in het ziekenhuis worden opgenomen meer kosten genereren dan patiënten met een goede ejectiefractie ( $E F \geq 40 \%$ ) (privé-communicatie Janssen, 1992). Een EF < 40\% genereert meestal hogere kosten wegens een intensievere behandeling en langere verpleegduur (zie Bijlage III). Wanneer de EF als koster- 
determinant voldoende discrimineert, kan op basis van het vorrkomen van het aantal patiënten met een EF $<40 \%$ (meer) inzicht in de mogelijke toekomstige kostenontwikkelingen van coronaire hartziekten (CHZ) worden verkregen. Als gevolg van bijvoorbeeld technologische ontwikkelingen overleven hoe langer hoe meer mensen een acuut myocard infarct (AMI). Echter in de gevallen waarbij deze mensen anders aan het infarct overleden waren (aangegeven als FMI 1 of FMI2), kan vaak maar een EF $<40 \%$ behouden worden. Door de stijging van het aantal infarctoverlevenden stijgt dus het aantal slechte EF's. Een relatieve stijging van het aantal $\mathrm{EF}<40 \%$ zou dan tot een extra stijgende ontwikkeling van de kosten van $\mathrm{CHZ}$ moeten leiden. Wij hebben een dergelijk toekomstpad in Hoofdstuk 6 nagebootst met behulp van een medisch programma intraveneuze thrombolytica (IVT).

Er kan een aantal criteria genoemd worden waaraan een kostendeterminant met betrekking tot $\mathrm{CHZ}$ moet voldoen. We hebben de volgende drie criteria geformuleerd, te weten:

a) een kostendeterminant moet een prognostische betekenis hebben;

b) er moet sprake zijn van een kostendiscriminerende betekenis op geaggregeerd niveau;

c) de kostendeterminant moet uniform, objectief en makkelijk meetbaar zijn tegen betaalbare prijzen.

De eerder genoemde prognostische variabelen zijn kransslagadervernauwing, angineuze pijnklachten, de plaats van het MI, en de EF. Alle vier kunnen geünterpreteerd worden als kostendeterminanten met een prognostische betekenis die op geaggregeerd niveau een kostendiscriminerende betekenis hebben.

De angineuze pijnklachten zijn echter moeilijk objectief meetbaar, terwijl de kransslagadervernauwingen alleen invasief met behulp van een coronair angiogram (CAG) tegen hoge kosten kunnen worden vastgesteld.

De belangrijkste kritiek tegen het gebruik van de plaats van het MI als kostendeterminant is het ontbreken van objectieve criteria waarmee de plaats van het MI gemeten kan worden (privé-communicatie, Janssen, 1991). Mogelijk inherent aan dit probleem zijn uit de literatuur weinig medisch-epidemiologische gegevens te verkrijgen over de plaats van het MI (zie Hoofdstuk 2).

Een EF $<40 \%$ kan alleen ontstaan als gevolg van een AMI. We laten een EF < $40 \%$ als gevolg van hartfalen ( $\mathrm{CHF}$ als niet-CHZ oorzaak) vanwege het eigen ziektebeeld en de afwijkende therapievorm die CHF heeft hier buiten beschouwing (zie Hoofdstuk 2). 
Met betrekking tot het eerste criterium wordt in Bijlage II beschreven dat de EF de belangrijkste prognostische variabele is met betrekking tot de levensverwachting. De fysiologische toestand waarin een eenmaal verslechterde EF verkeert zal zonder therapeutische behandeling steeds verder verslechteren. Aan deze therapeutische behandelingen zijn veel kosten verbonden die voor een belangrijk deel veroorzaakt worden door een lange zorg- en verpleegduur (zie verder Bijlage III). Na verloop van tijd zal de gestabiliseerde toestand van de EF uiteindelijk toch verergeren, waarna een nieuw AMI of een CHF optreedt (zie Hoofdstuk 3). Dit fysiologische proces van de restfunctie van de EF zal op geaggregeerd niveau tot een kostendiscriminerende betekenis leiden zoals blijkt uit de figuren $4.3-4.7$.

\section{Opnames}

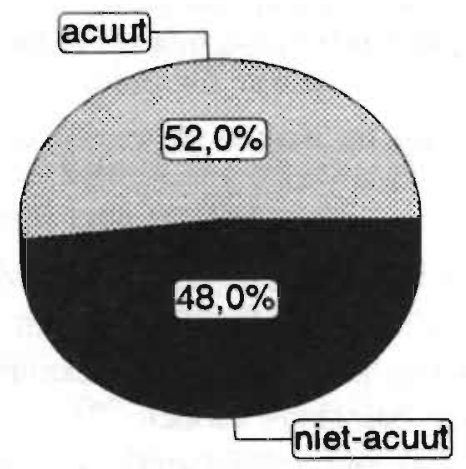

Kosten

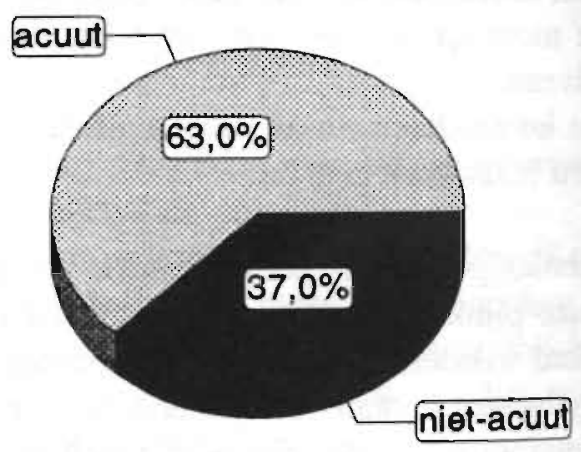




\section{Opnames}
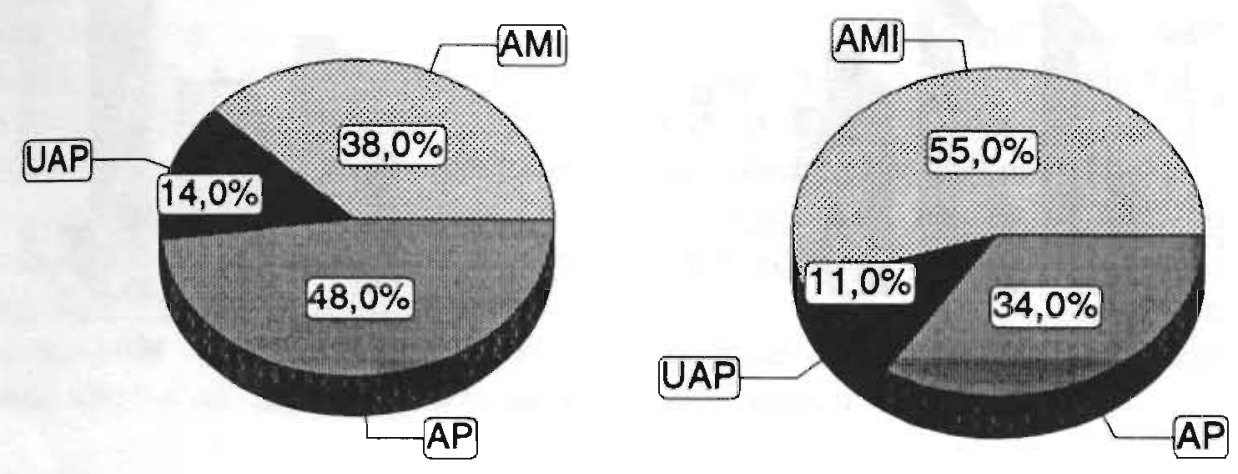

Figur 4.4 Verdeling opnametraject naar type manifestatievorm in 1988

\section{Opnames}

\section{Kosten}

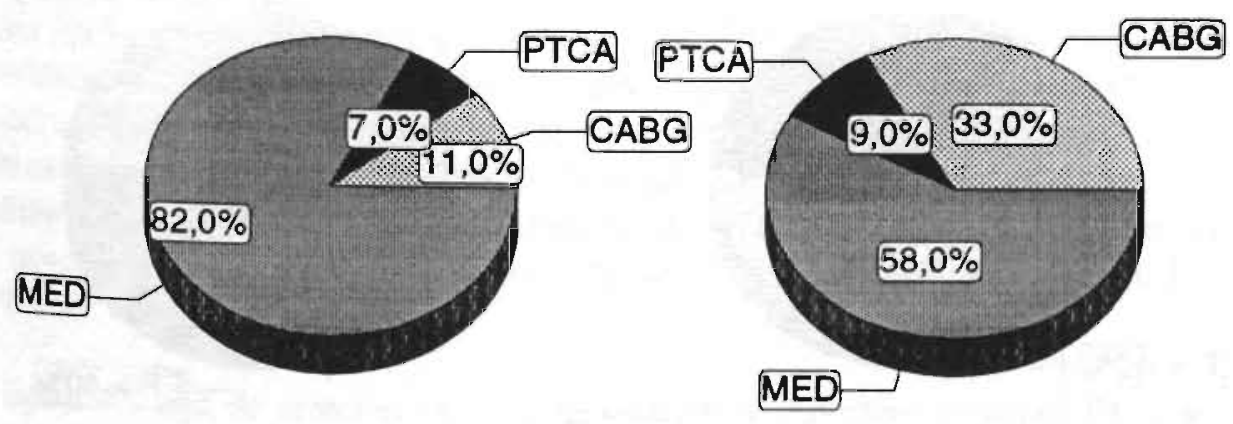



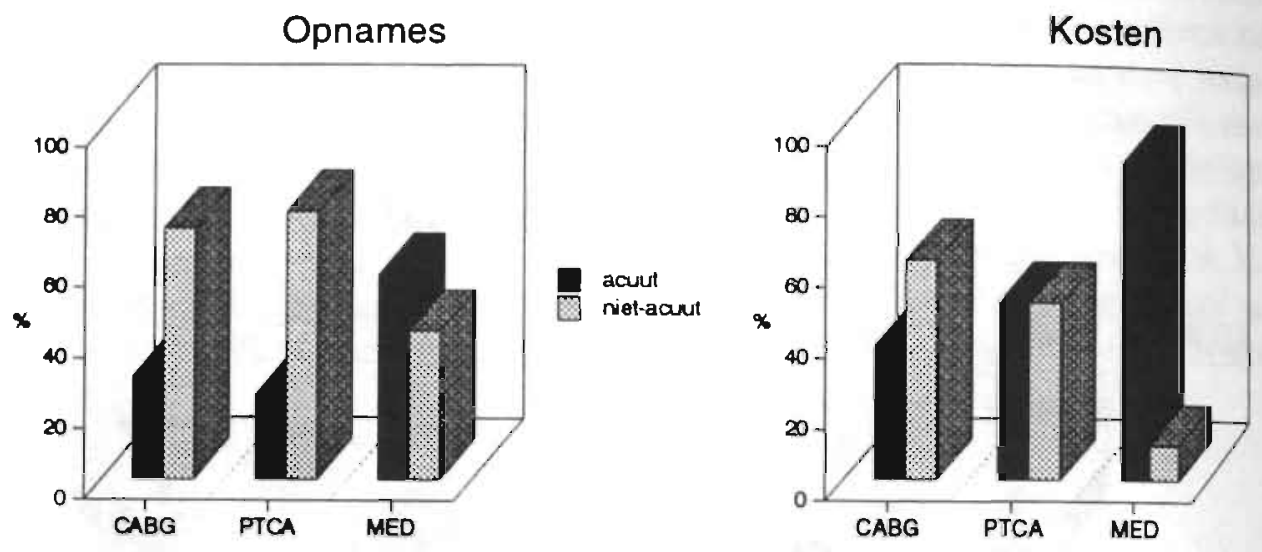

Figuur 4.6 Verdeling opnametraject per type therapeutische bebandeling naar type opname in 1988

\section{Opnames}

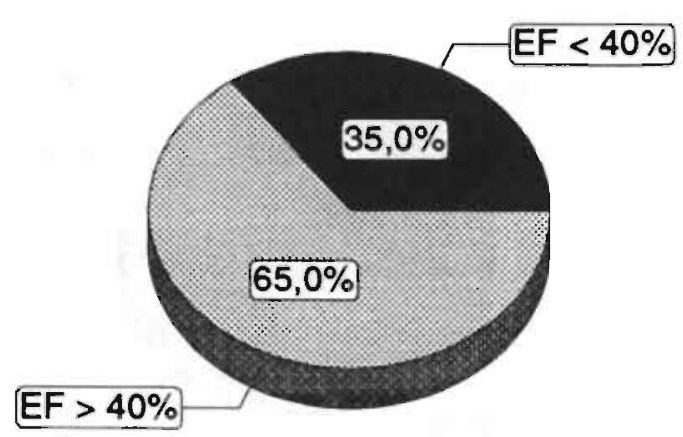

\section{Kosten}

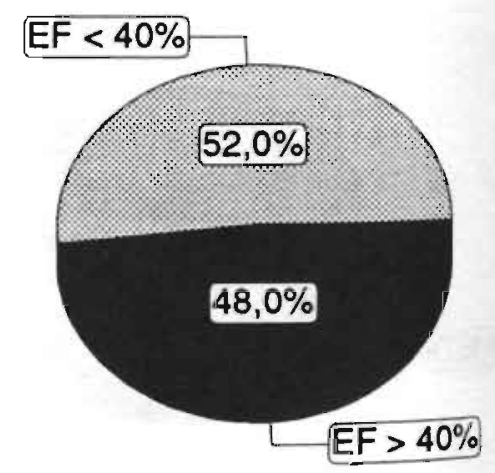


In de figuren 4.3 - 4.7 komt steeds hetzelfde beeld naar voren, namelijk dat een belangrijk deel van de kosten van het opnametraject gegenereerd werden door de acute opnames. De acute opnames worden bepaald door het type manifestatievorm (zie verder de Bijlagen II en III). De type therapeutische behandeling hangt voor een belangrijk deel samen met het type manifestatievorm (zie Bijlage II). Uit figuur 4.7 blijkt dat $52 \%$ van de kosten van het opnametraject verourzaakt worden door opnames met een $\mathrm{EF}<40 \%$, terwijl het aantal opgenomen patiënten met een EF $<40 \%$ ongeveer $35 \%$ van het totale aantal opnames bedraagt.

De EF is met behulp van een echocardiografie op relatief eenvoudige, uniforme en objectieve wijze en tegen redelijke kosten meetbaar. De kostprijs (het tarief) van een echocardiografie bedraagt $f 173,--$ per verrichting, waarvan $f 123,--$ honoraria medisch specialist (naar rato ziekenfonds en niet-ziekenfonds) en $f 50,--$ vergoeding ziekenhuis (COTG, 1989).

Concluderend voldoet de EF aan de drie genoemde criteria om als kostendeterminant met betrekking tot $\mathrm{CHZ}$ in aanmerking te komen.

Vervolgens zijn we nagegaan in welke mate de opnamekosten reageren wanneer het aantal opgenomen patiënten met een EF $<40 \%$ stijgt of daalt ten opzichte van het totale aantal opnames in 1988.

Zoals eerder genoemd hadden ca. 35\% van de patiënten die in 1988 opgenomen werden een EF $<40 \%$. Vervolgens laten we het aantal opnames met een EF < $40 \%$ respectievelijk dalen en stijgen, waarbij het totaal aantal opnames gelijk blijft aan het oorspronkelijke totale aantal opnames in 1988, te weten:

(i) het relatieve aandeel opnames EF < 40\% daalt van 35\% naar $27 \%$, (ii) het relatieve aandeel opnames EF < 40\% stijgt van $35 \%$ naar $43,6 \%$.

De daling van het relatieve aandeel opnames EF $<40 \%$ ten opzichte van de totale opnames wordt bereikt door het percentage AMI-patiënten dat met thrombolytica (IVT) wordt behandeld te verhogen van $20 \%$ naar $40 \%$ (zie Bijlage III en Hoofdstuk 2). De stijging van het relatieve aandeel opnames EF $<40 \%$ wordt veroorzaakt door een drastische daling te veronderstellen in het aantal AMI-patiènten dat een goede $\mathrm{EF}$ ( $\mathrm{EF} \geq 40 \%$ ) behoudt. De gevolgen van beide veronderstellingen hebben we ook doorberekend op de relatieve verhouding van het aantal opgenomen UAP en AP-patiënten dat in 1988 een $\mathrm{EF}<40 \%$ en een EF $\geq$ $40 \%$ had.

In figuur 4.8 zijn de effecten van een gewijzigde verhouding opnames $\mathrm{EF}<40 \%$ ten opzichte van de totale opnames weergegeven met een kostencurve en een sterftecurve. De kostencurve heeft betrekking op de kosten die tijdens de opname worden gemaakt. De kosten van patiënten die in het ziekenhuis overlijden zijn 
hierbij inbegrepen. De sterftecurve betreft de sterfte in het ziekenhuis en omvat zowel de operatiemortaliteit als de totale myocardinfarctsterfte (zie Bijlagen I en II).

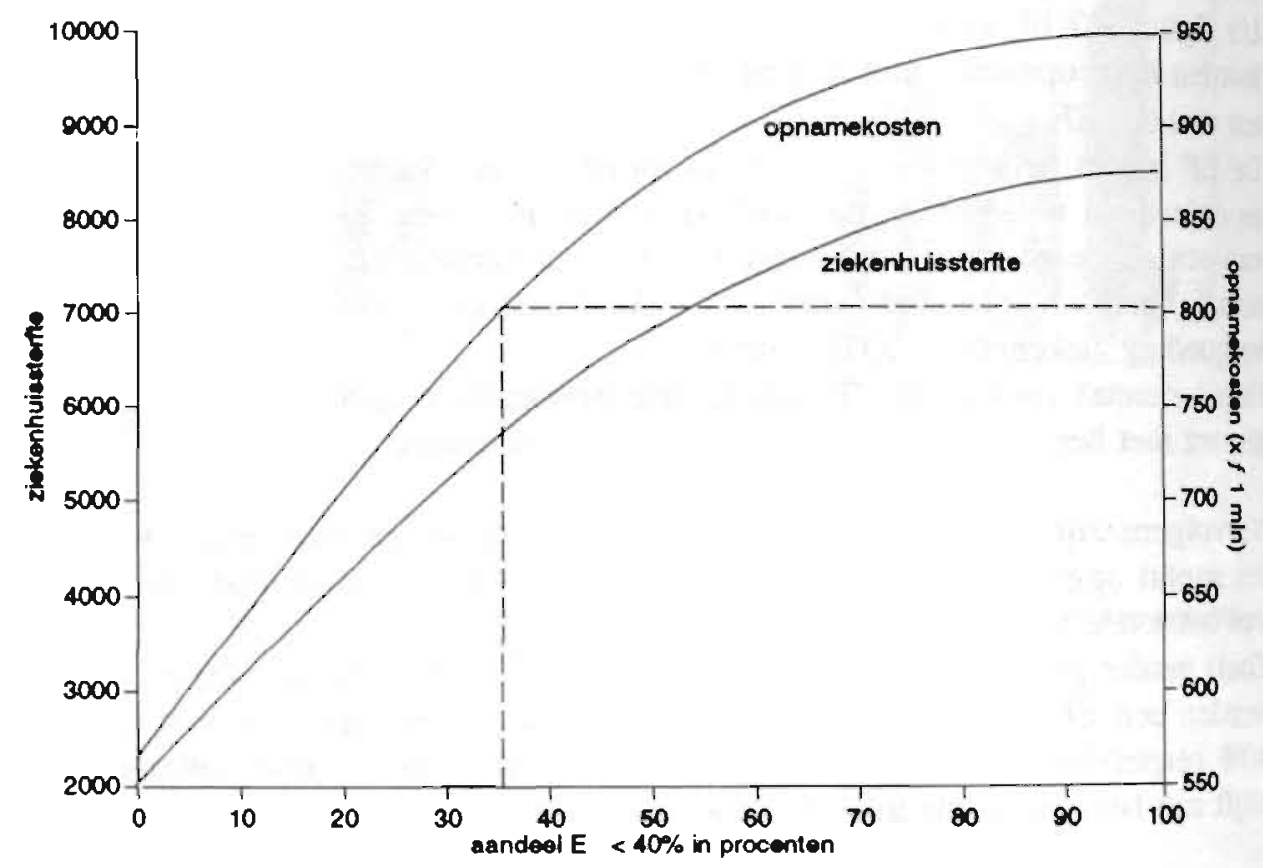

Figuur 4.8 De ejectiefractie $<40 \%$ als functie van kosten en sterfte

Het snijpunt van de kostencurve met de $y$-as in figuur 4.8 geeft dat gedeelte van de kosten aan waarbij het relatieve aandeel opnames EF $<40 \%$ ten opzichte van de totale opnames $0 \%$ is. Deze kosten worden onafhankelijk van de EF gemaakt en zijn aangeduid als de "vaste" opnamekosten. De kosten die variëren met de hoogte van EF zijn de "variabele" opnamekosten. De vaste opnamekosten maken in $1988 \mathrm{ca}$. $70 \%$ van de totale opnamekosten uit. In figuur 4.8 kan worden afgelezen dat bij een relatief aandeel opnames $\mathrm{EF}<40 \%$ van $35 \%$ het bijbehorende kostenplaatje ca. $f 810 \mathrm{mln}$. is. Dit bedrag komt overeen met $f 851.752 \mathrm{mln}$. $f \mathbf{4 2 . 3 0 2} \mathrm{mln}$. uit tabel 4.5 . Het bedrag van $f \mathbf{4 2 . 3 0 2} \mathbf{m l n}$. is in het model tot de kosten van het opnametraject gerekend, maar vallen als zodanig niet onder de opnamekosten.

Uit figuur 4.8 blijkt dat de kostencurve eerst een lineair verloop heeft, waarna de curve een afnemend stijgend (concaaf) verloop krijgt en vervolgens overgaat in 
een horizontaal verloop ten opzichte van de $\mathrm{x}$-as. Het concave verloop van de kostencurve wordt veroorzaakt door de stijging van de ziekenhuissterfte. Een toenemende sterfte heeft immers tot gevolg dat er steeds minder kosten gemaakt worden. Er bestaat een duidelijk causaal verband tussen de EF en de fatale myocard infarct (FMI) sterfte. In 1988 veroorzaakte FMI ca. 90\% van de totale CHZ-ziekenhuissterfte (zie Bijlage I). De sterftecurve heeft eveneens een concaaf verloop. Naarmate het relatieve aandeel opnames EF $<40 \%$ ten opzichte van de totale opnames de $100 \%$ nadert, wordt met betrekking tot de sterfte een soort biologisch maximum bereikt.

De kostencurve en de sterftecurve in figuur 4.8 hebben een nagenoeg identiek verloop. Zodoende kan via het verloop van de sterftecurve het verloop van de kostencurve benaderd worden. Het voordeel van deze benadering is dat het verloop van de sterftecurve voor elk jaar op vrij eenvoudige wijze bepaald kan worden. De EF kan door zijn prognostische betekenis als een krachtige kostendeterminant beschouwd worden voor het verkrijgen van inzicht in de mogelijke toekomstige kostenontwikkelingen van $\mathrm{CHZ}$. 


\section{SCENARIO'S CHZ}

5.1 Inleiding

5.2 Scenario-methode

5.3 CHZ-Basisscenario

5.4 Beschrijving Scenario's 


\subsection{Inleiding}

Het begrip scenario op het terrein van de gezondheidszorg en volksgezondheid kan worden omschreven als een beschrijving van een mogelijk toekomstbeeld teneinde zo'n volledig mogelijke informatie te geven over een toekomstig paj ten aanzien van een bepaald aspect van de gezondheid (vgl. ook Hoogeveen e.a., 1989). Het doel van scenarioanalyse is dan ook het transparant maken van de informatie op basis waarvan strategische besluitvorming plaats kan vinden.

Gebruikers van het ontwikkelde computermodel kunnen zelf scenario's formuleren en het model kan als analyse-instrument gebruikt worden om de effecten van hun scenario's zichtbaar te maken. De uitkomsten van zo'n scenario kunnen worden vergeleken met een zogenaamd basisscenario. Het basisscenario betreft de huidige startwaarden van het computermodel. Deze startwaarden reflecteren de huidige situatie en de waargenomen trends van de relevante aspecten van $\mathrm{CHZ}$.

Een scenario bestaat in ons model uit de volgende onderdelen:

(i) Bevolkingsontwikkelingen,

(ii) Autonome ontwikkelingen,

(iii) Gezondheidszorgprogramma's:

a) Preventie,

b) Medisch.

In Hoofdstuk 1 is reeds aangegeven dat het computerprogramma (genaamd CHZ Simulator) een instrument is om scenario's mee te bouwen. De bevolkingsontwikkelingen en de zogenaamde autonome trends kunnen in de CHZ-Simulator ingebracht worden als tijdsafhankelijke parameters.

De preventieprogramma's en de medische programma's vormen de input van he? te vormen toekomstig pad.

Het hoofdstuk is als volgt opgebouwd. In paragraaf 5.2 wordt de scenariomethode uitgewerkt. Hierbij wordt de relatie tussen het strategisch beleidsvormingsproces en de scenariomethodiek aangeduid. De uiteenzetting van het basisscenario vindt in paragraaf 5.3 plaats. In paragraaf 5.4 beschrijven we de scenario's met betrekking tot de preventie- en medische programma's. 


\subsection{Scenario-methode}

Er bestaat in de samenleving een tendens om hoe langer hoe meer kennis en inzicht te verkrijgen over mogelijke toekomstige ontwikkelingen op diverse terreinen van die samenleving. De scenariomethode kan hiervoor een uitkomst bieden. Hiermee bedoelen we een methode waarmee de toekomst beschouwd op basis van enerzijds zoveel als mogelijk integratie van kennis op het betreffende gebied en anderzijds mogelijke toekomstige ontwikkelingen over de nodige onzekere facetten.

De genoemde combinatie van enerzijds feitenkennis en anderzijds een scenario moet een dusdanig geïntegreerd geheel vormen dat hieruit een toekomstbeeld kan worden gededuceerd. De analyse van dit toekomstbeeld noemen wij scenarioanalyse.

Het gaat bij scenario-analyse niet om een voorspelling van de toekomst, maar meer om een voorbeschouwing op geleide van een scenario. Ieder ander scenario zal in het algemeen een ander toekomstbeeld genereren.

Er is een aantal randvoorwaarden (validering) te noemen die de scenariomethode bemoeilijkt (vgl. ook Bijl, 1991, en Van Genugten e.a., 1992):

(a) Er moet van een scenario een zekere geloofwaardigheid uitgaan. Het moet bijvoorbeeld naadloos aansluiten bij de huidige situatie en bij de waargenomen trend van de voorbije periode. Trends kunnen omgebogen worden, echter dit zal in de praktijk hoogstens op een glooiende wijze plaatsvinden, dus zonder knikpunten.

De scenariomethode vereist dus onderzoek naar de historische ontwikkelingen in de risicofactoren en in de behandelingspatronen van coronaire hartziekten.

(b) Een scenario moet aansluiten bij de medisch-epidemiologische kennis met betrekking tot het object van studie. Er zijn oorzakelijke relaties tussen de determinanten (risicofactoren) en het vo6rkomen van coronaire hartziekten die niet kunnen worden veronachtzaamd in een scenario. Een scenario zou een beperkt aantal uitgangspunten moeten definiëren, waarna een toekomstig pad kan worden afgeleid met behulp van de kennis op het betreffende gebied.

In onze scenariostudie heeft deze randvoorwaarde een belangrijke rol gespeeld. Bijvoorbeeld, een toekomstig pad met betrekking tot incidenties van coronaire hartziekten is niet een rechtstreeks onderdeel van een scenario. Onderdeel van het scenario zijn wel de preventieprogramma's, die in het model een verandering teweeg brengen van het risicoprofiel van de 
Nederlandse bevolking. Deze verandering werkt vervolgens op geleide van de modelrelaties door op de incidentiecijfers van coronaire hartziekten (zie Hoofdstuk 3).

Voor behandelingsstrategieën ligt het vormen van scenario's aanzienlijk moeilijker. Er zullen schattingen aanwezig moeten zijn over succespercentages en prognoses, wil men een uitspraak kunnen doen over de levensverwachting die met deze strategieën bereikt kan worden. Daar het bijvoorbeeld bij een verruiming van de indicatiestelling om een nieuwe groep patiënten gaat die voor operatie in aanmerking komt, kunnen we ons niet baseren op de bestaande literatuur in dit verband. Het succespercentage en de prognose vormt dan ook onderdeel van het scenario (zie paragraaf 5.4). In het model wordt vervolgens uitgerekend wat de gevolgen zijn voor de CHZ-morbiditeit en de CHZ-mortaliteit gedurende de simulatieperiode.

$\mathrm{Er}$ is in het model een aantal parameters opgenomen waarmee wijzigingen in dit soort modelwaarden kunnen worden aangebracht. De modelparameters staan beschreven in de in het computerprogramma opgenomen "Helptekst".

(c) Een scenario behoort consistent en samenhangend te zijn. In het geval dat een scenario uit meerdere onderdelen bestaat, mogen er geen interne tegenstrijdigheden aanwezig zijn. Bijvoorbeeld een scenario, gericht op scholingsprogramma's van de bevolking over het aanleren van reanimatietechnieken ten behoeve van "sudden death" (SD) patiënten, behoort samen te gaan met een afstemming op het ambulancevervoer en de inrichting van ambulances (vgl. het opname programma uit paragraaf 5.4 van dit hoofdstuk).

Het model coronaire hartziekten is opgezet als een instrument om scenario-analyse mee uit te voeren. Er is zoveel mogelijk kennis verzameld over:

de aanwezigheid van risicofactoren voor $\mathrm{CHZ}$ onder de Nederlandse bevolking;

de incidentie aan $\mathrm{CHZ}$ op basis van deze risicofactoren;

de recurrente incidenties aan $\mathrm{CHZ}$;

de indicatiestellingen voor operatieve en medicamenteuze behandelingen;

de sterftekansen aan $\mathrm{CHZ}$ en CHZ-operaties en de sterftekansen aan andere doodsoorzaken in de CHZ-bevolking;

de demografische ontwikkelingen met betrekking tot het verwachte geboortepatroon en de verwachte niet-CHZ-sterfte in de "gezonde" bevolking. 
Verder is zo goed mogelijk onderzocht wat de samenhang is van deze aspecten. Tevens is bekeken welke items een tijdtrend vertonen. Dit geheel vormt de datainvoer van het model.

Het scenario dat hieraan toegevoegd kan worden met het doel een toekomstbceld te creëren bestaat uit twee onderdelen:

(a) een tijdtrend voor de komende jaren van de modelparameters, waarmede een tijdtrend toegevoegd kan worden aan én of meerdere van de bovengenoemde aspecten (i) $t / m$ (vi).

(b) een combinatie van een aantal additionele gezondheidszorgprogramma's die tot doel hebben de ziekte $\mathrm{CHZ}$ een minder belangrijke rol voor de Nederlandse samenleving te laten spelen.

Het computerprogramma is zo opgebouwd dat het toekomstbeeld van een geformuleerd scenario steeds vergeleken kan worden met een standaardscenario, dat we het basisscenario genoemd hebben. In paragraaf 5.3 wordt het basisscenario verder uiteengezet.

Het basisscenario bevat geen additionele gezondheidszorgprogramma's, zijnde variaties of aanvullingen op het gangbare. In feite bestaat het alleen uit de door ons gekozen tijdtrends voor de diverse modelvariabelen. Deze keuzen zijn tot stand gekomen op basis van waargenomen trends van de voorbije jaren. Aldus kan het basisscenario worden opgevat als een verrassingsvrije voortzetting van de huidige trends.

Het basisscenario heeft in ons model alleen de functie als vergelijkingsgrondslag voor de scenario's. We willen aan het basisscenario geen voorspellende betekenis hechten. Kenmerkend voor verrassingsvrije scenario's is dat het accent wordt gelegd op de extrapolatie van het huidige gebruik van voorzieningen naar de toekomst, veelal gebaseerd op bevolkingsprojecties van het CBS (vgl. Van den Berg Jeths e.a., 1993). Het ziekte- en sterftepatroon in de komende 10-15 jaar zal wegens de verwachte vergrijzing van de Nederlandse bevolking (zie Honfdstuk 1) alleen daarom al een afwijkend beeld ten opzichte van het heden geven. We zijn van mening dat aan dergelijke extrapolaties hooguit een verkennend toekomstbeeld ontleend kan worden.

In Bijl (1991) wordt een uitvoerige beschrijving gegeven van de verschillende scenario-typologieën. Deze scenario-typologieën zijn weergegeven in figuur 5.1 (vgl. ook Van Doorn e.a., 1978, en Bijl, 1991). 


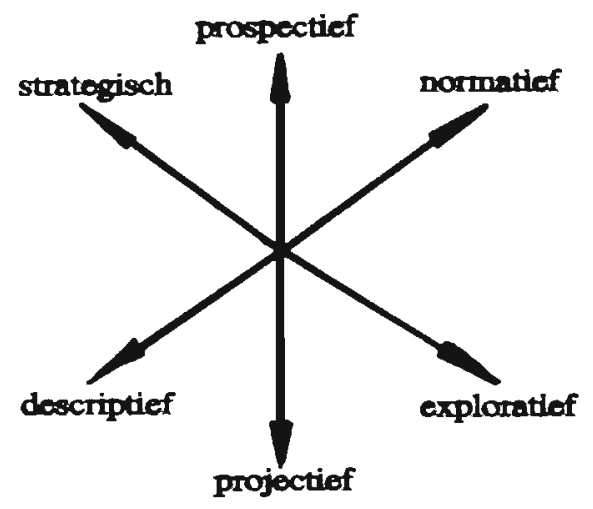

Figuur 5.1

Typologieën van scenario's

De in figuur 5.1 gegeven opsomming is niet limitatief. Bovendien hebben sommige typologieën een overlappende betekenis. We willen in dit proefschrift niet te diep op deze materie ingaan omdat door Bijl (1991) hier al ruimschoots voldoende aandacht aan is gegeven. Wel wijzen we in navolging van Bijl (1991) en Van Doorn e.a. (1978) erop dat bij de opzet van scenario-onderzoek in ieder geval een keus gemaakt moet worden over de "optiek van de scenario's". De twee belangrijkste typen zijn hier de projectieve scenario's en de prospectieve scenario's. De projectieve scenario's redeneren vanuit het heden naar de toekomst, terwijl de prospectieve scenario's vanuit een streefbeeld terugkijken naar het heden. Bijvoorbeeld, doelen kunnen ook gezien worden als bereikte doelstellingen die achteraf gemeten worden, van waaruit wordt teruggeredeneerd naar de huidige situatie.

Op basis van deze indeling kunnen we ons scenariomodel overwegend projectief, descriptief en exploratief noemen, hoewel op onderdelen van het model de andere typologieën eveneens van toepassing zijn. Een voorbeeld hiervan is ter illustratie in Hoofdstuk 7 opgenomen.

De gezondheidszorgprogramma's, als onderdeel van scenario's in ons model, beogen inzicht te geven in de wijze waarop bepaalde doelstellingen in de gezondheidszorg bereikt kunnen worden. We hebben de finale doelstellingen binnen de gezondheidszorg gedefinieerd in termen van sterftereductie en verbetering van kwaliteit van leven (vgl. tabel 5.1 verderop in dit hoofdstuk). Deze doelstellingen wil men op een doelmatige manier bereiken. 
Er worden strategieën geformuleerd die gericht zijn op het bereiken van de finale doelstellingen. Voorbeelden van deze strategieën zijn verminderen van verhoogde risicofactoren, voorkómen van herhaalde incidenties, substitutie van dure behandelingswijzen door goedkopere therapieën met behoud van dezelfde effectiviteit, en ontwikkelen van nieuwe technologieën gericht op vergroting van de effectiviteit van de behandeling bij eenzelfde of grotere doelmatigheid.

De gekozen strategieën worden geoperationaliseerd in de vorm van gezondheidszorgprogramma's. In het simulatiemodel worden twee groepen programma's onderscheiden, te weten:

Preventieprogramma's. Deze richten zich op de gezonde bevolking en bieden de mogelijkheid om de aanwezigheid van $\mathrm{CHZ}$-risicofactoren terug te dringen.

(ii) Medische programma's. Deze richten zich op personen die coronaire hartziekten hebben of gehad hebben (bijsturing ziekteproces). Een aantal medische programma's richten zich op de acute fase van de ziekte (bijv. reanimatieprogramma, therapieprogramma); andere richten zich op de CHZ-bevolking in een latente fase van de ziekte (bijv. CAGscreening programma).

In paragraaf 5.4 van dit hoofdstuk wordt een volledig overzicht gegeven van alle gezondheidszorgprogramma's die aangemaakt kunnen worden met het computerprogramma.

In figuur 5.2 wordt het beschreven strategisch beleidsvormingsproces met betrekking tot de scenariomethode weergegeven.

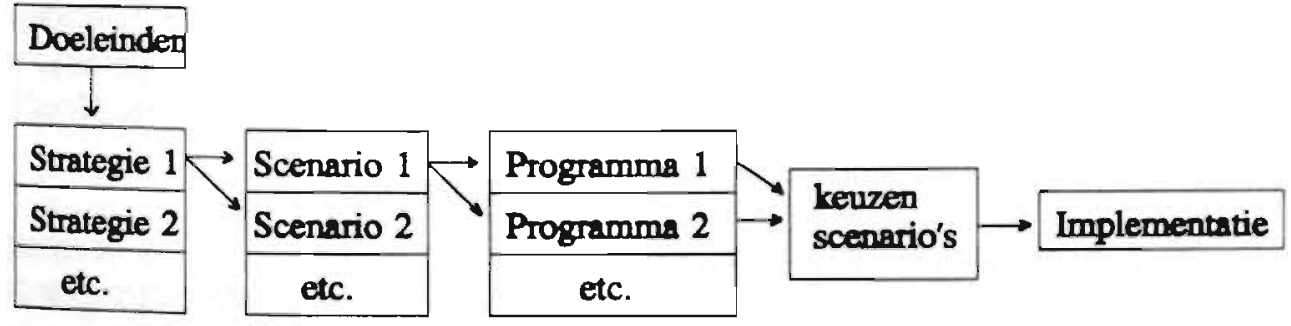

Figuur 5.2

Scenario's in strategische beleidsvorming

Er worden in figuur 5.2 op basis van de gestelde doeleinden strategieën geformuleerd en vertaald in gezondheidszorgprogramma's. Deze programma's dienen als input voor de scenario's. De scenariokeuzen duiden vervolgens de gezondheidszorgprogramma's aan waarmee het toekomstig pad gevormd gaat worden. 
Hiervoor zijn middelen nodig die vaak ter beschikking moeten komen uit een herallocatie van de reeds aangewende middelen. In Hoofdstuk 7 gaan we op dit herallocatieproces verder in.

\subsection{CHZ-Basisscenario}

Zoals eerder uiteengezet wordt het basisscenario gevormd door de verrassingsvrije voortzetting van de huidige trends en zijn er geen additionele gezondheidszorgprogramma's opgenomen.

In Bijlage I wordt gemotiveerd waarom we de trends van de drie risicofactoren roken, serumcholesterol, en diastolische bloeddruk in het basisscenario op een constant nivo hebben gehouden.

$\mathrm{Er}$ is in het basisscenario wel een zogenaamde technologie-trend opgenomen. Als gevolg van verbeterde technologie nemen we aan dat de operatiesterfte ieder jaar $0,5 \%$ daalt (deze aanname is met behulp van een modelparameter als zodanig ingesteld en kan dus door de gebruiker op een andere waarde ingesteld worden).

De scenariosimulatie omvat een periode van maximaal 22 jaar, gerekend vanaf 1 januari 1988 tot 1 januari 2010 . Het is mogelijk een kortere simulatieduur te kiezen. In de literatuur wordt meestal een simulatieduur van 15-20 jaar gekozen. De veranderingen tijdens de simulatieperiode in het basisscenario worden veroorzaakt door de volgende factoren:

een vergrijzing van de bevolking. Dit wil zeggen dat er momenteel in de bevolkingsgroepen 30-60 jaar meer mensen zitten dan in de lagere bevolkingsgroepen en meer dan in de hogere bevolkingsgroepen. Over 25 jaar zijn er dus relatief meer ouderen. Hierdoor zal de CHZ-incidentie uit de gezonde bevolking toenemen. We hebben de demografische ontwikkeling gebaseerd op de middenvariant van het CBS (zie Hoofdstuk 3).

(ii) een jaarlijkse reductie van de niet-CHZ-sterfte van $0,7 \%$ ten opzichte van de sterftegetallen voor 1988 . We hebben deze parameterwaarde zodanig gekozen, dat de niet-CHZ-sterfte reductie overeenkomt met de CBS-trend met betrekking tot de jaren '80. Er resulteert een totale levenswinst van ongeveer 1,5 jaar over de simulatieperiode van 22 jaar (zie Bijlage I). Dit versterkt het effect in (i) gesignaleerd.

Volgens onze schatting zal het gezamenlijke effect de CHZ-incidentie doen toenemen van 93.000 in 1988 tot 135.000 in 2010. Dit komt 0 vereen met een cumulatieve stijging van $1,6 \%$ per jaar. 
(iii) een inhaaleffect met betrekking tot de operatieve behandelingen $\mathrm{CABG}$ en PTCA. Dit inhaaleffect geldt met name voor de PTCA. In twee jaar tijd, van 1988 tot 1990, is het aantal operaties volgens de Commissie Coronair Angiografie (1990) gestegen van 13.900 tot 16.500 , een stijging van $9,3 \%$ op jaarbasis (zie Bijlage II). Kijken we echter naar de operaties afzonderlijk dan is er een groot verschil: CABG groeit $1 \%$ op jaarbasis en de PTCA 21\%. Zou deze trend zich voortzetten dan worden er in 2010 ongeveer 371.000 PTCA-operaties verricht en 10.300 CABG's. Men mag aannemen dat dit niet realistisch is en de huidige stijging wordt ons inziens veroorzaakt door een inhaaleffect. Volgens ons model komen er in 1988 nog ongeveer 9.000 patiënten, die nu een MED-behandeling krijgen, in aanmerking voor een operatieve behandeling. Op basis van de tijdseffecten genoemd onder (i) en (ii) groeit dit aantal tot ongeveer 13.000 in 2010 . In het basisscenario hebben we aangenomen dat het genoemde inhaaleffect op basis van de snelheid tussen 1988 en 1990 zal plaatsvinden. Op basis van deze uitgangspunten groeit over de periode tot 2010 het aantal jaarlijks uitgevoerde PTCA's maar liefst met 13.120 terwijl het aantal CABG's groeit met 3.816 .

De jaarlijkse kosten van het opnametraject stijgen behoorlijk gedurende de gesimuleerde periode van 22 jaar. Namelijk van $f 1.254,2 \mathrm{mln}$. in 1988 tot $f 1.909,8 \mathrm{mln}$. in 2010 . Dit betekent een cumulatieve stijging van ongeveer $2 \%$ per jaar. Voor een gedeelte is deze stijging te verklaren uit de groei van het CHZ-aanbod als gevolg van de vergrijzing; voor een ander gedeelte uit de genoemde verschuiving van de indicatiestellingen zich uitend in een inhaaleffect van het aantal operaties. Dit blijkt onder andere uit de kosten per opgenomen patiënt. Deze lopen op van $f 3.100$,-- in 1988 tot $f 3.400$,-- in 2010. Overigens is voor de kosten in de komende jaren het prijspeil van 1988 gehanteerd. Het heeft naar onze mening geen enkele zin de prijzen aan te passen voor verwachte prijsstijgingen. Enerzijds geeft dergelijke informatie een vertekent beeld over de werkelijke oorzaken van kostenstijgingen, anderzijds zouden de voor inflatie gecorrigeerde kostenstijgingen weer "wegverdisconteerd" worden door bij de vaststelling van de discontovoet het inflatiepercentage op te nemen (vgl. ook Drummond e.a., 1987).

Er is vanuit kostenoogpunt nog een trend te signaleren. Deze trend hebben we gededuceerd uit gesprekken met de beroepsbeoefenaars ten aanzien van CHZ. We doelen hier op een verschuiving van indicatiestellingen in de richting van duurdere behandelingen. Nieuwe technologieën, bijvoorbeeld, maken het mogelijk moeilijker ziektetoestanden operatief te behandelen. Het gevolg is niet alleen 
een verlenging van leven (dus meer kosten als neveneffect voor $\mathrm{CHZ}$ ), maar ook intensievere en duurdere zorgtrajecten voor de patiënten. Dit resulteert in een hogere kostprijs per behandeling.

We beëindigen deze paragraaf door nog eens aan te geven wat de belangrijkste gevolgen zullen zijn van de toename van de CHZ-incidentie in het basisscenario.

(i) De ziekenhuisbezetting en de bezetting van de $\mathrm{CCU}$-afdelingen zullen aanzienlijk stijgen. Het aantal jaarlijkse opnames stijgt van 78.110 in 1988 tot 109.600 in 2010. Het aantal opgenomen AMI's hiervan stijgt van 29.922 tot 40.514 , hetgeen extra intensieve zorg vereist (zie ook paragraaf Kostendeterminanten uit Hoofdstuk 4).

(ii) De zogenaamde $\mathrm{CHZ}$-bevolking zal aanzienlijk stijgen met een cumulatief effect voor het aantal ziekenhuisopnames. Dit effect wordt niet alleen veroorzaakt door de vergrijzing maar eveneens door een verbetering van de kwaliteit van de gezondheidszorg, waardoor patiënten langer blijven leven na de eerste $\mathrm{CHZ}$-manifestatie. Volgens onze schatting bestond de $\mathrm{CHZ}$ bevolking in 1988 uit ca. 400.000 personen (zie Hoofdstuk 3). In $2010 \mathrm{zal}$ deze bestaan uit ca. 540.000 personen.

(iii) De omvang van de personen met hartinsufficiëntie (CHF) zal eerst licht en later versneld stijgen. We hebben het gemiddeld aantal nog te leven jaren na de diagnose CHF op 3 jaren ingeschat. Het is aannemelijk dat dit de komende jaren zal stijgen, waardoor de CHF-groep extra snel zal toenemen. Dit betekent een toename van een arbeidsintensieve en kostenintensieve groep personen (zie ook Hoofdstuk 1). In 1988 bestond volgens onze schatting de CHF-groep uit ca. 65.000 personen. In 2010 zijn dat ongeveer 90.000 personen. Maar dit zal te zijner tijd vermoedelijk een onderschatting blijken te zijn.

\subsection{Beschrijving Scenario's}

Scenario's zijn ideeën en uitwerkingen met betrekking tot alternatieve toekomstige paden of trajecten. Zo'n alternatief toekomstig traject heeft invloed op de toekomstige ontwikkelingen van coronaire hartziekten. Het doel van de scenario's is gericht op de vergelijking van de toekomstige $\mathrm{CHZ}$-ontwikkelingen met die van het basisscenario. We hebben besproken dat er in principe drie vergelijkingsaspekten hiervoor in aanmerking komen: 
1) sterfte,

2) kwaliteit van leven, en

3) kosten.

Scenario's kunnen dus speciaal ingericht worden om specifieke verbeteringen in eén van deze aspecten aan te brengen.

De vergelijking op basis van kwaliteit van leven is in dit onderzoek buiten beschouwing gelaten (zie hoofdstukken 3 en 4).

In eerdere hoofdstukken is er gesteld dat het computerprogramma is voorzien van een zogenaamde userinterface. De gebruiker kan met behulp van deze userinterface zijn eigen gezondheidszorgprogramma instellen, dat wil zeggen de instelling van de diverse parameterwaarden en trends. Het scenario wordt gevormd door het betreffende gezondheidszorgprogramma, of desgewenst uit een samenvoeging van verschillende gezondheidszorgprogramma's.

Het opbouwen van een scenario in het computerprogramma of de CHZ-Simulator begint met de keuze van de bevolkingsgroep die tijdens de simulatie gevolgd zal worden, de zogenaamde simulatiepopulatie. In figuur 5.3 is het betreffende scherm uit de CHZ-Simulator te zien.

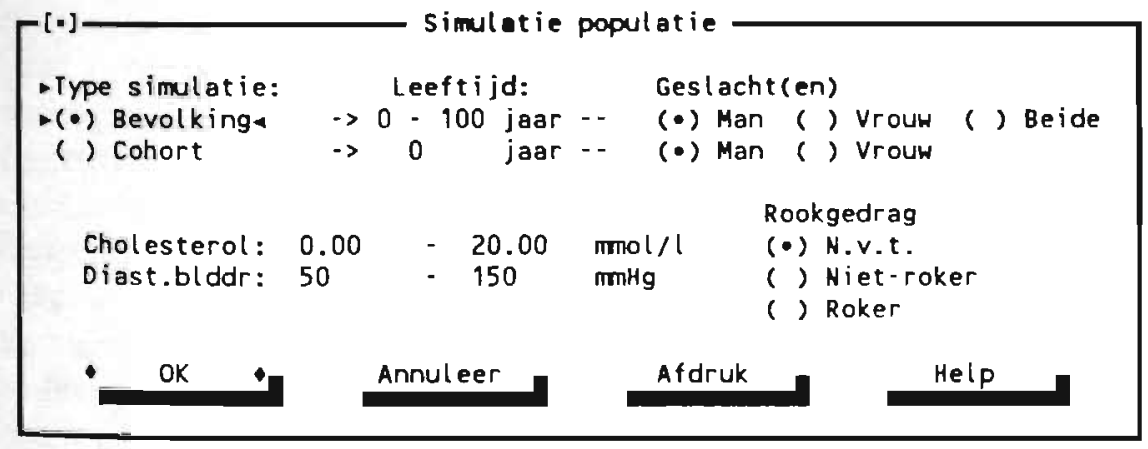

Figuur 5.3

Het Simulatiepopulatie-scherm uit de CHZ-Simulator

De bevolkingsparameters in figuur 5.3 betreffen leeftijd, geslacht, serumcholesterolgehalte, diastolisch bloeddrukniveau, en rookgedrag. De leeftijd, cholesterolgehalte, en diastolische bloeddruk worden ingevuld met minimum en maximum 
waarden. Het geslacht en het rookgedrag worden gespecificeerd in de vorm van een keuze naar geslacht en naar rookgedrag.

Er zijn twee soorten simulaties die essentieel van karakter verschillen, namelijk een bevolkingsstudie of een cohortstudie. Beide soorten simulaties zijn met de $\mathrm{CHZ}$-Simulator uit te voeren.

\section{Bevolkingsstudie}

Kiest de gebruiker voor een bevolkingsstudie dan betreft de simulatiepopulatie een bevolkingsgroep tussen 0 en 100 jaar, die of alleen man zijn, of alleen vrouw zijn, of die uit beide geslachten bestaat. Met behulp van het onderste gedeelte van het scherm kan nog een keuze gemaakt worden voor de drie genoemde risicokenmerken van de bevolkingsgroep. Het computerprogramma bezit een database die er voor zorgt dat na selectie van de risicofactoren dat gedeelte van de Nederlandse bevolking met de betreffende kenmerken in de CHZ-Simulator ingevoerd wordt. Tijdens de simulatie overlijden er personen en worden er personen gegenereerd (geboortes). De simulatiepopulatie uit een bevolkingsstudie heeft dus constant de vorm van een (doorsnede uit de) bevolking.

\section{Cohortstudie}

Indien een cohortstudie gekozen wordt, wordt er een groep personen van bepaalde leefijd en geslacht gekozen. Dit cohort groeit tijdens de simulatie niet aan maar zal via sterfte langzaam maar zeker verdwijnen. Ook hier kan een verdere specificatie via de risicofactoren aangebracht worden. In de aanvangssituatie zijn er in dit geval geen personen in de CHZ-bevolking. Na verloop van jaren vult de CHZ-bevolking zich met de overlevenden van een $\mathrm{CHZ}$-incidentie. De gezonde personen en de zieke personen uit het cohort worden net zolang in de tijd gevolgd totdat het cohort is uitgestorven. Dit betekent dat de cohortsimulatie in het model meestal langer duurt dan de simulatie van de bevolkingsstudie en voorbij het jaar 2010 gaat. Wij hebben een parameter ingebouwd waarmee een cohort gevormd kan worden bestaande uit 1 miljoen identieke personen van de gedefinieerde groep (een zgn. hypothetisch cohort). In het andere geval zal als cohort de geselecteerde deelgroep uit de Nederlandse bevolking in het model gebruikt worden.

Voor zowel een bevolkingsstudie als een cohortstudie kan voor het serumcholesterolniveau van de personen uit de simulatiepopulatie elk interval tussen 0 en 20 mmol/l worden gekozen. Voor het diastolische bloeddrukniveau betreft dit elk interval tussen 50 en $150 \mathrm{mgHg}$ en voor het rookgedrag "wel" of "niet" roken dan wel een combinatie van "wel en niet" roken "roken n.v.t.". 
In het model is een groot aantal parameters aangebracht die in de CHZ-Simulator gewijzigd kunnen worden (de zogenaamde modelparameters). In figuur 5.4 is een gedeelte van het betreffende invulscherm in de CHZ-Simulator te zien.

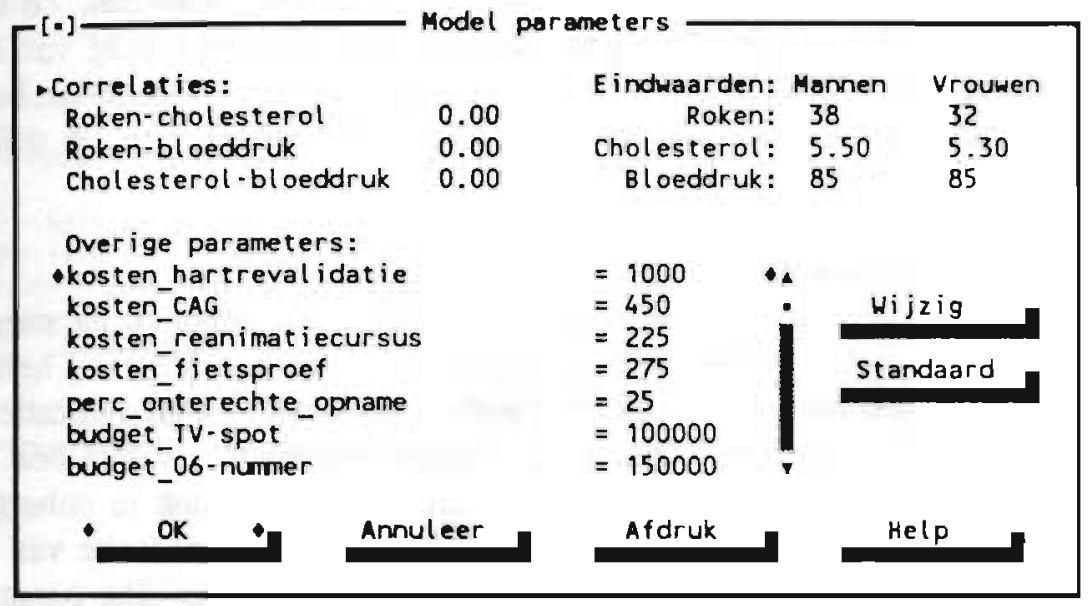

Figuur 5.4

Het Parameterscherm van de CHZ-Simulator

De gebruiker heeft de mogelijkheid om met behulp van deze modelparameters uit figuur 5.4 een eigen basisscenario samen te stellen. Het gewijzigde basisscenario kan zowel vergeleken worden met het basisscenario dat standaard in het model is gebouwd als met een ander scenario. Op deze manier kan onder meer worden nagegaan hoe gevoelig de uitkomsten zijn voor deze parameters.

We geven een korte toelichting op het parameterscherm uit figuur 5.4.

\section{(i) Correlaties}

Zoals te zien in figuur 5.4 bestaat er de mogelijkheid paarsgewijs correlaties aan te brengen tussen de risicofactoren. Er zijn op bevolkingsniveau in Nederland geen gegevens voorhanden die de mate van gezamenlijk vórkomen van de risicofactor weergeven (zie Bijlage I).

Toch zijn er vermoedens dat dit in zekere mate het geval is. We hebben er daarom voor gekozen de correlaties als variabele parameter in het model in te bouwen. Indien uit onderzoek mocht blijken dat er wel degelijk sprake is van structurele correlaties tussen de risicofactoren dan kan dit ook in het basisscenario aangebracht worden. 
(ii) Trends in de risicofactoren

In figuur 5.4 is te zien dat er voor mannen en vrouwen apart een trend in de risicofactoren aangegeven kan worden (zie Bijlage I). De zichtbare waarden zijn de waarden voor 1988. De in te vullen waarden zijn de waarden voor 2010. Het model gaat uit van een lineair verloop tussen deze twee waarden. Zo kan bijvoorbeeld eenvoudig worden nagegaan dat een cumulatieve daling van $1 \%$ van de mannelijke rokers leidt tot een rookpercentage van 30,5\% in 2010. Door dus 30,5 in het betreffende veld in te vullen realiseert het model deze 1\% daling (zie Bijlage I).

\section{(iii) Overige Parameters}

Onder overige parameters van het scherm van figuur 5.4 staan de parameters die met behulp van de CHZ-Simulator ingesteld kunnen worden. Wij hebben de niet-CHZ-sterfte parameter, de operatiesterfte parameter, en de indicatie-PTCA parameter al eerder genoemd. Onder de Overige Parameters vallen ook de disconto parameters waarmee de extra kosten en de levenswinst in cohortstudies verdisconteerd kunnen worden. In figuur 5.4 is slechts een gedeelte van de lijst zichtbaar. De volledige lijst is tezamen met de betekenis van elke parameter in de Help-tekst van de CHZ-Simulator opgenomen.

In Hoofdstuk 3 is beschreven dat er een keuze wordt gemaakt uit het aanbod van gezondheidszorgprogramma's waarmee een scenario samengesteld wordt (de scenario "input").

We geven vervolgens de beschrijving van verschillende gezondheidszorgprogramma's. Hierbij zijn er twee typen gezondheidszorgprogramma's te onderscheiden: preventieprogramma's en medische programma's.

$\mathrm{Bij}$ de beschrijving van elk gezondheidszorgprogramma is aangegeven op welke wijze de effecten van het betreffende programma in het computerprogramma gegenereerd worden.

\section{Preventieprogramma's}

In figuur 5.5 is het scherm uit de CHZ-Simulator te zien dat de gebruiker in staat stelt een preventieprogramma te kiezen. 


-Titel: Preventie programma
Type

Figuur 5.5

Het Preventieprogramma-scherm uit de CHZ-Simulator

Er is in figuur 5.5 een aantal zogenaamde preventieparameters opgenomen. Deze preventieparameters geven de startwaarden aan van elk preventieprogramma. Een toelichting hierover is opgenomen bij de bespreking van de preventieprogramma's verderop in deze paragraaf.

De effecten van de preventieprogramma's zijn afhankelijk van de gekozen preventieparameters. De waarden van de preventieparameters hebben we zoveel mogelijk afgeleid van de in de literatuur gebruikte waarden (zie Bijlage II).

Er worden in figuur 5.5 ook vijf doelgroepparameters aangegeven. De gebruiker kan met behulp van deze parameters de doelgroep naar leeftijd, geslacht, cholesterolniveau, hypertensieniveau, en rookgedrag specificeren.

De kosten worden bepaald door het volume te vermenigvuldigen met de kostprijs. Het volume bestaat uit het aantal personen dat reageert op de preventieprogramma's.

We onderscheiden twee typen kostprijzen: een vast bedrag per programma en een kostprijs per persoon.

De kostprijs in de vorm van een vast bedrag wordt elk jaar gemaakt. Dit vast bedrag is ter dekking van ontwikkelingskosten en uitvoeringskosten van het programma.

De kostprijs per persoon vertegenwoordigt de kosten die door de deelnemers voor het betreffende programma op jaarbasis gemaakt worden. De kostprijzen van deze programma's worden in Bijlage III behandeld. We maken een onderscheid tussen kostprijzen in het eerste jaar en in vervolgjaren omdat in het eerste jaar van de cholesterolverlagende programma's per deelnemer meer kosten wor- 
den gemaakt dan in de vervolgjaren. De kostprijs van de anti-rook programma's blijven in de vervolgjaren daarentegen gelijk aan die uit het eerste jaar.

We hebben de kostprijzen van de preventieprogramma's uitgedrukt in het prijsniveau van 1988.

De kostprijs van preventieprogramma's fluctueert rechtevenredig met de hoogte van de therapietrouw ("compliance"). Met therapietrouw bedoelen we het percentage personen uit de doelgroep dat daadwerkelijk het programma volgt. Alleen in het eerste jaar van het programma wordt bij een therapietrouw lager dan $100 \%$, toch de volledige kostprijs doorberekend. Dit zal eerder tot een onderschatting dan tot een overschatting van de kosten leiden, daar in de praktijk geneesmiddelen ook na het eerste jaar wel worden aangeschaft maar soms niet worden gebruikt.

We zijn ervan uitgegaan dat een verminderde therapietrouw ook leidt tot een daling in de effectiviteit van het betreffende gezondheidszorgprogramma.

Stel bijvoorbeeld dat een cholesterol reducerend medicatieprogramma wordt toegediend bij $10 \%$ van alle personen met een serumcholesterolgehalte $\geq 8 \mathrm{mmol} /$ en dat de therapietrouw $50 \%$ bedraagt. We nemen aan dat bij succes het verhoogde cholesterolgehalte met $25 \%$ gereduceerd wordt (vgl. Bijlage III). Ons model reageert hierop door vanaf het eerste jaar van het gezondheidszorgprogramma het cholesterolgehalte van $(50 \% * 10 \%=) 5 \%$ van de personen met verhoogd cholesterol te reduceren met $25 \%$. Er gaan dus minder personen het programma volgen. Een dalende effectiviteit als gevolg van een verminderde therapietrouw zal leiden tot minder gunstige kosten-effectiviteitsverhoudingen. Een dalende effectiviteit komt in dit geval tot uitdrukking in een stijging van het aantal CHZ-incidenten. Hierdoor stijgt niet alleen het aantal CHZ-sterften, maar zal er ook een stijging van de medische kosten door het toegenomen aantal opnames optreden.

Met de CHZ-Simulator kunnen preventieprogramma's apart of gecombineerd bestudeerd worden. Bij combinatie zijn de effecten cumulatief verwerkt. Via het resultatenscherm van de CHZ-Simulator zijn de resultaten van zo'n scenario te vergelijken met de uitkomsten van het basisscenario, waarin dergelijke programma's niet opgenomen zijn.

Er zijn 4 typen preventieprogramma's:

(i) Anti-rook Algemeen Programma,

(ii) Anti-rook Scholen Programma,

(iii) Cholesterol Medicatie Programma,

(iv) Cholesterol Dieet Programma. 


\section{(i)}

Anti-rook Algemeen Programma

Het uitgangspunt is het zogenaamde vijfstappenplan van Mudde (1989), waarbij de huisarts de centrale rol speelt (zie Bijlage III). Het aantal stoppers kan in de CHZ-Simulator zelf gekozen worden. Onze schatting is dat langs deze methode in de praktijk 15-20\% van de personen uit de doelgroep stopt met roken (Mudde, 1989, Van Ree, 1981). Verder bestaat er de mogelijkheid om de mate van therapietrouw in te schatten. Dit betreft het aantal reagerende personen uit de doelgroep dat blijvend stopt met roken. In het algemeen zal 30 à $40 \%$ van de stoppers gaandeweg weer roken (Van Ree, 1981, Hughes e.a., 1981).

Een optie in het computerprogramma betreft de mogelijkheid om bij het antirook programma een aanloopperiode en een afbouwperiode in te bouwen. Met aanloopperiode wordt het feit gesimuleerd dat bij stoppen met roken er niet direct een verbetering optreedt in de $\mathrm{CHZ}$-incidentiekansen. Deze verbetering bereikt geleidelijk de maximale score gedurende de aanloopperiode. In de literatuur wordt er gesproken van een aanloopperiode (cq. vertragingstijd) van 3-5 jaar (zie Hoofdstuk 2). Met de afbouwparameter wordt het feit gesimuleerd dat bij stoppen van een anti-rookcampagne mensen kunnen vervallen in hun oude gewoonten. Is "Afbouw" = 0 dan gebeurt dit direct na stoppen van de campagne. Is "Afbouw" = 5 dan gaat dit geleidelijk gedurende 5 jaar en indien afbouw een groot getal is; bijv. "Afbouw" = 50, dan zal dit het effect hebben dat de stoppers blijvende stoppers zijn geworden. Er zijn in de literatuur geen gegevens beschikbaar over de duur van de afbouwperiode.

Het effect van een anti-rookcampagne is in de $\mathrm{CHZ}$-Simulator verwerkt in de regressiecoëfficiënten van de jaarlijkse $\mathrm{CHZ}$-incidentievergelijkingen vanuit de gezonde bevolking.

\section{(ii) Anti-rook Scholen Programma}

Dit gezondheidszorgprogramma richt zich op de voorlichting aan scholieren van 12-18 jaar. Het doel is uiteraard te voorkomen dat personen ooit aanvangen met roken. Om dit programma na te bootsen is een tamelijk lange simulatieperiode vereist. Om namelijk het volle effect van een dergelijke campagne door te kunnen rekenen zullen de 12-18 jarigen toch minstens gevolgd moeten worden tot 60 -jarige leeftijd. We achten het niet zinvol om een periode langer dan 22 jaar te simuleren.

De manier waarop dit scenario gebruikt kan worden is als volgt:

Stel dat een "anti-rook scholen"-programma 10 jaar heeft gelopen voor een groep scholieren met leeftijdsbandbreedte 13 jaren. Beschouw als simulatiepopulatie de rokers en neem als doelgroep (bijv.) 40-53 jarigen. Hierbij is stilzwijgend aangenomen dat dit de groep personen was die destijds voorlichting op scholen kregen. Door een rookreductie aan te brengen kan het effect van deze voorlichting 
nagebootst worden. Hieraan kunnen de kosten van een voorlichtingscampagne gekoppeld worden.

Een tweede manier om een "anti-rook scholen"-programma na te bootsen verloopt via de modelparameters. Bij ouder worden van de doelgroep van dit programma (12-18 jarigen) stromen deze geleidelijk in de risicoleeftijd. Het percentage rokers in dat gedeelte van de bevolking, dat qua leeftijd CHZ-risico loopt, zal dus geleidelijk afnemen, als ging het om een dalende trend. Dit programma kan dan ook nagebootst worden via de modelparameter die de trend in het ro. kerspercentage weergeeft.

\section{(iii) Cholesterol Medicamenten Programma}

Dit programma is gericht op een reductie van het serumcholesterolgehalte, via toediening van geneesmiddelen. In Bijlage III is de samenstelling van een dergelijk programma uitgewerkt.

De opbouw van dit programma verloopt identiek aan die van de anti-rook programma's. Er kan een doelgroep worden gekozen met als éen van de kenmerken een serumcholesterolgehalte in een te specificeren interval tussen 0 en 20 $\mathrm{mmol} / \mathrm{l}$. Actieve programma's grijpen in het algemeen aan op een gehalte $\geq 8$ $\mathrm{mmol} / \mathrm{l}$ en soms wordt als afkappunt 6,5 of 6,0 genomen (zie Hoofdstuk 2 en Bijlage III).

Reductie betekent voor dit programma het percentage waarmede het serumcholesterolgehalte daalt bij strikte naleving van het medicamenteuze programma. Een bekend percentage in dit verband is 20 a 25 procent (zie Hoofdstuk 2).

Het effect van serumcholesterolreductie gaat analoog aan dat van de anti-rookcampagnes, namelijk via een daling van de $\mathrm{CHZ}$-incidenties op geleide van de betreffende regressievergelijkingen (zie Bijlage I). De aanloopperiode van cholesterolverlagende programma's bedraagt ca. 3 jaar (zie Hoofdstuk 2).

Verder is in het model een mogelijke afhankelijkheidsrelatie tussen het serumcholesterolgehalte en het bloeddrukniveau ingebouwd. In de literatuur wordt regelmatig melding gemaakt van het idee dat, bij een daling van de prevalentie van hypertensie, de prevalentie van verhoogd serumcholesterol stijgt in de bevol. king (vgl. Bijlage I met betrekking tot deze relatie). Initieel hebben we de bloeddrukparameter op 0 gesteld, daar er (nog) geen afdoende wetenschappelijke onderbouwing van deze hypothese aanwezig is. Desgewenst kan deze parameter ook gebruikt worden om de afhankelijkheidsrelatie tussen het rookgedrag en hel bloeddrukniveau aan te geven.

Er zijn met betrekking tot de opbouwparameter geen gegevens beschikbaar in de literatuur die iets zeggen over de duur van de afbouwperiode. Wij zijn uitgegaan van een afbouwperiode van 3 jaar, hoewel zonder meer te pleiten valt voor eell kortere periode (vgl. Hoofdstuk 2). 


\section{(iv) Cholesterol Dieet Programma}

Een andere en goedkopere manier om het serumcholesterol te reduceren gaat via een dieet met strikte professionele begeleiding. De uitwerking is in Bijlage III te vinden. Dit programma werkt identiek als het "Cholesterol Medicamenten" Programma. Echter de kosten zijn veel geringer. Overigens geldt dit ook voor de te verwachten reductie, hoewel dit mede samenhangt met de doelgroep en de intensiteit van de begeleiding.

Een tweede manier is om evenals bij het anti-rook scholen-programma de nabootsing te laten geschieden via de modelparameter die de trend in het cholesterol weergeeft.

\section{Medische Programma's}

De medische programma's zijn additioneel aan het opnametraject dat de patienten doorlopen (zie de toelichting over het opnametraject in Bijlage II). De bespreking van de medische programma's vindt verderop in deze paragraaf plaats. De kostprijzen van deze programma's worden uitgewerkt in Bijlage III. We hebben de kostprijzen van de medische programma's berekend tegen constante prijzen van 1988. De kostprijzen kunnen bestaan uit een vast bedrag en uit een kostprijs per persoon (vgl. de toelichting bij preventieprogramma's). De gebruiker kan voor elk medisch programma zijn eigen medische parameters en zijn eigen kost(prijzen)parameters aangeven.

De programma's zijn nauw gerelateerd aan de doelstellingen van de gezondheidszorg, te weten verbetering van de kwaliteit van leven en reductie van sterfte. In tabel 5.1 is de relatie van de programma's met deze doelstellingen weergegeven.

\begin{tabular}{|c|c|c|c|c|}
\hline & \multicolumn{2}{|c|}{ Verbetering kwaliteit van leven } & \multicolumn{2}{|c|}{ Reductie sterfte } \\
\hline & $\begin{array}{l}\text { Voork6́men } \\
\text { verslechtering }\end{array}$ & $\begin{array}{l}\text { Verbeteren } \\
\text { doorbloeding }\end{array}$ & $\begin{array}{l}\text { Voorkómen } \\
\text { AMI }\end{array}$ & $\begin{array}{l}\text { Voorḱ́men } \\
\text { fatale AMI }\end{array}$ \\
\hline Hartrevalidatie & $\mathbf{x}$ & & $\mathbf{x}$ & $\mathbf{x}$ \\
\hline CAG-screening & & & $\mathbf{X}$ & $\mathbf{X}$ \\
\hline Therapie & $\mathbf{x}$ & $\mathbf{x}$ & $\mathbf{x}$ & \\
\hline Reanimatie & & & & $\mathbf{x}$ \\
\hline Oprome & & & $\mathbf{x}$ & $\mathbf{x}$ \\
\hline Operatiecapacitelt & $\mathbf{X}$ & $\mathbf{X}$ & & \\
\hline
\end{tabular}

Tabel 5.1

Relatie Gezondheidszorgprogramma's en doelstellingen gezondheidszorg 
Er zijn 6 medische programma's:

(i) Hartrevalidatie Programma,

(ii) CAG-Screening Programma,

(iii) Therapie Programma,

(iv) Reanimatie Programma,

(v) Opname Programma,

(vi) Operatiecapaciteit Programma.

\section{(i) Hartrevalidatie Programma}

In figuur 5.6 is het scherm afgebeeld waarop het hartrevalidatie programma aan. gegeven kan worden.

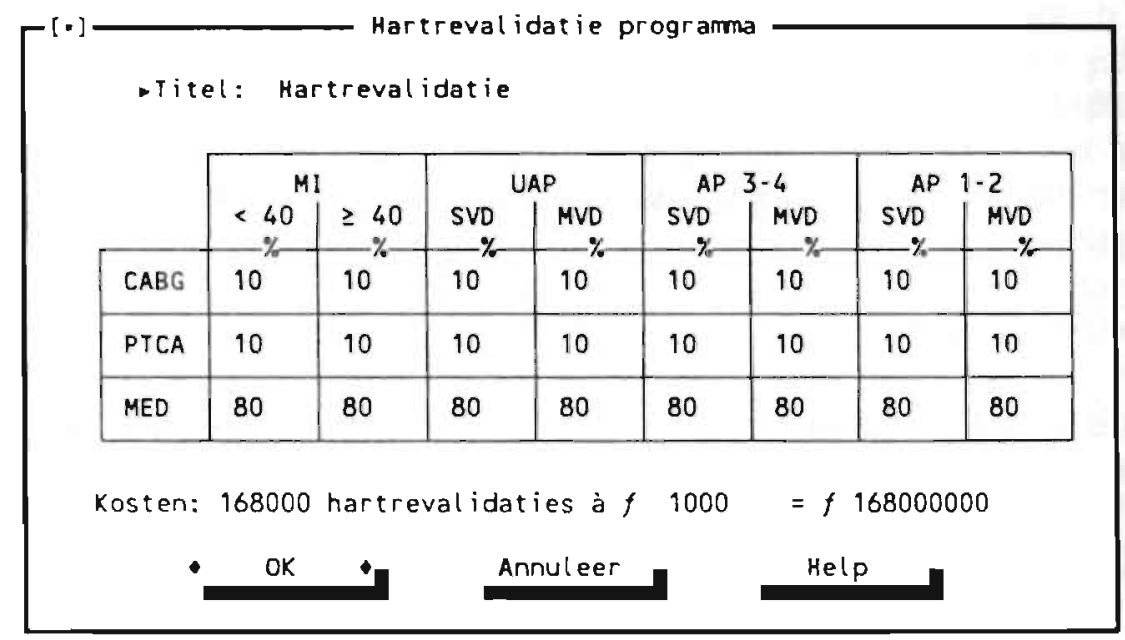

NB. De ingevulde getallen zijn willekeurig.

Figuur 5.6

Het Hartrevalidatie-scherm van de CHZ-Simulator

Zoals in figuur 5.6 te zien kan voor ieder combinatie van

(i) nlanifestatievorm van $\mathrm{CHZ}$,

(ii) ernst van de ziekte, en

(iii) behandelingstype, 
aangegeven worden, welk percentage van de betreffende patiënten in aanmerking komt voor een hartrevalidatie. De huidige percentages, zoals we die uit de literatuur hebben afgeleid (zie Hoofdstuk 2), zijn:

oud-MED $33 \%$ revalidatie (alleen voor AMI),

oud-CABG 50\% revalidatie (alle CHZ-vormen), oud-PTCA 25\% revalidatie (alle CHZ-vormen).

De effecten van het hartrevalidatie programma zijn tweeledig.

a) Een reductie van de snelheid van het natuurlijke proces van verslechtering van de globale toestand (kwaliteit) van het kransslagaderstelsel (zie Bijlage II).

b) Een reductie van de sterftekans aan SD en FMI1 bij optreden van een AMI onder de CHZ-bevolking.

De mate waarin deze effecten werken kan in het model met behulp van de modelparameters ingevuld worden (vgl. figuur 5.4 met betrekking tot parameterscherm eerder in deze paragraaf). De begininstelling is door ons zo gekozen dat in geval iedereen hartrevalidatie zou krijgen, dit een verhoging van de levensduur na de eerste $\mathrm{CHZ}$-incidentie van $20 \%$ met zich meebrengt (zie Erdman e.a., 1984).

Het effect van hartrevalidatie wordt geacht zowel fysisch als "mentaal" te zijn: Zo kan een hartrevalidatie programma aangrijpen op stress-hormonen als adrenaline. Stressbestendigheid kan aldus een positief verminderend effect hebben op de kans en de ernst van een hartaanval.

(ii) CAG-screening Programma

Dit programma is erop gericht om bij personen in de CHZ-bevolking de progressie van kransslagadervernauwingen preventief te ontdekken. In figuur 5.7 is het scherm uit de CHZ-Simulator te zien, waar een CAG-screening Programma uitgewerkt kan worden. 


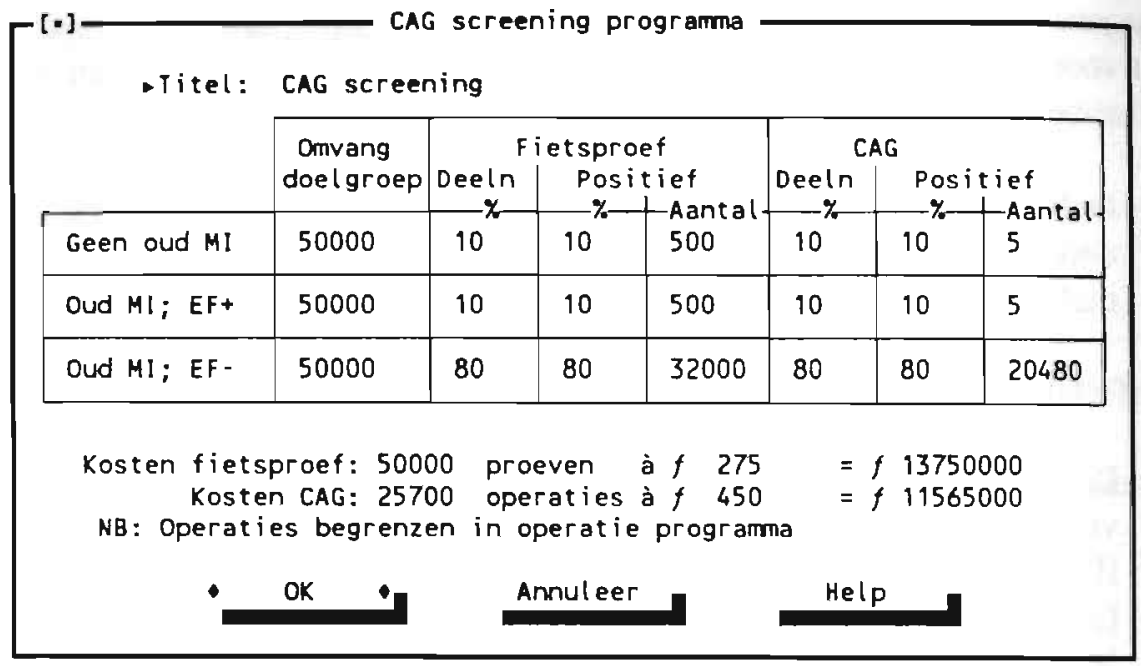

NB. De ingevulde getallen zijn willekeurig

Figuur 5.7 Het CAG-Screening-scherm van de CHZ-Simulator

In de praktijk zullen alle deelnemers met een positieve fietsproef in aanmerking komen voor een CAG. In feite zijn we op zoek naar personen in de CHZ-bevolking die gekenmerkt zijn als $\mathrm{K}^{-}$of $\mathrm{EF}^{+} / \mathrm{K}^{-}$(zie Bijlage II). In 1988 bestonden volgens onze schatting deze groepen beiden uit ongeveer 35.000 personen. Deze vormen samen ongeveer 70.000 oftewel $17,5 \%$ van de $\mathrm{CHZ}$-bevolking.

Toepassing van een $\mathrm{CAG}$ geeft inzicht in de plaats en de mate van afsluiting van de kransslagaders (zie Hoofdstuk 2). Een CAG wordt overwegend op klinische gronden verricht. De techniek verbetert zich constant en de handeling is steed minder belastend voor de patiënt. Het scenario in dit verband betreft het als routine-onderzoek verrichten van een CAG. We hebben afgezien van medischorganisatorische maatregelen die noodzakelijk zijn met betrekking tot de noodzakelijke CAG-capaciteiten en de poliklinische nabehandelingen in deze.

De modeleffecten van een CAG-screening programma zijn de volgende:

(a) Bij positieve CAG worden deze personen opgenomen als AP3-4/K- Ze worden onttrokken aan de groepen $\mathrm{K}^{-}$en $\mathrm{EF}^{+} / \mathrm{K}^{-}$. Mochten er meer pers0 nen dan aanwezig in deze groepen een positieve CAG hebben, dan worder deze personen onttrokken aan de $\mathrm{K}^{+}$en de $\mathrm{EF}^{+} / \mathrm{K}^{+}$groepen. 
(b) Er vindt een daling plaats van de "spontane" CHZ-incidentie vanuit de CHZ-bevolking. Dit geldt met name voor AMI.

In het model wordt het CAG-Screening Programma elk jaar herhaald vanwege het continue voortschrijdend proces van atherosclerose vorming.

\section{(iii) Therapie Programma}

Dit programma biedt de mogelijkheid om gangbare indicatiestellingen te wijzigen. Het idee is dat technologische mogelijkheden en jarenlange ervaringen gaandeweg een ruimere toepasbaarheid van de CABG- en PTCA-operaties met zich mee zullen brengen.

In figuur 5.8 is het scherm uit de CHZ-Simulator te zien waar dit programma aangebracht kan worden.

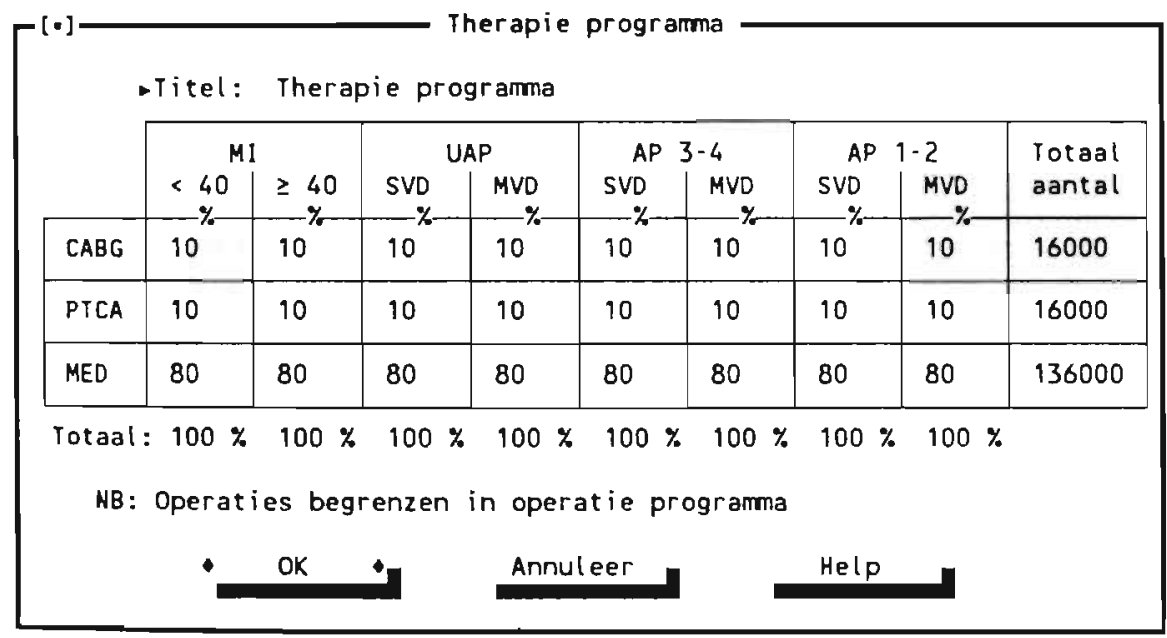

NB. De ingevulde getallen zijn willekeurig

Figuur 5.8

Het Therapie-scherm van de CHZ-Simulator

De huidige verdeling van de medische behandelingen is in tabel 5.2 te vinden. 


\begin{tabular}{|l|r|r|r|r|r|r|r|r|r|}
\hline \multirow{2}{*}{ Behandelingen } & \multicolumn{2}{|c|}{ MI } & \multicolumn{2}{c|}{ UAP } & \multicolumn{2}{c|}{ AP3-4 } & \multicolumn{2}{|c|}{ AP1-2 } & \multicolumn{2}{c|}{ Totas } \\
aartal \\
\cline { 2 - 9 } & $<40$ & $\begin{array}{r}> \\
=40\end{array}$ & SVD & MVD & SVD & MVD & SVD & MVD & \\
\hline CABG & 1 & 10 & 0 & 22 & 2 & 37 & 0 & 75 & 8370 \\
PTCA & 2 & 6 & 1 & 3 & 20 & 21 & 0 & 11 & 5558 \\
MED & 97 & 84 & 99 & 75 & 78 & 42 & 100 & 14 & 61796 \\
\hline
\end{tabular}

Tabel 5.2

Procentuele therapiekeuzes uitgesplitst naar manifestatie en emst van de ziekte, zoals gebruikt in het model

In de vorige paragraaf 5.3 is reeds aangehaald dat een CABG-operatie ook in 1990 vaker werd uitgevoerd dan een PTCA-operatie, hoewel de PTCA in opmars is door een vernuming van de indicatiestelling (zie Bijlage II).

Een realistisch scenario zou in dit verband kunnen zijn AMI te laten zoals het is, en voor UAP, AP3-4 en AP1-2 alle SVD middels PTCA te behandelen en alle MVD middels CABG.

Een therapieprogramma brengt in het model 2 soorten effecten te weeg.

(a) Veranderde therapiekeuzen leiden tot andere lengte van de ziekteperiode. We hebben dit elfect genormeerd op enerzijds de huidige situatie en anderzijds de verhouding tussen de drie extremen: iedereen MED, iedereen PTCA en iedereen CABG. Namelijk iedereen PTCA levert een levenswinst op van 0,9 jaren ten opzichte van iedereen MED en iedereen CABG levert een levenswinst op van 2,3 jaar ten opzichte van iedereen MED. Merk op dat de verhouding in deze levenswinsten 2:5 is.

(b) $\mathrm{Er}$ is een effect op de operatiesterfte. Indien personen met een slechtere toestand geopereerd worden zal deze stijgen en omgekeerd. Via de modelparameters kan hiervoor een keus gemaakt worden.

\section{(iv) Reanimatieprogramma}

Het reanimatieprogramma grijpt aan op SD. Uit de literatuur blijkt dat personen die door een SD getroffen worden, kunnen overleven wanneer binnen 4 minuten na het optreden reanimatie plaatsvindt (Gezondheidsraad, 1984/18). Er zijn drie reanimatieprogramma's zijn denkbaar (zie Bijlage III):

1) Scholingsprogramma's gericht op het aanleren van reanimatietechnieken,

2) Pcrmanente defibrillatiefaciliteiten in alle ambulances, en

3) Mobicle hulpposten. 
In de CHZ-Simulator hebben we gekozen voor de scholingsprogramma's, daar dit voor Nederland het meest geschikt lijkt (prive communicatie DGD-Maastricht, 1992).

In figuur 5.9 is het Reanimatiescherm te zien van de CHZ-Simulator. Dit is verwerkt in én scherm tezamen met het ambulance-respons programma. Onderdeel "A)" van het scherm betreft het reanimatieprogramma. Het reanimatie programma wordt in de userinterface opgeroepen als opname-programma. De parameters met betrekking tot het opname-scherm worden dan op " 0 " gezet.

\begin{tabular}{|c|c|c|c|c|c|}
\hline \multicolumn{6}{|c|}{ - Titel: Opname programma } \\
\hline \multirow[t]{5}{*}{ A) } & $\begin{array}{l}\text { Reanimatiecursus } \\
\text { omgeving patiënt }\end{array}$ & $\begin{array}{l}\text { Ormang } \\
\text { doelgroep }\end{array}$ & $\begin{array}{c}\text { Deel name } \\
\%\end{array}$ & $\begin{array}{l}\text { Ongevings - } \\
\text { grootte }\end{array}$ & $\begin{array}{l}\text { Totaat } \\
\text { aantal }\end{array}$ \\
\hline & Geen oud MI & 50000 & 10 & 10 & 50000 \\
\hline & Oud $\mathrm{MI}$; EF+ & 50000 & 10 & 4 & 20000 \\
\hline & Oud $\mathrm{MI}$; EF- & 50000 & 80 & 8 & 320000 \\
\hline & Kosten: 39000 & cursusse & n à $f$ & $=f 87$ & 750000 \\
\hline \multirow[t]{2}{*}{ B) } & $\begin{array}{l}\text { Ambulance respons } \\
\text { Onterechte opname }\end{array}$ & 25 & $\begin{array}{r}\text { Budg } \\
\text { Budget }\end{array}$ & $\begin{array}{l}\text { t TV-spot: } \\
\text { 06-numer: }\end{array}$ & $\begin{array}{l}100000 \\
150000\end{array}$ \\
\hline & OK & \multicolumn{2}{|c|}{ Annuleer } & Help & 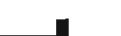 \\
\hline
\end{tabular}

N.B. De ingevulde getallen zijn willekeurig

Figuur 5.9

Het Reanimatie- en Opname-scherm van de CHZ-Simulator

In het reanimatieprogramma wordt de kans verhoogd dat bij SD reanimatie toegepast kan worden. Dit wordt gedaan door voor zogenaamde omgevingspersonen (bijv. familieleden) van oud-patiënten (de CHZ-bevolking) reanimatiecursussen te organiseren. De aantallen deelnemende personen kunnen naar keuze worden ingevuld. De cursussen worden periodiek herhaald.

Het gevolg is een reductie van de SD-incidentie uit de CHZ-bevolking. Een onbedoeld neveneffect is een stijging (zij het in geringere mate dan de SD-reductie) van de FMI1 en FMI2. De "SD-overlevenden" bereiken nu het ziekenhuis met AMI als effect van het reanimatieprogramma. 


\section{(v) Opnameprogramma}

Het opnameprogramma richt zich op een verkorting van de periode tussen moment van optreden AMI en het moment van opname in de CCU. De vertraging zit hem niet in de ambulancerit op zich maar in het signaleringsmoment (zie ook Bijlage III).

Het opnameprogramma bestaat uit voorlichting via de TV en een gratis 06-nummer om een ambulance op te roepen. Dit alles gericht om het opnameproces te verkorten. Het betreffende scherm is in figuur 5.9 te zien. Het programma betreft het gedeelte "B)" van het scherm. De parameters met betrekking tot het reanimatie-scherm worden vervolgens op hun beurt op "0" ingesteld.

Er zijn diverse effecten:

(a) Een reductie van FMI 1, daar de opname sneller plaatsvindt.

(b) Een afname van FMI2 en de operatiemortaliteit. Door de snellere opname zal de toestand van de patiënt relatief gunstiger zijn waardoor de behandeling een grotere kans op succes heeft.

(c) Een stijging van het percentage onterechte opnamen. Indien mensen opmerkzaam gemaakt worden op de symptomen van AMI, zullen er meestal uit angst voortkomende onterechte zelfdiagnoses ontstaan met een opname tot gevolg. In de Verenigde Staten zou ca. 50\% van alle CCU-opnames onterecht zijn (vgl. Weinstein e.a., 1985). Een van de oorzaken van dit hoge percentage onterechte CCU-opnames komt mogelijk voort uit de verhoogde ziekenhuis-toegankelijkheid via de mobiele coronary care unit (MCCU). We hebben dit percentage voor de Nederlandse situatie op 30\% ingeschat (vgl. Gezondheidsraad, 1984/16).

(d) Toepassing van het IVT vindt alleen plaats binnen 4 uur na het optreden van de AMI (zie Hoofdstuk 2). Bij versnelde opname zijn er dus meer kandidaten voor IVT. Dit werkt gunstig voor de verdere prognose van de patiënt.

Al deze effecten zijn evenredig verwerkt met de hoogte van het vast te stellen TV-Budget.

\section{(vi) Operatiecapaciteit}

Dit programma biedt de mogelijkheid de operatiecapaciteit te beperken of te verruimen.

Het betreffende invulscherm uit de CHZ-Simulator is in figuur 5.10 opgenomen. 


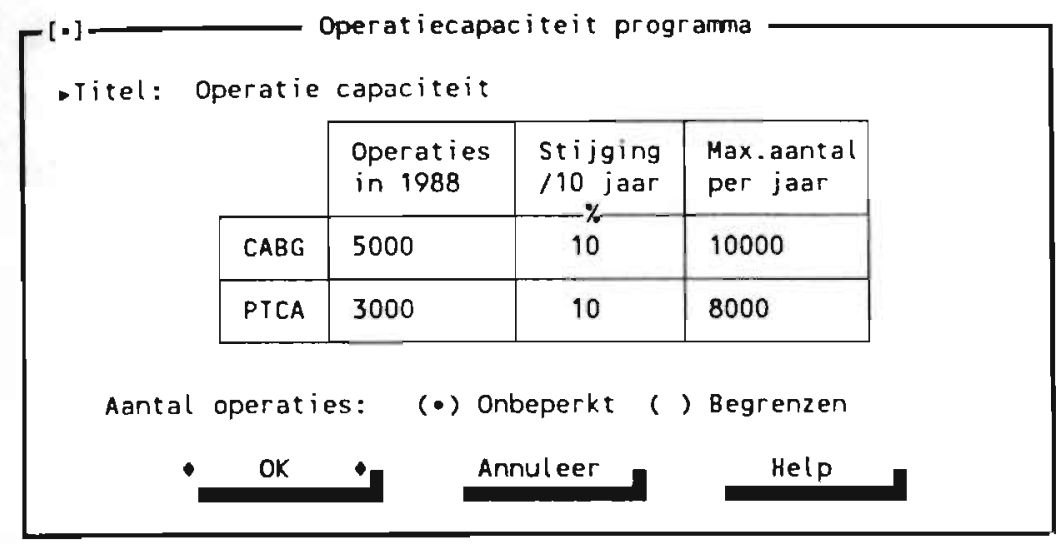

NB. De ingevulde getallen zijn willekeurig.

Figuur 5.10 Het Operatie Capaciteit-scherm van de CHZ-Simulator

Op twee manieren is de operatiecapaciteit af te grenzen. In de eerste plaats door een jaarlijkse procentuele stijging toe te staan vanuit het niveau in 1988. De tweede manier is een absoluut plafond. Beide begrenzers werken simultaan.

Overigens lijkt het aantal uitgevoerde CABG's zich te stabiliseren op een stijging van hooguit 1 a $2 \%$ per jaar, terwijl het aantal PTCA's tussen 1988 en 1990 met 44\% gestegen is (CCA, 1990). We hebben de betreffende modelparameters zodanig ingesteld dat de gesignaleerde groei van het aantal operaties in het model nagebootst wordt (zie de in de vorige paragraaf 5.3 genoemde trend in het basisscenario met betrekking tot CABG en PTCA).

De effecten naar gezondheid en kosten zijn indirect. Indien het toegestane aantal operaties overschreden wordt zal er een vervangende therapie plaatsvinden. In het programma geldt hiervoor de hiërarchie: PTCA vervangt CABG en MED vervangt PTCA bij overschrijden van het toegestane aantal operaties. 
6 SCENARIO-ANALYSE

6.1 Inleiding

6.2 Bevolkingsstudie CHZ Preventie scenario's

6.3 Cohortstudie CHZ Preventie scenario's

6.4 Bevolkingsstudie CHZ Medische scenario's

6.5 Cohortstudie CHZ Medische scenario's 


\subsection{Inleiding}

In dit hoofdstuk presenteren we de resultaten van een aantal CHZ-scenario's (de scenario-"output"). Dit heeft vooral de bedoeling als voorbeeld te dienen voor de mogelijkheden van het model. Daarnaast kan de lezer zich een indruk vormen wat voor scenario's zoals doorgerekend kunnen worden.

Zoals eerder genoemd in Hoofdstuk 5 hebben we een tijdsperiode van maximaal 22 jaar gesimuleerd. In verband met de snelle technologische ontwikkelingen en de onzekerheden in het model heeft het weinig zin een periode langer dan 22 jaar te simuleren. Een uitzondering vormt een kosteneffectiviteitsstudie, toegepast op een cohortstudie, waarbij het van belang is de totale levensverwachting te bepalen van het cohort.

In onze presentatie hebben we ervoor gekozen om de resultaten van de scenario's op jaarbasis met het basisscenario en eventueel andere scenario's te vergelijken. Op zich kan men hieruit een volledig beeld van de verschillen afleiden. We onderscheiden twee typen scenario's: 1) preventiescenario's, en 2) medische scenario's. De scenario's zijn ingedeeld bij het betreffende gezondheidsprogramma.

In figuur 6.1 is het scherm uit de CHZ-simulator opgenomen dat een overzicht geeft van de verschillende evaluatie-variabelen die beschouwd kunnen worden. Evaluatie-variabelen zijn kengetallen die de uitkomsten van de scenario's weergeven en gebruikt kunnen worden voor de analyse van de uitkomsten in vergelijking met de kengetallen van andere scenario's.

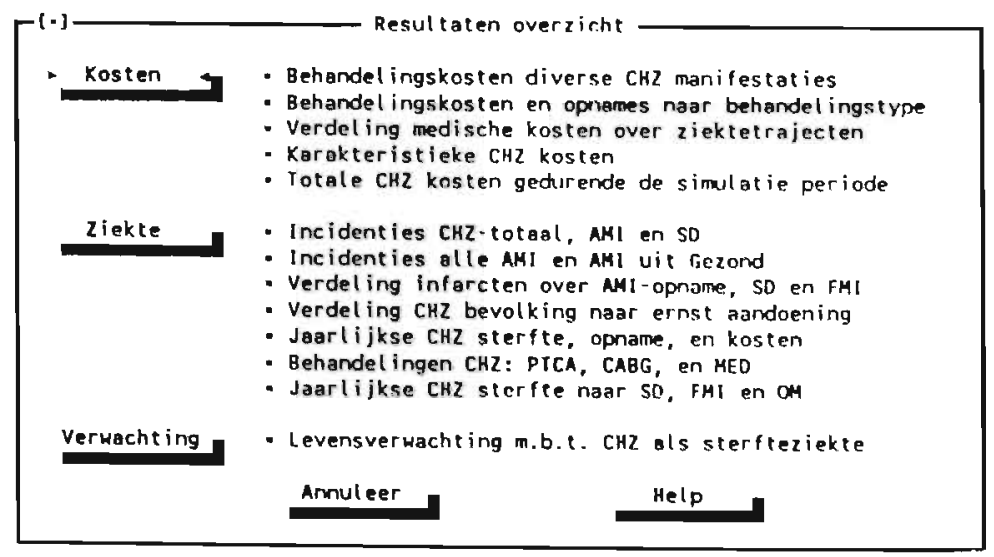

Figuur 6.1 Overzicht van evaluatie-variabelen van de $\mathrm{CHZ}$-simulator 
Hoewel per scenario ieder jaar vele kengetallen te presenteren zijn hebben we ervoor gekozen ons per scenario tot een klein aantal presentaties, die we relevant achten, te beperken. De meeste resultaten zijn intuïtief te onderbouwen.

De resultaten van scenariostudies betreffen lange termijn gevolgen. De lange termijn gevolgen kunnen niet gevalideerd worden met betrekking tot hun betrouwbaarheid. We hebben in Hoofdstuk 5 benadrukt dat de kwaliteit van een toekomstverkenning samenhangt met de volledigheid van inzichten met betrekking tot het betreffende werkterrein. Er blijven bij toekomstverkenningen nog zoveel "bekende" en "onbekende" onzekerheden, dat het ons niet erg zinvol lijkt om naar absolute uitkomsten van scenario's te kijken die een periode bestrijken langer dan zeg 5 jaar. Wat wel voor een langere periode gedaan kan worden is het onderling vergelijken van de uitkomsten van de verschillende scenario's. Het gaat dan met name om de verschillen, de relatieve betekenis, tussen de kengetallen van deze scenario's.

We zullen in dit hoofdstuk geen poging doen om alle figuren uitputtend te bespreken. De illustratie van een en ander blijft voorop staan.

We geven hier een samenvattend overzicht van de wijze waarop een scenarioanalyse in ons model plaatsvindt. Voor een verdere toelichting op deze methodologische bespreking verwijzen we naar Hoofdstuk 5 en naar onderdelen uit de Hoofdstukken 3 en 4.

Een scenario-analyse vindt plaats in de volgende stappen:

1. Bepaal de determinanten (risicofactoren) van de ziekte met betrekking tot de gekozen simulatiegroep.

2. Kwantificeer de relatie tussen de determinanten en de ziekte als functie van de tijd (het aanbrengen van wijzigingen in het verloop van de zogenaamde autonome trends).

3. Bepaal de huidige standaardprocedures van de medische therapieën voor de ziekte en de bijbehorende prognoses (gegeven in het bassisscenario).

4. Bepaal voor de onbekende aspecten de onzekerheidsmarges (de modelparameters).

5. Formuleer een scenario dat één of meerdere van de volgende onderdelen omvat (vgl. Bijl, 1991):

a) mogelijke toekomstige trajecten van de risicoprofielen (bijvoorbeeld gekoppeld aan preventieprogramma's,

b) mogelijke toekomstige paden met betrekking tot de effecten van medische programma's voor de gekozen simulatiegroep, en

c) keuzen voor de onzekere parameters (modelparameters). 
6. Bepaal voor dit scenario de mogelijke toekomstige effecten met betrekking tot (de kwaliteit van leven en) de levenswinst ten aanzien van de beschouwde ziekte en de mogelijke toekomstige kosten die samenhangen met gekozen gezondheidszorgprogramma's.

7. Formuleer een ander scenario en herhaal de vorige stap.

Op deze manier is de mogelijkheid ontstaan de uitkomsten van de scenario's onderling te vergelijken en om zekere planningsstrategieën op hun waarde te beoordelen.

Om scenario's onderling op hun kosteneffectiviteit te beoordelen is de volgende procedure als zodanig geaccepteerd:

(i) Bepaal het risicoprofiel van het cohort.

(ii) Leg een basisscenario vast. Bijvoorbeeld de rechtstreekse voortzetting van de huidige trends (vgl. de hierboven genoemde punten 2-4).

(iii) Formuleer de belangrijkste onderdelen van het scenario (vgl. punten 5-7 hierboven genoemd).

(iv) Bereken voor ieder scenario, aan te duiden als $s$, de extra kosten vergeleken met het basisscenario, alsmede de extra bijdrage aan de gezondheid van het cohort. Gewoonlijk betreft dit laatste aspect de extra winst in levensverwachting van het scenario ten opzichte van het basisscenario.

(v) Lat $\Delta c(s)$ respectievelijk $\Delta g(s)$ de extra kosten respectievelijk de extra winst in levensjaren voor scenario's zijn vergeleken met het basisscenari$o$, al dan niet verdisconteerd teruggebracht naar het aanvangsjaar van de simulatie.

(vi) Bereken $\Delta c(s) / \Delta g(s)$ als indicator (kosteneffectiviteitsratio) voor elk scenario. Het "beste" scenario is dat scenario waarvoor $\Delta c(s) / \Delta g(s)$ het kleinst is.

Het hoofdstuk is als volgt ingedeeld. We presenteren de resultaten van de doorgerekende preventie scenario's op bevolkingsniveau in paragraaf 6.2. In paragraaf 6.3 behandelen we preventiescenario's waarvan de preventieprogramma's met behulp van een cohortstudie zijn bepaald. De medische scenario's die met behulp van een bevolkingsstudie zijn gesimuleerd worden in paragraaf 6.4 behandeld. We geven in paragraaf 6.5 een aantal medische scenario's die toegepast op een cohortstudie zijn doorgerekend. De in dit hoofdstuk behandelde scenario's zijn doorgerekend met versie 2.1 van de CHZ-simulator. 


\subsection{Bevolkingsstudie CHZ Preventiescenario's}

De in deze paragraaf beschouwde preventiescenario's betreffen een bevolkingsstudie (zie Hoofdstuk 5). De preventiescenario's die met hehulp van een cohortstudie zijn gesimuleerd worden in de volgende paragraaf 6.3 besproken.

Er zijn twee typen preventieprogramma's:

1) cholesterol reducerende programma's, en

2) anti-rook programma's (zie Hoofdstuk 5).

Er is ook een combinatie van beide voorgaande programma's mogelijk. We hebben deze paragraaf ingedeeld in twee secties. De twee secties lopen analoog aan de twee typen preventieprogramma's, te weten:

A Cholesterol Reducerend Programma in Bevolkingsstudie,

B Anti-Rook Programma in Bevolkingsstudie.

\section{A. Cholesterol Reducerend Programma in Bevolkingsstudie}

We behandelen met betrekking tot het cholesterol reducerend programma twee verschillende typen bevolkingsstudies, te weten:

(i) Simulatiegroep Cholesterol Bevolking (niet-verhoogd DBD, niet-rokend),

(ii) Simulatiegroep Cholesterol Bevolking (verhoogd DBD, niet-rokend).

(i) Simulatiegroep Cholesterol Bevolking (niet-verhoogd DBD, nietrokend)

In de eerste bevolkingsstudie is een simulatiegroep Cholesterol Bevolking gevormd waarvan het risicoprofiel in tabel 6.1 is weergegeven.

Mannen en Vrouwen van 0-100 jaar

Cholesterol niveau

Diastolische bloeddruk

Rookgedrag

Tabel 6.1

Simulatiegroep Cholesterol Bevolking (niet-verboogd DBD, niet-rokend)

Er zijn twee preventieprogramma's op deze groep personen toegepast:

1) een cholesterol reducerend dieet programma, en

2) een cholesterol reducerend miedicatie programma. 
We hebben de scenario's die door deze twee programma's gevormd worden genoemd het Dieet-Chol-Bevolking scenario respectievelijk het Med-Chol-Bevolking scenario.

De beide programma's staan afgebeeld in tabel 6.2.

\begin{tabular}{|c|c|c|}
\hline & Programma Chol-Red.-Dieet & Programma Chol.-Red.-Med. \\
\hline Startjaar & 1993 & 1993 \\
\hline Eindjaar & 2005 & 2005 \\
\hline Aanlooptijd & 3 jaar & 3 jaar \\
\hline Afbouwtijd & 3 janr & 3 jaar \\
\hline Reactie & $100 \%$ & $100 \%$ \\
\hline Reductie & $10 \%$ & $25 \%$ \\
\hline Trouw & $100 \%$ & $100 \%$ \\
\hline Vaste kosten & f 2 mln p.j. & f 2 mln p.j. \\
\hline Kosten 1ste Jaar & $f 490,-$ p.p. p.j. & f 2100,-- p.p. p.j. \\
\hline Vervolgkosten & f $270,-$ p.p. p.j. & f $1600,-$ p.p. p.j. \\
\hline
\end{tabular}

Tabel 6.2

Cholesterol Reducerend Dieet Programma en Cholesterol Reducerend Medicatie Programma

We hebben om zuiver illustratieve redenen in tabel 6.2 als startjaar het jaar 1993 gekozen. Evengoed kan de gebruiker het jaar 1988 of elk ander jaar als startjaar kiezen. De in tabel 6.2 weergegeven reductiepercentages zijn reële getallen gebaseerd op literatuurstudies (zie Hoofdstuk 2). De vaste kosten zijn gemakshalve voor beide typen programma's op $f 2 \mathrm{mln}$. gesteld. Dit bedrag is gebaseerd op een geschatte kostprijs TV-spot (zie Bijlage III). De reductie $25 \%$ cholesterolmedicatie uit tabel 6.2 is gebaseerd op de toediening van $25 \mathrm{mg}$. Simvastatine per dag, inclusief dieet (zie ook Hoofdstuk 2).

In de figuren 6.2-6.3 zijn de effecten van de programma's voor het mogelijke toekomstige pad van de simulatiegroep met betrekking tot $\mathrm{CHZ}$ te vinden. Deze effecten zijn weergegeven via de karakteristieke kengetallen van coronaire hartziekten, namelijk CHZ-opname, CHZ-kosten en $\mathrm{CHZ}$-sterfte, allen op jaarbasis. 
Vergelijking van jaarlijkse $\mathrm{CHZ}$ kengetallen: sterfte, opnamen en kosten

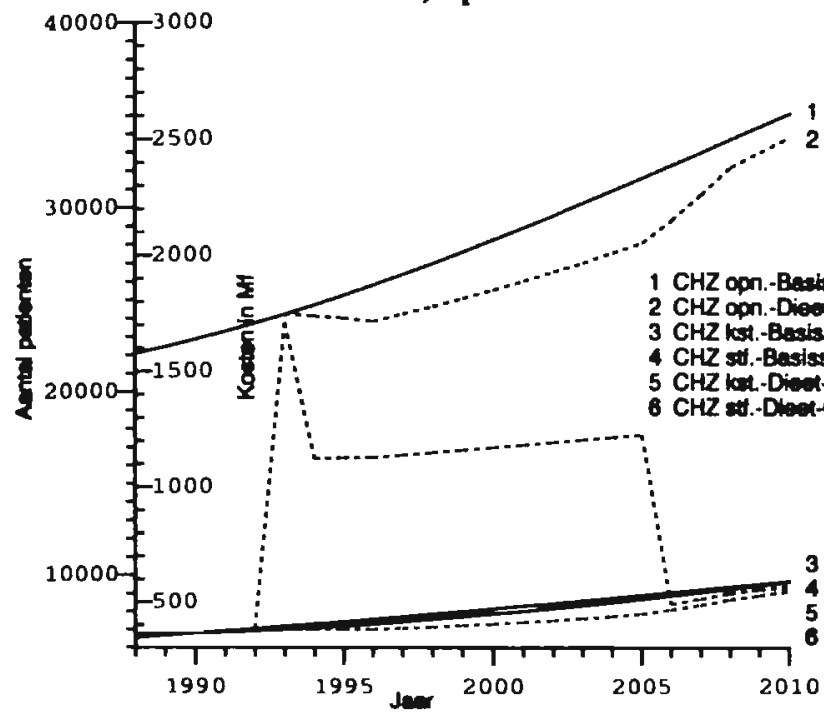

Figuur 6.2

Karakteristieke kengetallen van het Dieet-Chol-Bevolking scenario bij toepassing van het Cholesterol Reducerend Dieet Programma op de gehele Nederlandse bevolking

Vergelijking van jaarlijkse $\mathrm{CHZ}$ kengetallen:

sterfte, opnamen en kosten

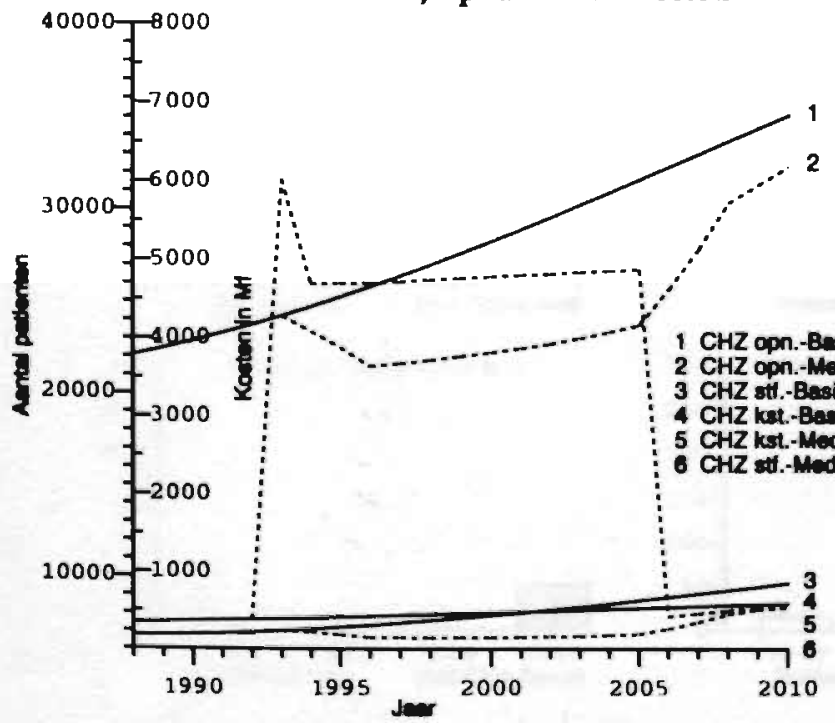

Figur 6.3 Karakteristieke kengetallen van het Med-Chol-Bevolking scenario bij toepassing van het Cholesterol Reducerend Medicatie Programma op de gehele Nederlandse bevolking 
De gezondheidseffecten van het medicamenteuze programma zijn aanmerkeljj sterker dan die van het dieet programma. Dit betekent uiteraard minder sterfte en minder opnamekosten. De preventie kosten van het medicamenteuze programma zijn echter dermate hoog dat de totale CHZ-kosten voor dit programma ongeveer 4 keer zo hoog zijn als die van het dieet programma (zie ook paragraaf 6.3). Di kostenpiek in 1993 voor beide scenario's wordt veroorzaakt doordat de kostprij. zen van zowel het medicatieprogramma als die van het dieetprogramma in het 1ste jaar hoger zijn dan in de vervolgjaren (zie Bijlage III). In 1996 vertonen de kosten- en opnamecurve een lichte knik. Deze knik hangt samen met de aanlooptijd van 3 jaar. Na 3 jaar bereikt het programma het maximale effect met betrekking tot de verlaging van de incidentiekansen. Na die periode nemen de opnames (en kosten) geleidelijk aan toe als gevolg van het vergrijzingseffect.

Er bestaat een soort tweede orde effect betreffende de situatie na afloop van de preventieprogramma's. In de figuren 6.2 en 6.3 is te zien dat na het jaar 2008 (afbouwtijd) de totale CHZ-opname voor beide scenario's nog steeds lager is dan in het basisscenario. Dit komt omdat de geringere incidentie van het preventieprogramma heeft geleid tot een geringere aangroei van de CHZ-bevolking. $\mathrm{De}_{\mathrm{e}}$ jaarlijkse secundaire incidentie uit deze CHZ-bevolking blijft zodoende ook achter hij het basisscenario. Dit effect treedt sterker op voor het Med-Chol-Bevol. kingscenario uit figuur 6.3. De verklaring hiervoor is dat dit scenario zoals hierboven genoemd een veel krachtiger preventieprogramma heeft dan het DieetChol-Bevolkingscenario.

In de figuren 6.4-6.5 worden de karakteristieke CHZ-kosten in 1993 (het aanvangsjaar) weergegeven. Het spreekt voor zich dat zowel de gemiddelde kosten per CHZ-behandeling als de gemiddelde kosten per CHZ-persoon voor het medcatie programma erg hoog zijn vergeleken met het dieet programma. 

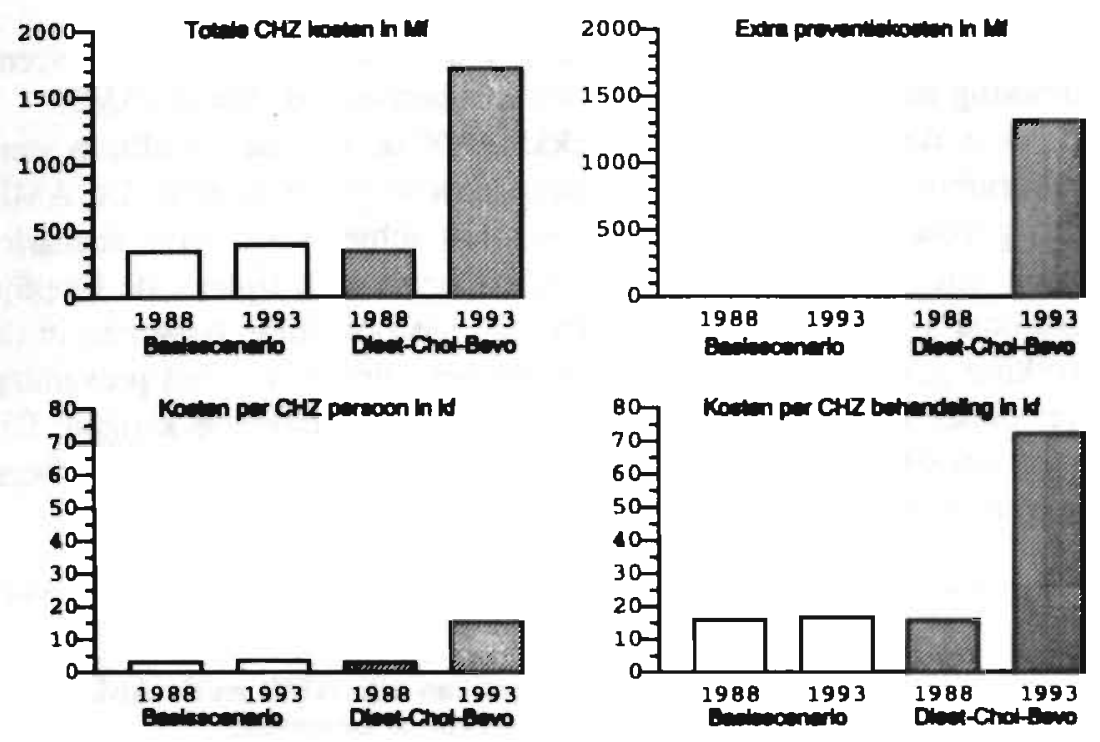

Figuur 6.4

Karakteristieke kosten van bet Dieet-Chol-Bevolking scenario bij toepassing van bet Cholesterol reducerend Dieet Programma op de gebele Nederlandse bevolking
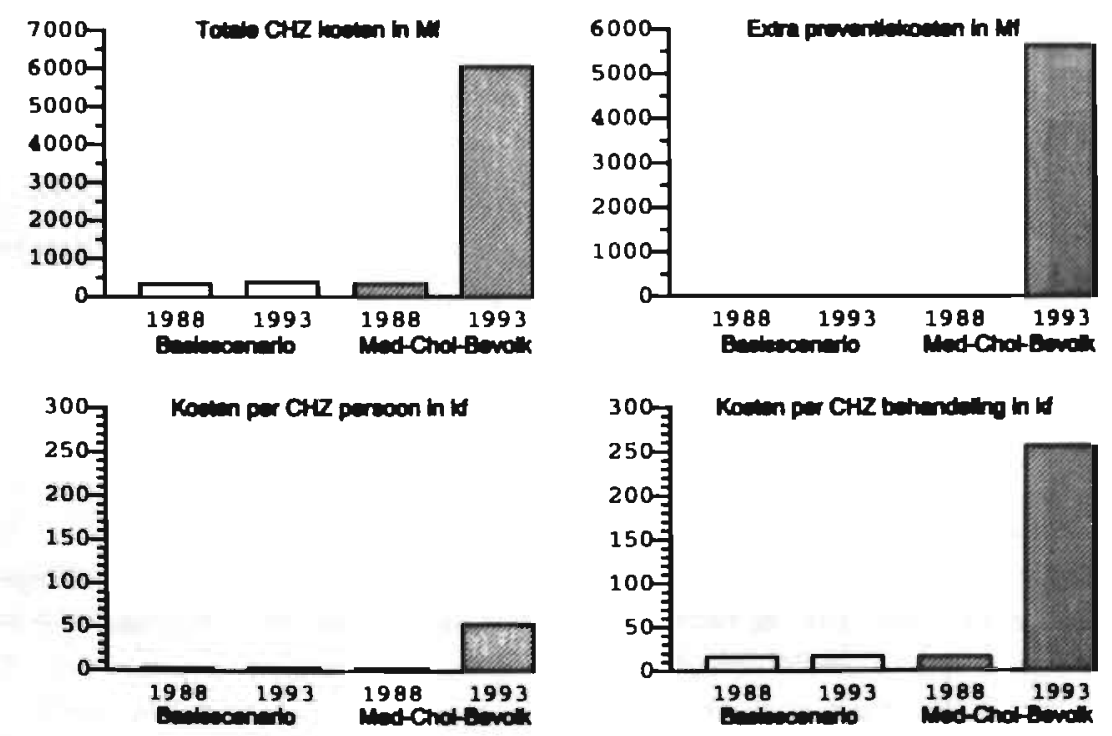

Figuur 6.5

Karakteristieke kosten van het Med-Chol-Bevolking scenario bij toepassing van het Cholesterol Reducerend Medicatie Programma op de gehele Nederlandse bevolking 
We presenteren in de figuren 6.6-6.7 de effecten van de twee scenario's met betrekking tot de incidenties van het acute myocard infarct (AMI).

$\mathrm{Er}$ is in deze figuren met betrekking tot de situatie na afloop van de preventieprogramma's een ander soort tweede orde effect te zien. De AMI-incidentie uit de "gezonde" bevolking (AMI-gezond) schiet voor beide scenario's na het jaar 2008 boven het basisscenario uit. Er heeft zich tijdens de looptijd van de programma's als het ware een reservoir van potentiële personen in de gezonde bevolking gevormd, die als gevolg van het aflopen van het preventieprogramma en het ouder worden in 2008 alsnog een AMI-incidentie krijgen. Dit effect treedt voor het Med-Chol-Bevolking scenario om dezelfde redenen (weer) in iets sterkere mate op dan voor het Dieet-Chol-Bevolkingscenario.

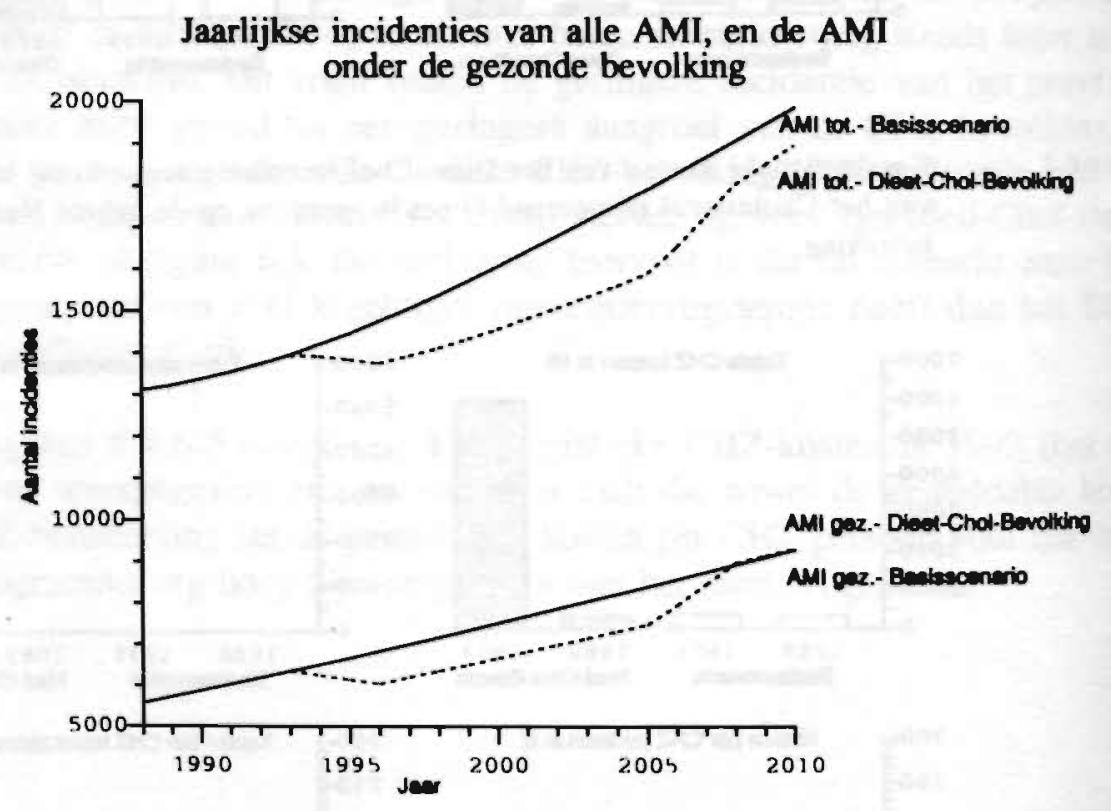

Figuur 6.6 Karakteristieke AMI-incidenties van bet Dieet-Chol-Bevolkingscenario bij toepassing van het Cholesterol Reducerend Dieet Programma op de gebele Nederlandse bevolking 


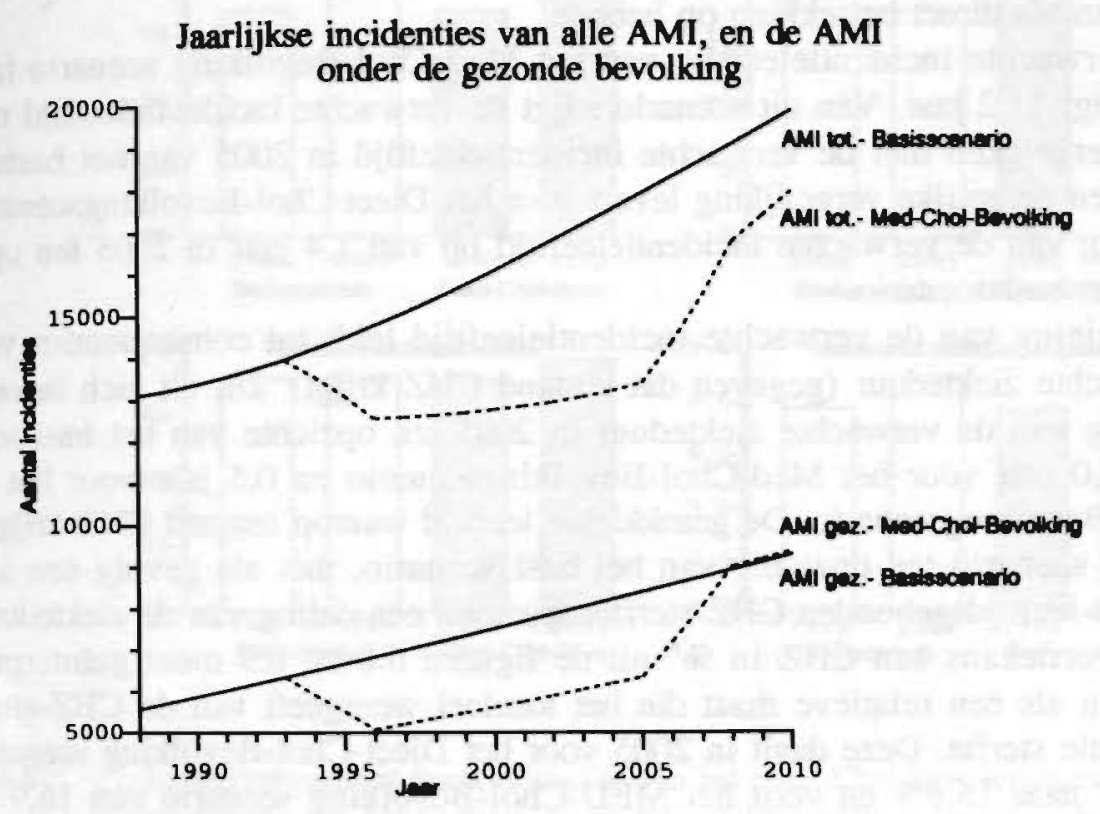

Figuur 6.7

Karakteristieke AMI-incidenties van het Med-Chol-Bevolkingscenario bij toepassing van het Cholesterol Reducerend Medicatie Programma op de gehele Nederlandse bevolking

De levensverwachting karakteristieken zijn in de figuren 6.8-6.9 opgenomen. Hierbij moet bedacht worden dat in het basisscenario de reductie van de nietCHZ-sterfte (in de gezonde bevolking en in de CHZ-bevolking) gesteld is op 0,7 $\%$ per jaar (zie Hoofdstuk 5 en Bijlage I). Dit betekent dat de sterften aan alle ziekten, behalve die van de CHZ-sterfte, met $0,7 \%$ per jaar afneemt. Deze parameter geeft als het ware de conditie van de bevolking weer met betrekking tot haar gezondheidstoestand.

Wat betreft de levensverwachting is het zinvol onderscheid te maken tussen de levensverwachting voor personen die aan $\mathrm{CHZ}$ overlijden (levensverwachting "gegeven wel $\mathrm{CHZ}$ ") en de levensverwachting voor personen die aan een andere doodsoorzaak overlijden (levensverwachting "gegeven geen $\mathrm{CHZ}$ "). In bijlage II testen we de gevoeligheid van de variabele "levensverwachting geen $\mathrm{CHZ}$ " op de levensverwachtingskengetallen. De levensverwachting voor de totale bevolking is dan een weging op basis van betrokken aantallen personen van deze twee getallen. De analyse van de levensverwachting richt zich dan eerst op het (potentieel) 
zieke gedeelte van de bevolking waar de effecten van een gezondheidszorg. programma direct betrekking op hebben.

De verwachte incidentieleeftijd van het Med-Chol-Bevolking scenario in 2005 bedraagt 71.2 jaar. Van dit scenario stijgt de verwachte incidentieleeftijd met 3,4 jaar vergeleken met de verwachte incidentieleeftijd in 2005 van het basisscenario. Een dergelijke vergelijking levert voor het Dieet-Chol-Bevolkingscenario een stijging van de verwachte incidentieleeftijd op van 1,4 jaar in 2005 ten opzichte van het basisscenario.

De stijging van de verwachte incidentieleeftijd leidt tot consequenties voor de verwachte ziekteduur (gegeven dat iemand CHZ krijgt). Dit uit zich in een verkorting van de verwachte ziekteduur in 2005 ten opzichte van het basisscenario met 1,0 jaar voor het Med-Chol-Bevolkingscenario en 0,5 jaar voor het DieetChol-Bevolkingscenario. De gemiddelde leeftijd waarop iemand CHZ krijgt stijgt in het scenario ten opzichte van het basisscenario, met als gevolg een stijging van de leeftijdsgebonden CHZ-sterftekansen en een daling van de ziekteduur.

De "sterftekans aan $\mathrm{CHZ}$ in \%" uit de figuren 6.8 en 6.9 moet geïnterpreteerd worden als een relatieve maat die het aandeel weergeeft van de CHZ-sterfte in de totale sterfte. Deze daalt in 2005 voor het Dieet-Chol-Bevolking scenario van $16,9 \%$ naar $15,6 \%$ en voor het MED-Chol-Bevolking scenario van $16,9 \%$ naar $13,8 \%$. Het gespaarde gedeelte van de bevolking zal in het model aan een nietCHZ-ziekte komen te overlijden. Het aandeel van de niet-CHZ-sterften neemt toe, terwijl dat van de CHZ-sterfte als gevolg van het scenario in 2005 juist afneemt (zie ook Hoofdstuk 7). In feite wordt er in het model voor wat betreft de sterftesubstitutie in de gezonde bevolking en in de CHZ-bevolking voor een deel rekening gehouden met het optreden van vervangende sterften (zie ook Hoofdstuk 7).

De gevolgen voor de levensverwachting in 2005 vergeleken met het basisscenario zijn dat deze stijgt voor het Med-Chol-Bevolking scenario met 0,9 jaar en voor het Dieet-Chol-Bevolkingscenario met 0,4 jaar. We merken op dat het begrip levensverwachting hier betrekking heeft op de totale bevolking. De levenswinst van de personen die in 2005 in het basisscenario wel $\mathrm{CHZ}$ kregen, maar als gevolg van een gezondheidszorgprogramma niet meer, is aanzienlijk meer en bedragen $2,4(3,4-1,0)$ respectievelijk $0,9(1,4-0,5)$ levensjaren. We komen hierop terug verderop in deze paragraaf bij de bespreking van de anti-rook campagne. 

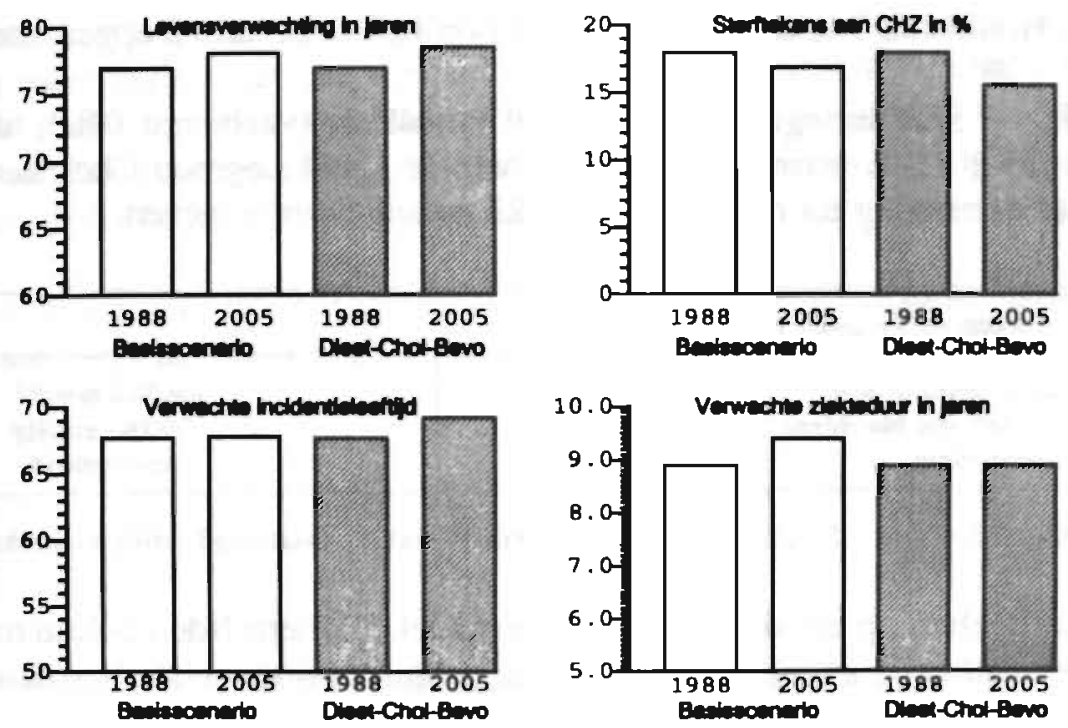

Figuur 6.8

Levensverwachting karakteristieken van het Dieet-Chol-Bevolkingscenario bij toepassing van bet Cholesterol Reducerend Dieet Programma op de gehele Nederlandse bevolking
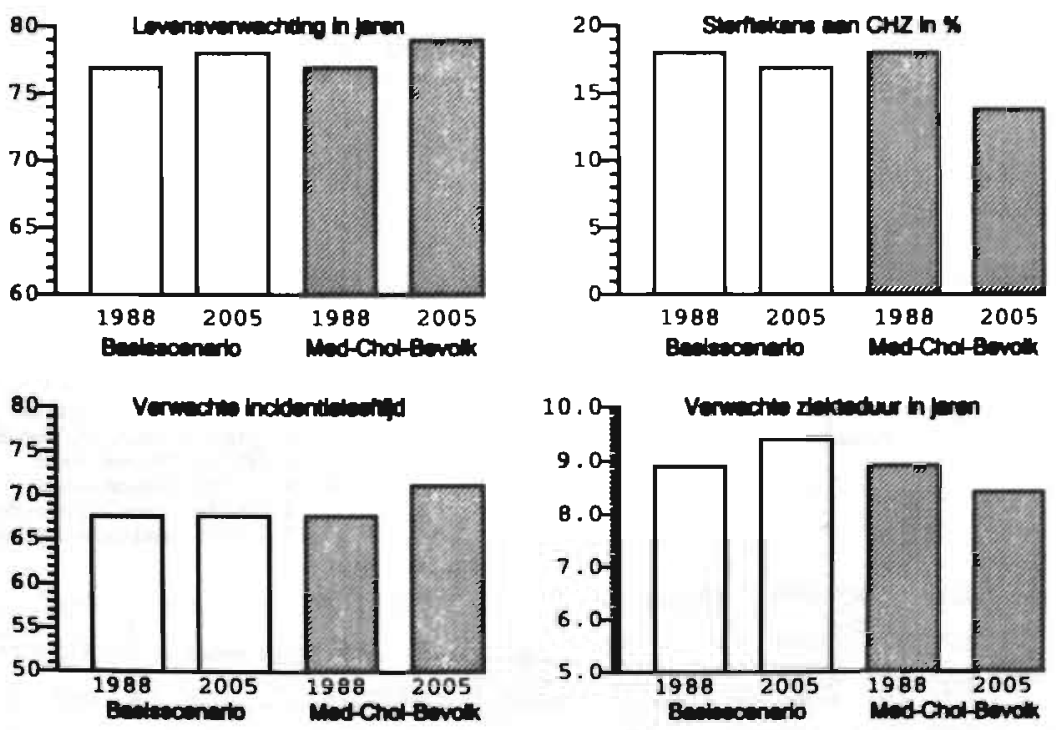

Figuur 6.9

Levensverwachting karakteristieken van het Med-Chol-Bevolkingscenario bij toepassing van het Cholesterol Reducerend Medicatie Programma op de gehele Nederlandse bevolking 
In Hoofdstuk 7 is een aantal variaties op beide scenario's opgenomen.

(ii) Simulatiegroep Cholesterol Bevolking (verhoogd DBD, niet-rokend) In tabel 6.3 worden de kenmerken van de simulatiegroep Cholesterol Bevolking met betrekking tot de tweede bevolkingsstudie weergegeven:

\begin{tabular}{|l|c|}
\hline Mannen en Vrouwen van 0-100 jaar \\
\hline Cholesternl niveau & $6,0-20,0 \mathrm{mmol}$ \\
Diastolische bloeddruk & $90-150 \mathrm{~mm} / \mathrm{Hg}_{\mathrm{g}}$ \\
Rookgedrag & niet-rokend \\
\hline
\end{tabular}

Tabel 6.3

Simulatiegroep Cholesterol Bevolking (verhoogd DBD, niet-rokend)

We hebben op de simulatiegroep uit tabel 6.3 hetzelfde cholesterolreducerende medicatieprogramma toegepast dat is gebruikt bij de eerste bevolkingsstudie (zie tabel 6.2 van deze paragraaf).

Het betreffende scenario is genoemd het Med-Chol-Hyp-Bevolkingscenario.

De karakteristieke kengetallen en de levensverwachting karakteristieken van het Med-Chol-Hyp-Bevolkingscenario zijn in de figuren 6.10-6.11 opgenomen.

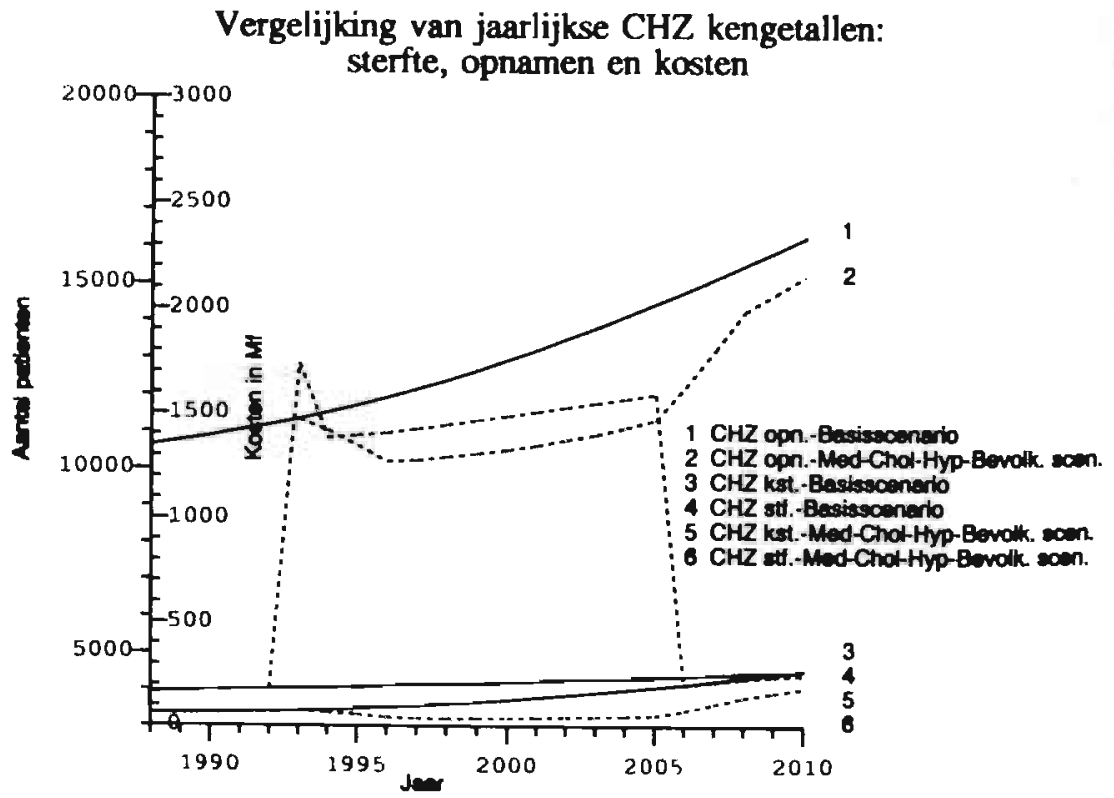

Figuur 6.10 Karakteristieke kengetallen van het Med-Chol-Hyp-Bevolking scenario bij toepassing van het Cholesterol Reducerend Medicatie Programma op de gehele Nederlandse bevolking 
De kosten van het Med-Chol-Hyp-Bevolking scenario uit figuur 6.10 liggen absoluut gezien aanzienlijk lager dan die van het Med-Chol-Bevolking scenario uit figuur 6.3. De reden hiervoor is dat de tweede simulatiegroep uit tabel 6.3 veel minder mensen omvat die beantwoorden aan het gestelde risicoprofiel, waardoor er ook minder medische consumptie optreedt.

We hebben in figuur 6.11 een vergelijking gemaakt tussen de gemiddelde kosten per CHZ-persoon van de drie scenario's.

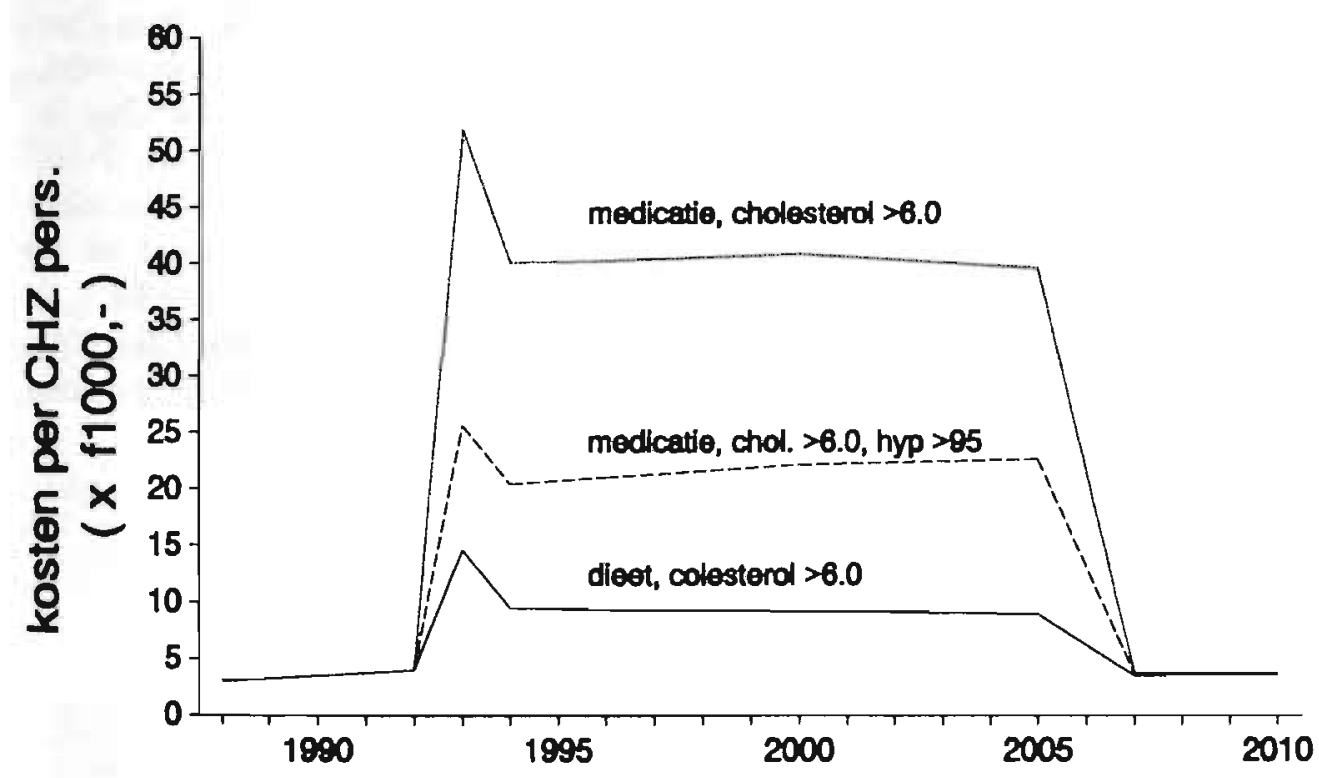

Figuur 6.11

Gemiddelde kosten per CHZ-persoon in $\mathrm{kf}$ van het Dieet-Chol-Bevolkingscenario, het Med-Chol-Bevolking scenario, het Med-Chol-Hyp-Bevolkingscenario bij toepassing van het Cholesterol Reducerend Medicatie Programma op de gehele Nederlandse bevolking

De curve met betrekking tot de gemiddelde kosten per CHZ-persoon van het Dieet-Chol-Bevolkingscenario heeft in tegenstelling tot de kostencurven van de andere twee scenario's een dalend verloop gedurende de looptijd van het preventieprogramma. De verklaring hiervoor is dat de $\mathrm{CHZ}$-bevolking zich met relatief meer mensen vult omdat er meer incidenties vanuit de gezonde bevolking optreden, terwijl er niet zoveel extra kosten meer gemaakt worden.

De gemiddelde kostencurve van het Med-Chol-Hyp-Bevolkingscenario uit figuur 6.11 ligt ver onder die van het Med-Chol-Bevolking scenario. In ons voorbeeld 
oefent het preventieprogramma geen directe preventieve invloed uit op de incidenties bij mensen met hypertensie. Er zullen in het Med-Chol-Hyp-Bevolking scenario meer mensen de CHZ-bevolking instromen, zonder dat er een evenredige stijging plaatsvindt van de preventiekosten. Het gevolg is dat de gemiddelde kosten per CHZ-persoon lager liggen.

Evenwel treedt er in figur 6.12 een fenomeen op met betrekking tot de aanwezigheid van een tweede verhoogde risicofactor (hypertensie naast verhoogd serumcholesterolgehalte) die een (extra) versterkend effect heeft op de kans op CHZ. Het fenomeen bestaat hieruit dat in geval van een preventieprogramma de verwachte levenswinst hoger is dan zonder de aanwezigheid van die tweede verhoogde risicofactor. De (verwachte) levenswinst in 2005 voor het Med-CholHyp-Bevolking scenario bedraagt 1,1 jaar in vergelijking met het basisscenario. In de figuren 6.8 en 6.9 bedroeg de levenswinst 0,9 jaar voor het Med-Chol-Bevolking scenario en 0,4 jaar voor het Dieet-Chol-Bevolking. De hogere levenswinst wordt simpelweg verklaard doordat de relatieve reductie met eenzelfde percentage bij een hoog aantal CHZ-incidenties in de aanvangssituatie tot een hogere absolute reductie leidt van die incidenties dan bij een laag aantal CHZ-incidenties. Feit blijft dat de levensverwachting in 2005 van het Med-Chol-Hypbevolking scenario uit figuur 6.12 lager is dan die van het Med-Chol-Bevolking scenario uit figuur 6.9 (78,3 jaar respectievlijk 78,9 jaar).

\section{Levensverwachting in relatie tot $\mathrm{CHZ}$}
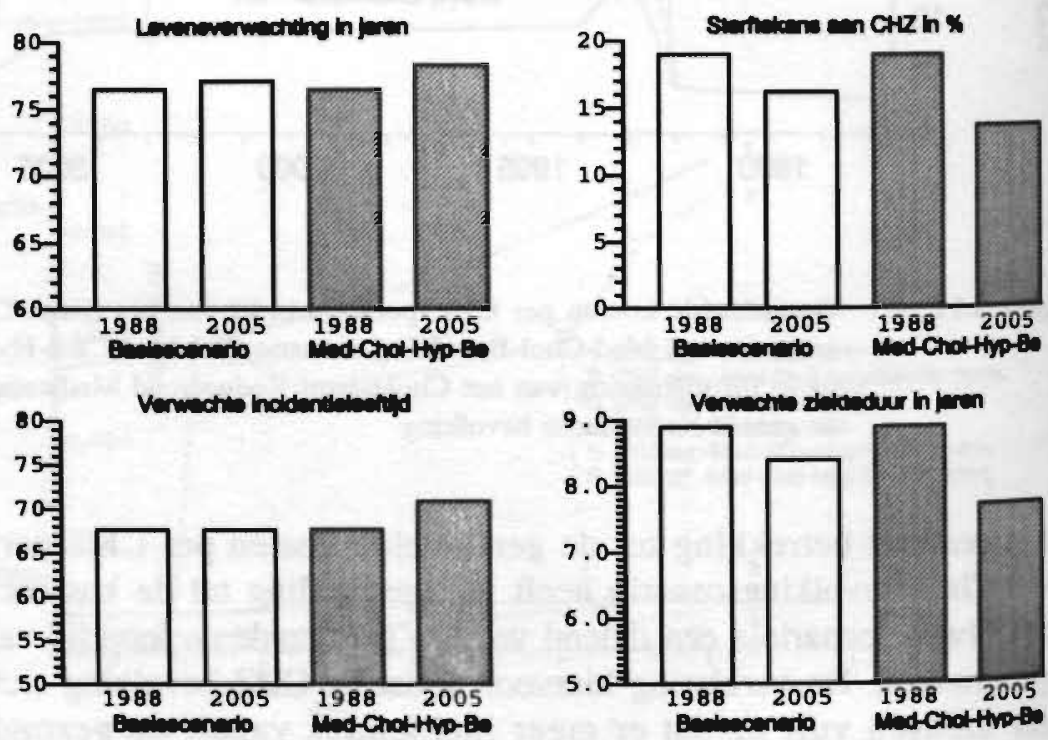

Figuur 6.12

Levensverwachting karakteristieken van het Med-Chol-Hyp-Bevolkingscenario bij toepassing van het Cholesterol Reducerend MedicatieProgramma op de gehele Nederlandse bevolking 


\section{B. Anti-Rook Programma in Bevolkingsstudie}

Er is met betrekking tot het anti-rook programma ter illustratie éen type bevolkingsstudie gesimuleerd.

In tabel 6.4 is het risicoprofiel van de simulatiegroep Roken Bevolking opgenomen.

\begin{tabular}{|l|c|}
\hline Mannen van 0 - 100 jaar \\
\begin{tabular}{l|c} 
Cholesterol niveau & $6,0-20,0 \mathrm{mmol}$ \\
Diastolische bloeddruk & $50-90 \mathrm{~mm} / \mathrm{Hg}$ \\
Rookgedrag & wel-rolkend
\end{tabular}
\end{tabular}

Tabel 6.4

Simulatiegroep Roken Bevolking (verhoogd chol, niet-verhoogd DBD)

De mannelijke Nederlandse bevolking vormt de simulatiegroep. De regressiecoefficiënten van de Framingham Heart Study (zie bijlage I) zijn vrij laag, reden waarom wij ervan afgezien hebben de gehele bevolking te simuleren.

Er is een anti-rookprogramma algemeen op deze simulatiegroep toegepast, zoals afgebeeld in tabel 6.5 .

We hebben het scenario genoemd het Stop-Ro-Algemeen-Chol-Bevolkingscenario.

\begin{tabular}{|l|c|}
\hline & Programma Chol.-Red.-Med. \\
\hline Startjaar & 1993 \\
Eindjaar & 2005 \\
Aanloopdjd & $4 \mathrm{jaar}$ \\
Afouwtijd & 4 Jaar \\
Reactie & $20 \%$ \\
Reductle & $100 \%$ \\
Trouw & $60 \%$ \\
Vaste kosten & f 2 min p.j. \\
Kosten 1ste jaar & f 116,- p.p. p.j. \\
Verrolgtosten & f 116,- p.p. p.j. \\
\hline
\end{tabular}

Tabel 6.5

Anti-Rook Programma Algemeen

We hebben in tabel 6.5 de reactie op $20 \%$ gesteld. Uit de praktijk blijkt vaak dat het aantal stoppers $20 \%$ van de interventiegroep bedraagt. Hiervan recidiveert $40 \%$. Met andere woorden de therapietrouw is $60 \%$ (vgl. Van Ree, 1981, Rose e.a., 1978). In Hoofdstuk 7 zijn hierover gevoeligheidsberekeningen opgenomen. 
De effecten van het anti-rookprogramma algemeen voor het scenario van de simulatiegroep zijn weergegeven in de figuren 6.13-6.14.

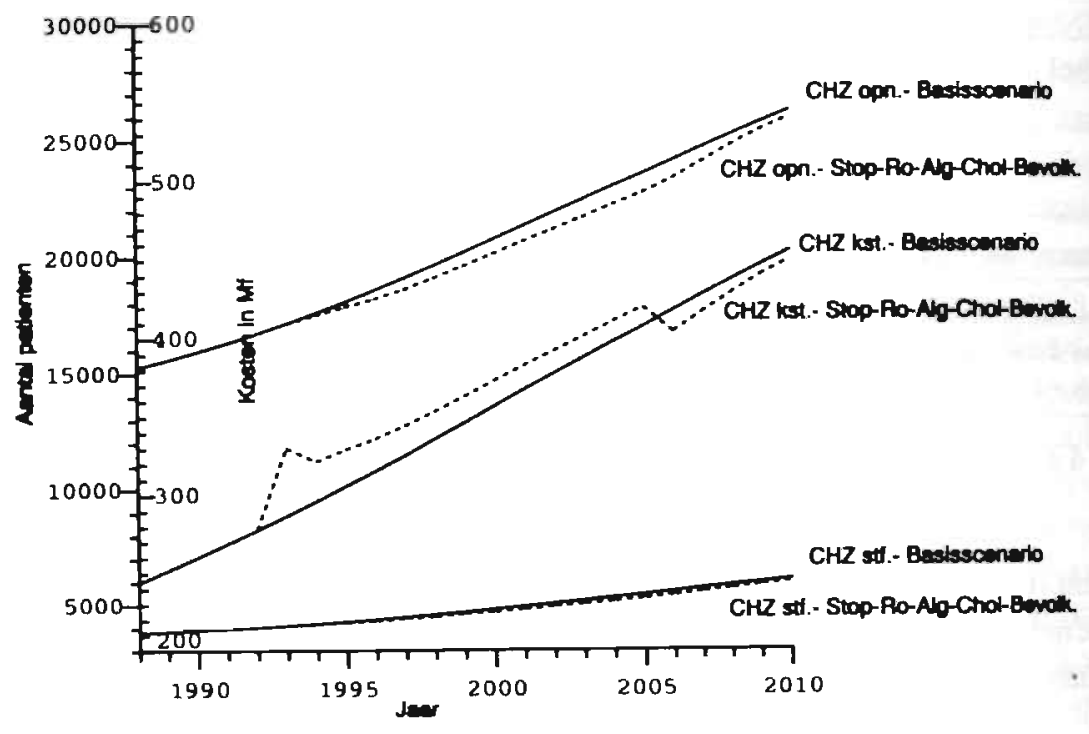

Figuur 6.13 Karakteristieke kengetallen van het Stop-Ro-Algemeen-Chol-Bevolking scenario bij toepassing van bet Anti-Rook Programma Algemeen op de mannelijke Nederlandse bevolking
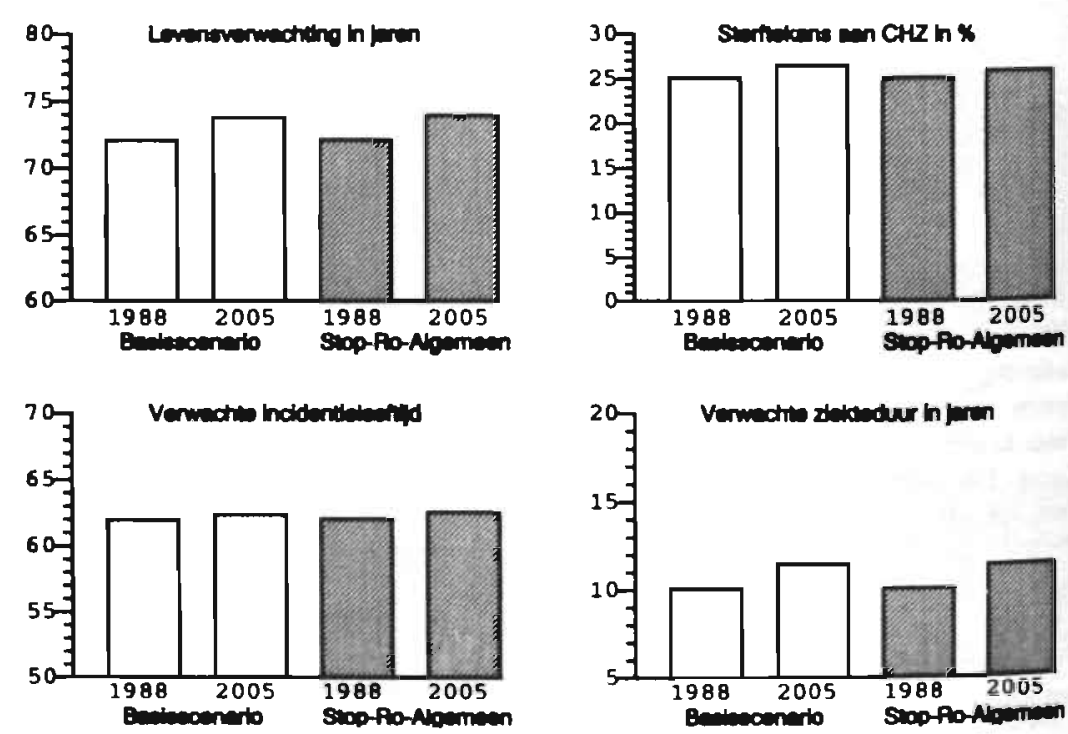

Figuur 6.14 Levensverwachting karakteristieken van het Stop-Ro-Algemeen-Chol-Bevolking scenario bij toepassing van het Anti-Rook Programma Algemeen op de mannelijke Nederlandse bevolking 
Er treedt in figuur 6.13 in vergelijking met de Chol-Bevolkingscenario's uit de vorige sectie ook een kostenpiek op in 1993, terwijl de kostprijzen van het antirookprogramma in alle jaren dezelfde zijn. De reden hiervoor is de lagere therapietrouw van $60 \%$. De kosten variëren rechtevenredig met de hoogte van de therapietrouw, behalve in het eerste jaar. In het eerste jaar van het scenario worden de kosten voor $100 \%$ meegenoemn (zie ook Hoofdstuk 7). Vanwege de lagere kostprijs liggen de preventiekosten in figuur 6.13 absoluut gezien ook veel lager dan die van met name het Med-Chol-Bevolkingscenario (vgl. figuur 6.3).

De knik in de kostenlijn (en de opnamelijn) in figuur 6.13 hangt samen met de aanlooptijd van 4 jaar.

We kunnen met betrekking tot figuur 6.14 het volgende opmerken. De verwachte incidentieleeftijd van het Stop-Ro-Algemeen-Chol-Bevolkingscenario is in 2005 met 0,1 jaar gestegen in vergelijking met die van het basisscenario. De ziekteduur is met 0,1 jaar gedaald, zodat per saldo er voor personen met CHZ geen levenswinst optreedt. De winst met betrekking tot de levensverwachting ligt voor het Stop-Ro-Algemeen-Cholesterol-Bevolking scenario echter op 0,1 jaar. De verklaring hiervoor is dat de gemiddelde leeftijd van het gedeelte van de bevolking dat niet aan $\mathrm{CHZ}$ overlijdt (de bespaarde bevolking) als gevolg van het anti-rook programma hoger is dan in de gezonde bevolking, waardoor de levensverwachting stijgt.

We hebben eerder gezien bij de bespreking van de cholesterol reducerende programma's in bevolkingsstudies dat de levenswinst "gegeven wel CHZ" hoger lag dan de levenswinst in de bevolking. Het idee is dat verhoogd cholesterol op oudere leeftijd een minder groot $\mathrm{CHZ}$-risico vormt in vergelijkijng met verhoogd cholesterol op jongere leeftijd. $\mathrm{Er}$ is in de Framingham Heart Study hiervoor een negatieve regressiecoëfficiënt ingevoerd, die de kans op CHZ bij een verhoogd cholesterol met het vorderen van de leeftijd doet afnemen. De gemiddelde leeftijd van de bespaarde bevolking zal in dit geval relatief jong zijn. De winst van de levensverwachting in de bevolking stijgt minder sterk in vergelijking met die "gegeven wel CHZ".

\subsection{Cohortstudie CHZ Preventiescenario's}

We bespreken nu de preventiescenario's die toegepast op een cohortstudie zijn doorgerekend.

In een preventiescenario op basis van een cohortstudie wordt een toekomstig pad uitgezet met betrekking tot de lotgevallen "gegeven wel CHZ" (en de daaraan verbonden medische kosten) uit de simulatiegroep die al dan niet als gevolg van een preventieprogramma bespaard zijn gebleven voor CHZ. In zo'n exercitie worden de verschillen van een preventiescenario ten opzichte van het basisscena- 
rio in vergelijking gebracht met verschillen die andere preventiescenario's hebben ten opzichte van het basisscenario.

De simulaticgroep bestaat bij aanvang (dus in 1988) uit een hypothetisch cohort van 1.00(0.000) mannen of vrouwen die allen een identiek risicoprofiel hebben en waar de preventieprogramma's ook na 2010 doorlopen (zie Hoofdstukken 4 en 5). Het cohort wordt gevolgd gedurende een fictieve prospectieve longitudinale studie tot het moment waarop iedereen uit deze groep uitgestorven is. Het cohort wordt tijdens de simulatie niet aangevuld met nieuwe mensen. De kosten en effecten van de scenario's worden in deze paragraaf niet-verdisconteerd teruggebracht naar 1988. In Hoofdstuk 7 komen we hierop terug.

We hebben de paragraaf analoog aan de verschillende preventieprogramma's ingedeeld in drie secties, te weten:

A Cholesterol Reducerend Programma in Cohortstudie,

B Anti-Rook Programma in Cohortstudie,

C Cholesterol Reducerend Programma gecombineerd met Anti-Rook Programma in Cohortstudie.

\section{A. Cholesterol Reducerend Programma in Cohortstudie}

Het risicoprofiel van de simulatiegroep Cholesterol Cohort betreffende een cohortstudie is in tabel 6.6 weergegeven.

\begin{tabular}{|l|c|}
\hline Mannen 35 jaar \\
\hline $\begin{array}{l}\text { Cholesterol niveau } \\
\text { Diastolische bloeddruk } \\
\text { Rookgedrag }\end{array}$ & $\begin{array}{c}7,5-8,5 \mathrm{mmol} / \mathrm{50}-90 \mathrm{~mm} / \mathrm{Hg} \\
\text { njet-rokend }\end{array}$ \\
\hline
\end{tabular}

Tabel 6.6

Simulatiegroep Cholesterol Hypo Cohort van $1 \mathrm{mln}$. mannen (niet-verhoogd $\mathrm{DBD}$, niet-rokend)

Het preventieprogramma bestaat uit een cholesterol reducerend medicatieprogramma, zoals weergegeven in tabel 6.7. Het betreffende scenario is genoemd Med-Chol-Cohortscenario. 


\begin{tabular}{|l|c|}
\hline & Programma Chol.-Red.-Med. \\
\hline Startjaar & 1988 \\
Eindjaar & sterfe cohort \\
Aanlooptijd & 0 jaar \\
Afbouwtijd & 0 jaar \\
Reactie & $100 \%$ \\
Reductie & $25 \%$ \\
Trouw & $100 \%$ \\
Vaste kosten & f 2 mln p.j. \\
Kosten Iste jaar & f 2100, - p.p. p.j. \\
Vervolgkosten & f 1600,- p.p. p.j. \\
\hline
\end{tabular}

Tabel 6.7 Cholesterol Reducerend Medicatie Programma

Karakteristieke resultaten van het scenario zijn weergegeven in figuur 6.15.

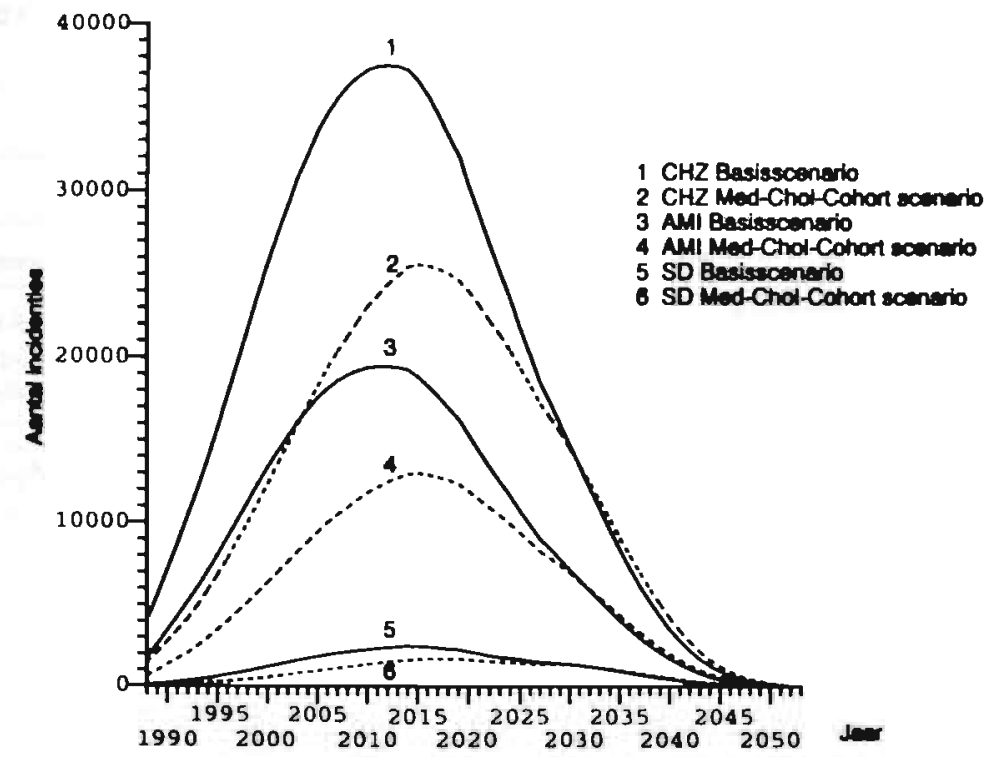

Figuur 6.15

Karakteristieke incidenties van het Med-Chol-Cohort scenario bij toepassing van het Cholesterol Medicatie Programma op een hypo cohort van $1 \mathrm{mln}$. Nederlandse mannen van 35 jaar

De resultaten van een scenario hangen uiteraard in hoge mate samen met de aanvangsleeftijd en het geslacht van het cohort. In Hoofdstuk 7 is een aantal variaties opgenomen, waarin deze relatie is uitgewerkt voor de variabelen gewonnen levensjaren, sterftekans aan CHZ en kosteneffectiviteit van het Med-CholCohortscenario. Daarbij is ook een gevoeligheidsanalyse weergegeven van variaties in de disconteringsfactor, therapietrouw en cholesterol reducerende effecten met betrekking tot kosten en effecten' van het Med-Chol-Cohort scenario. 
We geven hieronder een vergelijking van de extra kosten en extra effecten (levenswinst) die vier verschillende cholesterol reducerend medicatie scenario's IIV ten opzichte van het basisscenario genereren.

Het preventieprogramma van de vier scenario's betreft in alle gevallen een cholesterol reducerend medicatieprogramma. Dit programma heeft dezelfde karakteristieken als toegepast in figuur 6.15.

De vier scenario's verschillen in het risicoprofiel van de simulatiegroep, waarbij scenario I de standaard-simulatiegroep vertegenwoordigd. Hiermee wordt bedoeld dat er sprake is van én verhoogde risicofactor in de simulatiegroep. Het risicoprofiel van de standaardsimulatiegroep is zodanig gekozen dat deze identiek is aan dat van de simulatiegroep uit tabel 6.6. De scenario's waarvan de cohortstudie bestaat uit een variatie ten opzicht van de standaard-simulatiegroep worden aangegeven met opeenvolgende romeinse cijfers II-IV, zoals weergegeven in tabel 6.8. De standaard-simulatiegroep voor scenario I is identiek aan de simulatiegroep voor het Med-Chol-Cohort scenario. In tabel 6.8 wordt de vergelijking tussen de scenario's I-IV weergegeven.

\begin{tabular}{|c|c|c|c|c|}
\hline risicoprofiel & scenardo I & scenario II & scenario III & scenario IV \\
\hline $\begin{array}{l}\text { Cholesterol niveau } \\
\text { Diastolische bloeddruk } \\
\text { Rookgedrag }\end{array}$ & $\begin{array}{l}7,5-8,5 \mathrm{mmol} \\
50 \cdot 90 \mathrm{~mm} / \mathrm{Hg} \\
\text { niet-rokend }\end{array}$ & $\begin{array}{l}7,5-8,5 \mathrm{mmol} / \\
50-90 \mathrm{~mm} / \mathrm{Hg} \\
\text { wel-rokend }\end{array}$ & $\begin{array}{l}7,5-8,5 \mathrm{mmol} / / \\
90-150 \mathrm{~mm} / \mathrm{Hg} \\
\text { niet-rokend }\end{array}$ & $\begin{array}{l}7,5-8,5 \mathrm{mmol} \\
90-150 \mathrm{~mm} / \mathrm{Hg} \\
\text { wel-rokend }\end{array}$ \\
\hline
\end{tabular}

Tabel 6.8

Simulatiegroepen Hypo Cohort van Cholesterol Reducerend Medicatiescenario's I-IV

In de figuren 6.16-6.18 zijn de verkregen resultaten van vier Med-Chol-Cohor scenario's I-IV ten opzichte van het basisscenario gepresenteerd. De verschillen in levenswinst en preventiekosten tussen de scenario's I-IV in de figuren $6.16 \mathrm{en}$ 6.17 worden veroorzaakt door de verschillen in levensverwachting die er per scenario bestaan. Het risicoprofiel van de simulatiegroep met betrekking tot scenario IV genereert de laagste levensverwachting en dientengevolge de laagste preventiekosten. Evenals bij het Med-Chol-Hyp-Bevolking scenario uit figuur 6.12 doet zich ook hier het fenomeen voor dat de levenswinst hoger is wanneer er extra verhoogde risicofactoren aanwezig zijn. Hierbij lijkt roken in combinatie met verhoogd cholesterol (scenario II) een groter risico met betrekking tot de kans op $\mathrm{CHZ}$ te vormen dan hypertensie in combinatie met verhoogd cholesterol (scenario III). 


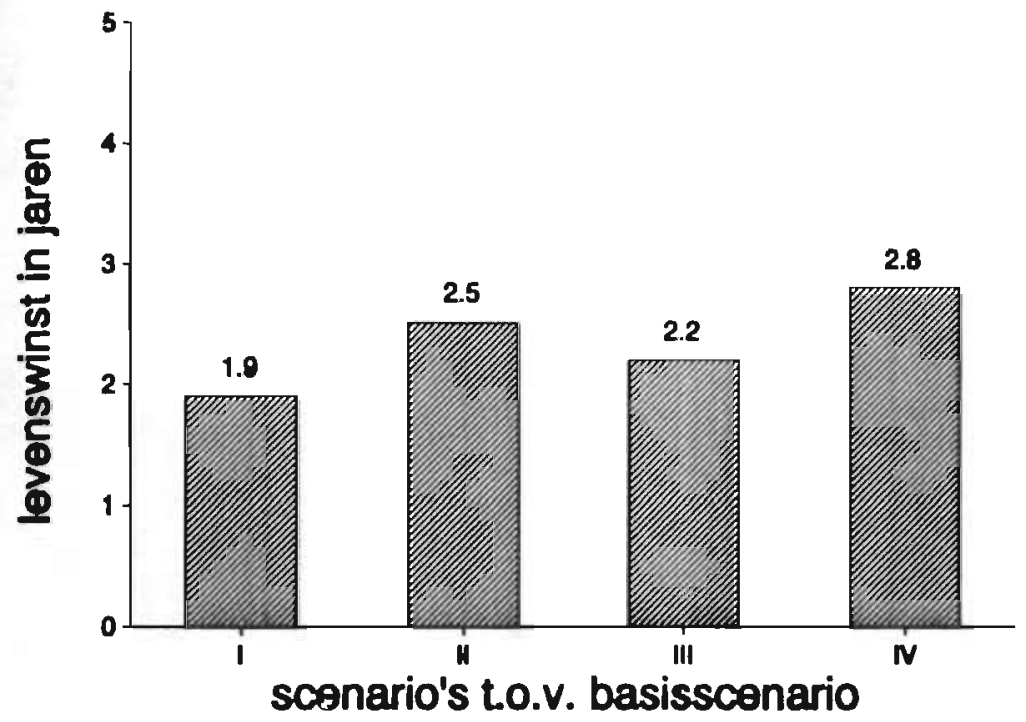

Figuur 6.16 Levenswinst van de Med-Chol-Cohort scenario's I-IV vergeleken met het basisscenario bij toepassing van het Cholesterol Reducerend Medicatie Programma op een bypo cobort van 1 mln. Nederlandse mannen van 35 jaar

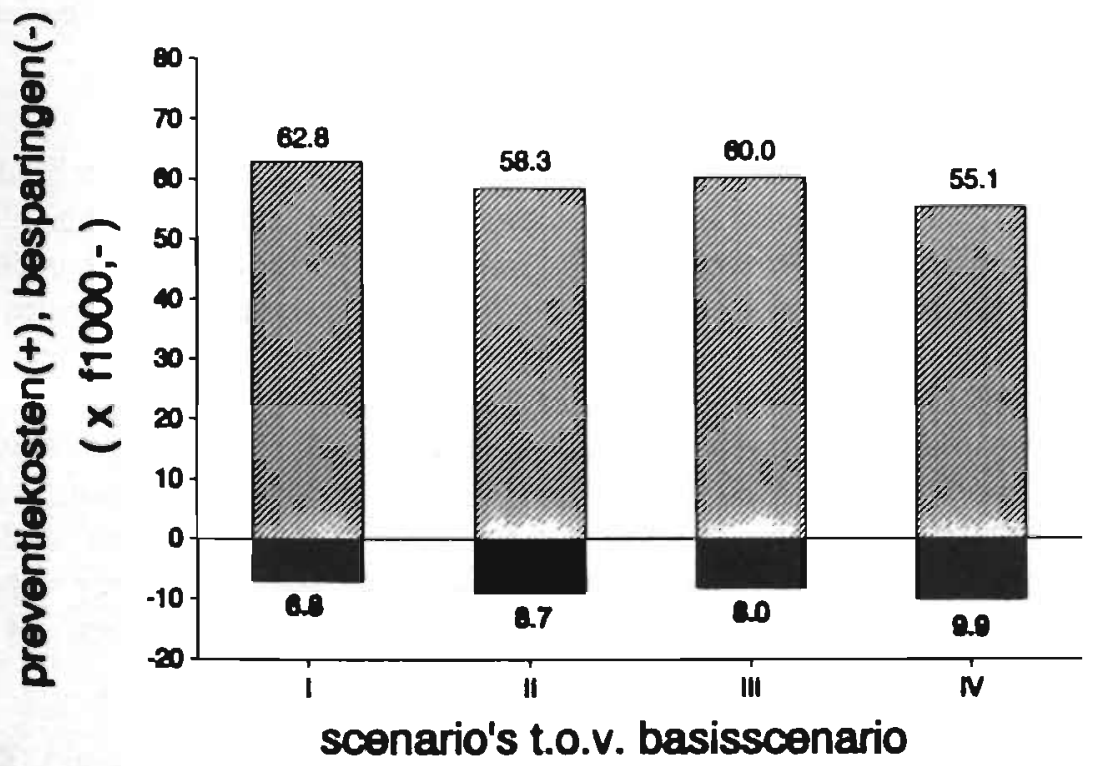

Figuur 6.17 De kosten van preventie respectievelijk besparingen op kosten medische behandelingen van de Med-Chol-Cohort scenario's I-IV vergeleken met het basisscenario bij toepassing van het Cholesterol Reducerend Medicatie Programma op een hypo cohort van $1 \mathrm{mln}$. Nederlandse mannen van 35 jaar 


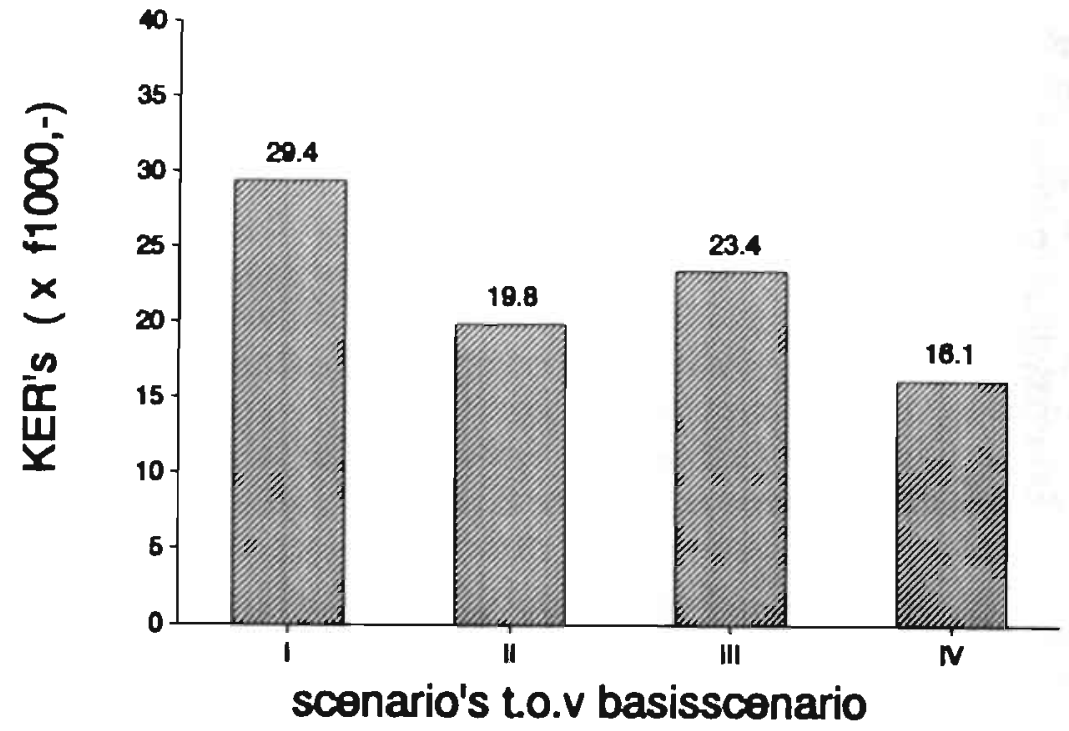

Figuur 6.18 Kosten per gewonnen levensjaar van de Med-Chol-Cohort scenario's I-IV vergeleken met het basisscenario bij toepassing van bet Cholesterol Reducerend Medicatie Programma op een hypo cohort van $1 \mathrm{mln}$. Nederlandse mannen van 35 jaar

Uit figuur 6.17 blijkt verder dat de besparing op de kosten medische behandelingen een fractie vormen van de kosten van preventie. Er is door Oster e.a. (1986), Weinstein e.a. (1985), en Russell (1985) reeds op gewezen dat de preventiekosten erg hoog kunnen oplopen en dat de besparingen op behandelingskosten hier niet tegen opwegen.

De kosten per gewonnen levensjaar of kosteneffectiviteitsratio's (KER's) uit figuur 6.18 worden berekend door het bedrag aan extra kosten van een scenario dat per saldo resteert (zie figuur 6.17) te delen door de levenswinst in jaren (zie figuur 6.16). Het bedrag aan extra kosten bestaat uit de kosten van preventie verminderd met de besparingen op kosten van de medische behandelingen (zie ook Hoofdstuk 4).

Scenario IV laat in figuur 6.18 de meest gunstige kosteneffectiviteitsratio (KER) zien. In dit scenario bestaat het risicoprofiel uit drie verhoogde risicofactoren (verhoogd chol, verhoogd DBD, wel-rokend). De verklaring bestaat uit het eerder gesignaleerde fenomeen dat de verwachte levenswinst hoger is en de verwachte kosten lager zijn naarmate er andere verhoogde risicofactoren zijn. 


\section{B. Anti-Rook Programma in Cohortstudie}

In tabel 6.9 is het risicoprofiel van de simulatiegroep Roken Cohort met betrekking tot een cohortstudie weergegeven.

\begin{tabular}{|l|c|}
\hline Mannen 35 jaar & \\
\hline Cholesterol nlveav & $0,0-6,0 \mathrm{mmol}$ \\
Diastolische bloeddruk & $50-90 \mathrm{~mm} / \mathrm{H}_{\mathrm{g}}$ \\
Rookgedrag & wel-rokend \\
\hline
\end{tabular}

Tabel 6.9

Simulatiegroep Roken Hypo Cohort van $1 \mathrm{mln}$. mannen (niet-verhoogd chol, niet-verhoogd DBD)

Het anti-rookprogramma algemeen is in tabel 6.10 opgenomen.

\begin{tabular}{|l|c|}
\hline & $\begin{array}{c}\text { Programma Ant- } \\
\text { Rook Algemeen }\end{array}$ \\
\hline Startjaar & 1988 \\
Elodjaar & sterne cohort \\
Aanlooptjjd & 0 Jarr \\
Afhouwtijd & 0 Jar \\
Reactie & $100 \%$ \\
Reductie & $100 \%$ \\
Trouw & $100 \%$ \\
Vaste kosten & f 100 min. p.J. \\
Kosten 1ste jaar & f 232,- p.p. p.J. \\
Vervolgkosten & f 232,- p.p. p.J. \\
\hline
\end{tabular}

Tabel 6.10

Anti-Rook Programma Algemeen

In tabel 6.10 zijn de reactie en de therapietrouw beide ingesteld op $100 \%$. We zijn bij de cohortstudie ervan uitgegaan dat er meer geld nodig is om $100 \%$ reactie en $100 \%$ therapietrouw te bereiken (zie ter vergelijking tabel 6.5). De vaste kosten zijn op het maximum ingesteld van $f 100 \mathrm{mln}$. per jaar. De kostprijzen van het programma zijn verdubbeld van $f$ 166,- naar $f$ 232,- per persoon per jaar. In Hoofdstuk 7 zijn we nagegaan in hoeverre een verdere verhoging van de kostprijzen invloed heeft op de kosteneffectiviteit van dit programma.

De Stop-Ro-Algemeen-Cohort scenario's II-IV waarbij in de cohortstudie variaties ten opzichte van de standaard-simulatiegroep zijn aangebracht, worden in tabel 6.11 gepresenteerd. Hierbij vertegenwoordigt het Stop-Ro-AlgemeenCohortscenario I de standaard-simulatiegroep. Het risicoprofiel van de standaard- 
simulatiegroep is qua methodiek weer identiek aan dat van de simulatiegroep uit tabel 6.9.

\begin{tabular}{|c|c|c|c|c|}
\hline \multicolumn{5}{|l|}{ Mannen van 35 Jaar } \\
\hline risicoproflel & scenario I & scenarto II & scemario III & scemarto IV \\
\hline $\begin{array}{l}\text { Cholesterol niveau } \\
\text { Diastollsche bloeddruk } \\
\text { Rookgedrag }\end{array}$ & $\begin{array}{l}0,0-6,0 \mathrm{mmol} \\
50-90 \mathrm{~mm} / \mathrm{Hg} \\
\text { wrel-rokend }\end{array}$ & $\begin{array}{l}6,0-20,0 \mathrm{~mol} \\
50-90 \mathrm{~mm} / \mathrm{Hg} \\
\text { wel-rokend }\end{array}$ & $\begin{array}{l}0,0-6,0 \mathrm{mmol} / 1 \\
90-150 \mathrm{~mm} / \mathrm{H}_{\mathrm{g}} \\
\text { wel-rokend }\end{array}$ & $\begin{array}{l}6,0-20,0 \mathrm{mmol} \\
90-150 \mathrm{~mm} / \mathrm{Hg} \\
\text { wel-rokend }\end{array}$ \\
\hline
\end{tabular}

Tabel 6.11

Simulatiegroepen Hypo Cohort van de Algemene Anti-Rook Campagne sces: rio's I-IV

De verkregen resultaten van de vier Stop-Ro-Algemeen-Cohort scenario's I-IV ten opzichte van het basisscenario zijn in de figuren 6.19-6.20 gepresenteerd.

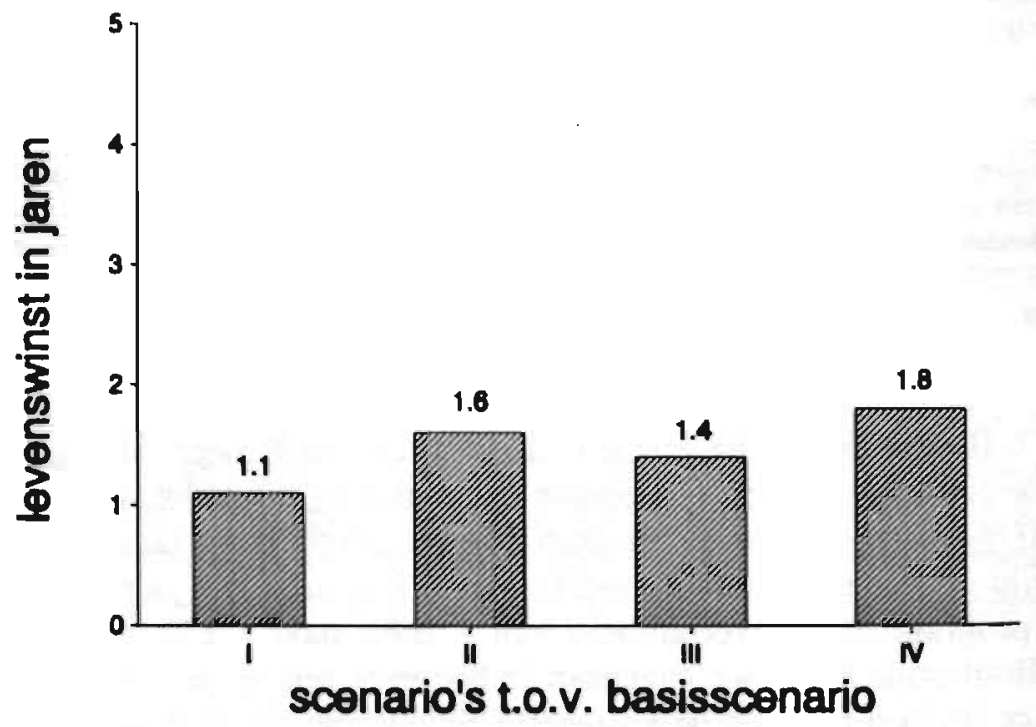

Figuur 6.19 Levenswinst van de Stop-Ro-Algemeen-Cobort scenario's I-IV vergeleken ma het basisscenario bij toepassing van het Anti-Rook Programma Algemeen of een hypo cohort van $1 \mathrm{mln}$. Nederlandse mannen van 35 jaar 


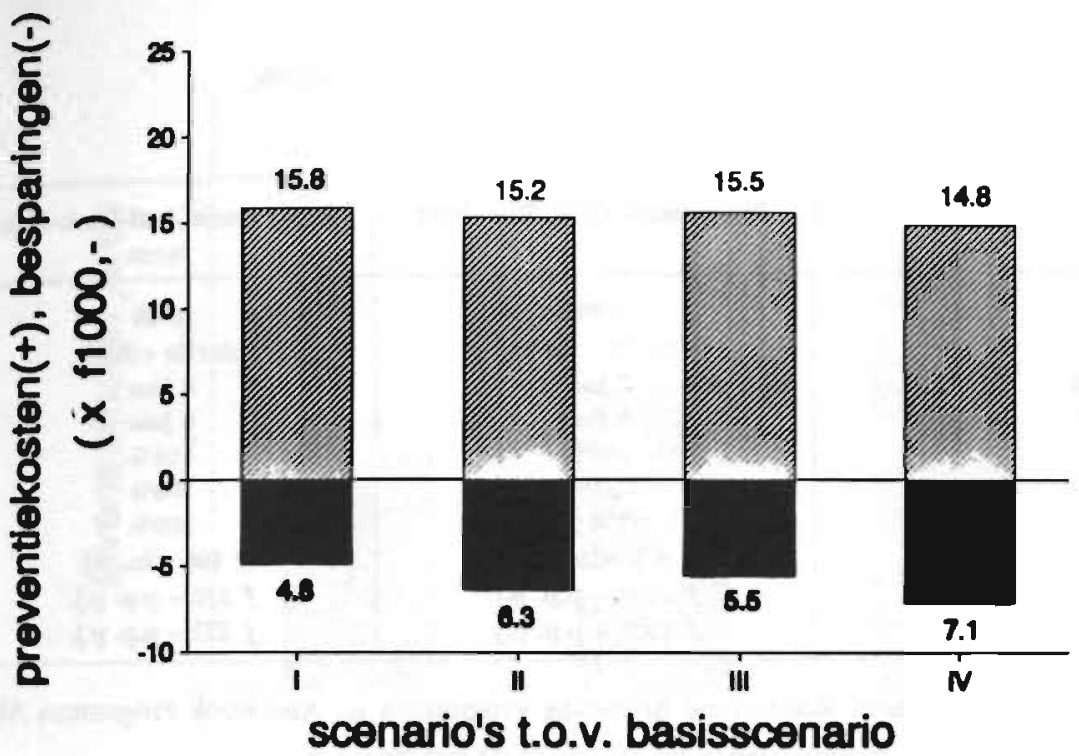

Figuur 6.20

De kosten van preventie respectievelijk besparingen op kosten medische behandelingen van de Stop-Ro-Algemeen-Cohort scenario's I-IV vergeleken met het basisscenario bij toepassing van het Anti-Rook Programma Algemeen op een hypo cohort van 1 mln. Nederlandse mannen van 35 jaar

We hebben er op deze plaats van afgezien om de resultaten van de anti-rook campagne scenario's te presenteren in de vorm van KER's. Hiervoor verwijzen we naar de sensitiviteitsanalyses uit Hoofdstuk 7. De levenswinst van de cholesterolverlagende scenario's is hoger dan die van de anti-rook campagne scenario's. Het is echter dankzij de veel lagere kostprijs dat de anti-rook campagne scenario's kosteneffectiever zijn dan de cholesterolverlagende scenario's.

\section{Cholesterol Reducerend Programma gecombineerd met Anti-Rook} Programma in Cohortstudie

Het risicoprofiel van de simulatiegroep Cholesterol Roken Cohort betreffende een cohortstudie volgt in tabel 6.12 .

\begin{tabular}{|c|c|}
\hline Mannen 35 jaar & \\
\hline $\begin{array}{l}\text { Cholesterol niveau } \\
\text { Diastolische bloeddruk } \\
\text { Rookgedrag }\end{array}$ & $\begin{array}{c}7,5-8,5 \mathrm{mmoh} \\
50-90 \mathrm{~mm} / \mathrm{Hg} \\
\text { wel-rokend }\end{array}$ \\
\hline
\end{tabular}

Tabel 6.12

Simulatiegroep Cholesterol Roken Hypo Cohort van $1 \mathrm{mln}$. mannen (niet-verhoogd DBD) 
De beide preventieprogramma's zijn in tabel 6.13 opgenomen.

\begin{tabular}{|c|c|c|}
\hline & Programma Chol-Red.-Med & $\begin{array}{c}\text { Progranma Anti-Rook-Age } \\
\text { meen }\end{array}$ \\
\hline Startjear & 1988 & 1988 \\
\hline Fundjaar & sterfte cohort & sterfte cohort \\
\hline Aanlooptijd & O Jaar & 0 Jaar \\
\hline Afbouwtjdd & 0 jaar & 0 jar \\
\hline Reactle & $100 \%$ & $100 \%$ \\
\hline Reductie & $25 \%$ & $100 \%$ \\
\hline Trouv & $100 \%$ & $100 \%$ \\
\hline Vaste kosten & f 2 mln p.j. & f $100 \mathrm{mln}$ p.j. \\
\hline Kosten 1ste jaar & f 2100, - p.p. p.j. & f 232,- p.p. p.j. \\
\hline Vervolgkosten & f $1600,-$ p.p. p.J. & f $232,-$ p.p. p.j. \\
\hline
\end{tabular}

Tabel 6.13

Cholesterol Reducerend Medicatie Programma en Anti-Rook Programma Algemeen

De twee preventieprogramma's kunnen met betrekking tot de simulatiegroep ieder afzonderlijk en gecombineerd geïnterpreteerd worden als een preventiestrategie. De simulatiegroep uit tabel 6.12 vertegenwoordigt het basisscenario, die wij weergeven als scenario I. Er kunnen drie preventie strategieën geformuleerd worden, waaruit drie gelijknamige scenario's II-IV zijn af te leiden. We hebben deze scenario's afgebeeld in tabel 6.14. De scenario's zijn genoemd Prev-RiskyCohort scenario's.

\begin{tabular}{|l|l|l|c|}
\hline \multirow{2}{*}{$\begin{array}{l}\text { Scenario's Simulatiegroep Cholesterol Roken } \\
\text { Hypo Cohort (niet verhoogd DBD) }\end{array}$} & \multicolumn{2}{|c|}{ Cholesterol Reducerend Medicatio Programma } \\
\cline { 3 - 4 } & \multicolumn{2}{|c|}{ niet } \\
\hline Ant-Rouk & niet & I & III \\
Programma Algemeen & wel & II & IV \\
\hline
\end{tabular}

Tabel 6.14

Scenario's II-IV vergeleken met Basisscenario I bij toepassing van het Cholesterol Reducerend Medicatie Programma en/of Anti-Rook Programma Algemeen op een bypo cohort van $1 \mathrm{mln}$. mannen van 35 jaar (chol: 7,5-8,5 mmoll, DBD: $50-90 \mathrm{mmHg}$, wel-rokend)

We hebben de resultaten van de scenario's II-IV ten opzichte van het basisscenario weergegeven in de figuren 6.21-6.23. 


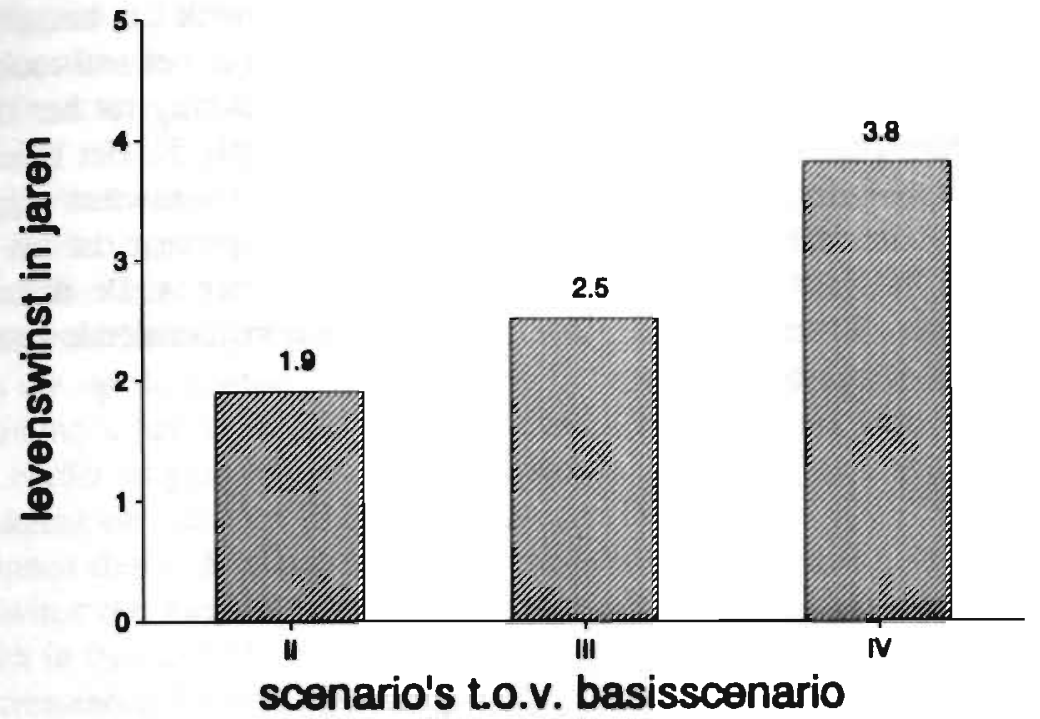

Figuur 6.21 Levenswinst van de scenario's II-IV vergeleken met het basisscenario bij toepassing van Cholesterol Reducerend Medicatie Programma en/of bet Anti-Rook Programma Algemeen op een hypo cohort van $1 \mathrm{mln}$. Nederlandse mannen van 35 jaar

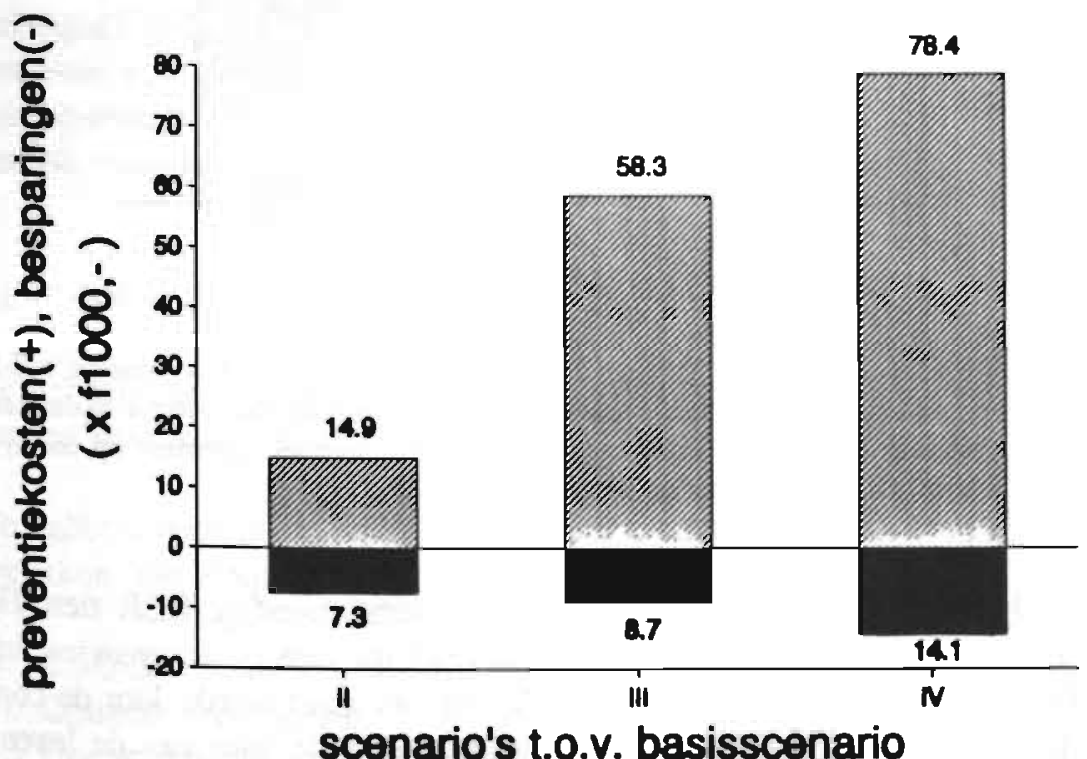

Figuur 6.22 De kosten van preventie respectievelijk besparingen op kosten medische behandelingen van de scenario's II-IV vergeleken met het basisscenario bij toepassing van het Cholesterol Reducerend Medicatie Programma en/of het AntiRook Programma Algemeen op een hypo cohort van $1 \mathrm{mln}$. Nederlandse mannen van 35 jaar 
Het cholesterol-reducerend scenario III uit tabel 6.14 is identiek aan het cholesterol-reducerend scenario II uit tabel 6.8. De simulatiegroep van het anti-rook campagne scenario II uit tabel 6.14 van sectie $C$ is met betrekking tot het cholesterolniveau kleiner dan de simulatiegroep uit 6.11 van sectie B. Het effect van een verkleinde simulatiegroep op de uitkomsten is dat de levenswinst stijgt respectievelijk de kosten dalen. De verklaring hiervoor is simpelweg dat het effect van het scenario "wegebt" naarmate de simulatiegroep groter is. De definiëring van de grootte van de simulatiegroep heeft daarmee een vrijbepalende betekenis voor de scenario-uitkomsten.

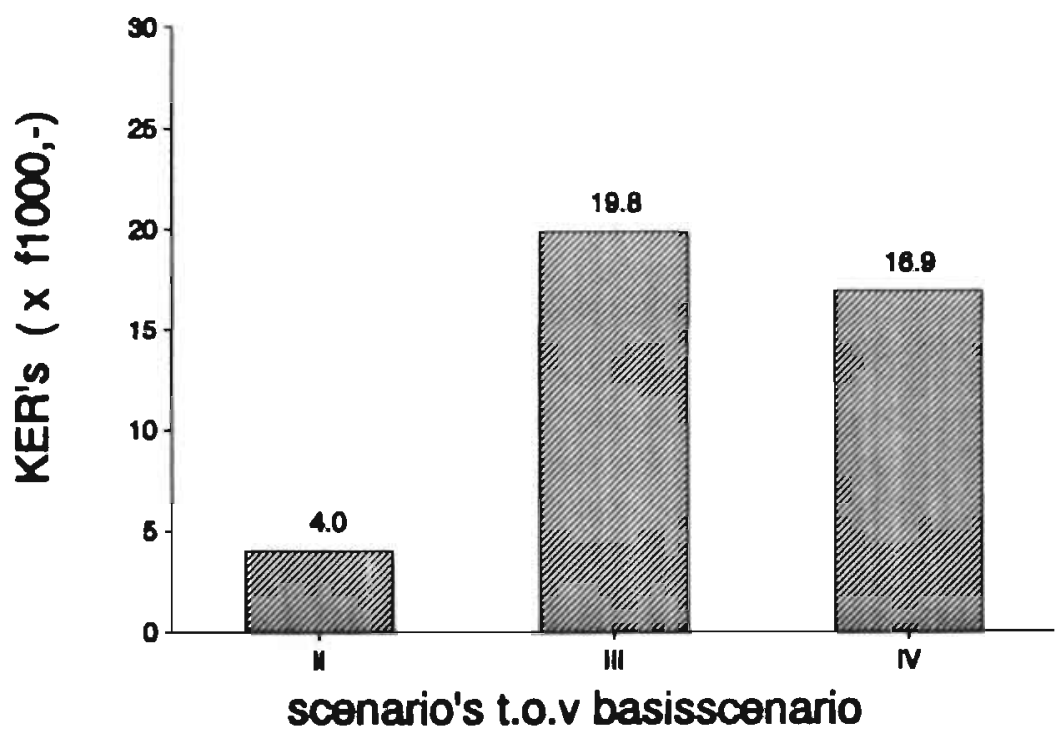

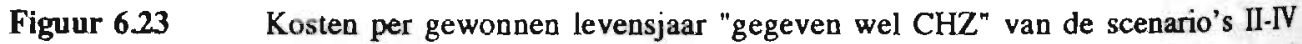
vergeleken met bet basisscenario bij toepassing van Cholesterol Reducerend Medicatie Programma en/of bet Anti-Rook Programma Algemeen op een bypo cohort van 1 mln. Nederlandse mannen van 35 jaar

Het Stop-Ro-Algemeen-Cohort scenario II laat de meest gunstige KER zien. Het Med-Chol-Cohort scenario III geeft de grootste bijdrage aan de levenswinst van het cohort. De levenswinst van het scenario IV dat gevormd wordt door de combinatie van beide preventieprogramma's is geringer dan de som van de levenswinsten van de scenario's II en III. Het versterkend effect van roken en verhoogd cholesterol tezamen met betrekking tot de $\mathrm{CHZ}$-incidentie neemt als gevolg van de preventieprogramma's degressief af (zie Hoofdstuk 2 en Bijlage I). Dit effect is eerder gesignaleerd bij de bespreking van preventiescenario's op bevolkingsniveau in de vorige paragraaf 6.2 . 
In de figuren 6.21 en 6.22 worden de levenswinst, de preventiekosten en de besparingen van de scenario's II-IV ten opzichte van het basisscenario I gepresenteerd. De totale extra kosten van bijvoorbeeld het Stop-Ro-algemeen-Cohort scenario II zijn ( $f 14.900,---f 7.300,--=) f 7.600$,-- per persoon uit het cohort, met een winst van 1,9 levensjaren.

Zoals eerder opgemerkt bij figuur 6.17 vallen de totale extra kosten van de preventiescenario's zo hoog uit door enerzijds het levenslange karakter van de "preventieve" behandelingen (zie Hoofdstuk 2), en anderzijds de beperkte besparingen die op de kosten van medische behandeling bereikt worden. Preventieprogramma's bereiken eigenlijk alleen dat het moment van optreden van de ziekte eerder uitgesteld dan afgesteld wordt, waardoor de kosten van medische behandeling op een later tijdstip alsnog gemaakt worden. De extra preventiekosten kunnen dan ook alleen verdedigd worden door te wijzen op de aanzienlijke levenswinst die met de preventieprogramma's behaald kan worden, zoals weergegeven in figuur 6.21.

De incrementele kosten van scenario III, in vergelijking met scenario II, bedragen $\{(f 47.900,---f 7.600,--)=\} f 40.300$,-- per persoon. De incremente levenswinst in dezelfde vergelijking bedraagt $(2.2-1.9=) 0,3$ levensjaren. Met andere woorden, is het waard om een extra bedrag van $f 40.300$,- per persoon te investeren in gezondheidszorgprogramma's met het doel om 0,3 extra levensjaren te verkrijgen? Hierbij is nog niet meegenomen de vraag wat het een en ander betekent voor iemands kwaliteit van leven, wanneer men zich zijn hele leven moet confirmeren aan een strak dieet-regime en "geneesmiddelenkuur" (het zogenaamde medicaliseringseffect).

\subsection{Bevolkingsstudie CHZ Medische scenario's}

We hebben alle medische scenario's in deze paragraaf gesimuleerd met behulp van een bevolkingsstudie.

We hebben voor de bevolkingsstudie drie medische programma's in de analyse betrokken (zie Hoofdstuk 5):

(i) CAG-Screening Programma,

(ii) Opname Programma,

(iii) Operatiecapaciteit Programma.

De keuzen voor deze programma's kunnen als volgt gemotiveerd worden. De problematiek die zich afspeelt rondom het opnameprogramma en het operatiecapaciteit programma is actueel. In de Nederlandse landelijke pers verschijnen berichten over te lange wachttijden hartoperaties (Jambroes versus Simons, Volks- 
krant, 1993) en over de noodzaak tijdig medische hulp in te roepen door de patiënt bij een vermoed AMI (zie Hoofdstukken 2 en 5). Het CAG-screeningprogramma sluit aan op de huidige ontwikkelingen met betrekking tot verfijnder diagnostische technieken, waardoor er eerder geanticipeerd kan worden op dreigende verstoringen met betrekking tot het atherosclerotische proces van de kransslagaders.

In deze paragraaf zullen de effecten van deze medische programma's met betrekking tot mogelijke toekomstpaden achtereenvolgens behandeld worden.

\section{(i) CAG-Screening Programma}

We hebben een CAG-screening programma uitgewerkt voor een bevolkingsstudie waarbij de totale Nederlandse bevolking de simulatiegroep vormt. De overige risicofactoren van de simulatiegroep behouden een algemeen risicoprofiel.

Het CAG-screening programma is gericht op het opsporen van personen in de $\mathrm{CHZ}$-bevolking waarvan de toestand van het kransslagaderstelsel dusdanig is dat er een vergrote kans op een acute $\mathrm{CHZ}$-manifestatie op korte termijn bestaat. Indien dergelijke personen opgespoord zijn, worden ze preventief opgenomen en behandeld.

In tabel 6.15 zijn de aantallen gescreende personen uit de verschillende deelgroepen van de $\mathrm{CHZ}$-bevolking weergegeven. De gekozen percentages deelnemers en aantallen positieven zijn willekeurig. Het scenario is het CAG-preventiescenario genoemd.

\begin{tabular}{|c|c|c|c|c|c|c|c|}
\hline & \multirow{3}{*}{$\begin{array}{l}\text { Omvang } \\
\text { Doelgroep }\end{array}$} & \multicolumn{3}{|c|}{ Fietsproef } & \multicolumn{3}{|c|}{ CAG } \\
\hline & & \multirow{2}{*}{$\begin{array}{c}\text { Deeln. } \\
\%\end{array}$} & \multicolumn{2}{|c|}{ Poditief } & \multirow{2}{*}{$\begin{array}{c}\text { Deeh. } \\
\%\end{array}$} & \multicolumn{2}{|c|}{ Positlef } \\
\hline & & & $\%$ & aantal & & $\%$ & antal \\
\hline Geen oud-MI & 299.615 & 50 & 50 & 74903 & 100 & 20 & 14980 \\
\hline Oad-MI, EF & 86.974 & 50 & 50 & 21743 & 100 & 75 & 16307 \\
\hline Oad-MI, EF & 4.577 & 50 & 50 & 1144 & 100 & 100 & 1144 \\
\hline
\end{tabular}

Tabel 6.15

CAG-Screening Programma

De directe kosten van het CAG-screeningprogramma zijn de volgende:

Kosten fietsproef : 183.825 proeven van $f 121$,-- per stuk $=f 23.665 .422,--$ Kosten CAG : 91.912 operaties van $f 3.010,--$ per stuk $=f 294.347 .900,--$ 
De effecten zijn te vinden in figuur 6.24. Door de CAG-screening zullen in eerste instantie de CHZ-opnames toenemen. Echter door de daling van het aantal AMI-opnames (6.900 minder in 2010) en SD (2.050 minder in 2010) zullen deze behoorlijk afnemen. Door de geringere sterfte en het lichtere type CHZ-incidentie blijven de mensen langer leven en zal de CHZ-bevolking op den duur weer toenemen. Tevens is er een langere verwachte ziekteduur. Door al deze effecten zullen de CHZ-incidenties en opnames in dit programma hoger liggen dan bij het basisscenario en zelfs sneller toenemen.

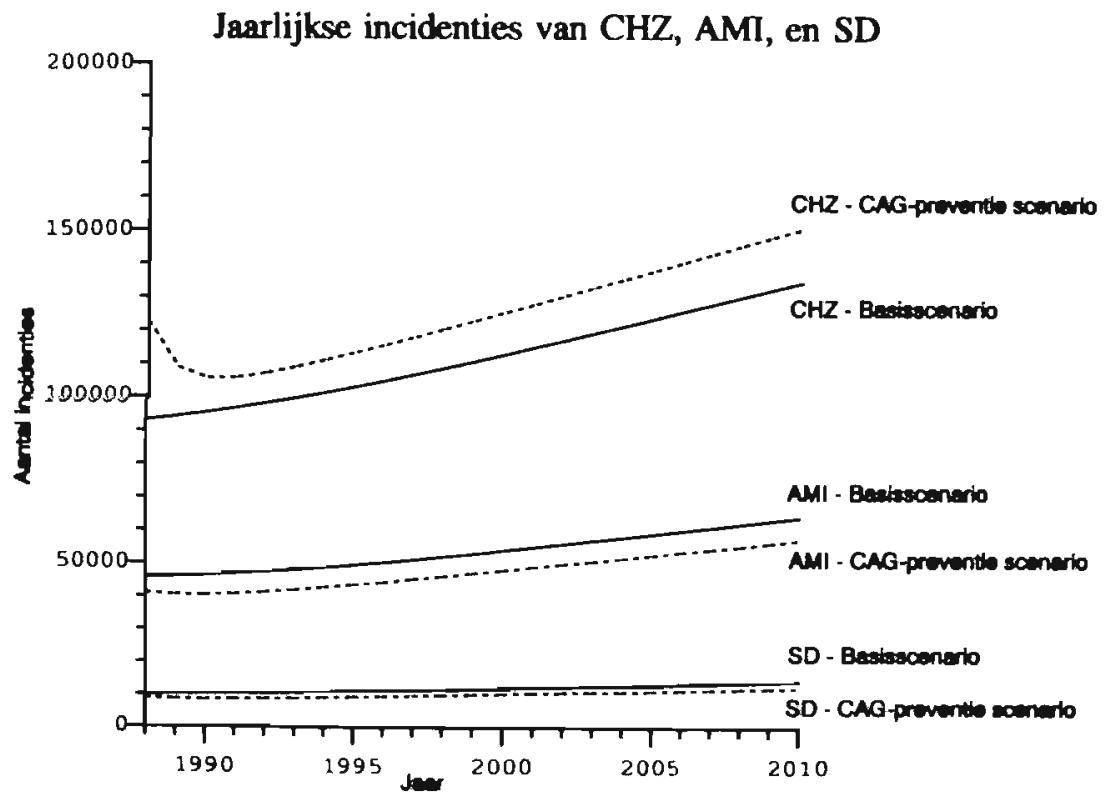

Figuur 6.24

Karakteristieke incidenties van CHZ, AMI en SD van bet CAG-Preventiescenario bij toepassing van het CAG-Screening Programma op de gebele Nederlandse bevolking

De gevolgen voor de levensverwachting zijn in figuur 6.25 weergegeven. De toename in de levensverwachting van het scenario in 2005 ten opzichte van het basisscenario met 0,5 jaar hangt samen met de bij figuur 6.24 reeds gesignaleerde daling van de AMI-sterfte en SD-sterfte. De verwachte incidentieleeftijd kan door het medische scenario niet beïnvloed worden. Deze is dan voor het basisscenario en het medische scenario gelijk. De levenswinst voor personen "gegeven wel CHZ" bestaat uit een stijging van de ziekteduur (met 1,3 jaar in 2005 van het scenario ten opzichte van het basisscenario). 
Levensverwachting in relatie tot $\mathrm{CHZ}$
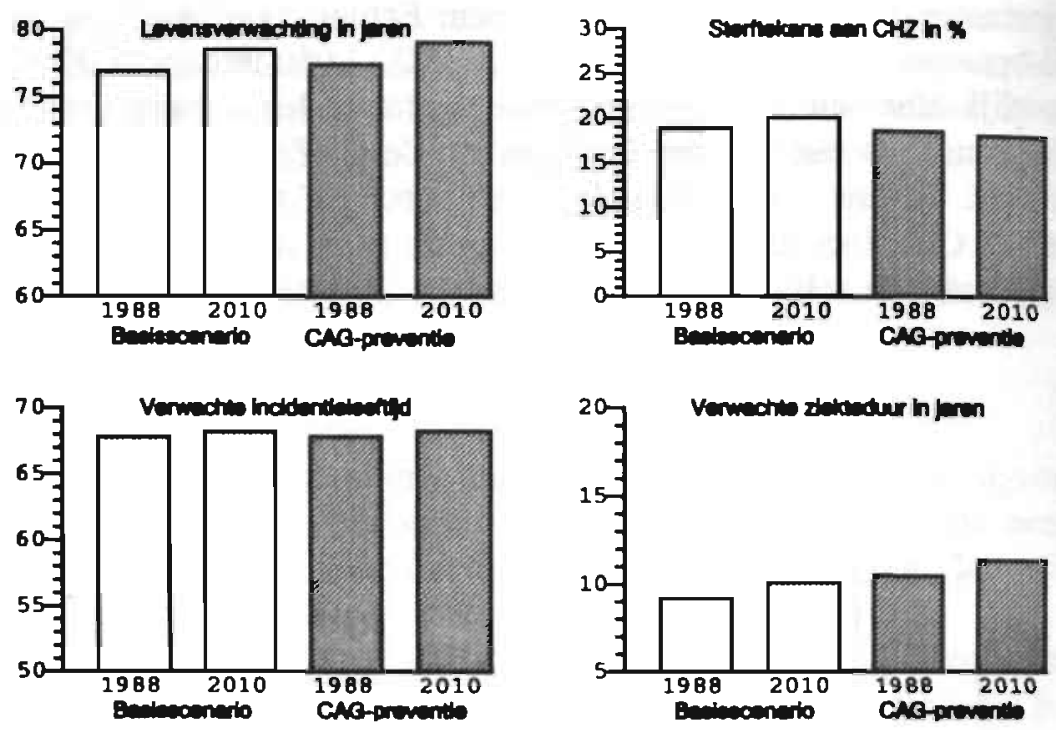

Figuur 6.25 l.evensverwachting karakteristieken van bet CAG-Preventie scenario bij toepassing van bet CAG-Screening Programma op de gehele Nederlandse bevolking

Een aardig effect dat de verbetering in kwaliteit van leven van de CHZ-patiënten weerspiegelt, is het feit dat in de CHZ-bevolking er in 2010 procentueel minder patiënten in de deelgroepen $\mathrm{K}^{-}, \mathrm{EF}^{+} / \mathrm{K}^{-}$en $\mathrm{EF}$ zitten en meer in de deelgroepen $\mathrm{K}^{+}$en $\mathrm{EF}^{+} / \mathrm{K}^{+}$(een stijging van $80 \%$ in het basisscenario naar $89 \%$ in het CAGPreventie scenario). Een vergelijking hiertoe wordt in figuur 6.26 gegeven. 
Procentuele verdeling van de $\mathrm{CHZ}$ bevolking naar toenemende ernst van het ziektestadium

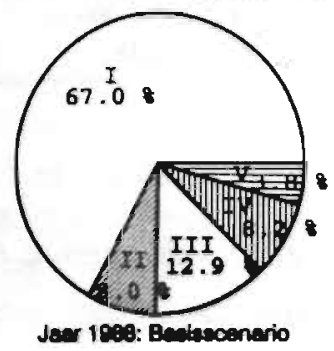

$$
\begin{aligned}
& \text { I- Geen oud-MI; K+ } \\
& \text { II - Geen oud-MI; K- } \\
& \text { III - Oud-MI; EF+; K+ } \\
& \text { IV - Oud-MI; EF+; K- } \\
& \text { V - Oud-Ml; EF- }
\end{aligned}
$$
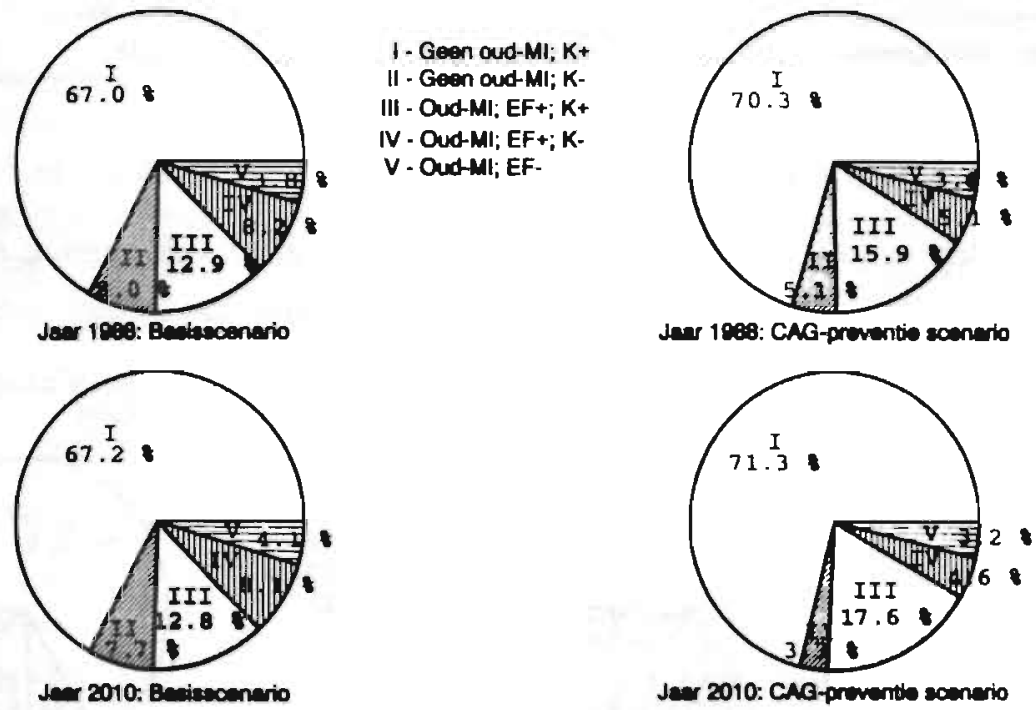

Figuur 6.26 Procentuele verdeling van de CHZ-bevolking naar ernst van het ziektestadium van het CAG-Preventiescenario bij toepassing van het CAG-Screening Programma op de gebele Nederlandse bevolking

\section{(ii) Opname Programma}

Er is voor de algemene bevolkingsstudie een opname programma gehanteerd.

Het opname programma is wellicht het eenvoudigst te realiseren programma met het grootste effect. Het bestaat uit een TV-campagne waarin de noodzaak van een vroegtijdige onderkenning van symptomen van AMI en een snelle opname uiteengezet worden. Het programma bestaat eenvoudigweg uit het vaststellen van een Budget TV-spot en de effecten zijn evenredig met de hoogte van het budget. In het scenario hebben we het maximale bedrag (10 mln gulden in het programma) genomen.

Het Budget 06-nummer is opgenomen om de kosten van het programma te verhogen. We hebben de kostprijs hiervan op $f 2 \mathrm{mln}$. ingeschat.

De gekozen invulwaarden voor het opname programma zijn in tabel 6.16 te vinden. Om het beeld van het effect met betrekking tot de kosten niet te vertroebelen hebben we de onterechte opnames op $0 \%$ gesteld. We hebben het scenario genoemd het FMI-preventiescenario. 
Badget TV-spot

Budget 06-nummer

Onterechte opnames f 9.999.999,.--

f 2000.000,--

$0 \%$

Tabel 6.16 Opname Programma

De effecten van dit programma voor het scenario zijn in de figuren 6.27 en 6.28 te zien.

Procentuele verdeling van de $\mathrm{CHZ}$ bevolking naar toenemende ernst van het ziektestadium
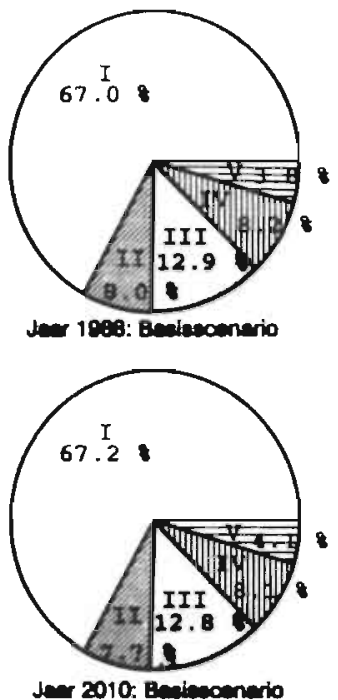

I- Geen oud-MI; K+ II - Geen oud-MI; KIII - Oud-MI; EF+; K+ IV - Oud-MI; EF+; K$V$ - Oud-Ml; EF-

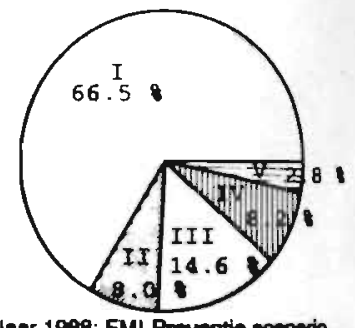

Jas 1088: FMI-Prourotio somaio

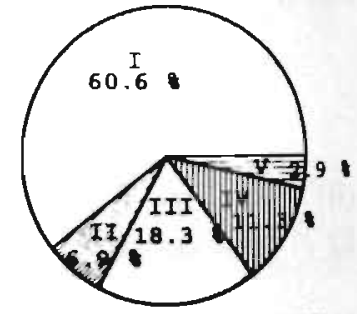

Jer 2010: FMIPT wente soor rio

Figuur 6.27 Procentuele verdeling van de CHZ-bevolking naar ernst van het ziektestadium van het FMI-Preventiescenario bij toepassing van het Opname Programma op de gehele Nederlandse bevolking

Het interessante aan figuur 6.27 is dat door het opname programma de gemiddelde gezondheidstoestand van de CHZ-bevolking in 2010 in kwaliteit afneemt (minder $\mathrm{K}^{+}$met $6,6 \%$, meer $\mathrm{EF}^{+}$met 5,5\%). Dit is een gevolg van het feit dat door het programma er meer mensen overleven na een AMI en toegevoegd worden aan de CHZ-bevolking in een relatief niet al te beste toestand. Uiteraard lopen hierdoor ook de totale CHZ-kosten van het scenario in 2010 op met circa $f 100 \mathrm{mln}$. (5\%) ten opzichte van het basisscenario (niet weergegeven). 
lopen hierdoor ook de totale CHZ-kosten van het scenario in 2010 op met circa $f 100 \mathrm{mln}$. (5\%) ten opzichte van het basisscenario (niet weergegeven).

De beschreven effecten worden in figuur 6.28 geaccentueerd. De sterfte ten gevolge van AMI of fatale myocard infarct (FMI) daalt in 2005 met $25 \%$ ten opzichte van het basisscenario. De SD-sterfte van het scenario gaat na een aanvankelijke daling in 1991 weer geleidelijk aan toenemen. De verklaring hiervoor is dat het gespaarde gedeelte van de "FMI-bevolking" na verloop van tijd een SD krijgt. Er is dus sprake van een uitgesteld sterfte effect.

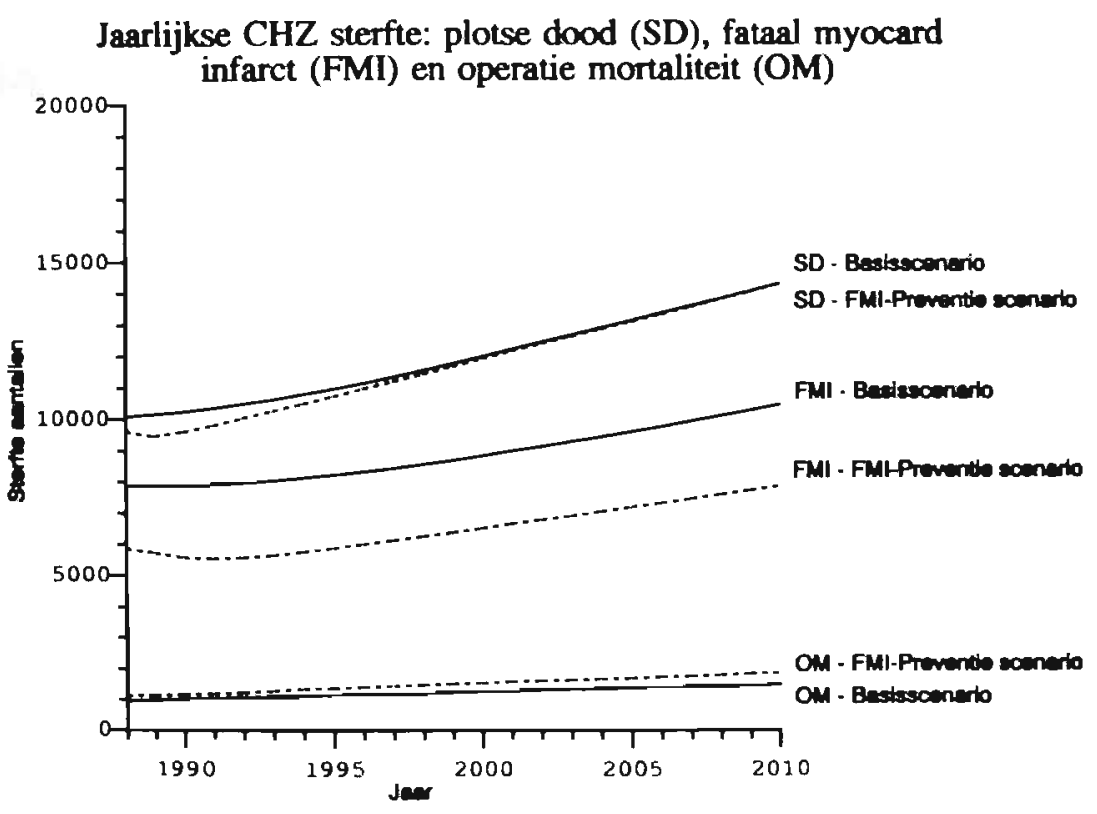

Figuur 6.28 De CHZ-sterfte van het FMI-Preventiescenario bij toepassing van het Opname Programma op de gehele Nederlandse bevolking

We hebben in Hoofdstuk 4 onder meer het begrip kostendeterminant besproken. Hierbij bleek dat de ejectie fractie (EF) voldeed aan de criteria om als kostendeterminant met betrekking tot $\mathrm{CHZ}$ in aanmerking te komen.

We hebben in dit verband de gevoeligheid van het opname programma getest door met behulp van de modelparameter intraveneuze thrombolytica (IVT) twee toekomstpaden na te bootsen. Het eerste toekomstpad leidt ertoe dat het aantal personen met een slechte EF in vergelijking met het FMI-preventiescenario uit figuur 6.27 afneemt, terwijl in het tweede toekomstpad het omgekeerde plaatsvindt. We hebben hiertoe IVT-parameter ingesteld op twee uiterste waarden: 
IVT $=100 \%$ respectievelijk IVT $=0 \%$. De standaard-waarde van deze modelparameter is ingesteld op IVT $=50 \%$. De instellingswaarde IVT $=100 \%$ wil zeggen dat de kans op een IVT-behandeling ten opzichte van de standaardsituatie is verdubbeld. Deze kans wordt beïnvloed door de "Budget TV-spot". Een "Budget TV. spot" van $f 0$,- betekent dat er geen IVT-behandelingen in het scenario plaatsvinden. Het maximale bedrag van de "Budget TV-Spot" is $f 10.000 .000,-$. In dit geval wordt de kans op een IVT-behandeling met "1" vermenigvuldigd.

We noemen het opname programma, waarvan de modelparameter IVT is gewijzigd, het IVT-programma. Het bijhorende scenario is aangeduid als het IVTpreventiescenario.

De effecten van het IVT-programma bij IVT $=100 \%$ respectievelijk IVT $=0 \%$ voor het scenario zijn in de figuren 6.29-6.30 te zien.

Procentuele verdeling van de $\mathrm{CHZ}$ bevolking naar toenemende ernst van het ziektestadium
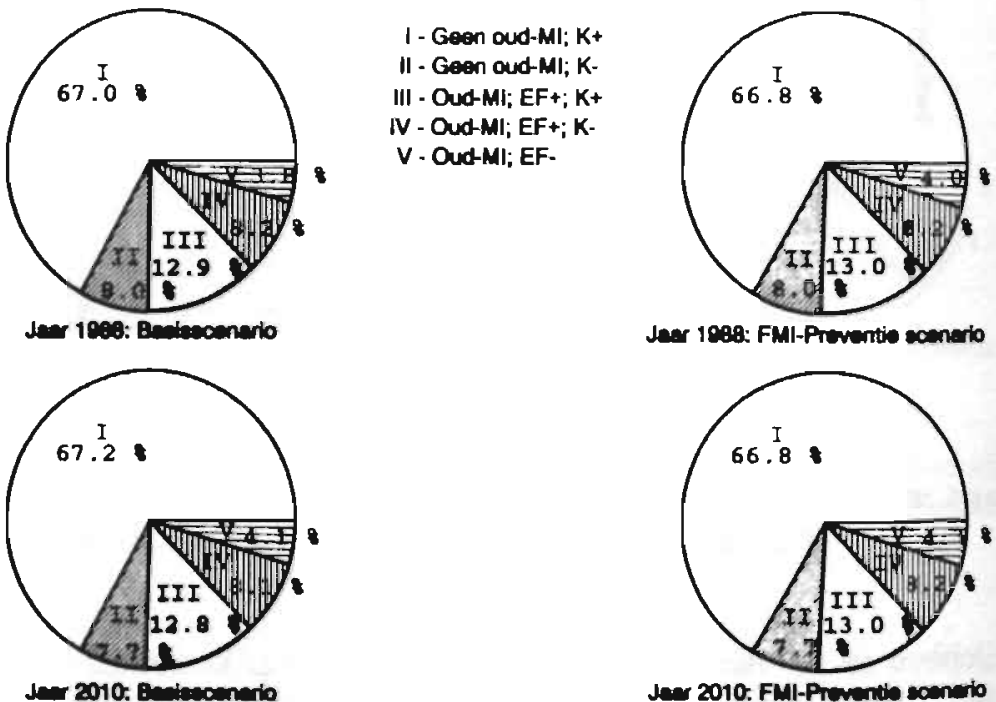

Jeer 10a8: FMI-Prwentio ecenerio

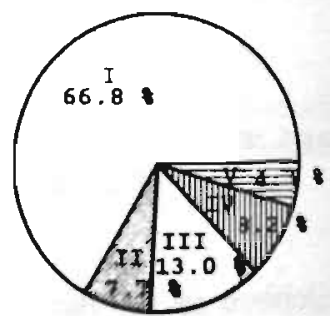

Jeer 2010. FMI-Preventiv coenvio

Figuur 6.29

Procentuele verdeling van de CHZ-bevolking naar ernst van het ziektestadium van het IVT-Preventiescenario bij toepassing van het IVT-Programma (IVT = $0 \%)$ op de gehele Nederlandse bevolking 
Procentuele verdeling van de $\mathrm{CHZ}$ bevolking naar toenemende ernst van het ziektestadium
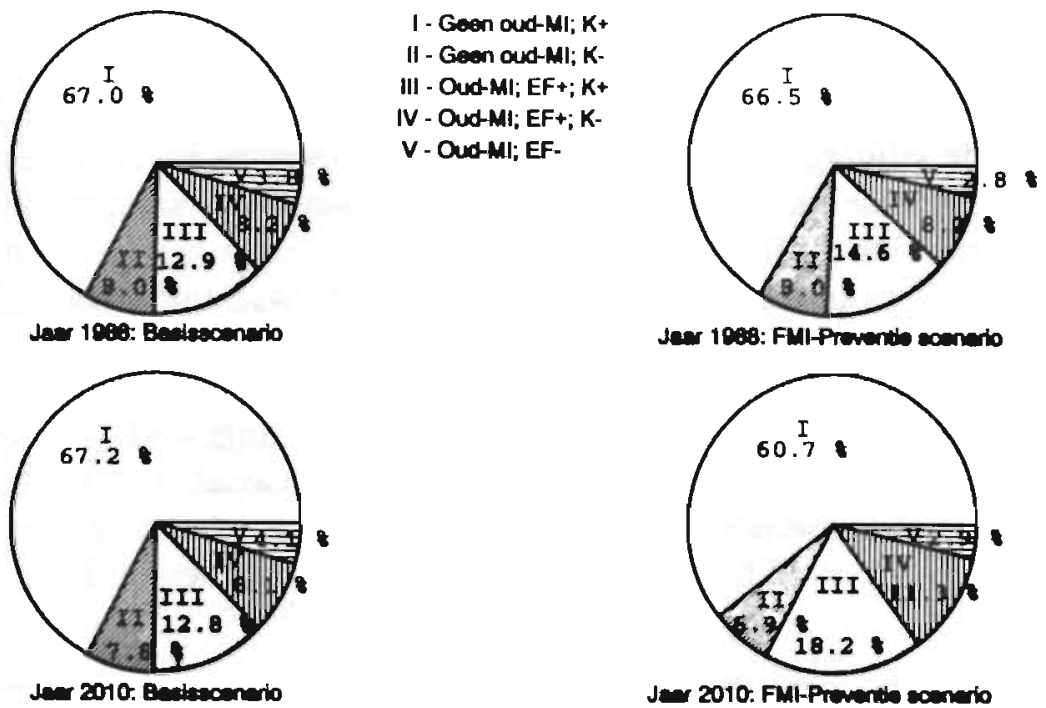

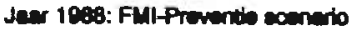

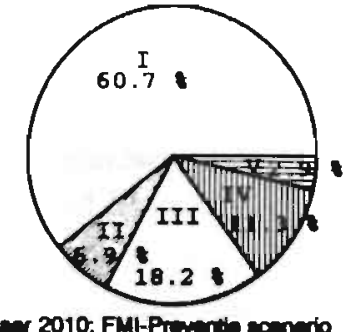

Figuur 6.30

Procentuele verdeling van de $\mathrm{CHZ}$-bevolking naar ernst van het ziektestadium van het IVT-Preventiescenario bij toepassing van het IVT-Programma (IVT = $100 \%$ ) op de gehele Nederlandse bevolking

Het IVT-programma beoogt dat er niet alleen meer mensen een AMI overleven, maar ook dat de AMI-overlevenden in een relatief betere toestand aan de CHZbevolking worden toegevoegd.

Uit de figuren 6.29 en 6.30 blijkt dat in 2010 het aantal personen met een EF22.639 respectievelijk 16.537 bedraagt voor beide scenario's. De totale CHZkosten zijn in $2010 f 1.999,-$ mln. respectievelijk $f 1.872,-$ mln. De kosten per CHZ-persoon bedragen $f 3.800$,- respectievelijk $f 3.000$,- (niet weergegeven).

Het relatieve kostenverschil per CHZ-persoon is groter dan dat van de totale CHZ-kosten. De verklaring hiervoor is dat het aantal overlevenden bij IVT = $100 \%$ dat in een minder ernstig ziektestadium terecht komt sterk stijgt, terwijl de totale kosten lager liggen dan bij IVT $=0 \%$. De gemiddelde kosten per persoon dalen in het scenario IVT $=100 \%$ in vergelijking met die van het scenario IVT $=0 \%$. Anders geformuleerd: er zijn in 2010 in de CHZ-bevolking voor het IVTpreventiescenario bij IVT $=0 \%$ minder personen, die echter meer kosten genereren dan bij IVT $=100 \%$. 
We hebben het operatiecapaciteit programma gebruikt voor een algemene bevolkingsstudie.

Dit programma biedt de mogelijkheid de operatiecapaciteit jaarlijks te beperken (of de stijging ervan te versnellen). Een operatiecapaciteit-beperkend scenario leidt geleidelijk tot een ongunstige prognose met betrekking tot degenen die in aanmerking komen voor een operatie. In feite is hiermee een aanzet gegeven voor de kwantitatieve onderbouwing van de "wachttijd voor operatie"-problema. tiek (zie ook Hoofdstuk 7).

We hebben een operatiecapaciteit programma uitgewerkt in combinatie met het in onder (ii) behandelde CAG-screening programma. Het additioneel toegevoegde operatiecapaciteit programma is te vinden in tabel 6.17 . Het betreffende scenario is genoemd het Budget OK/laag-CAG/Preventiescenario.

\begin{tabular}{|l|c|c|c|}
\hline & $\begin{array}{c}\text { Operaties } \\
\text { in } 1988\end{array}$ & $\begin{array}{c}\text { Stjigh } \\
\text { per jagr }\end{array}$ & $\begin{array}{c}\text { Max. antal } \\
\text { per jagr }\end{array}$ \\
\hline CABG & 8.325 & $40 \%$ & 9.200 \\
PTCA & 5.635 & $220 \%$ & 10.500 \\
\hline
\end{tabular}

Tabel 6.17 Operatiecapaciteit Programma laag

We hebben voor de stijgingspercentages uit tabel 6.17 het gemiddelde stijgingspercentage over de periode 1988-1992 gebruikt (CABG: van circa 8.300 in 1988 naar circa 9.200 in 1992, PTCA: van circa 5.600 in 1988 naar circa 10.500 in 1992). Het absolute plafond is gelijk aan de aantallen CABG's en PTCA's uit 1992 (CCA, 1994).

Kijken we naar de gevolgen van deze begrenzing op het aantal uitgevoerde operaties, dan zien we dat deze begrenzingen steeds actief zijn. In figuur 6.31 is dit afgebeeld en in figuur 6.32 is de onbegrensde situatie weergegeven. Opvallend is de snelle stijging vanaf 1991 van het aantal MED in figuur 6.31 indien het absolute plafond van de operatiebegrenzers actief worden (1991 voor CABG en 1992 voor PTCA). Uiteraard valt deze groei te verklaren uit de begrenzing van het aantal operaties, terwijl er als gevolg van het CAG-Preventiescenario een stijging van de CHZ-bevolking plaatsvindt. 


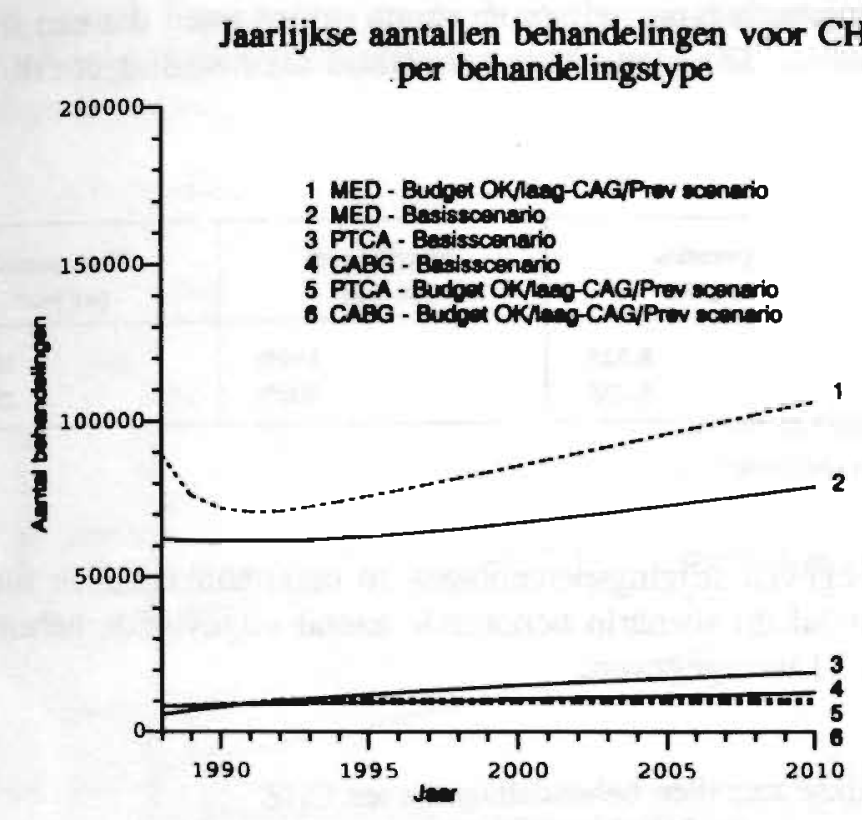

Figuur 6.31 Aantal uitgevoerde behandelingen van het Budget OK/laag-CAG/Prev scenario bij toepassing van het CAG-Screening Programma en het Operatiecapaciteit Programma laag op de gehele Nederlandse bevolking

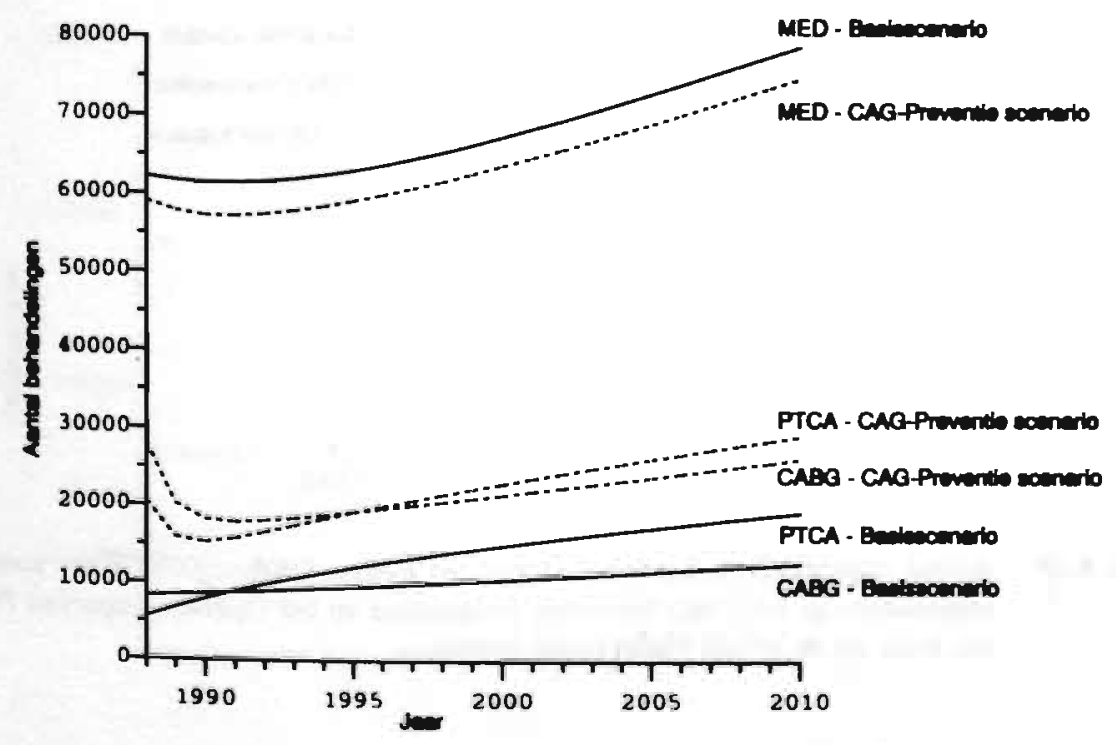

Figuur 6.32 Aantal uitgevoerde behandelingen van het CAG-Preventie scenario bij toepassing van het CAG-Screening Programma op de gehele Nederlandse bevolking 
In tabel 6.18 is een operatiecapaciteit programma opgenomen dat een stijgin beoogt in de capaciteiten. Dit scenario is aangeduid als het Budget $\mathrm{OK} / \mathrm{hoog}$ CAG/Prev scenario.

\begin{tabular}{|c|c|c|c|}
\hline & $\begin{array}{l}\text { Operaties } \\
\text { in } 1988\end{array}$ & $\begin{array}{c}\text { Stijging per } \\
10 \text { jaar }\end{array}$ & $\begin{array}{c}\text { Max.-anntal } \\
\text { per joar }\end{array}$ \\
\hline CABG & 8.325 & $100 \%$ & 15.000 \\
\hline PTCA & 5.635 & $300 \%$ & 25.000 \\
\hline
\end{tabular}

Tabel 6.18 Operacie Programma hoog

De in tabel 6.18 aangegeven stijgingspercentages en maximumaantallen zijn willekeurig gekozen. Het bij dit scenario behorende aantal uitgevoerde behandelingen wordt in figuur 6.33 weergegeven.

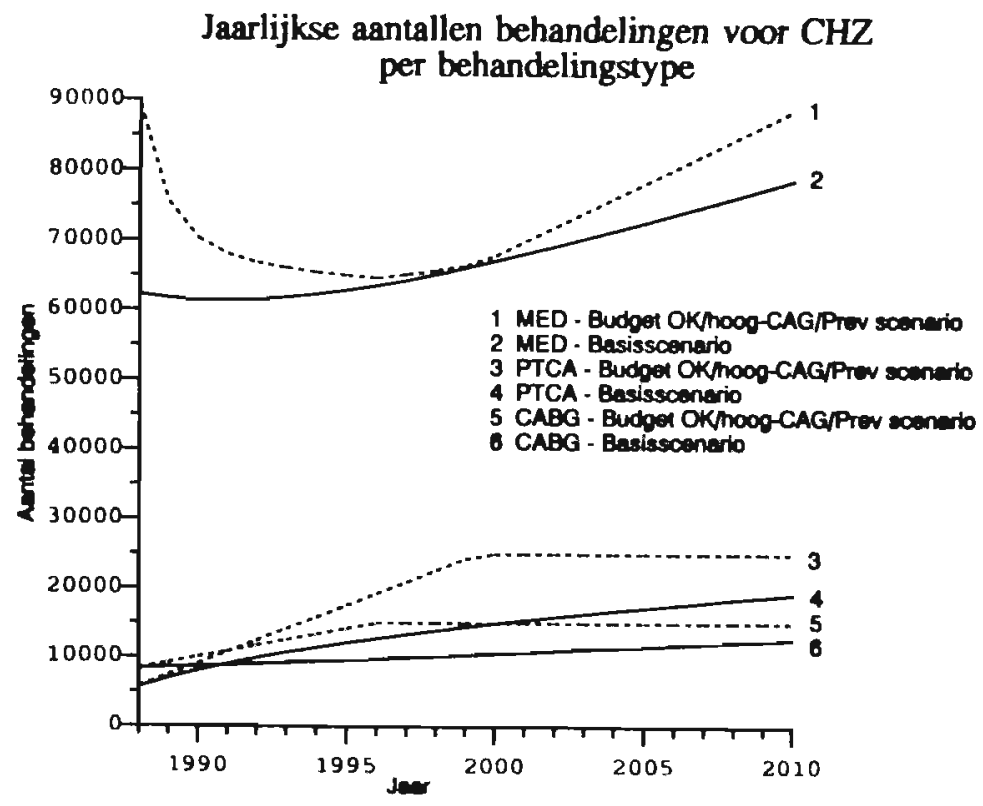

Figuur 6.33 Aantal uitgevoerde behandelingen van het Budget OK/hoog-CAG/Prev scenario bi: toepassing van het CAG-Screening Programma en bet Operatie Capaciteit Program ma boog op de gebele Nederlandse bevolking

Uit figuur 6.33 blijkt dat de absolute plafonds voor CABG en PTCA actief wor. den vanaf 1996 respectievelijk 2000. 
In onderstaande figuren 6.34 en 6.35 zijn de karakteristieke kengetallen gegeven van het Budget OK/laag-CAG/Prev scenario respectievelijk het Budget OK/hoogCAG/Prev scenario.

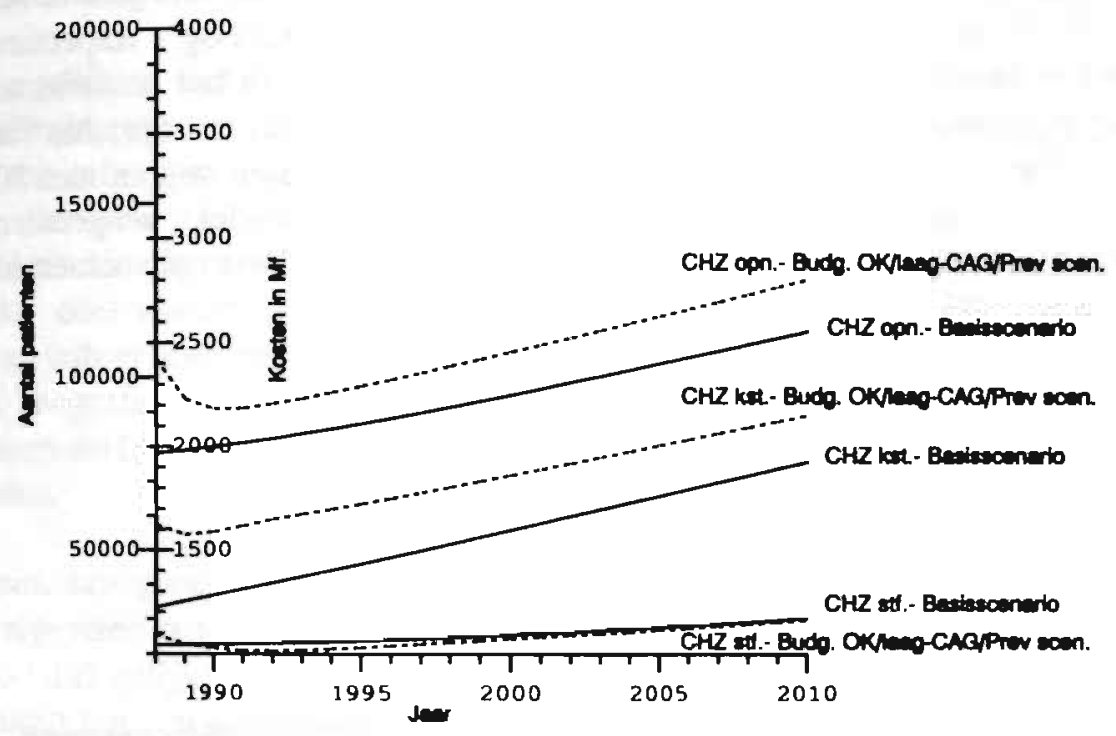

Figuur 6.34 Karateristieke kengetallen van het Budget OK/laag-CAG/prev scenario bij toepassing van het CAG-Screening Programma en het Operatie Capaciteit Programma hoog op de gebele Nederlandse bevolking

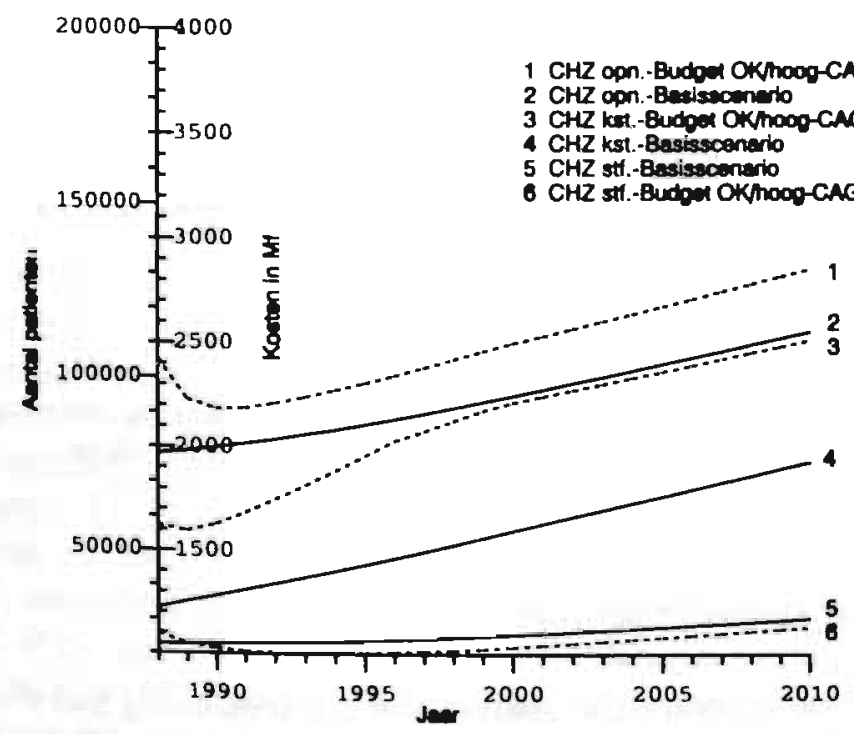

Figuur 6.35 Karateristieke kengetallen van het Budget OK/hoog-CAG/prev scenario bij toepassing van het CAG-Screening Programma en het Operatie Capaciteit Programma hoog op de gehele Nederlandse bevolking 
De CHZ-sterfte is in 2010 in het Budget OK/hoog-CAG/Prev scenario met 8,7q gedaald ten opzichte van het basisscenario. Deze daling bedraagt voor het Budget OK/laag-CAG/Prev scenario 1,7\%. De kosten zijn gestegen met 30,3\% res. pectievelijk $11,7 \%$. De levensverwachting in 2010 stijgt van 78,5 jaar in het basisscenario naar 78,9 jaar en 78,8 jaar in het Budget OK/hoog - respectievelijk Budget OK/laag-CAG/Prev scenario (niet weergegeven). In het scenario zonder operatie capaciteit beperking (CAG-Preventiescenario) daalt ten opzichte van het basisscenario in 2010 de CHZ-sterfte met $14,3 \%$, de kosten stijgen met $50,9 \%$, en stijgt de levensverwachting naar 79,0 jaar. De karakteristieke kengetallen van het CAG-Preventiescenario zijn in figuur 6.36 ter vergelijking opgenomen (de levensverwachtingkengetallen worden niet weergegeven).

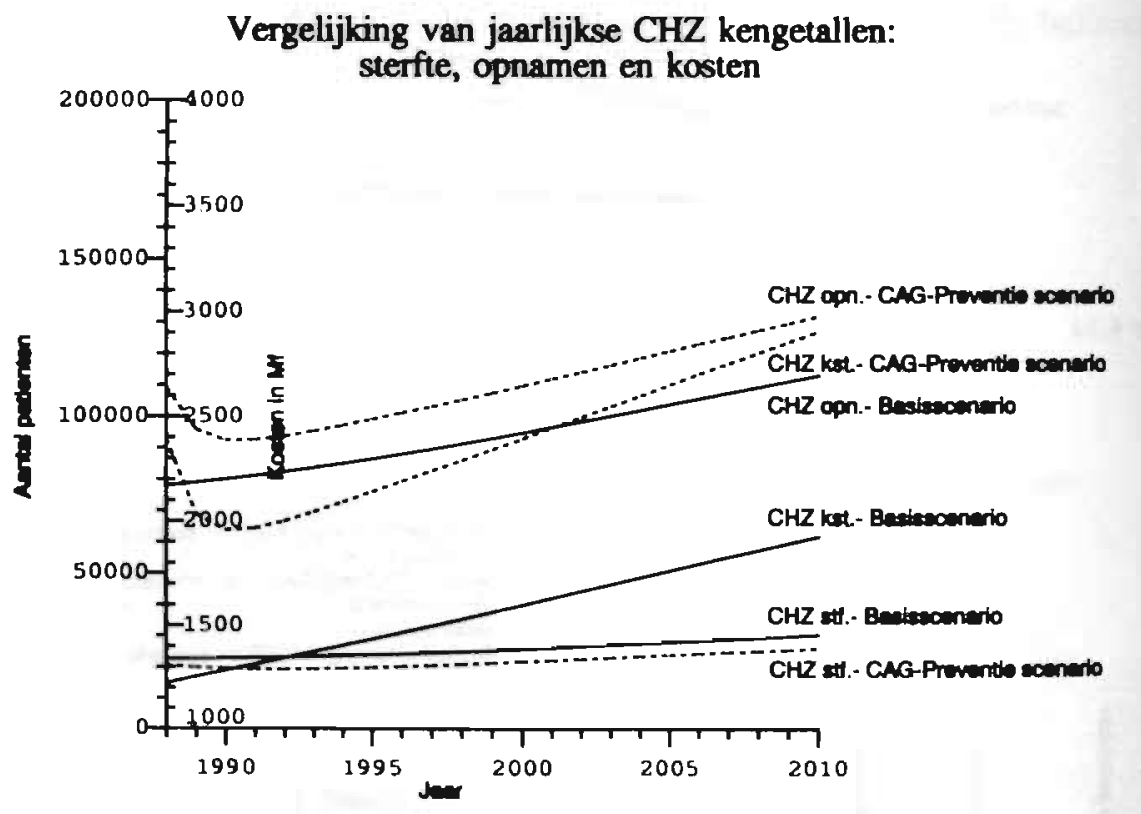

Figuur 6.36

Karateristieke kengetallen van het CAG Preventiescenario bij toepassing var het CAG-Screening Programma op de gehele Nederlandse bevolking

\subsection{Cohortstudie CHZ Medische scenario's}

In deze paragraaf wordt de economische analyse van een toekomstig pad besproken bij de toepassing van medische scenario's op een cohortstudie. Hierbij worden de resultaten van het medische scenario vergeleken met die van het basisscenario. De simulatiegroep bestaat evenals bij de cohortstudie van de preventiesce- 
nario's uit een hypothetisch cohort van $1 \mathrm{mln}$. mannen of vrouwen die homogeen zijn met betrekking tot hun risicoprofiel. Voor een verdere toelichting op de methodiek bij een cohortstudie wordt verwezen naar de inleiding en paragraaf 6.3 van dit hoofdstuk en naar Hoofdstuk 4.

In vergelijking met de preventiescenario's is het in ons model minder interessant de effecten van de medische programma's voor de simulatiegroep met behulp van een cohortstudie in de tijd te volgen.

Het betreffende medische programma zou in een cohortstudie op slechts het "zieke" deel van de simulatiegroep betrekking moeten hebben. De simulatiegroep uit het cohort zou dan alleen bestaan uit personen die voor het betreffende medische programma geindiceerd zijn. We hebben daartoe de simulatiegroep buiten de userinterface om zodanig ingesteld teneinde dat dit effect gedemonstreerd kan worden.

De simulatiegroep is ingesteld op een hypo-cohort dat bestaat uit mannen met een algemeen risicoprofiel. De verwachte incidentieleeftijd van een medisch scenario blijft gelijk aan die van een basisscenario. De levenswinst die een medisch scenario ten opzichte van het basisscenario genereert, vindt zijn basis in een stijging van de verwachte ziekteduur. De stijging van de ziekteduur is groter naarmate de aanvangsleeftijd van het cohort jonger is. We hebben om deze reden de aanvangsleeftijd van het cohort ingesteld op 35 jaar.

Er zijn twee medische programma's uit paragraaf 6.4 toegepast op een cohortstudie:

(i) CAG-Screening Programma,

(ii) Opname Programma.

(i) CAG-Screening Programma

Het scenario is aangeduid als het CAG-Cohort-Preventiescenario. Het CAGScreening Programma is dezelfde zoals afgebeeld in tabel 6.15 .

De levensverwachting van het scenario stijgt met 0,5 jaar ten opzichte van het basisscenario. De verwachte ziekteduur stijgt met 1,3 jaar. De extra kosten bedragen $f$ 11.226,-- per persoon. De kosteneffectiviteit wordt berekend door het bedrag aan extra kosten van $f$ 11.226,-- te delen door de levenswinst van 0,5 jaar, aangeduid als de kosteneffectiviteitsratio (KER). De KER bedraagt dan $f 22.451$,- per gewonnen levensjaar. Verdisconteerd tegen een discontovoet van $2 \%$ daalt de KER naar $f$ 18.993,-- per gewonnen levensjaar. Dit duidt erop dat de extra levensjaren op een eerder moment "in de tijd" worden gewonnen dan het bedrag dat aan extra kosten wordt besteed. 
In het CAG-Screening Programma uit tabel 6.15 van paragraaf 6.4 stellen we het aantal deelnemers uit de doelgroep Oud-MI, EF- op 0\%. De levenswinst en de winst in ziekteduur blijven gelijk aan 0,5 jaar respectievelijk 1,3 jaar. De extra kosten dalen licht van $f 11.226$,- naar $f 10.883$,-, waardoor de KER iets daalt naar $f$ 21.766,- per gewonnen levensjaar. Vervolgens wordt de instroom van patiënten met dit risicoprofiel (buiten de userinterface om) op 0 gesteld (de subgroepen $\mathrm{EF}<40 \%$ en EF- uit Bijlage II). De stijging van de verwachte ziekteduur ten opzichte van het basisscenario bedraagt 1,6 jaar. Dit is een stijging van 0,3 jaar extra ten opzichte van de simulatie waarbij de doelgroep Oud-MI, EF- op $0 \%$ was gesteld. De extra kosten blijven ongeveer stabiel, waardoor de kosteneffectiviteit van het scenario verder zal toenemen. We hebben met dit laatste voorbeeld een toelichting willen geven op onze opmerking aan het begin van deze paragraaf betreffende het "zieke deel van de simulatiegroep".

\section{(ii) Opname Programma}

Het scenario is genoemd het FMI-Cohort-Preventiescenario. Het opname programma is afgebeeld in tabel 6.16. De kosteneffectiviteit van dit programma is zeer gunstig. Enerzijds zijn de levenswinst en de winst in ziekteduur relatief gezien hoog $(0,7$ jaar respectievelijk 1,7 jaar), terwijl de extra kosten laag uitvallen met $f 467$,- per persoon. De KER bedraagt dan $f$ 667,- per gewonnen levensjaar.

We hebben het Budget TV-spot verhoogd van $f$ 9.999.999,-- naar maximaal $f 100 \mathrm{mln}$. per jaar en het Budget 06-nummer van $f 2.000 .000$,-- naar maximaal $f 100 \mathrm{mln}$. per jaar. Het programma is zodanig opgezet dat deze kostenverhogingen geen verdere verbetering van de effectiviteit teweegbrengen. Het bedrag aan extra kusten bedraagt $f 12.875,--$ per persoon, hetgeen een KER inhoudt van $f$ 18.393,-- per gewonnen levensjaar.

Tot slot is het zieke deel van de simulatiegroep specifiek gedefinieerd door de instroom van de zogenaamde $\mathrm{K}+$ en $\mathrm{K}$ - (en SVD en MVD) op 0 te stellen. De winst in ziekteduur in 2010 stijgt van 1,7 jaar naar 2,6 jaar. Het bedrag aan extra kosten is gedaald van $f 12.875$,-- naar $f 10.730,--$ per persoon. 
7 ALGEMENE BESCHOUWING

\subsection{Inleiding}

7.2 Sensitiviteitsanalyses

7.3 Vervangende ziekten en -sterften

7.4 Gezondheidsproductiefunctie

7.6 Programma Budgettering 


\subsection{Inleiding}

Het doel van het proefschrift is een beschouwing te geven over de vraag in hoe verre scenario-analyse nu gebruikt kan worden als een voor beleid geschikt eco nomisch analyse-instrument met betrekking tot de verschillende toekomsttra jecten (zie Hoofdstuk 1).

We hebben hiertoe in Hoofdstuk 6 verschillende scenario-analyses uitgevoerd of bevolkingsstudies en cohortstudies van zowel preventiescenario's als medisch scenario's. In deze analyses hebben we ons voor een belangrijk deel gericht o de verklaring van de verschillen in kosten- en effectenontwikkeling tussen d verschillende scenario's en het basisscenario. Er is hierbij gestreefd zoveel moge lijk inzicht te geven wat belangrijke samenhangen zijn tussen de evaluatie-varia belen van de CHZ-simulator (zie figuur 6.1. uit Hoofdstuk 6) en wat de moge lijkheden en/of beïnvloeding van sturing hiervan zijn. Naast het streven naar ee zo compleet mogelijke weergave van de werkelijkheid is het aanreiken va: "handvaten" voor het beleid ter beïnvloeding en sturing van die werkelijkhei én van de, zoniet de belangrijkste functie van een scenariomodel (zie ook Bij 1991). We hebben hierbij gestreefd naar het aanbrengen van een zo groot moge lijke reductie van de complexiteit van de werkelijkheid, binnen de randvoorwaar de dat ons scenario-model herkenbaar blijft voor de betreffende beroepsgroepe op het terrein van $\mathrm{CHZ}$ (zie ook Epiloog).

Een belangrijk onderdeel van de modelanalyse vormt de gevoeligheids- of sensi tiveiteisanalyse. Het gaat hierbij om het onderkennen van de variabelen die bi variatie in hun standaardwaarden van invloed zijn op de modeluitkomsten. I Hoofdstuk 1 hebben we reeds gewezen op het onzekerheidsaspect met betrekkin tot structuren, processen over verleden en heden, en mogelijke ontwikkelinge hiervan met betrekking tot de toekomst. In de epiloog komen we hierop uitge breid terug. Het zijn niet deze onzekere aspecten van een model en hun invloe op de modeluitkomsten die we bedoelen met gevoeligheidsanalyse. Het gaat $b$ gevoeligheidsanalyse om het onderkennen van epidemiologische variabelen al sterftekansen, de kansen op incidentie en de effectiviteit van behandelingen di niet exact bepaald kunnen worden. Hetzelfde geldt voor (bedrijfs)economisch variabelen als kostprijzen die van groot belang zijn voor de bepaling van de kos teneffectiviteit van een gezondheidszorgprogramma. In scenario-onderzoek spee dit aspect weliswaar een minder belangrijke rol dan bij kosten-effectiviteitsstu dies. Het is ons doel geweest het model zo goed mogelijk ingevuld te krijge met empirische gegevens (zie de bijlagen). In paragraaf 7.2 (onderdelen A en B voeren we een aantal sensitiviteitsanalyses uit.

In de markt van de gezondheidszorg werken de wetten van vraag en aanbod nit op dezelfde manier als in een markt van volkomen concurrentie (vgl. Heali 
1983). Men is daarom op zoek gegaan naar verde-lingsmethoden die de wetten van vraag en aanbod op de markt van de gezondheidszorg (voor een deel) kunnen vervangen.

In de gezondheidszorg moeten op beleidsniveau daarom steeds keuzen gemaakt worden in steeds moeilijker overzienbare situaties. De keuzen kunnen betrekking hebben op een (meer) efficiënte uitvoering van een dienst of van een bepaald productieproces (technische efficiëntie), of ze hebben betrekking op het nut dat aan de toedeling van een bepaald budget ontleend kan worden (allocatieve efficiëntie). De beide efficiëntievormen zijn in Hoofdstuk 4 besproken.

Het is vanuit dit perspectief dat de belangstelling voor economische evaluatie-onderzoek in de vorm van kosten-effectiviteitsonderzoeken in brede kring (steeds) groter wordt (vgl. Grenzen van Zorg, 1987). Economische evaluatie is een analysemethode waarmee de kosten en effecten van verschillende gezondheidszorgprogramma's met elkaar kunnen worden vergeleken (zie paragraaf 7.2). Deze vergelijkingen worden vaak gepresenteerd in de vorm van zogenaamde QALYleague tabellen. Er worden bijvoorbeeld vergelijkingen gemaakt tussen bestaande en nieuwe gezondheidszorgprogramma's, of er worden onderzoekingen gedaan naar de economische gevolgen van uitbreiding of inkrimping van een bepaald programma (het zogenaamde marginaliteitsprincipe). Economisch evaluatie-onderzoek kan inzicht geven in de vraag of een bepaald gezondheidszorgprogramma (meer) waarde voor zijn geld oplevert (het zogenaamde "more value for our money" criterium). Het economisch evaluatieonderzoek kan in deze zin het best vergeleken worden met de rentabiliteitsonderzoeken uit het bedrijfsleven.

Er worden bij economisch evaluatieonderzoek naast vergelijkingen op bevolkingsniveau (macroniveau) ook vergelijken op instellingsniveau (mesoniveau) en op het niveau van de individuele arts of individuele patiënt (microniveau) gemakt om tot een verantwoorde keuze tussen twee alternatieven te komen.

Voorbeelden van toepassingsgebieden van economische evaluatie zijn budgetonderhandelingen tussen enerzijds verzekeraars en instellingen en anderzijds tussen specialismen en directie van een instelling (of voorziening). Economische evaluatie kan in het eerste voorbeeld gebruikt worden als hulpmiddel voor een gefundeerde prioriteitenstelling (bijvoorbeeld in geval van indicatieverruimingen). In het tweede voorbeeld wordt de claim van de verschillende specialismen op een groter deel van het instellingsbudget gerechtvaardigd wanneer ze kunnen aantonen dat het gebruik van bepaalde voorzieningen of medische technologieën leidt tot een grotere doelmatigheid (vgl. Rutten e.a., 1992). In ons betoog zullen wij het economisch evaluatie-onderzoek beperkingen tot vergelijkingen op bevolkingsniveau.

Er zullen output criteria ontwikkeld moeten worden ter evaluering van de verdeling van produktiemiddelen over de verschillende aanwendingsmogelijkheden, zodanig dat daarmee een zo maximaal mogelijke behoeftebevrediging (welvaart) 
bereikt kan worden. Zoals hierboven al aangegeven is de QALY in de gezondheidszorg een veel gebruikt output-criterium (zie Hoofdstuk 4).

De gevolgen voor het overheidsbeleid in termen van allocatieve efficiëntie worden in economisch evaluatie-onderzoek met behulp van QALY's over het algemeen echter onvoldoende zichtbaar gemaakt. Dit aspect wordt in paragraaf 7.2, onderdeel $\mathrm{C}$, verder uitgewerkt.

Er is op verschillende plaatsen in het proefschrift reeds opgemerkt dat we met betrekking tot de toekomsttrajecten van $\mathrm{CHZ}$ zijn uitgegaan van onafhankelijkheid van doodsoorzaken. In paragraaf 7.3 schetsen we aan de hand van een voorbeeld tot welke onverwachte resultaten dit kan leiden wanneer hiermee wel rekening wordt gehouden (zie ook Epiloog).

Een economisch instrument dat meer inzicht geeft in de gevolgen van de verdeling van de schaarse middelen voor de volksgezondheid op macroniveau is de gezondheidsproductiefunctie. De gezondheidsproductiefunctie geeft de hoeveelheid gezondheid (output) aan die bij een bepaalde hoeveelheid gezondheidszorg (input) wordt geproduceerd. Er kan een vergelijking gemaakt worden tussen de verschillende geproduceerde hoeveelheden gezondheid (bijvoorbeeld weergegeven als QALY's) door een variatie aan te brengen in de verdeling van de beschikbare middelen. Het is vooralsnog theoretisch mogelijk om uit deze vergelijking het optimale verdelingspunt van de schaarse middelen over de verschillende gezondheidszorgprogramma's te vinden.

$\mathrm{Er}$ is in de gezondheidszorg weinig literatuur bekend over de wijze waarop de relatie tussen de inputs en outputs geoperationaliseerd zijn. Wij willen in paragraaf 7.4 aan de hand van twee voorbeelden toch een poging wagen de theorie rondom de gezondheidsproduktiefunctie meer te operationaliseren.

In de jaren ' 80 is de Nederlandse regering gestart met de ontwikkeling van een financieel overzicht van alle kosten en uitgaven in de gezondheidszorg (Financieel Overzicht Zorg of FOZ). Het FOZ heeft zich geleidelijk aan ontwikkeld tot een instrument waarmee de beleidmakers de financiële grenzen in de gezondheidszorg kunnen aangeven. Er bestaat echter geen wettelijk kader waarmee deze financiële grenzen afgedwongen kunnen worden (vgl. Janssen, 1992).

De Nederlandse gezondheidszorg is gebaseerd op een voorzieningenstructuur, zonder dat deze structuur is ingebed in een structuur van gezondheidszorgprogramma's. In het FOZ kunnen de bereikte effecten zodoende niet of moeilijk op hun effectiviteit (doeltreffendheid) en efficiëntie (doelmatigheid) worden beoordeeld. Immers de effecten kunnen niet op een effectieve wijze gerelateerd worden aan de gezondheidszorgprogramma's waar ze door gegenereerd worden. 
Er moet dus gezocht worden naar andere gezondheidszorgstructuren waarbinnen verdelingsanalyses van de beschikbare middelen kunnen worden gemaakt. De stelling is dat scenariostudies op bevolkingsniveau een belangrijk nieuw economisch analyse-instrument toevoegen aan de besluitvorming met betrekking tot het lange termijn beleid. Een effectief gebruik van scenariostudies hiervoor vereist dat er een structuur (een "framework") beschikbaar moet zijn waarmee richting gegeven kan worden aan het strategisch beleid op macroniveau. Wij hebben dit framework aangeduid als het beheersingsproces ("managerial process"), zijnde een systematisch en continue proces van nationale planning en programmering (vgl. WHO, 1981). Dit beheersingsproces vormt een conceptueel kader waarbinnen de verdelingsvraagstukken in de gezondheidszorg geplaatst kunnen worden.

Wij willen in paragraaf 7.5 ervoor pleiten dat het bestaan van een dergelijk kader een voorwaarde is voor de toepassing van enerzijds scenario-analyse als effectief economisch analyse-instrument, en anderzijds procedures op macroniveau met betrekking tot de verdeling van de schaars beschikbare middelen. Een voorbeeld van een dergelijke "verdelingsprocedure" is programma budgettering. Programma budgettering is een planningsmodel dat gericht is op het budgetteren van gezondheidszorgprogramma's.

Samenvattend hebben wij het hoofdstuk als volgt opgebouwd. We geven in paragraaf 7.2 een aantal sensitiviteitsanalyses met hieraan gekoppeld een discussie over de bruikbaarheid van de QALY-league-tabellen bij allocatieve efficiëntie. In paragraaf 7.3 worden aspecten met betrekking tot vervangende ziekten en -sterften behandeld. In paragraaf 7.4 gaan we in op een toepassing van de gezondheidsproductiefunctie. In paragraaf 7.5 is een beschouwing opgenomen over programma budgettering.

\subsection{Sensitiviteitsanalyse}

We geven in deze paragraaf een aantal sensitiviteitsanalyses met betrekking tot de cohortstudies genoemd in Hoofdstuk 6. De presentatie hiervan wordt geillustreerd met behulp van zogenaamde "incrementele league"-tabellen van kosten per gewonnen levensjaar. De paragraaf wordt afgesloten met enkele kritische kanttekeningen die in de literatuur bestaan met betrekking tot het gebruik van deze tabellen.

\section{A. Sensitiviteitsanalyses van bevolkingsstudies}

We hebben in figuur 6.8 uit Hoofdstuk 6 het Dieet-Chol-Bevolking scenario gepresenteerd. De kengetallen uit deze figuur worden in onderstaande tabel 7.1 weergegeven. 


\begin{tabular}{|l|r|r|r|r|}
\hline & \multicolumn{2}{|c|}{ Basisscenario } & \multicolumn{2}{c|}{ Dieet-Chol-Bevolling } \\
\hline & 1988 & 2005 & 1988 & 2005 \\
\hline Levensverwachting in jaren & 76.9 & 78.0 & 76.9 & 78.4 \\
Sterftekans CHZ in \% & 18.0 & 16.9 & 18.0 & 15.6 \\
Verwachting incidentele leefijd & 67.7 & 67.8 & 67.7 & 69.2 \\
Verwachting ziekteduur in jaren & 8.9 & 9.4 & 8.9 & 8.9 \\
\hline
\end{tabular}

Tabel 7.1

Kengetallen Dieet-Chol-Bevolking scenario bij 0,7\%

In tabel 7.1 is de "reductie niet-CHZ-sterfte parameter" ingesteld op 7\% (daling niet-CHZ-sterfte met $7 \%$ in 10 jaar, oftewel $0,7 \%$ per jaar). De volgende tabel 7.2 geeft de betreffende getallen weer bij een instelling van " 0 " reductie nietCHZ-sterfte.

\begin{tabular}{|l|r|r|r|r|}
\hline & \multicolumn{2}{|c|}{ Basisscenario } & \multicolumn{2}{c|}{ Dieet-Chol-Bevolking } \\
\hline & 1988 & 2005 & 1988 & 2005 \\
\hline Levensverwachting in jaren & 76.9 & 76.9 & 76.9 & 77.2 \\
Sterftekans CHZ in \% & 18.0 & 15.4 & 18.0 & 14.1 \\
Verwachting incidentele leeftjd & 67.7 & 67.4 & 67.7 & 68.7 \\
Verwachting zdekteduur in jaren & 8.9 & 9.0 & 8.9 & 8.6 \\
\hline
\end{tabular}

Tabel 7.2

Kengetallen Dieet-Chol-Bevolking scenario bij 0\%

In beide tabellen 7.1 en 7.2 daalt de sterftekans $\mathrm{CHZ}$ van het basisscenario in 2005 ten opzichte van 1988 omdat de sterfte aan niet-CHZ relatief sterker is gestegen dan aan CHZ. De gemiddelde leeftijd van de gezonde bevolking stijgt, waardoor de sterfte van leeftijdsgebonden ziekten toeneemt. De CHZ-sterfte blijft boven de leeftijd van circa 70 jaar "stabiel". De sterfte niet-CHZ neemt in het basisscenario uit tabel 7.2 als gevolg van de "reductie-uitschakeling" zodanig sterk toe, dat de sterftekans $\mathrm{CHZ}$ van het basisscenario uit tabel 7.2 sterker daalt dan die uit tabel 7.1 (daling van $18,0 \%$ naar $15,4 \%$ respectievelijk $16,9 \%$ ). De beschreven effecten worden als gevolg van het optreden van het scenario (natuurlijk) verder versterkt.

Een tweede opmerking over het basisscenario uit de tabellen 7.1 en 7.2 geldt met betrekking tot de incidentieleeftijd. Deze daalt in tabel 7.2 met 0,3 jaar (van 67,7 naar 67,4) en in tabel 7.1 stijgt deze met 0,1 jaar (van 67,7 naar 67,8). De verklaring hiervoor is als volgt. De $0,7 \%$ reductie niet-CHZ-sterfte heeft als neveneffect dat er meer mensen komen (het zogenaamde "gespaarde" gedeelte in de 
bevolking dat anders aan niet-CHZ was gestorven) die een $\mathrm{CHZ}$-incidentie krijgen. Het aantal $\mathrm{CHZ}$-incidenties uit de gezonde bevolking zal stijgen. Dit "gespaarde effect" met betrekking tot de CHZ-incidenties zal ook in de CHZ-bevolking optreden. In de regressiecoëfficiënten van de Frammingham Heart Study (FHS) is een leeftijdsparameter ingebouwd (zie Bijlage I). Omdat de gemiddelde leeftijd van het gespaarde gedeelte ouder wordt, stijgt als gevolg van deze regressiecoëfficiënt de verwachte incidentieleeftijd in 2005 .

Tot slot kunnen we opmerken dat de bereikte levenswinst van het Dieet-CholBevolking scenario in tabel 7.2 lager uitvalt dan die in tabel 7.1. De gevoeligheid van deze parameter voor de scenario-uitkomsten kunnen we tonen met behulp van het Med-Chol-Bevolking scenario uit Hoofdstuk 6. De betreffende vergelijking is in tabel 7.3 opgenomen.

\begin{tabular}{|l|r|r|r|r|}
\hline \multirow{2}{*}{ Het jagr 2005 } & \multicolumn{2}{|c|}{$0 \%$ reductie } & \multicolumn{2}{c|}{$0,7 \%$ reductie } \\
\cline { 2 - 5 } & Basisscenarlo & Med-Chol-Bev & Bassscenorio & Med-Chol-Bev \\
\hline Lev.verw. in Jaren & 76.9 & 77.7 & 78.0 & 78.9 \\
Sterftekans CHZ in \% & 15.4 & 12.4 & 16.9 & 13.8 \\
Verw.jnc. leeftijd & 67.4 & 70.7 & 67.8 & 71.2 \\
Verw. ziekteduur in jaren & 9.0 & 8.0 & 9.4 & 8.4 \\
\hline
\end{tabular}

Tabel 7.3

Vergelijking kengetallen Basisscenario en Med-Chol-Bevolking scenario in 2005 bij $0 \%$ reductie respectievelijk $0,7 \%$ reductie

Uit de vergelijking in tabel 7.3 valt uiteraard direct het verschil in levensverwachting op in de situatie met $0 \%$ reductie versus $0,7 \%$ reductie. De winst in levensverwachting valt terug van 0,9 jaar bij $0,7 \%$ reductie $(78,9$ jaar - 78,0 jaar) naar 0,8 jaar bij $0 \%$ reductie $(77,7$ jaar $-76,9$ jaar). Dit is een daling van circa $11 \%$. De daling van de winst in levensverwachting bij het Dieet-Chol-Bevolking scenario is eveneens 0,1 jaar, maar gerealiseerd bij een levenswinst van 0,4 jaar (tabel 7.1). Het effect van deze weliswaar gevoelige parameter op de scenariouitkomsten neemt af naarmate van het scenario zelf een krachtige werking uitgaat op de reductie van de CHZ-incidentie.

Er is in het model een aantal CHZ-parameters opgenomen die van invloed zijn op de reductie van de $\mathrm{CHZ}$-sterfte, te weten:

reductie-operatie-sterfte CABG 5\% (5\% reductie sterftekans per 10 jaar); reductie-operatie-sterfte PTCA 5\% (5\% reductie sterftekans per 10 jaar); indicatie-PTCA 150 (15\% verhoging PTCA geïndiceerde patiënten die nu MED-behandeling krijgen (zie ook Hoofdstuk 5)). 
In tabel 7.4 wordt weergegeven wat het effect op de uitkomsten van het DieetChol-Bevolking scenario is bij uitschakeling van de drie parameters (instelling op 0).

\begin{tabular}{|l|r|r|r|r|}
\hline & \multicolumn{2}{|c|}{ Basisscenarlo } & \multicolumn{2}{c|}{ Dieet-Chol-Bevolling } \\
\hline & 1988 & 2005 & 1988 & 2005 \\
\hline Levensverwachting in jaren & 76.9 & 78.0 & 76.9 & 78.4 \\
Sterftekans CHZ in \% & 18.0 & 17.1 & 18.0 & 15.8 \\
Verwachting incidentele leeftjd & 67.7 & 67.8 & 67.7 & 69.2 \\
Verwachting vekteduur in Jaren & 8.9 & 9.3 & 8.9 & 8.8 \\
\hline
\end{tabular}

Tabel 7.4

Kengetallen Dieet-Chol-Bevolking scenario bij uitschakeling reductieoperatie-sterfte CABG, reductie-operatie-sterfte-PTCA, en indicatie-PTCA

In het basisscenario uit tabel 7.4 stijgt de sterftekans CHZ in 2005 met $0,2 \%$ ten opzichte van het basisscenario uit tabel 7.1 (17,1\% versus $16,9 \%)$. De ziekteduur neemt toe met 0,1 jaar $(9,3$ jaar versus 9,4 jaar). Dezelfde effecten treden versterkt op bij het scenario. De gevoeligheid van deze parameters voor de scenariouitkomsten zijn veel geringer dan die van de "niet-CHZ-sterfte".

We demonstreren hier de gevoeligheid voor het model wanneer er een doelstellend scenario wordt geconstrueerd (zie Hoofdstuk 5). In het scenario zijn de volgende doelstellingen opgenomen (willekeurig gekozen):

1) het percentage mannelijke en vrouwelijke rokers is in 2010 te opzichte van 1988 met $34 \%$ respectievelijk $28 \%$ gedaald (instelling eindwaarden roken op 25);

2) het cholesterolgehalte is voor de hele bevolking in 2010 ten opzichte van 1988 met $9 \%$ gedaald (instelling eindwaarden cholesterol op 5.0 voor mannen en 4.8 voor vrouwen).

De dalende rooktrend wordt bereikt door een programma anti-rook voorlichting op scholen. Er is een begrensde doelgroep gevormd in de leeftijdsklasse 10-20 jaar. De kosten hiervan zijn ingesteld op $f 2 \mathrm{mln}$. vaste kosten per jaar en $f$ 144,-- per persoon per jaar (zie Bijlage III). De daling van het cholesterolgehalte wordt bereikt met een dieet-programma. De vaste kosten bedragen $f 2$ mln. per jaar. De kostprijs in het eerste jaar is $f 490,--$ per persoon en in het tweede en volgende jaren $f 270,--$ per persoon per jaar (zie Bijlage III). In beide programma's zijn de reactie en therapietrouw ingesteld op $100 \%$. Het startjaar is 
1988. De scenario's eindigen in 2010. Er wordt geen rekening gehouden met een aanlooptijd. De simulatiegroep bestaat uit de hele bevolking, die als risicoprofiel heeft: roken, cholesterolniveau van $6.0-20.0 \mathrm{mmol} / \mathrm{l}$, diastolisch bloeddrukniveau van 50 - $90 \mathrm{mmHg}$. Het scenario heet Doel-Risk-Bevolking-scenario.

De levensverwachting in 2010 stijgt van 76,8 jaar voor het basisscenario naar 77,2 jaar voor het Doel-Risk-Bevolking scenario (niet weergegeven). De kosten stijgen in 2010 met $f 142,9 \mathrm{mln}$. van $f 377,3 \mathrm{mln}$. naar $f 520,2 \mathrm{mln}$. (niet weergegeven). In figuur 7.1 worden de karakteristieke incidenties gepresenteerd.

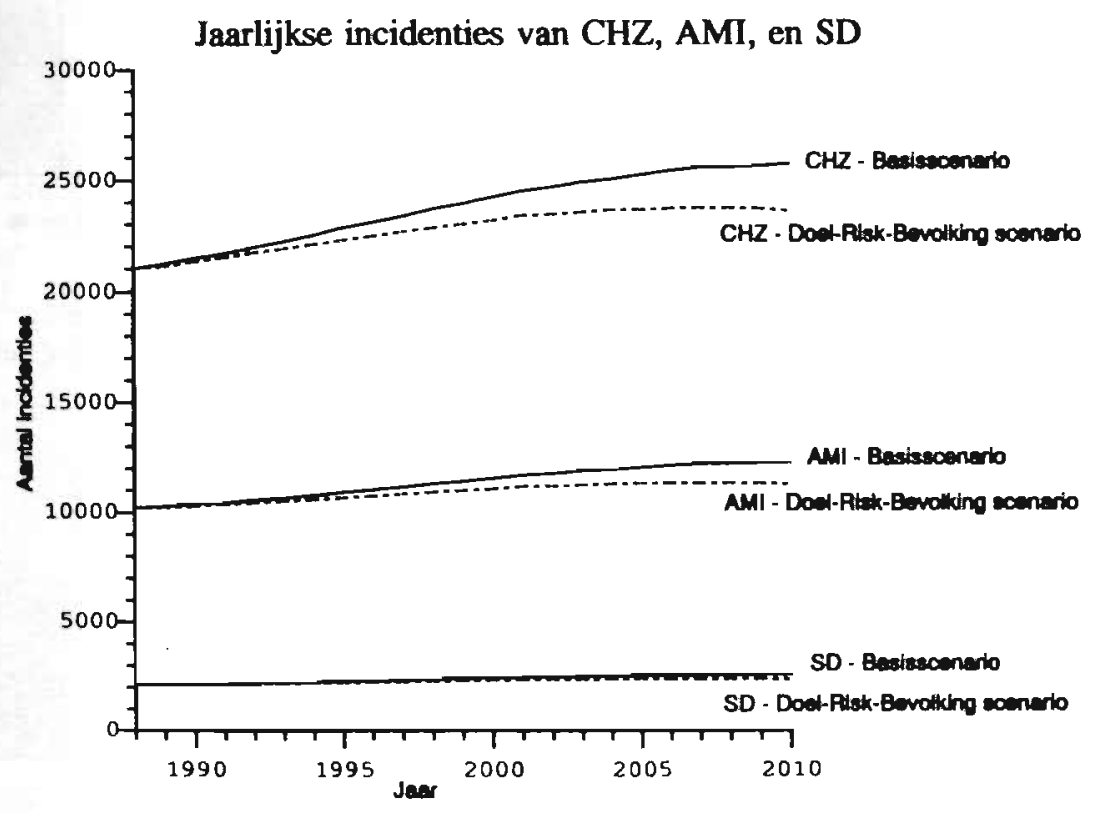

Figuur 7.1

Karakteristieke CHZ-incidenties van het Doel-Risk-Bevolking scenario bij toepassing van het Programma Anti-Rook Voorlichting op Scholen en het Cholesterol Reducerend Dieet Programma op de gebele bevolking

In de figuren 7.2 en 7.3 wordt de gevoeligheid van het percentage therapietrouw met betrekking tot de kosten van een scenario in een bevolkingsstudie gedemonstreerd. Het scenario is dezelfde als het Med-Chol-Bevolking scenario uit paragraaf 6.2 van Hoofdstuk 6. 

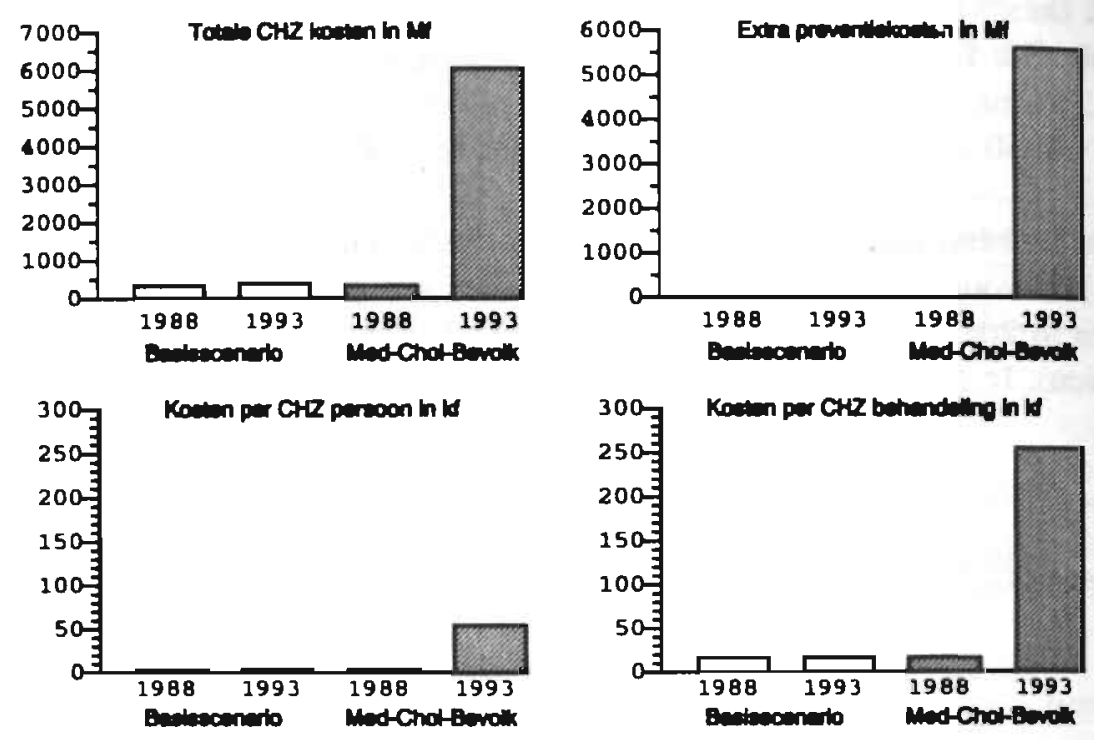

Figuur 7.2

Karakteristieke kosten van het Med-Chol-Bevolking scenario in 1993,0\% therapietrouw, bij toepassing van bet Cholesterol Reducerend Medicatie Programma op de gehele Nederlandse bevolking
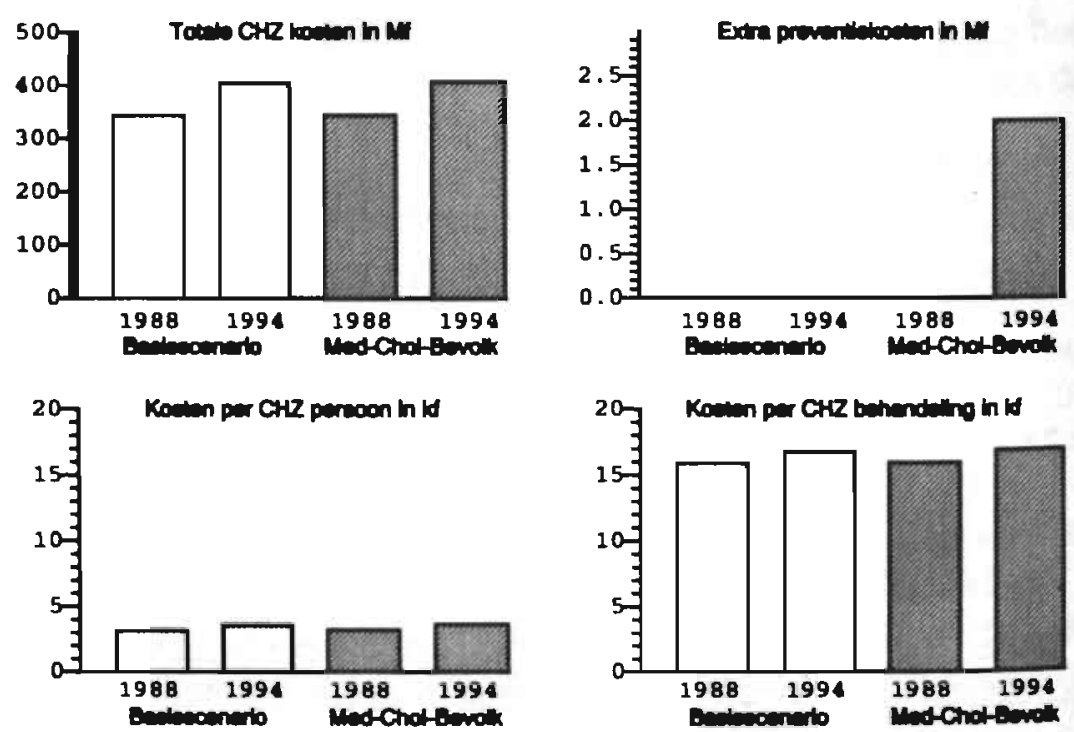

Figuur 7.3

Karakteristieke kosten van bet Med-Chol-Bevolking scenario in 1994, $0 \%$ therapietrouw, bij toepassing van het Cholesterol Reducerend Medicatie Programma op de gehele Nederlandse bevolking 
De vaste kosten van $f 2 \mathrm{mln}$. per jaar zijn onafhankelijk van de hoogte van de therapietrouw. In 1993 worden nog alle kosten gemaakt. In 1994 zijn er geen medicatiekosten meer. Het scenario laat als gevolg van de $0 \%$ therapietrouw ook geen levenswinst meer zien ten opzichte van het basisscenario.

De doelgroep in het Cholesterol Reducerend Medicatie Programma uit tabel 6.2 bestaat nu alleen uit de leeftijdsgroep van 50 - 60 jaar. De simulatiegroep blijft uit alle leeftijden bestaan. De overige kenmerken met betrekking tot het risicoprofiel, zoals genoemd in tabel 6.1, blijven onveranderd. Er worden nu minder mensen bereikt dan waar het programma voor bedoeld is. De kosten van het programma zullen in geval van een "begrensde" doelgroep in vergelijking met een "onbegrensde" doelgroep (= simulatiegroep) dalen. Evenzo geldt dit voor de bereikte levenswinst. In 2005 zijn de kosten en effecten van het Med-Chol-Bevolking scenario in geval van een begrensde - en een onbegrensde doelgroep $f 1.131,3$ mln. en 78,4 jaar respectievelijk $f 4.870,8 \mathrm{mln}$. en 78,9 jaar . De extra kosten en levenswinst in 2005 ten opzichte van het basisscenario bedragen $f 601,1 \mathrm{mln}$. en 0,4 jaar respectievelijk $f 4.340,6 \mathrm{mln}$. en 0,9 jaar. Het blijkt dat de scenario-uitkomsten zeer gevoelig zijn voor de mate waarmee de doelgroep in zijn leeftijd begrensd wordt.

We gaan in dit onderdeel na in hoeverre een beperking van de operatiecapaciteit een invloed heeft op de uitkomsten van het basisscenario. Er wordt geen ander medisch programma toegevoegd aan het operatiecapaciteit programma. De instelling is dezelfde als weergegeven in tabel 6.17. Hierbij zijn de gemiddelde stijgingspercentages voor CABG en PTCA over de periode 1988-1992 gebruikt (circa $4 \%$ respectievelijk $22 \%$ per jaar). Het absolute plafond is gelijkgesteld aan de aantallen CABG's en PTCA's uit 1992 (9.200 respectievelijk 10.500). Het scenario is Wachtlijstscenario genoemd. In de figuren 7.4 en 7.5 worden het aantal uitgevoerde behandelingen en de karakteristieke kengetallen van het Wachtlijstscenario weergegeven. 


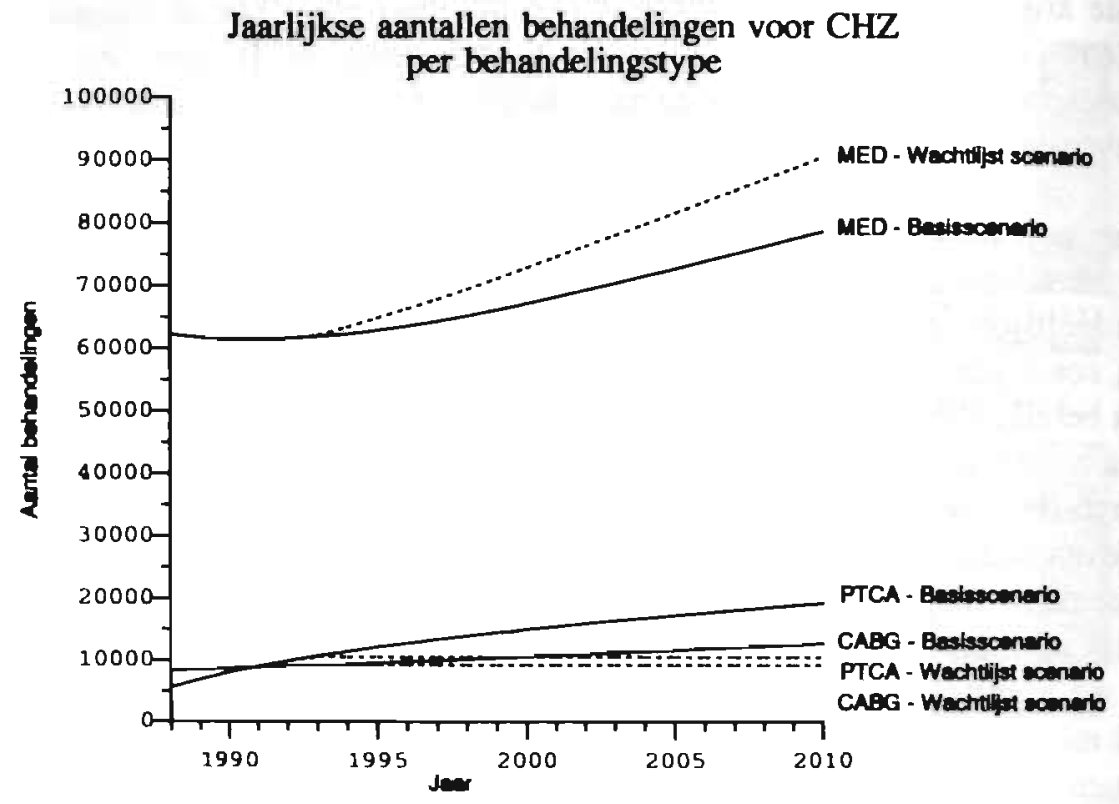

Figuur 7.4

Aantal uitgevoerde behandelingen van het Wachtlijstscenario bij toepassing van bet Operatiecapaciteit Programma laag op de gebele Nederlandse bew! king

Vergelijking van jaarlijkse $\mathrm{CHZ}$ kengetallen:

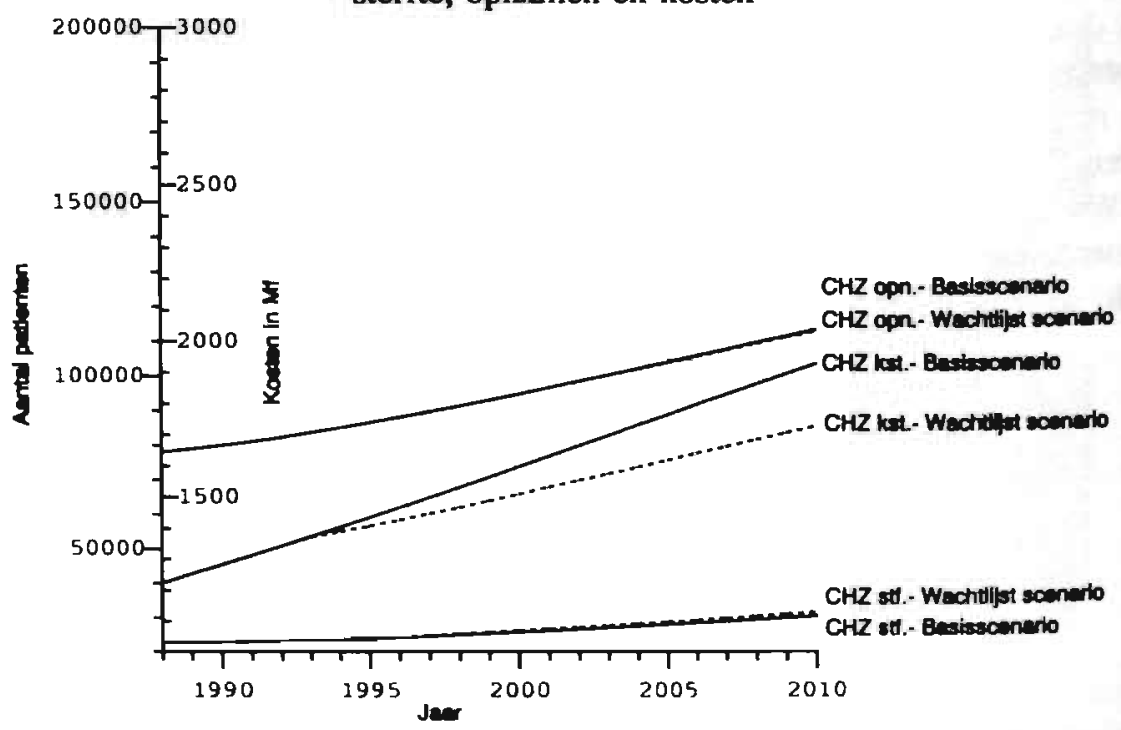

Figuur 7.5

Karakteristieke kengetallen van nel Wachthijstscenario bij toepassing val het Operatiecapaciteit Programma laag op de gehele Nederlandse bevolking 
De levensverwachting in 2010 van dit scenario is hetzelfde als van het basisscenario (niet weergegeven). Wel blijkt uit figuur 7.5 dat de $\mathrm{CHZ}$-sterfte in 2010 met $3,8 \%$ is gestegen, van 30.408 naar 31.552 personen. Dit effect uit zich in een daling van de verwachte ziekteduur met 0,2 jaar van 10,1 jaar naar 9,9 jaar in 2010 en een stijging van de sterftekans an CHZ van $20,1 \%$ naar $20,4 \%$ in 2010 (niet weergegeven). De getroffen personen zullen vooral mensen betreffen in de leeftijdscategorie boven de 55 jaar. De hogere CHZ-sterfte zal hierdoor gecompenseerd worden door een daling van de niet-CHZ-sterfte, met als gevolg een ongewijzigde levensverwachting in 2010.

Uit figuur 7.4 blijkt dat het aantal CABG's en PTCA's in 2010 met 3.499 respectievelijk 8.702 gedaald is ten opzichte van het basisscenario. Hiertegenover staat een drastische stijging van het aantal MED-behandelingen. Voor de kosten betekent deze (noodgedwongen) behandelingssubstitutie een daling van $f$ 199,7 mln. in 2010 (zie figuur 7.5), ondanks de forse toename in ziekenhuisopnames.

\section{B. Sensitiviteitsanalyse van Cohortstudies}

We hebben in Hoofdstuk 6 beschreven dat er meer geld nodig is om $100 \%$ reactie en $100 \%$ therapietrouw in een anti-rook campagne te bereiken. De vaste kosten zijn verhoogd van $f 2 \mathrm{mln}$. naar $f 100 \mathrm{mln}$. per jaar, terwijl de kostprijs van de campagne is verdubbeld van $f 116$,- naar $f 232$,- per persoon per jaar.

In tabel 7.5 wordt nagegaan in hoeverre de kosteneffectiviteit van het scenario wordt beïnvloed door de hoogte van de therapietrouw. De instellingswaarden met betrekking tot het risicoprofiel en het programma zijn dezelfde zoals weergegeven in de tabellen 6.9 en 6.10 uit Hoofdstuk 6.

\begin{tabular}{|c|c|c|c|}
\hline therapietrouw & $\begin{array}{c}\text { geen } \\
\text { verdiscontering }\end{array}$ & $\begin{array}{c}\text { discontovoet } \\
2 \%\end{array}$ & $\begin{array}{c}\text { discontovoet } \\
5 \%\end{array}$ \\
\hline $60 \%$ & $f 13.181,--$ & $f 18.793,--$ & $f 33.483,--$ \\
\hline $80 \%$ & $f 11.270,--$ & $f 15.780,--$ & $f 38.316,--$ \\
\hline $100 \%$ & $f 10.069,--$ & $f 13.977,--$ & $f 43.104,--$ \\
\hline
\end{tabular}

Tabel 7.5

Relatie therapietrouw en kosteneffectiviteit van bet Stop-Ro-Algemeen-Cohort scenario bij toepassing van het Anti-Rook Programma Algemeen op een hypo cohort van $1 \mathrm{mln}$. mannen van 35 jaar bij verschillende discontovoeten *

* NB: de kosten en effecten zijn verdisconteerd tegen dezelfde discontovoet 
De volgende tabel 7.6 geeft de relatie weer tussen de uitkomsten van het scenario en de hoogte van de kostprijs per persoon per jaar. De vaste kosten blijven ingesteld op $f 100 \mathrm{mln}$. per jaar. De therapietrouw bedraagt $100 \%$.

\begin{tabular}{|c|c|c|c|}
\hline kostprijs p.p.p.j. & $\begin{array}{c}\text { geen } \\
\text { verdiscontering }\end{array}$ & $\begin{array}{c}\text { discontovoet } \\
2 \%\end{array}$ & $\begin{array}{c}\text { discontovoet } \\
5 \%\end{array}$ \\
\hline$f 500,--$ & $f 19.778,--$ & $f 28.256,-$ & $f 87.400,--$ \\
\hline$f 1.000,--$ & $f 37.892,-$ & $f 54.896,-$ & $f 170.000,-$ \\
\hline$f 1.500,--$ & $f 56.005,--$ & $f 81.535,--$ & $f 252.685,-$ \\
\hline
\end{tabular}

Tabel 7.6

Relatie kostprijs per persoon per jaar en kosteneffectiviteit van het Stop-Ro. Algemeen-Cohort scenario bij toepassing van bet Anti-Rook Programma Algemeen op een bypo cohort van 1 mln. mannen van 35 jaar bij verschil. lende discontovoeten *

* NB: de kosten en effecten zijn verdisconteerd tegen dezelfde discontovot

De vergelijking tussen de tabellen 7.5 en 7.6 laat zien dat de kosteneffectiviteit van het scenario gevoeliger is voor mutaties in de hoogte van de kostprijs dan in de hoogte van de therapietrouw. Het is mogelijk het model te testen op het vo6rkomen van negatieve extra kosten van een programma. Een dergelijk fenomeen wordt afgebeeld in figuur 7.6.

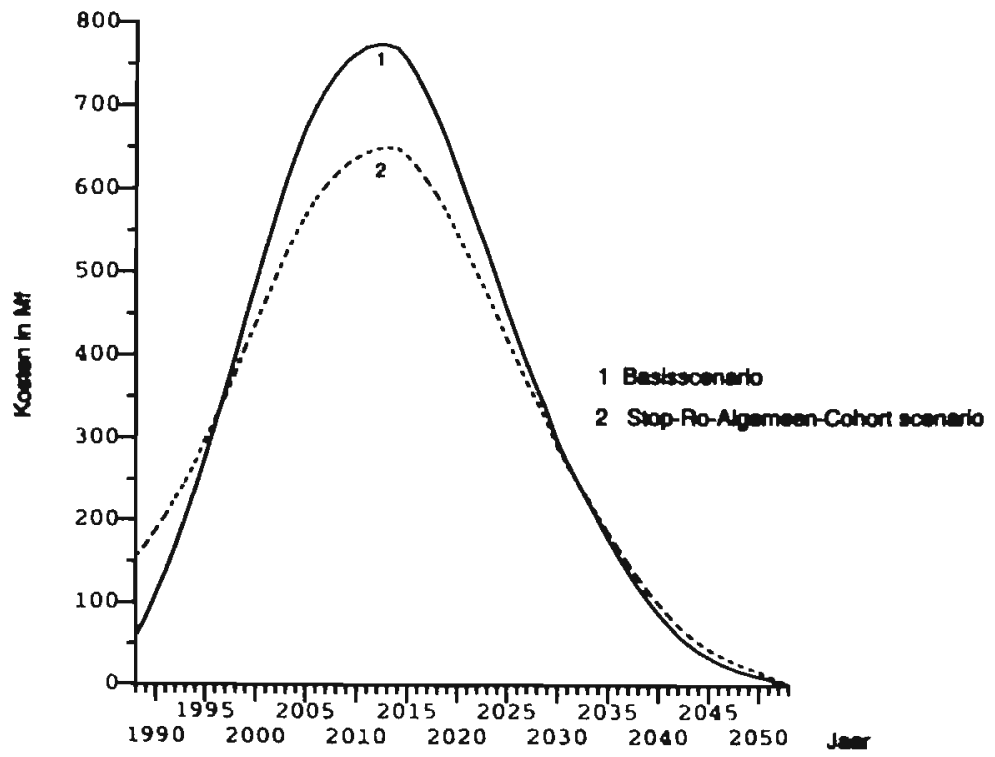

Figuur 7.6 Tutale CHZ-kosten 1988-2053 van het Stop-Ro-Algemeen-Cohort scenario hij toepassing van het Anti-Rook Programma Algemeen op een hypo cobort van $1 \mathrm{mln}$. mannen van 35 jaar 
Uit figuur 7.6 blijkt dat de kostenlijn van het scenario voor het grootste deel lager is dan die van het basisscenario. In het begin genereert het scenario als gevolg van de preventiekosten meer kosten dan het basisscenario. Naarmate de "looptijd" van het cohort toeneemt worden de besparingen in de kosten van medische behandelingen groter dan de preventiekosten. Deze situatie kan worden bereikt door het risicoprofiel van scenario II (of de scenario's III en IV) uit tabel 6.11 van Hoofdstuk 6 in een cohortstudie te simuleren met behulp van het antirookprogramma algemeen uit tabel 6.10. Hierbij zijn de vaste kosten bepaald op $f 2$ mln. per jaar en de kostprijzen op $f 116$,- per persoon per jaar (zie ook Bijlage III).

Vervolgens kunnen de paden worden uitgestippeld die leiden tot het gestelde doel (prospectief en strategisch). Grofweg vinden scenarioanalyses plaats binnen hetzij vooraf vastgestelde doelstellingenkaders, hetzij in doelzoekende beleidsprocessen (vgl. Meijer, 1990). Het is vooral dit laatste aspect, waar de signaleringsfunctie van scenario-analyse aan ontleend is. Deze signaleringsfunctie wil een verruiming van perspectief bieden, met als gevolg een zich op andere mogelijkheden dan het algemeen bekende (Schoonenboom, 1993).

De levenswinst van een cohortstudie hangt nauw samen met de aanvangsleeftijd van het cohort. In onderstaande figuur 7.7 is deze relatie uitgewerkt voor de variabele therapietrouw $100 \%$ en $60 \%$.

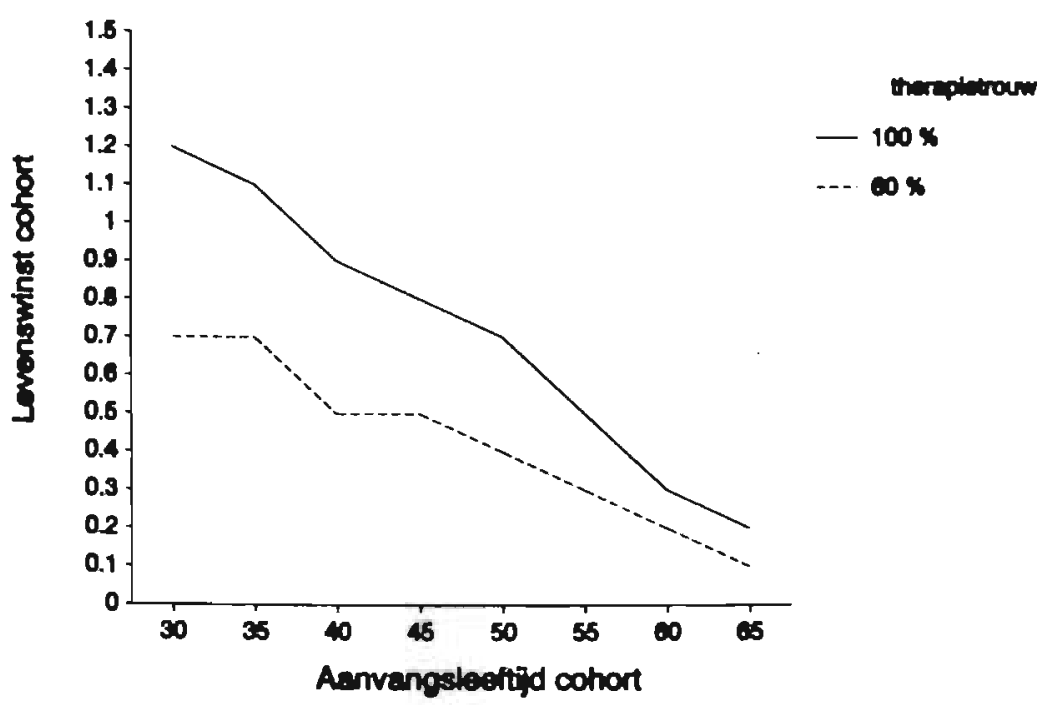

Figuur 7.7

Relatie aanvangsleeftijd en levenswinst van het Stop-Ro-Algemeen-Cohort scenario bij toepassing van het Anti-Rook Programma op een bypo cohort van $1 \mathrm{mlo}$. mannen bij verschillende therapietrouw 
Uit figuur 7.7 blijkt duidelijk de gevoeligheid van de levenswinst voor de therapietrouw. We hebben met betrekking tot de kosten aangenomen dat deze na het eerste jaar van het programma rechtevenredig fluctueren met de hoogte van de therapietrouw. Het gevolg is dat de kosteneffectiviteitsverhouding minder gevoelig wordt voor deze variabele, zoals blijkt uit tabel 7.5. Omdat onze aanname, zeker in het geval van controlebezoeken bij de doktersassistent, tot een onderschatting van de kosten zal leiden, zal de kosteneffectiviteit verslechteren. Hiervan is geen tabel weergegeven.

De onderstaande tabel 7.7 geeft de relatie weer tussen de aanvangsleeftijd en de aanlooptijd met betrekking tot de kosteneffectiviteit van het cohort.

\begin{tabular}{|c|r|r|r|}
\hline \multirow{2}{*}{ Aanvangsleeftijd } & Aanlooptijd & Geen verdiscontering & Discontovoet $2 \%$ \\
\hline \multirow{2}{*}{35 jaar } & 0 jaar & $f 10.069,--$ & $f 13.977,--$ \\
\cline { 2 - 4 } & 4 jaar & $f 10.175,--$ & $f 14.182,--$ \\
\hline \multirow{2}{*}{55 jaar } & 0 jaar & $f 13.085,--$ & $f 22790,--$ \\
\cline { 2 - 4 } & 4 jaar & $f 17.163,--$ & $f 24.325,--$ \\
\hline
\end{tabular}

Tabel 7.7

Relatie aanvangsleeftijd en aanlooptijd met betrekking tot kosteneffectiviteit van het Stop-Ro-Algemeen-Cohort scenario bij toepassing van het AntiRook Programma Algemeen op een hypo cohort van 1 mln. mannen van 35 en 55 jaar

De variabele aanlooptijd heeft op jongere aanvangsleeftijd minder invloed op de kosteneffectiviteit dan op oudere aanvangsleeftijd van het cohort. De kosten worden bij een aanlooptijd van 4 jaar van begin af aan meegerekend, terwijl de effecten pas na 4 jaar optreden. Op jongere aanvangsleeftijd staan deze extra kosten in geen verhouding tot het totale bedrag aan kosten die over de gehele "looptijd" van het cohort naar de aanvangsleeftijd worden teruggerekend (of teruggebracht). Op oudere aanvangsleeftijd is deze "looptijd" van het cohort uiteraard korter en krijgen de extra kosten relatief gezien meer gewicht.

De karakteristieke kengetallen met betrekking tot de levensverwachting en kosten hangen voor een belangrijk deel samen met de niet-CHZ-sterfte. Deze samenhang wordt in tabel 7.8 gedemonstreerd. 


\begin{tabular}{|c|c|c|c|c|c|c|}
\hline $\begin{array}{l}\text { Reductie } \\
\text { niet-CHZ- } \\
\text { sterfte }\end{array}$ & $\begin{array}{l}\text { winst } \\
\text { Levensver- } \\
\text { wachting }\end{array}$ & $\begin{array}{l}\text { winst } \\
\text { verwachte } \\
\text { incidentieleeftijd }\end{array}$ & $\begin{array}{l}\text { winst } \\
\text { verwachte } \\
\text { ziekteduur }\end{array}$ & $\begin{array}{l}\text { besparingen } \\
\text { (p.p.) }\end{array}$ & $\begin{array}{l}\text { prev.-kusten } \\
\text { (p.p.) }\end{array}$ & KER \\
\hline $14 \%$ & 1,7 jaar & 1,4 jaar & - 0,4 jaar & f 5.178,- & $f 16.728,--$ & $f$ 6.794,-- \\
\hline $7 \%$ & 1,1 jaar & 1,3 jaar & - 0,5 jaar & $f 4.769,-$. & $f 15.845, \cdots$ & f $10.069 . .-$ \\
\hline $0 \%$ & 0,8 jaar & 1,2 jaar & - 0,5 jagr & f 4.485 & f $15.345,--$ & f $13.574,--$ \\
\hline
\end{tabular}

Tabel 7.8

Relatie in de Reductie niet-CHZ-sterfte met de karakteristieke kengetallen en de kosteneffectiviteit van bet Stop-Ro-Algemeen-Cohort scenario vergeleken met het basisscenario bij toepassing van het Anti-Rook Programma Algemeen op een hypo cohort van 1 mln. mannen van 35 jaar

De reductie niet-CHZ-sterfte uit tabel 7.8 van $7 \%$ per 10 jaar $(0,7 \%$ per jaar) komt overeen met de standaardinstelling zoals gebruikt in het model. De gevoeligheid voor de levensverwachting van deze variabele is vanzelfsprekend vrij groot (zie ook Bijlage II).

In tabel 7.9 wordt nagegaan wat de invloed op de kosteneffectiviteit is wanneer de kosten van de medicatie (circa $f$ 1.300,- op jaarbasis) met $10 \%$ worden verhoogd respectievelijk verlaagd. We hebben de instellingswaarden genomen, zoals gebruikt in de tabellen 6.6 en 6.7 uit Hoofdstuk 6, en de kostprijs per persoon per jaar met $f$ 130,- verhoogd respectievelijk verlaagd.

\begin{tabular}{|c|c|c|c|}
\hline kostprijs p.p.p.j. & $\begin{array}{c}\text { geen } \\
\text { verdiscontering }\end{array}$ & $\begin{array}{c}\text { discontovoet } \\
2 \%\end{array}$ & $\begin{array}{c}\text { discontovoet } \\
5 \%\end{array}$ \\
\hline$+f 130,--$ & $f 39.064,--$ & $f 49.660,--$ & $f 77.718,--$ \\
\hline standaard & $f 29.436,--$ & $f 36.679,--$ & $f 54.263,--$ \\
\hline$-f 130,--$ & $f 26.778,--$ & $f 34.089,--$ & $f 53.740,--$ \\
\hline
\end{tabular}

Tabel 7.9

Relatie kostprijs per persoon per jaar en kosteneffectiviteit van bet MedChol-Cohort scenario bij toepassing van bet Cholesterol Medicatie Programma op een bypo cohort van 1 mln. mannen van 35 jaar bij verschillende discontovoeten

Opvallend uit tabel 7.9 blijkt de gevoeligheid van de kosteneffectiviteit bij een verhoging van de kostprijs, die veel sterker is dan bij een verlaging van de kostprijs. 
De relatie tussen de aanvangsleeftijd en de kosteneffectiviteit van het cohort wordt in tabel 7.10 weergegeven.

\begin{tabular}{|c|c|c|c|}
\hline anvangsleeftijd & geen verdiscontering & $\begin{array}{c}\text { discontoroet } \\
2 \%\end{array}$ & $\begin{array}{c}\text { discontovoet } \\
5 \%\end{array}$ \\
\hline $25 \mathrm{jagr}$ & f 32.514,-- & f 44.681,-- & f 88.747,- \\
\hline 30 Jom & f 28.716,-- & $f$ 40.823,-- & f 62.405,- \\
\hline 35 Jaar & f 29.436,-- & f 37.481,- & f 59.036,- \\
\hline 40 Jaar & f $28.927,--$ & f $38.009,--$ & f 55.654,- \\
\hline $45 \mathrm{j}$ jar & f $\mathbf{3 0 . 6 8 3 , - -}$ & f $38.789,--$ & f 52283 ,- \\
\hline $50 \mathrm{Jaar}$ & f 37.291,-- & f $46.637,--$ & f 48.955,-- \\
\hline 55 jaar & f 53.445,-- & f 49.968,-- & f 60.630,- \\
\hline 60 jaar & f 68.052,- & f 73.314,-- & f 83.364,-- \\
\hline
\end{tabular}

Tabel 7.10

Relatie aanvangsleeftijd en kosteneffectiviteit van bet Med-Chol-Cohort scenario bij toepassing van het Cholesterol Medicatie Programma op een hypo cohort van $1 \mathrm{mln}$. mannen van 35 jaar bij verschillende discontovoeten

In tabel 7.10 ligt de laagste kosteneffectiviteitsratio (KER) in geval van geen verdiscontering bij de aanvangsleeftijd 30 jaar. Hoe hoger het verdisconteringspercentage, hoe meer gewicht komt te liggen op de "looptijd" van het cohort. De laagste KER ligt bij een verdisconteringspercentage van $2 \%$ en $5 \%$ bij de aanvangsleeftijd 35 jaar respectievelijk 50 jaar.

Evenals het geval bij de niet-CHZ-sterfte hangen de karakteristieke kengetallen met betrekking tot de levensverwachting en de kosten voor een belangrijk deel samen met de reductie van de verhoogde risicofactorniveau's. De gevoeligheid van de scenario-uitkomsten hiervoor wordt in tabel 7.11 gedemonstreerd. 


\begin{tabular}{|c|c|c|c|c|c|c|}
\hline \multicolumn{7}{|l|}{ MANNEN } \\
\hline $\begin{array}{l}\text { percentage } \\
\text { reductie }\end{array}$ & $\begin{array}{l}\text { winst } \\
\text { levens- } \\
\text { verwachting }\end{array}$ & $\begin{array}{l}\text { winst } \\
\text { verwachte } \\
\text { inc.lin. }\end{array}$ & $\begin{array}{l}\text { winst } \\
\text { verwachte } \\
\text { inc.lift } \\
\end{array}$ & $\begin{array}{l}\text { bespartrgen } \\
\text { (p.p.) }\end{array}$ & $\begin{array}{l}\text { preventie- } \\
\text { kasten } \\
\text { (p.p.) }\end{array}$ & KER \\
\hline 20 & 1,6 jar & 3,8 jaar & - 1,0 jar & f $5.439,--$ & f 58.824,-- & f $33.366,--$ \\
\hline 25 & 1,9 jagr & 4,7 Jaar & - 1,2 Jasr & $f 6.451,--$ & f 59.617,-- & $f$ 27.982,- \\
\hline 30 & 2,2 Jaar & 5,6 Jaar & - 1,4 J $\mathrm{mar}$ & f 7.466,-- & $f 60.414,--$ & f $24.067,--$ \\
\hline \multicolumn{7}{|l|}{ VROUWEN } \\
\hline 20 & 0,7 Jar & 1,9 jaar & - 0,5 jaar & f $1.892,-$ & f 70.064,-- & f 97.388,-- \\
\hline 25 & 0,8 jaar & 2,4 Jaar & $-0,6 \mathrm{jmar}$ & f $2.286,-$ & f 70.449,-- & f $85.204,--$ \\
\hline 30 & 1,0 jaar & 2,9 jaar & - 0,7 jaar & f $2.690,--$ & f 70.846,-- & f 68.156,-- \\
\hline
\end{tabular}

Tabel 7.11

Relatie reductie verhoogde risicofactor met de karakteristieke kengetallen en de kosteneffectiviteit van het Med-Chol-Cohort scenario bij toepassing van het Cholesterol Medicatie Programma op een hypo cohort van 1 mln. mannen van 37 jaar

In tabel 7.11 zien we dat de preventiekosten en de besparingen stijgen naarmate het percentage reductie toeneemt. Per saldo is de stijging van de besparingen groter dan die van de preventiekosten. De stijging van de preventiekosten wordt veroorzaakt door een toename van de levensverwachting. De besparingen treden op als gevolg van een daling in de verwachte ziekteduur. In het model geldt een reductie van $25 \%$ als standaardinstelling. De gevoeligheid van deze variabele voor de verwachte incidentieleeftijd is duidelijk aanwezig.

We hebben eerder al beschreven dat de diagnostiek van $\mathrm{CHZ}$ door technologische ontwikkelingen zich constant aan het verbeteren is. De patiënt met al dan niet vermoede $\mathrm{CHZ}$ kan daardoor eerder in het medisch circuit terecht komen. Onzeker is met welke snelheid het atherosclerotische proces zich in de toekomst zal gaan presenteren en welke inzichten er zich met betrekking tot de behandelingsstrategie zullen gaan ontwikkelen. We hebben hiertoe een modelparameter ingebouwd waarmee de kans op een initiële CHZ-incidentie verhoogd dan wel verlaagd kan worden. In onderstaande tabel 7.12 wordt de gevoeligheid van deze variabele voor de scenario-uitkomsten weergegeven. 


\begin{tabular}{|c|c|c|c|c|c|c|}
\hline $\begin{array}{l}\text { Reductie CHZ } \\
\text { incidentie } \\
\text { mannen }\end{array}$ & $\begin{array}{l}\text { winst } \\
\text { Levensyer- } \\
\text { wachting }\end{array}$ & $\begin{array}{l}\text { winst } \\
\text { verwachte } \\
\text { incidentle- } \\
\text { leeftijd }\end{array}$ & $\begin{array}{l}\text { pinst } \\
\text { vermachte } \\
\text { ziekteduur }\end{array}$ & $\begin{array}{l}\text { besparingen } \\
\text { (p.p.) }\end{array}$ & $\begin{array}{l}\text { prev.-kosten } \\
\text { (p.p.) }\end{array}$ & KER \\
\hline$-10 \%$ per jaar & 1,8 jaar & 4,6 jagr & $-1,3 \mathrm{jmar}$ & f 6.271,- & f $65.398,--$ & f $32.848,--$ \\
\hline $0 \%$ & 19 jear & 4,9 jaar & - 1.3 jar & $f$ 6848,-- & f $62.776,--$ & f $29.436,-$ \\
\hline$-10 \%$ per jaar & 2,1 jasr & 4,9 jaxr & - 1,2 jagr & f $7307,--$ & f $53.137,--$ & f $25303,-$ \\
\hline
\end{tabular}

Tabel 7.12

Relatie Reductie $\mathrm{CHZ}$-incidentie mannen van het Med-Chol-Cohort scenario bij toepassing van het Cholesterol Medicatie Programma op een hypo cohurt van 1 mln. mannen van 3.5 jaar

C. Incrementele league tabellen van kosten per gewonnen levensjaar We geven hieronder in tabel 7.13 een overzicht van de incrementele kosten per gewonnen levensjaar van de Cohort-scenario's. Er is in tabel 7.13 geen verdiscontering toegepast op de weergegeven resultaten.

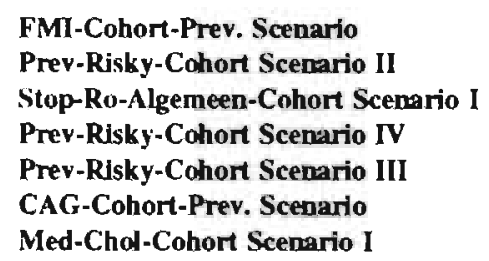

Tabel 7.13

Incrementele-league tabellen van kosten per gewonnen levensjaar van scenario's bij toepassing van gezondheidszorgprogramma's in bypo cohortstudies van $1 \mathrm{mln}$. mannen van 35 jaar

De "range" in de kosten-effectiviteitsuitkomsten van de verschillende scenario's worden in het onderdeel sensitiviteitsanalyse van deze paragraaf dan wel in Hoofdstuk 6 toegelicht. Deze tabel wil zeggen dat het scenario in de top van de tabel als het meest kosteneffectief beschouwd mag worden.

De verdisconteerde levenswinst in een cohortstudie wordt in de userinterface eenvoudig afgelezen door het verschil te bepalen tussen de verdisconteerde levensverwachting in het basisscenario respectievelijk in het betreffende scenario. De verdisconteerde levensverwachting van een scenario bestaat dan uit een we- 
ging van de verdisconteerde levensverwachting van personen uit het cohort die het model "niet" in komen (niet-CHZ- sterfte uit gezond) respectievelijk die het model ingaan "met CHZ" (CHZ-sterfte). In Hoofdstuk 6 is al toegelicht dat deze weging bestaat uit het betrokken aantal personen in beide groepen. De verdisconteerde levensverwachting van $\mathrm{CHZ}$-personen wordt gevormd door de som van de verdisconteerde incidentieleeftijd en de verdisconteerde ziekteduur (of verblijfsduur in het model met $\mathrm{CHZ}$ ).

Praktisch gezien treedt er met betrekking tot de door ons gehanteerde methodiek van de verdisconteerde ziekteduur een "oneerlijkheid" op. In een cohort van bijvoorbeeld 35-jarige mannen die te zijner tijd op bijvoorbeeld 60-jarige leeftijd CHZ krijgen, resulteert de verdisconteerde ziekteduur van die 60-jarige leeftijd naar de aanvangsleeftijd van 35 jaar in een heel klein getal. Het optimaliseren van een dergelijk mathematisch probleem zou ver buiten de doelstelling van dit proefschrift schieten. Wel dient de gebruiker zich bij de interpretatie van de verdisconteerde cohortanalyses rekenschap te geven van dit probleem (zie ook Johannesson, 1992). Een tweede methodologisch probleem betreft de vraag of de hoogte van de discontovoet al dan niet leeftijdsonafhankelijk mag zijn. In onze berekening is deze leeftijdsonafhankelijk gehanteerd. Men kan zich de vraag stellen of er een verschil in waardering bestaat tussen ouderen en jongeren met betrekking tot de kans op een extra levensjaar "nu" dan wel in de toekomst.

In Hoofdstuk 4 is er reeds op gewezen dat er in de literatuur vraagtekens bestaan over de bruikbaarheid van deze "incrementele QALY-league" tabellen voor het beleid met betrekking tot de verdeling van de schaarse middelen. Wat opvalt is dat in de literatuur een discussie hierover steeds terugkeert. We hebben voorbeelden gevonden van discussies tussen Calnan en Cribb (1985), Harris en Williams (1987), discussies in Medisch contact rond 1990, en meer recentelijk in de Canadian Med. Ass. Journal van 1992 en 1993 (Laupacis e.a., 1992, Gafni e.a., 1993, en de reacties daarop van Laupacis e.a., 1993).

De meest voorkomende bezwaren die uit deze discussies naar voren komen zijn:

(i) Er bestaan methodologische verschillen in de beoordeling van de kosten en de effecten (vgl. Van Doorslaer e.a., 1990, Evers, 1993). Voorbeelden zijn: het wel of niet betrekken van productiviteitsverliezen en indirecte medische kosten in de analyse; verschillende methoden van utiliteitsmeting die tot verschillende effectresultaten leiden; de toepassing van verschillende disconteringsfactoren met betrekking tot enerzijds de kosten en anderzijds de effecten die tot verschillende rangordes in KER's leiden.

(ii) Het is vaak niet mogelijk om uit de tabellen specificaties over leeftijd, geslacht, en andere patiëntkenmerken of over bijvoorbeeld therapietrouw en effectiviteit te verkrijgen. 
(iii) In de meeste studies zijn de kosten berekend tegen de gemiddelde kostprijs. Wanneer er sprake is van een uitbreiding van hetzelfde programma, dan moeten eigenlijk de marginale kosten per QALY berekend worden.

(iv) $\mathrm{Er}$ is een onvermijdelijke gelijkheid-bias in de KE-analyse, waardoor deze benadering discriminerend werkt voor ouderen en chronisch zieken. In de KL-analyse wordt geen onderscheid gemaakt tussen programma's die zich richten op de kwaliteit van leven en levensverlengende programma's (vgl. de discussie tussen Harris versus Williams, 1987, Calnan versus Cribb, 1985).

(v) De positie in de league tabel hoeft niets te zeggen over de werkelijke relatieve efficiëntie van het programma. In de analyse kan het programma bijvoorbeeld vergeleken zijn met een slecht referentieprogramma, waardoor er te gunstige effectverschillen ontstaan. Er is dan sprake van selectie-bias (Birch e.a., 1992).

(vi) Er is niks bekend over de verdeling en het gebruik van de beschikbare middelen binnen een gegeven budget. De keuze voor een bepaald programma kan tot gevolg hebben dat andere (bestaande) programma's niet meer uitgevoerd kunnen worden en mogelijke opbrengsten van die programma's verloren gaan. Zolang de opportuniteitskosten van die programma's niet bekend zijn, zou de KER als selectiecriterium in dit opzicht niet consistent zijn met het principe van allocatieve efficiëntie (vgl. Birch e.a., 1987).

(vii) Er wordt in de literatuur meestal niet gemotiveerd wat het KER-afbreekpunt is waar beneden de programma's niet meer uitgevoerd zouden mogen worden (zie ook Hoofdstuk 4).

(viii) De interpretatie van dit soort tabellen is doorgaans dat middelenallocatie naar programma's of technologieën zodanig plaats dienen te vinden dat de keuzen gemaakt moeten worden in volgorde van de toenemende KER, totdat het budget is uitgeput (Rutten, 1988). In Hoofdstuk 4 is de vraag al aan de orde gekomen hoe dit utilitair uitgangspunt (maximaal nut gegeven een bepaald budget) zich verhoudt met het egalitarisme.

(ix) De kosten-baten-analyse kan afhankelijk van de hoogte van de monetaire waardering van de effecten in vergelijking met de kosteneffectiviteitsanalyse tot een andere rangordening leiden van de kosteneffectiviteit van de gezondheidszorgprogramma's (vgl. Ament, 1991).

(x) Het gebruik van QALY's is gebaseerd op een utiliteitsschaal met betrekking tot de kwaliteit van leven. Het probleem hierbij is dat de beoordeling van een gezondheidstoestand door de respondent niet los gezien zal worden van de bijhorende prognose (vgl. Bijlage IV). Het gevolg is dat dimensies levensduur en kwaliteit van leven met betrekking tot de nutswaar- 
dering niet onafhankelijk van elkaar zijn en zodoende niet (zomaar) met elkaar vermenigvuldigd kunnen worden (Van Doorslaer e.a., 1990).

(xi) Een probleem inherent aan de QALY-benadering is dat er vanuit wordt gegaan dat individuele QALY's simpelweg kunnen worden opgeteld tot én geaggregeerde QALY. In de literatuur wordt dit probleem omzeild door te stellen dat met de utiliteitstheorie eerder iemands gezondheidstoestand wordt gemeten dan het nut dat daaraan ontleend kan worden (vgl. Wagstaff, 1991).

Als reactie op deze bezwaren willen wij eerst verwijzen naar de presentatie van onze incrementele kosten per gewonnen levensjaar tabel. De bezwaren genoemd onder de punten (i) tot en met (xi) zijn stuk voor stuk van toepassing op deze tabel. Een gedeelte van deze bezwaren zou natuurlijk weggenomen kunnen worden door een uitvoerige toelichting te geven over de gevolgde methodologische aanpak (bezwaar (i)), de patiëntkenmerken, therapietrouw en effectiviteit (bezwaar (ii)), de toelichting op het referentieprogramma (bezwaar (v)), en een uiteenzetting over de "impact" van het programma met betrekking tot het gebruik van de beschikbare middelen. Moeilijker wordt het al om tegemoet te komen aan de bezwaren genoemd onder (iii) en (iv). Deze beide problemen zouden ondervangen kunnen worden met behulp van gedetailleerde kosten-effectiviteitsstudies. Tot zover zouden de voordelen van kosten-effectiviteitsstudies zoals genoemd in de inleiding van dit hoofdstuk (paragraaf 7.1) zeker tot hun recht kunnen komen. De meer fundamentele kritiekpunten betreffen de bezwaren genoemd onder de punten (vi) tot en met (xi).

Het bezwaar onder punt (vi) richt zich eigenlijk op de practische uitvoerbaarheid de opportuniteitskosten van programma's aan te tonen. In de eerste plaats is het nodig dat de "impact" van de programma's zichtbaar wordt gemaakt. Er moet als het ware "gewikt en gewogen" worden om alle mogelijke combinaties van programma's die binnen een gegeven budget uitgevoerd kunnen worden op een rij te krijgen. In de tweede plaats moeten de baten van al deze programma's bekend zijn, zodanig dat die baten in dezelfde vergelijkbare eenheden zijn uitgedrukt. Hierbij ontkomt men niet aan de fundamentele discussie om deze baten in geld uit te drukken (zie Hoofdstuk 4). Dit probleem hangt dan weer samen met het bezwaar onder punt (ix), waardoor de basis van KER als selectiecriterium helemaal onderuit dreigt gehaald te worden.

Het probleem dat hier centraal staat is dat wanneer de opportuniteitskosten van de verloren of niet uitgevoerde programma's groter zijn dan de baten van de nieuwe of bestaande programma's, er niet meer voldaan is aan het Pareto-criterium. Het is het Pareto-criterium waar het principe van allocatieve (en technische) efficiënte op gebaseerd is. Er treedt maatschappelijk gezien per saldo een 
verlies op. We kunnen dit illustreren met een eenvoudig, maar zeer doeltreffend voorbeeld ontleend aan Birch en Donaldson uit J. Health Ec., 1987, waar we gemakshalve naar verwijzen.

Het principe van allocatieve efficiënte staat in nauw verband met de bezwaren genoemd onder de punten (vii) en (viii). Er wordt door Wagstaff (1992) een theoretisch voorbeeld gegeven op welke wijze via allocatieve efficiënte de keuze gemaakt kan worden over de grootte van de te vormen "trade-off" tussen efficiënte en equity. Het nieuwe "evenwichtspunt" ligt op de sociale welvaartsfunctie. In dit punt worden er minder QALY's bereikt dan in het Pareto-optimum. Het verschil in QALY's is als het ware de prijs die men moet betalen voor de mate van trade-off tussen efficiënte en equity. Tegelijkertijd sluiten we hierbij aan met de kritiek in punt (xi). In hoeverre kan een QALY gereflecteerd worden in een sociale welvaartsfunctie, wanneer het primair de individuele nutswaardering voor een bepaalde gezondheidstoestand reflecteert.

Er wordt met betrekking tot het bezwaar onder punt $(x)$ in de literatuur een alternatief aangedragen: de gezonde-jaar equivalenties of healty-years equivalent (HYE). In deze benadering wordt door de mensen een (toekomstig) profiel van levensduur en de daarbij behorende kwaliteit van leven in één keer beoordeeld (Van Doorslaer e.a., 1990). In deze benadering wordt het fundamentele probleem onder punt (xi) echter niet opgelost en daarmee ook niet de relatie met de sociale welvaartsfunctie.

In de scenario-methode met betrekking tot de door ons aangeduide bevolkingsstudies wordt er een relatie gelegd tussen de vraag hoeveel er van een bepaald project moet worden geïnvesteerd om een bepaald toekomstig doel te bereiken en wat de toekomstige implicaties van dat programma zijn met betrekking tot de beschikbare middelen. Wij twijfelen eraan in hoeverre een kosten-effectiviteitsanalyse van scenario's die middels een cohortstudie wordt uitgevoerd tot inzicht kan leiden in de verdeling van de schaarse middelen. Wat wel goed mogelijk lijkt, is om ex-post evaluaties, die bij op bevolkingsstudies toegepaste scenario's zijn uitgevoerd, te gebruiken als input bij cohort-studies voor de kosten-effectiviteitsbeoordeling van deze scenario's. Er worden dan scenario-studies verricht naar de economische gevolgen van bijvoorbeeld doelgroepselectie, therapietrouw en de uitbreiding of inkrimping van programma's. Het instrument van kosten-effectiviteitsanalyse wordt op deze manier weer gebruikt waar het oorspronkelijk voor gecreëerd was, namelijk als methode voor het verrichten van rentabiliteitsonderzoekingen en efficiencybeoordelingen van projecten.

We willen deze paragraaf afsluiten met een citaat uit Gerard e.a. (1993), die naar onze mening de bovenstaande discussie treffend weergeeft: 
"A number of conditions have to be recognised when defining the scope of QALY league tables as a policy instrument: only health gain is being sought from health care resources; the $Q A L Y$ is an acceptable measure of the utility of health; opportunity cost is defined in terms of QALY's foregone; the efficiency of all marginal health care expenditure at a local level is known; and, lastly any equity concerns, beyond the egalitarian notion implied by the "maximalisation of QALY's' rule, are deemed not relevant (Gerard e.a, 1993)"

\subsection{Vervangende ziekten en - sterften}

De sterfte aan hart- en vaatziekten en de sterfte aan kanker vormen in Nederland de twee belangrijkste doodsoorzaken. De uitschakeling van beide doodsoorzaken tegelijkertijd zou tot een grote winst van ca. 9,5 jaar in de levensverwachting van de totale bevolking leiden (Van Ginneken e.a., 1989).

Er bestaan voor elke doodsoorzaak meestal verschillende risicofactoren. Het wegnemen dan wel reduceren van de prevalentie van een belangrijke risicofactor betekent dat het relatieve aandeel van overige risicofactoren voor die betreffende doodsoorzaak toeneemt.

Risicofactoren kunnen ook meerdere ziekten tegelijkertijd beïnvloeden (vaak aangeduid als multifactoriële risicofactoren). Een anti-rook programma bijvoorbeeld kan leiden tot een incidentiedaling van zowel coronaire hartziekten als van longkanker.

Het fenomeen van vervangende ziekte- en sterfterisico's houdt in dat het wegnemen dan wel reduceren van de ene ziekte- of doodsoorzaak tot gevolg kan hebben dat het sterfte- of ziekterisico aan een andere oorzaak hoger wordt. Als een persoon bijvoorbeeld overlijdt aan een infectieziekte of aan een verkeersongeval, dan heeft die persoon geen kans meer om aan $\mathrm{CHZ}$ te overlijden. De sterftereductie aan infectieziekten betekent dat meer personen het risico lopen CHZ te krijgen.

We hebben in figuur 7.8 een model van vervangende ziekte- en sterfterisico's tussen $\mathrm{CHZ}$ en Overige Ziekten opgenomen. De pijlen in deze figuur geven de overgangen van patiëntenstromen tussen en binnen de verschillende gezondheidstoestanden weer. De patiëntenstromen bestaan uit deelgroepen die vanuit een bepaalde gezondheidstoestand naar een nieuwe gezondheidstoestand overgaan dan wel binnen dezelfde gezondheidstoestand blijven. De variabelen die de overgang tussen de gezondheidstoestanden beïnvloeden zijn preventieprogramma's en medische programma's. 


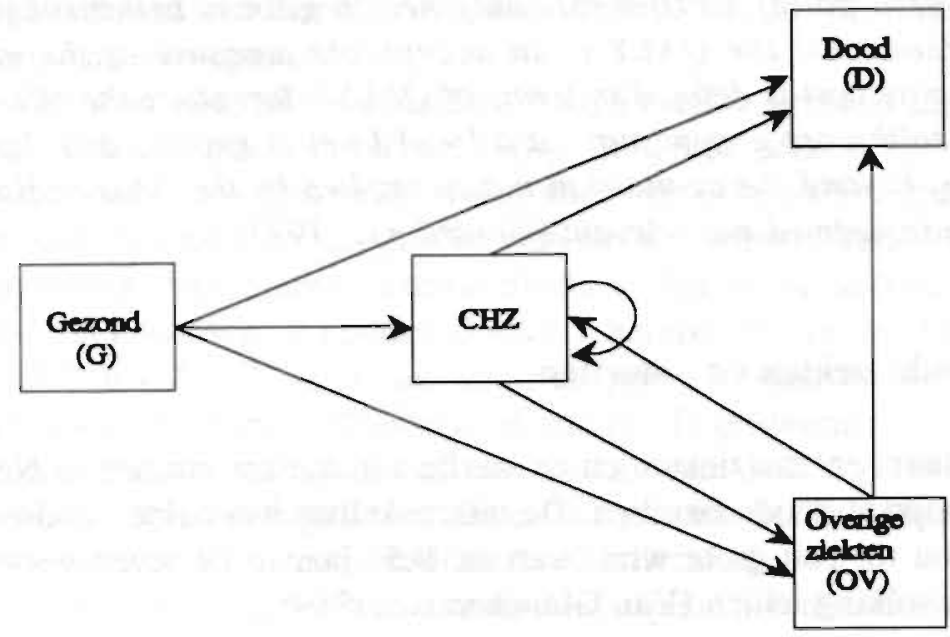

Figuur 7.8

Model van vervangende ziekte- en sterfterisico's tussen $\mathrm{CHZ}$ en Overige Ziekten

De ontwikkelingen in de sterfte en ziekte worden uitgebeeld in de vorm van overlevingscurven. Deze curven geven het aandeel van de bevolking weer dat op een bepaalde leeftijd nog in leven ("gewone" overlevingscurve of sterftecurve) respectievelijk gezond (ziektevrije overlevingscurve) is.

In een samenleving als die van Nederland krijgt de sterftecurve door de toegenomen levensverwachting een steeds meer rechthoekig karakter. Dit rechthoekige karakter van een overlevingscurve wordt door Fries (1980) aangeduid als rectangularisatie.

Het streven is a) het oppervlakte tussen de overlevingscurve en de ziektevrije overlevingscurve zo klein mogelijk te houden en b) het optreden van langdurige ziekten tot een $20^{\prime} \mathrm{n}$ laat mogelijk tijdstip in de levensfase uit te stellen (Fries, 1988). Hiervoor heeft Fries (1980) de term compressie van morbiditeit geïntroduceerd.

Er is sprake van compressie van morbiditeit wanneer de rectangularisatie van de ziektevrije overlevingscurve sneller gaat dan die van de sterftecurve. Het complement van de compressie van morbiditeit is de ziektevrije levensverwachting, de levensverwachting zonder beperkingen, of de gezonde levensverwachting (vgl. Barendregt e.a., 1993). 
De rectangularisatie van de sterftecurve in de Nederlandse bevolking is in figuur 7.9 uitgebeeld aan de hand van de sterfteontwikkelingen tussen 1840 en 1985 (ontleend aan Van der Maas, 1989). Uit figuur 7.9 blijkt dat:

a) de sterftecurve in 1985 tot de leeftijd van 40 jaar een nagenoeg horizontaal verloop heeft ten opzichte van de $\mathrm{x}$-as, en

b) de sterfterisico's hoe langer hoe meer naar hoge leeftijden verschuiven (vgl. Van Ginneken e.a., 1989).

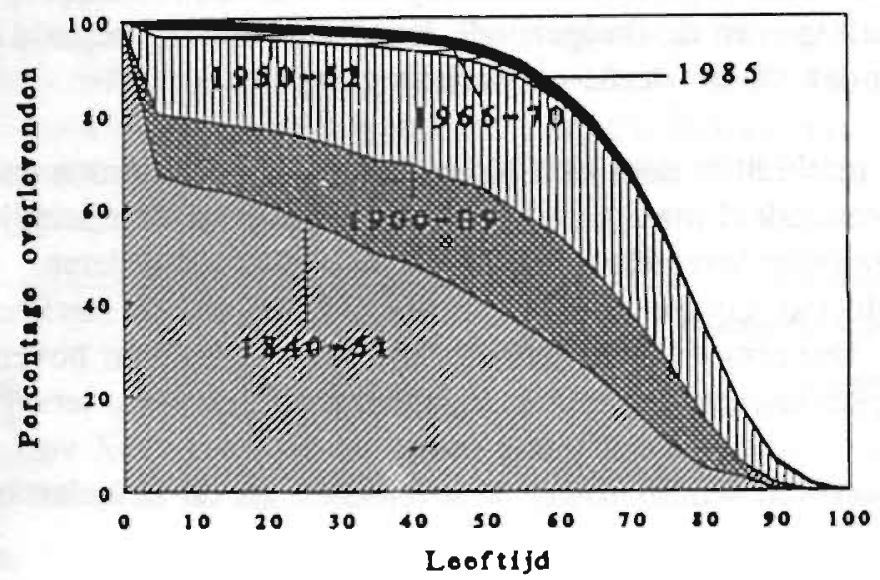

Figuur 7.9

De ontwikkeling van de sterfte onder mannen tussen 1840 en 1985 (bron: Van der Maus, 1989)

De sterftedaling in de afgelopen eeuw die uit figuur 7.9 blijkt kan gezien worden als het resultaat van een belangrijk verbeterde volksgezondheid (met name in de teruggang van de infectieziektesterfte). In de huidige fase van ontwikkeling wordt de Nederlandse volksgezondheid gekenmerkt door een toename van chronische ziekten.

Er kan uit figuur 7.9 niet afgelezen worden of verlenging van de levensverwachting ook gepaard gaat met het uitstellen van de eerste (langdurige) zickteverschijnselen. Er kunnen zich in dit verband twee uitersten voordoen. De rectangularisatie van de ziektevrije overlevingscurve gaat sneller of langzamer dan de rectangularisatie van de sterftecurve. 
In Nederland comprimeren de sterfterisico's zich rondom de gemiddelde levensverwachting. Het is nu de vraag of parallel aan de compressie van mortaliteil ook een compressie van morbiditeit optreedt (Van den Bos, 1993). Boshuizen e.a. (1990) hebben een trendanalyse verricht over de gezonde levensverwachting in Nederland voor de periode 1981-1990. Hieruit bleek dat de gezonde levensverwachting bij mannen sneller toenam dan de totale levensverwachting bij mannen. Bij vrouwen bestond de helft van het aantal gewonnen levensjaren uit ongezonde jaren (vgl. ook Van Ginneken, 1989). Uit een vergelijkende trendstudie met andere landen concluderen Boshuizen e.a. (1990) dat een toename van de levensverwachting over het algemeen gepaard gaat met een afnemend percentage leven in goede gezondheid (vgl. Kernboodschap no. 3 uit RIVM-rapport, 1993a, waarbij de ontwikkelingen in de (on)gezonde levensverwachting bepaald worden door andere ziekten dan die de sterfte-ontwikkeling bepalen).

De compressie van morbiditeit doet zich bijvoorbeeld voor bij mensen ouder dan 65 jaar, omdat de gemiddeld maximale levensverwachting na deze leeftijdsgrens de gemiddelde biologische levensduur hoe langer hoe meer zal naderen.

Een ander voorbeeld van compressie van morbiditeit betreft de sterftereductie van $\mathrm{CHZ}$. Volgens Dunning (1993) hebben de CHZ bij ouderen boven de 65 jaar een langere ziekteduur en een milder ziekteverloop gekregen, terwijl bij de jongere mannelijke bevolking (met name onder de 50 jaar) $\mathrm{CHZ}$ veel minder voorkomt. In dit voorbeeld schuift zowel de levensduur als de ziektelast hoe langer hoe meer op naar het biologisch levenseinde.

De inspanningen gericht op rectangularisatie van de ziektevrije overlevingscurve leveren een tweetal effecten op: (i) winst in kwaliteit van leven en (ii) de afname in het gebruik van de medische chronische zorg (kostenbesparing).

Tussen compressie van morbiditeiten en het optreden van vervangende ziekten en - sterften bestaat een nauwe relatie:

(i) De levenswinst die hijvoorbeeld bij de bestrijding van $\mathrm{CHZ}$ is behaald, zal vour een gedeelte teniet worden gedaan door de sterfte ten gevolge van een andere ziekte (bijvoorbeeld substitutie van $\mathrm{CHZ}$ door kanker). Er treedt geen (verdere, of geringere) rectangularisatie van de sterftecurve voor de totale bevolking op.

(ii) Het aandeel van langdurige zieken in de totale bevolking kan toenemen (bijvoorheeld toename kanker in de latente CHZ-periode). Er treedt een verschuiving op van de ziektevrije overlevingscurve in verticale richting 
waardoor het oppervlakte tussen de sterftecurve en de (langdurige) ziektevrije overlevingscurve toeneemt (decompressie van morbiditeit).

(iii) Een neveneffect is dat het gebruik van de gezondheidszorgvoorzieningen en de daarmee gepaard gaande kosten als gevolg van (i) en (ii) steeds verder toenemen.

We hebben in een voorbeeld de financieel-economische consequenties uitgewerkt die aan het optreden van vervangende ziekten en - sterften zijn verbonden.

Er is in dit voorbeeld van vervangende ziekten en - sterften een Dieet-CholBevolking scenario doorgerekend. De simulatiegroep heeft een niet-beperkend (algemeen) risicoprofiel (Beide geslachten, Chol: 0,0-20,0 mmol/l, DBD: 50-150 $\mathrm{mmHg}$, Rookgedrag: niet-rokend en rokend). Het aanvangsjaar is 1989. Het Dieet-Bevolking scenario eindigt in 2010. In tabel 7.15 is het cholesterol reducerend dieetprogramma weergegeven.

\begin{tabular}{|l|c|}
\hline & Programma Chol.-Red.-Dieet \\
\hline Startjaar & 1989 \\
Findjaar & 2010 \\
Aanlooptjjd & 0 jasar \\
Afbouwtjd & 0 jaar \\
Reactie & $100 \%$ \\
Reductie & $10 \%$ \\
Trouw & $100 \%$ \\
Vaste rosten & $f 2$ mln p.j. \\
Kosten Iste jaar & $f \mathbf{4 9 0 , - - ~ p . p . ~ p . j . ~}$ \\
Vervolgkosten & $f$ 270,-- p.p. p.j. \\
\hline
\end{tabular}

Tabel 7.15

Cholesterol Reducerend Dieet Programma

In figuur 7.10 zijn de karakteristieke kengetallen van scenario weergegeven. 


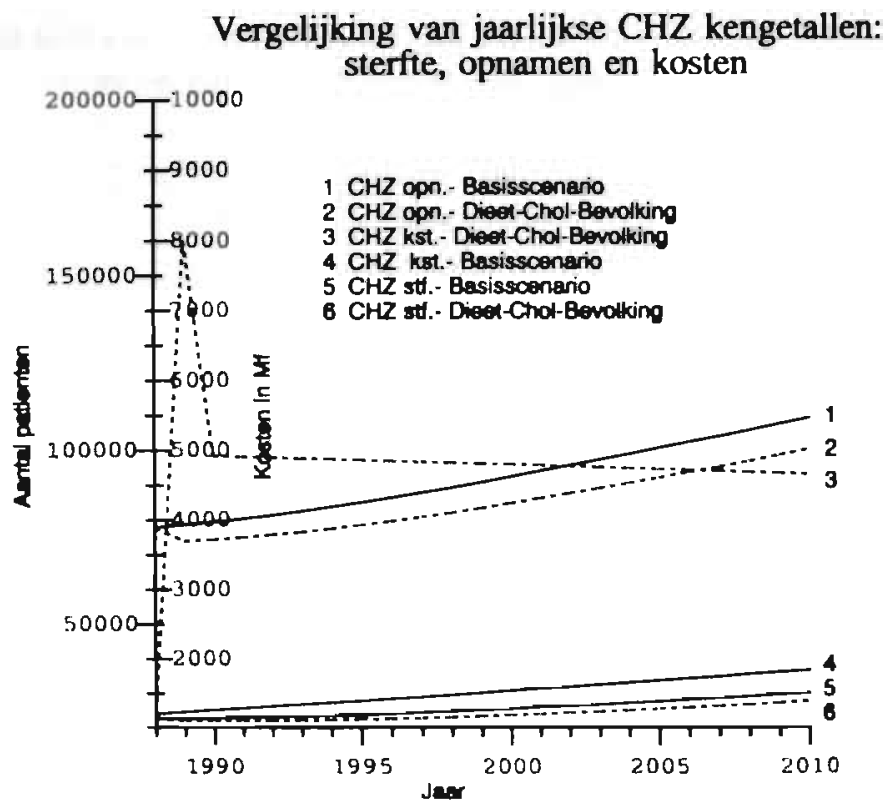

Figuur 7.10

Karakteristieke kengetallen van het Dieet-Chol-Bevolking scenario met 0,7\% niet-CHZ sterfte reductie per jaar bij toepassing van bet Cholesternl Reducerend Dieet Programma op de bevolking (chol: 0,0-20,0 mmof. dbd: $50-150 \mathrm{mmHg}$, rokend en niet-rokend)

In het eerste jaar (1989) daalt de CHZ-sterfte van het scenario met ca. 3\% ten opzichte van het basisscenario. De levenswinst die in 1989 wordt gerealiseerd bedraagt 0,4 jaar (niet weergegeven in figuur 7.10).

Vervolgens hebben we in onze scenarioresultaten de bevindingen verwerkt uit een onderzoek van Dugdale (1987). Uit dit onderzoek blijkt dat ten gevolge van een verlaging van het serumcholesterolgehalte in de gehele bevolking met $10 \%$ de sterfte aan hart-en vaatziekten met ca. $12 \%$ zou dalen, maar dat de sterfte aan kanker respectievelijk aan overige ziekten evenwel met ca. $10 \%$ respectievelijk ca. $11 \%$ stijgt. Dit betekent dat er in de totale sterfte geen levenswinst gerealiseerd wordt.

We kunnen de reductie van de eerder genoemde levenswinst van 0,4 jaar simuleren door de reductie niet-CHZ-sterfte in ons model in te stellen op $0 \%$ (een verlaging van de reductie niet-CHZ-sterfte met $0,7 \%$ per jaar). De stijging die met deze reductie in de omvang van de niet-CHZ-sterfte is aangebracht betekent in wezen dat we de sterftekansen voor het optreden van vervangende sterften hebben gecorrigeerd (vgl. Bannenberg, 1992). De voor de nieuwe situatie aangepaste scenario-resultaten worden in figuur 7.11 gedemonstreerd. 


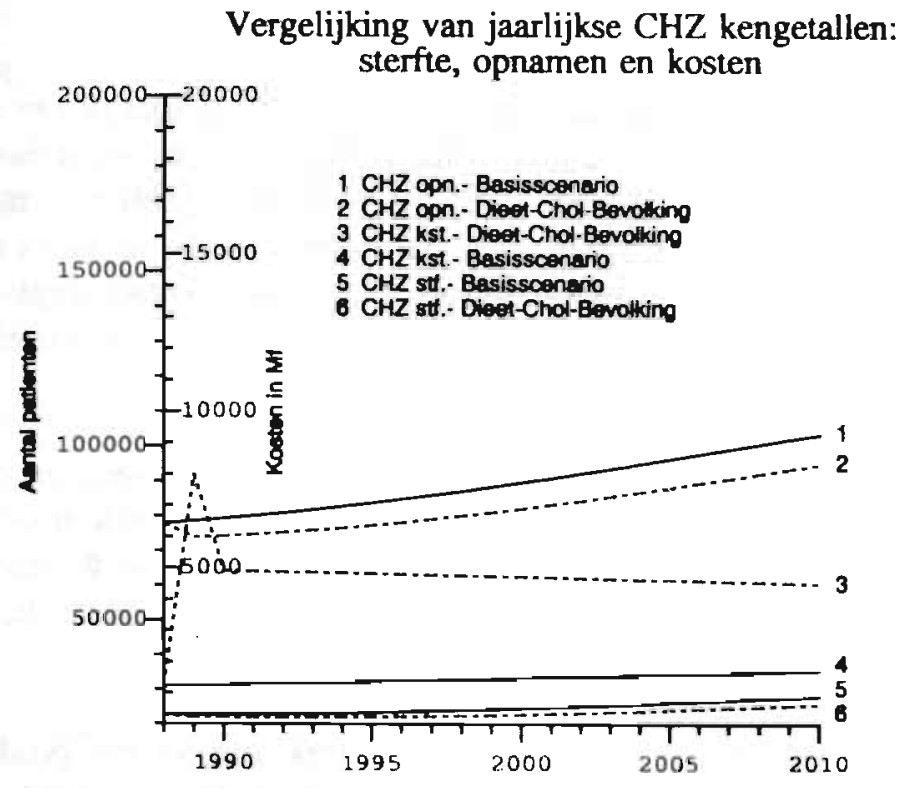

Figuur 7.11

Karakteristieke kengetallen van het Dieet-Chol-Bevolking scenario met $0 \%$ niet-CHZ-sterfte reductie per jaar bij toepassing van het Cholesterol Reducerend Dieet Programma op de bevolking (Chol: 0,0-20,0 mmóll, DBD: 50-150 mmHg, rokend en niet-rokend)

Uit figuur 7.11 blijkt dat door het instellen van de $0 \%$ niet-CHZ-sterfte reductie per jaar de winst met betrekking tot de $\mathrm{CHZ}$-sterfte zelfs wat toencemt in vergelijking met die uit figuur 7.10.

Als gevolg van de dalende incidenties uit de CHZ-bevolking (secundaire incidenties) nemen de CHZ-kosten ook iets af. De daling van de secundaire CHZ-incidenties kan verklaard worden doordat de CHZ-bevolking kleiner is geworden. De behandelingskosten ten behoeve van de vervangende ziekten zullen daar tegenover gaan stijgen (vgl. Hoofdstuk 1).

Uit het geschetste voorbeeld blijkt dat de keuze voor een gezondheidszorgprogramma door de invloed van het optreden van vervangende ziekten en -sterften tot mogelijk onverwachte resultaten kan leiden met betrekking tot de sterfte voor verschillende doodsoorzaken en de kosten van gezondheidszorg. 


\subsection{Gezondheidsproductiefunctie}

De gezondheidsproduktiefunctie geeft het verband weer tussen de gezondheidszorginspanningen en het produkt gezondheid. Het is mogelijk om met behulp van de gezondheidsproduktiefunctie te onderzoeken wat de winst in gezondheid (output) is bij een verandering in de besteding van de beschikbare middelen (input). Wanneer op de $x$-as de inputs staan en op de $y$-as de output is aangegeven, dan is het verloop van de gezondheidsproductiefunctie concaaf (vgl. de wet van de toe- en afnemende meeropbrengsten, waarbij elke extra toegevoegde eenheid input steeds minder aan de output bijdraagt).

Het produktieproces in de gezondheidszorg kan op microniveau en op macroniveau plaatsvinden. Op microniveau is het produktieproces rondom de "individuele" patiënt gesitueerd. Het produktieproces op macroniveau wordt beschouwd vanuit het perspectief van de maatschappij als geheel. Wij zullen het productieproces vanuit het macroperspectief bespreken.

Op macroniveau moeten de budgetten met betrekking tot het productieproces verdeeld worden over verschillende sociale sectoren. Bijvoorbeeld, wat zijn de verschillende bestedingscombinaties bij een gegeven budget tussen onderwijs en gezondheidszorg? De bestedingscumbinaties die mogelijk zijn binnen een bepaald budget worden weergegeven met behulp van een zogenaamde produktiemogelijkheden-curve ("production possibility curve") (vgl. Mooney, 1992). De produktie-mogelijkheden-curve duidt alle mogelijke bestedingscombinaties aan die bij een gegeven budget bereikt kunnen worden. De vorm van de produktiemogelijkheden-curve is concaaf ten opzichte van beide assen (vgl. de marginale opbrengstencurve). Er worden bijvoorbeeld minder eenheden voor produkt x geproduceerd naarmate er meer geld voor produkt y binnen hetzelfde budget wordt uitgegeven. De marginale opbrengst van elke extra eenheid van produkt y neemt af, waardoor de curve een concaaf verloop krijgt.

Als gevolg van bijvoorbeeld technologische ontwikkelingen is het mogelijk dat er meer eenheden produkt y worden geproduceerd zonder dat er eenheden produkt $x$ worden opgeofferd. De produktie-mogelijkheden-curve verschuift dan naar rechts (gegeven dat gezondheidszorg op de $\mathrm{X}$-as wordt afgebeeld).

De optimale bestedingscombinatie wordt bereikt in het punt waar de productiemogelijkheden-curve door de hoogste iso-nutcurve wordt geraakt. Een iso-nutcurve geeft alle mogelijke bestedingscombinaties weer die gelijk gewaardeerd worden. De vorm van de curve is convex. De gedachte hierachter is dat naarmate er meer eenheden produkt y worden opgeofferd, er successievelijk meer eenheden produkt $\mathrm{x}$ ter compensatie nodig zijn (vgl. de theorie van het vermin- 
derde marginale nut of "diminishing marginal utility"). We zouden voor de isonutcurve ook de term welvaartsfunctie kunnen gebruiken.

Wij willen in deze paragraaf twee voorbeelden uitwerken met betrekking tot de theorie rondom de gezondheidsproductiefunctie. Beide voorbeelden zijn met behulp van ons model geconstrueerd.

In het eerste voorbeeld wordt de gezondheidsproduktiefunctie met betrekking tot eén gezondheids- zorgprogramma gegeven. Deze is afgebeeld in figuur 7.12.

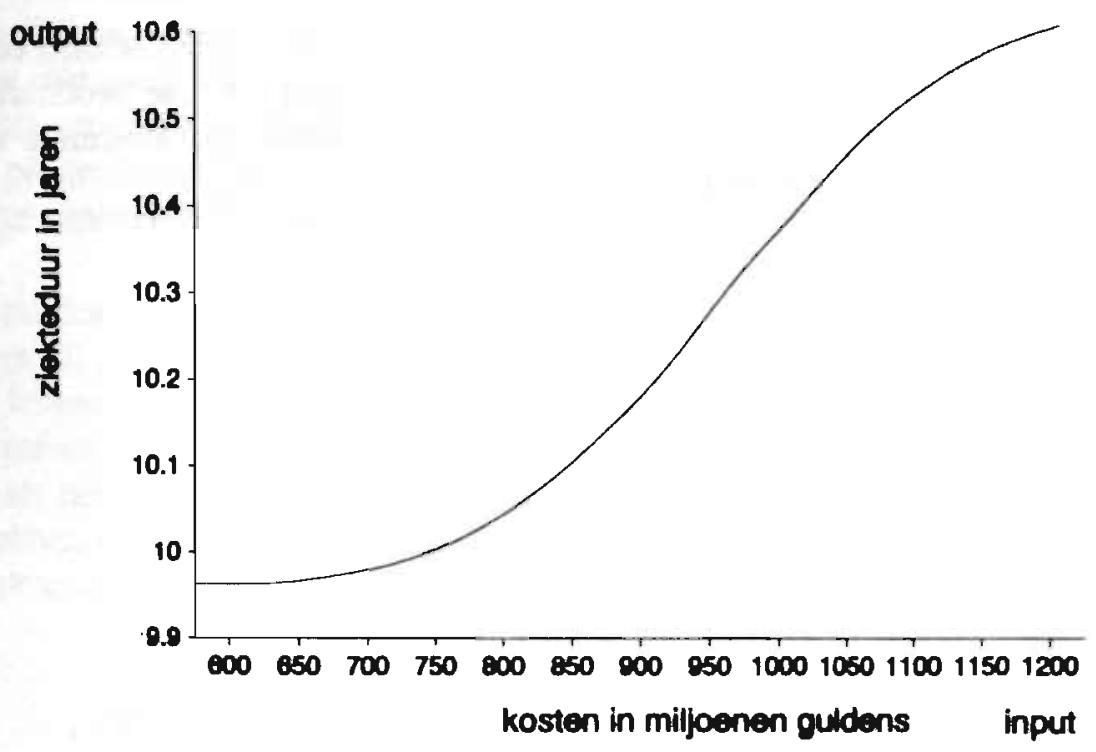

Figuur 7.12

Gezondheidsproduktiefunctie met betrekking tot éen gezondheidszorgprogramma, ontwikkeld in ons model

In figuur 7.12 staan op de $\mathrm{X}$-as de additionele produktiekosten van een operatiecapaciteit programma en op de $\mathrm{Y}$-as de opbrengsten vermeld. Wij hebben de opbrengsten uitgedrukt in ziekteduureenheden. De geconstrueerde gezondheidsproduktiefunctie uit figuur 7.12 laat zien de toename van het aantal ziekteduureenheden (de levensverwachting gegeven $\mathrm{CHZ}$ ) bij een gegeven stijging van de produktiekosten. De CHZ-produktiekosten en de CHZ-ziekteduur zijn geijkt op de situatie in 1988 . 
De produktiekosten bedragen in de aanvangssituatie $f 600 \mathrm{mln}$. Er vinden in dit punt alleen medicamenteuze behandelingen plaats. We breiden het produktiepakket vervolgens geleidelijk uit met behulp van het operatiecapaciteit programma. In het operatiecapaciteit programma kan het aantal operaties beperkt of verruimd worden (zie Hoofdstuk 5). We hebben dit programma gesimuleerd voor de gehele bevolking. In het risicoprofiel zijn geen specificaties aangebracht (bijvoordeeld roken: niet van toepassing).

De ziekteduur stijgt eerst bijna lineair met de stijging van de produktiekosten. Wanneer de produktiekosten ca $f 1,2$ miljard bedragen neemt de ziekteduur niet meer verder toe. De gezondheidsproduktiefunctie heeft eerst een licht concaaf verloop ten opzichte van de $\mathbf{X}$-as. Voorbij het produktiepunt van ca $f 1,2$ miljard krijgt de gezondheidsproduktiefunctie een meer horizontaal verloop.

In het tweede voorbeeld wordt gedemonstreerd op welke wijze binnen een bepaald budget het optimale verdelingspunt met betrekking tot de produktie van twee gezondheidszorgprogramma's bepaald kan worden. Het optimale verdelingspunt wordt in figuur 7.13 uitgebeeld.

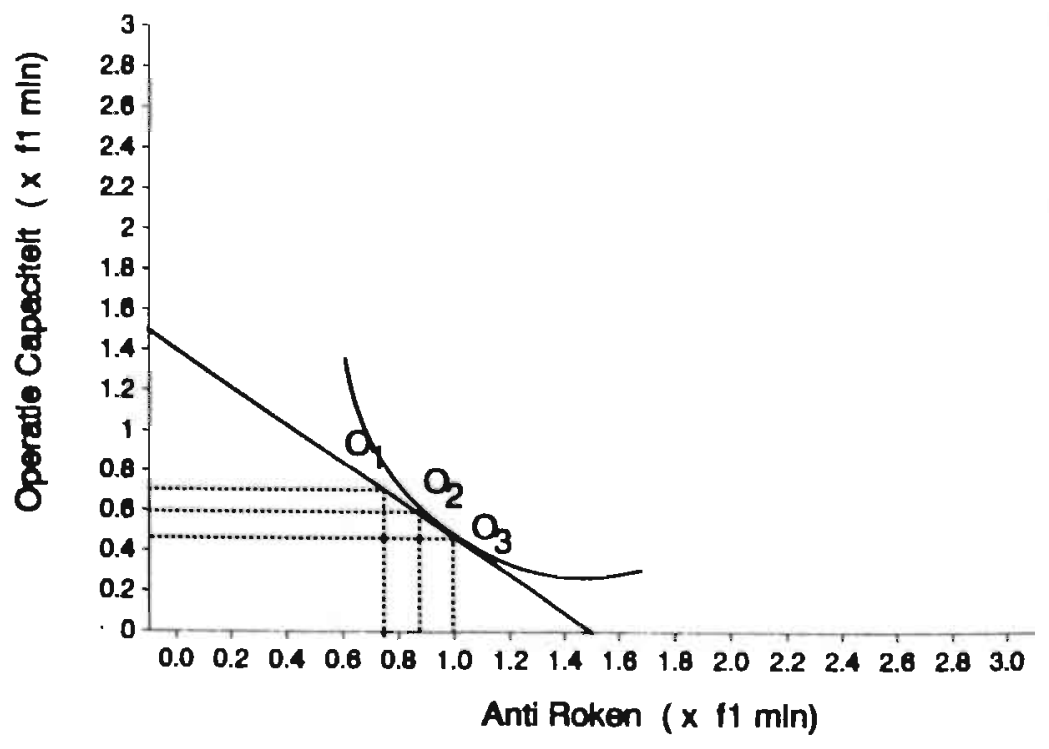

Figuur 7.13

Optimaal verdelingspunt twee gezondbeidszorgprogramma's bij een gegeven budget, ontwikkeld in ons model 
Er zijn in dit voorbeeld twee additionele gezondheidszorgprogramma's, een antirookprogramma en een operatiecapaciteit programma (zie Hoofdstuk 6). In beide programma's betreft de simulatiegroep de gehele bevolking. Er is een algemeen risicoprofiel ingesteld. Het kostenniveau van de bestaande gezondheidszorgprogramma's en de levensverwachting zijn geijkt op 1988.

In figuur 7.13 wordt op de $\mathrm{X}$-as het anti-rook programma en op de $\mathrm{Y}$-as het operatiecapaciteit programma weergegeven. Wij hebben ten behoeve van het voorbeeld verondersteld dat de baten (de levenswinst) van het anti-rook programma direct optreden.

De kosten van de betreffende programma's zijn op deze assen afgezet. Het budget voor zowel de bestaande gezondheidszorgprogramma's als de additionele gezondheidzorgprogramma's bedraagt totaal ca. f 1,5 miljard. Deze wordt in figur 7.13 weergegeven met behulp van de iso-budgetcurve. De iso-budgetcurve is vergelijkbaar met de produktie-mogelijkheden-curve. Op de iso-budgetcurve worden alle mogelijke bestedingscombinaties bij een gegeven budget weergegeven. Het verschil met de produktie-mogelijkheden-curve is dat de produkties van beide programma's in figuur 7.13 in geld zijn uitgedrukt in plaats van in natuurlijke eenheden. Ditzelfde geldt voor de iso-nutcurven.

In de punten $\mathrm{O} 1, \mathrm{O} 2$, en $\mathrm{O} 3$ op de iso-budgetcurve worden drie bestedingscombinaties bij het gegeven budget afgebeeld. Het computerprogramma berekent welke levenswinst wordt verkregen bij de investering van een bepaalde som geld in de verschillende gezondheidszorgprogramma's. De gezondheidsproduktiefunctie zit als het ware impliciet in het computerprogramma.

We hebben met ons model berekend dat in de bestedingscombinaties door de beide programma's gezamelijk de volgende levenswinst wordt gegenereerd:

\section{O1: 0,1 levenswinst \\ O2: 0,2 levenswinst \\ O3: 0,3 levenswinst}

Hoe meer we naar links van $\mathrm{O} 1$ op de iso-budgetcurve schuiven, des te kleiner de levenswinst wordt. Hetzelfde geldt voorbij het punt $\mathrm{O}$, wanneer we naar rechts op de iso-budgetcurve schuiven.

De iso-nutcurve wordt in figuur 7.13 gevormd door de levenswinst (iso-levenswinstcurve). De vorm van de iso-levenswinstcurve is convex. Hoe verder de isolevenswinstcurve van de oorsprong van figuur 7.13 afligt, hoe hoger de levenswinst is. In punt $\mathrm{O} 3$ raakt de iso-levenswinstcurve de iso-budgetcurve. Dit wil zeggen dat gegeven de hoeveelheid beschikbare middelen, de te bereiken levenswinst in punt $\mathrm{O} 3$ maximaal is. 
De levenswinstcurve wordt geconstrueerd door alle punten met dezelfde levenswinst die op de verschillende iso-budgetcurven liggen met elkaar te verbinden.

Zowel de niveaus als de vorm van de iso-levenswinstcurven kunnen veranderen, bijvoorbeeld in het geval van technologische ontwikkelingen. Er kunnen bij dezelfde gezondheidszorginspanning bijvoorbeeld meer operaties verricht worden. Anders geformuleerd: het operatiecapaciteit programma kan met minder inspanning dezelfde output bereiken, waardoor er binnen het totale budget van $f 1,5$ miljard meer geld beschikbaar is voor het anti-rook programma.

De gegeven voorbeelden illustreren dat er met behulp van de theorie rondom de gezondheidsproduktiefunctie verschillende (toekomst)paden kunnen worden uitgezet met betrekking tot de verdeling van de middelen in de gezondheidszorg. De kosteneffectiviteitsbeoordeling van de gezondheidszorgtracée's vereist vervolgens de toepassing van de kosten-baten benadering (zie Hoofdstuk 4).

\subsection{Programmabudgettering}

In programmabudgettering worden enerzijds de activiteiten verbonden aan de programmadoelstellingen en anderzijds de middelen toegewezen aan de gezondheidszorgprogramma's.

Een nevendoelstelling van programma budgettering in dit verband is het verzamelen van gegevens over het effectieve en efficiënte gebruik van de middelen in het heden en het verleden op zowel macroniveau als microniveau (vgl. Mooney e.a., 1980, en Mooney, 1992).

In tabel 7.16 is een voorbeeld gegeven van een budgetstructuur. De budgets worden in tabel 7.16 steeds verder onderverdeeld naar subprogramma's.

\begin{tabular}{|ll|}
\hline niveau 1 & Totale budget \\
niveau 2 & Programmabudgets (bljv. bejaardenzorg) \\
niveau 3 & Speclalismenbudgets (bijv. dermatologle) \\
niveau 4 & Afdellngsbudget (bijv. afdeling neurochirurgle) \\
\hline
\end{tabular}

Tabel 7.16 Een structuur van programma budgettering bron: Mooney, 1992 
De budgetstructuur uit tabel 7.16 bestaat uit patiëntenstromen verdeeld over ziektecategorieën, waarbij een specificatie naar patiëntkenmerken is aangebracht. In deze structuur zijn de gezondheidszorgprogramma's gebudgetteerd. De patiëntenstromen die door de verschillende gezondheidszorgprogramma's heenlopen worden verdeeld over de voorzieningen. De middelentoewijzing in programma budgettering vindt ruwweg plaats op basis van de geaggregeerde patiëntenstromen per voorziening. In de geschetste budgetstructuur uit tabel 7.16 wordt de verantwoordelijkheid ("accountability") voor de effectieve en efficiënte uitvoering van de deelbudgetten van de gezondheidszorgprogramma's gedelegeerd naar het management van de voorzieningen (mesoniveau). Deze verantwoordelijkheid wordt binnen de voorzieningen verder gedelegeerd naar de verantwoordelijke afdelingen en individuele zorgverleners (zie verderop in deze paragraaf). De structuur van programma-budgettering maakt het mogelijk het budgetteringsproces te gebruiken als sturingsinstrument voor management controle en kostenbeheersing (vgl. Groot e.a., 1993).

Bij toepassing van programma budgettering wordt de geleverde inspanning achteraf in relatie gebracht met de beoogde doelstellingen. Hierdoor kan men een indruk vormen over het verantwoorde gebruik van de toegewezen middelen ("accountability"). De gegevens over het gebruik van de voorzieningen en de effecten van de zorg op microniveau worden in de structuur van programma budgettering geaggregeerd tot data op macroniveau. Er wordt op deze wijze informatie verkregen waarmee prioriteiten tussen verschillende gezondheidszorgprogramma's gesteld kunnen worden. Het gaat bij de dataverzameling in dit verband om een kringloopproces, zoals weergegeven in figuur 7.14. 


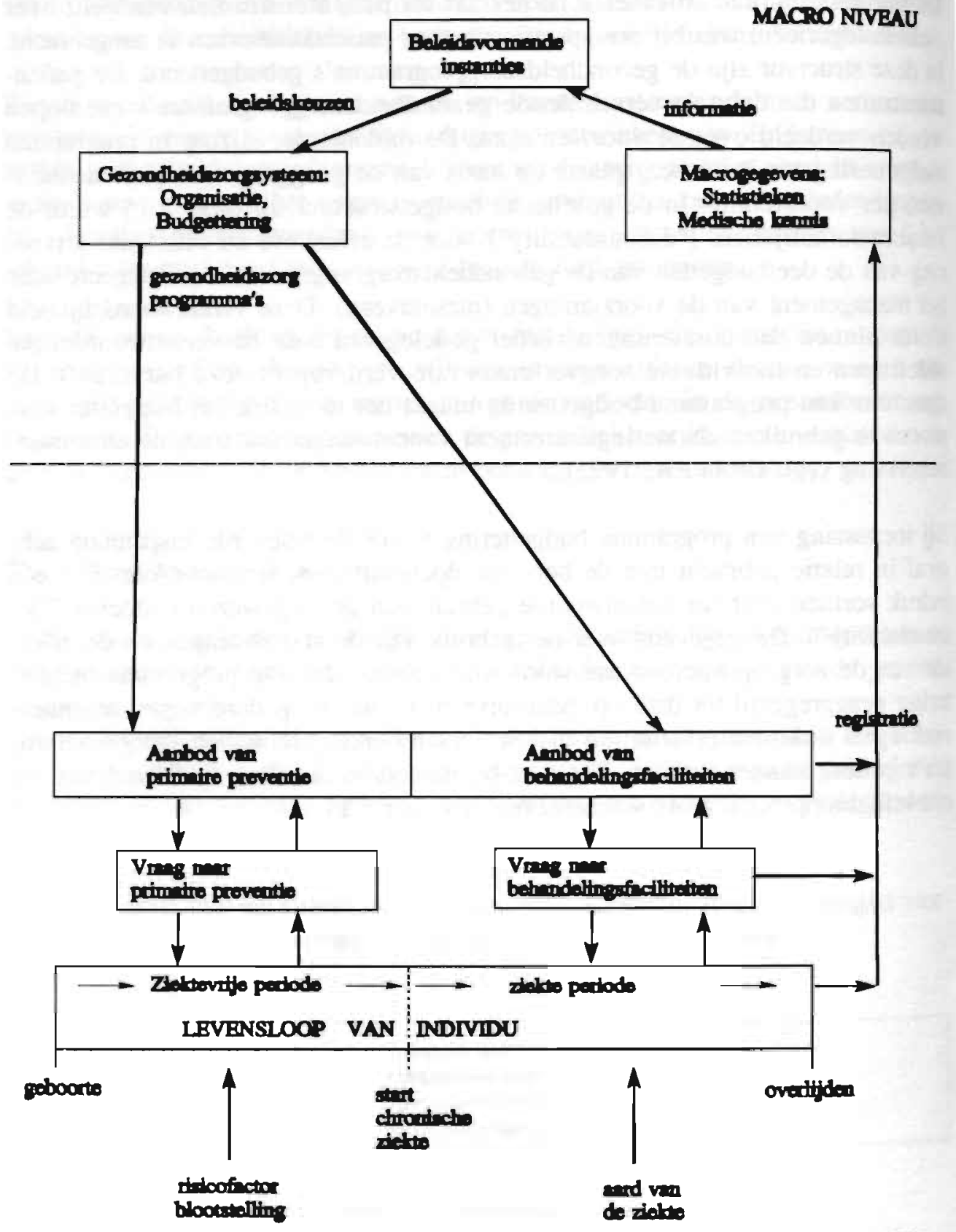

MTCBO NIVEAU

Figuur 7.14 Interactiediagram relatie micro- en macroniveau 
In figuur 7.14 presenteert op microniveau een patiënt zich met een bepaalde ziekte bij de arts. De arts maakt een therapiekeuze voor de behandeling gebaseerd op zijn kennis, de aanwezige capaciteit en de mogelijkheden van de techniek. De gemaakte keuze draagt vervolgens bij aan het verdere ziekteverloop en de levensverwachting van de patiënt. De som van alle gebeurtenissen op microniveau resulteert in de morbiditeitscijfers en sterftecijfers op macroniveau. De keuzen van gezondheidszorgprogramma's grijpen op hun beurt weer aan op het microniveau.

De formulering van de beleidsdoelstellingen, het opstellen van strategieën, en het maken van keuzen uit gezondheidsprogramma's geschiedt op macroniveau. Er is een sturingsmechanisme nodig dat het strategisch beleidsproces moet beheersen. Wij duiden dit sturingsmechanisme aan met het door de World Health Organization (1981) geïntroduceerde begrip beheersingsproces.

Het beheersingsproces wil een kader scheppen waarmee gezondheidsstrategieën geformuleerd en geëffectueerd kunnen worden. De gezondheidsstrategieën zijn gericht op het bereiken van gezondheidsdoelen (zie Hoofdstuk 5).

De scenarioanalyse past in dit strategisch beleidsproces. Er wordt een economisch evaluatieve methode aangedragen waarmee toekomstige paden met betrekking tot strategische beleidslijnen met elkaar vergeleken kunnen worden (zie Hoofdstuk 5). De scenario's worden in eerste instantie in absolute termen gepresenteerd zonder dat er (nog) sprake is van enige budgetbeperkingen (zie Hoofdstuk 6). Het is hierbij essentieel dat zoveel mogelijk scenario's die positieve effecten genereren worden ontwikkeld. Er wordt vervolgens een range van scenario-opties ("options") gepresenteerd waarbij de relevante kosten en effecten van elke optie worden beoordeeld (vgl. "option appraisal" uit Henderson e.a., 1984). Het hier bedoelde strategische beleidsproces richt zich meestal op verdelingsvraagstukken die zich afspelen op macroniveau (vgl. Meyer, 1990). Er zijn echter op operationeel niveau eveneens verdelingsmodellen nodig, zoals vraag en aanbod modellen met betrekking tot het aantal ziekenhuisopnames en het benodigde personeelsbestand. Deze verdelingsmodellen hebben gegevens nodig over mogelijke toekomstige ontwikkelingen met betrekking tot in de morbiditeit en dergelijke (vgl. Taket, 1991, en Rusnak, 1991). Op dit punt zien we een interactie tussen de scenarioanalyse op bevolkingsniveau en de verdelingsmodellen op operationeel niveau met betrekking tot het generen van data op respectievelijk macroniveau en microniveau.

Er zijn twee mechanismen vereist die zorg moeten dragen voor de continuïteit van het beheersingsproces: 


\section{(i) informatie-ondersteunende systemen}

Een van de problemen bij programma budgettering zal zijn het verkrijgen van gegevens met betrekking tot de gemaakte kosten en de verkregen effecten (vgl. Crebolder e.a., 1990). Er is bijvoorbeeld weinig bekend over de bijdrage van het huidige gezondheidszorgsysteem aan de factor gezondheid. Het oplossen van dit dataprobleem in de gezondheidszorg vereist de introductie van een landelijk systeem waarmee op routinematige basis de vereiste gegevens aangeleverd worden (zie ook Hoofdstuk 1).

(ii) evaluatiesystemen.

De programma budgettering vormt de sleutel waarmee het beheersingsproces op een effectieve wijze gestalte kan krijgen. De motivering hierachter is dat in programma budgettering de inspanningen op hun effectiviteit en efficiëntie beoordeeld kunnen worden. In een gezondheidszorgsysteem dat gestructureerd is op basis van gezondheidszorgprogramma's kan immers een relatie gelegd worden tussen de kosten en de effecten van de betreffende inspanning.

Het is noodzakelijk dat in het planningsproces de verantwoordelijkheden met betrekking tot de beoogde doelrealisatie van te voren wordt vastgelegd. Het concept van accountability kent vele vormen (vgl. Heald, 1983). Waar wij geïnteresseerd in zijn, is de zogenaamde "resource accountability". Deze vorm van accountability verwijst enerzijds naar de verantwoordelijkheid op macroniveau met betrekking tot de toewijzing van de middelen naar voorzieningen op microniveau, en anderzijds naar de verantwoordelijkheid op microniveau met betrekking tot de continuiteit van de geleverde prestaties.

Het concept van accountability valt binnen het bredere concept van "value-formoney auditing" (het afrekenen op basis van prestaties). Er wordt onderzocht of de bereikte resultaten ook op andere manieren verkregen kunnen worden en/of ze nog wel in de pas lopen met de huidige beleidsintenties. De value-for-money audit richt zich op beoordeling van het effectieve en efficiënte gebruik van de middelen op macroniveau en microniveau. We denken bij value-for-money auditing op macroniveau aan de toepassing van de partièle - en de volledige economische evaluatievormen die in Hoofdstuk 4 zijn besproken. Er zijn bij value-formoney auditing op microniveau soortgelijke evaluatievormen toepasbaar, bijvoorbeelden (partiële) evaluatievormen waarbij de werkelijke produktie wordt gerelateerd aan de standaardproduktie en standaardkwaliteit.

Programma budgettering verstrekt alleen informatie en is niet evaluatief in zichzelf. Dit betekent dat de verschillende economische evaluatievormen expliciet in de structuur van programma budgettering moeten worden ingebouwd. Hierdoor kan er worden beoordeeld in hoeverre bestaande en nieuwe gezondheidszorgprogramma's nog voldoen aan de (beongde) beleidsdoelstellingen. 
Er zal naast de value-for-money audit een beleidsaudit ingevoerd moeten worden. In een beleidsaudit zullen de keuzen met betrekking tot verdelingsaspecten gemotiveerd worden met behulp van economische waarderingstechnieken ("economic appraisal"). In economic appraisal worden alle factoren in ogenschouw genomen die direct of indirect in relatie staan tot de te nemen beslissing (vgl. Ludbrook e.a., 1984). In de medische audit (medical audit) wordt het doeltreffende gebruik van de middelen gekoppeld aan de kwaliteit en de kwantiteit van de geleverde zorg. In het klinisch beslissingsproces speelt de medische audit een belangrijke rol. Het is vanuit doelmatigheidsoverwegingen aan te bevelen in de klinische besluitvorming economische evaluatiemethoden als standaardprocedure te betrekken (vgl. de aanbevelingen van Rutten e.a., 1992, met betrekking tot Ontwikkelingsgeneeskunde). We hebben in figuur 7.15 een overzicht gegeven van de verschillende auditing systemen.

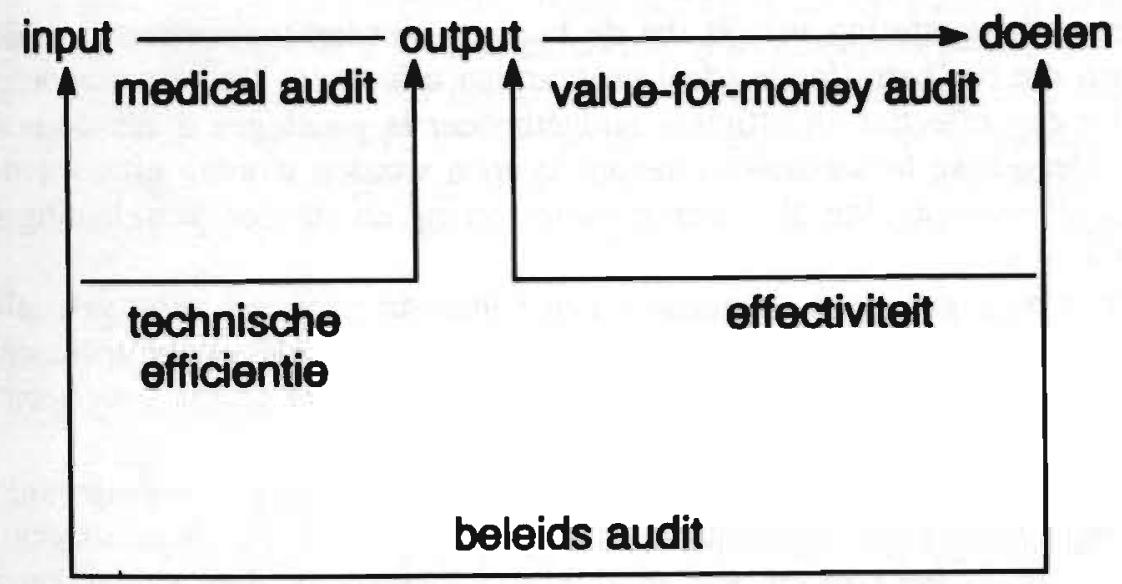

Figuur 7.15

Auditing systemen op micro- en macroniveau bron: bewerkt naar Boorsma (1986)

Samenvattend kan aan het beheersingsproces een aantal randvoorwaarden gesteld worden:

(i) een systeem van scenarioanalyse

(ii) programma budgettering

(iii) auditing systemen

(iv) data-informatie systemen 
De effecten van een programma worden het liefst gemeten in termen van gezondheidswinst (finale output). In de praktijk is de gezondheidswinst moeilijk meetbaar. Er is daarom een behoefte effecten te meten in termen van intermediaire outputs. De doelmatigheid en doeltreffendheid van inspanningen gemeten in termen van intermediaire outputs zullen door experts altijd herkend en beoordeeld kunnen worden. De praktische toepasbaarheid van intermediaire output maakt het mogelijk patiëntengroepen te identificeren die een behoefte hebben aan extra of een andere type verzorging en behandeling.

Er bestaat een planningsmethode die deze patiëntengroepen typeert als marginale patiëntengroepen. De planningsmethode zelf wordt marginale analyse genoemd (vlg. Mooney e.a., 1980). Men kan met behulp van het concept van marginale analyse evalueren hoeveel van een bepaald gezondheidszorgprogramma wordt uitgevoerd en op welke wijze de middelen over de marginale patiëntengroepen zijn verdeeld. Deze planningsmethode leent zich bij uitstek bij de toepassing van een systeem van programma budgettering.

Programma budgettering vereist dat de budgets worden toegewezen aan de instellingen die het betreffende (deel)programma uitvoeren. De verantwoordelijkheid voor een effectief en efficiënt budgetbeheer is gedelegeerd aan de budgethouder. Dergelijke beheersingssystemen kunnen worden worden uitgevoerd met beheersingsinstrumenten als interne budgettering en interne verrekening (vgl. Groot e.a, 1993).

Het is van belang dat een organisatie zijn beheersingsconcept eerst vaststelt, alvorens het beheersingssysteem te ontwikkelen. Het beheersingsconcept vertegenwoordigt de filosofie van de organisatie, die aan het beheersingssysteem ten grondslag ligt (vgl. Hasman e.a., 1990).

Een beheersingsconcept dat binnen het kader van de huidige stelselwijziging met betrekking tot de financiering en kostenbeheersing in de gezondheidszorg veel opgang maakt is het concept van produktlijnmanagement. Een kenmerkend aspect van de stelselwijzigingen is dat de verantwoordelijkheden met betrekking tot de zorgverlening meer bij de zorgverzekeraars en zorgaanbieders wordt gelegd (vgl. ZFR, 1992).

In produktlijnmanagement wordt het produktieproces verbonden aan het finale produkt. Het type patiënt vormt hierbij het finale produkt. De behandelingen voor een bepaald type patiënt worden zodanig geordend dat ze als het ware een produktieprogramma vormen van een bijelkaar horend pakket van activiteiten.

De toepassing van produktlijnmanagement vereist dat de patiëntencategorieën moeten worden geclassificeerd in subgroepen. Deze subgroepen zijn zoveel mogelijk homogeen met betrekking tot de medische behandeling en verpleging en de kosten die gegenereerd worden. De zogenaamde Diagnosis Related Groups (DRG's) zijn een voorbeeld van een dergelijk classificatiesysteem (vgl. Voss, 
1993). In feite betekent produktlijnmanagement niks anders dan een vorm van programmabudgettering op microniveau.

Een acceptatie van programma budgettering geeft een verandering in de manier waarop de middelenverdeling tot stand komt. In de huidige situatie van de $\mathrm{Ne}$ derlandse gezondheidszorg zijn beslissingen omtrent de verdeling van de middelen input georiënteerd. Dit wil zeggen dat de geldstromen zijn gericht op de type voorzieningen die de diensten leveren. In programma budgettering zijn de verdelingen output- of patiëntgeoriënteerd. De patiëntenstromen staan centraal bij de toewijzing van de budgets aan de gezondheidszorgprogramma's.

De invoering van programma budgettering zou betekenen dat de Nederlandse gezondheidszorg gestructureerd zal moeten worden op basis van gezondheidszorgprogramma's. Een dergelijke indeling leidt ertoe dat geldstromen, activiteiten, en doelgroepen naar gezondheidszorgprogramma's moeten worden onderscheiden.

Een algemene kritiek op programma budgettering is dat dit planningsmodel meer geschikt zou zijn voor een genationaliseerde gezondheidszorg (het zogenaamde Engelse model) dan voor een marktgeoriënteerde gezondheidszorg (het zogenaamde Amerikaanse model). Er bestaat de opvatting dat de toepassing van het beheersingsproces gemakkelijker is te bereiken in landen waar de gezondheidszorg meer aan regels is gebonden ("regulation by directives"). In marktgeoriënteerde gezondheidszorgsystemen zou de gezondheidszorg meer geregeld worden door het verbinden van (geldelijke) aansporingen ("incentives") aan bepaalde gezondheidszorgprogramma's ("regulation by incentives"). De "beheersing door incentives" kan echter ook beschouwd worden als een aanvullend sturingsinstrument in een onvolkomen markt waar "beheersing door planning" een noodzaak is (vgl. Drummond, 1990).

Er kunnen in programma budgettering "incentives" worden ingebouwd. Wij bedoelen hiermee beloningssystemen die gekoppeld zijn aan auditing systemen. De ontwikkeling van de verschillende auditing systemen kan hiermee als het ware afgedwongen worden (vgl. WHO, 1982). Het inbouwen van auditingsystemen maakt het mogelijk dat programma budgettering wordt gebruikt als beleidsinstrument om te komen tot een effectieve en efficiënte verdelingsprocedure van de schaarse middelen in de gezondheidszorg.

In de VS is in het midden van de jaren ' 60 als planningsmodel het concept van "Programme Planning Budgeting System" (PPBS) geïntroduceerd. In PPBS wordt uitvoering gegeven aan strategische plannen door de toewijzing van de vereiste financiële middelen en door de specificatie van de gekozen gezondheidszorgprogramma's in concrete operationele termen. Er wordt in PPBS vereist da 
de doelstellingen zijn gedefinieerd, er een wijde range van alternatieven in de beschouwing van strategieën en gezondheidszorgprogramma's wordt betrokken, er een analyse van zowel de kosten als opbrengsten plaatsvindt, en dat de geleverde inspanningen aan de doelstellingen gerelateerd worden.

Het falen van PPBS in die tijd werd veroorzaakt door een onvoldoende zekerheidsstelling van middelen om de gezondheidsprogramma's uit te voeren. Er bestonden ook politieke en bureaucratische weerstanden tegen de invoering van PPBS. Een herleving van de filosofie en de logica van PPBS vond plaats tijdens het presidentschap van Carter (vgl. Warner e.a., 1982).

Er kan tegen de achtergrond van een structuur van programma budgettering een aantal vragen gesteld worden (vgl. Mooney e.a., 1980). Bij wie ligt de besluitvorming over de vast te stellen doeleinden? Wie moet welke beslissingen nemen? Wie bestuurt de beslissingsnemers? Wiens waardeoordeel moet bij welke beslissing worden toegepast?

Wij hebben in dit verband in figuur 7.16 een suggestief overzicht opgenomen dat laat zien hoe programma budgettering toegepast kan worden in het huidige systeem van de Nederlandse gezondheidszorg.

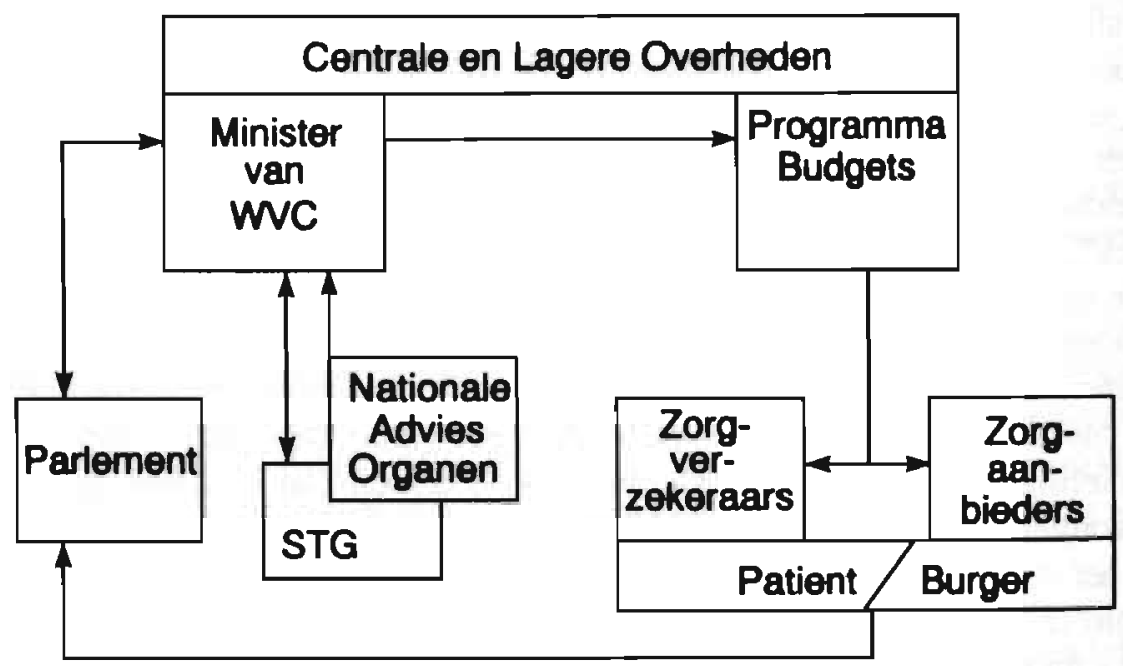

Figur 7.16 Programma Budgettering in Nederlands gezondheidszorgsysteem bron: bewerkt naar Janssen (1992)

In Nederland heeft de Minister van WVC de belangrijkste verantwoordelijkheid bij het bepalen van het gezondheidsbeleid. Er zijn in Nederland verschillende belangrijke adviesorganen met betrekking tot de ontwikkeling van het strategisch 
beleidsproces van de gezondheidszorg en de volksgezondheid (vgl. Boot e.a., 1988). Er zou onderzocht kunnen worden welke range van strategische opties er bestaat en met welke gezondheidszorgprogramma's de gekozen strategieën geoperationaliseerd kunnen worden. De Stuurgroep Toekomstscenario's Gezondheidszorg (STG) is verantwoordelijk voor de richting die aan de scenarioanalyse's gegeven kan worden. Het FOZ dient als een "masterplan" met betrekking tot de activiteiten die ontwikkeld moeten worden om de programma budgets gestalte te geven. Het Ministerie van WVC en het bestaande netwerk op provinciaal en gemeentelijk niveau worden belast met de toekenning van de programma budgets. De afrekening van de budgets per instelling (voorziening) kan via de bestaande financieringskanalen plaats blijven vinden. In het huidige systeem van externe budgettering worden de instellingen voorgefinancierd op basis van een door ziektekostenverzekeraar en instelling afgesproken budget. De parameters zouden in het hier voorgestelde systeem wel output georiënteerd moeten worden, gericht op de patiëntenstromen die de verschillende gezondheidszorgprogramma's per voorziening doorlopen.

In de huidige politieke constellatie bestaat een overheersende tendens de planning in de gezondheidszorg over te laten aan het onderhandelingsproces tussen de aanbieders van zorg en de zorgverzekeraars (marktpartijen). De stelling is dat in een niet-perfecte markt het niet mogelijk is tot een efficiënt gezondheidszorgstelsel te komen door alleen uit te gaan van de marktverhoudingen (concurrentie) tussen de genoemde marktpartijen (ontleend aan Roscam Abbing, uit de Volkskrant d.d. 15-05-1993).

Het alternatief dat wij in deze beschouwing voordragen sluit ons inziens aan bij de intentie van de Nota 2000 (1986) om de middelenverdelingen bij een gegeven budget te beargumenteren op basis van een verwachte bijbehorende gezondheidsopbrengst.

In de Nota 2000 (1986) wordt een aantal gezondheidsdoelen genoemd. Deze gezondheidsdoelen zijn geformuleerd op een hoog geaggregeerd niveau en moeten worden vertaald naar meer specifieke strategieën. In het beheersingsproces zijn de strategieën, de actieplannen, en de gezondheidszorgprogramma's gespecificeerd (vgl. WHO, 1981). Scenarioanalyse kan hierbij dienen als hulpmiddel voor het strategisch planningsproces met betrekking tot de keuze van de verschillende gezondheidszorgprogramma's (zie Hoofdstuk 5). In programma budgettering worden de activiteiten benoemd die zorgdragen voor de operationalisering van de geformuleerde programma's. 


\section{BIJLAGEN}




\section{EPIDEMIOLOGIE VAN CHZ}

\section{I.1 Inleiding}

I.2 CHZ-Risicofactoren Gezonde Bevolking

I.3 Incidenties Gezonde Bevolking

I.4 Incidenties CHZ-Bevolking

I.5 CHZ en niet-CHZ sterfte

I.6 Leeftijds- en Geslachtsafhankelijkheid 


\section{I.1 Inleiding}

Het CHZ-model simuleert patiëntenstromen in de gezonde en zieke (CHZ) Nederlandse bevolking. In verband hiermee zijn overgangskansen bepalend voor de wijze waarop het dynamische proces zich ontwikkelt. Er worden in het $\mathrm{CHZ}$-model drie categorieën van overgangskansen onderscheiden:

(i) de kansen op een CHZ-manifestatie in de gezonde bevolking (incidenties gezonde bevolking).

Deze incidenties worden in hoge mate bepaald door de aanwezigeid van (verhoogde) risicofactoren onder de bevolking.

(ii) de kansen betreffende de ontwikkelingen tijdens het ziekteproces.

Deze kansen zijn in feite gebaseerd op de prognose van het betreffende ziektestadium.

(iii) de kansen op overlijden aan een doodsoorzaak anders dan coronaire hartziekten.

De gegevens over de overgangskansen in de gezonde bevolking en tijdens het ziekteproces zijn verkregen uit literatuurstudies. In de praktijk worden dit s0ort overgangskansen eerst op individueel niveau (het microniveau) verzameld en geaggregeerd tot data op bevolkingsniveau (het macroniveau). De data op geaggregeerd niveau worden als gevolg van bijvoorbeeld beleidsbeslissingen als het ware teruggekoppeld naar handelingen op microniveau. Hierdoor ontstaat er binnen het model een voortdurende wisselwerking tussen data op microniveau en data op macroniveau. Om dit te bereiken, hebben we moeten afleiden op welke manier het macroniveau en het microniveau elkaar beinvloeden en hoe deze relaties kwantitatief vorm te geven zijn. Dit heeft geleid tot een modelmatige benadering waarin de begrippen risico, incidentie, behandeling, nazorg en additionele gezondheidszorgprogramma's de kembegrippen zijn.

Er zijn weinig leeftijds- en geslachtsspecifieke gegevens beschikbaar met betrekking tot de incidentie, morbiditeit en behandeling van $\mathrm{CHZ}$. De benodigde gegevens hieromtrent zijn voor een belangrijk deel gebaseerd op de databestanden van de Stichting Informatiecentrum Gezondheidszorg (SIG). Voorzover er gegevens ontbraken, zijn die data verkregen uit privé-communicatie.

Deze bijlage is als volgt ingedeeld. In paragraaf $\mathbf{I} .2$ worden de $\mathrm{CHZ}$-risicofactoren in de gezonde bevolking beschreven. De behandeling van de $\mathrm{CHZ}$-incidenties uit de gezonde bevolking respectievelijk uit de $\mathrm{CHZ}$-bevolking vindt in de paragrafen $\mathrm{I} .3$ en I.4 plaats. De CHZ-sterfte en de niet-CHZ sterfte worden in 
paragraaf I.5 besproken. Tot slot wordt in paragraaf I.6 een overzicht gepresenteerd van de leeftijds- en geslachtsspecifieke kansen met betrekking tot $\mathrm{CHZ}$.

\subsection{CHZ-Risicofactoren Gezonde Bevolking}

Naast leeftijd en geslacht zijn er drie risicofactoren in het model meegenomen, te weten serumcholesterolgehalte, diastolische bloeddruk en rookgewoonte. Deze drie risicofactoren worden hieronder besproken.

\section{Serumcholesterolgehalte (hypercholesterolaemie)}

In de literatuur worden met betrekking tot het ontstaan van hypercholesterolaemie vaak de volgende variabelen genoemd: totale calorie opname uit verzadigd vet, obesitas, roken, gebrek aan lichaamsbeweging en orale anti-conceptie (Gezondheidsraad, 1984/16, Stalenhoef, 1989).

Het serumcholesterolgehalte wordt meestal bepaald door de meting van het serum-totaal-cholesterol. Deze meting geschiedt door het afnemen van een bloedmonster. Het cholesterolprofiel wordt bij voorkeur gemaakt uit een reeks van drie metingen die over een langere periode verspreid zijn (Erkelens, 1987). De meeteenheid is de mmol/l.

Het serum-totaal-cholesterol kan worden onderscheiden in vijf soorten lipoproteïnen. De belangrijkste lipoproteïnen zijn "low density lipoproteïn" (LDL) en "high density lipoproteïn" (HDL). Een hoog HDL/LDL-cholesterolverhouding in het serum verlaagt het risico op CHZ (Gezondheidsraad, 1984/16, Mensink e.a., 1989).

Een verhoogd serumcholesterolgehalte is de enige onafhankelijke risicofactor met betrekking tot de progressie van atherosclerose. De andere risicofactoren zijn cholesterol afhankelijk (vgl. Arntzenius, 1988). Volgens Mancini (uit: Arntzenius, 1990) en de Helsinkie Heart Study (Arntzenius, 1988) zou een verhoogde LDL-waarde de enige onafhankelijke risicofactor zijn die de progressie van atherosclerose beïnvloedt. Over deze visie bestaat hoe langer hoe meer consensus. De regressie van atherosclerose zou dan het best samenhangen met een kunstmatige verhoging van de HDL-fractie. Dit heeft vervolgens een verlaging van de LDL-fractie tot gevolg. Er zijn niet veel gegevens bekend met betrekking tot de prevalentie van de HDL-cholesterol-ratio in de gezonde bevolking.

Een risicofactor is (sterk) verhoogd wanneer het niveau na meerdere metingen een bepaalde grenswaarde heeft overschreden. Wij duiden deze grenswaarde aan als het afkappunt. De Nederlandse Cholesterol Consensus heeft in 1987 de cho- 
lesterolniveau's aan de hand van de volgende afkappunten vastgesteld (Erkelens, 1987):

$\begin{array}{lll}<5,0 \mathrm{mmol} / 1 & - & \text { ideaal } \\ 5,0-6,4 \mathrm{mmol} / 1 & - & \text { normaal } \\ 6,5-8,0 \mathrm{mmol} / 1 & - & \text { verhoogd } \\ >8,0 \mathrm{mmol} / 1 & - & \text { sterk verhoogd }\end{array}$

Op basis van deze indeling hebben wij de gezonde bevolking in drie cholesterolniveau's gestratificeerd, te weten: $<6,5 \mathrm{mmol} / 1,6,5-8,0 \mathrm{mmol} / 1$, en $>8,0$ $\mathrm{mmol} / \mathrm{l}$.

\section{Verhoogde Bloeddruk (Hypertensie)}

De factoren die het ontstaan van hypertensie bevorderen zijn in het algemeen overgewicht (sterker bij jongeren dan bij ouderen), zoutgebruik, (overmatig) alcoholgebruik, stress en orale anti-concepticie (Gezondheidsraad, 1984/16). Hypertensie is een verhoogde risicofactor voor $\mathrm{CHZ}$. Het is in de literatuur niet eenduidig of bloeddrukverlaging het $\mathrm{CHZ}$-risico ook vermindert (Jonkers e.a.; 1977, Grimm, 1986). Uit de Framingham Heart Study (Kannel e.a., 1987) blijkt dat wanneer het serumcholesterolgehalte nagenoeg niet is verhoogd, het CHZ-risico van hypertensie relatief laag is. De bloeddrukverlaging heeft dan met betrekking tot het $\mathrm{CHZ}$-risico niet veel betekenis. Dit zou een verklaring kunnen zijn voor de tegenstrijdige resultaten die in de hypertensie-trials met betrekking tot de incidentiedaling van $\mathrm{CHZ}$ zijn gevonden. Ook is het zo dat sommige antihypertensiva een serumcholesterolverhogend effect hebben, waardoor het bloeddrukverlagend effect met betrekking tot het $\mathrm{CHZ}$-risico wegvalt (Koopmans e.a., 1987). Wij beschouwen hypertensie daarom meer als een variabele die de progressie van het atherosclerotisch proces verder kan versnellen wanneer er andere verhoogde $\mathrm{CHZ}$-risicofactoren reeds aanwezig zijn.

De hypertensieprevalentie kan in drie verschillende parameters worden uitgedrukt: de diastolische bloeddruk (DBD), de systolische bloeddruk (SBD), en een combinatie van beide. De meeteenheid is $\mathrm{mmHg}$. Het hypertensieprofiel word meestal vastgesteld aan de hand van drie gescheiden metingen (De Groot e.a., 1988). De Gezondheidsraad (1990) beveelt in dit verband een minimum van drie metingen aan, met een tussenpoos van éen week tussen elke meting.

De Hypertensie Consensus Bijeenkomst (1990) definieert de normale en verhoogde bloeddrukwaarden bij de volgende afkappunten: 


$\begin{array}{lcccc}\text { normaal } & <90 & \mathrm{mmHg} & <140 & \mathrm{mmHg} \\ \text { borderline } & 90-94 & \mathrm{mmHg} & 140-159 & \mathrm{mmHg} \\ \text { licht } & 95-104 & \mathrm{mmHg} & \geq 160 & \mathrm{mmHg} \\ \text { matig } & 105-114 & \mathrm{mmHg} & & \\ \text { ernstig } & \geq 115 & \mathrm{mmHg} & & \end{array}$

In de meeste epidemiologische studies is de hypertensie-prevalentie in de DBD uitgedrukt. In de literatuur pleiten verschillende auteurs echter al jaren voor een herwaardering van de SBD. Volgens Dawber (1980) en Kannel e.a. (1980) zouden analyses met betrekking tot de Framingham Heart Study aantonen dat de SBD een betere voorspeller is met betrekking tot de CHZ-sterfte dan de DBD. Omdat wij afhankelijk zijn van de beschikbare data, is in het model de DBD gebruikt bij de beschrijving van de hypertensie-prevalentie.

De hypertensie-gradaties die de Hypertensie Consensus Bijeenkomst heeft vastgesteld komen vaak niet met de literatuur overeen. De WHO (1978) neemt voor een verhoogde bloeddruk de afkappunten $\geq 95 \mathrm{mmHg}$ en/of $\geq 160 \mathrm{mmHg}$. Deze afkappunten worden ook door de verschillende epidemiologische studies gehanteerd. Wij hebben een combinatie gemaakt van de afkappunten, genoemd in de definities van de Nederlandse Cholesterol Consensus en de WHO-definitie, en een verhoogde DBD gesteld op > $95 \mathrm{mmHg}$. Zodoende zal in het model drie DBD-categorieën worden onderscheiden: $<90 \mathrm{mmHg}, 90-95 \mathrm{mmHg}$, en $>95$ $\mathrm{mmHg}$.

\section{Roken}

Wij beschouwen met betrekking tot het roken alleen het roken van sigaretten als risicofactor van CHZ. Het blijkt namelijk dat sigaar- of pijprokers veel minder roken "over" de longen dan sigaretten rokers en daardoor een veel lager $\mathrm{CHZ}$-risico lopen (Otten e.a., 1988).

Het roken oefent door toediening van nicotine en koolmonoxyde een directe invloed uit op de incidentie van CHZ. Nicotine heeft een samentrekkende werking op de bloedvaten waardoor de doorstroming van het bloed verslechtert. Koolmonoxyde verdringt het zuurstof uit het bloed. Het effect is dat beide stoffen, autonoom van elkaar, een atherosclerotische werking op de wanden van de bloedvaten uitoefenen (Baan, 1989).

Wij hebben uit de literatuur geen duidelijk beeld kunnen krijgen in hoeverre het aantal sigaretten dat iemand rookt van invloed is op de CHZ-incidentie. Tevens zijn er onvoldoende gegevens beschikbaar met betrekking tot het aantal sigaretten dat naar leeftijd en geslacht gerookt wordt. In ieder geval is de hoogte van het $\mathrm{CHZ}$-risico na het stoppen met roken onafhankelijk van het aantal gerookte 
sigaretten en de duur dat gerookt is (Rosenberg e.a., 1990). Een belangrijk uitgangspunt voor ons is dat via de Framingham Heart Study de regressiecoëfficiënt voor roken uitsluitend bekend is met betrekking tot de factor wel of niet roken We hebben in ons model gekozen voor een categorisering die uitgaat van wel of niet roken en die onafhankelijk is van het aantal gerookte sigaretten per dag.

In tabel I.1 wordt een overzicht gegeven van de verschillende preventie projecten in Nederland op het terrein van CHZ.

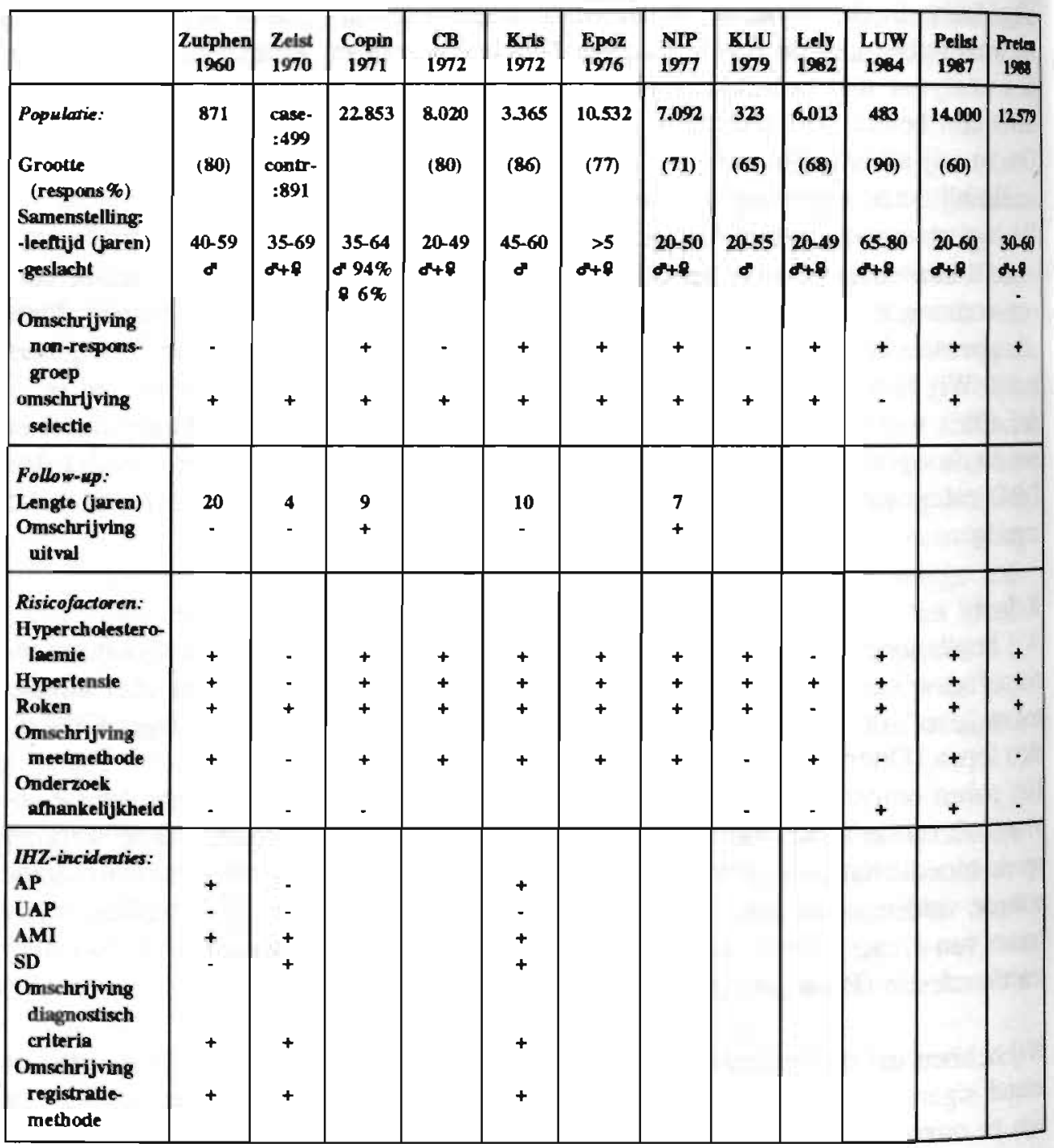

Tabel I.1

Overzicht van de kwaliteit en de bruikbaarheid van de belangrijkste Nederlandse studies met betrekking tot risicofactoren voor $\mathrm{CHZ}$ 
legenda:

$\begin{array}{ll}\text { Zutphen } & \text { - Zutphen-studie (Keys, 1980, Voedingsraad, 1984, Krombout e.a., 1984) } \\ \text { Zeist } & \text { - Project Zeist (Magnus e.a., 1978, Matroos e.a., 1979, Magnus e.a., 1980) } \\ \text { Copin } & \text { - Commissie Opsporing en Preventie Ischaemische Hartziekten (Jonkers e.a., 1981, } \\ & \text { 1982) } \\ \text { CB } & \text { - Consultatie Bureau Projecten Risicofactoren Hart- en Vaatziekten (Meyler e.a., } \\ & \text { 1976, De Haas, 1977) } \\ \text { Kris } & \text { - Kaunas-Rotterdam Interventie Studie (Sturmans e.a., 1977, Appels e.a., 1988) } \\ \text { Epoz } & \text { - Epidemiologisch Preventief Onderzoek Zoetermeer (Valkenburg e.a., 1980, } \\ \text { NIP } & \text { Hotman e.a., 1980) } \\ \text { KLU } & \text { - Nijmegen Interventie Project (Van Ree, 1981, Van Ree e.a., 1985/1) } \\ \text { Lely } & \text { - Koninklijke Luchtmacht (Hulshof e.a., 1984) } \\ \text { LUW } & \text { - Lelystad Studie (Van Loo e.a., 1987) } \\ & - \text { Afstudeerprojekt bijvakgroep Voeding (Landbouw Universiteit Wageningen) (Bos } \\ \text { Peilst } & \text { boom e.a., 1988) } \\ \text { Preten } & \text { - Peilstationsproject Hart- en Vaatziekten (Kromhout e.a., 1987) }\end{array}$

In het overzicht uit tabel I.1 wordt de methodologische kwaliteit en de kwaliteit met betrekking tot de bruikbaarheid van deze projecten geëvalueerd. Op de horizontale as staan de projecten genoemd, op de verticale as de methodologischedan wel bruikbaarheidscriteria.

Om te kunnen scoren op de methodologische- en bruikbaarheidscriteria is geïnventariseerd of en in welke mate de publikaties van de projecten aandacht besteden aan de verschillende criteria, te weten:

\section{(i) Populatie}

Een heel belangrijke vraag is of dat deel van de onderzoekspopulatie dat in het model in beschouwing wordt genomen representatief is voor de Nederlandse bevolking. De samenstelling van de onderzoekspopulatie naar leeftijd en geslacht is hiervoor van belang. De selectiemethode die heeft geleid tot de vorming van de onderzoekspopulatie is over het algemeen goed omschreven.

Behalve de samenstelling is ook de grootte en de respons van de onderzoekspopulatie van belang. In de tabel I.1 staat, achter het getal dat deze grootte aangeeft, tussen haakjes (indien bekend) het responspercentage aangegeven. In de meeste projecten is aandacht besteed aan de non-respons-populatie in de vorm van een beschrijving van de redenen van non-respons, en eventueel een omschrijving van enkele persoonskenmerken van deze groep, doorgaans leeftijd en geslacht. Een steeksproefgewijze controle om te onderzoeken of deze nonrespons-groep qua samenstelling daadwerkelijk afwijkt van de respons-groep is alleen in de Zutphen-studie, de Lelystad-studie en de KRIS-studie gedaan. 


\section{(ii) Duur follow-up}

Voor de prospectieve projecten wordt de follow-up lengte in jaren aangegeven. Bij het CB-project is behalve een transversale screening van de gehele onderzoekspopulatie de hieruit geselecteerde risicogroep nog gedurende 1 jaar gevolgd. De groep die zich om wat voor reden dan ook onttrekt aan follow-up, is niet altijd goed omschreven.

\section{(iii) Risicofactoren}

Per project staat aangegeven welke risicofactoren belicht worden, of de meetmethodiek goed omschreven staat, en of er een poging is gedaan om een eventuele onderlinge afhankelijkheid in het vorrkomen van de risicofactoren in kaart te brengen.

Opvallend is het gebrek aan eenduidigheid in de beschrijving van de risicofactoren. Zo zijn de meetmethoden vaak niet goed vergelijkbaar. Zo kan men bijvoorbeeld voor een individu het gemiddelde van een aantal bloeddrukmetingen niet vergelijken met de laagste of hoogste waarde van een aantal bloeddrukmetingen. Voor de bloeddrukmeting is niet altijd dezelfde apparatuur gebruikt. En voor de cholesterolmeting is niet altijd dezelfde analyse-techniek gebruikt. Tevens zijn de data moeilijk vergelijkbaar door het gebruik van verschillende afkappunten om de meetwaarden in categorieën te rubriceren.

\section{(iv) CHZ-incidenties}

Er zijn drie projecten waarin incidenties van $\mathrm{CHZ}$ gemeten zijn, gerelateerd aan de prevalenties van de risicofactoren (Zutphen-studie, KRIS-follow-up-studie, Zeist-project). Door de kleine populatie-omvang of door de korte follow-up duur is de omvang van de incidentie-aantallen erg klein. De verschillende ziekte-manifestaties staan in de tabel vermeld, evenals de score op de omschrijving van de diagnostische criteria en de registratie-methodiek.

\section{Keuze bruikbare projecten}

Voor het sigaretten roken zijn de prevalenties het best gedocumenteerd. Naast de informatie uit de bovenstaande projecten, is dit vooral te danken aan de publikaties van Van Reek (1983 en 1984) en de Stichting Volksgezondheid en Roken (1985).

Informatie over prevalenties van hypercholesterolaemie en hypertensie is moeilijker te traceren. De bevindingen van de diverse onderzoeksprojecten laten zich heel moeilijk combineren. Voor de prevalentie van hypercholesterolaemie lijken de EPOZ-studie, het COPIH-project en het Peilstations-project het meest bruikbaar. Voor de prevalentie van hypertensie zijn dat eveneens de EPOZ-studie, het COPIH-project en het Peilstations-project, maar ook de Lelystad-studie. Deze 
projecten scoren hoog als het om de representativiteit van de onderzoekspopulatie gaat, en zijn van recente datum.

Bij het grofweg vergelijken van de data van de verschillende projecten valt het op dat in de COPIH-populatie hogere cholesterol-waarden gemeten zijn dan in de EPOZ-populatie en veél hoger dan in de Peilstations-populatie. Een verklaring voor dit gegeven hebben wij niet kunnen achterhalen.

Voor de diastolische bloeddruk geldt ongeveer hetzelfde. Weer geeft de COPIHpopulatie de hoogste tensies, gevolgd door de EPOZ-populatie en de Peilstationspopulatie. Voor de bloeddruk volgens de WHO-definitie (combinatie van diastolische en systolische bloeddruk) komen de tensies van de EPOZ-populatie en de Lelystad-populatie redelijk goed overeen, zeker voor de subpopulatie beneden de 50 jaar, en deze zijn opnieuw beduidend lager dan die van de COPIH-populatie. Opmerkelijk is dat de frequentie van de 'borderline' bloeddrukwaarden van de mannen van EPOZ boven de 50 jaar hoger is dan die van de mannen van COPIH. Dit geldt nog sterker voor de groep vrouwen van EPOZ boven de 50 jaar. Zowel het aantal vrouwen met 'borderline', als ook het aantal vrouwen met verhoogde tensiewaarden is hoger of gelijk aan de waarden van de COPIH-vrouwen boven de 50 jaar.

Er is met betrekking tot de trend in de prevalenties van de drie CHZ-risicofactoren de volgende keuzen gemaakt.

\section{(i) Trend Cholesterol}

Wij nemen aan dat de trend in het verleden een lichte daling in het serumcholesterolgehalte vertoont. Deze aanname is gebaseerd op gegevens uit het COPIHproject (Jonkers e.a., 1981, 1982), het RIFOH (Kromhout e.a., 1987) en het Peilstationsproject (Kromhout e.a., 1987). In de leeftijdsgroep 40-44 jaar voor mannen bedraagt de geschatte verdeling begin zeventiger jaren $(65 \%, 30 \%, 5 \%)$ tegenover $(75 \%, 23 \%, 2 \%)$ eind jaren tachtig.

De cholesteroltrend in het verleden kan niet met voldoende betrouwbare gegevens onderbouwd worden (vgl. Verschuren e.a., 1992). Wij houden de huidige verdeling van de bevolking over de drie cholesterolniveau's voor de toekomst constant. In de tabel I.1 wordt de huidige verdeling van de drie cholesterolniveau's naar leeftijd en geslacht weergegeven. De gegevens zijn hierbij gebaseerd op het Peilstationsproject.

We gaan met betrekking tot cholesterol dus niet uit van een autonome trend. Door twee oorzaken kan in ons model het toekomstige risicoprofiel met betrekking tot cholesterol zich wijzigen. Dit betreft in de eerste plaats preventie programma's gericht op het geven van dieetvoorschriften en/of op het toedienen van cholesterolverlagende middelen aan personen uit risicogroepen. De tweede oorzaak betreft de leeftijdsopbouw van de Nederlandse bevolking. Daar het choles- 
terolniveau gemiddeld licht stijgt met de jaren, zal een bevolking bestaande uit meer ouderen een ongunstiger risicoprofiel hebben.

\section{(ii) Trend Bloeddruk}

De bloeddruktrend uit het verleden laat een ambivalent beeld zien. De meeste studies vertonen een licht dalende trend. Dit beeld gaat op zowel voor mannen als vrouwen. Wij hebben de trend gebaseerd op de resultaten van COPIH (Jonkers e.a., 1981, 1982), KRIS (Sturmans e.a., 1977, Appels e.a., 1988), Peilstationsproject (Kromhout e.a., 1987) en PreTensie (Relyveld, 1989). Een aanzienlijk groter gedeelte van de bevolking heeft bijvoorbeeld in de studies uit begin zeventiger jaren (COPIH, KRIS) een bloeddruk > 95 mmHG dan in de meer recente studies.

Wij veronderstellen dat de huidige verdeling van de bevolking naar de drie bloeddrukniveau's voor de toekomst constant blijft. In de tabel 1.3 wordt de huidige verdeling weergegeven. Hierbij zijn we uitgegaan van de gegevens uit het Peilstationsproject en de PreTensie-studie. Onze veronderstelling impliceert dat er geen autonome trend met betrekking tot hypertensie aanwezig is. Wel kan in het model het vororkomen van hypertensie onder de bevolking veranderen op basis van gezondheidsbevorderende preventie programma's of op basis van gerichte toediening van anti-hypertensiva. Evenals het geval bij cholesterol, zal als gevolg van de vergrijzing de relatieve aanwezigheid van de risicofactor hypertensie toenemen onder de Nederlandse bevolking.

\section{(iii) Trend Roken}

Het percentage rokers bij mannen is van $90 \%$ in 1958 afgenomen tot $37 \%$ in 1989. Bij vrouwen nam het percentage rokers eerst toe van $29 \%$ in 1958 tot $42 \%$ in 1970. Na 1970 is het gedaald tot 33\% in 1989. Voor 1990 vertonen deze percentages bij mannen een licht stijgende lijn die zich in 1991 en 1992 gestabiliseerd heeft op $34 \%$. Het percentage rokers bij vrouwen heeft zich voor de periode 1990-1992 gestabiliseerd op 30.31\% (privé communicatie, Stichting Volksgezondheid en Roken). In de tabel I.4 is de verdeling van de rookprevalenties naar geslacht weergegeven. De gegevens zijn overgenomen van de Stichting Volksgezondheid en Roken (Baan, 1989).

De afgelopen 5 jaar zijn veel mensen gestopt met roken. Echter dachten we twee jaar geleden nog dat het gerechtvaardigd was van een dalende trend van $1 \%$ per jaar van het aantal rokers uit te gaan, nu is het zo dat eerder een stijgende trend voor de komende jaren verwacht kan worden. We hebben er voor gekozen met betrekking tot het roken een constant niveau aan te houden.

Concluderend is er in de Nederlandse literatuur alleen voor roken een trend gedocumenteerd. Wel zijn er gegevens beschikbaar met betrekking tot het serum- 
cholestrolgehalte en het bloeddrukniveau. Het zal waarschijnlijk nog een aantal jaren duren voordat uit deze gegevens cholesterol- en bloeddruktrends kunnen worden afgeleid.

In het algemeen valt over een langere tijdperiode moeilijk van "autonome" trends te spreken. Vaak gaat het om golfbewegingen die al dan niet bewust beïnvloed worden door preventie programma's. Om dit probleem te ondervangen kan in het model apart voor mannen en vrouwen een trend in de risicofactoren aangegeven worden.

In de tabellen I.2-I.4 is voor ieder van de drie risicofactoren uitgewerkt hoe de leeftijdsafhankelijke verdeling naar geslacht over de Nederlandse bevolking eruit ziet.

\begin{tabular}{|l|r|r|r|r|r|r|r|r|r|}
\hline Mrnmen & $30-34$ & $35-39$ & $40-44$ & $45-49$ & $50-54$ & $55-59$ & $60-64$ & $65-69$ & 270 \\
\hline$<6,5 \mathrm{mmol} /$ & 90 & 80 & 75 & 70 & 65 & 60 & 60 & 60 & 60 \\
\hline $6,5-8,0 \mathrm{mmo} / \mathrm{m}$ & 9 & 19 & 23 & 27 & 30 & 30 & 30 & 30 & 30 \\
\hline$>8,0 \mathrm{mmol} /$ & 1 & 2 & 2 & 3 & 5 & 10 & 10 & 10 & 10 \\
\hline
\end{tabular}

\begin{tabular}{|l|r|r|r|r|r|r|r|r|r|}
\hline Vrouwen & $30-34$ & $35-39$ & $40-44$ & $45-49$ & $50-54$ & $55-59$ & $60-64$ & $65-69$ & 270 \\
\hline$<6,5 \mathrm{mmoh}$ & 93 & 90 & 87 & 80 & 60 & 60 & 60 & 60 & 60 \\
\hline $6,5-8,0 \mathrm{mmoh}$ & 6 & 9 & 11 & 18 & 25 & 30 & 30 & 30 & 30 \\
\hline$>8,0 \mathrm{mmol}$ & 1 & 1 & 2 & 3 & 5 & 10 & 10 & 10 & 10 \\
\hline
\end{tabular}

Tabel I.2

Verdeling van mannen en vrouwen over de drie cholesterol niveau groepen per leeftijdsklasse in percentages, zoals gebruikt in ons model 


\begin{tabular}{|l|r|r|r|r|r|r|r|r|r|}
\hline Mannen & $30-34$ & $35-39$ & $40-44$ & $45-49$ & $50-54$ & $55-59$ & $60-64$ & $65-69$ & 270 \\
\hline$<90 \mathrm{mmHg}$ & 93.5 & 91.6 & 89.6 & 87.5 & 84.8 & 82.1 & 79.0 & 76.0 & 71.5 \\
\hline $90-95 \mathrm{mmHg}$ & 4.4 & 5.4 & 6.2 & 7.0 & 8.3 & 9.5 & 11.0 & 12.3 & 13.5 \\
\hline$>95 \mathrm{mmHg}$ & 2.1 & 3.0 & 4.2 & 5.5 & 6.9 & 8.4 & 10.0 & 11.7 & 15.0 \\
\hline
\end{tabular}

\begin{tabular}{|l|r|r|r|r|r|r|r|r|r|}
\hline Vrouwen & $30-34$ & $35-39$ & $40-44$ & $45-49$ & $50-54$ & $55-59$ & $60-64$ & $65-69$ & $\geq 70$ \\
\hline$<90 \mathrm{mmHg}$ & 93.4 & 91.7 & 90.0 & 87.7 & 84.6 & 81.0 & 77.8 & 74.7 & 70.2 \\
\hline $90-95 \mathrm{mmHg}$ & 5.5 & 6.3 & 7.0 & 8.2 & 9.4 & 11.0 & 12.2 & 13.3 & 148 \\
\hline$>95 \mathrm{mmHg}$ & 1.1 & 2.0 & 3.0 & 4.1 & 6.0 & 8.0 & 10.0 & 12.0 & 15.0 \\
\hline
\end{tabular}

Tabel I.3

Verdeling van mannen en vrouwen over de drie hypertensie niveau groepea per leeftijdsklasse in percentages, zoals gebruikt in ons model

\begin{tabular}{|c|c|c|c|c|c|c|c|c|c|c|c|}
\hline joar & '58 & '63 & '67 & '70 & '75 & 79 & '81 & '82 & '83 & 84 & 89 \\
\hline \multicolumn{12}{|c|}{ mannen } \\
\hline $15-19$ & - & - & 58 & 55 & 46 & 29 & 27 & 18 & 23 & 17 & 13 \\
\hline $20-34$ & 91 & 78 & 79 & 77 & 68 & 56 & 49 & 45 & 46 & 48 & 40 \\
\hline $35-49$ & 91 & 85 & 80 & 77 & 69 & 58 & 50 & 44 & 50 & 48 & 40 \\
\hline $50-64$ & 89 & 81 & 82 & 78 & 68 & 61 & 51 & 45 & 47 & 49 & 43 \\
\hline $65+$ & 88 & 76 & 83 & 74 & 66 & 47 & 51 & 43 & 41 & 43 & 39 \\
\hline $15-65+$ & 90 & 82 & 78 & 75 & 66 & 52 & 47 & 41 & 44 & 44 & 37 \\
\hline \multicolumn{12}{|c|}{ vrouwen } \\
\hline $15-19$ & - & - & 57 & 57 & 48 & 39 & 30 & 27 & 28 & 24 & 21 \\
\hline $20-34$ & 46 & 45 & 58 & 57 & 58 & 52 & 48 & 45 & 48 & 44 & 39 \\
\hline $35-49$ & 32 & 38 & 46 & 48 & 47 & 40 & 39 & 36 & 39 & 36 & 32 \\
\hline $50-64$ & 18 & 20 & 26 & 27 & 29 & 30 & 28 & 27 & 25 & 29 & 28 \\
\hline $65+$ & 5 & 3 & 13 & 13 & 12 & 13 & 13 & 13 & 12 & 12 & 12 \\
\hline $15-65+$ & 29 & 32 & 42 & 42 & 40 & 38 & 36 & 33 & 35 & 33 & 29 \\
\hline totanl & 60 & 57 & 60 & 59 & 53 & 45 & 41 & 37 & 40 & 39 & 33 \\
\hline
\end{tabular}

Tabel I.4

Roken in Nederland (1958-1989): Percentage rokers per leeftijdsgroep naar geslacht 
Het v66rkomen van de verschillende risicofactoren is hierbij onafhankelijk van elkaar verondersteld. De afhankelijkheid van risicofactoren houdt in dat de risicofactorcombinaties niet gelijk verdeeld zijn over alle deelgroepen in de gezonde bevolking. Het belang hiervan is dat risicofactoren met betrekking tot de kans op CHZ een multiplicatief effect op elkaar hebben (Stalenhoef, 1989/2, TunstallPedoe, 1989). Het is onduidelijk in hoeverre er gesproken kan worden van dergelijke afhankelijkheden in de verdeling van de bevolking over de risicofactoren. In het model is de mogelijkheid ingebouwd om zelf correlatiecoëfficiënten tussen risicofactoren aan te brengen.

Twee opmerkingen willen we in dit verband nog plaatsen.

(a) We zijn in ons model uitgegaan van de "marginale" verdelingen van de risicofactoren. We bedoelen hiermee de verdelingen zoals weergegeven in de bovenstaande tabellen I.2 en I.4. Het gevolg is dat niet alle correlatiecoëfficiënten tussen -1 (geen correlatie) en +1 (hoge correlatie) kunnen optreden. Neem als extreem voorbeeld dat alleen mannen roken en alleen vrouwen een verhoogd serumcholesterol hebben, dan zal steeds de correlatie tussen deze risicofactoren 0 (geen informatie) zijn. De correlatie is in dit voorbeeld dus volledig bepaald door de marginale verdelingen. In de CHZ-Simulator kan weliswaar elk getal tussen -1 en +1 voor de correlatie ingevuld worden, maar intern in het programma wordt dit evenredig verwerkt naar de maximaal haalbare correlatie.

(b) Het effect op de $\mathrm{CHZ}$-incidenties kan bij correlaties op individueel niveau aanzienlijk zijn. Op bevolkingsniveau echter wordt het effect "uitgemiddeld". Bij hoge correlatie zijn er meer mensen met een hoog risico, echter ook meer met een laag risico, zodat op bevolkingsniveau de totale $\mathrm{CHZ}$ incidentie zich niet veel zal wijzigen.

De preventieprogramma's grijpen aan op de risicogroepen. Voor de berekening van de incidenties van de $\mathrm{CHZ}$-manifestaties is gebruikt gemaakt van de logistische regressies uit de Framingham Heart Study. Hiervoor is het vereist om het gemiddelde risicofactorniveau per leeftijdscategorie te berekenen. Er is eerst een schatting gemaakt van de totale verdeling van het serumcholesterolgehalte volgens de drie categorieën $<6,5 \mathrm{mmol} / \mathrm{h}, 6,5-8,0 \mathrm{mmol} / \mathrm{l}$, $>8,0 \mathrm{mmol} / \mathrm{l}$ over de $\mathrm{Ne}$ derlandse bevolking. In het computerprogramma is deze verdeling verder verfijnd. Door aan te nemen dat deze verdeling bij benadering een scheef normale verdeling volgt, kan op basis van de aantallen personen in de drie bovenstaande categerieën het gemiddelde en de variantie van de normale verdeling geschat 
worden. Met behulp van deze geschatte verdeling kunnen dan de gemiddelden berekend worden over de drie categorieën.

Deze zelfde methode is eveneens toegepast bij de verdelingsfuncties van de diastolische bloeddruk. De resultaten zijn te vinden in de figuren I.1 en I.2.
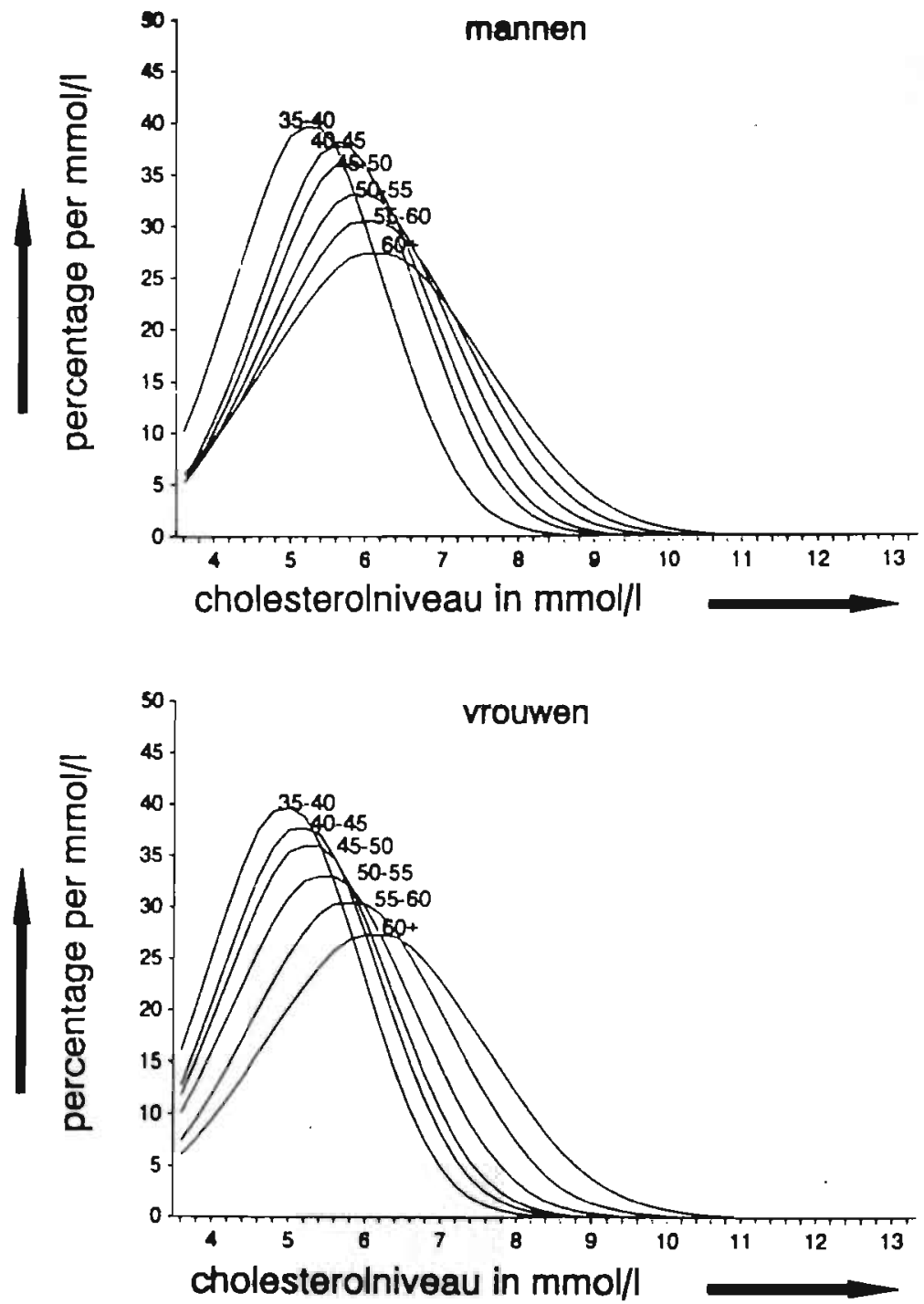

Figuur I.1

Benadering verdelingsfunctie voor Nederlandse bevolking met betrekking tot serumcholesterolgehalte 

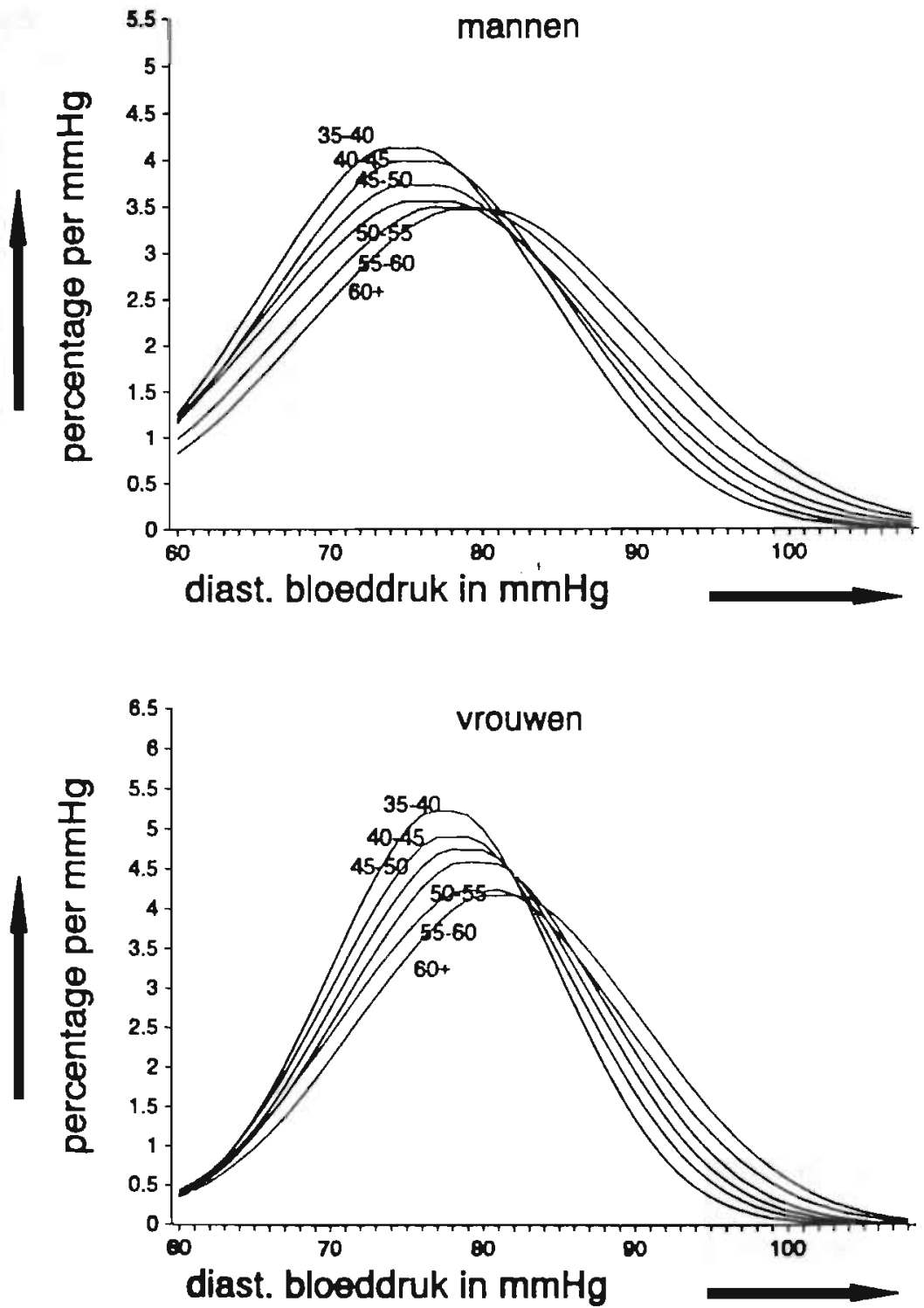

Figuur $\mathbf{2} 2$

Benadering verdelingsfunctie voor Nederlandse bevolking met betrekking tot diastolische bloeddruk 


\section{I.3 Incidenties Gezonde Bevolking}

In het model worden de volgende vier CHZ-manifestatievormen beschouwd: plotse hartdood (SD), acuut myocard infarct (AMI), instabiele angina pectoris (UAP), en angina pectoris (AP). De incidentie van het acute myocard infarct (AMI) van de diverse risicogroepen in de gezonde bevolking dient als uitgangspunt voor de bepaling van incidenties van de UAP- en AP-manifestatievormen.

De incidenties van UAP en AP verhouden zich tot de initiële AMI-incidentie via een veronderstelde evenredigheid. We hebben op basis van door Hartunian e.a. (1981) gepubliceerde data van de Framingham Heart Study de volgende evenredigheidsverhouding tussen de verschillende $\mathrm{CHZ}$-manifestatievormen aangenomen:

a) de initiële AMI-incidentie (AMI+SD) is ongeveer gelijk aan de initiële AP-incidentie (AP1-2+AP3-4),

b) de initiële UAP-incidentie bedraagt $30-35 \%$ van zowel de initiële AMIincidentie als de initiële AP-incidentie.

De gemeenschappelijke etiologie van de manifestatievormen is hierbij als argument genomen. Het is algemeen erkend dat de CHZ-manifestatievormen uitingen zijn van hetzelfde pathofysiologisch mechanisme met betrekking tot de atherosclerosevorming. De drie acute manifestatievormen SD, AMI, en UAP worden gekenmerkt door overeenkomstige initiële acute veranderingen van het endotheel van de kransslagaders.

De genoemde gemeenschappelijke etiologie vormt de onderbouwing van de veronderstelling die we gemaakt hebben, dat in ons model de jaarlijkse incidenties van de vier manifestatievormen van jaar tot jaar dezelfde evenredigheid vertonen voor iedere risicogroep. (Dit houdt dus onder andere geslachts- en leeftijdsafhankelijkheid in). In de praktijk zal van jaar tot jaar zo'n vaste evenredigheid niet helemaal opgaan. De historische incidentie cijfers wekken de indruk dat het aandeel van het acuut myocard infarct in de totale incidentie van coronaire hartziekten daalt (STG, 1989). Het veronderstelde evenredige verband tussen de jaarlijkse initiële incidenties van de verschillende CHZ-manifestatievormen valt moeilijk te verifiëren met behulp van de bestaande registraties op dit terrein. De registratie van de jaarlijkse nieuwe gevallen van angina pectoris (AP) en instabiele angina pectoris (UAP) is zeer onvolledig (STG, 1989).

De CHZ-incidentie neemt gegeven een bepaald niveau van de risicofactoren toe met de stijging van de leeftijd. De verdeling man/vrouw zal hierbij weinig veranderen. De mannen in de gezonde bevolking hebben in de leeftijd tot ca. 60 jarr 
een hogere $\mathrm{CHZ}$-kans dan vrouwen. De $\mathrm{CHZ}$-incidentie bij vrouwen neemt na de leeftijd van 60 jaar toe.

De evenredigheidscoëfficiënten die voor iedere risicogroep de jaarlijkse incidentie bepaald uit de incidenties van het acute myocard infarct staan in tabel I.5. In feite zijn deze evenredigheidscoëfficiënten geslachts- en leeftijdsafhankelijk. De in tabel I.5 gepresenteerde gegevens betreffen de gemiddeldes op bevolkingsniveau, zoals in overeenstemming met de SIG-gegevens uit 1988 (zie ook volgende paragraaf I.4). Een tijdtrend in de bevolkingsopbouw (bijvoorbeeld de komende "dubbele" vergrijzing) kan nagebootst worden door deze evenredigheidscoëfficiënten tijdsafhankelijk te maken.

Vanuit de gezonde bevolking :

\begin{tabular}{|r|r|r|r|r|r|}
\hline AMI & UAP & AP3-4 & AP1-2 & SD & FMI-buiten ZH \\
\hline 1 & 0.38 & 0.166 & 1.052 & 0.319 & 0.161 \\
\hline Vanuit de CHZ-bevolking: & \multicolumn{7}{|l|}{} \\
\hline AMI & UAP & AP3-4 & AP1-2 & SD & FMI-buiten ZH \\
\hline 1 & 0.378 & 0.804 & 0.0 & 0.261 & 0.251 \\
\hline
\end{tabular}

Tabel I.5

Evenredigheidscoëfficiënten voor de incidenties van de verschillende $\mathrm{CHZ}$ manifestatievormen, zoals in het model gebruikt

In de literatuur wordt een constante geslachtsspecifieke evenredigheidsverhouding per leeftijdsgroep aangegeven tussen de verschillende $\mathrm{CHZ}$-manifestatievormen (vgl. Hartunian e.a., 1981, Weinstein e.a., 1987). Deze geslachtsspecifieke evenredigheidsverhoudingen per leeftijdsgroep zijn in de door ons berekende incidenties gebruikt als ijkpunt. De "man:vrouw"-geslachtsspecifieke CHZ-incidenties uit Gezond respectievelijk uit de $\mathrm{CHZ}$-bevolking zijn in het model gebruikt op basis van de verhouding 2:1 resp. 3:1 (STG, 1989, SIG, 1992, Hartunian e.a., 1981). Andere geslachtsspecifieke ijkpunten betreffen het aantal opnames, operaties en sterften (SIG, 1992, CBS, 1991).

De initiële AMI-incidenties hebben we afgeleid van twee databronnen:

1) de opnamegegevens van het SIG (SIG, 1992), en

2) de Framingham Heart Study (Kannel e.a., 1987). 
Het totaal aantal eerste opnames met AMI als hoofddiagnose in 1988 bedraag 27.387 (SIG, 1992). Het aantal eerste opnames betreft zowel initiële als recurrente opnames. Op basis van door Hartunian e.a. (1981) gepubliceerde gegevens over de FHS hebben we de initiële AMI-opnames vastgesteld op 14.700, waarvan 12.950 klinische AMI-opname en 1750 AMI-thuis (Fracheboud, 1987, STG, 1989).

Het aantal initiële SD en FMI1 incidenties bedraagt 4.500 (STG, 1989), zijnde de totale sterfte $<24$ uur buiten het ziekenhuis. Het onderliggend criterium met betrekking tot SD en FMI1 is een AMI die er aan voorafgaat (Schatzkin e.a., 1984). De (totale) initiële AMI-incidentie bedraagt 19.200 (14.700+4.500).

De regressiecoëfficiënten zijn in de Framingham Heart Study (Kannel e.a., 1987) afgeleid uit de empirisch waargenomen aantallen personen met $\mathrm{CHZ}$ in de diverse risicogroepen. De initiële AMI-incidenties die met behulp van deze regressiecoëfficiënten berekend worden, zijn leeftijds- en geslachtsspecifiek en geijkt op basis van de SIG-opnames 1986, 1988, en 1990 met betrekking tot het aantal initiële AMI-opnames. In de volgende paragraaf I.4 lichten wij toe dat de som van de SIG-opnames bestaat uit personen die voor de eerste keer een $\mathrm{CHZ}$-manifestatie meemaken (initiële opnames), personen die in hetzelfde jaar voor de tweede keer worden opgenomen (recurrente opnames), en personen die vroeger reeds een CHZ-manifestatie gehad hebben maar dit jaar voor de eerste keer worden opgenomen (secundaire opnames). Zodoende kunnen we de opnames indelen in twee typen opnames: eerste opnames uit de gezonde bevolking (initiële opnames), danwel uit de CHZ-bevolking (secundaire opnames) en tweede opnames die in hetzelfde jaar van de eerste opname plaatsvinden (recurrente opnames).

De coëfficiënt $\beta_{0}$ (intercept) is dus geschat met behulp van de historische gegevens betreffende het aantal myocard infarcten. In onderstaande figuur I.3 zijn de modeluitkomsten betreffende het totale aantal opgenomen acute myocard infarcten en de historisch bekende gegevens met elkaar vergeleken. 


\section{Opnames Acuut Myocardinfarct}

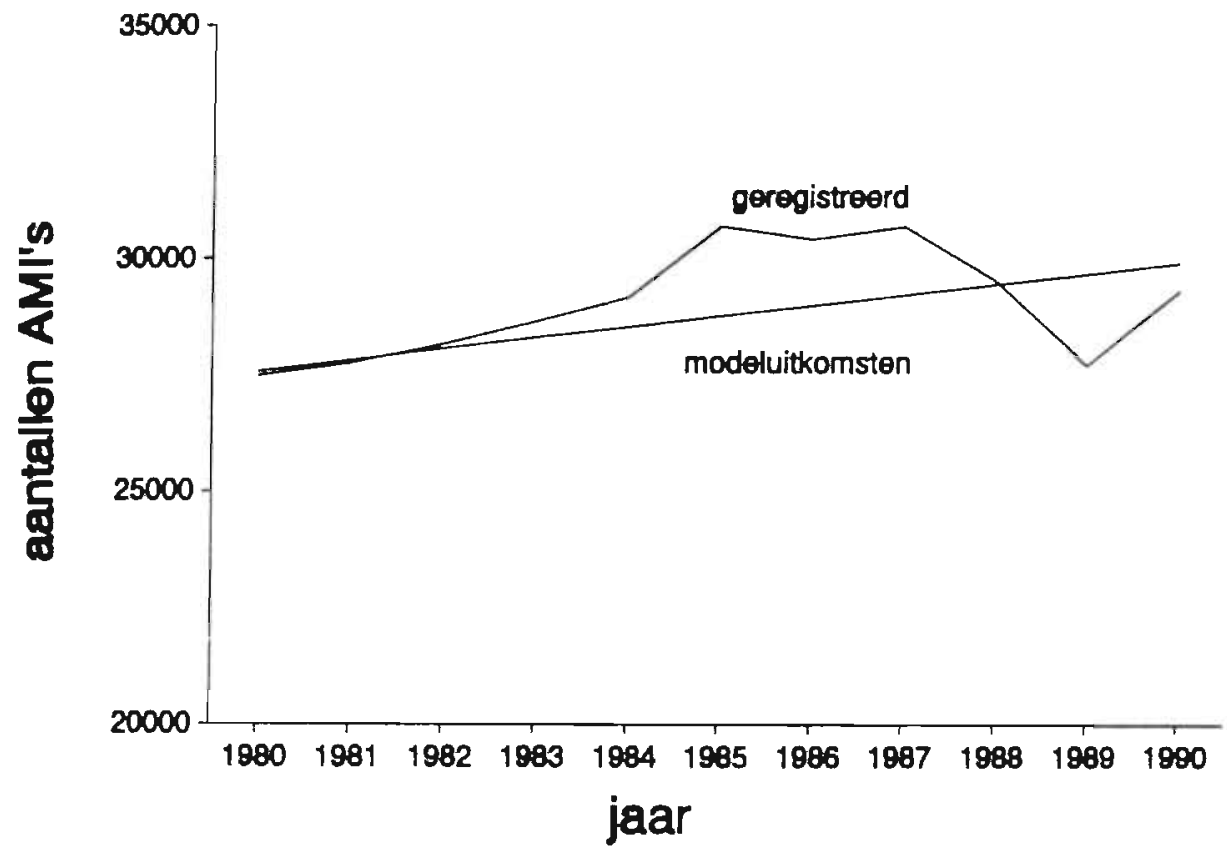

Figuur [.3

Acute Myocard infarcten, gemeten en voorspeld

De toepassing van regressiecoëfficiënten uit de FHS houdt in dat we de relatieve risico's van de onderscheiden risicofactoren gelijkstellen voor Nederland en voor Framingham. Deze veronderstelling is van belang voor de doorrekening van de effecten van de preventie programma's op de CHZ-incidenties.

De initiële AP-incidentie in het model bedraagt 19.100. Dit aantal is als volgt benaderd.

De SIG (1992) vermeldt met betrekking tot 198816.506 opnames onder ICDcode 414 (coronair atherosclerose). We hebben deze code geïnterpreteerd als AP1-2. Het is bekend dat na verloop van een aantal jaren de angineuze klachten in de meeste gevallen zich geleidelijk aan verergeren tot AP3-4, waarna ziekenhuisopname is geindiceerd. In de literatuur varieert dit opnamepercentage van $5 \%$ tot $17 \%$ (Hartunian e.a., 1981, Cutter, 1982, Laird-Meeter, 1988/2, Gezondheidsraad, 1984/18). Op basis van privé-communicatie (Janssen, 1991) hebben we dit percentage gesteld op ca. $11,5 \%$. Dit betekent dat het interval waarin de AP-klachten zich kunnen verergeren ca. 7-8 jaar duurt, hetgeen overeenkomt met ca. 2.600 initiële AP3-4 opnames per jaar. Het totale aantal initiële AP-opnames 
(AP1-2+AP3-4) bedraagt zodoende $19.100(16.500+2.600)$ (zie ook de paragraaf behandelingstrajecten uit bijlage II).

In tabel I.6 is een overzicht gegeven van de initiële CHZ-incidenties in 1988.

\begin{tabular}{|l|r|}
\hline AMI + SD/FMI1 & 19.200 \\
AP & 19.100 \\
UAP & 6.000 \\
\hline CHZ & 44.300 \\
\hline
\end{tabular}

Tabel I.6

Initiële $\mathrm{CHZ}$-incidenties in 1988 , zoals in het model gebruikt

\section{I.4 Incidenties CHZ-Bevolking}

In het model heeft iedere CHZ-persoon de kans op maximaal twee incidenties per jaar. Wij onderscheiden twee tijdfasen $<1$ jaar en $\geq 1$ jaar (zie bijlage II). Analoog aan de twee tijdfasen zijn er vier typen CHZ-incidenties, te weten:

a) primaire - of initiële incidentie aan het begin van een jaar,

b) recurrente incidentie een half jaar na de initiële incidentie,

c) secundaire incidentie aan het begin van een (volgend) jaar,

d) recurrente incidentie een half jaar na de secundaire incidentie.

De initiële incidentie vindt plaats in de gezonde bevolking. De secundaire incidentie komt voort uit de CHZ-bevolking. De kans op het ontstaan van een nieuwe stenose kan zich volgens de literatuur uitstrekken over een periode die varieert van 1-20 jaar of langer (vgl. Weinstein e.a., 1982). Wij beschouwen het aantal jaren in de tijdfase $\geq 1$ jaar als ex́n geheel.

De recurrente incidenties vinden plaats in hetzelfde jaar van de vorige CHZ-incidentie. Ze worden gevoed uit de groep van patiënten die na de eerste opname uit het ziekenhuis ontslagen zijn. Zodoende gaat een recurrente incidentie aan een 2de-opname vooraf. Iedere CHZ-patiënt kan maximaal 2 maal per jaar worden opgenomen in een ziekenhuis. We veronderstellen dat de tijdsperiode tussen de eerste opname en de tweede opname gemiddeld een half jaar bedraagt (zie ook de paragraaf behandelingstrajecten uit Bijlage II).

Een recurrente incidentie kan zich in de praktijk meerdere malen binnen hetzelfde jaar voordoen. Het aantal personen dat na elke recurrente incidentie nog in leven is neemt vanwege de slechte prognose sterk af. Er zijn weinig gegevens in 
de literatuur beschikbaar over het aantal personen dat voor de tweede of derde keer een recurrente incidentie binnen hetzelfde jaar krijgt. Wij zijn er daarom van uitgegaan dat een recurrentie incidentie zich maar eenmaal binnen hetzelfde jaar kan manifesteren.

De incidenties tijdens het CHZ-ziekteproces in 1988 zijn geijkt op SIG-gegevens die op 1988 betrekking hebben (SIG, 1992). In de volgende tabel I.7 zijn in dit verband de belangrijkste ijking gegevens met betrekking tot 1988 te vinden.

\begin{tabular}{|l|r|r|}
\hline ICD-code & \multicolumn{1}{|c|}{ SIG } & \multicolumn{1}{c|}{ Model } \\
\hline 410 (ac. myocard infarct) & 29.531 & 29.719 (AMI) \\
\hline 411 (ov.Subacut Isch.Hartz) & 11.098 & 11.100 (UAP) \\
\hline 412 (ood-myocard infarct) & 780 & 0 \\
\hline 413 (angina-pectoris) & 18.350 & 19.900 (AP3-4) \\
\hline 414 (ov.chron. Isch.Hartz) & 16.506 & 16.500 (AP1-2) \\
\hline
\end{tabular}

Tabel I.7

Vergelijking van de SIG-gegevens en de modeluitkomsten met betrekking tot totale opnames

Wij hebben de in tabel I.7 genoemde ICD-codes in het model als volgt gebruikt: ICD-code 410 - AMI; ICD-code 411 - UAP; ICD-code 413 - AP3-4; ICD-code 414 - AP1-2.

In het model zijn de opnames met ICD-code 412 (oud-MI) op nul gesteld. Wij hebben de oud-MI geïnterpreteerd als AP3-4. Het aantal ICD 413-opnames is hiervoor in de plaats verhoogd tot 19.900 . De ICD-code 410 betreft de AMI-opnames. Het aantal eerste opnames met AMI als hoofddiagnose in 1988 bedraagt 27.387 (SIG, 1992). Dit betekent dat er $(29.531-27.387 \Rightarrow) 2.144$ recurrente AMI-opnames geweest zijn. Op basis van een publikatie van Hoogendoorn (1990) zijn deze gegevens met betrekking tot 1988 in geringe mate aangepast, zoals weergegeven in tabel I.8.

\begin{tabular}{|l|r|}
\hline $\begin{array}{l}\text { eerste opname AMI } \\
\text { tweede oprame AMI }\end{array}$ & 27.027 \\
\hline Total & 2690 \\
\hline
\end{tabular}

Tabel I.8

Eerste en tweede opname AMI, zoals in het model gebruikt 
In deze publicatie geeft Hoogendoom ook gegevens over de AMI-sterfte, die zowel binnen als buiten het ziekenhuis optreedt. Vandaar dat we de "Hoogendoom cijfers" aangehouden hebben.

De SD/FMI1-sterfte bedraagt in 1988 voor de initiële AMI-incidenties 4.500 (STG, 1989). Via de SIG-gegevens uit 1988 (SIG, 1992), STG (1989) en Hoogendoorn (1990) hebben we een schatting gemaakt van de SD/FMIl-sterfte bij de secundaire AMI-incidentie (5.713) en bij de recurrente incidentie (3.130). De AMI-incidenties uit de CHZ-bevolking (secundaire incidenties) kunnen nu worden gevonden. Het resultaat van al deze overwegingen met betrekking tot 1988 is te vinden in tabel I.9.

\begin{tabular}{|l|r|r|r|r|}
\hline Type AMI & \multicolumn{1}{l|}{$\begin{array}{l}\text { Totale } \\
\text { incidenties }\end{array}$} & SDMMII & AMI-thais & AMI-0pnme \\
\hline $\begin{array}{l}\text { AMI-mcidentie nit } \\
\text { gezonde bevolking }\end{array}$ & 19.200 & 4.500 & 1.750 & 12.950 \\
\hline $\begin{array}{l}\text { AMI-inddentle uit } \\
\text { CHZ-bevollding }\end{array}$ & 19.790 & 5.713 & 0.00 & 14.077 \\
\hline Recurrente AMI (zelfde jaar) & 5.820 & 3.130 & 0.00 & 2.690 \\
\hline Totaal & 44.810 & 13.343 & 1.750 & 29.717 \\
\hline
\end{tabular}

Tabel I.9

AMI-incidenties, zoals in het model gebruikt

In tabel 1.10 worden de secundaire incidenties uit de CHZ-bevolking in 1988 gepresenteerd.

\begin{tabular}{|l|r|}
\hline AMI (opname) & 14.077 \\
SII + FMI1 & 5.713 \\
UAP & 3.610 \\
AP3-4 & 7.700 \\
\hline Totad & 31200 \\
\hline
\end{tabular}

Tabel I.10

Secundaire incidenties uit de CHZ-bevolking, zoals in het model gebruikt

Hierbij moet bedacht worden dat van de 5.713 AMI's uit tabel I.9 die leiden tot SD+FMI1 er 2.200 uit de CHF-bevolking afkomstig zijn (AMI/CHF). De optredende recurrentie na het le ontslag is afgeleid uit Berreklouw e.a. (1989). Na een CABG-behandeling zou dit 5-10\% bedragen en na een PTCA-behandeling 
bedraagt dit gemiddelde $30 \%$. In de volgende tabel 1.11 is te zien hoe we deze percentages met betrekking tot 1988 verdeeld hebben over de diverse combinaties.

\begin{tabular}{|l|r|r|r|r|}
\hline incidentie nit gezond & oud-AMI & oud-UAP & oud-AP3-4 & oud-AP1-2 \\
\hline oud-CABG & $\cdot 042$ & $\cdot 041$ & $\cdot 044$ & -040 \\
\hline oud-PTCA & $\cdot 387$ & $\cdot 265$ & $\cdot 277$ & $\cdot 332$ \\
\hline
\end{tabular}

\begin{tabular}{|l|r|r|r|c|}
\hline incidentie uit CHZ-bev. & ond-AMI & oud-UAP & oud-AP3-4 & oud-AP1-2 \\
\hline oud-CABG & .099 & .099 & .099 & - \\
\hline oud-PTCA & .306 & .40 & .40 & - \\
\hline
\end{tabular}

Tabel I.11

De recurrentiekansen na een operatie tijdens de eerste opname, zoals in het model gebruikt

De recurrentiekans na een MED-behandeling is afgeleid uit de recurrentie na een PTCA-behandeling en bedraagt gemiddeld $25 \%$.

We merken op dat in het model de gegevens uit de tabellen I.10 en I.11 communicerende vaten zijn. Des te meer recurrentie in hetzelfde jaar, des te minder incidentie uit de CHZ-bevolking en omgekeerd daar hun som vast ligt door de gegevens uit de tabellen I.6 en I.7. De volgende tabel I.12 (recurrente incidenties in hetzelfde jaar) is dan met betrekking tot 1988 ook niks anders dan tabel I.7 (totale opnames), gecombineerd met tabel I.9 (AMI-incidenties), verminderd met de som uit tabel I.6 (initiële incidenties) en tabel I.10 (secundaire incidenties).

\begin{tabular}{|l|r|}
\hline AMI(opname) & 2.690 \\
SD+FMII & 3.130 \\
AP3-4 & 1.490 \\
UAP & 9.600 \\
\hline Total & 16.910 \\
\hline
\end{tabular}

Tabel I.12

Recurrente manifestaties, zoals in het model gebruikt 


\section{I.5 CHZ en niet-CHZ sterfte}

De sterfte in 1988 in het model is als volgt opgebouwd:

1) Totale sterfte in de bevolking;

2) Niet-CHZ sterfte in CHZ-bevolking;

3) $\mathrm{CHZ}$-sterfte.

\section{Totale sterfte in de bevolking}

In tabel I.13 worden de kengetallen gepresenteerd met betrekking tot de totale sterfte in de bevolking in 1988, zoals wij deze in het model hebben toegepast.

\begin{tabular}{|c|c|c|c|}
\hline levensverwachthng & \multicolumn{3}{|c|}{ blj de geboorte } \\
\hline $\begin{array}{l}\text { gemiddeld } \\
\text { uitschaleling } \mathrm{CHZ} \\
\text { gegeven geen } \mathrm{CHZ} \\
\text { geven wel } \mathrm{CHZ}\end{array}$ & $\begin{array}{r}\text { Man } \\
73,7 \text { jaar } \\
76,81 \text { jaar } \\
73,12 \text { jaar } \\
75,57 \text { jaar }\end{array}$ & $\begin{array}{r}\text { Vrouw } \\
80,3 \text { Jaar } \\
81,74 \text { Jaar } \\
79,93 \text { jaar } \\
81,5 \text { jaar }\end{array}$ & $\begin{array}{l}\text { Beide } \\
76,9 \text { jor } \\
79,28 \text { jar } \\
76,90 \text { jar } \\
77,0 \text { jar }\end{array}$ \\
\hline
\end{tabular}

Tabel $\mathbf{1 . 1 3}$

Kengetallen levensverwachting bij de geboorte voor Nederlandse bevolking. zoals in het model gebruikt

De levensverwachting bij de geboorte voor de totale bevolking is geijkt op gegevens van het CBS met betrekking tot 1988 (CBS,1991).

Opvallend is de zogenaamde "Kuipers" paradox, namelijk dat de levensverwachting voor personen die overlijden aan $\mathrm{CHZ}$ (gegeven dat iemand $\mathrm{CHZ}$ krijgt) hoger is dan voor personen die overlijden aan niet- $\mathrm{CHZ}$ (gegeven dat iemand geen $\mathrm{CHZ}$ krijgt). Wij hebben met betrekking tot de Kuipers paradox een gevoeligheidsanalyse in het model doorgerekend. Daaruit bleek dat bij toename van de reductie aan overige sterfteoorzaken (niet-CHZ sterfte) de levensverwachting van personen die aan $\mathrm{CHZ}$ overlijden de algemene levensverwachting van de totale bevolking gaat naderen. De verklaring hiervoor ligt bij een stijging van de verwachte CHZ-sterftekans die hoger is dan de stijging van de levensverwachting "gegeven wel CHZ" in geval van een hogere niet-CHZ sterfte reductie.

We kunnen de "Kuipers" paradox illustreren aan de hand van het volgende voorbeeld. Het voorbeeld dat we hier gaan uitwerken betreft de invloed van de parameter "niet-CHZ-sterfte", waarmede we de sterfte aan niet-CHZ-doodsoorzaken bedoelen. Deze parameter grijpt aan op de niet-CHZ sterfte in zowel de gezonde bevolking als in de zieke ( $\mathrm{CHZ}$ ) bevolking van het model (zie hoofdstuk 3 ). In 
het basisscenario hebben we een sterftereductie van $7 \%$ per 10 jaar ingevoerd, gebaseerd op de CBS-trend met betrekking tot de periode 1983-1988. Deze reductie leidt tot een maximale schatting van een stijging van de levensverwachting van 1,5 jaar voor de komende 22 jaar. De levensverwachting die we op basis van deze "niet-CHZ-sterfte" parameter berekenen voor de periode 19882010 is hierbij geijkt op de CBS-middenvariant (CBS, 1992).

In tabel $\mathrm{I} .14$ is de invloed van onzekerheid in deze parameter weergegeven op de belangrijkste incidentiecijfers. We zouden tabel $\mathbf{I} .14$ kunnen vergelijken met de incidentiecijfers die berekend worden bij een sterftereductie "niet-CHZ sterfte" van $7 \%$.

\begin{tabular}{|c|c|c|c|}
\hline \multirow{2}{*}{$\begin{array}{l}\text { reductle } \\
\text { niet-CHZ-sterfte } \\
\text { per } 10 \text { jaar }\end{array}$} & \multicolumn{3}{|c|}{ Incidenties in 2010} \\
\hline & CHZ & AMI & SD \\
\hline $0 \%$ & 123.035 & $\mathbf{5 7 . 7 8 7}$ & 12.879 \\
\hline $5 \%$ & 126.384 & 59.502 & 13.284 \\
\hline $10 \%$ & 133.726 & 63.370 & 14.591 \\
\hline $15 \%$ & 138.044 & 65.580 & 15.204 \\
\hline $20 \%$ & 143.270 & 68.273 & 16.026 \\
\hline
\end{tabular}

Tabel 1.14

Invloed van de "Reductie niet-CHZ-sterfte" parameter op de verwachte $\mathrm{CHZ}$-incidenties in 2010

In figuur I.4 zijn de consequenties van deze variaties in de essentiële levensverwachtingskengetallen weergegeven.

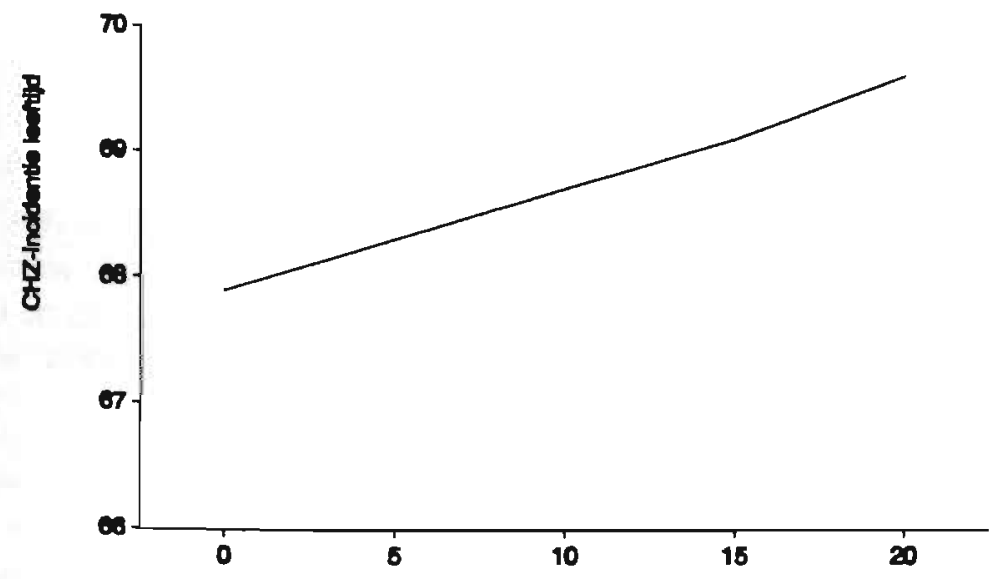




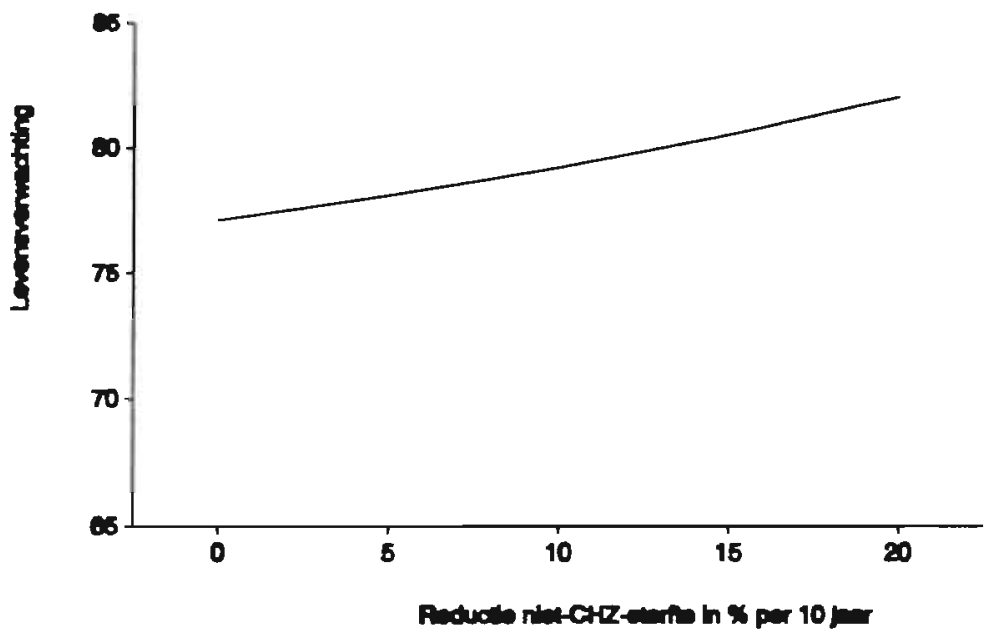

Figuur I.4

Invloed variatie in de parameter "Reductie niet-CHZ-sterfte op de karakteriscieke levensverwachtingskengetallen voor het jaar 2010 bij toepassing of de gebele Nederlandse bevolking

Uit figuur I.4 blijkt dat de levensverwachting in 2010 stijgt conform de CBS trend. Vergelijk hierbij toename van 2,1 jaar wanneer we de reductie instellen op $10 \%$. Het exponentiële gedrag van de levensverwachtingscurve is terug te voeren op een verschil in asymptotisch gedrag van de $\mathrm{CHZ}$ en niet-CHZ-sterft bij hogere leeftijden.

\section{Niet-CHZ sterfte in CHZ-bevolking}

We hebben voor de gemiddelde niet-CHZ sterfte in de $\mathrm{CHZ}$-bevolking een sterftepercentage van ca. $3 \%$ in 1988 gebruikt. Het percentage van 3\% wordt berekend over de populatie in de $\mathrm{CHZ}$-bevolking nadat de incidentie van $\mathrm{CHZ}$ en de incidentie van $\mathrm{CHF}$ is verminderd. Dit kan worden toegelicht aan de hand van de getallen die in het model zijn toegepast. De grootte van de $\mathrm{CHZ}$-bevolking in 1988 is door ons berekend op 398.500 personen. De CHZ-incidentie en de CHFincidentie uit de CHZ-bevolking in 1988 bedragen 28.900 respectievelijk 14.916 personen. Er resulteren ca. 355.000 personen in de CHZ-bevolking in 1988 waarvan de niet-CHZ sterfte uit 11.268 personen bestaat. 
We geven nu een toelichting op de berekening van de $3 \%$ niet-CHZ sterfte in de CHZ-bevolking.

In de algemene bevolking ligt het gemiddelde sterftepercentage in 1988 op ca. $1,8 \%$ per jaar, zoals blijkt uit tabel I.13. De berekeningen zijn gemaakt op basis van CBS-gegevens (1991).

\begin{tabular}{|c|c|c|c|}
\hline $\begin{array}{l}\text { leeftijds- } \\
\text { klassen }\end{array}$ & $\begin{array}{l}\text { aandeel } \\
\text { leeftuldsopbouw }\end{array}$ & sterfiequotiznt & genulddeld \\
\hline $\begin{array}{l}<40 \text { Jaar } \\
40-64 \text { Jaar } \\
65-79 \text { Jaar } \\
\geq 80 \text { Jagr }\end{array}$ & $\begin{array}{l}.285 \\
.443 \\
.173 \\
.049\end{array}$ & $\begin{array}{l}.00085 \\
.0056 \\
.0327 \\
.199\end{array}$ & $\begin{array}{l}.00024 \\
.00276 \\
.00566 \\
.00975\end{array}$ \\
\hline total & & & .0184 \\
\hline
\end{tabular}

Tabel 1.15

Gemiddelde sterftepercentages algemene bevolbing

De leeftijdsopbouw in de CHZ-bevolking is ouder dan die in de algemene bevolking. Hieromtrent hebben wij veronderstelt dat $2 / 3$ van de populatie in de $\mathrm{CHZ}$ bevolking ouder is dan 65 jaar. De CHZ-bevolking jonger dan 40 jaar zal nihil zijn. Dat betekent dat ca. $1 / 3$ van de $\mathrm{CHZ}$-bevolking een leeftijd heeft die ligt tussen de 40 en 65 jaar. De gewogen toepassing van deze leeftijdsverdeling op de sterftequotiënten in de algemene bevolking resulteert in een sterftepercentage van ca. $3 \%$.

\section{CHZ-sterfte}

De CHZ-sterfte is onderverdeeld in de CHZ-sterfte buiten het ziekenhuis en de CHZ-sterfte binnen het ziekenhuis (ziekenhuissterfte). We hebben vijf typen CHZ-sterfte gedefinieerd: 1) DSD ("na AMI"), 2) FMI1, 3) FMI2, 4) UAPoperatiesterfte, en 5) AP-operatiesterfte. De sterftegegevens met betrekking tot 1988 zijn verkregen uit publicaties van Hoogendoorn (1990), STG (1989), SIG (1992), CBS (1991) en de gangbare literatuur over operatiesterftepercentages.

De vermelde CHZ-sterftegegevens betreffen de sterfte waarbij $\mathrm{CHZ}$ de belangrijkste onderliggende doodsoorzaak (hoofddiagnose) is. De sterfte met $\mathrm{CHZ}$ als nevendiagnose wordt in de CBS-doodsoorzaakstatistieken geregistreerd als sterfte tengevolge van een andere ziekte. Een uitzondering geldt met betrekking tot de $\mathrm{CHZ}$-operatiesterfte. In het geval van $\mathrm{CHZ}$-operatiesterfte wordt deze sterfte beschouwd als de sterfte ten gevolge van $\mathrm{CHZ}$. 
De DSD en FMI1 worden in het model gerekend tot de CHZ-sterfte buiten het ziekenhuis. Deze zijn met betrekking tot 1988 in tabel I.16 weergegeven.

\begin{tabular}{|l|r|}
\hline Sterfte-oorzaak & model \\
\hline DSD & 10.040 personen \\
FMI1 & 3.303 personen \\
\hline Totaal & 13.343 personen \\
\hline
\end{tabular}

Tabel 1.16

CHZ-sterfte buiten het ziekenhuis, zoals in het model gebruikt

Wij veronderstellen dat er geen SD-overlevenden zijn in 1988. Er zijn volgens Hoogendoorn (1990) in 198813.343 personen elders (buiten het ziekenhuis) overleden.

De DSD en FMI1 worden in een publicatie van de STG (1989) geschat op 9.400 respectievelijk 3.400 personen. De gegevens uit de genoemde STG-publicatie hebben betrekking op 1985. De FMI1 is hierbij aangeduid als de sterfte bij aankomst in het ziekenhuis of direct erna overleden op de EHBO van het ziekenhuis (niet geregistreerd als ziekenhuisopname). In de STG-publicatie (1989) wordt de DSD van 9.400 personen niet duidelijk aangegeven. Wij hebben de DSD in die publicatie geïnterpreteerd als de totaalsom van 1) de sterfte overleden vór komst van de huisarts $(4.400), 2$ ) de sterfte thuis $(500)$, en 3 ) de sterfte acute hartdood (4.500).

De FMI2 bestaat uit de AMI-operatiemortaliteit (OM) en de sterfte ten gevolge van een fataal AMI. De FMI2-opbouw met betrekking tot 1988 wordt in tabel I.17 weergegeven (vgl. Hoogendoorn, 1990).

\begin{tabular}{|l|r|}
\hline Sterfte-corzaak & model \\
\hline $\begin{array}{l}\text { AMI-operatiesterfe } \\
\text { fatale AMI-sterfte }\end{array}$ & 414 personen \\
\hline Totaal & 4.518 personen \\
\hline
\end{tabular}

Tabel I.17

FMI2, zoals in het model gebruikt

De berekening van de AMI-operatiesterfte wordt toegelicht in de tabel 1.25 en verder. In tabel I.17 resteert er 4.518 fatale AMI-sterfte. De totale AMI-sterfle 
(18.275 personen) in het model is opgebouwd uit het totaal van tabel I.16 (13.343 personen) en tabel I.17 (4.932 personen).

De fatale AMI-sterfte van 4.518 personen genoemd in tabel $\mathrm{I} .17$ bestaat uit 3.118 fatale AMI "na AMI" en 1.400 fatale AMI "na UAP" (zie de paragraaf behandelingstrajecten uit bijlage II). Er ontwikkelt zich een UAP in ca. 10-15\% van de gevallen tot een AMI met fatale afloop (FMI2) (De Feyter e.a., 1986, Kaiser e.a., 1989, Ambrose e.a., 1989). Wij hebben dit percentage op 12\% vastgesteld.

Wij veronderstellen dat alle fatale AMI's (zowel "na AMI" als "na UAP") worden gekenmerkt door een EF $<40 \%$. Verder is er aangenomen dat alle AMI-opnames waarbij de afgesloten kransslagader "na T" en "na PTCA" dicht blijft een $\mathrm{EF}<40 \%$ hebben (zie Bijlage III).

In tabel $\mathrm{I} .18$ wordt de verdeling weergegeven van de EF over de ziekenhuissterfte in 1988 zoals wij deze in het model hebben toegepast. De verdeling in tabel I.18 ligt ten grondslag aan de verdeling van de EF over de therapeutische behandelingen (zie Bijlage II).

\begin{tabular}{|l|r|r|r|r|}
\hline EF> 40\% & AMI & UAP & AP $_{3-4}$ & AP $_{1.2}$ \\
\hline CABG & 63 & 78 & 155 & 56 \\
\hline PTCA & 132 & 27 & 101 & 4 \\
\hline MED & 0 & 0 & 0 & 0 \\
\hline
\end{tabular}

\begin{tabular}{|l|r|r|r|r|}
\hline EF $<40 \%$ & AMI & UAP & $\mathbf{A P}_{3-4}$ & AP $_{1.2}$ \\
\hline CABG & 7 & 22 & 70 & 0 \\
\hline PTCA & 213 & 7 & 20 & 0 \\
\hline MED & 3.118 & 1.400 & 0 & 0 \\
\hline
\end{tabular}

Tabel I.18

Verdeling EF over ziekenhuissterfte, zoals in het model gebruikt

In de regel overlijden AP- en UAP-patiënten niet aan het betreffende symptoom, maar aan een MI of SD (of een andere ziekte als nevendiagnose). Wij nemen aan dat de AP- en UAP-sterfte het gevolg is van operatiesterfte (operatiemortaliteit). In privé-communicatie met het CBS is dit vermoeden bevestigd.

In tabel 1.19 volgt een uitsplitsing van de UAP- en AP-operatiemortaliteit in 1988. 


\begin{tabular}{|l|r|r|}
\hline ICD-code & CBS & model \\
\hline 411/UAP & 145 & 134 \\
413/AP3-4 & 336 & 346 \\
414/AP1-2 & $(59)$ & 60 \\
\hline Totaal & $481+(59)$ & 540 \\
\hline
\end{tabular}

Tabel I.19

UAP- en AP-operatiemortaliteit, zoals in het model gebruikt

De onder ICD 414 in tabel I.19 tussen haakjes aangegeven CBS-sterfte hebben wij geïnterpreteerd als AP1-2 operatiesterfte. In het model is de AP1-2 operatiesterfte afgerond op 60 personen. Het CBS vermeldt onder ICD 414 een sterfte van 4.698 personen (zie tabel I.21). Wij hebben aangenomen dat de APl-2 operatiesterfte is begrepen in dit aantal. Volgens opgave van het CBS (1991) zijn er geen sterften onder ICD 412.

De totale CHZ-ziekenhuissterfte in het model bestaat uit de FMI2 en de UAP , AP3-4 -, en AP1-2 -operatiemortaliteit (OM). In tabel 1.20 is de CHZ-ziekenhuissterfte in 1988 opgenomen.

\begin{tabular}{|l|r|}
\hline Sterfte-0orzak & model \\
\hline FMI2 & 4.932 \\
OM & 540 \\
\hline Totaal & 5.472 \\
\hline
\end{tabular}

Tabel 1.20

CHZ-ziekenhuissterfte, zoals in het model gebruikt

De STG (1989) vermeldt dat de CHZ-ziekenhuissterfte in 19855.300 personen betreft. Deze sterfte wordt in de STG-publicatie omschreven als de sterfte na verpleging in het ziekenhuis.

De verdeling van de totale sterfte overige $\mathrm{CHZ}$ (ov.isch.hartz.) in 1988 wordt in tabel I.21 weergegeven. 


\begin{tabular}{|l|r|r|}
\hline ICD-code & CBS & model \\
\hline 413/414/OM & $481+(59)$ & 540 \\
414/AP1-2 & $4.698-(59)$ & 4.639 \\
\hline totagl & 5.179 & 5.179 \\
\hline
\end{tabular}

Tabel $\mathbf{I . 2 1}$

Verdeling sterfte overige $\mathrm{CHZ}$, zoals in het model gebruikt

De SD (CHZ-sterfte) met CHF als uitgebreid onderliggend lijden wordt in de doodsoorzaakstatistieken geregistreerd als de sterfte aan coronair atherosclerose (ICD 414). We geven de SD "na CHF" aan met de notatie SD/CHF. Het CBS maakt in de ICD 414 sterfte geen onderscheid tussen de SD/CHF en de AP1-2 operatiesterfte. De 4.639 personen uit tabel I.21 zijn dan ook in ons model gelabeld als CHZ-sterfte.

De totale CHZ-sterfte in de Nederlandse bevolking in 1988 is 23.454 personen (CBS, 1991). De CBS-sterfte is in tabel I.22 over de diagnosegroepen als volgt verdeeld.

\begin{tabular}{|l|r|}
\hline $\begin{array}{l}\text { Acuut myocard infarct } \\
\text { ov. isch. hartx. }\end{array}$ & 18.275 \\
\hline Total & 5.179 \\
\hline
\end{tabular}

Tabel I.22

CBS CHZ-sterfte

De totale operatiemortaliteit in tabel 1.23 in 1988 bedraagt $954(414+540)$ personen.

\begin{tabular}{|l|r|r|r|}
\hline Monifestatle & CABG & PTCA & Totagl \\
\hline AMI & 70 & 345 & 414 \\
UAP & 100 & 34 & 134 \\
AP3-4 & 225 & 121 & 346 \\
AP1-2 & 56 & 4 & 60 \\
\hline Total & 451 & 504 & 954 \\
\hline
\end{tabular}

Tabel I.23 Totale operatiemortaliteit, zoals in het model gebruikt 
Er is een AMI/CHF-instroom van 2.200 personen. Deze is in tabel 1.24 over de AMI-sterfte als volgt verdeeld:

\begin{tabular}{|l|r|}
\hline Sterfte-0orzalk & model \\
\hline FMI1 & \\
FMI2 & 440 personen \\
\hline
\end{tabular}

Tabel 1.24

Verdeling AMI-sterfte "na CHF", zoals in het model gebruikt

De verdeling van de AMI/CHF-sterfte in tabel I.24 over FMI1 en FMI2 is gebaseerd op de volgende verdeelsleutel. De totale AMI-sterfte bedraagt 18.275 (zie tabel I.22). Hierin is de $2.200 \mathrm{AM} / \mathrm{CHF}$-sterfte opgenomen. De voor AMI/CHFsterfte opgeschoonde AMI-sterfte is dan 16.075. De 3.300 FMI1 bedraagt ca. $20 \%$ van de opgeschoonde AMI-sterfte. We hebben deze verhouding doorberekend op de AMI/CHF-sterfte met tabel $\mathrm{I} .24$ als resultaat.

In tabel I.25 is de gemiddelde operatiesterfte, uitgedrukt in kansen, afgebeeld.

\begin{tabular}{|l|r|r|}
\hline Manifestatie & CABG & PTCA \\
\hline AMI & $.05(1 *$ AP3-4) & $.17(5 * A P 3-4)$ \\
UAP & $.10(2 *$ AP3-4) & $.17(5 *$ AP3-4) \\
AP3-4 & $.05(3,8 * .013)$ & $.035((3,0 / 2,5) *(.011 / .014))$ \\
AP1-2 & $.04(3 * .013)$ & $.025(1,8 * .0 .14)$ \\
\hline
\end{tabular}

Tabel 1.25

Gemiddelde operatiesterftekans, zoals gebruikt in het model

We zijn voor de schatting van de operatiesterftekansen in tabel I.25 uitgegaan van de operatiesterftekans bij AP-3. In de literatuur worden er met betrekking tot AP3-4 de volgende gemiddelde operatiesterftekansen gevonden:

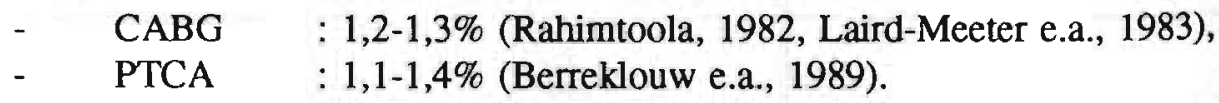

De epidemiologische interventiestudies (of trials) concentreren zich voomamelijk op mannen in de gemiddelde leeftijd van 55 jaar die voor de eerste keer een hartoperatie ondergaan. Er is zodoende relatief weinig data beschikbaar over de morbiditeit en operatiesterfte van $\mathrm{CHZ}$ met betrekking tot vrouwen, oudere leef- 
tijden en her-operaties. Deze operatiekarakteristieken hebben een verhoogde operatiesterfterisico in zich.

Wij hebben de hierboven genoemde operatiesterftepercentages met betrekking tot CABG/AP3-4 vermenigvuldigd met een correctiefactor 3,8 voor leeftijd $\geq 65$ jaar, geslacht, en her-operatie. Deze correctiefactor of vermenigvuldigingsfactor hebben we geschat op basis van het relatieve operatiesterfterisico van de genoemde operatiekarakteristieken die hierover in de literatuur (weliswaar sporadisch) vermeld staan. Hierbij heeft de operatiemortaliteit in tabel I.23 gediend als ijkpunt. Een tweede vermenigvuldigingsfactor is een verhoogd operatiesterfterisico met betrekking tot AMI en UAP in relatie tot AP3-4. De CABG/AMI betreft een oud-MI. We hebben het CABG-operatiesterfterisico met betrekking oud-MI gelijk verondersteld aan dat van $C A B G / A P 3-4$. In de literatuur is aangegeven dat het CABG/UAP-operatiesterfterisico twee maal het CABG/AP3-4-operatiesterfterisico bedraagt (Kaiser e.a., 1989). Het operatiesterfterisico van CABG/AP1-2 is een fractie lager ingeschat ten opzichte van AP3-4. De vermenigvuldigingsfactor voor PTCA/AP3-4 is ingeschat op 2,5-3,0. De overige vermenigvuldigingsfactoren zijn vastgesteld op basis van privé-communicatie (Janssen, 1992), SIG (1992) en literatuur over PTCA (Chaitman, 1989, Yusuf e.a., 1988).

Deze operatiesterftepercentages worden respectievelijk in de tabel I.26 en tabel I.27 per manifestatievorm weergegeven. Vervolgens zijn de operatiesterftepercentages verdeeld naar de mate van kransslagadervernauwing (SVD, MVD) en de hoogte van de $\mathrm{EF}(\mathrm{EF} \geq 40 \%$, $\mathrm{EF}<40 \%)$.

\begin{tabular}{|rl|r|r|}
\hline Manifestatie & EF $\geq 40 \%$ & \multicolumn{1}{|c|}{ EF $<40 \%$} \\
\hline AMI & SVD & $.02(1 * A P 3-4)$ & $.036(1 * A P 3-4)$ \\
& MVD & $.05(1 * A P 3-4)$ & $.083(1 * A P 3-4)$ \\
UAP & SVD & $.04(2 * A P 3-4)$ & $.072(2 * A P 3-4)$ \\
& MVD & $.10(2 * A P 3-4)$ & $.166(2 * A P 3-4)$ \\
AP3-4 SVD & $.02(4 * .005)$ & $.036(1.8 * .02)$ \\
AP1-2 SVD & $.05(2.5 * .02)$ & $.083(1.7 * .05)$ \\
MVD & $.016(3.2 * .005)$ & $.03(1.9 * .016)$ \\
& MVD & $.04(25 * .016)$ & $.068(1.7 * .04)$ \\
\hline
\end{tabular}

Tabel 1.26

CABG-operatiesterftepercentages, zoals in het model gebruikt

In tabel $\mathrm{I} .26$ staat centraal het SVD/CABG-operatiesterfterisico met betrekking tot AP3-4 / EF $\geq 40 \%$. Deze is vastgesteld op 0,5\% (Rahimtoola, 1982). De vermenigvuldigingsfactor 4 is een afronding van de bij tabel $\mathrm{I} .25$ genoemde correctiefactor van 3,8. Het gemiddelde MVD/CABG-operatiesterfterisico met be- 
trekking tot AP3-4 is volgens Rahimtoola (1982) 1,4\%. Dit is een factor 2,8 ten opzichte van het SVD-operatiesterfterisico van $0,5 \%$. Deze vermenigvuldigingsfactor is afgerond op 2,5. We hebben aangenomen dat de vermenigvuldigingsfactor met betrekking tot een EF $<40 \% \quad 1,5-2$ bedraagt voor zowel SVD als MVD. Voor het overige is dezelfde methodiek gebruikt als bij tabel I.25.

\begin{tabular}{|c|c|c|}
\hline Manifestatle & $E F \geq 40 \%$ & EF $<40 \%$ \\
\hline $\begin{array}{ll}\text { AMI } & \text { SVD } \\
\text { MVD }\end{array}$ & $\begin{array}{l}.043(8.5 * A P 3-4) \\
.425(8.5 * A P 3-4)\end{array}$ & $\begin{array}{r}.149(8.5 * A P 3-4) \\
.64(8.5 * A P 3-4)\end{array}$ \\
\hline SVD & $.025(5 * A P 3-4)$ & $.088(5 * A P 3-4)$ \\
\hline MVD & $.25(5 * A P 3-4)$ & $.375(5 * \mathrm{AP3}-4)$ \\
\hline AP3-4 SVD & $.005(2.5 * .002)$ & $.0175(3.5 * .005)$ \\
\hline MVD & $.05(10 * .005)$ & $.075(1.5 * .05)$ \\
\hline AP1-2 SVD & $.0028(1.4 * .002)$ & $.0098(3.5 * .0028)$ \\
\hline MVD & $.025(9 * .0028)$ & $.039(1.6 * .025)$ \\
\hline
\end{tabular}

Tabel I.27

PTCA-operatiesterftepercentages, zoals in het model gebruikt

De PTCAVAP3-4 operatiesterftepercentages zijn afgeleid uit een publicatie van Holmes (1988):

$\begin{array}{lll}\text { SVD } & .002 & .007(3,5 * .002) \\ \text { MVD } & .016(8 * .002) & .026(1,6 * .016)\end{array}$

We hebben de vermenigvuldigingsfactor uit tabel 1.25 gebruikt als correctiefactor met betrekking tot AP3-4/SVD. De factor 8 (MVD=8*SVD) uit de publicatie van Holmes (1988) is verhoogd naar 10. Evenzo zijn de overige vermenigvuldigingsfactoren van 3,5 en 1,6 (verlaagd naar 1,5) gebruikt in tabel 1.27. De overige vermenigvuldigingsfactoren sluiten aan bij die uit tabel I.25.

\section{I.6 Leeftijds- en Geslachtsafhankelijkheid}

In onderstaande grafieken zijn de jaarlijkse incidentie- en sterftekansen naar leeftijd en geslacht weergegeven in percentages. 


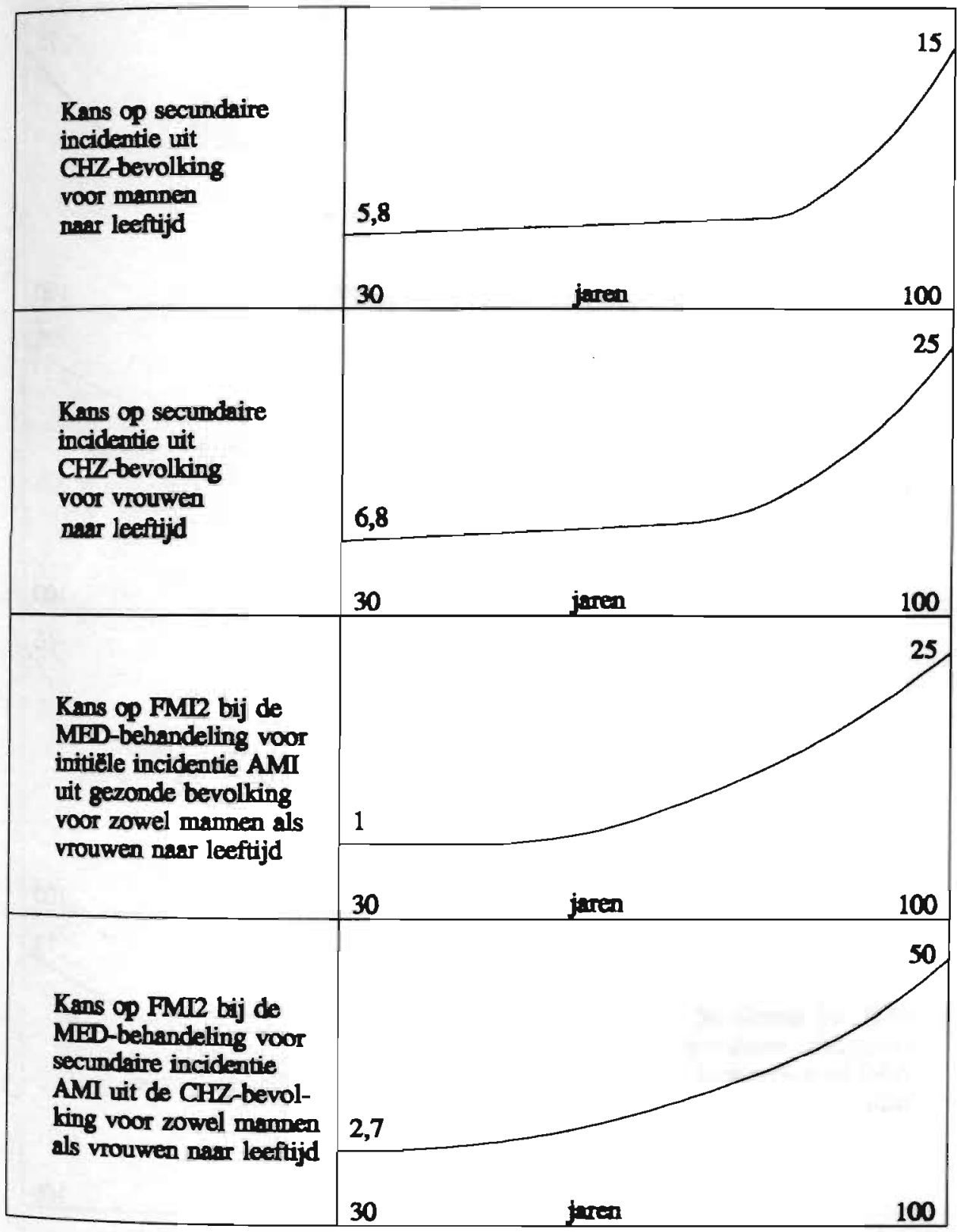




\begin{tabular}{|l|l|}
\hline $\begin{array}{l}\text { SD bij initible of } \\
\text { secundaire incidentie } \\
\text { AMI voor mamen } \\
\text { naar leeftijd }\end{array}$ & \\
\cline { 2 - 2 } & 0 \\
\hline
\end{tabular}




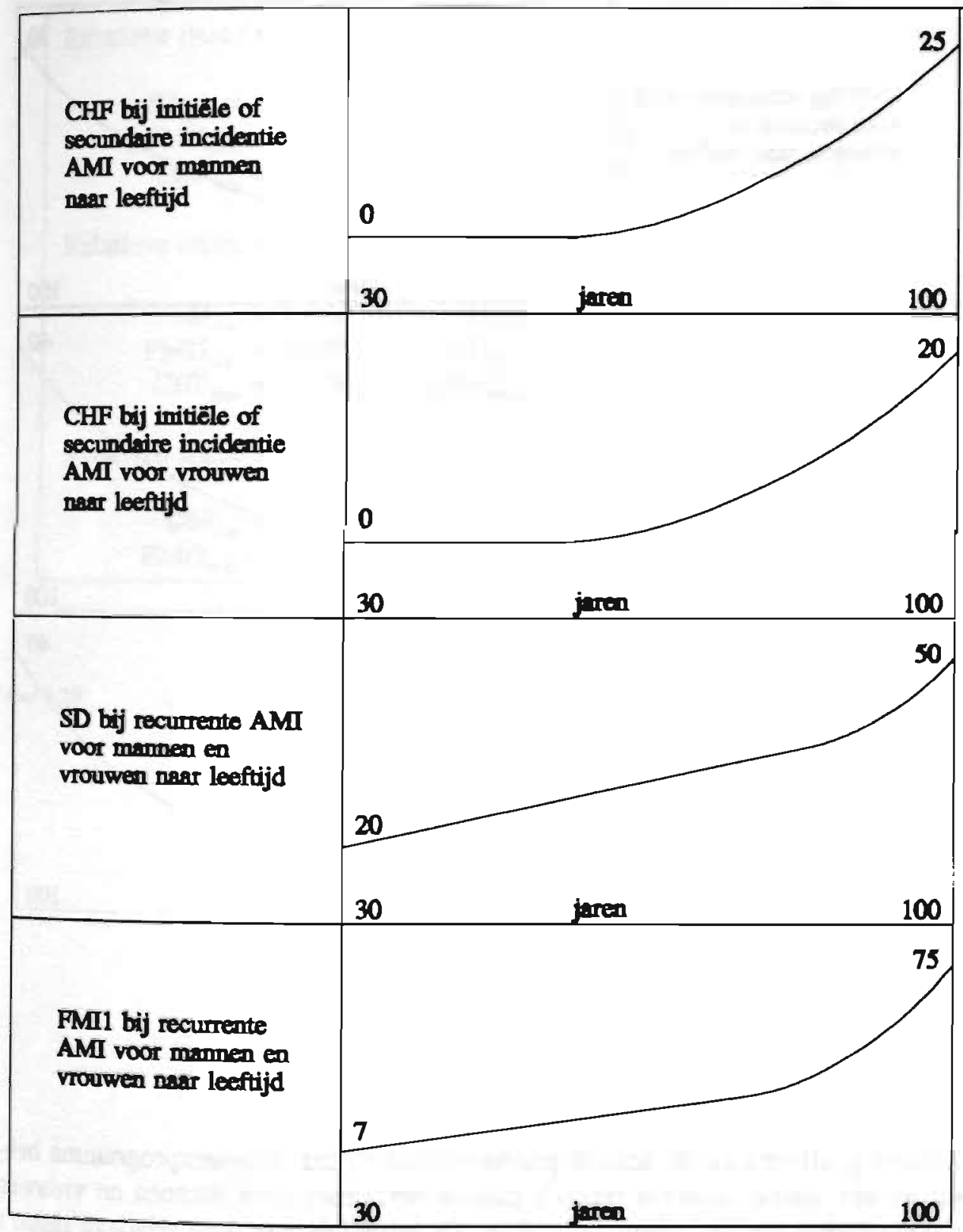




\begin{tabular}{|l|l|}
\hline $\begin{array}{l}\text { CHF bij recurrente AMI } \\
\text { voor mannen en } \\
\text { vrouwen naar leeftijd }\end{array}$ & 0 \\
\cline { 2 - 3 } & 30 \\
\hline \multirow{2}{*}{$\begin{array}{l}\text { Operatiemortaliteit voor } \\
\text { zowel CABG als PTCA } \\
\text { voor mamnen nasr } \\
\text { leeftijd }\end{array}$} & \\
\hline
\end{tabular}

Tabel I.28

Kansen leeftijds- en geslachtsafhankelijk

Uit deze grafieken en de actuele patiëntenflows in het computerprogramma hebben we een aantal relatieve risico's kunnen berekenen voor mannen en vrouwen in vergelijking met de gehele bevolking. De betekenis van deze relatieve risico's is dat indien een simulatie niet wordt uitgevoerd voor de gehele bevolking maar voor een deelbevolking van een bepaald geslacht (de zogenaamde cohortstudies), de diverse kansen gecorrigeerd moeten worden met de betreffende relatieve risico's. 
Relatieve risico's bij flows vanuit de Gezonde bevolking:

$$
\begin{array}{rlrl}
\mathrm{SD}_{\text {mm }}= & =.825 & \mathrm{SD}_{\text {row }} & =1.353 \\
\mathrm{FMII}_{\text {mm }} & =0.871 & \mathrm{FMI} 1_{\text {row }}=1.258 \\
\mathrm{CHF}_{\text {mm }}=1.110 & \mathrm{CHF}_{\text {rwow }}=0.780
\end{array}
$$

Relatieve risico's bij flows vanuit de CHZ-bevolking:

$$
\begin{aligned}
\mathrm{SD}_{\text {man }} & =0.841 & \mathrm{SD}_{\text {now }} & =1.299 \\
\mathrm{FMII}_{\text {mex }} & =0.889 & \mathrm{FMIl}_{\text {now }} & =1.208 \\
\mathrm{CHF}_{\text {mex }} & =1.134 & \mathrm{CHF}_{\text {now }} & =0.748
\end{aligned}
$$

Relatieve risico's onafhankelijk van de herkomst van de flow:

$$
\mathrm{OM}_{\operatorname{mm}}=0.723 \quad \mathrm{OM}_{\text {voum }}=1.594
$$

$\mathrm{FMI}_{\text {mm }}=0.834 \quad \mathrm{FMI}_{\text {now }}=1.356$ 
II ONDERDELEN CHZ-MODEL

II.1 Inleiding

II.2 Prognostische Variabelen CHZ

II.3 Stratificatie Bevolking naar Risicogroepen

II.4 Behandelingstrajecten

II.5 Indicatiestelling Therapeutische Behandelingen

II.6 Verdeling CHZ-gebeurtenissen over Therapeutische Behandelingen 


\section{II.1 Inleiding}

In onze benadering is de gang van de verschillende modelpatiënten door het me. disch circuit zo goed mogelijk nagebootst. De uitwerking van het medisch circuit is geschied aan de hand van aantallen te verrichten handelingen (het zogenaamde volume). Door aan iedere handeling een prijskaartje te hangen, kunnen dus in principe de totale jaarlijkse kosten berekend worden. Het ontwikkelde model simuleert een bepaalde tijdsperiode en de jaarlijkse kosten gedurende deze perio de kunnen eventueel met behulp van discontering opgeteld worden.

In dit hoofdstuk vindt de uitwerking van het medisch circuit plaats in de vorm van behandelingstrajecten in relatie met ziekteverlopen. De behandelingstrajecten detailleren voor elke CHZ-vorm de verschillende typen medische behandelingen De therapiekeuzen in het model worden bepaald op basis van een stratificatie van de indicatiestellingen. De indicatiestellingen geven de criteria aan op basis waarvan de patiënten voor een bepaalde therapie worden geïndiceerd. Wij hetben deze criteria gebaseerd op patiëntkenmerken. Hiervoor zijn genomen de indcatoren die bepalend zijn voor de prognose van het (natuurlijke) ziekteproces van $\mathrm{CHZ}$. Deze indicatoren zijn de type manifestatievorm, de anatomische en fysilogische kenmerken van de kransslagaders, de ejectiefractie en de onafhankelijke variabelen leeftijd en geslacht. Daarenboven is uiteraard de behandelingsstrategie medebepalend.

De stratificatie van de bevolking naar risicofactoren is in het model uitgewerk als een dynamisch systeem. Hiermee bedoelen we dat uitgaande van de opdeling van de gezonde en zieke bevolking in de deelgroepen, er ieder jaar een herindeling plaatsvindt van de bevolking over deze groepen. Dit geschiedt door voor iedere groep na te gaan hoe deze personen zich in de loop van een jaar verspreiden over de mogelijke groepen die ze in én jaar kunnen bereiken. Ze kunnen natuurlijk ook in dezelfde groep blijven zitten.

Indien nu voor iedere risicogroep van de gezonde bevolking en iedere deelgroep van de CHZ-bevolking de overgangskansen, om na 1 jaar in een eventueel andere groep te belanden, bekend zijn, dan is het mogelijk om op basis hiervan de verdeling van de Nederlandse bevolking na zo'n jaar over de diverse groepen te bepalen.

De paragraafindeling van deze bijlage is als volgt. In paragraaf II.2 worden de prognostische variabelen met betrekking tot $\mathrm{CHZ}$ beschreven. De stratificatie var de bevolking naar risicogroepen is in paragraaf II.3 opgenomen. De behande lingstrajecten worden in paragraaf II.4 gepresenteerd. In paragraaf II.5 wordt de indicatiestelling van therapeutische behandelingen voor 1988 gegeven, zoals wi die in het model gebruikt hebben. Tot slot volgt in paragraaf II.6 een beschrij 
ving van de wijze waarop wij de CHZ-gebeurtenissen over de therapeutische behandelingen verdeeld hebben.

\section{II.2 Prognostische Variabelen CHZ}

Prognostische variabelen zijn variabelen die als bepalend beschouwd kunnen worden voor de incidentie(s) en het verdere ziekteverloop. Een slechte prognose betekent een verhoogde kans op een herhaalde CHZ-manifestatie, en daarmee de verhoogde kans op sterfte.

De AMI is naast de SD met betrekking tot de prognose de meest dominante manifestatievorm. De prognostische AMI-parameters die in het model gebruikt worden zijn leeftijd, geslacht, het restniveau van de EF (oftewel de restfunctie van de hartspier), de incidentietype (1ste of 2 de incidentie), en de tijdsduur (de tijd tussen de 1ste en 2de incidentie).

De prognoses bij AP en UAP worden bepaald door leeftijd, geslacht, de anatomische afwijkingen van de kransslagaders, de ernst van de angineuze klachten, het restniveau van de EF, de tijdsduur en de incidentietype.

In de literatuur worden vaak de volgende prognostische variabelen genoemd:

a) de kransslagaderstenose (\%),

b) de ejectiefractie (EF),

c) de plaats van de kransslagaderstenose (P),

d) het aantal vernauwde kransslagaders (vaatlijden of vessel disease, aangegeven met VD),

e) de mate van angineuze klachten (AP1-4),

f) de kwaliteit van het kransslagaderstelsel (K),

g) leeftijd en geslacht,

h) risicofactoren,

i) factor tijd.

a) kransslagaderstenose (\%)

De kransslagaderstenose duidt de mate aan waarin een kransslagader vernauwd is. Er is eigenlijk al sprake van $\mathrm{CHZ}$ wanneer de kransslagaderstenose $\geq 50 \%$ bedraagt. De type $\mathrm{CHZ}$-manifestatievorm hangt nauw samen met de kransslagaderstenose, te weten:

- $100 \%$ stenose (totale afsluiting)

- $\geq 90 \%$ stenose (ernstige afsluiting)

- $50-90 \%$ stenose (gedeeltelijke afsluiting) 
In het algemeen geldt, hoe ernstiger de stenose, hoe ernstiger de manifestatievorm en hoe slechter de prognose.

De therapeutische behandeling geneest het ziektebeeld als zodanig niet. Er kan na korte of lange tijd een herstenose ontstaan. Men spreekt van een herstenose (nieuwe stenose) wanneer een verlies van minstens $50 \%$ van de bereikte verwijding en/of als een nieuwe vemauwing van minstens $30 \%$ ontstaat (Berreklouw, 1988/1, Holt e.a., 1988).

De oorzaken van een herstenose staan nog ter discussie. Uit de literatuur is bekend dat er grote verschillen bestaan tussen de snelheid waarmee een herstenose na de verschillende therapeutische behandelingen kan optreden. Sommige auteurs menen dat onvolledige revascularisatie de oorzaak of én van de oorzaken is van een (snelle) herstenose. Er zijn hoe langer hoe meer aanwijzingen dat een herstenose niet op dezelfde plaats van de oorspronkelijke stenose hoeft op te treden (King III e.a., 1989, Janssen, privé-communicatie, 1992, Berreklouw, 1992).

\section{b) ejectiefractie (EF)}

De ejectiefractie (EF) is een globale maat voor de hoeveelheid bloed die per hartslag wordt rondgepompt. In de gezonde bevolking wordt een $\mathrm{EF} \geq 50 \%$ als niet belemmerend beschouwd (Gezondheidsraad, 1984/18).

Een slechte EF kan ontstaan door beschadiging van de hartspier ten gevolge van een acuut myocard infarct (AMI). Wij hebben een slechte EF gelijkgesteld aan een fractie van $39 \%$ of lager (EF $<40 \%)$. Deze drempelwaarde is gekozen omdat hiermee de beste aansluiting met de literatuur kan worden verkregen. In de praktijk wordt een fractie van rondom $30 \%$ veelal beschouwd als een slechte EF.

Hoe groter of hoe vollediger het infarct, hoe groter de kans op een verminderde pompfunctie van de hartspier, en hoe groter de kans op een nieuw AMI (Gersh e.a., 1989). Er ontstaat een vicieuze cirkel met uiteindelijk de kans op sterfte ten gevolge van een infarct. Zodoende is de EF de meest belangrijke prognostische variabele met betrekking tot $\mathrm{SD}$, fatale MI, operatiesterfte, CHF, en nieuw AMI (Gersh e.a., 1989).

De EF wordt bepaald met behulp van een echocardiografie (echo). Hierdoor is het mogelijk de EF op relatief eenvoudige, uniforme en objectieve wijze te meten (privé-communicatie, Janssen, 1992). Wij hebben daarom aangenomen dat steeds bekend is welk percentage van de AMI's (en oud-MI) een slechte EF geeft.

Een eenmaal verminderde EF wordt door een therapeutische behandeling niet meer verbeterd. Hooguit kan de toestand van de EF gestabiliseerd worden met als doel een verdere vermindering van EF te voorkómen (Gezondheidsraad. 1984/18). In geval van een $E F \leq 20 \%$ biedt de therapie geen daadwerkelijke ver- 
betering meer. In deze situatie is de therapie gericht op de verbetering of op het behoud van de kwaliteit van leven. Wij hebben deze toestand gekarakteriseerd als CHF.

\section{c) de plaats van de kransslagaderstenose (P)}

De kransslagaderstenose kan door een therapeutische behandeling reduceren, waardoor de functionaliteit van de hartspier weer toeneemt.

Een stenose kan zich op vier plaatsen in de kransslagaders voordoen, te weten: 1) hoofdstam van de linker coronaire arterie (LMCA), 2) "right anterior descending" of "right coronary artery" (RCA), 3) "left anterior descending" (LAD), en 4) "circumflex coronary arteries" (Cx). De plaats van de stenose in de kransslagaders is voor ons model een (te) gedetailleerde prognostische variabele. Er zijn in de literatuur weinig gegevens bekend met betrekking tot de verdeling van het aantal vernauwde kransslagaders (VD) naar de plaats van de stenose en de daaraan gekoppelde prognose. Wij hebben de plaats van de kransslagaderstenose in het model daarom buiten beschouwing gelaten.

\section{d) het aantal vernauwde kransslagaders (VD)}

Het aantal vernauwde kransslagaders (VD) en de plaats van de kransslagaderstenose (P) zijn de twee variabelen die de grootte van het bedreigde weefselgebied het meest bepalen.

Het aantal vernauwde kransslagaders kan zich voordoen in én kransslagader (1VD), gelijktijdig in twee (2VD) of drie (3VD) kransslagaders en in de hoofdstam of "left main disease" (LMD). Hoe meer kransslagaders gelijktijdig vernauwd zijn, hoe slechter de prognose met betrekking tot de kans op een herhaalde CHZ-manifestatie (Barneveld e.a., 1985, Rahimtoola, 1982). Een LMD is hierbij dominanter dan een 3VD.

De literatuur geeft onvoldoende (gedetailleerde) gegevens met betrekking tot de verdeling van het aantal vernauwde kransslagaders over de CHZ-manifestatievormen. Er zijn wel gegevens beschikbaar over de verdeling van het aantal vernauwde kransslagaders in deelgroepen. Het meest bekend is de indeling naar deelgroepen met én kransslagadervernauwing (1VD) respectievelijk twee of meerdere kransslagadervernauwingen ( $\geq 2 \mathrm{VD}$ ). De in de literatuur gangbare notaties zijn respectievelijk SVD (single vessel disease) en MVD (multiple vessel disease). Wij hebben deze twee deelgroepen met betrekking tot de verdeling van het aantal vernauwde kransslagaders over de CHZ-manifestatievormen in ons model gebruikt. Het aantal vernauwde kransslagaders kan alleen invasief met behulp van een coronair angiogram (CAG) vastgesteld worden. 


\section{e) angineuze klachten (AP)}

In de meeste gevallen gaat een kransslagaderstenose gepaard met symptomen van angina pectoris. Als vuistregel geldt, hoe erger de angineuze pijnklachten, dan wel hoe sneller het tempo van verergering (UAP), hoe groter de kans op een herhaalde CHZ-manifestatie (Laird-Meeter, 1988/2).

De mate van angineuze klachten komt niet altijd overeen met het aantal vernauwde kransslagaders, zodat ze niet als elkaars synoniem beschouwd kunnen worden. De AP geeft eveneens aan in hoeverre het hart met betrekking tot de doorbloeding in staat is geweest collaterale verbindingen aan te leggen. Zodoende kan dezelfde mate van vaatlijden, afhankelijk van de mate van doorbloeding, gepaard gaan met zowel een lichte als een ernstige mate van AP.

We veronderstellen dat door het opheffen van de kransslagaderstenose de angineuze klachten in de meeste gevallen ook verdwijnen of sterk verminderen.

Angineuze klachten zijn relatief makkelijk maar moeilijk objectief meetbaar. Er zijn verschillende classificatieschema's, die in Bijlage IV zijn uitgewerkt. De New York Heart Asociation (NYHA) classificatieschema is het meest bekend.

\section{CI.ASSIFICATIE AP-TOESTANDEN}

AP-toestanden volgens de New York Heart Association (vertaling uit: Stam, e.a., 1986)

AP1: Patiënten met een hartziekte die niet leidt tot beperking van de lichamelijke activiteit. Gewone lichamelijke inspanning leidt niet tot overmatige moeheid, hartkloppingen, kortademigheid of angina pectoris.

AP2: Patiënten met een hartziekte die leidt tot geringe beperking van de lichamelijke activiteit. Zij voelen zich goed in rust. Gewone lichamelijke inspanning leidt tot moeheid, hartkloppingen of angina pectoris.

AP3: Patiënten met een hartziekte die leidt tot aanzienlijke beperking van de lichamelijke activiteit. $\mathrm{Zij}$ voelen zich goed in rust. Minder dan gewone lichamelijke inspanning leidt al tot moeheid, hartkloppingen, kortademigheid of angina pectoris.

AP4: Patiënten met een hartziekte die geen enkele vorm van lichamelijke activiteit toelaat zonder dat klachten optreden. Symptomen van angina pectoris kunnen zelfs in rust optreden. Elke lichamelijke inspanning leidt tot een toename van klachten.

Dit classificatieschema is gebaseerd op het oordeel van cardiologen. Hierdoor ijin er met betrekking tot de verschillende functieklassen veel interpretatieverschillen. Andere classificatieschema's genoemd in Bijlage IV hebben aanvullende specificaties aangebracht, waardoor de kans op interpretatieverschillen kleiner is geworden (vgl. Stam e.a., 1986, Goldman e.a., 1986). Hoewel die andere classi- 
ficatieschema's een theoretisch betere indeling geven, breng de veclvoud aan items met zich mee dat die classificatieschema's minder praktisch zijn in het gebruik. Zodoende bestaat er in de praktijk met betrekking tot de AP-classificatie geen objectieve meettechniek.

In de literatuur zijn onvoldoende (gedetailleerde) gegevens aanwezig met betrekking tot de verdeling van angineuze klachten (AP) over de vier typen AP volgens het NYHA-classificatieschema (AP1 tot en met AP4). Wij hebben de vier AP-typen samengevoegd tot twee typen die als homogeen verondersteld kunnen worden met betrekking tot zowel het klachtenniveau als de prognose. De twee AP-typen zijn de volgende:

- AP1-2 (weinig angineuze klachten),

- AP3-4 (veel angineuze klachten).

Er is sprake van chronische AP3-4 wanneer na intensieve medicatie ook een operatie niet meer tot de mogelijkheden behoort. In het model wordt chronische AP3-4 beschouwd als CHF.

\section{f) kwaliteit kransslagaderstelsel (K)}

De "kwaliteit van het kransslagaderstelsel" $(K)$ is een door ons geïntroduceerd begrip dat de kwaliteit van het weefselgebied en dat van de kransslagaders weerspiegelt die na de therapeutische behandelingen resteren. Echter de kwaliteit van het kransslagaderstelsel wordt door nieuwe atherosclerotische progressie voortdurend bedreigd.

In het model fungeert de $\mathrm{K}$ als een variabele waarmee de snelheid van het optreden van herstenose en daarmee de kans op een nieuwe CHZ-incidentie gemanipuleerd kan worden. De $\mathrm{K}$ hangt hierbij in hoge mate af van het oorspronkelijk aantal vernauwde kransslagaders (SVD versus MVD). Wij hebben de K als volgt ingedeeld:

- K+ (behoorlijke tot redelijke kwaliteit kransslagaders),

- K- (matige tot slechte kwaliteit kransslagaders).

Ons begrip "kwaliteit van het kransslagaderstelsel" overlapt voor een gedeelte het in het scenariorapport "Het hart van de toekomst. De toekomst van het hart" (1986) geïntroduceerde begrip vaatleeftijd. De vaatleeftijd is een soort biologische leeftijd die kan worden geïnterpreteerd als een aanpassing van de kalenderleeftijd op basis van een risicoprofiel. In deze benaderingswijze functioneert de vaatleeftijd als een prognostische indicator met betrekking tot zowel de incidentie en de mortaliteit van $\mathrm{CHZ}$. Het nadeel van het begrip vaatleeftijd is dat ze 
niet aansluit op de literatuur met betrekking tot $\mathrm{CHZ}$. Hierdoor kan het traceren van mogelijke toekumstige ontwikkelingen op dit terrein binnen een dergelijk model niet gebaseerd worden op basis van de bestaande literatuur. Een van de gevolgen hiervan betreft de onmogelijkheid om met name preventie kosten aan de scenario's toe te kennen. De mate waarin de verschillende sturende grootheden de incidentie doen veranderen, wordt door de onderzoekers namelijk als het ware teruggeredeneerd vanuit de (veranderende) mortaliteit (vgl. Meijler e.a., 1987).

Het verschil met onze benadering is dat wij de $\mathrm{K}$-parameter niet gebruikt hebben als een prognostische variabele met betrekking tot de initiële $\mathrm{CHZ}$-incidentie en de $\mathrm{CHZ}$-mortaliteit. De CHZ-sterfte vindt plaats in het brugmodel als een afgeleide van met name de EF. De initiële CHZ-incidentie komt in ons model tot stand met behulp van de Framingham Heart Study regressiecoëfficiënten, waarbij de initiële incidenties geijkt zijn op de specifieke Nederlandse gegevens (zie Bijlage I).

\section{g) leeftijd en geslacht}

De CHZ-incidentie en CHZ-sterfte zijn sterk geassocieerd met de leeftijd (Ulvenstam e.a., 1985, Califf e.a., 1989). Uit de literatuur is bekend dat CHZ-incidenties bij vrouwen in de gezonde bevolking veelal op een later tijdstip plaatsvinden. De CHZ-prognose voor vrouwen daarentegen is in het algemeen slechter dan die voor mannen, zodat tegen het levenseinde vrouwen "versneld" aan CHZ overlijden (Kannel e.a., 1979, MFR, 1992).

Op een aantal plaatsen in het model hebben we de diverse kansen leeftijds- en geslachtsafhankelijk gemaakt.

In alle gevallen zijn deze afhankelijkheden bepaald aan de hand van SIG (1992) materiaal. In Bijlage I geven we een overzicht op welke plaatsen in ons model de overgangskansen leeftijds- en geslachtsafhankelijk zijn gemaakt.

\section{h) risicofactoren}

Risicofactoren (of determinanten) zijn van invloed op de (toekomstige) gezondheidstoestand van de bevolking. Wij maken een onderscheid tussen $\mathrm{CHZ}$-risicofactoren die in de gezonde bevolking vórkomen en de CHZ-risicofactoren bij patiënten die al getroffen zijn geweest door een $\mathrm{CHZ}$-manifestatievorm (CHZ-bevolking).

In de CHZ-bevolking is de behandeling erop gericht dat de CHZ-patiënt zijn levenswijze met betrekking tot de $\mathrm{CHZ}$-risicofactoren (of risicogedrag) zal aanpassen. In de meeste gevallen stoppen rokers na een $\mathrm{CHZ}$-gebeurtenis met roken. De verhoogde bloeddruk en het verhoogde serumcholesterolgehalte worden met een dieet onderdrukt. In de literatuur zijn met betrekking tot de prevalentie van de $\mathrm{CHZ}$-risicofactoren in de $\mathrm{CHZ}$-bevolking weinig gegevens te verkrijgen. Wij 
veronderstellen dat de risicofactoren in de CHZ-bevolking geen rol van betekenis spelen.

De belangrijkste risicofactoren die in het model gebruikt worden met betrekking tot de initiële CHZ-incidenties zijn:

1) leeftijd,

2) geslacht,

3) het serumcholesterolgehalte,

4) hypertensie, en

5) roken.

De risicofactoren leeftijd en geslacht vormen onafhankelijke risicofactoren.

Er worden in de literatuur een twintigtal risicofactoren met betrekking tot $\mathrm{CHZ}$ genoemd (vgl. Gezondheidsraad, 1984/16, Van der Maas e.a., 1989).

Er bestaat nog veel onduidelijkheid over het relatieve gewicht dat aan de verschillende risicofactoren met betrekking tot $\mathrm{CHZ}$ toegekend moet worden. Obesitas bijvoorbeeld heeft een hoog relatief risico voor $\mathrm{CHZ}$. De obesitas-prevalentie en het daarmee samenhangende attributieve risico op bevolkingsniveau daarentegen zijn voor CHZ laag (vgl. Jansen e.a., 1991).

De kennis over de oorzakelijke factoren voor $\mathrm{CHZ}$ reikt (nog) niet zover dat daarmee de $\mathrm{CHZ}$-incidentie volledig verklaard kan worden. Er wordt bijvoorbeeld hoe langer hoe meer een belangrijke rol toegedacht aan stress-hormonen zoals adrenaline die een hartaanval kunnen uitlokken.

Kannel (1976) presenteert een schatting van de populatie-attributieve risico's (PAR). Deze geven bij benadering aan welk percentage van de incidentie van het hartinfarct in de totale bevolking toegeschreven kan worden aan de prevalentie van een bepaalde risicofactor. Beschouwt men voor vaste leeftijd de systolische bloeddruk, dan bedraagt het PAR bij een systolische bloeddruk $>150 \mathrm{mmHg}$ $24 \%$. Voor een serumcholesterolgehalte $>250 \mathrm{mg} \%$ (of $6,48 \mathrm{mmol} / 1$ ) bedraagt het PAR ca. $33 \%$, en voor het roken van sigaretten zelfs ca. $37 \%$. Wanneer men alle drie genoemde risicofactoren plus de genoemde niveaus tegelijk in beschouwing neemt, dan blijkt het PAR daarvan ca. $48 \%$ te zijn.

\section{i) de tijdfactor}

In het model worden twee tijdfasen onderscheiden. De twee tijdfasen zijn het eerste jaar van de CHZ-manifestatie ( $<1$ jaar) respectievelijk de daarop volgende jaren $(\geq 1$ jaar $)$.

Er zijn twee aspecten aan de tijdfactor verbonden, een prognostisch aspect en een kostenaspect. De factor tijd heeft een prognostische betekenis omdat de kans op een nieuwe CHZ-gebeurtenis afneemt naarmate er meer tijd verstrijkt na de 
laatste CHZ-gebeurtenis. De prognose wordt echter slechter naarmate de $\mathrm{CHZ}$ gebeurtenissen zich sneller gaan herhalen. Het kostenaspect met betrekking tot de factor tijd verklaart zich doordat de therapiekeuzen (indicatiestellingen) voor een belangrijk deel samenhangen met de tijdsduur die ligt tussen de vorige CHZ-incidentie en de nieuwe CHZ-incidentie.

Het model is opgebouwd uit een brugmodel en een morbiditeitsmodel. We heb. ben het brugmodel verbonden aan de tijdfase $<1$ jaar en het morbiditeitsmodel aan de tijdfase $\geq 1$ jaar. In het morbiditeitsmodel verblijven de groepen van patiënten die langer dan éen jaar na de laatste $\mathrm{CHZ}$-gebeurtenis in een latente CHZ-toestand verkeren. Deze groepen zijn aangeduid als de CHZ-bevolking. We hebben de behandelingsgangen die door de patiëntenstromen middels behandelingstrajecten doorlopen worden ook verdeeld naar de genoemde twee tijdfasen, waardoor ze parallel lopen aan de tijdfasen van het brugmodel en het morbiditeitsmodel. In de paragraaf behandelingstrajecten verderop in deze bijlage vindt de bespreking plaats van de behandelingstrajecten. Zodoende zijn er in het brugmodel drie typen behandelingstrajecten: 1) het voortraject, 2) het opnametraject, en 3) het follow-up traject $<1$ jaar. Het follow-up traject $\geq 1$ jaar is ondergebracht bij het morbiditeitsmodel.

\section{II.3 Stratificatie Bevolking naar Risicogroepen}

De Nederlandse bevolking kan in het model op het hoogste aggregatieniveau in twee toestanden verkeren: de toestand Gezond (geen CHZ) en 2) de toestand Ziek (wel CHZ). Vervolgens zijn deze beide groepen verder uitgesplitst.

Eens per jaar, op 1 januari, wordt de bevolking verdeeld over de homogene deelgroepen in de gezonde bevolking (subgroepen toestand Gezond) en over de homogene deelgroepen in de CHZ-bevolking (subgroepen toestand CHZ). De homogeniteit duidt aan dat de personen, die tot eenzelfde groep gerekend worden, als identiek mogen worden beschouwd ten aanzien van coronaire hartziekten. Voor een groep bestaande uit gezonde personen betekent dit onder andere dat hun kansen op het verkrijgen van de diverse vormen van coronaire hartziekten ongeveer gelijk zijn. Voor een groep bestaande uit personen met coronaire hartziekten betekent dit, dat deze patiënten min of meer in hetzelfde stadium van de ziekte verkeren en dat hun prognoses dezelfde zijn.

De derde laag van de indeling in groepen vindt met name plaats binnen de ziektegroepen. In de praktijk blijkt de intensiteit van de behandeling sterk samen te hangen met diverse patiënt-kenmerken, die de ernst van het stadium verfijnder uitdrukken (bijvoorbeeld aantal aangedane kransslagaders, resterende functionaliteit van het linker ventrikel). Deze opdeling is vooral noodzakelijk zowel van- 
uit prognostisch oogpunt als vanuit kostenoogpunt. Intensievere behandelingen zijn uiteraard duurder.

Wij hebben er naar gestreefd de stratificatie van de bevolking naar risicogroepen zoveel mogelijk met het CHZ-ziekteproces in overeenstemming te laten komen. In figuur II.1 wordt het CHZ-ziekteverloop in sterk vereenvoudigde vorm gepresenteerd.

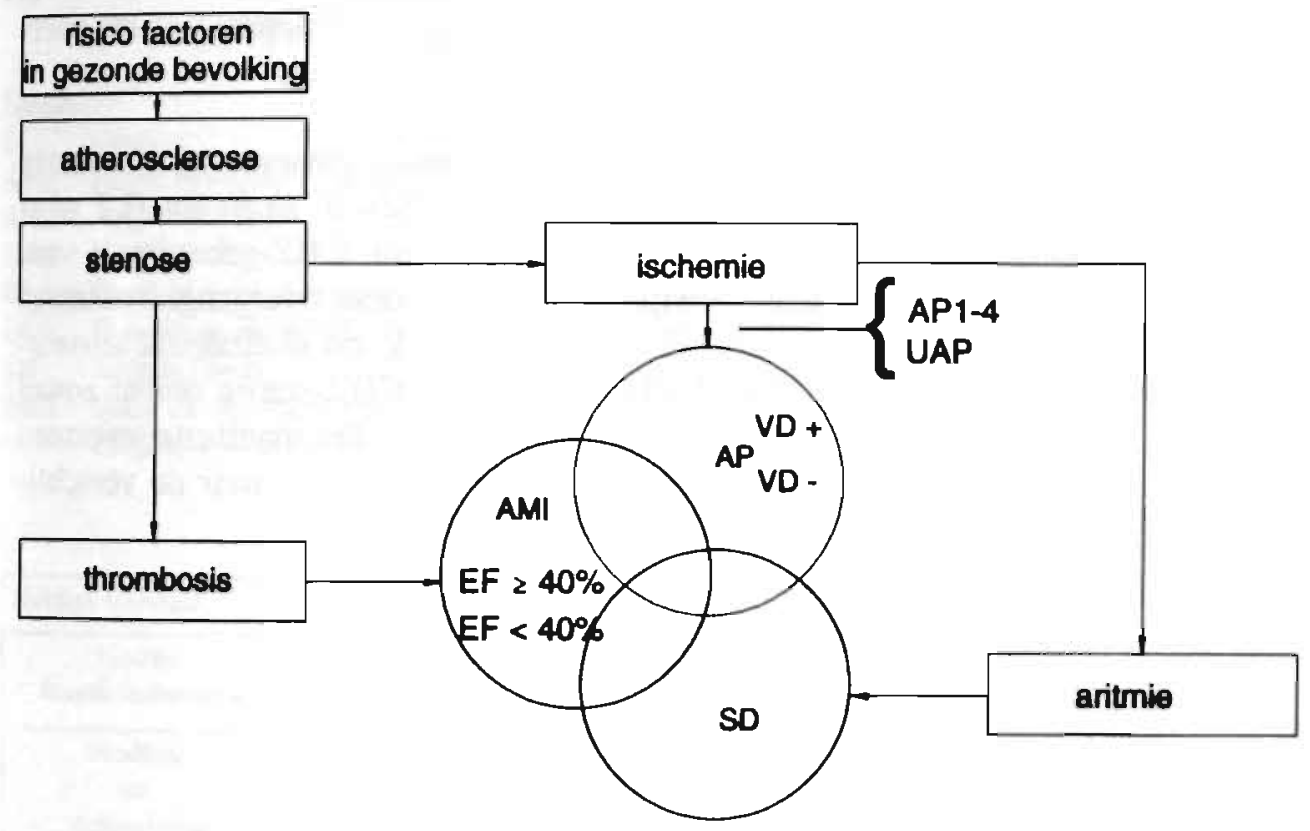

Figuur II.1 Schematische weergave ziekteverloop van $\mathrm{CHZ}$

Het atherosclerotisch proces wordt in figuur II.1 in gang gezet door de aanwezigheid van (verhoogde) risicofactoren in de gezonde bevolking. Er ontstaat stenosevorming met als gevolg ischemie. Thrombosis is de aanduiding voor het (nagenoeg) geheel afsluiten van een vernauwde kransslagader door een bloedstolsel, met als gevolg een acuut myocard infarct (AMI). De hoogte van de ejectiefractie (EF) die na een AMI resteert (restniveau $E F$ ) wordt aangeduid met $E F \geq$ $40 \%$ (redelijk tot goed) en EF $<40 \%$ (matig tot slecht). De angineuze pijnklachten die zich bij ischemie van de hartspier uiten zijn aangeduid met AP1-4 (angina pectoris klasse 1 tot en met klasse 4). De UAP wordt door ons hier weergegeven als een bijzondere variant van een emstige mate van AP (klasse AP3 tot 
AP4). Het aantal vernauwde kransslagaders is aangegeven met single vessel disease (SVD) en multiple vessel disease (MVD). SVD en MVD staan voor 1 tot 2 kransslagadervernauwingen respectievelijk 2 of meer kransslagadervernauwingen. De plotse hartdood (SD) treedt op als gevolg van aritmiën.

Elke manifestatievorm is uitgebeeld met een cirkel. De toestanden die bij de manifestatievormen horen zijn relatief kortdurende toestanden. Al dan niet ten gevolge van een therapeutische behandeling verwordt de toestand waarin de patiënt verkeert tot een latente vorm van $\mathrm{CHZ}$. Als gevolg van een herhaalde incidentie wordt de latente $\mathrm{CHZ}$-toestand als het ware geactiveerd. Het gebied waarin de cirkels van de verschillende manifestatievormen elkaar overlappen laat de overgang naar een nieuwe manifestatievorm zien.

De verschillende $\mathrm{CHZ}$-gebeurtenissen die zich kunnen presenteren als eerste manifestatievorm worden in de figuren II.2 en II.3 gegeven. In figuur II.2 worden de overgangen weergegeven die ontstaan wanneer een $\mathrm{CHZ}$-gebeurtenis vanuit de gezonde bevolking ontstaat, terwijl in figuur II.3 deze overgangen ontstaan vanuit een latente toestand van CHZ. Een CHZ-patiënt komt uiteindelijk te overlijden aan niet-CHZ-sterfte (DOV) of CHZ-sterfte. De CHZ-sterfte omvat zowel de sterfte aan SD (DSD) als de sterfte aan AMI (DMI). De manifestatievormen zijn voor de overzichtelijkheid in de figuren niet onderscheiden naar de verschillende prognostische kenmerken (of subgroepen). 


\begin{tabular}{|c|c|l|l|l|l|c|}
\hline Huidige toestand & \multicolumn{6}{|c|}{ G E Z O N D } \\
\hline $\begin{array}{c}\text { Eerste } \\
\text { Manffestatievorm }\end{array}$ & $\begin{array}{c}\text { AP1-2 } \\
\text { of }\end{array}$ & UAP & AMI & SD & SOD & geen \\
\hline $\begin{array}{c}\text { Stadium } \\
\text { na } \\
\text { behandeling }\end{array}$ & $\begin{array}{c}\text { latent CHZ } \\
\text { of } \\
\text { CHF }\end{array}$ & $\begin{array}{l}\text { Iatent CHZ } \\
\text { of DMI } \\
\text { of DSD }\end{array}$ & $\begin{array}{l}\text { Istent CHZ } \\
\text { of DMI } \\
\text { of CHF }\end{array}$ & $\begin{array}{l}\text { latent CHZ } \\
\text { of } \\
\text { DSD }\end{array}$ & DOV & G \\
\hline
\end{tabular}

Figuur II.2

Overgangen van de toestand gezond naar een toestand na afloop van de bebandeling van een manifestatie van $\mathrm{CHZ}$

Legenda:

G Gezond

AMI Acuut Myocard Infarct

AP Angina Pectoris

UAP Unstable AP

DMI Dood in samenhang met een MI

DOV Dood door niet-CHZ oorzaak

SD Sudden Death

DSD Dood na een sudden death

CHF Congestive Hear Failure

\begin{tabular}{|c|l|l|l|l|l|c|}
\hline Huidige toestand & \multicolumn{5}{|c|}{ latent CHZ } \\
\hline $\begin{array}{c}\text { Nlenwe } \\
\text { Manifestatievorm }\end{array}$ & AP3-4 & UAP & AMI & SD & DOV & Geen \\
\hline $\begin{array}{c}\text { Stadium } \\
\text { na } \\
\text { Behandeling }\end{array}$ & $\begin{array}{l}\text { Iatent CHZ } \\
\text { of } \\
\text { CHF }\end{array}$ & $\begin{array}{l}\text { Iatent CHZ } \\
\text { of DMI } \\
\text { of CHF }\end{array}$ & $\begin{array}{l}\text { latent CHZ } \\
\text { of DMI } \\
\text { of CHF }\end{array}$ & $\begin{array}{l}\text { Istent CHZ } \\
\text { of } \\
\text { DSD }\end{array}$ & DOV & $\begin{array}{l}\text { Latent } \\
\text { CHZ }\end{array}$ \\
\hline
\end{tabular}

Figuur $\Pi 1.3$

Toestandsovergangen van CHZ-patiënten (geclassificeerd als AP1-2 of MI+AP1-2) ten gevolge van een recurrente manifestatie van $\mathrm{CHZ}$

Legenda:

G Gezond

AMI Acuut Myocard Infarct

AP Angina Pectoris

UAP Unstable AP

DMI Dood in samenhang met een MI

DOV Dood door niet-CHZ oorzaak

SD Sudden Death

DSD Dood a een sudden death

CHF Congestive Heart Failure

MI Myocard Infarct 


\section{Subgroepen toestand Gezond}

De risicofactoren in het model zijn leeftijd, geslacht, serumcholesterolniveau, diastolische bloeddruk en rook gedrag. We hebben gekozen voor 99 leeftijdscategorieën, beginnende bij de 0 -jarigen tot de 100 -jarigen, 2 geslachten, 3 niveaus serumcholesterol $(<6,5 \mathrm{mmol} / \mathrm{l}, 6,5-8,0 \mathrm{mmol} / \mathrm{l}$, en $\geq 8 \mathrm{mmol} / \mathrm{l}), 3$ niveaus diastolische bloeddruk (<90 mmHG, $90-95 \mathrm{mmHg}$, > $95 \mathrm{mmHg}$ ), en 2 typen rookgewoontes (rokers en niet-rokers). De keuzen voor deze afkappunten zijn in Bijlage I toegelicht. In wezen laten we de CHZ-incidenties uit Gezond het model pas instromen vanaf de leeftijd 30 jaar, zodat er 61 leeftijdscategorieën zijn (de groep 0 -jarigen tot 30 -jarigen vertegenwoordigt én leeftijdscategorie).

Er zijn $71 * 2 * 3 * 3 * 2=2.556$ subgroepen in de toestand Gezond. Deze subgroepen kunnen worden geïnterpreteerd als homogene risicogroepen. Elke risicogroep heeft een eigen risicoprofiel. Iedere risicoprofiel vertegenwoordigt een unieke combinatie van de vijf risicofactoren.

\section{Subgroepen toestand CHZ}

De zieke personen verkeren na afloop van een CHZ-manifestatie in een bepaalde latente CHZ-toestand. Een latente CHZ-vorm heeft een verhoogde (relatieve) kans op een nieuwe CHZ-gebeurtenis. Deze nieuwe CHZ-gebeurtenis kan optreden in zowel het eerste jaar van de vorige CHZ-gebeurtenis (recurrente incidentie) als in de CHZ-bevolking (secundaire incidentie) (zie Bijlage I).

Op de verhoogde kansen zijn met name het restniveau van de ejectiefractie (EF) en de kwaliteit $(K)$ van het kransslagaderstelsel van invloed (zie vorige paragraaf). Aldus onderscheiden wij 5 typen latente $\mathrm{CHZ}$-vormen (5 "subgroepen toestand $\mathrm{CHZ}$ "), te weten:

$\mathrm{K}^{+} \quad$ Personen die (nog) geen hartinfarct gehad hebben, maar wel een opname ten gevolge van AP. De globale kwaliteit van de kransslagaders is nog behoorlijk.

$\mathrm{K}^{-} \quad$ Personen die (nog) geen hartinfarct gehad hebben, maar wel een opname ten gevolge van AP. De globale kwaliteit van de kransslagaders is matig tot slecht.

$\mathrm{EF}^{+} / \mathrm{K}^{+}$Personen die minstens 1 keer een hartinfarct gehad hebben. De hartfunctie is nog redelijk: ejectiefractie $\geq 40 \%$. De globale kwaliteit van de kransslagaders is nog behoorlijk.

$\mathrm{EF}^{+} / \mathrm{K}^{-}$Personen die minstens 1 keer een hartinfarct gehad hebben. De hartfunctie is nog redelijk: ejectiefractie $\geq 40 \%$. De globale kwaliteit van de kransslagaders is matig tot slecht.

EF $^{-} \quad$ Personen die minstens 1 keer een hartinfarct gehad hebben. De hartfunctie is matig tot slecht: ejectiefractie $<40 \%$. 
Deze 5 subgroepen zijn naar geslacht en leeftijd onderscheiden. Er wordt geen onderscheid gemaakt naar de hoogte van de risicofactoren.

Wij hebben met betrekking tot de onderscheiding van de CHZ-subgroepen een aantal uitgangspunten in het model verwerkt:

(i) De keuze die met betrekking tot een bepaalde therapeutische behandeling is gemaakt bepaalt mede het verdere ziekteverloop. De prognostische betekenis van de therapeutische behandeling wordt impliciet door de "kwaliteit van het kransslagaderstelsel" $(K)$ en het restniveau van de EF aangegeven. Zodoende zijn de 5 "sub-groepen toestand CHZ" in het model gekoppeld aan de laatste therapeutische behandeling.

Dit betekent dat uit het brugmodel geen patiënten van het type $\mathrm{K}^{-}$in de latente $\mathrm{CHZ}$-toestand kunnen stromen. De introductie van de deelgroep $\mathrm{K}^{-}$ stelt ons zodoende in staat om het resultaat van de therapeutische behandeling daadwerkelijk in het model aan te geven. Namelijk patiënten die als $\mathbf{K}^{-}$ het ziekenhuis binnenkomen verlaten deze weer als $\mathrm{K}^{+}$bij geslaagde behandeling. Hetzelfde geldt voor $\mathrm{EF}^{+} / \mathrm{K}^{-}$. We nemen dus aan dat een geslaagde behandeling leidt tot een redelijke kwaliteit van het kransslagaderstelsel.

(ii) De CHZ-bevolking kent patiëntenstromen die van de $\mathrm{K}^{+}$naar de $\mathrm{K}^{-}$en van de $\mathrm{EF}^{+} / \mathrm{K}^{+}$naar de $\mathrm{EF}^{+} / \mathrm{K}$ - gaan. Deze stromen reflecteren het geleidelijke proces van verslechtering van de kwaliteit van het kransslagaderstelsel. Wij hebben deze patiëntenstromen voor de $\mathrm{K}^{+}$naar $\mathrm{K}^{-}$op jaarlijks $3 \%$ van de totale $\mathrm{K}^{+}$-groep vastgesteld. Voor de patiëntenstroom van $\mathrm{EF}^{+} / \mathrm{K}^{+}$naar de $\mathrm{EF}^{+} / \mathrm{K}^{-}$betreft dit $17 \%$ van de totale $\mathrm{EF}^{+} / \mathrm{K}^{+}$-groep. De reden dat deze laatste kans aanzienlijk hoger is komt omdat deze mensen in het verleden een hartinfarct meegemaakt hebben.

(iii) In het eerste jaar van de CHZ-gebeurtenis onderscheiden zich de sub-toestanden "zonder recurrentie", "wel recurrentie", en "na recurrentie". De patiëntenstroom in de subtoestand "zonder recurrentie" komt overeen met de patiëntenstroom waarbij in hetzelfde jaar van het eerste ontslag geen recurrente manifestatie optreedt. De patiëntenstromen die in de subtoestand "wel recurrentie" terecht komen worden in hetzelfde jaar van de eerste gebeurtenis voor de tweede keer opgenomen en komen na het tweede ontslag in de subtoestand "na recurrentie" terecht. Deze laatste twee patiëntenstromen zijn niet identiek zijn omdat er tijdens de recurrentie in hetzelfde jaar een aantal mensen zal overlijden. Aan het einde van het eerste jaar gaan de patiëntenstromen zonder recurrentie en na recurrentie gezamenlijk over naar de CHZ-bevolking. 
In het algemeen zullen de personen die in de sub-toestand "na recurrentie" terecht komen een slechtere conditie van de kwaliteit van het kransslagader. stelsel gekregen hebben. Bij de meeste personen in deze subgroep zal ook een verdere verslechtering van het restniveau van de EF zijn opgetreden. Deze personen komen veelal terecht in de subtoestand EF- of via het "bakje" $\mathrm{EF}+/ \mathrm{K}+$ in de chronische toestand EF-/K-.

\section{CHZ-gebeurtenissen}

In het model kunnen $5 \mathrm{CHZ}$-gebeurtenissen (manifestaties) plaatsvinden, te weten:

SD, AMI, UAP, AP3-4, en AP1-2. Elke CHZ-gebeurtenis kan worden onderscheiden in 5 typeringen:

$\begin{array}{ll}- & \text { SVD, } \\ - & \mathrm{MVD}, \\ - & \mathrm{EF} \geq 40 \%+\mathrm{SVD}, \\ - & \mathrm{EF} \geq 40 \%+\mathrm{MVD}, \\ - & \mathrm{EF}<40 \% .\end{array}$

De SVD (Single Vessel Disease) en de MVD (Multiple Vessel Disease) zijn typeringen die worden gebruikt bij de manifestaties AP1-2, AP3-4 en UAP. De andere typeringen hebben betrekking op een AMI waarbij EF de resterende functionaliteit van de hartspier uitdrukt. Voor de overlevenden van een SD zal steeds $\mathrm{EF}<40 \%$ gelden.

Deze 5 typeringen zijn de anatomische voorbodes van de meer klinisch gebaseerde indeling die bij de CHZ-bevolking gemaakt is. Zo zal een AP1-2 van type SVD bijna steeds leiden tot een $\mathrm{K}^{+}$-patiënt. Maar ook een AP3-4 met MVD zal bij geslaagde behandeling leiden tot een $\mathrm{K}^{+}$-patiënt. Het is dus niet zo dat SVD met $\mathrm{K}^{+}$overeenkomt, MVD met $\mathrm{K}^{-}$, enz. De hier geïntroduceerde typering is gemaakt in verband met de indicatiestellingen en prognoses met betrekking tot de ziekteduur en dus de kosten van de behandelingen.

De manifestatievormen AP1-2, AP3-4, en UAP behouden in de initiële fase als het ware per definitie een goede restniveau van de EF ( $E F \geq 40 \%$ ). Zoals eerder toegelicht kan er alleen een verlaagde EF ontstaan als gevolg van een AMI (zie vorige paragraaf $\Pi .2$ in dit hoofdstuk).

Elk ziektestadium in de latente CHZ-toestand kan gevolgd worden door eén van de verschillende vormen van een nieuwe $\mathrm{CHZ}$-manifestatievorm, te weten: SD, AMI, UAP en AP3-4. De AP1-2 vindt alleen als initiële incidentie plaats.

De UAP en AP3-4 die volgen op $\mathrm{K}+$ respectievelijk $\mathrm{EF}+/ \mathrm{K}+$ kennen een onderscheiding naar SVD of MVD, respectievelijk naar EF $\geq 40 \%+$ SVD of EF $\geq$ 
40\% + MVD. Een UAP of AP3-4 die plaatsvinden na een EF-, respectievelijk $\mathrm{K}$-, respectievelijk EF+/K-, worden getypeerd als EF < 40\%, MVD, respectievelijk $\mathrm{EF} \geq 40 \%$ + MVD.

Wanneer er een AMI optreedt, vindt de definiëring per definitie plaats uit een subgroep met een $\mathrm{EF} \geq 40 \%$ of een $\mathrm{EF}<40 \%$. Bijvoorbeeld, een AMI na een $\mathrm{K}+$ kent een onderscheiding naar $\mathrm{EF} \geq 40 \%+\mathrm{SVD}$ of $\mathrm{EF}<40 \%$, terwijl een $\mathrm{AMI}$ na $\mathrm{K}$ - onderscheiden wordt naar $\mathrm{EF} \geq 40 \%+\mathrm{MVD}$ of $\mathrm{EF}<40 \%$.

\section{II.4 Behandelingstrajecten}

Een medische behandeling brengt kosten met zich mee. Het is daarom van belang te weten hoe vaak iedere medische behandeling jaarlijks verricht wordt. Wij hebben behandelingstrajecten ontwikkeld teneinde het jaarlijkse aantal medische behandelingen te kunnen bepalen.

De behandelingstrajecten komen volgtijdelijk globaal overeen met de behandelingsfasen waarin de $\mathrm{CHZ}$-patiënten verkeren. Wij onderscheiden drie typen behandelingstrajecten:

1) een voortraject,

2) een opnametraject, en

3) een follow-up traject.

Het follow-up traject wordt onderscheiden in twee tijdsperioden: het follow-up traject gedurende het eerste jaar na de manifestatie $(<1$ jaar) en het follow-up traject voor de periode na het eerste jaar na de manifestatie ( $\geq 1$ jaar). Het voortraject en het opnametraject spelen zich af in het brugmodel. Het follow-up traject start in het brugmodel en gaat aan het eind van het eerste jaar over in het morbiditeitsmodel.

Er zijn binnen een behandelingstraject behandelingsgangen gedefinieerd die door de verschillende patiëntenstromen doorlopen worden. Een patiëntenstroom bestaat uit een homogene groep van personen die dezelfde patiëntkenmerken hebben. Een behandelingsgang wordt uitgedrukt als kansen op bepaalde medische behandelingen.

De basisschema's in de behandelingstrajecten zijn opgebouwd uit beslis-, kansen behandelknopen. De beslisknopen worden aangegeven met "Arts", omdat deze betrekking hebben op een therapiekeuze die door een arts gedaan wordt. De kansknopen hebben twee betekenissen. Ze geven aan of een therapie succesvol dan wel niet-succesvol is geweest en of een diagnostisch onderzoek een positieve dan wel een negatieve uitslag heeft gegeven. De diagnostische onderzoekingen dienen vooral ter ondersteuning van de keuzen in de "Arts-knooppunten". In het 
basisschema wordt de testuitslag door een coronair angiogram (CAG) bepaald. In feite worden de kansknopen hier gebruikt als middel om de natuurlijke variatie in het ziektebeloop te representeren.

De behandelknopen komen overeen met de 3 typen therapeutische behandelingen MED, CABG en PTCA. Patiënten met een AMI die snel genoeg in het ziekenhuis arriveren kunnen een behandeling met intraveneuze thrombolytica (IVT) krijgen. Een succesvolle behandeling wordt gevolgd door ontslag naar het follow-up traject.

Bij elke overgangskans tussen twee behandelingen kunnen patiënten sterven. Om het overzicht te bewaren wordt in de stroomschema's de uitval wegens sterfte niet overal aangegeven. Alleen de operatiesterfte en de zogenaamde fatale $\mathrm{MI}$ in het ziekenhuis na opname (FMI2) zijn in geaggregeerde vorm opgenomen. In de schema's komt een niet succesvolle behandeling overeen met overlijden. In geval van een MED-behandeling wordt dit gecodeerd als FMI2 (fatale MI tijdens de behandelfase) en in geval van een operatie wordt dit gecodeerd als OM, dat staat voor operatie mortaliteit (zie ook Bijlage I).

\section{Voortraject}

In de regel wordt een $\mathrm{CHZ}$-patiënt eerst dan opgenomen wanneer de symptomen alarmerend worden of wanneer een hartinfarct (MI) al dan niet gevolgd door een hartstilstand plaatsvindt. De instroom in het voortraject bestaat uit patiënten met (vermoede) initiële coronaire pijnklachten die al dan niet als AP worden gediagnostiseerd. De AMI- en UAP-patiënten kennen geen voortraject vanwege het acute karakter van de manifestatievorm.

Het voortraject gaat aan het opnametraject vooraf. De initiële AP-patiënt blijf onder geregelde poliklinische controle staan totdat een (eventuele) ziekenhuisopname volgt. Een poliklinische controle omvat een medicamenteuze behandeling, aangevuld met periodieke diagnostische testen, inspanningstesten, echocardiografie etc. De berekening van het aantal personen in 1988 dat het voortraject binnenkomt is gebaseerd op gegevens van het SIG (1992) met betrekking tot 1988 en de Gezondheidsraad (1984/18).

De periode tussen het zich openbaren van klachten of verschijnselen van $\mathrm{CHZ}$ en de kritische fase in het ziekteverloop speelt zich grotendeels af bij de cardioloog. Elk jaar wordt ca. $12 \%$ van het aantal patiënten dat via de cardioloog/poli instroomt opgenomen als AP3-4 (Gezondheidsraad, 1984/18). Het grootste deel van de cardioloog/poli-instroom (ca. 73\%) wordt opgenomen voor diagnostisch onderzoek met behulp van de CAG (CCA enquête, 1989). Het resterende deel (ca. $15 \%$ ) blijft 7 jaar in het voortraject. Deze patiënten zijn ten onrechte als AP gediagnostiseerd en worden na 7 jaar van verdere medische controle ontslagen (Laird-Meeter e.a., 1988/2, Gezondheidsraad, 1984/18). 
Het voortraject wordt in figuur $\amalg .4$ afgebeeld. Hierbij moet men zich realiseren dat de posities huisarts en cardioloog meerdere keren kunnen worden bezocht.

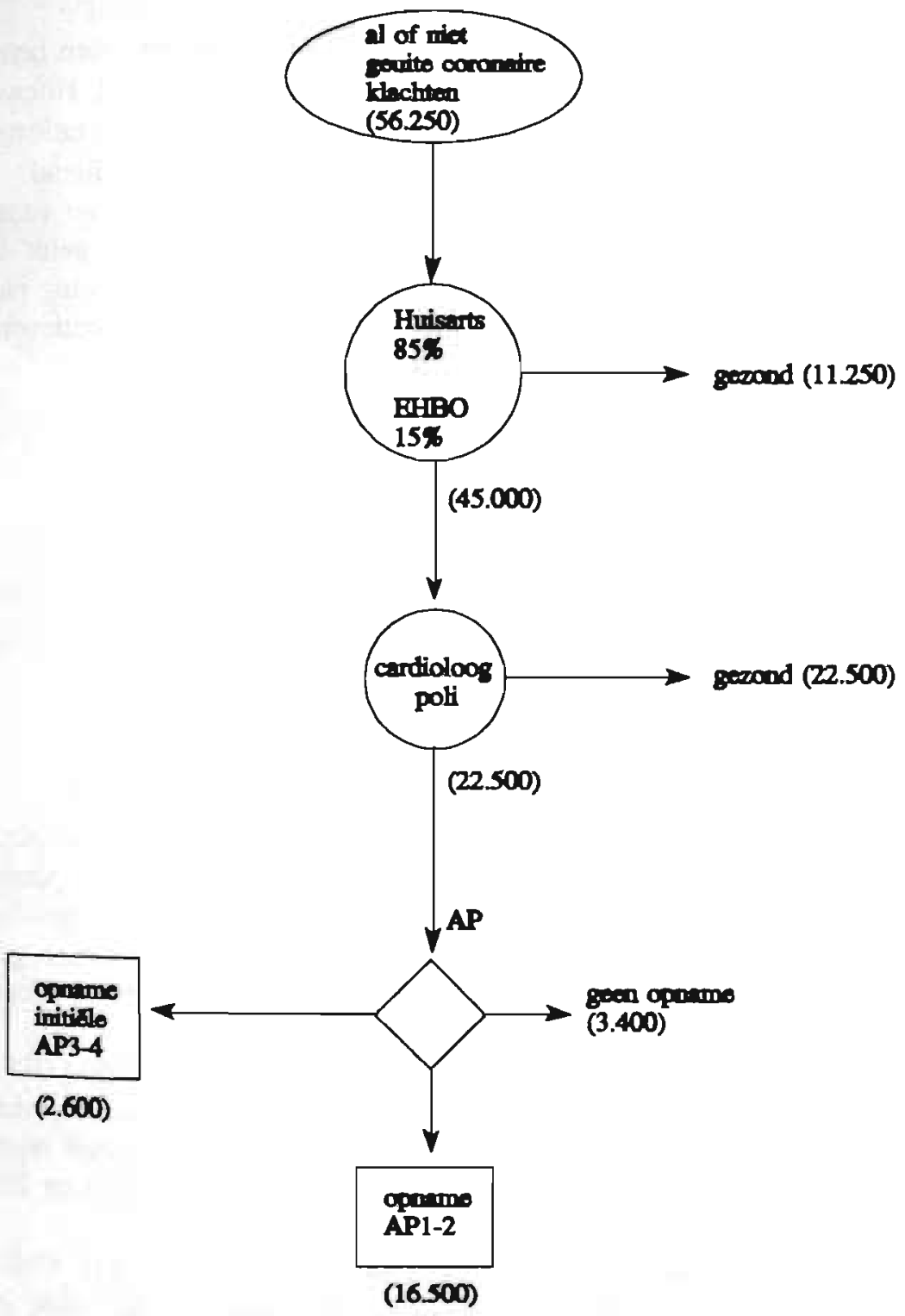

Figuur II.4

Het voortraject voor de personen met initiële AP-manifestaties.

De aantallen hebben betrekking op het jaar 1988 


\section{Opnametraject}

Het opnametraject geeft alle therapeutische behandelingen weer die tijdens de ziekenhuisopname (klinische opname) verricht worden. De type manifestatievom bepaalt welk opnametraject gekozen wordt. We onderscheiden een AMI-, een UAP- en een AP-opnametraject. Het AP-opnametraject kent een initiële AP1-2- en een AP3-4-opnametraject. De opnametrajecten hebben allen hetzelfde basisschema en worden in figuren II.5 tot en met II.8 afgebeeld. Hoewel de stroomschema's voor elkaar identiek zijn, zijn voor de vier manifestatievormen de intensiteit waarmede de diverse knopen doorlopen worden verschillend.

Het AP1-2 opnametraject in figuur II.5 betreft uitsluitend de instroom vanuit de gezonde bevolking. Voor de opnametrajecten AMI, UAP en AP3-4 geldt dat de totale instroom de som is van de instroom vanuit de gezonde bevolking plus de instroom van oud-patiënten met de desbetreffende recurrente manifestatievormen. In de opnametrajecten wordt het volgende weergegeven:

1) opnames,

2) CHF-uitstroom,

3) therapeutische behandelingen,

4) CAG's,

5) FMI2 sterfte,

6) operatiemortaliteit,

7) ontslagen na 2de opname,

8) ontslagen zonder CHZ-recurrentie.

Wij veronderstellen dat alle opnames als "terecht" zijn gediagnostiseerd.

De CHZ-patiënten met CHF vormen een aparte groep. Deze patiënten stromen vanwege de afwijkende therapievorm het opnametraject uit als CHF-patiënten. De behandeling van de CHF-patiënten wordt in het model niet verder gevolgd. De kans op binnenkomst in het ziekenhuis (EHBO) met een ambulance is gekoppeld aan de manifestatievorm. Alle SD-patiënten, 50\% van de AMI-patiënten, en $50 \%$ van de UAP-patiënten worden per ambulance vervoerd.

De fatale MI-sterfte die buiten het ziekenhuis (FMI1) optreedt en de DSD worden niet als opname beschouwd. De FMI1 duidt de 24-uursterfte aan voordat een opname op een verpleegafdeling of een coronary care unit (CCU) heeft plaatsge-vonden. Wij hebben de sterfte die thuis, in de ambulance, of op de EHBO plaatsvindt tot de FMI1 gerekend.

De sterfte in het ziekenhuis (ziekenhuissterfte) wordt gevormd door de FMI2, de UAP- en AP-operatiesterfte. De FMI2 bestaat uit de som van de fatale AMIsterfte in het ziekenhuis na opname en de AMI-operatiesterfte. We rekenen tot de fatale AMI-sterfte ook de sterfte ten gevolge een nieuw hartinfarct (peri-M) en ritmestoornissen die in het ziekenhuis optreden. Meestal is in geval van een 
peri-MI een spoed operatie geïndiceerd. We hebben deze verfijning niet in de stroomschema's opgenomen. De overlevenden van peri-MI worden ontslagen. Veronderstel is dat deze patiënten in aanmerking komen voor een $2 \mathrm{e}$ opname in hetzelfde jaar.

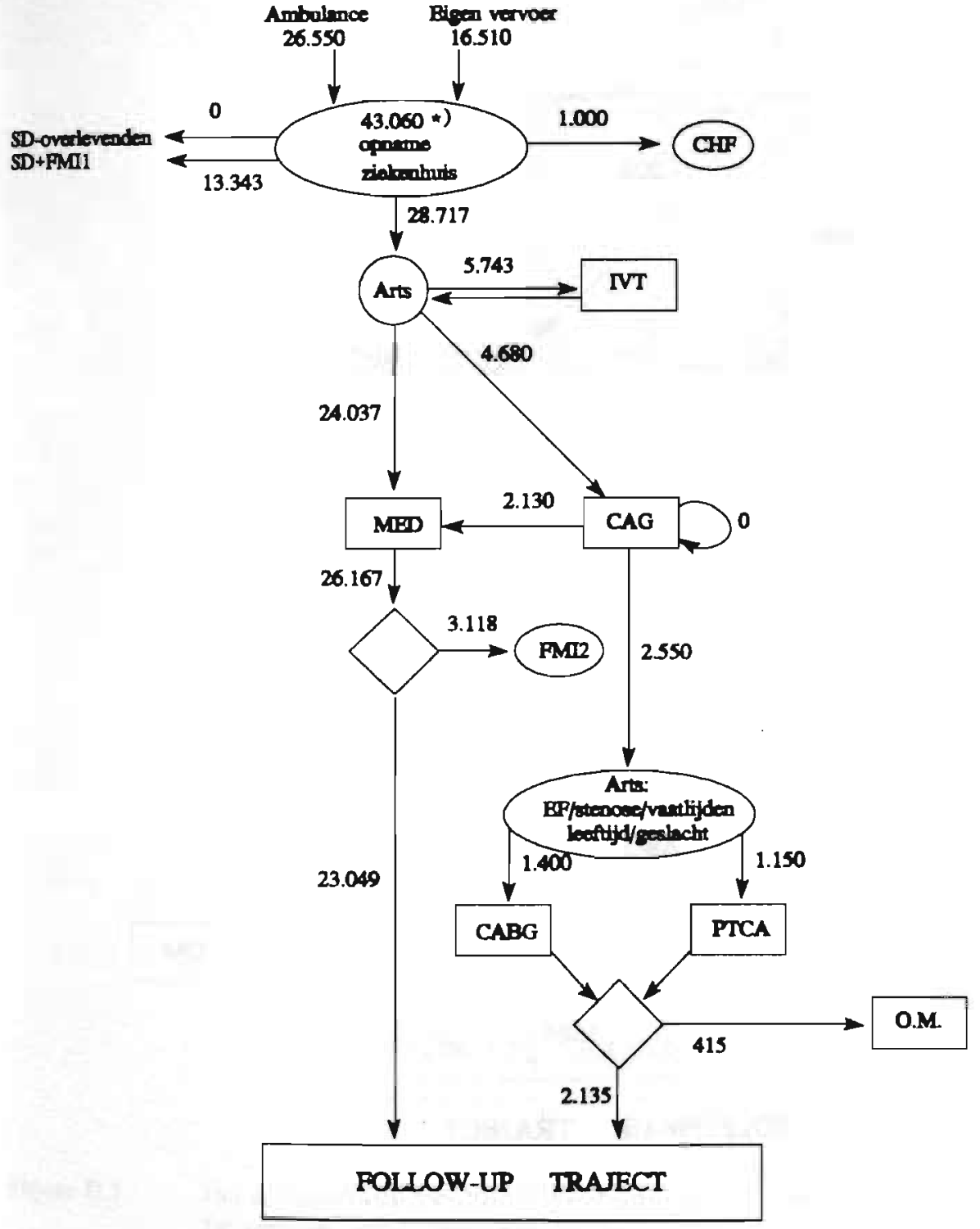

Figuur II.5 Het stroomschema voor bet opnametraject van AMI-patiënten.

De aantallen hebben betrekking op 1988 


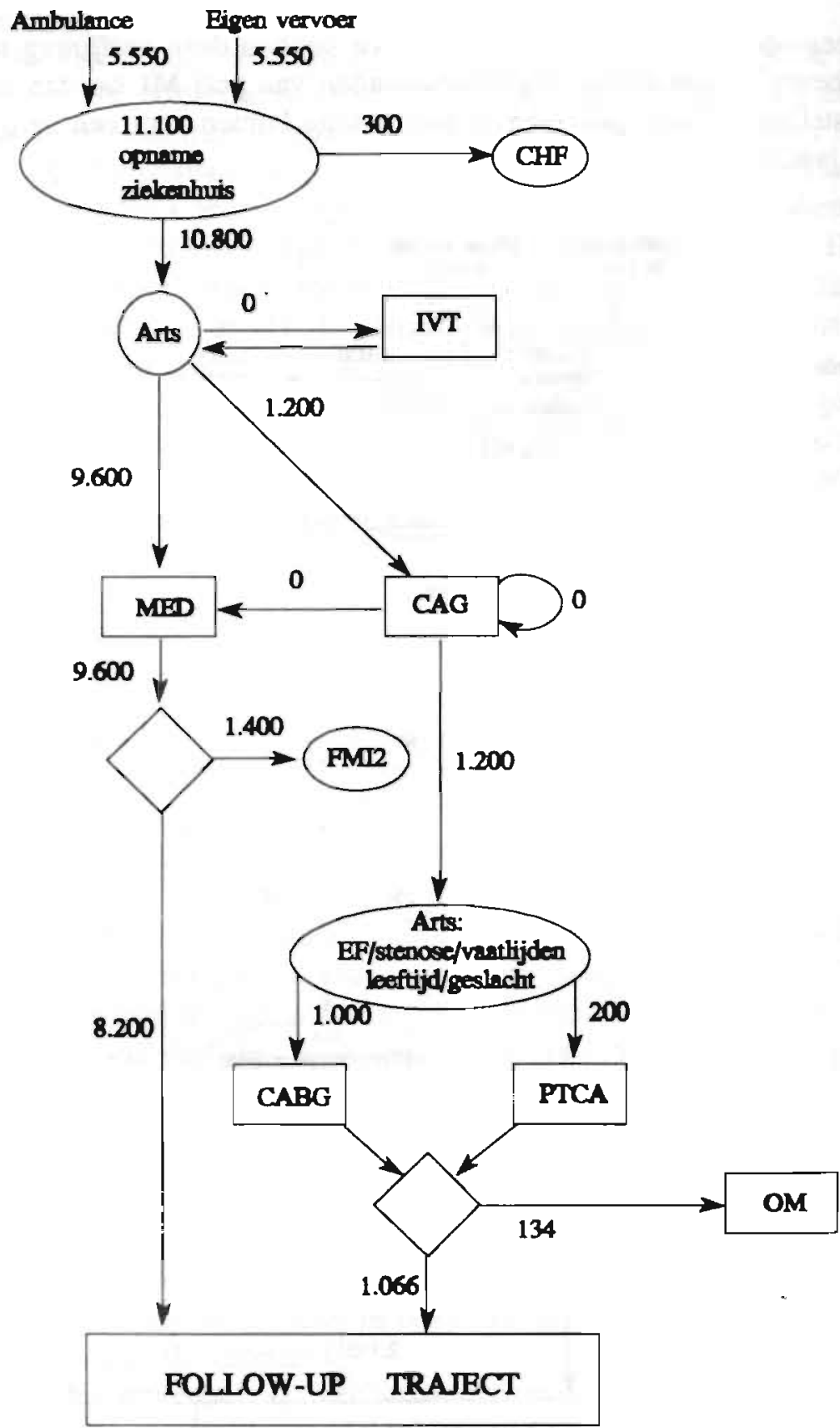

Figuur II.6

Het stroomschema voor het opnametraject van UAP-patiēnten. De aantallen hebben betrekking op 1988 


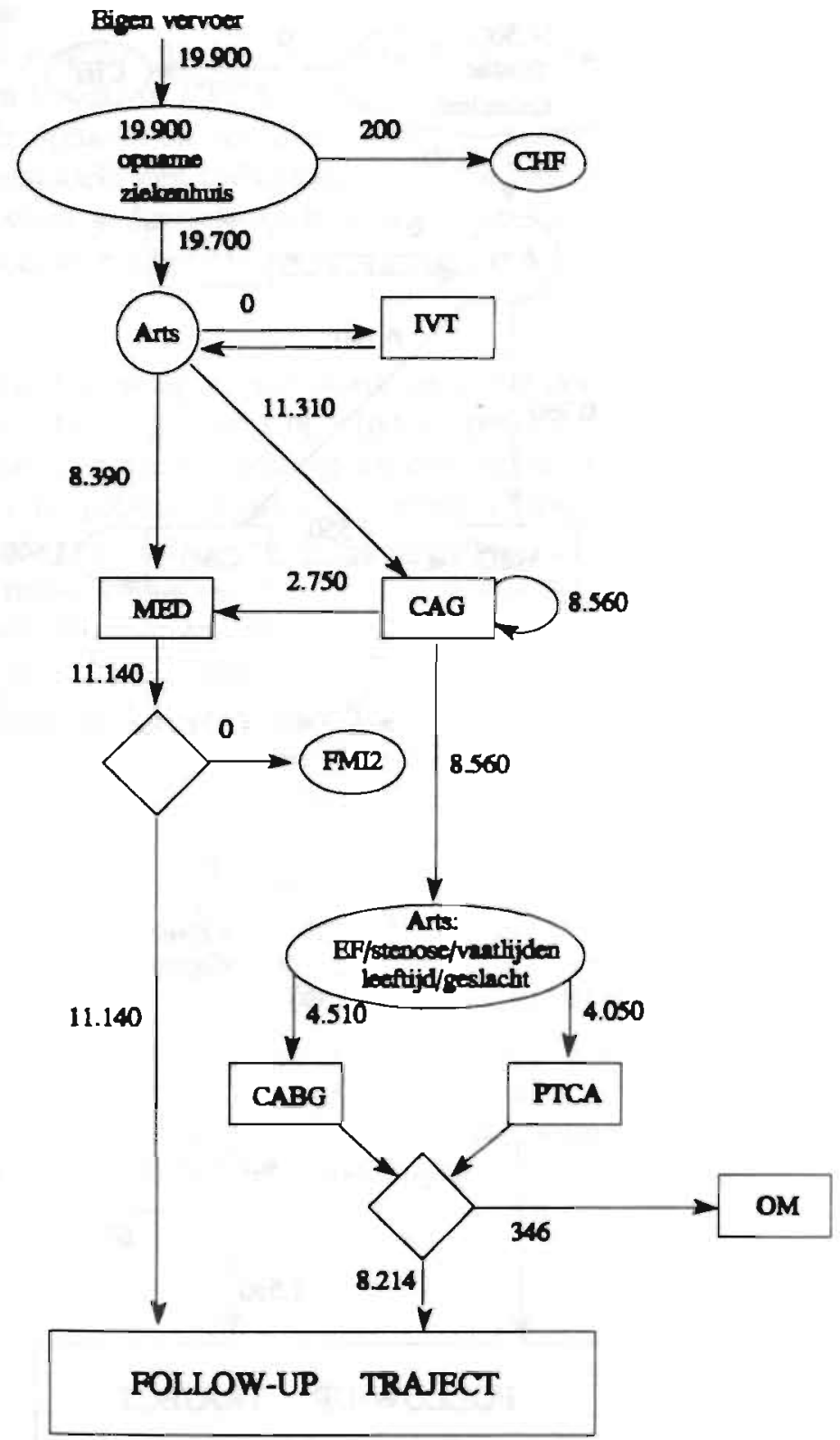

Figuur II.7

Het stroomschema voor het opnametraject van AP3-4 patièntén.

De aantallen hebben betrekking op 1988 


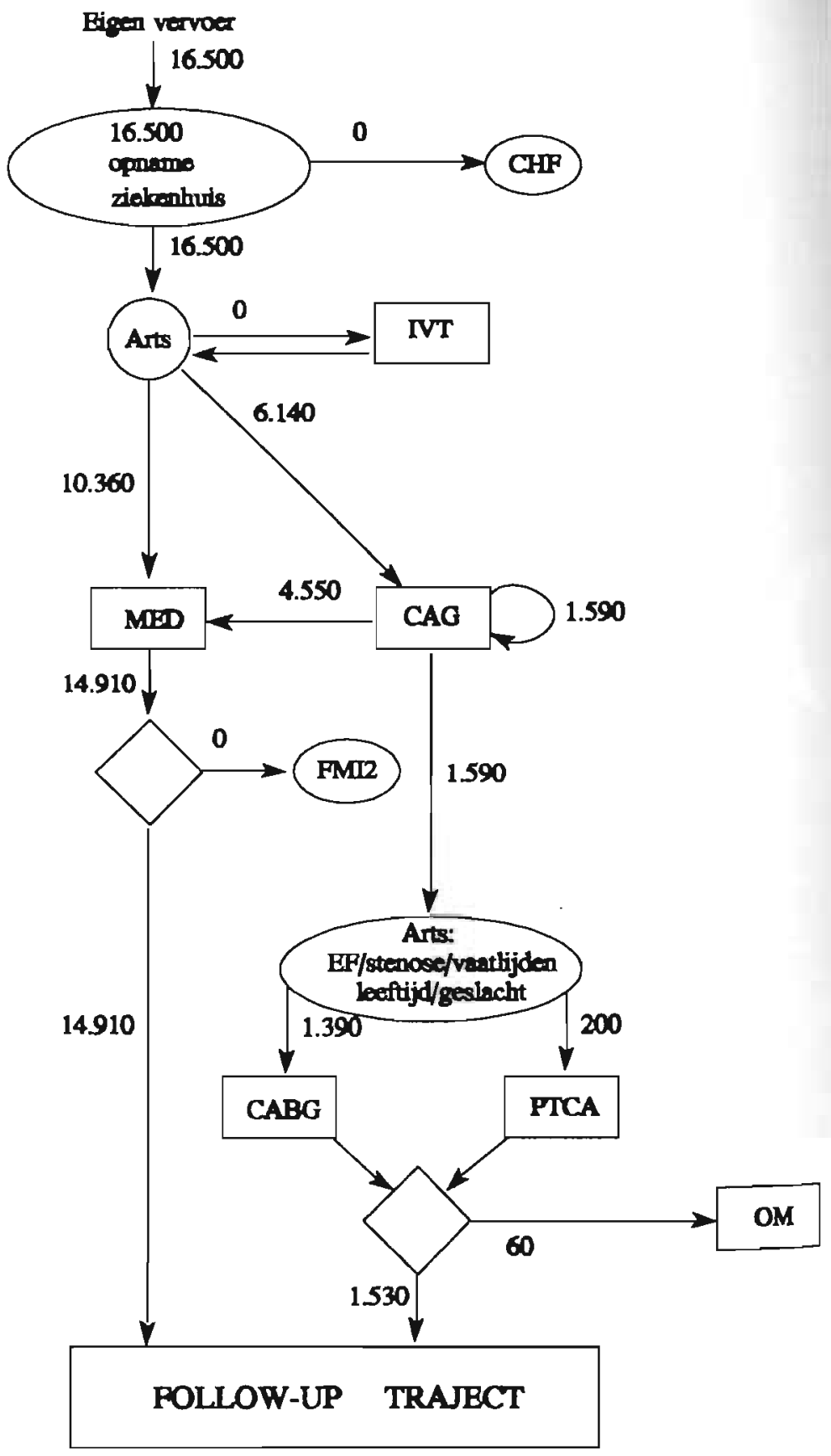

Figuur II.8 Het stroomschema voor het opnametraject van AP1-2 patiënten. De aantallen hebben betrekking op 1988 
Een AP1-2 opname wordt hoofdzakelijk ten behoeve van een beleidsbepalende (diagnostiek) CAG geïndiceerd. In een beperkt aantal gevallen wordt MVD vastgesteld, waarna een CABG of PTCA volgt.

Tussen een initiële opname en een eventuele heropname in hetzelfde jaar veronderstellen we gemiddeld een tijdsperiode van een half jaar. Hoewel niet in de figuren getekend, vindt gedurende dit half jaar eveneens een follow-up therapie plaats (zie de toelichting bij het follow-up traject).

\section{Follow-up traject}

De instroom van het follow-up traject wordt gevormd door de ontslagen uit het opnametraject. Het follow-up traject bestrijkt de periode vanaf het moment van ontslag uit het ziekenhuis tot het moment dat een nieuwe gebeurtenis optreedt of tot het moment dat de patiënt vrij is van verdere follow-up behandelingen. De follow-up behandelingen bestaan uit diagnostische onderzoekingen, medicatie, hartrevalidatie, en thrombosedienst.

Het follow-up traject is zoals eerder vermeld modelmatig opgeknipt in twee perioden. Namelijk de periode, volgend na de opnarne in hetzelfde jaar van optreden van de $\mathrm{CHZ}$, en de follow-up gedurende de periode na het eerste jaar.

$\mathrm{Na}$ ontslag uit het ziekenhuis volgt in de regel ontslagmedicatie van ca. 1 à 2 maanden, een poliklinische nacontrôle bestaande uit periodieke diagnostische testen (inspanningstesten, ECG's, laboratoriumbepalingen, thoraxfoto's e.d.), medische consulten en hartrevalidatie. Een deel van de ontslagen patiënten wordt doorverwezen naar een verpleeghuis. Deze patiënten worden in het model geïdentificeerd als hartinsufficiënt en worden niet verder gevolgd in het model.

Figuur II.9 geeft schematisch de eerste fase van het follow-up traject weer met daarin opgenomen de ondersteunende behandelingen Hartrevalidatie, Thrombosedienst en CAG. Afhankelijk van het gevolgde beleid volgt een groter of kleiner deel van de patiëntenpopulatie deze behandelingen. 


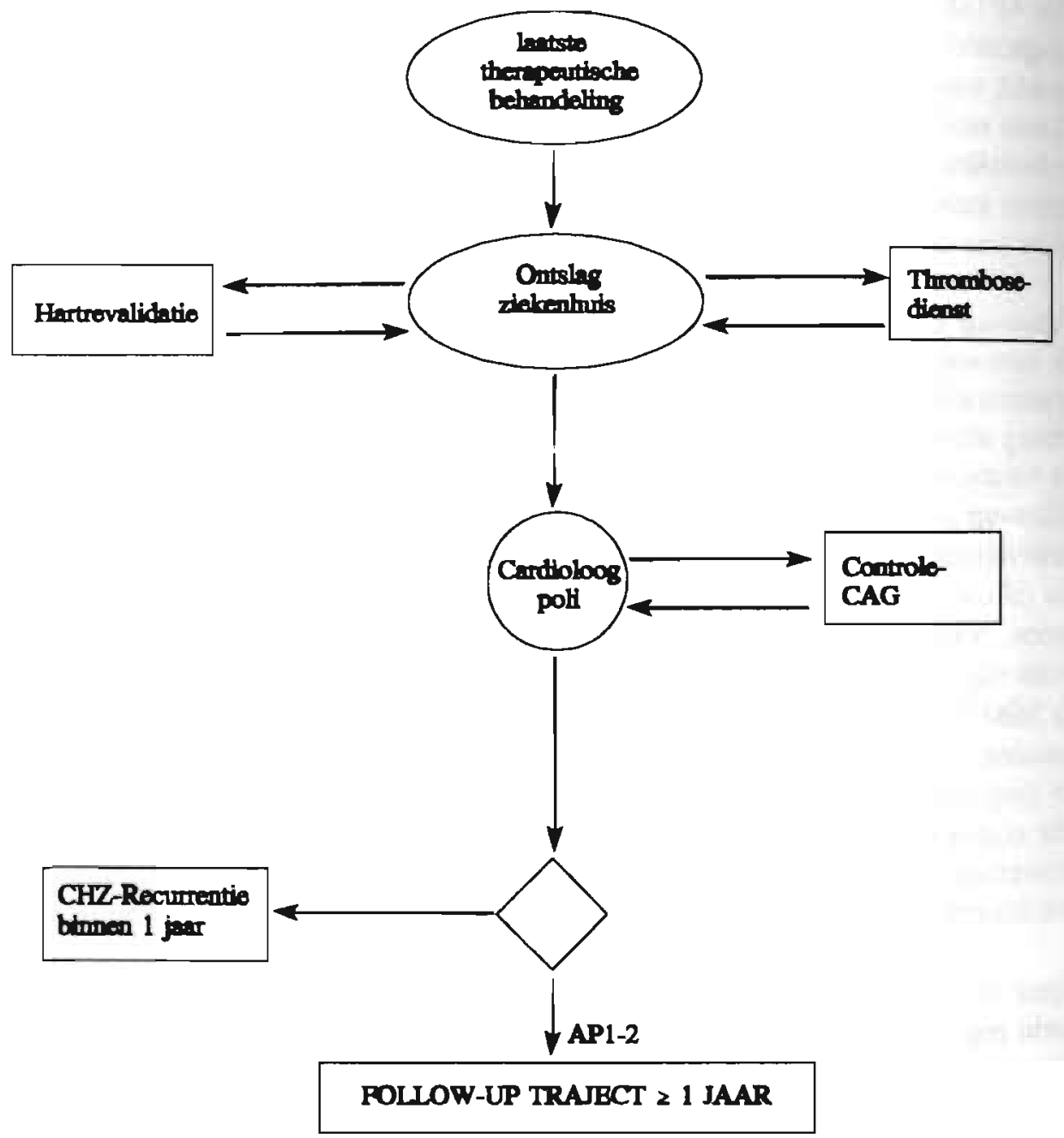

Figuur II.9

Stroomschema van het follow-up traject $<1$ jaar na ontslag uit het ziekenhuis

In een aantal gevallen wordt een CAG uitgevoerd. Bij een positieve uitslag van de CAG (vaak gedefinieerd als herstenose) kan besloten worden de patiënt opnieuw op te nemen. In geval de uitslag van de CAG negatief is wordt verondersteld dat de patiënt alleen nog vervolgmedicatie krijgt en/of periodiek een aantal diagnostische testen ondergaat. 
In ons model wordt een follow-up traject $<1$ jaar geacht 1 jaar te duren in het geval er geen recurrente manifestatie optreedt. Vindt er wel een recurrente manifestatie plaats dan duurt het tussenliggende follow-up traject gemiddeld een half jaar. Na ontslag van een opname ten gevolge van een recurrente manifestatie vindt er uiteraard ook een follow-up fase plaats. Hiervoor nemen we gemiddeld een $1 / 2$ jaar. De reden dat deze tijd korter genomen is, is dat we er van uitgaan dat de toestand van een dergelijke patiënt slechter is dan in het eerste geval, zodat de totale nabehandelingsfase korter duurt. De patiënt overlijdt sneller of krijgt sneller een volgende recurrente $\mathrm{CHZ}$-manifestatie.

De tweede fase van het follow-up traject is een voortzetting van de afbouwing van de medicatie en de frequentie van controlebezoeken aan de cardioloog (en eventueel de huisarts). In figuur $\Pi$.10 wordt het stroomschema van het follow-up traject $\geq 1$ jaar weergegeven. De duur van het traject hangt in het simulatiemodel samen met het restniveau van de ejectiefractie van de patiënt. 


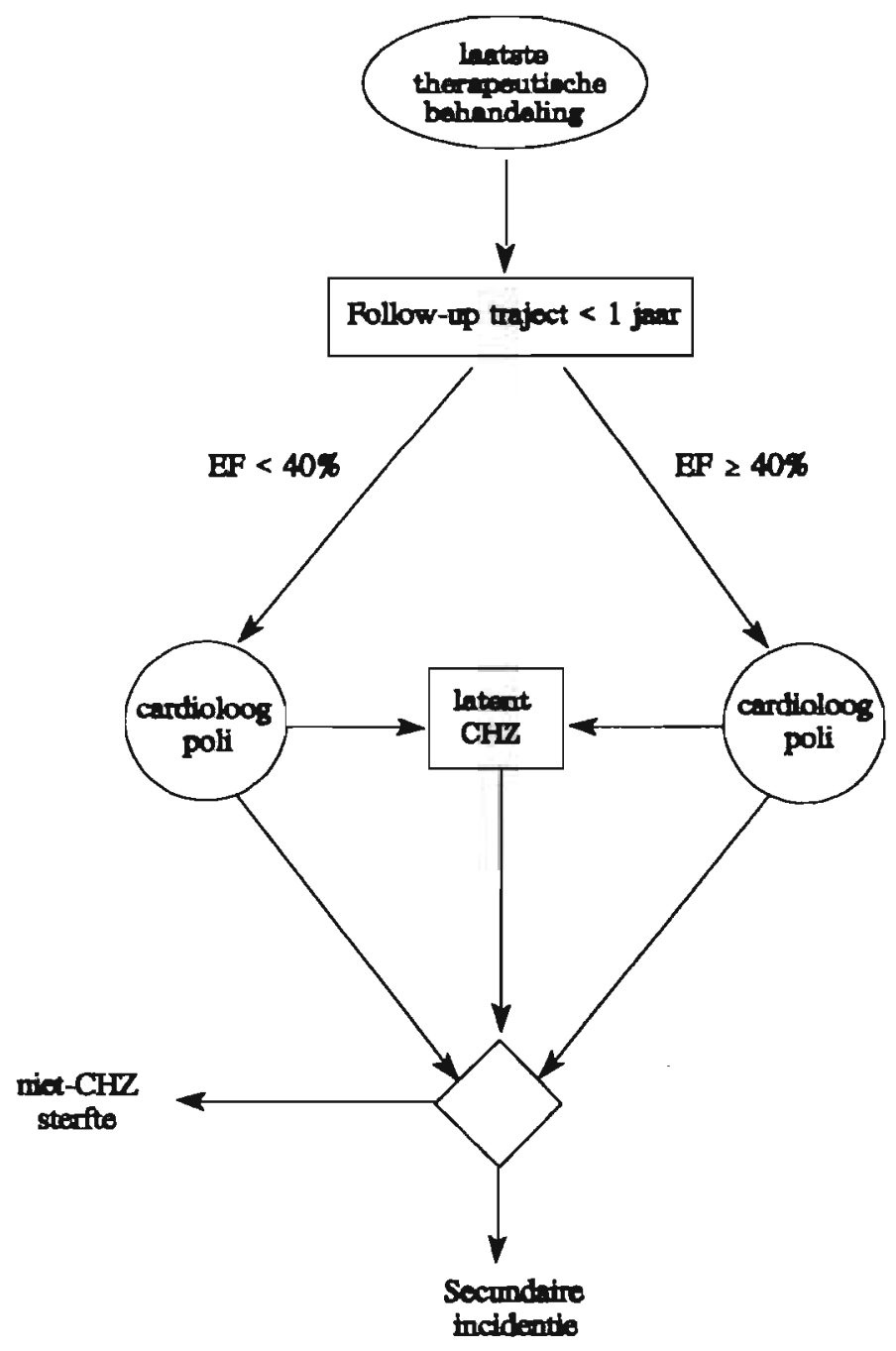

Figuur II.10 Stroomschema van bet follow-up traject $\geq 1$ jaar 


\section{II.5 Indicatiestelling Therapeutische Behandelingen}

In het model worden de gemaakte therapiekeuzen bepaald door een stratificatie van de indicatiestellingen. De indicatiestelling is in de praktijk doorgaans gebaseerd op patiënt-kenmerken, de kennis van de arts, de heersende opvattingen omtrent de beste behandelingswijzen, de technologische ontwikkeling en de beschikbare capaciteiten.

Wij hebben om praktische redenen (beschikbaarheid van data) de indicatiestelling (alleen) gebaseerd op patiënt-kenmerken. De kennis van de arts is sterk afhankelijk van de genoten opleiding en de ervaring die de arts heeft opgebouwd. De opvattingen omtrent de beste behandelingswijzen zullen door nieuwe inzichten als gevolg van technologische ontwikkelingen steeds bijgesteld worden. De indicatiestellingen kunnen per cardioloog verschillen. De beschikbare capaciteiten (of capaciteitsrestricties) zullen voor een belangrijk deel gebaseerd zijn op overwegingen van meer strategische aard.

In tabel II. 1 worden de criteria uitgewerkt op basis waarvan een patiënt voor een bepaalde therapie kan worden geïndiceerd. De toepassing hiervan in ons model wordt in de volgende paragraaf $\Pi$. 6 behandeld. De weergegeven indicatiestellingen zijn gebaseerd op bevindingen uit de literatuur en uit privé-communicatie (Janssen, 1991). 


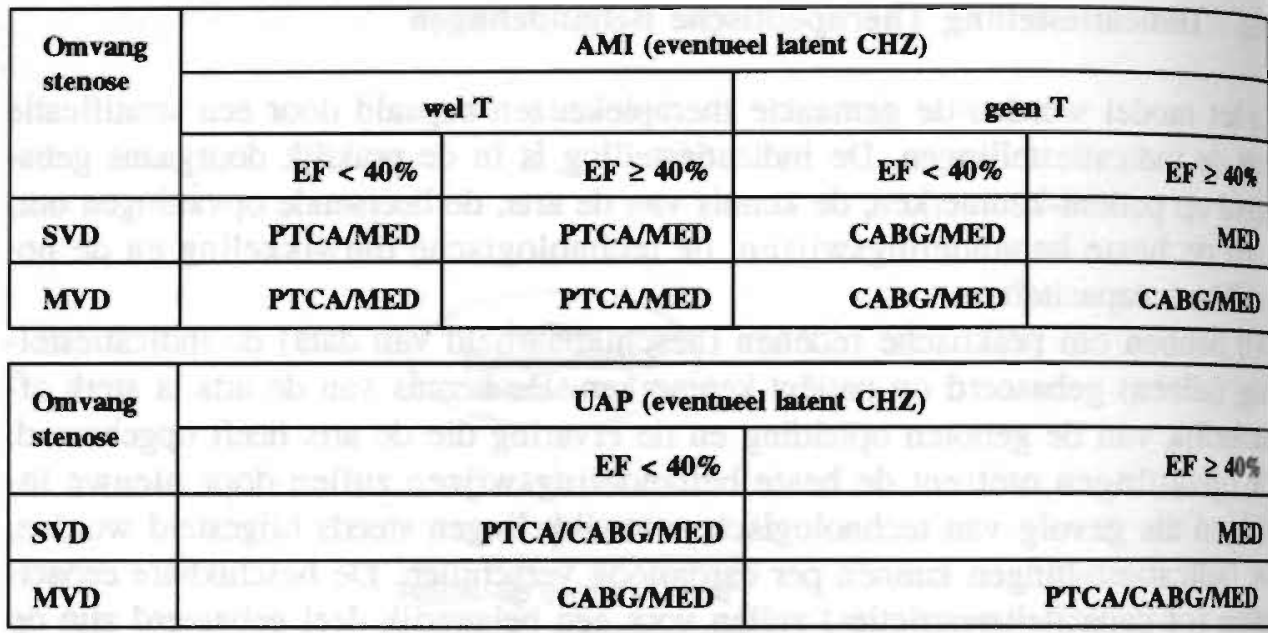

\begin{tabular}{|c|c|c|c|c|}
\hline \multirow{3}{*}{$\begin{array}{l}\text { Omvang } \\
\text { stenose }\end{array}$} & \multicolumn{4}{|c|}{ AP (eventueel latent $\mathbf{C H Z}$ ) } \\
\hline & \multicolumn{2}{|c|}{ EF $<40 \%$} & \multicolumn{2}{|c|}{$\mathrm{EF} \geq \mathbf{4 0 \%}$} \\
\hline & AP3-4 & $\geq 65 \mathrm{jr}^{*}$ & AP3-4 & $\geq 65 \mathrm{Jr} \cdot$ \\
\hline SVD & $\begin{array}{c}\text { PTCA } \\
\text { CABG/MED }\end{array}$ & CABG/MED & PTCAMMED & PTCAMED \\
\hline MVD & CABG/MED & CABG/MED & $\begin{array}{r}\text { CABG/ } \\
\text { PTCA/MED }\end{array}$ & CABG/MED \\
\hline
\end{tabular}

\begin{tabular}{|c|c|c|c|c|}
\hline \multirow{3}{*}{$\begin{array}{l}\text { Omvang } \\
\text { stenose }\end{array}$} & \multicolumn{4}{|c|}{ AP1-2 } \\
\hline & \multicolumn{2}{|c|}{ EF $<40 \%$} & \multicolumn{2}{|c|}{ EF $\geq 40 \%$} \\
\hline & AP1-2 & $\geq 65 j r^{*}$ & AP1-2 & $\geq 65 \mathrm{jr} .^{\circ}$ \\
\hline SVD & - & - & MED & PTCAMED \\
\hline MVD & - & - & PTCA/MED & CABG/MED \\
\hline
\end{tabular}

* In de kolom $\geq 65$ jr. word bedoeld petsonen van 65 jaar en ouder met AP3-4

Tabel II.1 Schema betreffende de operatieve indicatiestellingen.

Het spreekt voor zich dat de EF een belangrijke therapie bepalende factor is, $z 0$ als uit tabel II.1 blijkt. Hoewel we in ons model hier slechts ten dele gebruik var maken speelt ook de omvang van het vaatlijden een belangrijke rol. Een derde variabel, die een meer impliciete rol speelt, is de mate van stenose. 
De operaties onder de kolommen "AMI en UAP" hebben allen een spoedkarakter terwijl bij de AP de operatie op basis van planning geschiedt.

De AMI-behandeling bestaat uit het geven van geneesmiddelen die gericht zijn op:

1) het tegengaan van ritmestoornissen,

2) het oplossen van de bloedstolsels (thrombus) die de kransslagader(s) hebben afgesloten, en

3) verwijding van de kransslagaders.

Wanneer na thrombolyse een stenose van $\geq 70 \%$ blijft bestaan, is een spoedPTCA geïndiceerd (Vermeer, 1987). Een succesvolle thrombolyse wordt gevolgd door MED. Een spoed-CABG komt na een thrombolytische behandeling niet voor. Een PTCA vindt met betrekking tot AMI alleen plaats wanneer er een (mislukte) thrombolytische behandeling aan is voorafgegaan (Janssen, privé-communicatie, 1991). De AMI-CABG wordt tijdens dezelfde opname uitgevoerd, maar pas nadat het AMI zich heeft gestabiliseerd. De AMI-patiënten die geïndiceerd zijn voor een CABG hebben een verhoogd risico op een recurrente CHZgebeurtenis in hetzelfde jaar (Gardner e.a., 1989).

De medische behandeling van een UAP is het meest te vergelijken met die van een AMI.

De AP is het meest voorkomend indicatiegebied met betrekking tot zowel CABG, PTCA, als MED.

De CABG-indicaties hebben betrekking op hogere risicogroepen. Een risicogroep is een homogene patiëntengroep met een bepaald risico-profiel (of patiëntkenmerken). De CABG-patiënt-kenmerken met betrekking tot een hoge risicogroep zijn oudere leeftijd > 65 jaar, EF $<40 \%$, AP3-4, MVD, en

stenose $\geq 70 \%$. Voor patiënten met meerdere hoge risicokenmerken is de kans op een recurrente $\mathrm{CHZ}$-gebeurtenis in hetzelfde jaar sterk verhoogd. Een contraindicatie bestaat voor een chirurgische ingreep bij een EF $<20 \%$ (Gezondheidsraad, 1984/18). De indicatiestelling met betrekking tot een CABG schuift hoe langer hoe meer op in de richting van hogere risicogroepen door enerzijds de technologische ontwikkeling van de CABG en anderzijds de opkomst van de PTCA.

Een $C A B G$ op jonge leeftijd wordt zolang mogelijk uitgesteld. Hoe jonger de leeftijd waarop de eerste CABG plaatsvindt, hoe groter de kans op een herCABG. Een her-CABG heeft een hoger operatiesterfterisico. In dit verband vormen de PTCA, maar ook de MED, in toenemende mate een alternatief voor het uitvoeren van een $\mathrm{CABG}$ op jonge leeftijd. Er zijn dan meer mogelijkheden om 
een $\mathrm{CABG}$ op oudere leeftijd te doen, waardoor het hoge operatiesterfterisico van een her-CABG ontlopen wordt. Het nadeel is dat een PTCA kan mislukken. Een spoed-CABG na een mislukte PTCA heeft zowel een verhoogd operatiesterfterisico als een sterk verhoogde AMI-incidentie die rondom de operatie kan plaatsvinden (peri-MI).

Een PTCA is geïndiceerd wanneer de medicamenteuze behandeling niet ( $\mathrm{vol}$ doende) helpt. De PTCA-indicatiegebieden zijn SVD/MVD, AP3-4, EF $\geq 40 \%$, en stenose 50-70\%. Het PTCA-indicatiegebied blijft zich uitbreiden door onder meer de technologische ontwikkeling van de catheters (David, 1988). Zo bestond tot voor kort een contra-indicatie voor een PTCA bij een LMD (privé-communicatie, Janssen, 1992).

De MED is geïndiceerd met betrekking tot de volgende patiënt-kenmerken: EF $\geq 40 \%$, AP1-2, SVD, chronische AP3-4, AMI in acute fase.

\section{II.6 Verdeling CHZ-gebeurtenissen over Therapeutische Behandelingen}

De Commissie Coronair Angiografie (CCA) maakt jaarlijks een schatting van het aantal PTCA's en CABG's die verricht zijn. In het model zijn de operaties geijkt op de CCA-gegevens over 1988 en 1990, zoals weergegeven in tabel II.2. We hebben tabel II.2 aangevuld met de meest recente cijfers over 1991 en 1992.

\begin{tabular}{|l|r|r|r|r|}
\hline Operaties & 1938 & 1990 & 1991 & 1992 \\
\hline CABG & 8.300 & 8.500 & 8.700 & 9.170 \\
\hline PTCA & 5.600 & 8.000 & 8.700 & 10.500 \\
\hline
\end{tabular}

Tabel II.2 Aantallen operaties in 1988- en 1992

Het aantal opnames in 1988 met $\mathrm{CHZ}$ als nevendiagnose dat voor een hartoperatie is geïndiceerd, bedraagt op basis van de nu ter beschikking staande gegevens (SIG, 1992) naar schatting minder dan 5\%. Vanwege dit geringe aantal hebben wij het aantal operaties uit tabel II.2 hiervoor niet gecorrigeerd. De gegevens van de Stichting Informatiecentrum voor de Gezondheidszorg (SIG) vermelden het aantal ziekenhuisopnames per manifestatievorm. Op basis van gecombineerde gegevens, verkregen uit privé-communicatie (Janssen, 1991), de operatiesterftepercentages uit de literatuur en de SIG (1992) met betrekking tot 1988, is een verdeling gemaakt van de CHZ-manifestatievormen over de PTCA's en CABG's. 
De verdeling van de CHZ-manifestatievormen over het aantal MED's resteert per saldo.

In tabel II.3 is de verdeling van de manifestatievormen over het aantal opnames in 1988 weergegeven. De verdeling van de manifestatievormen over het aantal ontslagen volgt in tabel II.4.

\begin{tabular}{|c|c|c|c|c|}
\hline Menifestatie & CABG & PTCA & MED & Totad \\
\hline $\begin{array}{l}\text { AMI } \\
\text { UAP } \\
\text { AP3-4 } \\
\text { AP1-2 }\end{array}$ & $\begin{array}{l}1.400 \\
1.000 \\
4.510 \\
1.390\end{array}$ & $\begin{array}{r}1.150 \\
200 \\
4.050 \\
200\end{array}$ & $\begin{array}{r}26.167 \\
9.600 \\
11.140 \\
14.910\end{array}$ & $\begin{array}{l}28.717 \\
10.800 \\
19.700 \\
16.500\end{array}$ \\
\hline Totonal & 8.300 & 5.600 & 61.817 & 75.717 \\
\hline
\end{tabular}

Tabel II.3 Verdeling CHZ-manifestaties over therapeutische behandelingen in 1988

\begin{tabular}{|l|r|r|r|r|}
\hline Mrnifestatie & ond-CABG & ond-PTCA & ond-MED & Totan \\
\hline ond-AMI & 1.330 & 805 & 23.049 & 25.184 \\
oud-UAP & 900 & 166 & 8.200 & 9.266 \\
oud-AP3-4 & 4.285 & 3.929 & 11.140 & 19.354 \\
oud-AP1-2 & 1.334 & 196 & 14.910 & 16.440 \\
\hline Totaal & 7.849 & 5.096 & 57.299 & 70.244 \\
\hline
\end{tabular}

Tabel II.4 Verdeling therapeutische behandelingen bij laatste ontslag in 1988

In het totaal aantal ontslagen zijn 16.910 patiënten dubbel meegeteld. Deze patiënten hebben na het eerste ontslag in 1988 een recurrente incidentie gekregen en zijn voor de 2 de keer in hetzelfde jaar opgenomen.

In tabel II.5 is een overzicht gegeven van de verdeling van de CHZ-manifestatievormen over het aantal CAG's. 


\begin{tabular}{|c|c|c|c|c|c|c|}
\hline $\begin{array}{l}\text { Manifestatie- } \\
\text { vormen }\end{array}$ & $\begin{array}{r}\mathbf{C A G} \\
\text { na } \\
\mathrm{CABG}^{\mathbf{3}}\end{array}$ & $\begin{array}{r}\text { CAG } \\
\text { PTCA }^{\text {n) }}\end{array}$ & $\begin{array}{r}\text { CAG } \\
\mathrm{ma} \\
\mathrm{T}^{2}\end{array}$ & $\begin{array}{r}\text { CAG } \\
\text { met } \\
\text { PTCA }^{2)}\end{array}$ & $\begin{array}{r}\mathbf{C A G} \\
\text { met } \\
\mathbf{C A B G}^{2}\end{array}$ & $\begin{array}{r}\text { CAC } \\
\text { zonde } \\
\text { operent }\end{array}$ \\
\hline AMI & 291 & 297 & 2.130 & 1.150 & 1.400 & \\
\hline UAP & 360 & 60 & & 200 & 1.000 & \\
\hline AP3-4 & 1.396 & 838 & & 4.050 & 4.510 & $11.310^{1 / 4}$ \\
\hline AP1-2 & 53 & 65 & & 200 & 1.390 & $6.140^{1 / 2}$ \\
\hline TOTAAL & 2.100 & 1.260 & 2.130 & 5.600 & 8.300 & 17.45 \\
\hline
\end{tabular}

Typen CAG:

1) CAG vóór Operatie

2) CAG ujdens Operatie

3) CAG na Operatie

4) Diagnostische CAG

5) CAG tijdens opname na $T$.

Tabel II5 Verdeling manifestatievorm naar CAG in 1988

Deze verdeling uit tabel II.5 is gebaseerd op gegevens van SIG (1992) met betrekking tot 1988, privé-communicatie (Janssen, 1981) en literatuurstudies. Het totale aantal CAG's in 1988 bedraagt 36.840 (CCA, 1988). De CCA (privécommunicatie, 1992) vermoedt dat in $198810 \%$ meer CAG's zijn uitgevoerd dan opgegeven. We veronderstellen dat deze $10 \%$ CAG's zijn verricht als nevendiagnose. Zoals eerder aangegeven laten we de nevendiagnoses in het model buiten beschouwing. Er zijn ca. 5.600 CAG's met PTCA en 8.300 CAG's met CABG uitgevoerd (CAG tijdens operatie). De verdeling van de CAG's over PTCA en CABG is dezelfde als de verdeling van de CHZ-manifestatievormen over de therapeutische behandelingen. Er kan aan een electieve operatie een CAG voorafgaan (CAG vo6r operatie). Het aantal electieve operaties bedragl 10.150. Het aantal CAG's vo6r operatie hebben we hieraan gelijkgesteld. Er resteren $(17.450-10.150=) 7.300$ CAG's. Wij hebben deze 7.300 CAG's over de AP-groep als volgt verdeeld: 2.750 CAG's/AP3-4 en 4.550 CAG's/AP1-2. Deze CAG's hebben een diagnostische functie met betrekking tot een (eventuele) MED-opname (diagnostische CAG's). De diagnostische CAG's zijn geïndiceerd wegens electrocardiografische veranderingen die bij tredmolen-test en dergelijke zijn ontdekt (AHCPR, 1991). 
In de SIG-gegevens zijn correcties aangebracht betreffende de verdelingen van de operaties en de ziekenhuissterften naar de type manifestatievorm. Dit overzicht wordt in tabel II.6 gegeven.

\begin{tabular}{|l|r|r|r|}
\hline \multirow{2}{*}{ ICD-codes } & SIG & \multicolumn{2}{|c|}{ moded } \\
\cline { 2 - 4 } & sterten & operaties & sterten \\
\hline 410 (AMI) & 4.926 & 2550 & 4.933 \\
411 (UAP) & 0.134 & 1.200 & 134 \\
413 (AP3-4) & 0.106 & 8.560 & 346 \\
414 (AP1-2) & 0.305 & 1.590 & 60 \\
\hline Total & 5.471 & 13.900 & 5.473 \\
\hline
\end{tabular}

Tabel II.6 Verdeling operaties en ziekenhuissterfte naar type manifestatievorm in 1988

Er bestaat de indruk dat in de opgaven die de SIG ontvangt niet gedetailleerd genoeg naar manifestatievorm worden ingevuld, waardoor de ICD 414 (AP1-2) fungeert als restpost (zie Bijlage I). De verdeling van ICD 413 en 414 over de SIG-operaties vormt als het ware het spiegelbeeld van de verdeling die wij in het model hanteren.

De sterfte is zodanig geijkt dat deze overeenkomt met de gegevens gepubliceerd door Hoogendoorn (1990), CBS (1991) en de in de literatuur vermelde operatiesterftepercentages (zie Bijlage I).

In de twee volgende tabellen II.7 en II.8 wordt een verdeling gegeven van de verschillende typeringen van $\mathrm{CHZ}$-gebeurtenissen over de therapeutische behandelingen bij opname en de verschillende $\mathrm{CHZ}$-subgroepen in de CHZ-bevolking bij ontslag, zoals gebruikt in het model.

\begin{tabular}{|l|r|r|r|r|}
\hline subgroepen & CABG & PTCA & MED & opnames \\
\hline SVD & $\cdot 12$ & .44 & .70 & .62 \\
\hline MVD & $\cdot 88$ & .56 & $\cdot 30$ & .38 \\
\hline $\mathrm{EF} \geq 40 \%$ & $\cdot 80$ & .85 & .62 & .66 \\
\hline $\mathrm{EF}<40 \%$ & $\cdot 20$ & $\cdot 15$ & .38 & .34 \\
\hline
\end{tabular}

Tabel II.7 Procentuele Cverdeling CHZ-subgroepen over Opnames 


\begin{tabular}{|l|r|r|r|r|}
\hline subgroepen & CABG & PTCA & MED & opmomes \\
\hline $\mathrm{K}^{+}$ & $\cdot 90$ & $\cdot 94$ & $\cdot 75$ & $\cdot 78$ \\
\hline $\mathrm{K}^{-}$ & $\cdot 10$ & $\cdot 06$ & $\cdot 25$ & $\cdot 22$ \\
\hline $\mathrm{EF}^{+}$ & $\cdot 80$ & $\cdot 88$ & $\cdot 67$ & $\cdot 70$ \\
\hline $\mathrm{EF}^{-}$ & $\cdot 20$ & $\cdot 12$ & $\cdot 33$ & $\cdot 30$ \\
\hline
\end{tabular}

Tabel II.8 Procentuele verdeling CHZ-subgroepen over Ontslagen

De procentuele verdeling van de verschillende typeringen van $\mathrm{CHZ}$-gebeurtenissen over de opnames met betrekking tot CABG en PTCA in tabel II.7 is gebaseerd op publicaties van Hartz e.a. (1992), Kouchoukos (1989) en Laird-Meeter (1988/1). Er zijn met betrekking tot de verdeling over de MED-opnames vrijwel geen gegevens te verkrijgen. Wij hebben ons hierbij voornamelijk gebaseerd op een artikel van Rogers (1980) en gegevens verkregen uit privé-communicatie (Janssen, 1991).

In de tabel II.8 die de procentuele verdeling de subgroepen in de CHZ-bevolking over het aantal ontslagen weergeeft, hebben we als uitgangspunt genomen dat gemiddeld $30 \%$ van het aantal ontslagen een EF $<40 \%$ heeft (Janssen, privécommunicatie, 1991).

In het model heeft $34 \%$ van de opnames in 1988 een EF < 40\%. Dit aandeel is geijkt op het aantal ontslagen waarbij de EF $<40 \%$ was. Volgens Janssen (privécommunicatie, 1991) waren er in $198830 \%$ ontslagen met een EF < 40\%.

Het aandeel EF $<40 \%$ in het totaal aantal opnames kan zich in de tijd wijzigen. De AMI is de enige manifestatievorm die een EF $<40 \%$ kan genereren. Het AMI-aandeel in de totale CHZ-incidentie in Nederland is sinds 1972 gedaald. Hierbij kan er sprake zijn van een uitgesteld incidentie-effect, waardoor de AMIincidenties op oudere leeftijd toenemen. Er kunnen zich ook technologische ontwikkelingen voordoen die een gunstige invloed hebben op het behoud van het restniveau van de EF. Een voorbeeld is de toediening van thrombolytica, waarvan de verwachting is dat deze op grote schaal toegepast zal gaan worden. 


\begin{tabular}{|c|c|c|c|c|}
\hline Manifestatie & Behandeling & Alloop & $\mathrm{EF} \geq \mathbf{4 0 \%}$ & $\mathrm{EF}<40 \%$ \\
\hline \multirow{6}{*}{ AMI } & \multirow{2}{*}{ CABG } & Ontslag & 1.196 & 133 \\
\hline & & Dood & 63 & 7 \\
\hline & \multirow{2}{*}{ PTCA } & Ontslag & 673 & 132 \\
\hline & & Dood & 132 & 213 \\
\hline & \multirow{2}{*}{ MED } & Ontslog & 11.041 & 12008 \\
\hline & & Dood & o & 3.118 \\
\hline Manifestatie & Behandeling & Afloop & $\mathrm{EF} \geq \mathbf{4 0 \%}$ & $\mathrm{EF}<40 \%$ \\
\hline \multirow{6}{*}{ UAP } & \multirow{2}{*}{ CABG } & Ontslag & 714 & 186 \\
\hline & & Dood & 78 & 22 \\
\hline & \multirow{2}{*}{ PTCA } & Ontslag & 138 & 28 \\
\hline & & Dood & 27 & 7 \\
\hline & \multirow{2}{*}{ MED } & Ontslong & 6.284 & 1.916 \\
\hline & & Dood & 0 & 1.400 \\
\hline Manifestatie & Behandeling & Afloop & $E F \geq 40 \%$ & $E F<40 \%$ \\
\hline \multirow{6}{*}{$A P 3-4^{\circ}$} & \multirow{2}{*}{ CABG } & Ontslag & 3.073 & 1.212 \\
\hline & & Dood & 155 & 70 \\
\hline & \multirow{2}{*}{ PTCA } & Ontsleg & 3.480 & 449 \\
\hline & & Dood & 101 & 20 \\
\hline & \multirow{2}{*}{ MED } & Ontslag & 6.160 & 4.980 \\
\hline & & Dood & $\mathbf{0}$ & $\mathbf{0}$ \\
\hline
\end{tabular}

'Voor AP1-2 geldt dat iedereen een ejectiefractie $\geq 40 \%$ heeft

Tabel II.9 Verdeling EF over CABG, PTCA en MED 


\section{KOSTPRIJZEN CHZ}

\section{III.1 Inleiding}

III.2 Kostprijzen Preventieprogramma's

III3 Kostprijzen Medische Behandelingen 


\section{III.1 Inleiding}

In deze bijlage bespreken wij de kostprijzen van de verschillende preventiepro. gramma's en medische behandelingen. De kostprijzen uit deze bijlage worden in het model gebruikt voor de berekening van de CHZ-kosten in 1988 en voor de berekening van de kosten van de verschillende CHZ-scenario's.

Een gezondheidszorgprogramma (of een interventie) bestaat uit én of meerdere behandelingen, waarbij een behandeling is opgebouwd uit éen of meerdere verrichtingen. Een verrichting is in bedrijfseconomische zin een activiteit die een bepaald beslag legt op de produktiemiddelen.

Een kostprijsbepaling vereist dat een verrichtingenprofiel van de betreffende behandeling moet worden opgesteld. Het beslag dat de behandeling legt op de produktiemiddelen wordt gemeten en vermenigvuldigd met de prijzen (kosten) van die produktiemiddelen. Aldus wordt met deze vermenigvuldiging de kostprijs van de behandeling verkregen (kostprijs $=$ hoeveelheid produktiemiddelen $\mathrm{x} d e$ prijs produktiemiddelen).

Wij hebben van een behandeling de gemiddelde kostprijs berekend, waarbij we zijn uitgegaan van de totale kosten per eenheid produkt (vgl. Winter, 1993). In het algemeen geldt hoe hoger het aggregatieniveau waarop de patiëntenstromen de verschillende behandelingen doorlopen, hoe grover het verrichtingenprofiel van een medische behandeling. In ons model speelt de behandelingsgang van de patiëntenstromen zich af op bevolkingsniveau. Zodoende is het model (nog) te grof om er de marginale kosten van een behandeling mee te kunnen berekenen. De marginale kosten zijn de kosten die door veranderingen in het produktieproces worden opgeroepen. Bijvoorbeeld, bij welke uitbreiding van het operatieprogramma gaan de vaste kosten variëren? De extra kosten die hierdoor ontstaan vormen de marginale kosten van het operatieprogramma. In meer gedetailleerde studies zou met deze marginale kosten rekening gehouden moeten worden.

Wanneer de benodigde gegevens met betrekking tot een kostprijsbepaling ontbreken, moet (noodgedwongen) teruggevallen worden op de tarieven. De (kost)prijzen van de artsenhonoraria, de medicamenten en de (niet-invasieve) diagnostische verrichtingen zijn in het model gebruikt volgens de gepubliceerde tarieven. Het tarief is in veel gevallen geen goede representant van de (kost)prijs van de betreffende behandeling (of verrichting). De in de praktijk gebruikte tarieven weerspiegelen niet altijd de werkelijke kosten van de verloren gegane produktiefactoren (Van Hout, 1990). Het tarief dat de basis vormt van het gedeclareerde bedrag vertegenwoordigt eerder de uitgavenkant dan de kostenkant van een verrichting (of behandeling). Zo liggen de tarieven van eenvoudige diagnostische bepalingen (laboratorium, ECG) vaak boven de kostprijs van die bepalingen. In 
meer gedetailleerde kostprijsberekeningen moet met deze kostprijscorrecties rekening gehouden worden.

De kostprijzen (en tarieven) zijn zoveel mogelijk uitgedrukt in het prijsniveau van het jaar 1988.

De preventieprogramma's zijn gericht op personen zonder $\mathrm{CHZ}$ die echter wel een verhoogd $\mathrm{CHZ}$-risico hebben. Behandeld worden de kostprijzen van opsporing en controle van verhoogde risicofactoren, cholesterolverlagende dieet-programma's, cholesterol- en hypertensieverlagende middelen en anti-rook campagnes.

We hebben de medische behandelingen onderscheiden naar therapeutische behandelingen, onderhoudsbehandelingen, en behandeling chronisch zieken. De therapeutische behandelingen zijn verrichtingen die gemaakt worden om sterfte te voorkómen, klachten te verminderen en (nieuwe) CHZ-manifestaties te voork6men of zolang mogelijk uit te stellen. De onderhoudsbehandelingen betreffen de follow-up behandelingen die plaatsvinden na ontslag uit het ziekenhuis. De behandeling chronisch zieken is bedoeld om de kwaliteit van leven zoveel mogelijk te verbeteren dan wel zolang mogelijk te behouden.

Deze bijlage is als volgt ingedeeld. In paragraaf III.2 worden de kostprijzen behandeld met betrekking tot de preventieprogramma's. We bespreken in paragraaf III.3 de kostprijzen van de medische behandelingen.

\section{III.2 Kostprijzen Preventieprogramma's}

De basis van het computerprogramma is een weergave van de huidige gangbare situatie. Dit geldt zowel voor preventie-aspecten als behandelingsaspecten. We noemen de gangbare situatie het basisscenario. Een scenario wordt verkregen via wijzigingen en aanvullingen op dit basisscenario, bijvoorbeeld in de vorm van preventieprogramma's. Onderstaand bespreken we de kostprijzen van dergelijke gezondheidszorgprogramma's, te weten:

i) Opsporing en Controle verhoogde Risicofactoren

ii) Cholesterolverlagend Dieet-Programma

iii) Cholesterolverlagend Medicamenteus Programma

iv) Hypertensieverlagend Medicamenteus Programma

v) Anti-Rook campagne Huisarts

vi) Anti-Rook campagne Scholen

Wij gaan er van uit dat aan de preventieprogramma's vaste kosten in de vorm 
van advertentiekosten, voorlichtingsprogramma's, gratis 06-lijn en dergelijke verbonden kunnen zijn. Deze vaste kosten worden gemaakt ongeacht het aantal mensen dat op het specifieke preventieprogramma reageert. De vaste kosten bedragen voor elk preventieprogramma naar schatting $f 2 \mathrm{mln}$. per jaar.

De kostprijzen van de betreffende preventieprogramma's zijn berekend onder de veronderstelling dat alle personen uit de doelgroep daadwerkelijk het programma volgen (zogenaamd 100\% therapietrouw).

\section{Kostprijs Opsporing en Controle Verhoogde Risico-factoren}

Voor de berekening van de kostprijs van opsporing en controle verhoogde risicofactoren zijn de volgende uitgangspunten gehanteerd:

I. De vaststelling van zowel een initieel serumcholesterolgehalte als een initiel bloeddrukniveau gebeurt in de scenario's met 3 gescheiden metingen. Het basisscenario gaat uit van 2 gescheiden metingen. Alle initiële metingen worden zowel in het basisscenario als in de scenario's uitgevoerd door de huisarts. De laboratoriumbepalingen bij hypertensie bestaan uit urine-eiwit $(f 0,38)$, serumkreatine $(f 7,50)$, serumkalium $(f 7,50)$ en totaal cholesterol $(f 6,--)$. De totale kostprijs van de laboratoriumbepalingen bedraagt afgerond $f 21,-$.

Een van de aanbevelingen uit het Nijmeegs Interventie Project (Van Ree, 1981) is om de opsporing en behandeling van risicofactoren in én hand te leggen. De huisarts zou door zijn positie in het gezondheidszorgsysteem deze plaats - in samenwerking met een doktersassistent - kunnen innemen. In een recentelijk advies schrijft de Gezondheidsraad (1990) in dit verband dat zowel het aanvragen van de cholesterolbepalingen als het beoordelen van de uitslag in een arts-patiënt relatie door de huisarts dienen te geschieden.

Wij hebben de kostprijs van een huisartsenconsult vastgesteld op $f$ 27,-- per consult (gewogen gemiddelde naar rato aantal ziekenfonds- en niet-ziekenfonds patiënten).

De meting van het cholesterolgehalte geschiedt meestal door het afnemen van een bloedmonster (Gezondheidsraad, 1990). Een betrouwbare diagnostisering van het serumcholesterolgehalte bestaat bij voorkeur uit 3 metingen, verspreid over een langere periode, waarna een cholesterolprofiel gemaakt kan worden (Cholesterol Consensus Bijeenkomst, uit: Erkelens, 1987, Stalenhoef, 1989/2, Van Ree e.a., 1989, Tunstall-Pedoe, 1989). De kostprijs van een cholesterolbepaling is opgebouwd uit een reeks van drie cholesterolbepalingen en bedraagt $f$ 18,-- (DCC, 1990). 
Met betrekking tot het aantal initiële bloeddrukmetingen beveelt Russell (1985) 3 gescheiden bezoeken aan met tenminste 2 metingen per bezoek, verspreid over een langere periode. De Gezondheidsraad (1990) beveelt een minimum van 3 metingen aan met tussenpozen van 1 week. Uit een in 1985 door de Vrije Universiteit gehouden enquête over hypertensie blijkt dat $76 \%$ van de huisartsen drie metingen verricht (De Groot e.a., 1988).

Bij een vastgestelde hypertensie volgt een diagnostische evaluatie, die is opgebouwd uit anamnese, algemeen lichamelijk onderzoek en laboratoriumonderzoek. Deze laatste bestaat uit de volgende bepalingen (Van Der Feen e.a., 1990):

in serum: kalium $(f 7,50)$, kreatine $(f 7,50)$, cholesterol $(f 6,--)$, glucose ( $f$ 6,--),

- in urine: eiwit $(f 0,38)$, glucose $(f 0,38)$, sediment $(f 1,50)$.

De tussen haakjes vermelde bedragen zijn de tarieven die het Diagnostisch Centrum Maastricht (D.C.C.) op basis van het prijspeil 1-1-1989 aan de huisarts voor de aangevraagde diagnostische onderzoekingen doorberekend.

Volgens De Groot e.a. (1988) bestaan de basale laboratoriumbepalingen uit het urine-eiwit, het serumkreatine, het serumkalium en het totaal cholesterol.

II. In het basisscenario worden alle controleconsulten door de huisarts verricht. Het basisscenario heeft bij hypertensie en hypercholesterolaemie 4 respectievelijk 2 controleconsulten per jaar.

In de scenario's wordt ervan uitgegaan dat de controleconsulten onder verantwoordelijkheid van de huisarts naar de doktersassistent zijn gedelegeerd. In dat geval bedragen de kosten van een consult de helft van een normaal huisartsenconsult. In de scenario's bedraagt het aantal controleconsulten bij hypertensie gemiddeld 6 per jaar. Elk half jaar vindt opnieuw een laboratoriumonderzoek plaats. Hypercholesterolaemie kent 2 controleconsulten per jaar, waarbij ook een cholesterolbepaling wordt uitgevoerd. Naast de controle consulten voor hypertensie en cholesterol vindt in de scenario's $2 x$ per jaar een extra huisartsenconsult plaats.

In de praktijk blijkt de huisarts 2/3 van de hypertensiecontroles zelf te doen. De assistent doet alleen in $5 \%$ van de gevallen de controles zelfstandig. De overige $28 \%$ van de hypertensiecontroles worden door de huisarts om en om met de assistent gedaan (Van Ree e.a., 1985/2).

Het Nijmeegs Interventie Project toont verder aan dat de inzet van doktersassistenten in de huisartsenpraktijk bij de initiële screening en controle tijdens de follow-up effectief is (Van Ree, 1981). In dit project voerden de assistenten het 
controleprogramma vanaf het 2 de controleconsult zelfstandig uit. In geval de as. sistenten onder supervisie van de huisarts de metingen verrichten, wordt aange. nomen dat het consult dan de helft van een normaal huisartsenconsult bedraagt (privé communicatie, Van Ree, 1990).

De Hypertensie Consensus Bijeenkomst (1990) stelt dat bij een therapeutisch goed ingestelde hypertensiepatiënt de controlefrequentie gemiddeld $4 \mathrm{x}$ per jaar bedraagt. Voor regelmatige hypertensiecontrole zijn volgens Van Ree e.a. (1985/1) 6 metingen per jaar nodig.

Volgens Levy (1986) moeten de cholesterolcontroles $2-4 \mathrm{x}$ per jaar gebeuren. Door verschillende bronnen (Gezondheidsraad, 1990) wordt gemotiveerd dat dieettrouw (en therapietrouw in het algemeen) mede afhangt van de arts-patiënt relatie. Naast de controleconsulten, bestaande uit voorlichting, bloeddrukcontrole, bloedafname e.d. door de doktersassistent, nemen wij daarom in de scenario's ook 2 huisartsenconsulten op.

In tabel III. 1 is de kostprijs Opsporing en Controle verhoogde Risicofactoren per persoon op jaarbasis weergegeven. 
Cholesterol

basiscenarto

scenorito

1) kostprijs opsporing (énmallg)

\begin{tabular}{|c|c|c|}
\hline $\begin{array}{l}\text { hulsartsenconsult } \\
\text { chalesterolbepaling }\end{array}$ & $\begin{array}{l}2 * f 27,--=f 54,-- \\
2 * f 18,-=f 36,-\end{array}$ & $\begin{array}{l}3 * f 27,--=f 81,- \\
3 * f 18,-=f 54,--\end{array}$ \\
\hline totan & $f 90,-$ & f 135 , \\
\hline
\end{tabular}

2) kostprijs controle per jaar

controle-consult

huisartsenconsult

cholesterolbepaling

total

Hypertensie

basisscenarto

scenario

1) kostprijs opsporing (Génmalig)

\begin{tabular}{|c|c|c|}
\hline $\begin{array}{l}\text { huisartsenconsult } \\
\text { laboratoriumbepaling }\end{array}$ & $\begin{array}{l}2 * f 27,-=f 54,- \\
1 * f 21,-=f 21,-\end{array}$ & $\begin{array}{l}3 * f 27,-=f 81,- \\
1 * f 21,-=f 21,-\end{array}$ \\
\hline totaal & $f 75,-$ & f 102,- \\
\hline \multicolumn{3}{|c|}{ 2) kostprijs controle per jaar } \\
\hline $\begin{array}{l}\text { controle-consult } \\
\text { huisartsenconsult } \\
\text { laboratoriumbepaling }\end{array}$ & $\begin{array}{l}4 * f 27,-=f 108,- \\
f--,- \\
2 * f 21,-=f \quad 42,-\end{array}$ & $\begin{array}{l}6 * f 13,50=f 81,- \\
2 * f 27,-=f 54,- \\
2 * f 21,-=f 42,-\end{array}$ \\
\hline totad & $f 150,-$ & $f 177,-$ \\
\hline
\end{tabular}

Tabel III.1

Kostprijs Opsporing en Controle verhoogde Risicofactoren

\section{Kostprijs Cholesterolverlagend Dieet-Programma}

Het totaal aan serumcholesterol wordt bepaald door het cholesterol in het voedsel en door de hoeveelheid die in het lichaam zelf wordt geproduceerd. Daarbij zijn voeding en overgewicht de voor het serumcholesterolgehalte bepalende variabelen (Gezondheidsraad, 1990).

In de voeding zijn verzadigde vetten en vetzuren aanwezig die de LDL-cholesterolgehalten doen stijgen (Gezondheidsraad, 1990). Bij de keus van voedings- en leefgewoonten gaat het erom de laatstgenoemden te verlagen en de relatieve 
HDL-cholesterolfractie te verhogen. De HDL-fractie wordt onder andere verh. oogd door veel lichaamsbeweging, stoppen met roken, gewichtsreductie en verhoging alcoholconsumptie (Levy, 1986). Bij vrouwen beïnvloedt het gebruik van orale anticonceptica het HDL-cholesterol in negatieve zin (Grobbee e.a., 1989). Andere stoffen die invloed hebben op het serumcholesterolgehalte zijn het cholesterolgehalte van de voeding zelf en het gehalte van de vezelstoffen (STG, 1990/2).

Een dieetadvies volgt bij een cholesterolgehalte $\geq 6,5 \mathrm{mmol} / \mathrm{l}$. Wanneer de cholesterolwaarde $\geq 8,0 \mathrm{mmol} /$ is, kan het dieet worden aangevuld met een medicamenteuze behandeling (Cholesterol Consensus Bijeenkomst, uit: Erkelens, 1987).

Het uitgangspunt voor de berekening van de kostprijs van het cholesterolverlageade dieet-programma is de volgende:

Het basisscenario kent geen systematische dieet-controle. In het dieet-programma geeft een diëtist in het 1ste jaar het dieetvoorschrift. Na het lste consult in het lste jaar volgen nog 2 vervolgconsulten. Het nakomen van de dieetvoor. schriften wordt systematisch gecontroleerd door de doktersassistent. Aangenomen is dat de begeleiding van voedings-en gedragsadviezen tijdens de controleconsulten van de risicofactoren wordt gedaan. Zodoende hoeft voor de dieetcontrole geen extra kosten in rekening gebracht te worden. Verondersteld is dat door de intensieve controle geen terugval naar het initiële niveau van de risicofactor plaatsvindt.

Een systematische controle op het nakomen van de dieetvoorschriften is nodig om te voorkómen dat de bereikte resultaten bij de behandeling van verhoogd cholesterol op langere termijn weer verloren gaan. Uit de Evaluatiestudie Nijmeegs Interventie Project (Van Ree e.a., 1985/1 en 1985/2) blijkt dat na 3-5 jaar bij degenen die uitsluitend een leef- en voedingsadvies kregen, in nagenoeg alle gevallen het risiconiveau weer terugviel tot het niveau van voor de behandeling (de zogenaamde afbouwtijd). Volgens een enquête gehouden onder hypertensiepatiënten werd na de programmaperiode $33 \%$ minder dan $5 x$ per jaar, $42 \%$ niet meer regelmatig en $25 \%$ nooit meer gecontroleerd. De Gezondheidsraad (1990) beveelt aan dat bij een initieel verhoogd cholesterolgehalte de huisarts en de diëtist samen nagaan welke veranderingen in het voedingspatroon aangebracht moeten worden. Voor het bereiken van een blijvende dieettrouw zou een maximale steun van jaarlijks 2 huisartsbezoeken, 4 vervolgconsulten bij de diëtist en 1 serie van 3 cholesterolbepalingen nodig zijn.

De dieettrouw kan ook bereikt worden door de doktersassistent bijvoorbeeld na een consultatie met de diëtist onder supervisie van de huisarts de verdere follow- 
up te laten verzorgen. De doktersassistent kan een registratie maken van het risicoprofiel, het bijhouden van een signaleringssysteem, voorlichting geven over voedings- en leefgewoonten, bloeddrukcontroles verrichten en hypercholesterolemie begeleiden (De Haan, 1989).

De kostprijs voeding bestaat uit de meerkosten van het dieet. De meerkosten van het dieet zelf zijn nihil (Gezondheidsraad, 1990). De Vries e.a. (1991) onderschrijven deze stelling aan de hand van een onderzoek waarin de kostprijs berekend werd van drie dieetvarianten bij hypercholesterolemie. De zogenaamde goedkope en modale varianten van het dieet vallen niet duurder uit dan het referentievoedingspakket. De dure variant bedraagt $f 0,65$ per dag meer dan de referentievoeding. Kennelijk hebben preventieve maatregelen niet zozeer hun prijs in geld, maar in levensplezier (Katan, 1985). De kostprijs diëtist is opgebouwd uit de diëtisttarieven voor het 1 ste consult en vervolgconsult die $f 60,--$ respectievelijk $f$ 15,-- bedragen (Gezondheidsraad, 1990). De kostprijs sport is een schatting gebaseerd op Russell (1985). De kostprijzen opsporing en controle verhoogde risicofactoren zijn besproken bij tabel III-1.

De kostprijs per persoon op jaarbasis van een Cholesterolverlagend Dieet-programma is in tabel III.2 weergegeven.

\begin{tabular}{|c|c|}
\hline 1ste Jaar & \\
\hline 1) kostprijs opsporing & $f$ 135,- \\
\hline 2) kostprijs controle & f 117,- \\
\hline 3) kostprijs diëtist ( $f 60,--+2 * f 15,--$ ) & $f 90,-$ \\
\hline 4) Lostprijs voeding & nimp \\
\hline 5) kostprijs sport & f $150,-$ \\
\hline totand & $f 492-$ \\
\hline \multicolumn{2}{|l|}{ 2de e.v. Jaren } \\
\hline 1) kostprijs controle & f 117,- \\
\hline 2) kostprijs sport & f $150,-$ \\
\hline totaal & f $267,-$ \\
\hline
\end{tabular}




\section{Kostprijs Cholesterolverlagend Medicamenteus Programma}

Wij hebben onze keuze met betrekking tot de serumcholesterolverlagende medicatie die met het model uitgetest wordt laten vallen op een combinatie van diet therapie en HMG-CoA reductaseremmers. De kostprijzen van controleconsulten, dieettherapie en laboratoriumbepalingen zijn eerder in deze paragraaf aan de orde geweest. De tarieven van de geneesmiddelen zijn door ons bepaald aan de hand van gegevens uit het Farmacotherapeutisch Kompas (1989) en uit privé-communicatie (Straver, apotheker te Maastricht, 1990). Men moet zich hierbij realiseren dat het om een snel veranderende markt gaat. Prijzen wijzigen, nieuwe genees. middelen met andere eigenschappen dienen zich regelmatig aan. Dit kan sterke invloed hebben op de tariefopbouw.

De jaarlijkse kosten van toediening van Simvastatine bij $100 \%$ therapietrouw bedragen $f$ 1.274,-- (365 dagen $\times f 3,49$ ), voor $20 \mathrm{mg}$ per dag (Farmacotherapeutisch Kompas, 1989). Hier bovenop komen de zogenaamde mark-up kosten van $f$ 44,-- (4 x $f \quad 10,95$ per receptregel per kwartaal).

Uit de tot nu toe beschikbare gegevens blijkt dat de cholesterolremmers geen ernstige bijwerkingen geven (Erkelens, 1987, Van Zwieten, 1988, Hunninghake, uit: Arntzenius, 1990, Gezondheidsraad, 1990). Er hoeven geen additionele medische kosten opgevoerd te worden ten aanzien van de bijwerkingen.

Een medicamenteuze therapie zonder de combinatie met dieet schijnt een aanzienlijk mindere cholesteroldaling op te leveren (Hunninghake, uit: Arntzenius, 1990). In die zin kan medicamenteuze cholesterolverlaging ook niet gezien worden als remplaçant voor dieet (Erkelens, 1988). In dit programma gaat het dan ook steeds om een combinatie van de beide methoden.

Er zijn 8 controle-consulten in het eerste jaar en 2 controle-consulten per jaar in de volgende jaren. Elk jaar vinden er twee cholesterolbepalingen plaats. Daarnaast worden in het eerste jaar en in het tweede en de volgende jaren 8 respectievelijk 2 leverfunctiebepalingen per jaar uitgevoerd. De genoemde aantallen hebben zowel betrekking op het basisscenario als op de scenario's.

De kostprijs leverfunctiebepaling is $f$ 24,-- (Gezondheidsraad, 1990). De kostprijzen opsporing, controle-consulten, en cholesterolbepalingen zijn eerder in deze paragraaf behandeld.

In de kostprijsbepaling zijn de kostprijzen diëtist en sport van het eerste jaar uit het cholesterolverlagend dieet-programma opgenomen en met betrekking tot het tweede en volgende jaren alleen de kostprijs sport. 
De tabel III.3 geeft weer de kostprijs per persoon op jaarbasis van een Cholesterolverlagend Medicamenteus programma.

\begin{tabular}{|c|c|c|}
\hline & basisscenario & scenario \\
\hline \multicolumn{3}{|l|}{ 1ste Jaar } \\
\hline 1) opsporing & f $90,--$ & f $135,-$ \\
\hline 2) dleetprogramma & $f 90,-+f 150,-f 240,-$ & $f 90,-+f 150,-\quad f \quad 240,--$ \\
\hline 3) stmvastatine ( $f 1.274,--+f 44,--)$ & $f$ 1.318,-- & f 1.318,-- \\
\hline 4) controle-consulten & $8 * f 27,--$ & $8 * f 13,50$ \\
\hline 5) leverfunctiebepaling & $8 * f 24,--$ & $8 * f 24,-$ \\
\hline 6) cholesterolbepaling & $2 * f 18,-\quad f \quad 36,-$ & $2 * f 18,-$ \\
\hline 7) huisartsenconsult &,--- & $2 \approx f 27,-$ \\
\hline totaal & f 2.092,- & f 2083,-- \\
\hline
\end{tabular}

\begin{tabular}{|c|c|c|c|c|}
\hline \multicolumn{5}{|l|}{ 2de e.v Jaren } \\
\hline 1) dieetprogramma & \multicolumn{2}{|r|}{$f 150,--$} & \multicolumn{2}{|r|}{$f \quad 150,-$} \\
\hline 2) sinvastatine & \multicolumn{2}{|r|}{ f 1.318,- } & \multicolumn{2}{|r|}{ f 1.318,- } \\
\hline 3) controle-consult & $2 * f 27,-$ & f 54,-- & $2 * f 13,50$ & f $27,--$ \\
\hline 4) leverfunctiebepaling & $2 * f 24,-$ & $f \quad 48,-$ & $2 * f 24,-$ & $f \quad 48,-$ \\
\hline 5) cholesterolbepaling & $2 * f 18-$ & f $36,-$ & $2 * f 18-$ & $f \quad 36,-$ \\
\hline 6) hulsartsenconsult & &,--- & $2 * f 27, \cdots$ & $f \quad 54,-$ \\
\hline totand & & f $1.606,-$ & & f 1.633,- \\
\hline
\end{tabular}

Tabel III.3

Kostprijs Cholesterolverlagend Medicamenteus programma

Kostprijs Hypertensieverlagend Medicamenteus Programma

We gaan bij de kostprijsberekening van het hypertensie programma uit van de zogenaamde "stepped care": $100 \mathrm{mg}$ atenolol plus $50 \mathrm{mg}$ hydrochloorthiazide voor de minder ernstige gevallen (75\%) en voor ernstige gevallen (25\%): 200 $\mathrm{mg}$ atenolol, $50 \mathrm{mg}$ resp. $100 \mathrm{mg}$ hydrochloorthiazide en $3-5 \mathrm{mg}$ prazosine.

De kostprijzen van deze geneesmiddelen op jaarbasis bij $100 \%$ therapietrouw bedragen als volgt: 
Atenolol $\quad .75 * 100 \mathrm{mg}+.25 * 200 \mathrm{mg} \quad f 347,--+f 44,--=f 391,-$ Hydrochloorthiazide $.75 * 50 \mathrm{mg}+.25 * 100 \mathrm{mg} \quad f 145,--+f 44,--=f 189,-$ Prazosin .25*3mg $\begin{aligned} \frac{f 57,--}{f 549,--}+f 44,-- & =\frac{f 101,--}{f 681,--}\end{aligned}$

In de kostprijs medicatie is geen rekening gehouden met de kosten van eventuele bijwerkingen. De kostprijs bijwerkingen zou in een meer gedetailleerde studie (kosteneffectiviteitsstudie anti-hypertensiva) wel berekend moeten worden.

Er zijn 12 controle-consulten en 4 laboratoriumbepalingen in het eerste jaar. Dit geldt zowel voor het basisscenario als voor de scenario's.

De kostprijzen van opsporing, dieet, controle-consulten en laboratoriumbepalingen zijn eerder in deze paragraaf behandeld.

De kostprijs per persoon op jaarbasis van een Bloeddrukverlagend Medicamenteus Programma staat in tabel III.4 vermeld. 


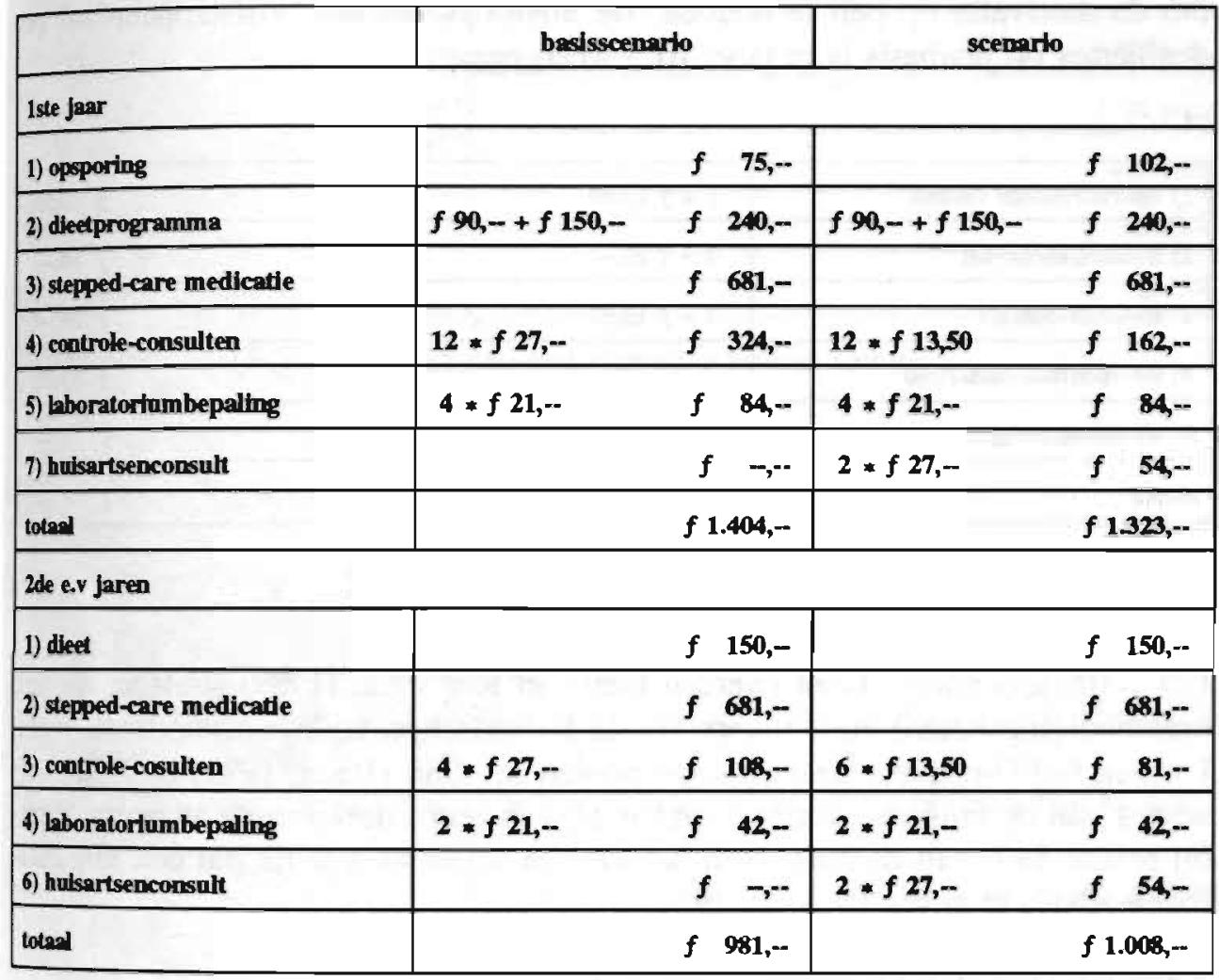

Tabel III.4

Kostprijs Bloeddrukverlagend Medicamenteus programma

\section{Kostprijs Anti-Rookcampagne Huisarts}

Met betrekking tot de kostprijs van een anti-rookcampagne is het volgende uitgangspunt geformuleerd:

Het anti-rook campagne programma dat kan worden opgenomen in een scenario is naar voorbeeld van het "vijfstappenplan in de huisartsenpraktijk" (Mudde, 1989). Het basisscenario heeft geen stoppen-met-roken programma.

Het "vijfstappenplan in de huisartsenpraktijk", uiteengezet door Mudde (1989), bestaat uit het voorschrijven door de huisarts van nicotinekauwgum, verstrekken van een zelfhulpgids e.d., het afspreken van een stopdag en het geven van begeleiding na de stopdag. In een voorbereidend consult onderzoekt de doktersassiStent de motivatie bij de roker om met roken te stoppen. Vervolgens vinden er twee huisartsenconsulten plaats, bestaande uit een stop-met-roken-advies en de eigenlijke stopdag. Na afloop spreekt de doktersassistent 2 vervolgconsulten af 
om de motivatie op peil te houden. De kostprijs van het "vijfstappenplan" pe: deelnemer op jaarbasis is in tabel MI.5 weergegeven.

\begin{tabular}{|l|lc|}
\hline 1) voorbereidend consult & $1 * f 13,50$ & $f 13,50$ \\
\hline 2) huisartsenconsult & $2 * f 27,--$ & $f 54,-$ \\
\hline 3) controle-consult & $2 * f 13,50$ & $f 27,-$ \\
\hline 4) vooritichtingsmateriaal & & $f 13,50$ \\
\hline 5) nicotinekauwgum & $.10 * f 63,50+.05 * f 37,25$ & $f \&,-$ \\
\hline totaal & & $f 116,-$ \\
\hline
\end{tabular}

Tabel III.5

Kostprijs Anti-Rook Campagne Huisarts scenario

Het "vijfstappenplan" komt overeen met Van Ree's e.a. (1989) strategie die een ontmoedigingsbeleid voor rokers via de huisartsenpraktijk een noodzaak vind. Uit een NIPO-enquête naar rookgewoonten in 1988 (Baan, 1989) blijkt dat hei advies van de huisarts zwaarwegend is bij een groot deel van de stoppers. Daarbij rekent $84 \%$ van de huisartsen het tot hun verantwoordelijk om een stop-metroken-advies te geven (Mudde, 1989).

\section{Kostprijs Anti-Rookcampagne Scholen}

Wij hebben als voorbeeld voor een anti-rookcampagne scholen de voorlichtingscampagne "Rookpreventie bij Nederlandse kinderen" van De Vries (1989) gebruikt.

De doelgroep in de anti-rookcampagne zijn scholieren in de leeftijd 10-19 jaar. Er zijn in $1988 \mathrm{ca}$. 2,2 mln. personen in de leeftijdsklasse 10-19 jaar. We nemen aan dat de doelgroep opgesplitst kan worden in groepen van ca. 25 scholieren. Het aantal groepen dat gevormd kan worden bedraagt $88.000(2,2 \mathrm{mln}$. personen/25 groepsleden).

Het anti-rook programma is opgebouwd uit 5 voorlichtingseenheden per jaar die elk drie uur duren. Het totaal aantal uren per groep is 15 (5 eenheden $* 3$ uur). Er zijn 1.320 .000 arbeidsuren ( 88.000 groepen $* 15$ uur). We veronderstellen dat het aantal arbeidsuren per trainer/deskundige 240 uur bedraagt. Het benodigde aantal trainers is 5.500 (1.320.000 uren/240 uur per trainer). De salariskosten zijn vastgesteld op $f 50.000$,-- per trainer. Deze kosten worden vermeerderd met een opslagpercentage van $15 \%$ ter dekking van de overheadkosten. In tabel III. 6 is de berekening van de kostprijs van de Anti-Rook campagne Scholen opgenomen. 


\begin{tabular}{|c|c|}
\hline selartskosten & f $275 \mathrm{mln}$ \\
\hline overheadkosten & f $41 \mathrm{mln}$. \\
\hline totad & f $316 \mathrm{mbn}$ \\
\hline kostprijs per groep & f $3.590,-$ \\
\hline kostprljs per scholier & $f \quad 144,-$ \\
\hline
\end{tabular}

Tabel III.6 Kosqrijs voor het Anti-rook campagne Scholen scenario

\section{III.3 Kostprijzen Medische behandelingen}

Wij hebben ten behoeve van de kostprijsberekeningen de medische behandelingen ingedeeld analoog aan Je indeling van de behandelingstrajecten naar voor-, opname-, en follow-up traject, te weten:

1) medische behandelingen voordat een opname plaatsvindt (medische behandelingen voortraject),

2) medische behandelingen tijdens een opname (medische behandelingen opnametraject),

3) medische follow-up behandelingen na ontslag uit het ziekenhuis (medische behandelingen follow-up traject).

Er zijn per traject verrichtingenprofielen van de verschillende medische behandelingen opgesteld. Informatie over de verrichtingenprofielen is voor een belangrijk deel afkomstig van cardiologen bij het Academisch Ziekenhuis Maastricht (AZM) en het St. Jozef Ziekenhuis te Kerkrade (L). Veel gegevens over de werkelijke kostprijzen zijn verstrekt door het COTG.

We behandelen vervolgens de kostprijzen van a) medische behandelingen voortraject, b) medische behandelingen opnametraject, en c) medische behandelingen follow-up traject. De medische behandelingen follow-up traject worden nog onderverdeeld naar het follow-up traject $<1$ jaar en het follow-up traject $\geq 1$ jaar.

\section{a) Kostprijzen Medische behandelingen Voortraject}

In figuur III.1 is het (deel)traject Huisarts (HA/EHBO) opgenomen. De percentages tussen haakjes die in deze figur staan vermeld, verwijzen naar de fracties van het aantal patiënten met $\mathrm{CHZ}$ dat de behandelingsgang in het deeltraject doorloopt. Op basis van deze fracties in figuur III.1 worden de kostprijzen in tabel III.7 afgeleid. 


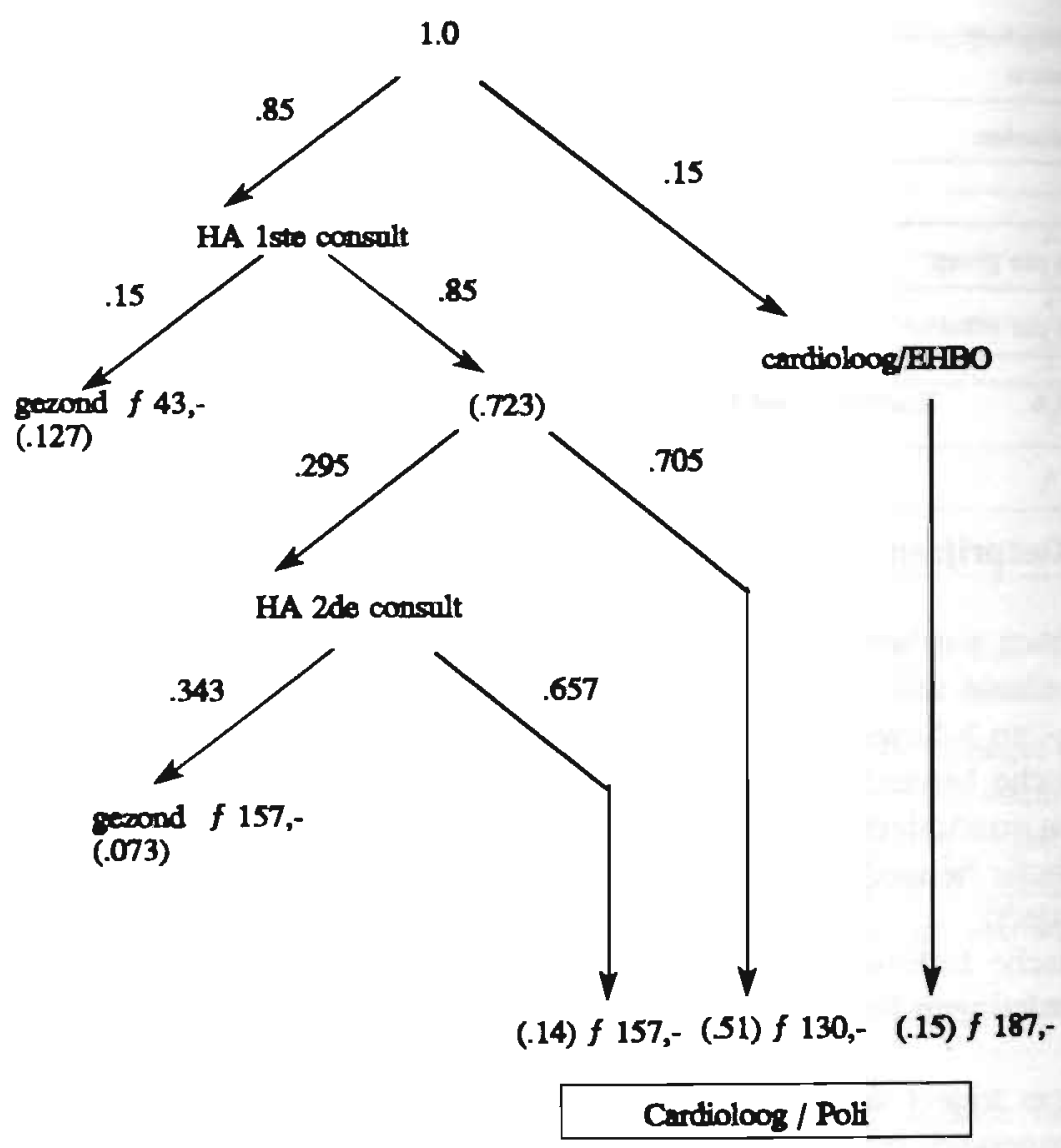

Figuur III.1 Voortraject Huisarts (HAEEHBO)

De patiënten met (vermoede) coronaire klachten starten bij de huisarts (85\%) 0 bij de cardioloog/EHBO (15\%). De huisarts verklaart een gedeelte na 1 à 2 con sulten (ca. 13\%) direct "gezond". Het overige gedeelte krijgt medicatie voor geschreven. De patiënt wordt doorgestuurd naar de cardioloog $(51 \%)$ of komt te rug op vervolgconsult $(21 \%)$. Indien de patiënt op het vervolgconsult (vermoede coronaire klachten blijft uiten, zal de huisarts de patiënt naar de cardioloo (14\%) verwijzen. In het andere geval wordt de patiënt door de huisarts alsno gezond (ca. 7\%) verklaard (Janssen, privé-communicatie, 1991).

In tabel III.7 zijn de kostprijzen per persoon van Huisarts/Gezond en Huis arts/Cardioloog/Poli weergegeven. 


\begin{tabular}{|c|c|}
\hline $\begin{array}{l}.127 * f \quad 42,79 \\
.073 * f 156,96\end{array}$ & $\begin{array}{lr}f & 5,43 \\
f & 11,46\end{array}$ \\
\hline $\begin{array}{l}\text { Huisarts / gezond } \\
.14 * f 156,96 \\
.51 * f 129,96 \\
.15 * f 186,96\end{array}$ & $\begin{array}{cc}f & 16,89 \\
f & 21,97 \\
f & 66,28 \\
f & 28,04\end{array}$ \\
\hline $\begin{array}{l}\text { Huisarts / Cardioloog / Poli } \\
\text { Totaal Huisarts / EHBO }\end{array}$ & $\begin{array}{l}\text { f } 116,29 \\
\text { f } 133,-\end{array}$ \\
\hline
\end{tabular}

Tabel III.7

Kostprijs Voortraject HA/EHBO per persoon

De totale kostprijs van het traject Huisarts en EHBO bedraagt :

$(f 17,--+f 116,--\Rightarrow) f 133,--$

In figuur III.2 wordt het (deel)traject cardioloog/poli weergeven. De cijfers tussen haakjes verwijzen naar de fracties van het aantal personen dat het betreffende onderzoek ondergaat.

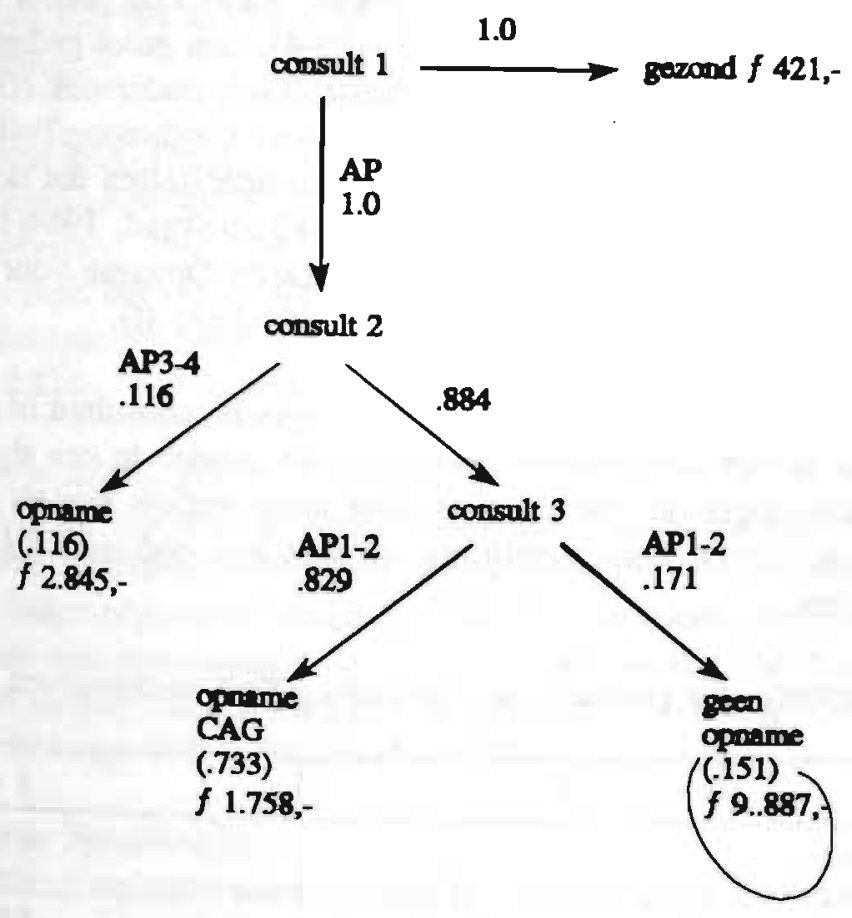

Figuur III.2

Voortraject Cardioloog/Poli 
Wij gaan ervan uit dat het eerste cardiologische consult binnen 2-4 weken na het laatste huisartsenconsult plaatsvindt. De gemiddelde AP-patiënt krijgt 2 \̀ 3 cra . diologische consulten per jaar. Er is tussen het eerste consult en het tweede corsult een standaardperiode van vier weken opgenomen. Daarna vindt er standaard om elke vijf maanden een vervolgconsult plaats.

De patiënt krijgt bij elk cardiologisch consult nieuwe of aanvullende medicaile voorgeschreven en er wordt (standaard) een ECG afgenomen. Een aanvullend diagnostisch onderzoek vindt plaats met betrekking tot de diagnosestelling AP3 4. De patiënt ondergaat een aantal overige diagnostische onderzoekingen (bijvoorbeeld, $75 \%$ fietsergometrie, $10 \%$ nucleair inspanningsonderzoek, en $20 \%$ echocardiografie).

In het eerste consult (consult 1) zal de cardioloog de diagnose AP bevestigen of de patiënt gezond verklaren. Het aantal patiënten dat na het eerste cardiologische consult gezond wordt verklaard is ca. $60 \%$ (Gezond).

De resterende $40 \%$ krijgt een tweede consult. De beide fracties zijn in figur III. 2 voor de overzichtelijkheid op $100 \%$ gesteld. Bij een klein deel van deze groep van patiënten verergeren de AP-klachten zich in hetzelfde jaar. In hel tweede consult vindt de diagnosestelling AP3-4 plaats, waarna de patiënt geindceerd wordt voor een electieve opname (Opname AP3-4). Een groot gedeelte van de groep AP1-2 wordt opgenomen voor nader diagnostisch onderzoek (Opname AP1-2). Een gedeelte van de AP-patiënten in het Traject Cardioloog/Poli word uiteindelijk niet opgenomen (Geen opname). Wij veronderstellen dat deze patiënten 7 jaar onder behandeling blijven (vgl. Gezondheidsraad, 1984/18). De kosten van deze behandelingen zijn in de kostprijs Geen Opname voor 7 jaar meegerekend (zie de paragraaf behandelingstrajecten uit bijlage II).

We maken geen onderscheid tussen het aantal cardiologische consulten in een agemeen ziekenhuis en in een academisch ziekenhuis. Er zouden in een algemeen ziekenhuis ca. 2-4 cardiologische consulten per jaar meer gedaan worden (prive. communicatie, Janssen, 1991). Deze verfijning moet in een gedetailleerd model wel aangebracht worden.

In tabel III.8 is de kostprijs per persoon van Cardioloog/Poli weergegeven.

\begin{tabular}{|l|r|}
\hline Cardioloog/Gezond & $f$ 421,- \\
\hline Cardioloog/Opname AP3-4 & f 2245,- \\
Cardioloog/Opname AP1-2 & f 1758,- \\
Cardicloog/Geen Opname & f 9887,- \\
\hline
\end{tabular}

Tabel III.8

Kostprijzen Voortraject Cardioloog/Poli per persoon 


\section{b) Kostprijzen Medische behandelingen Opnametraject}

In het opnametraject bestaat de medische behandeling voornamelijk uit de therapeutische behandelingen CABG, PTCA en MED. In het opnametraject zijn naast deze drie therapeutische behandelingen ook opgenomen de CAG, de AMI-thuis behandeling, de Ambulance, de Reanimatie, de FMI, en de CHF-behandeling.

We bespreken eerst de kostprijzen van CAG, AMI-thuis behandeling, Ambulance, Reanimatie, de FMI1, en CHF-behandeling. Vervolgens vindt de bespreking plaats van de methodiek die is toegepast bij de kostprijsberekening van de therapeutische behandelingen CABG, PTCA (en Thrombolytica), en MED. Daarna volgt een toelichting op de kostprijsberekening van elk van deze drie therapeutische behandelingen afzonderlijk.

\section{Kostprijs CAG}

De kostprijs van een CAG bedraagt $f 3.010$,-- per geval. Deze kostprijs is inclusief de opnameduur van 3 verpleegdagen. De CAG-kostprijs exclusief opnameduur bedraagt $f 2.280$,-- per persoon (CAG exclusief verpleegdagen). Bij de berekening van de CAG-kostprijs zijn wij uitgegaan van een gewogen gemiddelde naar rato van het aantal CAG's in een academisch ziekenhuis en een algemeen ziekenhuis.

\section{Kostprijs AMI-thuis}

De kostprijs AMI-thuis op jaarbasis is $f 3.214,--$. Hierin zijn begrepen de kosten van consulten, diagnostische onderzoekingen en medicatie. Wij rekenen deze kosten mee voor een periode van 4 jaar. Gedurende deze periode krijgt een AMI-thuispatiënt deze vorm van medische behandeling. De totale kostprijs wordt $4 * f 3.214,--=f 12.856,--$ per persoon.

\section{Kostprijs Ambulance}

De kostprijs van een ambulancerit is door ons geraamd op $f 400$,-- per rit. Er zijn geen gegevens beschikbaar waarmee de ambulancekostprijs naar de verschillende diagnosegroepen onderscheiden kan worden. Wij nemen aan dat de kostprijs van een ambulancerit in geval van een acute CHZ-manifestatie meer bedraagt dan de gemiddelde kostprijs of tarief, dat in de regio Maastricht gemiddeld $f$ 350,-- bedraagt (DGD-Maastricht, 1990).

\section{Kostprijs Reanimatie}

Wij hebben verondersteld dat een reanimatiecursus 2 jaar duurt. Er kunnen 1000 personen voor een tweejaarlijks budget van naar schatting $f 50.000,--$ getraind worden. De kostprijs reanimatie bedraagt dan $f 25$,-- per persoon. 
Een van de gezondheidszorgprogramma's met betrekking tot de scenario's (het opnameprogramma) heeft tot gevolg dat patiënten met een Plotse Hartdood (SD) kunnen overleven. De behandeling van deze patiënten veronderstellen we iden. tiek aan de AMI/MED (zie Kostprijs MED). Deze kostprijs bedraagt $f$ 21.445,-$\mathrm{Er}_{\mathrm{r}}$ is in samenhang met het opname programma ook een ambulance programma In het ambulance programma zijn twee kostenparameters opgenomen: een TV. spot en een gratis 06-lijn. De TV-spot (Postbus 51) is gericht op het tijdig inroepen van een ambulance in geval van een vermoed AMI. We hebben de kosprijs van een TV-spotje geraamd op $f 2 \mathrm{mln}$. per jaar.

De gratis 06-lijn geeft gerichte voorlichting over het herkennen van de symptomen van een AMI. We veronderstellen dat een medisch team van ca. 10 personen hiervoor ter beschikking staat. De kostprijs van een dergelijk "live" 06-lijn is geschat op $f 2 \mathrm{mln}$. per jaar.

Als gevolg van het ambulance programma zal een aantal AMI's ten onrechte worden opgenomen. De kostprijs hiervan is gelijkgesteld aan de kostprijs van 2 CCU-dagen, zijnde $(2 \times f 1.450,--=) f 2.900,--$ per opname.

\section{Kostprijs FMI1}

De kostprijs FMI1 komt overeen met de kostprijs van $1 \mathrm{CCU}$-verpleegdag. De gemiddelde CCU-kostprijs bedraagt $f 1.450,--$ per verpleegdag, berekend naar rato van het aantal AMI-opnames in de twee typen ziekenhuizen.

\section{Kostprijs CHF-behandeling}

De kostprijs van de CHZ-patiënt waarbij zich tijdens de opname CHF ontwikkell is gelijkgesteld aan de kostprijs van $1 \mathrm{CCU}$-verpleegdag. We veronderstellen dar aan dit type CHZ-patiënt een klein bedrag aan opnamekosten moet worden toegerekend, alvorens deze patiënt overgaat naar de toestand CHF. De kostprijs is op $f 1.450,--$ per persoon vastgesteld. De kosten van CHF-patiënten worden in het model verder niet berekend.

De prijsopbouw van de (routine) diagnostiek bestaat uit een vergoeding voor de medisch specialist en een vergoeding voor het ziekenhuis. In de praktijk blijkt de vergoeding voor de medisch specialist voor een aantal diagnostische verrichtingen in het gedeclareerde verpleegtarief begrepen te zijn. In onze kostprijsberekeningen wordt zoveel mogelijk uitgegaan van de werkelijke kostprijzen. Op basis van dit beginsel is een netto kostenbedrag per verpleegdag berekend waarin de vergoeding voor de medisch specialist nog niet begrepen is. Volgens deze methodiek van kostprijsberekening bestaat er dan ook geen gevaar voor dubbeltellingen. De berekening van de netto kosten per verpleegdag wordt verderop in deze paragraaf toegelicht. 
Methodiek kostprijsberekening therapeutische behandelingen We hebben de CABG, PTCA (en Thrombolytica), en MED gedefinieerd als therapeutische behandelingen. Andere therapeutische behandelingen zijn Reanimatie, Ambulance, en Hartrevalidatie. In deze sectie behandelen we alleen de kostprijsmethodiek met betrekking tot CABG, PTCA (en Thrombolytica), en MED. De kostprijzen Ambulance en Reanimatie zijn eerder in deze paragraaf besproken. De bespreking van de kostprijs Hartrevalidatie vindt verderop in deze paragraaf plaats. Wanneer we in deze sectie verwijzen naar therapeutische behandelingen worden uitsluitend CABG, PTCA (en Thrombolytica), en MED bedoeld.

Elke therapeutische behandeling kent zijn eigen (unieke) ligduur. De gehanteerde ligduur is gebaseerd op ervaringsgegevens uit de praktijk. Hierbij hebben het Academisch Ziekenhuis Maastricht (AZM) en het St. Jozef Ziekenhuis te Kerkrade model gestaan. De sterfte aan een operatie (PTCA, CABG) is in de kostprijsberekening gedefinieerd als de operatiesterfte.

We hebben bij de kostprijsbepaling van de therapeutische behandelingen de volgende methodiek toegepast.

Eerst is de kostprijs van een zogenaamde standaardbehandeling berekend. Een standaardbehandeling is een therapeutische behandeling die electief is geïndiceerd. Een therapeutische behandeling is electief geïndiceerd als er sprake is van een AP3-4 met een EF $\geq 40 \%$. Er zijn drie typen standaardbehandelingen, te weten:
1) standaard-CABG,
2) standaard-PTCA,
3) standaard-MED.

De indicatiestelling van een therapeutische behandeling met betrekking tot een andere manifestatievorm is aangeduid als een variatie op de standaardbehandeling. Deze variaties kunnen leiden tot verschillen in zorgintensiteit, ligduur, medicatie, diagnostiek, en concultfrequenties. De gegevens hierover zijn verkregen uit privé-communicatie (Janssen, 1991). De zogenaamde standaardkostprijs wordt gecorrigeerd met de meer- en minder kosten die door de variaties op de standaardbehandeling gegenereerd worden.

De kostprijzen van de therapeutische behandelingen hangen voor een belangrijk deel samen met de verhoogde risicokenmerken (zie Bijlage I): 


\section{(i) de type manifestatievorm}

De type manifestatievorm bepaalt de urgentiegraad van de opname. De behandelingstherapie wordt weer voor een belangrijk deel door de urgentiegraad van de opname bepaald. Acute opnames generen in vergelijking met electieve opnames veelal een langere en een meer zorgintensieve verpleegduur. De electieve opnames worden vaker als electieve operatie geïndiceerd.

\section{(ii) de hoogte van de $\mathrm{EF}$}

Een opname met een slechte EF (EF < 40\%) kan afhankelijk van de manifestatievorm en de type therapeutische behandeling een langere en een meer zorg- en behandelingsintensieve ligduur genereren.

\section{(iii) leeftijds- en geslachtsinvloeden}

Over het algemeen brengt de behandeling van oudere ( $>65$ jaar) CHZ-patiënten een hogere kostprijs met zich mee dan die van jongere $\mathrm{CHZ}$-patiënten (De Mol, 1985). Ook zouden vrouwelijke patiënten hogere kostprijzen veroorzaken dan mannelijke. Met de ter beschikking staande gegevens is het niet goed mogelijk de kostprijzen van de medische behandelingen te differentiëren naar leeftijd en geslacht. De zorg- en behandelingsintensiteit die rondom een opname met een EF $<40 \%$ plaatsvindt zou leeftijdsonafhankelijk zijn (Janssen, privé-communicatie, 1991). We hebben in de kostprijsbepaling daarom geen onderscheid aangebracht naar leeftijd en geslacht.

\section{(iv) fysiologische en anatomische kenmerken}

De kostprijzen worden niet gedifferentieerd naar het aantal vernauwde kransslagaders (1-VD, 2-VD, 3-VD, LMD) hoewel dit kenmerk zonder meer van invloed is op de ligduur en dergelijke en dus op de kostprijs. De reden is dat er geen voldoende gegevens beschikbaar zijn om een differentiatie in de kostprijzen hiervoor aan te brengen.

In de kostprijsberekeningen van de therapeutische behandelingen is gebruik gemaakt van de volgende gegevens.

(i) Kostprijsverschillen tussen verschillende typen ziekenhuizen

Er kunnen ruwweg drie typen ziekenhuizen onderscheiden worden:

1) het algemeen ziekenhuis,

2) het academisch ziekenhuis, en

3) het zogenaamde academisch geoutilleerd algemeen ziekenhuis. 
Tussen een algemene ziekenhuis en een academisch ziekenhuis kunnen kostprijsverschillen als gevolg van verschillende oorzaken bestaan. Een academisch ziekenhuis heeft meer zware functies (grotere personeelsbezetting per bed), een topreferentie functie (de zogenaamde "last resort"-functie) en meer vierkante meters met betrekking tot de huishouding en onderhoud vanwege een grotere omvang van de nevenafdelingen.

De MED is de enige therapeutische behandelingsvorm die in zowel een algemeen ziekenhuis als in een academisch ziekenhuis plaatsvindt. Een PTCA en $\mathrm{CABG}$ worden uitgevoerd in academische ziekenhuizen en in de academisch geoutilleerde algemene ziekenhuizen. Wij hebben om praktische redenen verondersteld dat de kostprijzen van operaties, die in beide typen ziekenhuizen plaatsvinden, gelijk zijn.

De kostprijzen van zowel een standaard-CABG als een standaard-PTCA zijn inclusief de kosten van rente en afschrijving. Het uitgangspunt is dat de kostprijzen het werkelijk beslag weergeven dat op de produktiemiddelen wordt gelegd. De financieringswijze van de academische ziekenhuizen brengt echter met zich mee dat in de gedeclareerde bedragen de kapitaalskosten niet worden doorberekend. Wij hebben de kapitaalskosten die in de standaard-CABG kostprijs en de standaard-PTCA kostprijs van een academisch ziekenhuis zijn opgenomen gelijkgesteld aan de kapitaalskosten van de academisch geoutilleerde algemene ziekenhuizen.

(ii) Kostprijzen opname verpleegafdeling

De kostprijs van de opname op een verpleegafdeling wordt bepaald door de kostprijs per verpleegdag te vermenigvuldigen met de verpleegduur. Afhankelijk van de manifestatievorm, het type therapeutische behandeling en de hoogte van de EF varieert de verpleegduur van 3 dagen tot 6-8 weken.

De kostprijs per verpleegdag wordt gevormd door een vast en een variabel kostprijsbestanddeel. Wij hebben het vaste bestanddeel van de kostprijs per verpleegdag aangectuid als de netto kosten per verpleegdag (a). Het variabele kostprijsbestanddeel per verpleegdag bestaat uit een verrichtingenprofielkostprijs (b).

(a) netto kosten per verpleegdag

Wij verstaan onder de "netto kosten per verpleegdag" de kostprijs van verpleegkundige zorg per verpleegdag in een ziekenhuis, bestaande uit de kosten van de klinische verpleegfunctie, exclusief de kosten van medicamenten en toedieningssystemen, en de toe te rekenen kosten van de klinisch ondersteunende functie. De netto kosten per verpleegdag van een algemeen ziekenhuis en een acadeisch ziekenhuis bedragen respectievelijk $f$ 209,-- en $f 261,--$. In berekening van de netto kosten per verpleegdag wordt geen rekening gehouden met de kapitaalskosten van academische ziekenhuizen. Er zijn geen gepubli- 
ceerde gegevens hierover bekend. Reeds eerder is toegelicht dat de academische ziekenhuizen geen kapitaalskosten in hun declaraties doorberekenen. De kostprijs van $f$ 261,-- geeft een onderschatting weer van de netto kosten per verpleegdag van academische ziekenhuizen.

De benodigde data is verkregen uit publicaties van NZi (1988), COTG (1987) en uit privé-communicatie (Van Aalst, 1990, Janssen, 1990).

\section{(b) kostprijs verrichtingenprofiel}

De kostprijs verrichtingenprofiel is opgebouwd uit de kostprijs medicatie, diagnostiek, consulten, en intensive care. Er kunnen verschillende verrichtingenprofielen samengesteld worden. Het verrichtingenprofiel hangt hierbij af van de manifestatievorm, de hoogte van de EF, en de type ziekenhuis. Gegevens over de opbouw van de verrichtingenprofielen en de daarbij horende kansen en frequenties zijn verkregen uit privé-communicatie met cardiologen die bij het Academisch Ziekenhuis Maastricht, het Algemeen Ziekenhuis Kerkrade en het Algemeen Ziekenhuis Sittard zijn aangesloten. De kostprijs van elk verrichtingenprofiel wordt bepaald door het aantal verrichtingen met de prijs van die verrichting te vermenigvuldigen. Wij hebben de honoraria, prijzen van diagnostiek en prijzen van geneesmiddelen overgenomen uit publicaties van Honorering Huisartsenhulp (1987), NZi (1987), Farmacotherapeutisch Kompas (1989), Honorering Medisch Specialistische Hulp door Ziekenfondsen (1987), Particuliere Tarieven Medisch Specialistische Hulp COTG (1988, 1989), Winter (1988), KISG (1990) en aangevuld met gegevens verkregen uit privé-communicatie (Van Aalst, 1991, Janssen, 1991, Straver, 1991).

\section{(iii) Kostprijzen intensive care}

Wij onderscheiden drie typen gespecialiseerde en zorgintensieve verpleegafdelingen: 1) cardiologische coronary care (CCC/CU), 2) coronary care unit (CCU) en 3) de medium care unit (MCU). De kostprijzen van deze drie typen intensive care staan in tabel III.9 vermeld. De gegevens zijn bewerkt naar Bams e.a. (1985) en Spangenberg (1988).

\begin{tabular}{|l|r|r|}
\hline Typen Intensive Care & Algemeen Zekenhuis & Academisch Zlekenhub \\
\hline CCCICU & $f 2345,-$ & $f 2605,-$ \\
\hline CCL: & $f 1.427,-$ & $f$ 1583,- \\
\hline MCU & $f 813,--$ & $f$ 891,- \\
\hline
\end{tabular}

Tabel III.9

Kostprijzen intensive care 
Zoals eerder vermeld geven we nu een korte toelichting op de kostprijsberekening van elke therapeutische behandeling afzonderlijk.

\section{Kostprijs CABG}

De standaard-CABG kostprijs bedraagt $f 24.950,--$ per opname. Dit bedrag is inclusief de honoraria die de medisch specialisten in rekening brengen. Wij hebben de bepaling van de standaardkostprijs gebaseerd op de kostprijsgegevens die door het COTG (1987) zijn gepubliceerd. De COTG-publicatie (1987) betrof een onderzoek naar functiegerichte budgettering, in welk verband ook kostprijsgegevens met betrekking tot CABG en PTCA opgenomen waren.

De verschillen in zorgintensiteit en dergelijke die optreden als gevolg van een variatie op de standaardbehandeling, worden doorberekend in de standaardCABG kostprijs als zijnde meer- en minderkosten.

\section{Kostprijs PTCA}

De standaard-PTCA kostprijs is $f 9.000,--$ per opname. Hierin zijn begrepen de honoraria van de medisch specialisten. De standaardkostprijsbepaling van de PTCA is gebaseerd op gepubliceerde kostprijsgegevens van het COTG (1987). De variaties op de standaard-PTCA leiden tot de meer- en minderkosten die in de standaard PTCA-kostprijs worden doorberekend.

In de PTCA-kostprijzen is geen rekening gehouden met de eventuele kosten van CABG-standby. Het is onduidelijk welke regeling hiervoor in de praktijk is getroffen. Volgens Van der Werf (1984) hoeven de CABG-standby kosten niet doorberekend te worden wanneer er sprake is van overcapaciteit op de operatiekamer en alternatieve inzetbaarheid tijdens de standby. In een PTCA kosten-effectiviteitsstudie zouden de PTCA-kostprijzen verder onderzocht kunnen worden met betrekking tot doorberekening van de CABG-standby kosten.

Uit de praktijk blijkt dat vaak aansluitend op het CAG-onderzoek direct tot een PTCA wordt overgegaan. Uiteraard alleen in de gevallen dat de anatomische toestand dit toestaat. In die gevallen hoeft de PTCA-kostprijs in het model niet verhoogd te worden met de kostprijs van de CAG. (Zie ook verderop).

\section{Thrombolytica (IVT) in relatie tot PTCA}

In ca. $20-25 \%$ van het totaal aantal AMI's wordt een thrombolytische medicatie toegediend. Van dit aantal blijft in ca. $20 \%$ van de gevallen de kransslagader gesloten, waarna een spoed-PTCA volgt. In geval van een mislukte PTCA is de operatiemortaliteit hoog, vanwege een sterk vergrote kans op peri-MI dan wel herhaald AMI. 
In onderstaande figuur III.3 wordt dit (kans) proces in een stroomschema weergegeven.

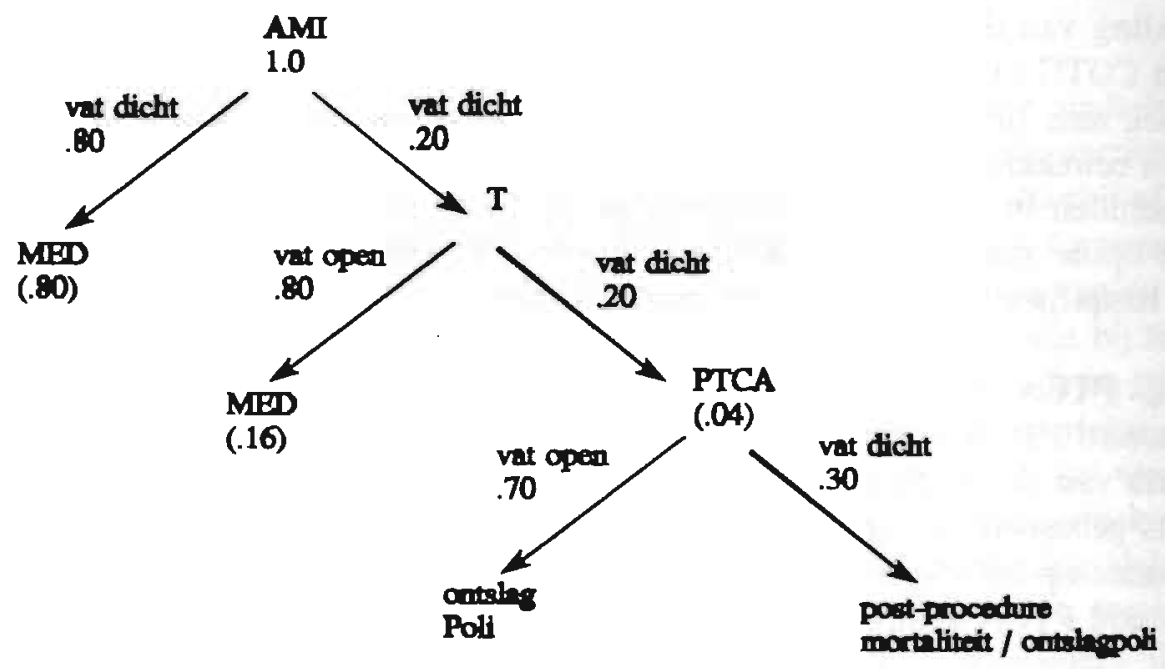

Figur III.3 Traject AMI+T (thrombolytica) gerelateerd aan een spoed PTCA

Uit figuur III.3 blijkt ondermeer dat de AMI-gevallen, waarbij de afgesloten kransslagader zich na een thrombolytische behandeling heropent, overgaan naar het zgn. MED-traject.

Overigens willen we hierbij aantekenen dat "open gaan" van een afgesloten kransslagader als gevolg van thrombolytica, in feite betrekking heeft op het open gaan van de grotere kransslagaders in het getroffen gebied. Tevens veronderstellen we dat in die gevallen een ejectiefractie $\geq 40 \%$ behouden kan worden (zie figuur III.3).

\section{Kostprijs IVT}

De thrombolytische behandeling $(\mathrm{T})$ bestaat nagenoeg geheel uit de toediening van Streptokinase. De Streptokinase wordt intraveneus (IV) toegediend. Gerekend tegen de dagprijs ziekenhuisapotheek bedraagt de kostprijs IVT $f$ 1.014,--De toestand "AMI, vat dicht", is de toestand waarbij beoogd wordt de afgesloten kransslagader met de PTCA te heropenen. Uit figuur III. 3 blijkt dat er (.70* 
$1.150 \Rightarrow 805$ geslaagde PTCA's zijn. Het getal van 1.150 PTCA's kan in figuur II. 5 van Bijlage II afgelezen worden. In het geval dat de afgesloten kransslagader na PTCA dicht blijft is de ligduur aanzienlijk hoger. $(.30 * 1.150=345$ mislukte PTCA's). We nemen aan, dat alle mislukte PTCA's uiteindelijk ten gevolge van Peri-MI of aan een latere AMI zullen overlijden. Gedurende deze periode behouden de mislukte PTCA's wel de volledige kostprijs. Modelmatig kan zowel bij een geslaagde als bij een mislukte PTCA operatiesterfte optreden. De kostprijzen worden in beide gevallen tot de helft gereduceerd.

\section{Kostprijs MED}

De kostprijs van een standaard-MED berekenend door de kostprijs per verpleegdag te vermenigvuldigen met de verpleegduur. We hebben de netto kosten per verpleegdag verhoogd met de kostprijzen van medicatie, diagnostiek, honoraria, en intensive care. De aldus verkregen kostprijs van een standaard-MED bedraagt $f 1.434,--$ per opname in een algemeen ziekenhuis en $f 1.642,--$ per opname in een academisch ziekenhuis. De gemiddelde kostprijs MED is $f 1.461,--$ per opname (gewogen gemiddelde berekend naar rato van het aantal opnames MED in een algemeen ziekenhuis (87\%) en in een academisch ziekenhuis (13\%)). De verdeling van het aantal opnames in 1988 over de type ziekenhuizen is afgeleid van gegevens die door de SIG (1992) met betrekking tot 1988 zijn verstrekt. Als gevolg van variaties op een standaard-MED ontstaan er meer- en minderkosten die doorberekend zijn op de standaardkostprijs MED.

In tabel III.10 wordt een samenvattend overzicht gegeven van de kostprijzen van CABG, PTCA, en MED. De kostprijs IVT en de kostprijzen van de CAG's zijn niet in deze tabel opgenomen.

\begin{tabular}{|c|c|c|c|c|c|}
\hline Behandeling & Ejectiefractie & AMI & UAP & AP3-4 & AP1-2 \\
\hline \multirow{2}{*}{ CABG } & $\mathrm{EF}<40 \%$ & $f$ 46.395,-- & f 28.752,- & f 27.262,- &,$- \cdots$ \\
\hline & $E F \geq 40 \%$ & $f 34.679, \ldots$ & f 24.950,-- & f 24.950,-- & f 24.950,- \\
\hline \multirow{2}{*}{ PTCA } & EF $<40 \%$ & $f 36.865,--$ & f 11.865,- & f $9.000,-$ & $f \quad-,--$ \\
\hline & $\mathrm{EF} \geq 40 \%$ & f $14.774,-$ & f 11.865,- & f $9.000,-$ & $f 9.000,-$ \\
\hline \multirow{2}{*}{ MED } & EF $<40 \%$ & f 21.445,-- & $f 4.608,--$ & $f$ 1.461,-- & $f \quad-\cdots$ \\
\hline & $\mathrm{EF} \geq 40 \%$ & $\begin{array}{l}f 5.899,- \\
\text { f } 9.729,-\end{array}$ & $f$ 4.608,- & $f$ 1.461,- & $f$ 1.461,- \\
\hline
\end{tabular}


Een AMI/MED met een $E F \geq 40 \%$ kan al dan niet zijn voorafgegaan door een IVT. In geval van een geslaagde IVT bedraagt de kostprijs AMI/MED $f$ 5.899,De kostprijs van AMI/MED zonder IVT of in geval van mislukte IVT is $f 9.729,--$.

In geval van operatiemortaliteit worden de kostprijzen tot de helft gereduceerd. De kostprijs in geval van FMI2 reduceert tot $25 \%$. De FMI2 treedt modelmatig alleen op wanneer er sprake is van AMI en UAP bij EF < 40\%. In beide gevallen bedraagt de FMI2-kostprijs $(25 \% * f 21.445,-=) f 5.361,--$.

Wij hebben eerder aangenomen dat een acute (spoed) opname en een electieve opname zijn geïndiceerd bij een AMI en UAP, respectievelijk bij AP3-4 en AP1. 2.

In het model wordt de kostprijs van een electieve $C A B G$ verhoogd met de kostprijs van CAG vo6r operatie ( $f 3.010,--)$ en de kostprijs van CAG tijdens operatie $(f 2.280,--)$. De kostprijs van een electieve PTCA wordt alleen verhoogd met de kostprijs van een CAG vór operatie $(f 3.010,--)$. De kostprijs CAG tijdens operatie is reeds begrepen in de PTCA-kostprijs.

De kostprijs van een acute CABG wordt verhoogd met de kostprijs CAG tijdens operatie ( $f 2.280,--)$.

\section{c) Kostprijzen Medische behandelingen Follow-up traject}

Wij gaan bij de bespreking van deze kostprijzen eerst in op de toegepaste methodiek. Daarna volgt een toelichting op de kostprijzen Medische behandelingen Follow-up traject $<1$ jaar respectievelijk Medische behandelingen Follow-up traject $\geq 1$ jaar.

\section{Methodiek Kostprijsberekening Follow-up behandelingen}

$\mathrm{Er}$ is bij de kostprijsberekeningen een onderscheid gemaakt tussen follow-up behandelingen in het eerste jaar ( $<1$ jaar) en de follow-up behandelingen in het tweede en volgende jaren na ontslag ( $\geq 1$ jaar).

De follow-up behandelingen $<1$ jaar worden onderscheiden analoog aan de drie ziektetoestanden die in Bijlage II zijn besproken ("zonder recurrentie", "na recurrentie", en "wel recurrentie"). De ziektestoestanden "wel recurrentie" en "na recurrentie" hebben betrekking op de perioden v6or respectievelijk na het moment van een eventuele 2e CHZ-opname gedurende het le jaar.

De follow-up kostprijzen "zonder recurrentie" worden beschouwd als de kostprijs van de follow-up behandelingen $<1$ jaar die op jaarbasis gemaakt worden. In geval van "na recurrentie" zijn de follow-up kostprijzen gelijk aan de helft van de follow-up kostprijzen "zonder recurrentie". De follow-up kostprijzen "wel recurrentie" zijn hoger dan de helft van de follow-up kostprijzen "zonder recur- 
rentie". De follow-up behandelingen "wel recurrentie" vinden in de eerste zes maanden plaats. We hebben verondersteld dat recurrente gebeurtenissen gemiddeld een half jaar na het ontslag optreden. De patiënt die binnen zes maanden een recurrente CHZ-gebeurtenis krijgt genereert extra behandelingen. Er wordt meer ontslagmedicatie voorgeschreven en er zijn meer overige diagnostische onderzoekingen aan het eerste poliklinische consult verbonden.

De kostprijzen van follow-up behandelingen $\geq 1$ jaar hebben betrekking op (verwachte) toekomstige behandelingen van patiënten die in 1988 een $\mathrm{CHZ}$ gebeurtenis hebben gehad.

Wij zijn er van uitgegaan dat de CHZ-populatie die in de toekomst een followup behandeling ondergaat, op dezelfde wijze over de follow-up behandelingen wordt verdeeld als de CHZ-populatie die in 1988 een follow-up behandeling heeft ondergaan. De veronderstelling hierachter is dat de verdeling van de CHZpopulatie over de follow-up behandelingen in zeer geringe mate in de tijd verschuift. De kostprijzen van de follow-up behandelingen $\geq 1$ jaar zijn berekend aan de hand van het behandelingsprofiel van de betreffende patiëntenpopulatie uit 1988.

We hebben om deze reden de kostprijzen van follow-up behandelingen die in een bepaald jaar $(t+1)$ plaatsvinden daarom niet verdisconteerd naar het jaar $(t)$ waarin de laatste $\mathrm{CHZ}$ gebeurtenis (laatste incidentie) plaatsvond.

De begeleiding van het follow-up traject vindt bij alle ziekenhuizen plaats. Ook bij die algemene ziekenhuizen zonder academische outillage die de PTCA's en de CABG's uitbesteden aan daartoe uitgeruste centra.

$\mathrm{Er}$ is geen onderscheid gemaakt tussen het aantal cardiologische consulten in een algemeen ziekenhuis en een academisch ziekenhuis. Volgens de gegevens verkregen uit privé-communicatie (Janssen, 1991) zou in een algemeen ziekenhuis meer cardiologische follow-up consulten plaatsvinden dan in een academisch ziekenhuis. In een gedetailleerde kostprijsberekening moet dit onderscheid wel worden uitgewerkt.

In het follow-up traject worden de kostprijzen van de follow-up behandelingen niet gedifferentieerd naar de type manifestatievorm, omdat ze daar onvoldoende voor discrimineren. De ontslagmedicatie en de verdere follow-up behandeling hangen meer samen met het restniveau van de ejectiefractie (EF $<40 \%, \mathrm{EF} \geq$ $40 \%$ ) en de in het ziekenhuis uitgevoerde therapeutische behandelingen (aangegeven als oud-CABG, oud-PTCA, oud-MED). Wij onderscheiden met betrekking tot de laatst uitgevoerde therapeutische behandeling drie homogene follow-up behandelingsgroepen: 
a) oud-CABG follow-up behandelingen,

b) oud-PTCA follow-up behandelingen,

c) oud-MED follow-up behandelingen.

Concluderend kunnen de kostprijzen medische behandelingen follow-up trajer worden ingedeeld in 24 kostprijsgroepen, te weten:

- < 1 jaar: 3 (toestanden) $\times 2$ (EF) $\times 3$ (oud-therapeutische behandelingen)= 18 kostprijsgroepen,

- $\geq 1$ jaar: $\quad 2$ (EF) $\times 3$ (oud-therapeutische behandelingen) $=6$ kostprijggroepen.

We vinden de 18 respectievelijk 6 kostprijsgroepen terug in tabel III.13 respertievelijk tabel III.14 die beide verderop in deze paragraaf gepresenteerd worden.

\section{Kostprijzen medische behandelingen Follow-up Traject $<1$ jaar}

De kostprijs van de cardioloog/poli in het follow-up traject $<1$ jaar behorende bij de drie therapeutische behandelingen tijdens de opname worden vervolgens gepresenteerd. Het stroomschema voor de drie behandelingstypen is identiek. De kostprijzen kunnen echter verschillen. We presenteren in figuur II.4 alleen hel stroomschema voor het oud-CABG follow-up traject $<1$ jaar. 
De kostprijzen oud-PTCA en oud-MED follow-up behandelingen $<1$ jaar zijn op dezelfde wijze berekend als de kostprijs oud-CABG follow-up behandeling < 1 jaar. Een uitzondering betreft het cardiochirurgisch consult dat alleen in de kostprijsberekening oud-CABG follow-up behandeling $<1$ jaar voorkomt.

Alle patiënten ontvangen ontslagmedicatie bij het verlaten van het ziekenhuis. $\mathrm{Na} 1$ maand vindt het eerst cardiologische consult plaats. Parallel maar onafhankelijk van het cardiologische consult krijgen alle ontslagen CABG-patiënten gemiddeld 2 cardio-chirurgische consulten. Wegens het ontbreken van gegevens worden aan de cardio-chirurgische consulten geen behandelingsconsequenties verbonden. Tijdens het eerst cardiologische consult wordt medicatie voor een periode van 4 weken voorgeschreven. $\mathrm{Na}$ afloop van dit medicatievoorschrift komen patiënten terug voor een tweede cardiologisch consult. De patiëntengroep EF $\geq 40 \%$ krijgt hierna nog 2 cardiologische consulten, terwijl bij de patiëntengroep EF $<40 \%$ dit aantal 3 bedraagt. Een EF $<40 \%$ indiceert agressieve (0nderhouds)medicatie en intensieve diagnostische onderzoekingen. De kans op een nieuwe incidentie is groter bij een $\mathrm{EF}<40 \%$. Opgeteld levert dit de volgende consult/frequentie op:

- Ejectiefractie < 40\%: 5 consulten in 1ste jaar,

- Ejectiefractie $\geq 40 \%$ : 4 consulten in 1 ste jaar.

Bij elk cardiologisch consult wordt standaard een ECG verricht. De frequentie van de consulten is afhankelijk van de ejectiefractie. De poliklinische kosten bestaan uit kosten van medicatie, diagnostisch onderzoek en consulten. Een belangrijk onderdeel van de diagnostische onderzoekingen zijn CAG's na een operatieve ingreep. Vanwege het ontbreken van gegevens hebben we in onze studie (nog) geen behandelingsconsequenties aan de CAG's verbonden. Verder doorloopt de patiënt een kans (knoop) op een recurrente CHZ-manifestatie binnen 1 jaar. Wanneer zich geen $\mathrm{CHZ}$-recurrentie heeft voorgedaan gaat de patiënt aan het einde van het jaar over naar het follow-up traject $\geq 1$ jaar.

Uit de gegevens in tabel III.11 van de Commissie Coronair Angiografie (CCA, 1989) blijkt dat in 1988 het volgende aantal CAG's in de follow-up fase heeft plaatsgevonden.

\begin{tabular}{|l|r|}
\hline CAG na CABG & 2100 \\
CAG na PTCA & 1260 \\
\hline Totagl & 3.360 \\
\hline
\end{tabular}

Tabel III.11

Aantal CAG's in follow-up traject 


\section{Kostprijzen Medische behandelingen Follow-up Traject $\geq 1$ Jaar}

Voor de kostprijsberekening is het belangrijk onderscheid te maken naar het restniveau van de EF. Zoals al eerder toegelicht genereert een toestand met een EF $<40 \%$ meer kosten wegens een intensievere behandeling en nazorg. Daarenboven hebben patiënten met een slechte EF een sterk verhoogde kans op CHF, SD en FMI.

In een periode van 2-5 jaar worden de consulten, de medicatie en de diagnostische onderzoekingen afhankelijk van het restniveau van de EF geleidelijk afgebouwd, zoals gepresenteerd in tabel III.12.

\begin{tabular}{|l|r|r|}
\hline lantste therapeutische behandeling & EF < 40\% & EF $\geq 40 \%$ \\
\hline oud-CABG & 1 jagr & 4 jagr \\
\hline oud-PTCA & 1 joar & 1,5 jar \\
\hline oud-MED & 1,5 jar & 1,5 jagr \\
\hline
\end{tabular}

Tabel III.12

Gemiddelde medicatieduur Follow-up traject $\geq 1$ jaar, gedifferentieerd naar de laatste therapeutische behandeling

In geval van een $E F \geq 40 \%$ is in tabel III. 12 verondersteld dat de medicatie na een CABG-behandeling in ca. 5 jaar wordt afgebouwd. Bij een EF $<40 \%$ blijft een intensieve medicatie voorgeschreven. Hierbij wordt aangenomen dat binnen 2 jaar een nieuwe gebeurtenis zich zal voordoen. We veronderstellen dat zo'n gebeurtenis gemiddeld optreedt op de helft van de onderscheiden periode. Zodoende zijn voor de kostenberekeningen voor patiënten met EF $<40 \%$ de medicatieperioden gemiddeld gelijk aan 1 jaar. Omdat de kans op een nieuwe gebeurtenis bij $\mathrm{EF} \geq 40 \%$ lager is, wordt verondersteld dat de medicatieperiode bij EF $\geq$ 40\% gemiddeld 4 jaar duurt.

De medicatieperiode na een PTCA behandeling in tabel III.12 duurt gemiddeld 2 jaar bij een EF $<40 \%$ en eveneens 2 jaar bij een EF $\geq 40 \%$. Gecorrigeerd voor het optreden van een nieuwe gebeurtenis is de gemiddelde medicatieperiode bij een $\mathrm{EF}<40 \% 1$ jaar en bij EF $\geq 40 \% 1,5$ jaar.

De medicatieperiode na een MED behandeling in tabel III.12 duurt 3 jaar respectievelijk 2 jaar bij EF $<40 \%$ respectievelijk EF $\geq 40 \%$. Gecorrigeerd voor het optreden van een nieuwe gebeurtenis is de gemiddelde medicatieperiode geschat op 1,5 jaar zowel bij een EF $<40 \%$ als EF $\geq 40 \%$.

Een ander eerder genoemd criterium, dat eveneens een kostendiscriminerende betekenis heeft, is de behandelingskeuze die in het opnametraject heeft plaatsge- 
vonden. De behandelingskeuzen zijn CABG, PTCA en MED.

Onderstaand worden nu de kostprijzen voor cardioloog/poli in het follow-up tra ject $\geq 1$ jaar uitgewerkt, die voor de nazorg van elk van deze drie behandelings. groepen uit het opnametraject worden gemaakt.

Ook voor het follow-up traject $\geq 1$ jaar zijn de stroomschema's voor de drie behandelingsvormen CABG, PTCA en MED identiek. We presenteren in figur III.5 het stroomschema oud-CABG follow-up traject $\geq 1$ jaar

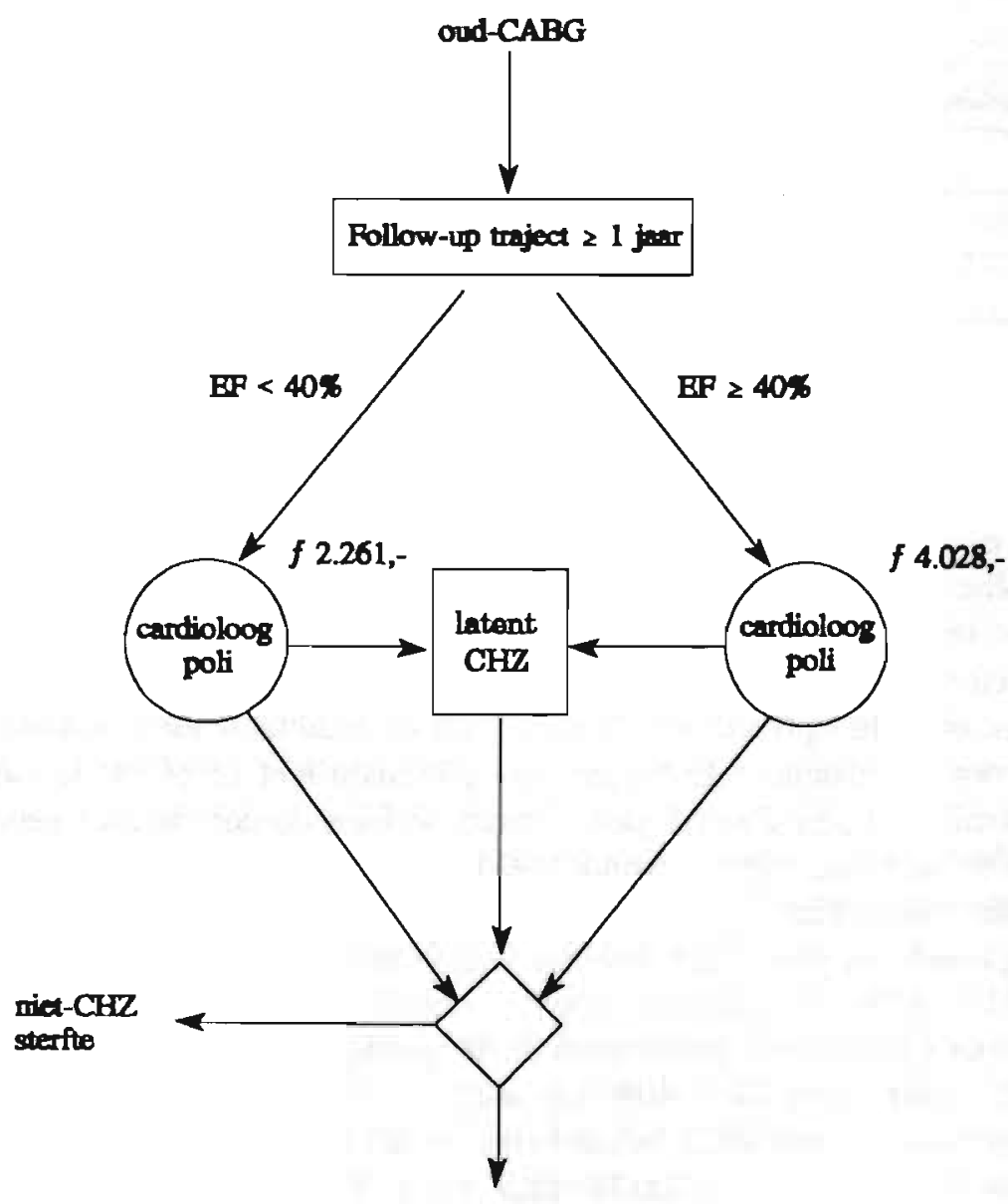

CHZ-Rocurrentio

Figuur III.5

Stroomschema van het follow-up traject $\geq 1$ jaar voor oud-CABG patiënter en de gemiddelde kostprijs per traject 
In het algemene stroomschema van het follow-up traject $\geq 1$ jaar vindt in de beslisknoop cardioloog/poli de nazorg plaats gedurende een aantal jaren (zie Bijlage II). Indien er zich geen nieuwe gebeurtenis voordoet (CHF, sterfte niet-CHZ of incidentie $\mathrm{CHZ}$ ), worden de patiënten na ontslag van nazorg "gestationeerd" in de CHZ-bevolking. Deze groep is "vrij" van coronaire pijnklachten en vertoont geen tekenen van hartinsuffi-ciëntie. Deze groep heeft wel een verhoogde kans op een nieuwe $\mathrm{CHZ}$-incidentie en $\mathrm{CHF}$ in vergelijking met personen zonder een $\mathrm{CHZ}$ voorgeschiedenis.

In tabellen III.13 en III.14 volgt een samenvattend overzicht van de kostprijzen van de medische behandelingen follow-up traject.

\begin{tabular}{|l|l|l|l|l|}
\hline \multirow{4}{*}{ EF $<40 \%$} & $\begin{array}{l}\text { laatste medische } \\
\text { behandeling }\end{array}$ & $\begin{array}{l}\text { wel } \\
\text { recurrentile }\end{array}$ & $\begin{array}{l}\text { na } \\
\text { recurrentle }\end{array}$ & $\begin{array}{l}\text { geen } \\
\text { recurrentle }\end{array}$ \\
\cline { 2 - 5 } & oud-MED & $f 1.462,-$ & $f 1.261,-$ & $f 2.523,-$ \\
& oud-CABG & $f 1.246,-$ & $f 1.023,-$ & $f 2.047,-$ \\
& oud-PTCA & $f 1.330,-$ & $f 1.148,-$ & $f 2.297,-$ \\
\hline
\end{tabular}

\begin{tabular}{|c|c|c|c|c|}
\hline \multirow{2}{*}{$E F>40 \%$} & $\begin{array}{l}\text { laatste medische } \\
\text { behandeling }\end{array}$ & $\begin{array}{l}\text { wel } \\
\text { recurrentie }\end{array}$ & $\begin{array}{l}\text { na } \\
\text { recurrentie }\end{array}$ & $\begin{array}{l}\text { geen } \\
\text { recurrentle }\end{array}$ \\
\hline & $\begin{array}{l}\text { oud-MED } \\
\text { oud-CABG } \\
\text { ond-PTCA }\end{array}$ & $\begin{array}{ll}f & 811,- \\
f & 600,- \\
f & 719,-\end{array}$ & $\begin{array}{l}f \quad 669,- \\
f \quad 463,- \\
f \quad 596,-\end{array}$ & $\begin{array}{l}f \text { 1.338,- } \\
f \quad 926,- \\
f \quad 1.191,-\end{array}$ \\
\hline
\end{tabular}

Tabel III.13

Kostprijzen medische behandelingen follow-up traject $<1$ jaar

\begin{tabular}{|l|l|l|}
\hline $\begin{array}{l}\text { laatste medische } \\
\text { behandeling }\end{array}$ & EF $<40 \%$ & FF $\geq 40 \%$ \\
\hline oud-MED & f $3.249,--$ & f $1.787,-$ \\
oud-CABG & f $2.261,--$ & f.028,-- \\
oud-PTCA & f $2.641,--$ & $2.513,--$ \\
\hline
\end{tabular}

Tabel III.14

Kostprijzen medische behandelingen follow-up traject $\geq 1$ jaar

Wij rekenen tot de medische behandelingen follow-up traject ook de Hartrevalidatie en Thrombosedienst. Er volgt een korte toelichting op de kostprijsberekening van beide behandelingen. 


\section{Kostprijs Hartrevalidatie}

$\mathrm{Na}$ ontslag uit het ziekenhuis krijgt een bepaald aantal patiënten Hartrevalidatie. Dit wordt meestal bepaald bij het hartchirurgisch consult. De kostprijsbepaling van Hartrevalidatie is gebaseerd op een kostenstudie van hartrevalidatie in Lim. burg (Gosselink, 1989). In de studie van Gosselink (1989) is geen rekening ge. houden met de overheadkosten. Wij hebben de kostprijs hiervoor verhoogd. $D_{t}$ kostprijs hartrevalidatie bedraagt gemiddeld $f 1.000,--$ per persoon.

\section{Kostprijs Thrombosedienst}

Alle ontslagen AMI en UAP patiënten gaan bij de Thrombosedienst voor controle in verband met stolsel-vorming in het bloed. De kostprijs van de thrombosedienst is vastgesteld op gemiddeld $f 313,--$ per persoon. 


\section{EEN VOORBEELD VAN TOEKENNING UTILITEITEN}

\section{IV.1 Inleiding}

IV.2 Meettechnieken

IV.3 Functieclassificatie voor CHZ-Patiënten

IV.4 Enkele Studies naar QALY's

IV.5 Beschrijving Utiliteitsonderzoek CHZ-Ziektetoestanden IV.6 Utiliteitswaarden 


\section{IV.1 Inleiding}

Utiliteiten worden gebruikt bij het evalueren van effecten van medische interventies op de kwaliteit van leven van een bepaalde ziekte. Medische interventie heeft niet alleen invloed op de overleving, maar ook op de kwaliteit van leven Om de effecten van verschillende medische interventies met elkaar te kunnen vergelijken bestaat er de behoefte om aan de kwaliteit van de resterende levensjaren een waarde toe te kennen: een utiliteitswaarde.

Kwaliteit van leven is een begrip dat op verschillende wijzen gedefinieerd kan worden. In medische zin wordt gesproken van die aspecten van het bestaan die voor het functioneren en het welbevinden van belang zijn. Overwegingen betreffende kwaliteit van leven zouden dan ook een belangrijke plaats kunnen innemen bij beslissingen in de gezondheidszorg. Naast medische zijn er uiteraard ook niet-medische kenmerken van personen die een rol spelen in de kwaliteit van leven. Dit betreft inkomen, opleiding, arbeidsbeleving, enz.

Onder utiliteiten verstaan wij de waardering (of het nut) die door een individu aan een bepaalde gezondheidstoestand wordt toegekend. Het geeft de subjectieve waardering aan van hoe een persoon zijn leven beleeft. De waardering voor een bepaalde gezondheidsuitkomst kan worden gekwantificeerd, hetgeen inhoudt dat aan iedere mogelijke uitkomst een persoonlijk nut (utiliteit) wordt toegekend. Utiliteiten worden vooral gebruikt wanneer (Drummond e.a., 1987) een gezondheidszorgprogramma zowel morbiditeit als mortaliteit beïnvloedt en een gezamenlijke waarde van beide effecten als uitkomst gewenst is.

Vanuit economisch oogpunt is het van belang analysemodellen te ontwikkelen die een vergelijking mogelijk maken tussen verschillende gezondheidszorgprogramma's. Met behulp van een kosten-effectiviteitsanalyse kunnen verschillende alternatieven die eenzelfde doel willen bereiken worden vergeleken (Van Doorslaer e.a., 1988). Moeilijker wordt het een vergelijking te maken tussen programma's waarin meerdere aspecten een rol spelen, zoals een kwaliteit van leveneffect en een overlevingsaspect.

In de kosten-utiliteitsanalyse (Drummond e.a., 1987) wordt dit probleem ondervangen. Het voordeel van deze benadering is dat in principe programma's met verschillende doelen en met ongelijksoortige gevolgen met elkaar kunnen worden vergeleken. Kosten-utiliteitsanalyse kan beschouwd worden als een uitbreiding van kosten-effectiviteitsanalyse, waarbij de gezondheidseffecten worden uitgedrukt in quality adjusted life years of QALY's (Van Doorslaer e.a., 1988).

De QALY is een effectmaat die rekening houdt met zowel de kwantiteit (levensduur in jaren) als de kwaliteit van leven (de utiliteit van ieder extra levensjar afgewogen tegen de situatie van optimale gezondheid). Aan de winst in levensja- 
ren wordt aldus een utiliteitswaarde toegekend. De utiliteitswaarde geeft de kwaliteit weer van de gezondheidstoestand die in de periode van levenswinst is verkregen. Deze waarde wordt weergegeven door een getal tussen 0 en 1 , waarbij 0 staat voor de minst gewaardeerde gezondheidstoestand (dood) en 1 voor de meest gewenste gezondheidstoestand (volledige gezondheid). Dit getal vertegenwoordigt de eerder besproken utiliteit. In kosten-utiliteitsanalyse worden de gewonnen levensjaren gecorrigeerd met deze tussen 0 en 1 gelegen factor.

We willen in deze bijlage een voorbeeld van toekenning utiliteiten behandelen. De praragraafindeling is als volgt. In paragraaf IV.2 wordt een kort overzicht gegeven van de verschillende meettechnieken. We geven in paragraaf IV.3 verschillende functieclassificatieschema's voor patiënten met angineuze pijnklachten. In paragraaf IV.4 volgen enkel studies naar QALY's. Ons voorbeeld van toekenning utiliteiten wordt in de paragrafen IV.5 en IV.6 uitgewerkt. De beschrijving van het utiliteitsonderzoek naar de verschillende CHZ-ziektetoestanden wordt in paragraaf IV.5 gegeven. In paragraaf IV.6 volgt een overzicht van de gevonden utiliteitswaarden.

\section{IV.2 Meettechnieken}

Voor het meten van utiliteiten bestaan diverse technieken of methoden, waarvan de meest gebruikte zijn:

Rating Scale

Visual Analogue Scale

Standard Gamble

Time Trade Off

We verwijzen voor een toelichting op de genoemde meettechnieken naar de betreffende literatuur en handboeken (vgl. Drummond e.a., Von Neumann e.a., 1953, Torrance 1987). In ons onderzoek is gebruik gemaakt van een waarderingsstudie van Bonsel e.a. (1988). De studie van genoemde auteurs was gebaseerd op de Visual Analogue Scale methode. Een toelichting op de studie van Bonsel e.a. (1988) en de uitwerking ervan wordt in de paragrafen IV.4 en IV.5 van deze Bijlage gegeven.

Elke meetmethode heeft zich eigen nadelen, die hieronder in het kort besproken worden.

De Rating Scale methode bestaat ruwweg uit een lijn met eindpunten, waarop de verschillende gezondheidstoestanden in volgorde van preferentie moeten worden aangegeven. De uitkomsten van de Rating Scale methode zullen in vergelijking 
met die van met name de Standard Gamble methode een discrepantie vertonen, omdat individuen in situaties van zekerheid anders antwoorden dan in situaties met bepaalde risico's. De Rating Scale methode kan goed toegepast worden in situaties waarbij goed bekend is in welke gezondheidstoestand de patiënt verkeert.

De Visual Analogue Scale is een variant op de Rating Scale. De waarderingen van de proefpersonen komen tot stand via bijvoorbeeld het tekenen van een lijn op een beeldscherm. Het voordeel van deze methode ligt in zijn eenvoud. In de studie van Bonsel e.a. (1988) is deze methode toegepast door aan respondenten vragen voor te leggen met betrekking tot de waardering van ziektetoestanden. Er spelen in zo'n situatie minder onzekerheden dan bij het uitvoeren van een operatie, waarvan de afloop niet goed te voorspellen is. Feit blijft dat door de respondenten onvermijdelijk prognostische aspecten aan de te waarderen ziektetoestanden gekoppeld zullen worden (zie bijvoorbeeld dimensie " $\mathrm{D}$ " van de "Kwaliteit van Leven-items" uit paragraaf IV.4). De onzekerheid met betrekking tot de gezondheidstoestand van de patiënt zal hierdoor vergroot worden.

De Standard Gamble methode meet in hoeverre een respondent bij de keuze voor een bepaalde medische behandeling in vergelijking met "niets doen" bereid is een risico op een slechtere gezondheidstoestand te nemen om een toestand van volledige gezondheid te bereiken. Het nadeel van de Standard Gamble methode is dat het in de praktijk vaak moeilijk blijkt te zijn gezondheidstoestanden te relateren aan kansen. Bovendien blijken kleine variaties in de referentie gezondheidstoestanden van invloed op de waarderingen die de respondenten geven, hetgeen niet het geval zou mogen zijn. Een ander nadeel betreft het ontbreken van een tijdsaspect in deze methode.

De Time Trade Off methode meet evenals de Rating Scale methode de waarde die aan een ziektetoestand gegeven kan worden. Het verschil is dat in de Time Trade Off methode de keuze uit twee altematieven wordt geboden door de toestand ziek te laten vergelijken met een optimale toestand gezond. De methode meet dan hoeveel tijd (aantal levensjaren) men bereid is "in te leveren" om de rest van zijn leven klachtenvrij door te brengen. Ook hier geldt weer de vraag hoe onzeker de prognostische aspecten zijn met betrekking tot de gezondheidstoestand van de patiënt.

\section{IV.3 Functieclassificatie voor CHZ-patiënten}

Binnen de cardiologie is het classificeren van patiënten naar hun functionele toestand van bijzonder belang om de volgende redenen (Stam, e.a., 1986):

1. de beoordeling van het effect van een behandeling,

2. de beoordeling van eventuele progressie van de aandoening, 
3. indicatiestelling vanwege het grote aantal therapeutische mogelijkheden.

In de praktijk bestaan hiervoor een aantal classificatieschema's, waarbij er vele verschillen in interpretatie zijn.

Het meest bekende classificatieschema is dat van de New York Heart Association (NYHA). Deze werd in de jaren '60 ontwikkeld en is zeer eenvoudig in gebruik. In het NYHA-classificatieschema worden 4 functieklassen onderscheiden voor AP, variërend van geheel a-symptomatisch tot volledig invalide.

\section{CLASSIFICATIE AP-TOESTANDEN}

AP-toestanden volgens de New York Heart Association (vertaling uit: Stam, e.a., 1986)

AP1: Patiënten met een hartziekte die niet leidt tot beperking van de lichamelijke activiteit. Gewone lichamelijke inspanning leidt niet tot overmatige moeheid, hartkloppingen, kortademigheid of angina pectoris.

AP2: Patiënten met een hartziekte die leidt tot geringe beperking van de lichamelijke activiteit. $\mathrm{Zij}$ voelen zich goed in rust. Gewone lichamelijke inspanning leidt tot moeheid, hartkloppingen of angina pectoris.

AP3: Patiënten met een hartziekte die leidt tot aanzienlijke beperking van de lichamelijke activiteit. $\mathrm{Zij}$ voelen zich goed in rust. Minder dan gewone lichamelijke inspanning leidt al tot moeheid, hartkloppingen, kortademigheid of angina pectoris.

AP4: Patiënten met een hartziekte die geen enkele vorm van lichamelijke activiteit toelaat zonder dat klachten optreden. Symptomen van angina pectoris kunnen zelfs in rust optreden. Elke lichamelijke inspanning leidt tot een toename van klachten.

De classificatie is niet tot stand gekomen via meting met objectieve instrumenten, maar is gebaseerd op het oordeel van specialisten ten aanzien van de ziektetoestand van de patiënt. De te onderscheiden functieklassen laten dan ook veel ruimte open voor interpretatieverschillen. Hoofdkenmerk van een goed classificatiesysteem is dat onafhankelijke derden tot dezelfde conclusies komen (Selzer e.a., 1972).

In 1972 werd door de Canadian Cardiovascular Society (CCS) een classificatieschema met meer gedetailleerde criteria gepubliceerd, dat werd overgenomen in verschillende andere studies, waaronder de Coronary Artery Surgery study (Goldman e.a.,1981). In dit classificatieschema worden in tegenstelling tot dat 
van de NYHA voorbeelden van activiteiten gegeven die als een soort leidraad kunnen dienen bij de indeling.

Functionele classificatie van de Canadian Cardiovascular Society (Stam, e.a., 1986)

AP1: Gewone lichamelijke activiteiten, zoals lopen en trap lopen, leiden niet tot angina pectoris. Wel bij intensieve, snelle of langdurige inspanning tijdens werk of recreatie.

AP2: Geringe beperking van gewone activiteiten. Snel lopen of een trap opgaan; tegen een helling oplopen; lopen of trap lopen na maaltijden, in de kou, tegen de wind, onder emotionele stress, of slechts tijdens de eerste uren na het ontwaken. Vlak-lopen over een afstand van meer dan 2 blokken en oplopen van meer dan 1 normale trap in normaal tempo en onder normale omstandigheden.

AP3: Aanzienlijke beperking van normale lichamelijke activiteit. Vlak-lopen over een afstand van 1 tot 2 blokken en oplopen van 1 trap onder normale omstandigheden en in normaal tempo.

AP4: Niet in staat om enige vorm van lichamelijke vorm van activiteit te verrichten zonder klachten: angina pectoris kan in rust optreden.

Door de aanvullende specificaties is de kans op interpretatieverschillen kleiner. Ook bij deze classificatie bestaat geen zekerheid omtrent reproduceerbaarheid en validiteit.

Door Goldman e.a. (1981) werd een Specific Activity Scale (SAS) ontwikkeld, teneinde aan de problemen van de voorgaande classificatieschema's het hoofd te bieden. Ook hier zijn een aantal specifieke activiteiten als voorbeeld gegeven, echter gemeten in zogenaamde metabole equivalenten (MET), teneinde de reproduceerbaarheid van deze indeling te vergroten. Onder een metabole equivalent wordt verstaan het equivalent zuurstofgebruik tijdens een bepaalde activiteit, om de belastbaarheid bij ergonomisch onderzoek zo goed mogelijk te voorspellen. Het MET verbruik bij AP is te vinden in onderstaand overzicht. 
Schaal van specifieke activiteiten voor functionele classificatie van cardiale toestand (Stam, e.a., 1986):

AP1: (7-10 MET $^{1}$ ): De patiënt kan elk van de volgende activiteiten volbrengen zonder te stoppen:

dragen van ongeveer $10 \mathrm{~kg}$ op een trap van 8 treden, dragen van een voorwerp van ongeveer $35 \mathrm{~kg}$, sneeuw scheppen, skiën, basketball, squash of handbal spelen, joggen, lopen in een tempo van ongeveer $8 \mathrm{~km} / \mathrm{u}$.

AP2: (5-7 MET): De patiënt voldoet niet aan de criteria van klasse 1, maar kan elk van de volgende activiteiten volbrengen zonder te stoppen:

een last 8 treden naar boven dragen, coïtus, tuinieren, harken, wieden, lopen in een tempo van $8 \mathrm{~km} / \mathrm{u}$.

AP3: (2-5 MET): De patiënt voldoet niet aan de criteria van klasse 1 of 2 , maar kan elk van de volgende activiteiten volbrengen zonder te stoppen:

een trap van 8 treden aflopen, douchen, beddelakens verschonen, dweilen, ruiten zemen, wandelen in een tempo van ongeveer $4 \mathrm{~km} / \mathrm{u}$, aanduwen van een motormaaier, bowlen, aankleden zonder onderbreking. AP4: ( $\leq 2$ MET) Geen van bovenstaande activiteiten.

MET: metabole equivalenten zuurstofgebruik, $1 \mathrm{MET}=3,5 \mathrm{ml} \mathrm{O} / \mathrm{kg} / \mathrm{min}$

Eveneens door Goldman e.a. (1981) werd een vergelijkend onderzoek verricht naar reproduceerbaarheid en validiteit van de NYHA, CCS en SAS criteria. De resultaten van dit onderzoek waren ten aanzien van reproduceerbaarheid (bij een vergelijking tussen 2 onderzoekers):

SAS en CCS schalen: $\quad 73 \%$ NYHA schaal: $\quad 56 \%$ 
Ten aanzien van validiteit (gemeten via een zogenaamde tredmolen test) waren deze percentages:

NYHA:

CCS:

SAS:
$51 \%$

$59 \%$

$68 \%$

Het lijkt dus aannemelijk dat het SAS schema op grond van betrouwbaarheid en validiteit de voorkeur verdient. Het schema heeft als nadeel dat het door de kwantitatieve indeling in de praktijk minder praktisch is.

\section{IV.4 Enkele studies naar QALY's}

Door Bonsel e.a. (1988) werd een utiliteitsmeting verricht in het kader van een studie naar de kosten en effecten van harttransplantatie. Deze studie bestond uit 2 onderdelen.

In het eerste onderdeel werd een methodologisch en empirisch onderzoek naar het vaststellen van de waardering door gezonde personen van ziektetoestanden verricht. Men zou dit de algemene maatschappelijke waardering van ziektetoestanden kunnen noemen. De waarderingen zijn gemeten via een door de personal computer afgenomen interview bij ca. 70 (gezonde) beoordelaars waarbij de visual analogue scale als meettechniek werd gebruikt. Voor de waardering is gebruik gemaakt van 4 verschillende dimensies van gezondheid. De dimensies zjjn vervolgens onderverdeeld in 5 kwaliteit van leven-items, oplopend in graad van ernst. Onderstaand zijn de dimensies en de verschillende onderverdelingen (items) opgenomen. 


\section{KWALITEIT VAN LEVEN-ITEMS PER DIMENSIE VAN GEZONDHEID (Bonsel e.a., 1988)}
A. Lokatie (intensiteit van behandeling)
1. gewoon thuis,
2. thuis, geregeld op medische controle,
3. thuis, maar onder strenge poliklinische controle, slikt zware pillen,
4. tijdelijk in het ziekenhuis,
5. in het ziekenhuis onder "intensive care".

\section{B. Medische symptomen}

1. geen klachten of ziekteverschijnselen,

2. geringe klachten, geen pijn,

3. vrij snel kortademig en moe, soms pijn,

4. bij de minste inspanning kortademig en moe, matige pijn,

5. voortdurend hevige pijn en ademnood.

C. Lichamelijk functioneren

1. in staat normaal alles te doen, zowel binnens- als buitenshuis (aankleden, lopen, fietsen, werken),

2. in staat binnenshuis alles te doen, maar buitenshuis beperkt (kan niet fietsen, geen boodschappen doen),

3. in staat zichzelf te verzorgen, maar slechts in beperkte mate in staat tot lopen,

4. met moeite in staat tot in en uit bed komen, hulp nodig bij de verzorging,

5. ligt in bed, tot niets in staat.

D. Psychologisch welbevinden en subjectieve medische prognose

1. geen psychische klachten en vertrouwen in de toekomst,

2. af en toe somber, maar vertrouwen in de toekomst,

3. gespannen, wel vertrouwen in de toekomst, maar kijkt niet te ver vooruit,

4. depressief, matig vertrouwen in de toekomst, kijkt niet te ver vooruit,

5. gespannen en depressief, leeft bij de dag en vreest het ergste.

Een gezondheidstoestand wordt "dus gedefinieerd door een combinatie van 4 items, ieder afkomstig van een verschillende dimensie". Gebaseerd op de antwoorden van de beoordelaars heeft elke item binnen iedere dimensie een gewicht gekregen. Hoewel ons niet duidelijk is hoe deze gewichten tot stand zijn gekomen mogen we aannemen dat deze gewichten in é́n of andere statistische zin zo goed mogelijk de bijdragen van ieder item afzonderlijk in de totale score weer- 
geven. In de onderstaande tabel IV.1 worden de gewichten per item ( $1 \mathrm{tm} 5)$ weergegeven, gedifferentieerd naar de 4 dimensies (A tm D).

\begin{tabular}{|l|l|l|l|l|}
\hline Dimensie & A & B & C & D \\
\hline Item & & & & \\
\hline 1 & 0 & 0 & 0 & 0 \\
\hline 2 & 0.49 & 0.65 & 0.11 & 0.21 \\
\hline 3 & 0.86 & 0.81 & 0.33 & 0.46 \\
\hline 4 & 0.70 & 0.91 & 0.63 & 0.72 \\
\hline 5 & 1 & 1 & 1 & 1 \\
\hline
\end{tabular}

Overgenomen van Bonsel e.a., 1989

Tabel IV.1 Gewicht items gedifferentieerd naar 4 dimensies

Bij de toepassing van deze gewichten tot een gezamenlijke score is gebruik gemaakt van een regressieformule die de respondent uitkomsten het beste benaderde. De gebruikte formule luidde: $V=0,80-0,1 / A_{i}-0,28 B_{j}-0,08 C_{k}-0,20 D_{l}$, waarbij $A_{i}, B_{j}, C_{k}$ en $D_{1}$ de gevonden dimensiegewichten voorstellen.

In het tweede deel van deze waarderingsstudie werden de gezondheidstoestanden bij harttransplantatiepatiënten in verschillende perioden door middel van een enquête in beeld gebracht. Op grond van de enquête-antwoorden werd de gezondheidstoestand van de patiënten door het panel op ieder van de vier dimensies ingedeeld, waar aan de verschillende items gewichten waren toegekend. Vervolgens is de uiteindelijke waarde van een gezondheidstoestand berekend door de scores van de afzonderlijke dimensies gewogen op te tellen aan de hand van bovenstaande formule. Bovenstaande formule kan eenvoudig op een getal tussen 0 en 1 genormeerd worden door te stellen $V_{1}=V / 0,80$. Het aldus gevonden antwoord is een maat voor de kwaliteit van leven bij de beschouwde toestand.

Vanaf de interventie vond een periode-indeling plaats, waarbij elke periode met een kwaliteit van leven factor vermenigvuldigd werd. Uiteindelijk werden de kwaliteitsgewogen perioden opgeteld (Bonsel e.a., 1988). 
De utiliteitswaarden vooraf aan en 13 maanden na de transplantatie lagen tussen 0.15 en 0.30 respectievelijk tussen 0.55 en 0.85 . Deze uitkomsten werden uiteindelijk gebruikt bij de berekening van QALY'S.

Deze methode van Bonsel is door ons toegepast op verschillende stadia van het ziekteproces bij coronaire hartziekten. Hierbij hebben we gebruik gemaakt van dezelfde gewichten voor de verschillende dimensies als in Bonsel e.a. (1989).

Weinstein e.a. (1982) publiceerden een analyse over de kosten-effectiviteit van coronary artery bypass surgery (CABG) in vergelijking met een behandeling met medicamenten voor patiënten met AP. De gezondheidswinst werd uitgedrukt in QALY's. De analyses hadden betrekking op een 55 -jarige man met vaatlijden (1,2,3 kransslagaders of LMD). Voor AP is een onderscheid gemaakt in ernstige en lichte AP. Door het ontbreken van empirische gegevens zijn voor de utiliteiten bepaalde veronderstellingen gedaan:

1. een patiënt met milde AP klachten en een rustige levensstijl: 0.9 ,

2. een patiënt met matige tot ernstige klachten en een actieve levensstijl: 0.7 ,

3. een patiënt met zeer ernstige AP klachten of een extreme psychische belasting: 0.5 .

Alle utiliteiten zijn op jaarbasis.

Als voorbeeld werden vervolgens de gewonnen QALY'S berekend voor CABG bij ernstige AP klachten:
2 VD: 1.1 QALY,
3 VD: 3.2 QALY,
LMD: $\quad 6.2$ QALY.

Ament e.a. (1986) hebben eveneens utiliteiten vastgesteld en QALY'S bepaald in een kosten-effectiviteitsstudie van open-hartchirurgie (CABG). Door 9 cardiologen werd een schatting gemaakt van de overlevingskansen van patiënten met $A P$, ingedeeld naar het aantal aangedane kransslagaders (1,2,3, LMD) en de mate van de AP, ingedeeld in de categorieën van de New York Heart Association:

API: geen klachten (verder niet meegenomen in de analyse),

$\mathrm{AP2}$ : geringe klachten,

AP3: matige klachten,

AP4: hevige klachten.

Voor de bepaling van de waardering van AP is gebruikt gemaakt van 3 methodes: de Standard Gamble, de Time Trade-off en de Visual Analogue Scale.

In de eerste plaats werd een schriftelijke proefenquête gehouden onder een groep studenten waarbij de 3 meettechnieken werden gebruikt. De gegeven gezondheidssituaties waren gebaseerd op overleving $(15,10,5$ jaar) en de mate van AP $(1,2,3,4)$. Eerst is gevraagd de AP-combinaties ordinaal te rangschikken op een 
VA-schaal en vervolgens werden de SG en de TTO-technieken toegepast. Een herhalingsenquête vond plaats met behulp van de computer en gelijktijdig werd een utiliteitsenquête afgenomen bij een groep huisartsen en specialisten. De defnitieve enquête werd in het Academisch Ziekenhuis Maastricht onder specialisten en verpleegkundigen verricht. De gemiddelde utiliteiten afkomstig uit de Time Trade-off en de Standard Gamble, uitgedrukt in een schaal van 0 - 1, waren voor:

AP2: $\quad 0.8$

AP3: $\quad 0.6$

AP4: $\quad 0.3$

Vervolgens werden met behulp van schattingen over de levensverwachting en de berekende utiliteiten de QALY'S bepaald. De QALY'S bedroegen voor CABG ten opzichte van een behandeling met medicijnen als volgt:

AP2: 1

AP3: $\quad 3$

AP4: $\quad 4,5$

\section{IV.5 Beschrijving utiliteitsonderzoek CHZ-ziektetoestanden}

Teneinde utiliteitswaarden van $\mathrm{CHZ}$-ziektetoestanden te berekenen, is gebruik gemaakt van de door Bonsel e.a. (1988) uitgevoerde waarderingsstudie met betrekking tot de gezondheidstoestanden van patiënten die een harttransplantatie ondergingen. Zoals eerder beschreven zijn hiervoor 4 verschillende dimensies van gezondheid gebruikt. Deze zijn vervolgens onderverdeeld in 5 kwaliteit van leven-items, oplopend in graad van ernst. Voor de tabel wordt verwezen naar paragraaf IV.4.

Met behulp van én Delphi-onderzoeksmethode zijn de utiliteiten van de verschillende respondenten met betrekking tot gegeven CHZ-ziektetoestanden gemeten. Hoewel het begrip Delphi-onderzoek steeds bekender raakt willen we toch in het kort de essentie weergeven.

In Nederland is in de gezondheidszorg reeds ervaring opgedaan met deze methode, bijvoorbeeld bij sommige van de scenariostudies.

Delphi is een methode van schriftelijke ondervraging van een panel in een aantal ronden die gekenmerkt worden door (Postma e.a., 1987):

1. Anonimiteit: de deelnemers zijn onderling niet bekend, waardoor ongewenste beinvloeding wordt tegengegaan. Directe, persoonlijke interactie kan $\mathbf{z 0}^{-}$ wel de consensusvorming als de kwaliteit van de door de discussie naar vo- 
ren gebrachte groepsmening nadelig beïnvloeden door: conformiteit, dominante groepsleden, overbodige informatie en slecht controleerbare uitkomsten van discussie.

2. Iteratie en feedback: na iedere ronde worden de antwoorden van alle panelleden geanalyseerd, samengevat en teruggerapporteerd aan elk afzonderlijk panellid. Hierdoor worden de panelleden geinformeerd over elkaars mening, zonder in directe confrontatie te treden. Door de verschillende rondes kan een kwalitatief zo goed mogelijk antwoord van iedere deelnemer worden verkregen.

3. Statistische samenvatting van de groepsantwoorden: hiermee kan de spreiding in opinies worden weergegeven.

Voor de uitvoering van het Delphi-onderzoek was een proefpanel samengesteld, bestaande uit een 7-tal cardiologen van het Academisch Ziekenhuis Maastricht. Aangenomen werd dat zij uit oogpunt van hun deskundigheid en ervaring in staat waren de gezondheidstoestanden te waarderen. De objectieve gezondheidstoestand in strikt medische zin is via de patiënt vaak slechts ten dele meetbaar.

In het proefonderzoek hebben 2 Delphi-ronden plaatsgevonden. Aan de hand hiervan is de vragenlijst op de praktische toepasbaarheid getoetst. Na de eerste vragenronde zijn de antwoorden van de panelleden geanalyseerd. De vragen met sterk uiteenlopende antwoorden, zijn opnieuw aan de panelleden voorgelegd, waarna zoveel mogelijk consensus werd bereikt.

Onze vragenlijst bestond uit 2 delen. In het 1 ste deel werd het proefpanel gevraagd de gegeven $\mathrm{CHZ}$-ziektetoestanden te waarderen, door aan de ziektetoestand per dimensie een combinatie van 4 kwaliteit van leven-items toe te kennen, die de gegeven ziektetoestand het beste weergeven.

Op advies van de vakgroep Cardiologie van het Academisch Ziekenhuis Maastricht, zijn in de vragenlijst twee patiëntkenmerken aangebracht:

\section{Periode}

De periode waarin de waardering van de CHZ-ziektetoestand plaatsvindt, is in de meeste gevallen gesteld op 1 maand, omdat pas dan van een min of meer stabiele toestand gesproken kan worden. Hierbij zijn twee opties aangegeven:

- 1 maand na opname en behandeling (operatie danwel medicatie),

- 1 maand na manifestatie van de (laatste) ziektetoestand, echter "zonder" dat nog een behandeling heeft plaatsgehad. 


\section{Ejectiefractie}

Als globale maat voor de hoeveelheid bloed die per hartslag wordt ge. pompt, wordt de ejectiefractie (EF) als cardiologische parameter gebruikt. Een slechte EF is van invloed op de klachtenbeleving: er treedt kortademigheid en ernstige vermoeidheid op bij gewone lichamelijke inspanning. In de literatuur wordt als afkappunt veelal een EF van $40 \%$ gekozen. Om deze redenen wordt een onderscheid gemaakt tussen een $\mathrm{EF}<40 \%$ en een $\mathrm{EF}$ ? $40 \%$.

In deel 2 van de enquête werden de panelleden gevraagd de gemiddelde duur in maanden aan te geven dat een CHZ-patiënt in een bepaalde ziektetoestand verkeert, totdat een nieuwe ziektetoestand zich manifesteert of een nieuwe behandeling ter voorkoming van een herhaalde manifestatie nodig is. Deze duur is nodig voor het berekenen van de QALY'S.

De vragenlijst en de bijbehorende toelichting zijn integraal hieronder opgenomen.

\section{TOELICHTING OP DE VRAGENLIJST VOOR HET PROEFPANEL DELPHI-ONDERZOEK CHZ}

Aan de hand van de hiernavolgende vragenlijst, die uit 2 delen bestaat, willen wij aan de hand van uw eigen werkervaring uw mening ten aanzien van het volgende vragen:

1. de gemiddelde beleving van de ziektetoestand van een patiënt met coronairlijden met betrekking tot kwaliteit van leven (deel 1);

2. de gemiddelde duur dat een patiënt met coronairlijden zich in een bepaalde ziektetoestand bevindt, totdat een nieuwe $\mathrm{CHZ}$-manifestatie of een nieuwe behandeling ter voorkóming van zo'n manifestatie zich voordoet (deel 2). Het eerste deel van de vragenlijst bestaat uit 8 clusters waarin de vragen naar de ziektetoestanden (vraag $3.1 \mathrm{t} / \mathrm{m} \mathrm{3.8}$ ). Het tweede deel is opgebouwd uit 4 vragen (vraag $3.9 \mathrm{t} / \mathrm{m} \mathrm{3.12).}$

De ziektetoestanden die in de vragenlijst opgenomen zijn luiden als volgt:

1. AP2

2. AP3

3. AP4

4. UAP

5. (vroeger $\mathrm{CABG})+\mathrm{AP2}$

6. (vroeger $\mathrm{CABG})+\mathrm{AP} 3$

7. (vroeger $\mathrm{CABG})+\mathrm{AP} 4$
08. (vroeger AP2) + MI

09. (vroeger AP3) + MI

10. (vroeger AP4) + MI

11. (vroeger $\mathrm{MI})+\mathrm{AP} 2$

12. (vroeger MI) + AP3

13. (vroeger MI) + AP4

14. MI 
De patiëntkenmerken zijn:

1. de hoogte van de $\mathrm{EF}$ ( $\mathrm{EF}<40 \%$ en $\mathrm{EF} \geq 40 \%$ ),

2. de periode waarover de waardering van de CHZ-toestand plaatsvindt. Afhankelijk van de vraagstelling betreft de periode:

- 1 maand na opname en behandeling, of

- 1 maand na manifestatie van de (laatste) ziektetoestand, echter "zonder" dat nog een behandeling heeft plaatsgevonden.

De betekenis van de gebruikte afkortingen in de vragenlijst zijn:

1. AP: Angina Pectoris. De definiëring van de AP-toestanden die wij hanteren stamt van de omschrijving van de New York Heart Association (Stam e.a., 1986),

2. MI: Myocard Infarct,

3. UAP: "Unstable Angina Pectoris",

4. CABG: Coronary Artery Bypass Grafting",

5. EF: Ejectiefractie. 


\section{INVULINSTRUCTIE}

\section{DEEL 1}

Voor de invulling van de vragenlijst dient u gebruik te maken van de bijgevoegde tabel waarin de kwaliteit van leven-indicatoren, onderverdeeld in 5 items, staan vermeld. Vervolgens verzoeken wij $U$ per ziektetoestand met een kruis aan te geven welke combinatie van 4 items, ieder afkomstig van een verschillende dimensie, het beste die betreffende ziektetoestand weergeeft. Hieronder volgt een voorbeeld ter verduidelijking.

\section{Voorbeeld:}

Gegeven: huidige ziektetoestand, 1 maand na de manifestatie, zonder behandeling:

\section{Ziektetoestand $\quad K$ waliteit van leven-items per dimensie} van gezondheid

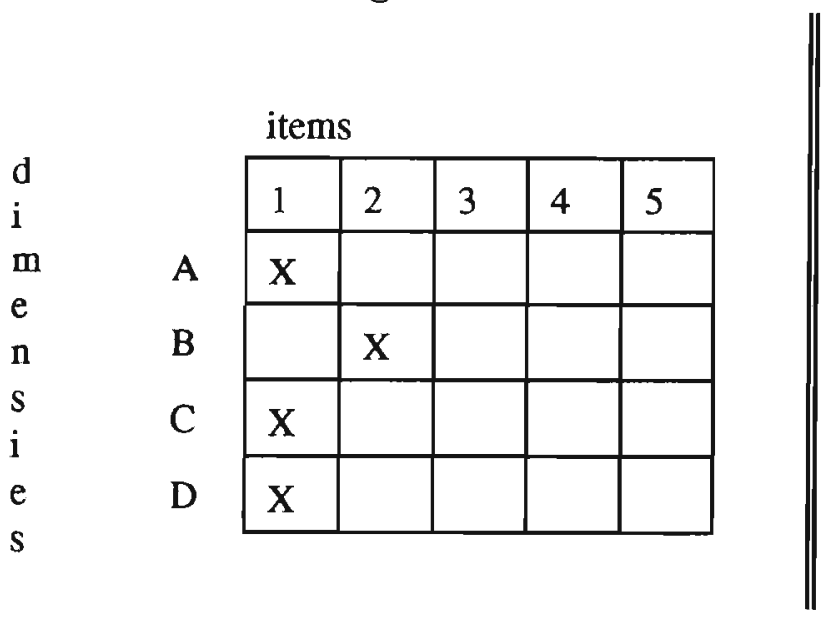

Uit deze antwoorden blijkt dat $U$ verwacht dat een patiënt met ziektetoestand AP2:

item 1 uit dimensie $A$ : gewoon thuis is, item 2 uit dimensie B : geringe klachten, en geen pijn heeft, item 1 uit dimensie $C$ : normaal in staat is alles te doen, item 1 uit dimensie D : geen psychologische klachten heeft en vertrouwen heeft in de toekomst. 


\section{DEEL 2}

In de hokjes van een ziektetoestand geeft $U$ aan hoelang ( in maanden ) naar uw mening een CHZ-patiënt in een bepaalde ziektetoestand verkeert, voordat een nieuwe $\mathrm{CHZ}$-gebeurtenis zich voordoet.

Bij voorbaat dank voor uw medewerking.

\section{Te waarderen ziektekenmerken voor DEEL 1 van de vragenlijst}

3.1 Huidige ziektetoestand met EF $<40,1$ maand na de opname (met behandeling) van:

1. MI

2. (vroeger AP2) + MI

3. (vroeger AP3) + MI

4. (vroeger AP4) + MI

3.2 Ziektetoestand met EF $<40,1$ maand na de AP-manifestatie (nog zonder behandeling) van:

1. (vroeger MI) + AP2

2. (vroeger $M I)+A P 3$

3. (vroeger MI) + AP4

3.3 Huidige ziektetoestand met $\mathrm{EF}<\mathbf{4 0}, 1$ maand na de opname (met behandeling), van:

1. (vroeger MI) + AP2

2. (vroeger MI) + AP3

3. (vroeger MI) + AP4

3.4 Huidige ziektetoestand met EF $\geq 40,1$ maand na de opname (met behandeling) van:

1. MI

2. (vroger AP2) + MI

3. (vroeger AP3) + MI

4. (vroeger AP4) + MI

3.5 Ziektetoestand met $\mathrm{EF} \geq 40,1$ maand na de manifestatie (nog zonder behandeling) van:

1. (vroeger MI) + AP2

2. (vroeger MI) + AP3

3. (vroeger MI) + AP4

3.6 Huidige ziektetoestand met $\mathrm{EF} \geq 40,1$ maand na de opaame (met behandeling), van:

1. (vroeger MI) + AP2

2. (vroeger MI) + AP3

3. (vroeger MI) + AP4 
3.7 Ziektetoestand, 1 maand na de manifestatie (nog zonder behandeling) van:
1. AP2
2. AP3
3. AP4
4. UAP
5. (vroeger $\mathrm{CABG})+\mathrm{AP4}$

3.8 Huidige ziektetoestand, 1 maand na de opname (met behandeling), van:

1. AP2

2. AP3

3. AP4

4. (vroeger $\mathrm{CABG}$ ) + AP2

5. (vroeger $\mathrm{CABG}$ ) + AP3

6. (vroeger $\mathrm{CABG}$ ) + AP4

In deel II van de vragenlijst wordt gevraagd hoelang (in maanden) een $\mathrm{CH}^{\mathrm{H}}$ patiënt in een ziektetoestand verkeert, voordat een nieuwe $\mathrm{CHZ}$-gebeurtenis zi presenteert:

3.9 Hoelang duurt ziektetoestand AP tot volgende AP-klasse of opname:
1. AP2
2. AP3
3. AP4
4. (vroeger $\mathrm{CABG}$ ) + AP4
5. (vroeger $\mathrm{MI})+\mathrm{AP2}$
6. (vroeger MI) + AP3
7. (vroeger MI) + AP4

3.10 Hoelang duurt ziektetoestand AP tot MI:
1. AP2
2. AP3
3. AP4
4. (vroeger $\mathrm{CABG}$ ) + AP4
5. (vroeger $\mathrm{MI})+\mathrm{AP2}$
6. (vroeger $\mathrm{MI})+\mathrm{AP} 3$
7. (vroeger MI) + AP4

3.11 Hoelang duurt ziektetoestand MI tot AP:
1. MI
2. (vroeger AP2) + MI
3. (vroeger AP3) + MI
4. (vroeger AP4) + MI

3.12 Hoelang duurt ziektetoestand UAP tot MI:

1. UAP 


\section{VOORBEELD VAN INVULBLAD}

3.1 Huidige ziektetoestand met $\mathrm{EF} \leq 40,1$ maand na de opname (met behandeling) van:

\section{ZIEKTETOESTAND}

1. MI

items

d
i
m
e
n
s
i
e
s

\begin{tabular}{|l|l|l|l|l|}
\hline 1 & 2 & 3 & 4 & 5 \\
\hline & & & & \\
\hline & & & & \\
\hline & & & & \\
\hline & & & & \\
\hline
\end{tabular}

2. (vroeger AP2) + MI

d
i
m
i
i
e
s items

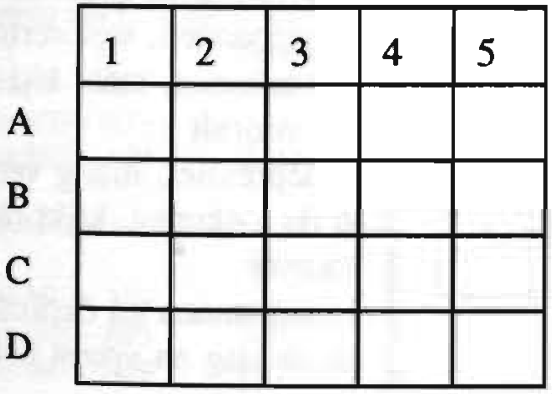

Kwaliteit van leven-items per dimensie van gezondheid A. Lokatie (intensiteit van behandeling)

1. gewoon thuis

2. thuis, geregeld op medische controle

3. thuis, maar onder strenge poliklinische controle, slikt zware pillen

4. tijdelijk in het ziekenhuis

5 . in het ziekenhuis onder "intensive care"

B. Medische symptomen

1. geen klachten of ziekteverschijnselen

2. geringe klachten, geen pijn

3. vrij snel kortademig en moe, soms pijn

4. bij de minste inspanning kortademig en moe, matige pijn 5. voortdurend hevige pijn en ademnood 
3. (vroeger AP3) + MI

items

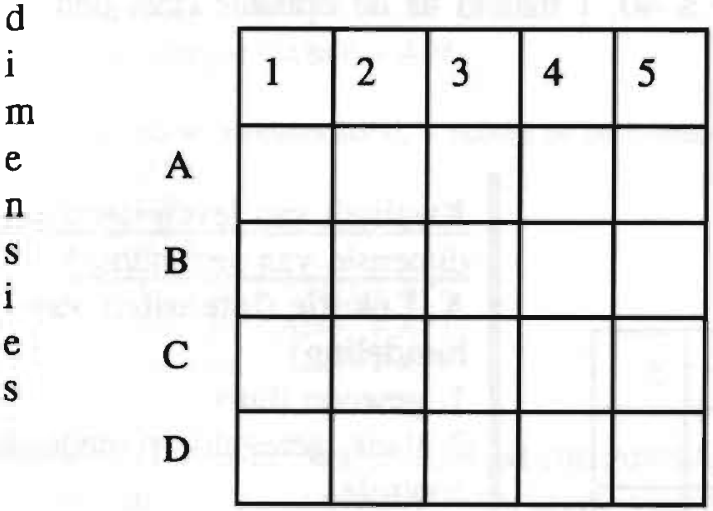

4. (vroeger AP4) + MI

items

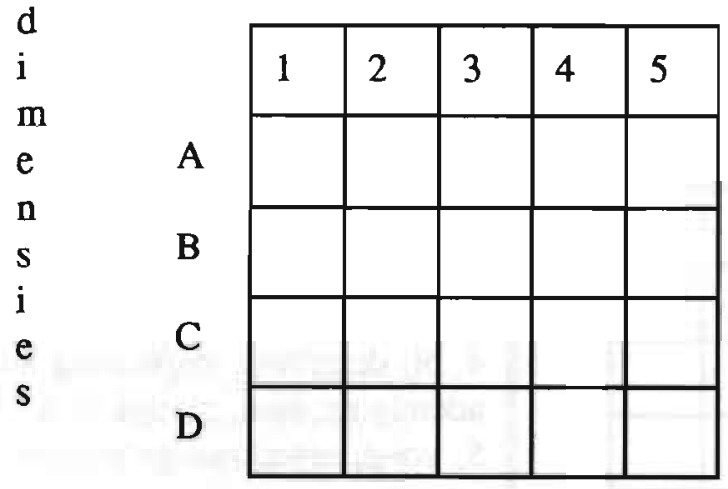

C. Lichamelijk functioneren

1. in staat normaal alles te doen, zowel binnen- als buitenshuis 3 . (aankleden, lopen, fietsen, werken)

2. in staat binnenshuis alles te doen, maar buitenshuis beperkt (kan niet fietsen, geen boodschappen doen)

3. in staat zichzelf te verzorgen, maar slechts in beperkte mate in staat tot lopen

4. met moeite in staat tot in en uit bed komen, hulp nodig bij de verzorging

5. ligt in bed, tot niets in staat

D. Psychologisch welbevinden en subjectieve medische prognose

1. geen psychische klachten en vertrouwen in de toekomst

2. af en toe somber, maar vertrouwen in de toekomst

3. gespannen, wel vertrouwen in de toekomst, maar kijkt niet te ver vooruit

4. depressief, matig vertrouwen in de toekomst, kijkt niet te ver vooruit

5. gespannen en depressief, leeft bij de dag en vreest het ergste 


\section{IV.6 Utiliteitswaarden}

Dit gedeelte van onze studie beschouwen we als een soort voorstudie naar het ontwikkelen van QALY's voor verschillende stadia van coronaire hartziekten. Het was dan ook geenszins de bedoeling om uitkomsten te verkrijgen, die met voldoende statistische betrouwbaarheid beschouwd kunnen worden als nu reeds toepasbare QALY's. Ons panel bestond uit 7 cardiologen. Met betrekking tot de waardering, in de zin van utiliteit, van de diverse ziektetoestanden bestond er na een terugkoppeling een grote mate van eenstemmigheid onder de respondenten. Voor bijna alle gevallen was voor alle dimensies het verschil in itembeoordeling hoogstens 1 niveau. Nergens was het verschil meer dan 2 niveaus. Dit betrof deel I van de enquête.

In onderstaande tabel IV. 2 is de gevonden utiliteitswaarde voor de verschillende ziektetoestanden te vinden.

\section{Tabel IV.2 Utiliteitenswaarden CHZ-toestanden}

3.1 Huidige ziektetoestand met $\mathrm{EF}<40,1$ maand na de opname (met behandeling) van:
1. MI
Score
2. (vroeger AP2) + MI
0.56
0.34
3. (vroeger AP3) + MI
0.34
4. (vroeger AP4) + MI
0.25

3.2 Zielatoestand met EF $<40,1$ maand na de AP-manifestatie (nog zonder behandeling) van:
1. (vroeger $\mathrm{MI})+\mathrm{AP2}$
Score
2. (vroeger $\mathrm{MI})+\mathrm{AP3}$
0.40
3. (vroeger MI) + AP4
0.32
0.15

3.3 Huidige ziekatcostand met $\overline{E F}<40,1$ maand na de opname (met behandeling), van:
1. (vroeger MI) + AP2
Score
2. (vroeger MI) + AP3
0.34
3. (vroeger MI) + AP4
0.21
0.07

3.4 Huidige ziekletoestand met $\mathrm{EF} \geq 40,1$ maand na de opname (met behandeling) van:
1. MI
Score
2. (vroeger AP2) + MI
0.81
0.58
3. (vroeger AP3) + MI 0.56
4. (vroeger AP4) + MI
0.56 
35 Ziektetoestand met $E F \geq 40,1$ maand na de manifestatie (nog zonder behandeling) van:
1. (vroeger MI) + AP2
0.56
2. (vroeger MI) + AP3 0.25
3. (vroeger $\mathrm{MI})+\mathrm{AP4} \quad 0.23$

3.6 Huidige ziektetoestand met $\mathrm{EF} \geq 40,1$ maand na de opname (met behandeling), van:
1. (vroeger MI) + AP2
Score
2. (vroeger MI) + AP3
0.56
3. (vroeger MI) + AP4
0.25
0.23

3.7 Ziektetcestand, 1 maand na de manifestatie (nog zonder behandeling) van:
1. AP2
Score
2. AP3
0.50
3. AP4
0.32
4. UAP
0.23
5. (vroeger $\mathrm{CABG}$ ) + AP4 0.30

3.8 Huidige ziektetoestand, 1 maand na de opname (met behandeling), van:
1. AP2
Score
2. AP3
0.58
3. AP4
0.42
4. (vtoeger $\mathrm{CABG})+\mathrm{AP2}$
0.23
5. (vroeger $\mathrm{CABG}$ ) + AP3
0.51
6. (vroeger $\mathrm{CABG})+\mathrm{AP4}$
0.34
0.23

Voor de panelleden was deel II van de enquête veel moeilijker te beantwoorden Hier bleek duidelijk dat de cardioloog vooral in het hier en nu gewend is de patiënt te beoordelen. Vastomschreven denkbeelden omtrent de (gemiddelde) lengte van de diverse ziektestadia waren schaars aanwezig. Een reden hiervoor kan ook zijn dat in de praktijk er een grote spreiding aanwezig is in deze perioden, waardoor het moeilijk is om eén getal te noemen. Het is voor ons dan ook zeer de vraag of het zinvol is te streven naar vaste lengtes van de diverse ziekteperioden. Meer in overeenstemming met de werkelijkheid lijkt het om voor ieder van deze perioden een kansverdeling te bepalen die uitdrukt wat de kansen op de diverse perioden-duur zijn. Zo'n kansverdeling kan dan gebruikt worden in een simulatie door per keer dat deze in de simulatie gebruikt wordt zogenaamde stochastische trekkingen te doen. Voor het bepalen van een dergelijke kansverdeling is uiteraard een veel groter panel nodig dan wanneer men slechts in het gemiddelde geïnteresseerd is.

In onderstaande tabel IV. 3 staan de gemiddelde waarden, voor wat ze waard zijn, weergegeven van de respondenten van onze enquête. 
Tabel IV.3 Ziekteduur CHZ-toestand tot eerstvolgende gebeurtenis of behandeling

39 Hoelang duurt ziektetoestand AP tot volgende AP-klasse of opname:
1. AP2
2. AP3
$18 \mathrm{mnd}$
3. AP4
2 weken
4. (vroeger $\mathrm{CABG})+\mathrm{AP4}$
3 dagen
5. (vroeger MI) + AP2
3 dagen
6. (vroeger MI) + AP3
$6 \mathrm{mnd}$
7. (vroeger MI) + AP4
10 dagen
3 dagen gemiddelde duar

3.10 Hoelang duurt ziektetoestand AP tot MI:
1. AP2
2. AP3
36 mnd
3. AP4
$12 \mathrm{mnd}$
4. (vroeger $\mathrm{CABG}$ + AP4
$2 \mathrm{mnd}$
5. (vroeger MI) + AP2
$1 \mathrm{mnd}$
6. (vroeger MI) + AP3
$15 \mathrm{mnd}$
7. (vroeger MI) + AP4
4 mnd
2 weken

gemiddelde duur

3.11 Hoelang duurt ziektetoestand MI tot AP:
1. MI
2. (vroeger $\mathrm{AP2}$ ) + $\mathrm{MI}$
18 mnd
3. (vroeger AP3) + MI
$18 \mathrm{mnd}$
4. (vroeger AP4) + MI
$10 \mathrm{mnd}$
$6 \mathrm{mnd}$

gemiddelde duar

3.12 Hoelang duurt ziektetoestand UAP tot MI:
1. UAP
1 mnd

gemiddelde duur 


\section{OP- EN AANMERKINGEN M.B.T. VRAGENLIJST PROEFPANEL ZIEKTETOESTANDEN CHZ}

Een algemeen punt van kritiek met betrekking tot deel I was dat de vragen niet gedifferentieerd waren naar leeftijd en geslacht. In tegenstelling tot wat meestal in de literatuur wordt aangetroffen vonden de panelleden dat de met name variabele leeftijd van grote invloed is op de beleving van de ziektetoestand. De meeste respondenten hebben daarom een 55-jarige man als uitgangspunt voor de beantwoording van de vragen genomen. In de vraagstelling was de tijdsperiode van 1 maand gesteld. De hieronderliggende aanname is dat behoudens acute gevallen het verdere verloop van de behandelingsstrategie na 1 maand bepaald wordt.

Een aantal respondenten zag liever dat het criterium voor een slechte ejectiefractie bij de grens van $30 \%$ in plaats van $40 \%$ werd gelegd. Dit criterium is gekozen om zoveel mogelijk aansluiting te krijgen met de relevante literatuur.

Bij vraag 3.1.3 "(vroeger AP3) + MI" wordt bedoeld dat sprake is van een AP3 op chronische basis waarna een MI heeft plaatsgevonden. Het complement is vraag 3.2.2. "(vroeger MI) + AP3" waarmee bedoeld wordt een stabiele AP met een oud-MI als voorgeschiedenis. In aansluiting hierop zou vraag 3.7.4. "UAP" gedifferentieerd moeten worden naar enerzijds een progressie vanuit AP2 naar AP3 en anderzijds vanuit AP3 naar AP4. De in vraag 3.7. gestelde tijdsperiode van 1 maand is in geval van UAP dan ook te lang en zou veranderd moeten worden in enkele dagen. Aanbevolen werd om deel I uit te breiden met een vraag over "(vroeger CABG) + AP, nog zonder behandeling".

Over deel II kwam de algemene opmerking dat de beantwoording van de daarin gestelde vragen benaderd zou kunnnen worden door terug te redeneren vanuit de kans om in een nieuwe ziektetoestand of opname te geraken. Daarom zou de vraagstelling in deel II ook naar geslacht en leeftijd gedifferentieerd moeten worden. In de vragen 3.1.1. en 3.4.1. moet de term MI omschreven worden als "(laatste) MI". Hetzelfde geldt voor de vragen met betrekking tot AP2 (3.7.1., 3.8.1.), AP3 (3.7.2., 3.8.2.), AP4 (3.7.3., 3.8.3.), en UAP (3.7.4.). Deze vragen moeten gelezen worden als "(laatste) AP2", "(laatste) AP3", "(laatste) AP4" respectievelijk "(laatste) UAP". In deel II zouden de vragen uitgebreid kunnen worden met een vraag over "hoelang duurt CABG + AP tot MI".

Een aantal respondenten vond dat een aantal items strakker dan wel meer herkenbaar gedefinieerd moeten worden. 


\section{EPILOOG}

We sluiten het proefschrift af met een aantal opmerkingen, discussiepunten en conclusies. Er worden hiertoe de volgende punten besproken, te weten:

(i) Validiteit van het model en scenario's;

(ii) Tekortkomingen van het model;

(iii) Bruikbaarheid model en scenariostudie voor het beleid;

(iv) Aanbevelingen nieuw onderzoek.

(i) Validiteit van het model en scenario's

l) Validiteit van het model

De validiteit van een model heeft betrekking op het inhoudelijk aspect van het model, namelijk dat er gemeten wordt wat men wilt meten. In Hoofdstuk 3 hebben wij de kengetallen genoemd waarmee de gegevens kunnen worden afgelezen die informatie geven over een toekomstig pad met betrekking tot CHZ. De toekomstige paden worden in het model dan gecreërd door het gebruik van gezondheidsprogramma's. In Hoofdstuk 6 bespreken we de evaluatie-variabelen die de scenario-uitkomsten met behulp van deze kengetallen weergeven.

Er is in Hoofdstuk 3 reeds op gewezen dat de beschrijving van de werkelijkheid een complex proces is. Er zijn vele onzekerheden van het het verleden en het heden (zie ook punt (ii) "Tekortkomingen van het model" verderop in de Epiloog). Het gevolg is dat er "fouten" blijven in het model. Deze "fouten" vragen om een validering van het model.

De validatie van een model wordt vaak onderverdeeld in drie groepen (Van Genugten e.a., 1992):

conceptuele validering,

data validering,

operationele validering.

De conceptuele validering van het model betreft de juistheid en bruikbaarheid van de theoriëen en aannames die wij gemaakt hebben met betrekking tot het ziekteproces van CHZ enerzijds en de determinanten van een CHZ-gebeurtenis anderzijds. Deze theorièen en aannames zijn besproken in met name de Hoofdstukken 2 en 3 en in Bijlage II. De bespreking over de bruikbaarheid komt aan de orde in punt (iii) "Bruikbaarheid model en scenariostudie voor het beleid" van de Epiloog. De juistheid van aan het (conceptuele) model ten grondslag liggende theoriëen en aannames kunnen wij staven met het feit dat het model goed aansluit bij de structuren van de beschikbare data-bestanden. 
Hierbij speelt dan vervolgens het probleem van de data validatie met betrekking tot de juistheid en bruikbaarheid van de data. De dataverantwoording geven we in de Bijlagen I, III, en IV. Zoals al op meerdere plaatsen in het proefschrift be. nadrukt (en ook weer verderop in de Epiloog) vormt de huidige medische kennis betreffende $\mathrm{CHZ}$ de basis van het model. De epidemiologische relaties met betrekking tot de kansen op een CHZ-gebeurtenis, de behandelingskansen, en de sterftekansen vormen eigenlijk een afgeleide van deze medische kennis. De vele "bekende" en "onbekende" onzekerheden in medische kennis van het heden en verleden betreffende $\mathrm{CHZ}$ maken het dan ook niet zinvol ori de statistische variantie van de gebruikte variabelen in het model met betrekking tot de onzekerheden in de toekomst te verklaren.

De operationele validering van het model wordt in belangrijke mate bepaald door de "fouten" met betrekking tot de conceptuele validering en data validering.

Er wordt bij operationele validatie onderzoek gedaan naar de bruikbaarheid van de modelresultaten. De modelresultaten betreffen de scenario-uitkomsten in vergelijking met die van het basisscenario. De bruikbaarheid van de modelresultaten wordt in belangrijke mate bepaald door de mate van complexiteitsreductie van de werkelijkheid. In Hoofdstuk 7 is hierover al opgemerkt dat het gaat om inzicht in de samenhangen en de mogelijkheden tot sturing en beïnvloeding ervan.

De aspecten met betrekking tot operationele validiteit die hierbij een rol spelen zijn in navolging van Van Genugten e.a. (1992) de volgende:

- historische validering,

- gevoeligheidsanalyse,

- onzekerheidsanalyse, en

- modelvergelijkingen.

De historische validering wordt verderop onder punt b) "ijkpunten" behandeld. De sensitiviteitsanalyse is besproken in paragraaf 7.2. De onzekerheidsanalyse behandelen we verderop onder punt a) "onvoorspelbare factoren". Er is met betrekking tot de modelvergelijkingen weining vergelijkingsmateriaal op het terrein van CHZ-scenario's in Nederland beschikbaar. We bespreken onder punt 2) "Validering van scenario's" het model van Weinstein e.a. (1987).

Binnen Nederland is er op het terrein van $\mathrm{CHZ}$ nog onderzoek gedaan door Martens (1992). Dit onderzoek betrof meer een kosteneffectiviteitsanalyse van cholesterolverlagende geneesmiddelen dan een scenariostudie als zodanig. De resultaten van onze cohortstudies met betrekking tot cholesterolverlagende middelen zouden met die van Martens (1992) vergeleken kunnen worden.

De resultaten van anti-rookcampagnes die op een cohortstudie zijn toegepast kunnen vergeleken worden met die van Tsjevat (1992). We hebben deze verge- 
lijkingen niet uitgewerkt omdat de gevolgde methodologie en gebruikte gegevens onvoldoende gedocumenteerd zijn in genoemde publicaties.

Er zijn voorts een aantal modellen te noemen die meerdere diagnosecategorieën bestrijken: Prevent (Gunning-Schepers, 1989), TAM (Barendregt, 1993), en Targets (RIVM, 1993b).

Er zijn door Van Genugten e.a. (1992) een aantal vergelijkingen gemaakt tussen modellen van de verschillende scenariostudies, te weten:

Ongevallen en traumatologie (Lapré en Markenbach, 1988),

Chronische ziekten (Casparie en Verkleij, 1990)

Kanker (Cleton en Coebergh, 1985)

Hart- en vaatziekten (1) (Dunning en Wils, 1986)

Hart- en vaatziekten (2) (Boas en Vrieze, 1992).

We verwijzen voor deze vergelijkingen naar de desbetreffende studie van genoemde auteurs. De studie Hart- en Vaatziekten (2) moet gelezen worden als "Een Simulatiemodel voor Toekomstanalyse van Coronaire Hartziekten" (Vrieze e.a., 1994). Het is deze studie waarop het proefschrift is gebaseerd (zie Hoofdstuk 2).

Er is door Bijl (1991) een vergelijking gegeven van enkele procedures van scenarioconstructies. De vergelijkingen die Van Genugten e.a. (1992) en Bijl (1991) weergeven, beperken zich (vooralsnog) tot de opsomming van een aantal criteria waar een scenariostudie als dan niet aan voldaan heeft. Er is door Bijl (1991) duidelijk een poging ondernomen om deze criteria zodanig te kiezen dat er evaluatieve conclusies aan de scenario-ontwerpen verbonden kunnen worden. We kunnen op deze plaats slechts volstaan door te verwijzen naar zijn opsomming van criteria en verantwoording ervan (Bijl, 1991, pag. 115).invoegen op blz. 4

Er zijn met betrekking tot de operationele validering een tweetal punten waar we meer expliciet op in willen gaan, te weten: de invloed van onvoorspelbare factoren en ijkingsproblemen.

a) onvoorspelbare factoren

Er heeft zich de voorbije jaren op het terrein van de coronaire hartziekten een verschuiving voorgedaan van acute zorg naar chronische zorg (zie Hoofdstuk 1). Minstens twee oorzaken zijn hiervoor aan te wijzen: 
- De technologische ontwikkeling zorgt ervoor dat meer patiënten overleven. Als gevolg hiervan verkeren deze patiënten gemiddeld gezien in een slech. te fysiologische toestand (slechte ejectiefractie).

- $\quad$ Door de verfijnde diagnostische technieken (CAG, TL, Ergometrie e.d.) kan eerder geanticipeerd worden op dreigende verstoringen, waardoor de patiënten langer in de toestand angina pectoris verblijven.

Een manier om dit proces te analyseren is door naar de zogenaamde even. wichtsverdeling van het dynamische systeem te kijken. Gegeven een be. paalde instroom (via Gezond en CHZ-bevolking) en gegeven een bepaalde uitstroom (via FMI-sterfte, SD-sterfte, operatiesterfte en sterfte aan niet$\mathrm{CHZ}$ ) is er uniek bepaald een zogenaamde evenwichtsverdeling van de zieke groep, zijnde dat aantal, dat indien gebruikt als beginwaarde, constant blijft in de tijd. Startend vanuit een "willekeurige" verdeling gaat de verdeling sprongsgewijs naar de evenwichtsverdeling. Op basis van de inen uitstroomgegevens van 1988 vinden we een evenwichtsverdeling van personen met oud-MI en personen met AP (en geen oud-MI). In de praktijk zal zo'n evenwichtsverdeling zich niet voordoen. Het is duidelijk dat in zo'n situatie als gevolg van plotseling onvoorspelbare factoren er een nieuwe evenwichtsverdeling gezocht zal moeten worden.

In Bijlage $\mathrm{I}$ is een figuur gepresenteerd waarin het voorspelde en het geregistreerde aantal opgenomen acute myocardinfarcten (AMI) over de periode 19701990 in Nederland met elkaar zijn vergeleken. Hierbij is toegelicht dat de incidentie van het AMI als uitgangspunt dient voor de bepaling van de incidenties van de overige CHZ-manifestatievormen. Wat we kunnen opmerken is dat de geregistreerde uitkomsten vanaf 1982 eerst naar boven en vanaf 1988 naar beneden fluctueren ten opzichte van de modeluitkomsten.

Inmiddels zijn de SIG-gegevens over 1991 en 1992 bekend. Hieruit blijkt dat het aantal AMI-opnames 29.094 respectievelijk 27.974 bedragen. Het totale aantal CHZ-opnames laat vanaf 1990 een plotselinge scherpe stijging zien, die voor een groot gedeelte verklaard kan worden uit een stijging van de AP1-2 opnames. Paradoxaal heeft de vanaf 1988 reeds ingezette dalende CHZ-sterfte zich doorgezet. In Hoofdstuk 1 hebben we hierover al enige beschouwende opmerkingen gemaakt. Het is in dit stadium van ons onderzoek onduidelijk of deze ontwikkelingen te wijten zijn aan veranderende medische inzichten die structureel van aard zijn, dat er sprake is van incidentele autonome factoren, of dat er veranderingen zijn aangebracht in de bestaande registratiemethoden. Het (destijds) door de STG geïnitieerde systeem van "Signaleringsrapportage", waarin nieuwe ontwikkelingen op het terrein van $\mathrm{CHZ}$ worden bijgehouden, zou hiervoor een welkome uilkomst kunnen bieden. 
b) voldoende ijkpunten (zogenaamde historische validering).

We geven in onderstaande tabel 1 een overzicht van een aantal belangrijke ijkpunten over de periode 1988-1992.

\begin{tabular}{|c|c|c|c|c|c|}
\hline opnames totaal & 1988 & 1989 & 1990 & 1991 & 1992 \\
\hline $\begin{array}{l}\text { opnames totaal } \\
\text { model } \\
\text { geregistreerd }{ }^{01}\end{array}$ & $\begin{array}{l}76.171 \\
76.265\end{array}$ & $\begin{array}{l}77.119 \\
75.462\end{array}$ & $\begin{array}{l}78.124 \\
81.569\end{array}$ & $\begin{array}{l}79.245 \\
84.095\end{array}$ & $\begin{array}{l}80.428 \\
86.075\end{array}$ \\
\hline $\begin{array}{l}\text { opnomes AMI } \\
\text { model } \\
\text { geregistreerd }{ }^{\text {(1) }}\end{array}$ & $\begin{array}{l}30.438 \\
29.531\end{array}$ & $\begin{array}{l}30.640 \\
27.734\end{array}$ & $\begin{array}{l}30.894 \\
29.326\end{array}$ & $\begin{array}{l}31.201 \\
29.094\end{array}$ & $\begin{array}{l}31.552 \\
27.794\end{array}$ \\
\hline $\begin{array}{l}\text { CHZ-sterite } \\
\text { model } \\
\text { geregistreerd }^{\text {2) }}\end{array}$ & $\begin{array}{l}23.596 \\
23.454\end{array}$ & $\begin{array}{l}23.714 \\
22.746\end{array}$ & $\begin{array}{l}23.852 \\
22.396\end{array}$ & $\begin{array}{l}24.030 \\
21.836\end{array}$ & $\begin{array}{l}24.227 \\
21.094\end{array}$ \\
\hline $\begin{array}{l}\text { ziekenhuiksterfte } \\
\text { model } \\
\text { geregtstreerd }^{\left.{ }^{11}\right)}\end{array}$ & $\begin{array}{l}5.490 \\
5.471\end{array}$ & $\begin{array}{l}5.538 \\
4.943\end{array}$ & $\begin{array}{l}5.583 \\
4.953\end{array}$ & $\begin{array}{l}5.638 \\
4.757\end{array}$ & $\begin{array}{l}5.681 \\
4.493\end{array}$ \\
\hline
\end{tabular}

7) Stichting Informatiecentrum Gezondheidszorg (SIG)

") Centraal Bureau voor de Statistiek (CBS)

Tabel 1

Vergelijking geregistreerde- en modeluitkomsten over de periode 1988-1992

In de volgende tabel worden de CBS- (1988) en modeluitkomsten met betrekking tot de gemiddelde levensverwachting over de periode 1988-2010 met elkaar vergeleken (zie ook Bijlage I).

\begin{tabular}{|l|c|c|c|c|}
\cline { 2 - 5 } & \multicolumn{2}{|c|}{ CBS-middenvartant } & \multicolumn{2}{c|}{ model } \\
\cline { 2 - 5 } & $\mathrm{V}$ & $\mathrm{M}$ & $\mathrm{M}$ & $\mathrm{V}$ \\
\hline 1988 & 73,7 & 80,3 & $\mathbf{7 3 , 7}$ & 80,3 \\
\hline 1990 & 74,0 & 80,5 & 73,9 & 80,4 \\
\hline 1995 & 74,5 & 80,9 & 74,3 & 80,7 \\
\hline 2000 & 74,8 & 81,3 & 74,7 & 81,1 \\
\hline 2010 & 75,0 & 81,5 & 75,5 & 81,7 \\
\hline
\end{tabular}

Tabel 2

Vergelijking gemiddelde levensverwachting CBS en model 1988-2010 
De conclusies die we met betrekking tot de validering van het model kunnen trekken zijn de volgende.

De huidige versie van het model is geijkt op basis van diverse CHZ-gegevens met betrekking tot 1988, de periode daaraan voorafgaand, en 1990. De verwerking van nieuwe informatie zal leiden tot een continu aanpassingsproces van het model. Er zullen hiervoor nieuwe medische inzichten en epidemiologische relaties in het model verwerkt moeten worden. Volgens de nieuwe stand van zaken zal de huidige versie van het model eigenlijk "nu" al aangepast moeten worden. Deze aanpassingen zouden voorlopig eruit kunnen bestaan dat met behulp van de modelparameters uit de userinterface de initiële incidenties "opgehoogd" en de CHZ-sterfte "verlaagd" kunnen worden volgens de geregistreerde uitkomsten. Het zijn de CHZ-gegevens over de komende periode die pas uitkomst kunnen bieden over de vraag in hoeverre er sprake zal zijn van structureel veranderde relaties tussen de verschillende modelvariabelen. In Hoofdstuk 3 is hierover al benadrukt dat het model zodanig "flexibel" is opgebouwd dat dergelijke aanpassingen zonder meer mogelijk zijn.

2) Validiteit van scenario's

Er worden met behulp van een model scenario's gegenereerd. De validiteit van scenario's wil zeggen dat er in dit verband een aansluiting moet zijn van die scenario's op de werkelijkheid.

De validiteit met betrekking tot de scenario's wordt getoetst aan de helderheid, de geloofwaardigheid, en de interne consistentie van de beschreven ontwikkelingen (zie Van Genugten e.a., 1992). In Hoofdstuk 5 zijn we hierop reeds uitvoerig ingegaan.

In onze benadering hebben we er naar gestreefd dat het model enerzijds herkenbaar is voor de medische beroepsgroep en anderzijds aansluit op de bestaande kennis en inzichten in de literatuur. Wij hebben met betrekking tot deze twee uitgangspunten lering kunnen trekken uit de kritiek die destijds door de medische beroepsgroep op het scenariorapport "Het hart van de toekomst. De toekomst van het hart" (1986) is geuit (zie Bijlage II). Het is enerzijds door deze kritiek en anderzijds door de methodologische onmogelijkheid om in het model van het scenariorapport uit 1986 kostprijzen te verbinden dat de STG in 1988 de opdracht verleende tot twee nieuwe onderzoeksprojecten op het terrein van $\mathrm{CHZ}_{2}$ (zie Hoofdstuk 1). We behandelen deze kostprijzen in Bijlage III. Een belangrijk vernieuwend aspect bij de kostenberekeningen is de introductie van de behandelingstrajecten geweest (Bijlage II). 
Een andere onderzoeksgroep die specifiek op het terrein van $\mathrm{CHZ}$ een scenarioonderzoek op bevolkingsniveau heeft gedaan is die van Weinstein e.a. (1987). Er zijn drie essentiële verschillen tussen het model van Weinstein en dat van ons. In de eerste plaats is er een verschil met betrekking tot hun brugmodel. In het brugmodel van Weinstein e.a. (1987) worden de eerste 30 dagen na AMI beschreven. Deze periode is gekozen omdat er dan een verhoogde CHZ-sterftekans optreedt. In ons brugmodel bestrijkt de tijdsperiode een lengte van 1 jaar. In de tweede plaats zijn de therapeutische behandelingen in het Weinstein model verspreidt over het brug- en het ziektemodel, terwijl deze bij ons alleen in het brugmodel plaatsvinden. Het derde en meest essentiële verschil betreft de door ons geïntroduceerde CHZ-bevolking. Zodoende hebben we een aangrijpingspunt ontwikkeld waarmee alternatieve toekomsttrajecten met betrekking tot het latente ziekteproces en secundaire incidenties kunnen worden uitgezet. Hiermee is bereikt dat modelscenario's ook in de praktijk betekenis hebben.

\section{(ii) Tekortkomingen van het model}

We hebben op verschillende plaatsen in het proefschrift direct of indirect er reeds op gewezen dat het model een aantal tekortkomingen kent.

\section{1) Voortdurende onzekerheden van het heden en het verleden.}

Zoals in Hoofdstuk 1 besproken is het probleem bij toekomststudie niet alleen dat de toekomst onbekend is, maar tevens dat het verleden en het heden de nodige onzekerheden in zich hebben.

Medische kennis is iets wat voortdurend evolueert en wat nooit volledig of afgerond is. $\mathrm{Zo}$ is algemeen aanvaard dat coronaire hartziekten veelal veroorzaakt worden door atherosclerose van de kransslagaders. Maar welke factoren nu precies, in causale zin, dit atherosclerotisch proces in gang zetten en met welke snelheid of hoever dit proces precies gevorderd moet zijn om zich als "ziekte" te presenteren is niet bekend en de opvattingen hieromtrent wijzigen voortdurend. Naturlijk, roken, serumcholesterol, hypertensie, enz. hebben er allemaal mee te maken. Maar hoe en in welke mate precies zal nog jaren onderwerp van discussie blijven (zie ook Hoofdstuk 2).

Een manier om onbekendheid met de precieze aard van het ziekteproces te compenseren gaat via de bestudering van empirische verslaggeving van ziekteverlopen. Hierbij is men aangewezen op registraties. Helaas echter worden gegevens vaak onvolledig en onbetrouwbaar verzameld en opgeslagen en zijn deze zelden op de juiste wijze gestructureerd voor het doel waarvoor ze later gebruikt worden. Daarbij komt dat het onderhavige onderzoek bedoeld is om inzichten op bevolkingsniveau te realiseren, terwijl studies vaak betrekking hebben op niet-representatieve deelgroepen van de bevolking. 
Om deze tekortkoming zoveel mogelijk op te vangen is er door ons een systeem ontwikkeld dat enerzijds gevuld kan worden met huidige kennis en stand van 2 . ken en dat anderzijds voldoende flexibel is om nieuwe inzichten te verwerken. Drie informatiebronnen hebben ons ter beschikking gestaan.

1. Medische kennis zoals te vinden in de handboeken en dat algemeen geaccepteerd is. Voor zover nodig en relevant is deze kennis aangevuld met expert-meningen uit privé-communicatie.

2. Gegevens. uit databestanden. Voorbeelden zijn de Framingham Heart Study gegevens zoals door ons geprojecteerd op de Nederlandse situatie, de gegevens uit het Peilstationsproject Hart- en Vaatzieken betreffende de verdeling van risicofactoren onder de Nederlandse bevolking en de tarieven voor medische handelingen zoals bekend bij het COTG.

3. De nationale en internationale literatuur. Vele honderden artikelen zijn bestudeerd op bruikbaarheid. Veelal gaat het hierbij om epidemiologische studies die bijvoorbeeld verbanden leggen tussen behandelingen en prognoses.

2) Vervangende ziekten en vervangende sterften.

Dit aspect is in paragraaf 7.3 reeds aan de orde gekomen. Er is in de literatur weinig onderzoek naar dit probleem gedaan. In ons model wordt de sterfte tengevolge van $\mathrm{CHZ}$ gezien als te beïnvloeden variabele via hetzij preventie programma's ter voorkoming van CHZ, hetzij via invoering van nieuwe medische technologieën. Wat wij dan ook gebruikt hebben in ons model is de verwaching van het geboortepatroon en de verwachte leeftijdsspecifieke sterfte aan niet-CHZ oorzaken. Hiervoor is de totale verwachte sterfte gecorrigeerd voor de verwachte CHZ-sterfte. We zijn hierbij uitgegaan van onafhankelijkheid van doodsoorzaken. Dit is ongetwijfeld niet in overeenstemming met de werkelijkheid. Echter in Hoogenveen (1990) is aangegeven dat het verschil in uitkomsten na volledige eliminatie van een doodsoorzaak voor een model met en zonder afhankelijkheid van doodsoorzaken slechts 0,2 gewonnen levensjaren bedraagt. Daar de door ons geformuleerde scenario's niet gericht zijn op eliminatie van de doodsoorzaak CHZ maar op reductie, veroorzaakt de onafhankelijkheidskeuze dus een geringere fout dan 0,2 gewonnen levensjaren.

We hebben in Hoofdstuk 6 al beschreven dat de onafhankelijkheid van doodsoorzaken in ons model maar ten dele optreedt. Het gespaarde gedeelte van de bevolking dat zonder een interventie anders aan $\mathrm{CHZ}$ was overleden ondergat in het model dezelfde niet-CHZ-sterftekansen als een ander persoon van dezelfde leeftijd en geslacht die geen $\mathrm{CHZ}$ heeft. Wat we niet weten is in hoeverre de daling aan CHZ-sterfte leidt tot de stijging van de specifieke sterfte aan bijvoor- 
beeld kanker. Verder wordt er geen rekening gehouden met de beïnvloeding van andere ziekten door dezelfde risicofactoren.

Een zaak van geheel andere orde met betrekking tot het aspect van vervangende ziekten en - sterften betreft de indirecte medische kosten (zie Hoofdstuk 4). De kosten van medische voorzieningen, die in dergelijke gevallen optreden, kunnen leiden tot een (onbeheersbare) stijging van de totale kosten van de gezondheidszorg. Een treffend voorbeeld hiervan is gegeven door Vrieze e.a. (1994). Het uitgangspunt dient te zijn dat optredende indirecte medische kosten eigenlijk zondermeer een onderdeel moeten vormen van kostenberekeningen in scenariostudies. De economische vraag rijst of eventuele extra kosten en een toename van "niet CHZ-sterften" als gevolg van het optreden van vervangende ziekten en sterften opwegen tegen de (resterende) levenswinst die met een CHZ-interventie wordt behaald.

\section{3) Verdelingsaspecten in de gezondheidszorg.}

Er kan met behulp van het door ons ontwikkelde model (nog) geen inzicht gekregen worden in de gevolgen van de verdeling van de schaarse middelen voor de volksgezondheid op macroniveau. We hebben in paragraaf 7.4 een pleidooi willen geven om in de gezondheidszorg op beleidsniveau meer aandacht te geven aan de toepassing van de gezondheidsproduktiefunctie. De gezondheidsproduktiefunctie en de daarmee samenhangende theorie zou een economisch instrument zijn, waarmee inzicht verkregen kan worden in een zo optimaal mogelijke verdeling van de schaars beschikbare middelen binnen een bepaalde ziektecategorie, tussen verschillende ziektecategorieën, en zo mogelijk tussen verschillende maatschappelijke sectoren als bijvoorbeeld gezondheidszorg en onderwijs.

Er is door ons noch empirisch, noch theoretisch, onderzoek gedaan naar de operationalisering van dit instrument. Het enige wat we hierover concreet kunnen zeggen is dat de gezondheidsproduktiefunctie als het ware impliciet in het computerprogramma wordt geoperationaliseerd (zie paragraaf 7.4). De daarbij horende isonutcurve is fictief. Wel is het mogelijk het computerprogramma zodanig in te stellen, dat deze isonutcurve geconstrueerd kan worden. Daarvoor is het echter noodzakelijk dat er een "budgetbeperking" in het model wordt ingebouwd. Programmatisch gezien vereist een dergelijke executie een toevoeging van een extra module aan het computerprogramma en nieuw onderzoek. Hiermee sluiten we aan op de vierde tekortkoming van het model dat in het volgende punt 4 wordt besproken.

4) Budgetbeperkingen.

In Hoofdstuk 1 is er reeds op gewezen dat sinds de publicatie van de Nota 2000 (1986) en eerder ten tijde van staatssecretaris Hendriks, er een verschuiving 
waameembaar is in de motiveringen bij het toekennen van middelen aan sectoren binnen de gezondheidszorg. Enerzijds is meer het "welbevinden" dan alleen de "afwezigheid van ziekte" centraal in de beleidsaandacht komen te staan. Anderzijds is het besef groeiende dat de verdeling van de middelen moet geschieden uit een zogenaamd "gesloten budget". In Hoofdstuk 4 hebben we erop gewezen dat er dan een spanningsveld ontstaat tussen de utilitaristische - en egalitaire verdelingsprincipes. Beide filosofieën kunnen tot een uiteenlopende besluitvorming leiden (zie ook Gezondheidsraad, 1986/29).

Bij een dergelijk uitgangspunt van maximalisatie van de gezondheidsopbrengst dienen zich verscheidene problemen aan:

a) Voor een beoordeling van het nut van een toedeling van een zeker budget aan een bepaalde sector in de gezondheidszorg, zou de relatie tussen de omvang van het toegewezen budget en de gezondheidswinst te beschrijven moeten zijn. Dit zou idealiter niet alleen kwalitatief het geval moeten wezen maar ook kwantitatief. Dit is in de huidige praktijk met de huidige meetinstrumenten geen eenvoudige zaak. Vaak zullen middelenverdelingen aanleiding geven tot nieuwe prognoses. Bijvoorbeeld de invoering van een nieuwe operatietechniek zal leiden tot andere vervolgtrajecten van het ziekteproces en aldus tot andere prognoses. Kwantitatieve kennis van de lange termijn gevolgen van een dergelijke toewijzing is onmisbaar bij de evaluatie van de waarde van zo'n toewijzing. De klinische epidemiologie, het wetenschapsgebied dat voor de aanlevering van dit soort informatie zou moeten zorgdragen, richt zich per definitie op de verwerking en analyse van gegevens die betrekking hebben op situaties die gepasseerd zijn. Extrapoleren van dit soort kennis op nieuwe toekomstige situaties vereist een gedegen onderbouwing en is lang niet altijd mogelijk.

b) Toepassing van het concept gezondheidsopbrengst vereist een zekere consensus over de relevante kengetallen met behulp waarvan gezondheid te meten is. Voor de hand liggend is enerzijds de hoeveelheid ziekte onder de bevolking en anderzijds de geschiktheid van het gezondheidszorgsysteem om ook chronisch zieke mensen nog zo lang mogelijk een leefbaar leven te bieden. Twee evenzeer zinvolle kengetallen zijn (i) het aantal jaren vrij van (chronische) ziekte en (ii) de kwaliteit van leven gedurende de (chronische) ziekteperiode.

De discussie omtrent de meest karakteristieke kengetallen is zeker niet afgerond. Ook al omdat een direct verband tussen de totale inspanningen van de gezondheidszorg en een aantal van deze kengetallen niet steeds duidelijk is en door sommigen zelfs betwijfeld wordt. 
c) Nauw gerelateerd aan het bovengenoemde aspect van de keuze van de kengetallen is het tijdsaspect. Middelentoewijzingen nu, bijvoorbeeld op het terrein van de preventie, vertonen pas meetbare invloeden op de genoemde kengetallen na verloop van een bepaalde tijdsperiode. Bijvoorbeeld, reductie van rookgewoonten van de bevolking zal pas na verloop van enkele jaren werkbare invloed hebben op de incidentie van longkanker en coronaire hartziekten, hetgeen mutatis mutandis geldt voor de totale uitgaven van de gezondheidszorg. Tevens worden toekomstige ontwikkelingen in dit verband mede bepaald door de omvang en de kwaliteit van het gezondheidszorgsysteem gedurende de komende tijd.

Aldus hebben we een situatie waarbij uitgaven en opbrengsten op geheel verschillende momenten in de tijd plaatsvinden en het is de vraag of deze zo maar aan elkaar gekoppeld kunnen worden. Bovendien zorgen de snelle technologische ontwikkelingen op geneeskundig terrein voor een extra complicatie bij toekomstanalyses.

Door het Ministerie van WVC zijn de laatste jaren via de STG een aantal scenariostudies opgezet met het doel oplossingen te verkrijgen voor bovengenoemde probleemaspecten van beleidskeuze motivering (zie Hoofdstuk 1). De onderhavige studie kan eveneens in dat licht worden geplaatst.

Onze scenariostudie in deze kent een tekortkoming omdat wij uitgaan van een open-eindfinanciering. Het is daarom niet goed mogelijk om in dit stadium van het onderzoek een antwoord te geven op vraagstelling (iii) uit Hoofdstuk 1 van dit proefschrift:

"Wat is de bijdrage van de scenariomethode aan de doelmatigheid en doeltreffendheid van de gezondheidszorg met betrekking tot CHZ?"

De beantwoording van deze vraagstelling in kwantitatieve termen vereist een gesloten budget, omdat alleen in een gesloten financieringssysteem de opportuniteitskosten van niet uitgevoerde programma's zichtbaar gemaakt kunnen worden (vgl. Ament, 1991).

Het is vanuit deze context dat we in paragraaf 7.5 het concept van programmabudgettering hebben besproken. Dit concept is ingebracht om op kwalitatieve wijze te kunnen verwoorden in hoeverre en onder welke voorwaarden de scenariomethode een bijdrage kan leveren aan een efficiënte en effectieve gezondheidszorg. 
(iii) Bruikbaarheid model en scenariostudie voor het beleid

1) Bruikbaarheid model voor het beleid.

Scenariostudies richten zich op de analyse van toekomstige trajecten. Toekomstige trajecten zijn een product van de huidige trends, bijsturing van beleidsvormende instanties en invloeden van minder goed voorspelbaar economisch en sociaal gedrag van de samenleving. Voor de gezondheidszorg geldt verder nog dat de incidentie en prevalentie van ziekte in de tijd wisselende beelden laat zien, alhoewel de veranderingen zich in het algemeen traag voltrekken.

De toekomst is dus maar in beperkte mate te overzien. Analyse van de toekomst bezit steeds een zekere fictie. Om deze fictie zo veel mogelijk te reduceren is kennis van de huidige situatie en de onderlinge verbanden tussen de deelaspecten van het object van studie een onmisbaar startpunt. Anderzijds is medische kennis altijd maar een momentopname. Medische kennis evolueert voortdurend al dan niet op geleide van technologische ontwikkelingen.

Bovenstaande beschouwingen over de onzekerheid van zicht op toekomst heeft er toe geleid dat onze benadering gericht is geweest op het ontwikkelen van een "framework". Een structuur dat ons in staat stelt toekomstbeelden te genereren en te analyseren. De basis van het "framework" is de huidige relevante medische kennis voor de ziektecategorie coronaire hartziekten. De basisstructuur is dusdanig flexibel ingericht dat nieuwe medische inzichten of reductie van onzekerheden eenvoudig aangebracht kunnen worden. De uiteindelijke vorm van het "framework" is een computer simulatieprogramma dat toegerust is met een gebruikersinterface.

Op deze wijze zijn we erin geslaagd een produkt te ontwerpen dat niet alleen op dit moment als analyse-instrument voor toekomstige trajecten gebruikt kan worden, maar dat evenzeer in de komende jaren als zodanig kan dienen. Het ontworpen analyse-instrument heeft dus een permanent karakter, waarbij constante aanpassing aan de jongste gegevens mogelijk is.

De bovengenoemde algemene toepasbaarheid van het ontwikkelde model gaat nog verder. De gekozen benadering voor de ziektecategorie coronaire hartziekten is evenzeer van toepassing op andere (chronische) ziekten. Toepassing van ons model op andere ziektecategorieën zou neerkomen op modelvorming en dataverzameling. Het computer-simulatiemodel blijft toepasbaar onder aanpassing van de gebruikte termen.

Samenvattend voldoet de bruikbaarheid van het model aan de criteria die door de STG (Van Genugten e.a., 1992) zijn ontwikkeld, te weten:

1) bruikbaarheid voor het ontwikkelen van scenario's,

2) bruikbaarheid voor integratie van verschillende scenarioprojecten,

3) bruikbaarheid voor kostenberekeningen. 
2) Bruikbaarheid scenariostudie van het beleid

Er worden door de STG (Van Genugten e.a., 1992) drie criteria genoemd die de scenario's op hun bruikbaarheid toetsen, te weten:

1) voldoende heldere scenario's,

2) consequentie-analyse van scenario's,

3) vergelijking van scenario's.

De genoemde drie criteria komen allen in Hoofdstuk 6 uitvoerig aan bod.

De waarde van scenariostudies dient meer te worden afgemeten aan de bruikbaarheid voor actuele beleidsbeslissingen die een strategische waarde hebben, dan aan de eventuele juistheid van het uitgezette toekomstige traject.

We zijn er in dit verband van overtuigd dat het instrument dat we ontwikkeld hebben door diverse beleidsvormende instanties gebruikt kan worden.

a) In de eerste plaats is daar de overheid. Het model stelt de overheid in staat lange termijn strategieën te evalueren op hun effecten op de gezondheidszorg en in het bijzonder coronaire hartziekten. Daarnaast is er inzicht in de kostenontwikkelingen. Voor de overheid gaat het dus om de vertaalslag van macro-beleid naar micro-gezondheid.

b) In de tweede plaats zijn er de verzekeringsmaatschappijen. Voor de verzekeringsmaatschappijen is inzicht in de lange termijn ontwikkelingen van coronaire hartziekten essentiële informatie voor meerjaren afspraken met de beroepsgroepen. Evenzeer van belang hierbij is de relatie tussen kostprijzen (eventueel tarieven) en de totale kosten. Deze toepassing kan gekenschetst worden als de relatie tussen het meso- en micro-niveau.

c) Als derde noemen we de Nederlandse Hartstichting, die zich ontwikkeld heeft tot belangenvertegenwoordiger van hartpatiënten. Voor de Nederlandse Hartstichting is de denkrichting precies andersom dan voor de overheid, namelijk hoe vertaald het micro-gebeuren (het patiëntniveau) zich naar macro-cijfers, met het doel de beleidsvormende instanties van overtuigende informatie te voorzien. Ook hiertoe is het model een uitstekend hulpmiddel.

d) Voor ziekenhuizen en specialisten kan het model in zoverre strategische waarde hebben, dat gesimuleerd kan worden wat gezondheidseffecten van gewijzigde indicatiestellingen voor behandelingen zijn. In de besprekingen met de verzekeringsmaatschappijen kan dit van groot nut zijn.

e) Als laatste gebruikersgroep noemen we collega-onderzoekers. Het model kan diverse onderzoeksvragen ondersteunen. Om er enkele te noemen. Wat zijn de kostendeterminanten van coronaire hartziekten? Wat is de relatie tussen bevolkingsontwikkelingen en risicogedrag met de incidentie en prevalentie van coronaire hartziekten? Wat is de invloed van terugdringing van coronaire hartziekten op de incidentie van andere ziekten? 
Voor ieder van de gebruikersgroepen is het uiteraard niet zo dat het model direc een concrete vraag kan beantwoorden. Vaak zullen er additionele gegevens in het model ingebracht moeten worden. Onze ervaring is dat, afhankelijk van de uitgebreidheid van de vraagstelling, de tijdsduur vooral bepaald wordt door de nood. zaak van gegevensverzameling.

Het ligt in de lijn der bedoelingen dat de overheid de resultaten van scenariostr. dies verwerkt in strategische beleidsplannen. In 1992 is bij het Rijksinstitut voor de Volksgezondheid en Milieuhygiëne (RIVM) een specifieke afdeling gevormd onder de naam Volksgezondheid Toekomstverkenningen. De taak van deze afdeling is gegevens over de volksgezondheid te verzamelen, analyseren en te integreren. Op basis van hun rapportage en de gereedgekomen scenario-studies zal volgens de STG (1993) de Nota Gezondheidsbeleid in 1994 aan de Tweede Kamer worden aangeboden. Inmiddels is een eerste rapportage door het RIVM (1993a) gepubliceerd. In Hoofdstuk 1 is een overzicht opgenomen van de deelterreinen die de scenariostudies bestrijken.

\section{(iv) Aanbeveling nieuw onderzoek}

In deze dissertatie wordt beschreven op welke wijze scenario-analyse gebruikt kan worden als een voor het beleid geschikt economisch analyse instrument. Hierbij werd het aandachtsgebied beperkt tot coronaire hartziekten (CHZ).

Voor de komende periode kan dit aandachtsgebied als volgt uitgebreid worden.

1) Uit de literatuur is bekend dat er een sterftesubstitutie tussen $\mathrm{CHZ}$ en kanker plaatsvindt, ook wel aangeduid als het fenomeen van vervangende ziekte- en sterfterisico's. Er kunnen met behulp van de scenariomethode verschillende toekomstige trajecten met betrekking tot CHZ en kanker worden uitgezet. Het simultaan simuleren van gezondheidszorgprogramma's met betrekking tot deze twee ziektencategorieën kan inzicht geven in de vraag wat de kosten en effecten zijn van het optreden van vervangende ziekten en -sterften.

2) De ontwikkelde methodologie met betrekking tot scenario-analyse zou verder ontwikkeld kunnen worden tot een algemeen toepasbare methodologie voor chronische ziekten. Hierbij verdient het aanbeveling om nauwe aansluiting te zoeken bij het project Toekomstscenario's van het RIVM en het TAM-project van het instituut Maatschappelijke Gezondheidszorg (iMG).

3) In nauwe samenhang met scenario-analyse staat het doel om economische (sturings)instrumenten met betrekking tot de efficiënte allocatie van de schaarse middelen in de gezondheidszorg te ontwikkelen. Een geschilt economisch instrument hiervoor is de gezondheidsproductiefunctie. Een 
nauwe samenwerking met andere instituten is voor de operationalisering van dit instrument een vereiste.

4) Een effectief gebruik van scenariostudies vereist dat er een structuur beschikbaar moet zijn waarmee verdelingsanalyses kunnen worden geoperationaliseerd. Een voorbeeld van een dergelijke "verdelingsprocedure" is programma budgettering. De beleidsmatige invalshoek van programma budgettering zou verder uitgewerkt moeten worden.

5) Het is voor het gebruik van scenariostudies door het beleid van belang dat er duidelijke criteria worden ontwikkeld met betrekking tot scenarioconstructies en dat er evaluatieve conclusies aan deze criteria kunnen worden verbonden. $\mathrm{Er}$ is in dit verband door de STG een tweetal projecten ontwikkeld die methodologische richtlijnen - respectievelijk richtlijnen voor kostprijsberekeningen met betrekking tot scenariostudies gaan geven. Wij willen in een aantal nog uit te brengen publicaties onze eigen scenariostudie evalueren aan de hand van criteria die liggen op medisch, epidemiologisch, economisch en toegepast wiskundig terrein. 
380 


\section{LITERATUUR}

Abbott R.D., McGee D.L. (1987): Section 37: The probability of developing certain Cardiovascular diseases in eight years at specified values of some characteristics. In: Kannel W.B., Woolf P.A., Garrison R.J. (eds.): The Framingham Study. An epidemiological investigation of cardiovascular disaese. DHEW Pub No (NIH) 87-2284, Public Health Service. Bethesda, Maryland.

Admiraal P.H., Veenbergen J.G., Heesters J.P. Aanbod van gezondheidszorg. In: Lapré R.M., Rutten F.F.H. (1998): Economie van de Gezondheidszorg. De Tijdstroom. Lochem.

AHCPR (1990): (Abstract): Silent ischemia during exercise may not indicate a unique, high-risk group of patients. Public Health Service; nr. 125: p. 3.

AHCPR (1991): Simple, new method devised for evaluating heart disease risk. Publ Health Service; nr. 148 :p. 2.

Ambrose J.A., Alexopoulos D. (1989): Thrombolysis in unstable angina: Will the beneficial effects of thrombolytic therapy in myocardial infarction apply to patients with unstable angina. JACC; 13 ,nr. 7 :pp. 1666-1671.

Ament A.J.H.A., Haan G., Heemels G. (1986): Kosten-effectiviteitsstudie open hartchirurgie. Rapportnummer 86.1. Vakgroep Economie van de Gezondheidszorg, Rijksuniversiteit Limburg. Maastricht.

Ament A.J.H.A., Rutten F.F.H. (1988): Hoofdstuk 10: Evaluatie. In: Economie van de Gezondheidszorg; Leerboek voor universitair en hoger beroeponderwijs. R.M. Lapre, F.F.H. Rutten (eds). Uitgeversmaatschappij De Tijdstroom. Lochem.

Ament A. (1991): Optimale inzet van schaarse middelen in de gezondheidszorg. Rationalisering door ratio's? Vakgroep Economie van de Gezondheidszorg, Rijksuniversiteit Limburg. Maastricht.

Andriessen J.E. (1980): Economie in theorie en praktijk. Deel twee. Bewerkt door Schöndorff R. en Cohen N. Elsevier. Amsterdam/Brussel.

Appels A., Sturmans F., Mulder P. (1988): De KRIS follow-up studie. I Methode van data-verzameling. T Soc Gezondheidsz; 66. 
Applefeld M.M. (1986): Chronic Congestive Heart Failure; Where Have We Been? Where Are We Heading? Am J Med; 80, (suppl 2B) :pp. 73-77.

Arntzenius, A.C., Kromhout D.K., Barth J.D., Reiber J.H.C. (1985): Diet, Lipoproteins, and the progression of Coronary Atherosclerosis. The Leiden Intervention Trial. $N$ Engl J Med; 312.

Arntzenius A.C. (1988): Helsinki Heart Study. Onderzoek naar primaire preventie met Gemfibrozil bij mannen (40-55 jaar) met dyslipidemie. Hart Bulletin; vol. 19.

Arntzenius A.C. (1990): Regressie van Atherosclerose; Het reversibel zijn van de afwijkingen. Hart Bulletin; 21.

Arntzenius A.C. (1990/1): Derde internationale cardiovasculaire farmacotherapie symposium. Kyoto, oktober, 1989. Hart Bulletin; 21 :pp. 25-27.

Atlanta Nieuwsbrief 1 (1991): ISIS-3 resultaten. Nieuwsbrief.

Baan B. (1989): Hart- en vaatziekten en roken. Stichting Volksgezondheid en Roken, 's Gravenhage. Medifo; nr. 3 :pp. 35-39.

Bams J.L., Miranda D.R. (1985): Outcome and costs of intensive care. A followup study on 238 ICU-patients. Intensive Care Med; 11 :pp. 234-241.

Bannenberg A.F.I. (1992): Model en indicatoren voor de berekening van gezondheidswinst en gezondheidsverlies door gezondheidsbeleid. T Soc Gezondheidsz, 70, nr. 11.

Banta H.D. (1984): Embracing or rejecting innovations: clinical diffusion of health care technology. In: Reiser S.J. (red.): The machine at the bedside. Cambridge University Press.

Barendregt J.J., Bonneux L., TAM Onderzoeksgroep (1993): Ziektevrije overlevingen: resultaten van een dynamisch model. $T$ Soc Gezondheids; 2.

Barner H.B., Standeven J.W., Reese J. (1985): Twelve-year experience with internal mammary artery for coronary artery bypass. $J$ Thorac Cardiovasc Surg: 90, nr. 5: pp. 668-675. 
Bameveld P.C., Jambroes G., Tweel van der I., Hitchcock J.F. (1985): Resultaten van coronaire-bypassoperaties bij vrouwen. Ned Tijdschr Geneeskd; $129 \mathrm{nr}$. 43 :pp. 2063-2067.

Barsky A.J., Hochstrasser B., Coles N.A., Zisfein J., O’Donnell C., Eagle K.A. (1990): Myocardial Ischemia; Is the Person or the Event Silent? Special Communications. JAMA; 264, (9): pp. 1132-1135.

Barth J.D. (1986): Progression and Regression of Coronary Atherosclerosis. Role of diet, lipoproteins and lipases. Dissertatie. Universiteit van Amsterdam.

Becker A.E. (1988): Atherosclerose - een dynamisch-morfologische beschouwing. In: Van der Werf T., Arntzenius A.C.: Atherosclerose en coronaire insufficiëntie. Bunge/ICIN.

Bell S.E. (1986): A new model of medical technology development. A case study of Des. Sociology of Health Care, 4.

Berreklouw E., Hoogsteen J., Wandelen van R., Verkroost M., Schonberger J., Bavinck H., Michels R., Bonnier H., El Gamal M., Wijnen J., Netelbeek, Haan G., Vos J., Lubsen K. (1989): Bilateral mammary artery surgery or PTCA for multivessel coronary artery disease? A cost-benefit analysis. (niet gepubliceerd).

Berreklouw S. (1988/1): (Letters to the editor) Vergelijking tussen PTCA en bypass-operaties met Aa. mammariae. Ned Tijdschr Geneeskd; 132, nr. 25 :p. 1167.

Berreklouw S. (1988/2): Beta-receptorblokkerende middelen en hartinfarct (Referat). Ned Tijdschr Geneeskd; 132 :pp. 971-972.

Berreklouw S. (1992): Is er verband tussen plaats van infarct en vernauwing? Ned Tijdsch Geneeskd; 136, nr. 26.

Bijl R. (1991): Constructie van toekomstscenario's. Beleidsgericht scenarioonderzoek, toegepast op het gebied van de geestelijke volksgezondheid en de geestelijke gezondheidszorg. NcGv-reeks 91-19. Dissertatie. Utrecht.

Birch S., Donaldson C. (1987): Applications of cost-benefit analysis to health Care: departures from welfare economic theory. $J$ Health Ec; 6 :pp 211-25. 
Birch S., Gafni A. (1992): Cost effectiveness/utility analyses. Do current deaision rules lead us to where we want to be? $J$ Health Ec; 11.

Black A.J.R., Roubin G.S., Sutor C., Moe N., Jarboe J.M., Douglas J.S., King II S.B. (1988): Comparative costs of percutaneous transluminal coronary angioplas. ty and coronary artery bypass grafting in multivessel coronary artery disease. Am J Cardiol; 62 :pp. 809-811.

Bleeker J.K., Lamers L.M., Raat H. (1990): Voordracht t.b.v. Gezondheidszorg. onderzoeksdag; Hulpzoekgedrag bij een acuut hartinfarct. Middenkatern T So GezondheidszG; nr. 11 :pp. 7-8.

Bonsel G.J., Bot M.L., Boterblom A., Van 't Veer F. (1988): De kosten en effecten van Harttransplantatie. Deelrapport 2C: Resultaten. Instituut voor Maal. schappelijke Gezondheidszorg, Erasmusuniversiteit. Rotterdam.

Boorsma P.B. (1986): Value for money auditing: hoe en waarom? In: Nivra geschriften (1986): Waar voor je geld? (Value for money auditing). Kluwer, No. 40. Deventer.

Boot J.M., Knapen M.H.J.M. (1988): De Nederlandse gezondheidszorg. Aula. Het Spectrum BV.. Utrecht.

Boshuizen H.C., Perenboom R.J.M., Van de Water H.P.A. (1992): Trends in Gezonde Levensverwachting in Nederland 1981-1990. Deel I: Resultaten. TNO. NIPG, no. 92.098 .

Califf R.M., Harrell F.R., Lee K.L., Rankin J.S., Hlatky M.A., Mark D.B., Jones R.H., Muhlbaier L.H., Oldham H.N., Pryor D.B. (1989): The evolution of medcal and surgical therapy for coronary artery disease. JAMA; 261, nr. 14 :pp. 2077-2085.

Calman K.C. (1984): Quality of life in cancer patients - an hypothesis. J of Medical Ethics; 10.

Campeau L.M.D. (Letters to the editor) (1975): Grading of Angina Pectoris. Circulation; 60, (suppl I): pp. 1-5.

CBS (Centraal Bureau voor de Statistiek) (1988): Overleden naar doodsoorzaak. leeftijd en geslacht. Sdu. CBS-publikaties, Serie A1. Voorburg. 
CBS (Centraal Bureau voor de Statistiek) (1989): Bevolkingsprognose voor Nederland, 1988-2050. Sdu. CBS-publikaties. Den Haag.

CBS (Centraal Bureau voor de Statistiek) (1991): Statistisch jaarboek 1991. Sdu. CBS-publikaties. Den Haag.

CBS (Centraal Bureau voor de Statistiek) (1992): Bevolkingsprognose voor Nederland, 1991-2050. Supplement bij bevolkingsprognose voor Nederland 19882050. Sdu. CBS-publikaties. Den Haag.

CBS (Centraal Bureau voor de Statistiek) (1992/1): Statistisch jaarboek 1992. Sdu. CBS-publikaties. Den Haag.

CBS (Centraal Bureau voor de Statistiek) (1993): Statistisch jaarboek 1993. Sdu. CBS-publikaties. Den Haag.

CBSH (Centraal Bureau Speciale Honorering) (1987): Ziekenfondstarieven per 1-1-1988. Uit: Honorering van specialistische hulp door ziekenfondsen. $C B S H$ klapper, December, D-23.

CCA (Commissie Coronair Angiografie) (1989): Commissie Coronair Angiografie-enquete 1988. Nederlandse Vereniging voor Cardiologie. (niet gepubliceerd).

CCA (Commissie Coronair Angiografie) (1990): Commissie Coronair Angiografie-enquête 1990. Nederlandse Vereniging voor Cardiologie. (niet gepubliceerd).

CCA (Commissie Coronair Angiografie) (1994): Commissie Coronair Angiografie-enquête 1991, 1992. Nederlandse Vereniging voor Cardiologie. (niet gepubliceerd).

Chaitman B.R. (1989): More on the Saga of Routine Emergency Coronary Angioplasty for Acute Myocardial Infarction. JACC; 13, nr. 6 :pp. 1260-1261.

Charro De F.Th., Ineveld van B.M. (1989): Hoofdstuk 14: De kosteneffectiviteitsanalyse. Uit: Medische Technology Assessment en gezondheidsbeleid. Habbema J.D.F., Casparie A.F., Mulder J.H. en Rutten F.F.H. (eds). Samson Stafleu. Alphen aan den Rijn.

Commissie Keuzen in de zorg (1991): Kiezen en delen. Advies in hoofdzaken van de commissie Keuzen in de zorg. Ministerie van Welzijn, Volksgezondheid en Cultuur, (8) 
Cook D.G., Shaper A.G. (Letters to the editor) (1989): Stopping smoking and risk of ischaemic heart disease. The Lancet; Apr. 895.

COTG (1987): Functiegerichte budgettering Algemene Ziekenhuizen. Centrad. Orgaan Tarieven Gezondheidszorg, December.

COTG (1988): Cardiologie: Tarieven voor declaraties aan particuliere patienten met ingang van 1 januari 1989. Centraal Orgaan Tarieven Gezondheidszorg, November.

COTG (1989): Algemene tarievenlijst voor nevenverrichtingen (ingangsdatum I januari 1990). Centraal Orgaan Tarieven Gezondheidszorg.

Crebolder H.F.J.M., Vrieze O.J., Fransen G., Kuipers J., Limonard Ch. (1990): Thuiszorg en patientenstromen. Coördinatie van classificatie- en registratiesystemen. $M C$; nr. 24.

Cribb A. (1985): Debate Quality of life in cancer patients - a response to Calman K.C. J. of Medical Ethics; 11.

Cutter G.R., Oberman A., Kouchoukos N., Rogers W. (1982): Epidemiologic study of candidates for coronary artery bypass surgery. Circulation; 66, (Suppl III) :pp. 6-15.

CvZ (College voor Ziekenhuisvoorzieningen) (1988): Advies inzake concepplanningsbesluit voor hartchirurgie. $C v Z$.

David G.K. (1988): Ontwikkeling in 10 jaar angioplastiek van kransvaten. Ned Tijdschr Geneesk; 132, nr. 11 :pp. 480-482.

Dawber T.R., Thomas H.E., Doyle (1980): The epidemiology of artherosclerosic disease. Harvard University Press. Cambridge. Massachusetts.

DCC (Diagnostisch Centrum) (1990): Kostprijzen diagnostisch onderzoek (documentatie). Diagnostisch centrum Academisch Ziekenhuis Maastricht (AZM). November. (niet gepubliceerd)

De Feyter P.J., Serruys P.W., Soward A., Brand van den M., Bos E., Hugenhull P.G. (1986): Coronary angioplasty for early postinfarction unstable angina. Circulation; 74, nr. 6 :pp. 1365-1370. 
De Feyter P.J., Suryapranata H. (1991): Acute coronary artery disease: Current state of interventional cardiology in acute coronary artery disease. Neth $J$ Cardiol; Vol 4 :pp. 9-22.

De Groot R.P., Zuiderveld U. (1988): Huisartsen over hypertensie. $M C$; 43, nr. 48 :pp. 1501-1503.

De Haan J. (1989): De rol van de assistente bij preventie in de huisartsenpraklijk. Medifo; nr. 3 :pp. 11-13.

De Mol B.A.J.M. (1985): Kostenontwikkeling open-hartchirurgie in relatie tot nieuwe technieken en wachtlijsten. $M C ; 40$, nr. 14 :pp. 422-424.

De Vries H. (1989): Smoking Prevention in Dutch adolescents. Datawyse. Dissertatie. Maastricht.

De Vries J.H.M., Katan M.B. (1991): De kosten van het dieet bij hypercholesterolemie. Ned Tijdschr Geneeskd; 135, nr. 6 :pp. 215-218.

DGD (Districts Gezondheids Dienst) (1990): Aantal spoedritten per ambulance voor de afdeling cardiologie in 1989; indeling naar tijdsduur. Zuidelijk Zuid Limburg Afdeling Ambulancevervoer. DGD.

Drummond M.F. (1980): Principles of economic appraisal in health care. Oxford University Press.

Drummond M.F., Stoddart G.L., Torrance G.W. (1987): Methods for the Economic Evaluation of Health Care Programmes. Oxford University Press.

Drummond M.F. (1987/1): Resource allocation decisions in health care: a role for quality of life assessment? J Chron Dis; no. 6.

Drummond M.F. (1990): Allocating Resources. Int $J$ of Techn Ass in Health Care; 6.

Drummond M.F. Output Measurement for Resource-Allocation Decisions in Health Care. In: McGuire A., Fenn P., Mayhew K. (1991): Providing Health Care. The Economics of Alternative Systems of Finance and Delivery. Oxford University Press. 
Duchateau A.M.J.A., Jansen P.A.F., Jong de P.E., Leeuw de P.W., Man in 't Veld A.J. (1990): Medicamenteuze behandeling. Hart Bulletin; 21, nr. 5: pp. 181-187.

Dugdale, A.E. (1987): Serum Cholesterol and Mortality Rates. The Lancet.

Dunning A.H. Prioriteitsstelling in gezondheidsonderzoek. Verkenningen verkend. In: Stuurgroep Toekomstscenario's Gezondheidszorg (1993): STG-Bulletin, no. 36 .

Erdman R.A.M., Hugenholtz P.G., Van Knippenberg F.C.E., Laird-Meeter K. (1990): Quality of life assessment in congestive heart failure. A psychologist's and cardiologist's point of view. Neth J Cardiol; 3.

Erkelens D.W. (1987): Cholesterol-consensus in Nederland. Ned Tijdschr Geneeskd; 131, nr. 36 :pp. 1564-1569.

Erkelens, D.W. (1988): (40ste KNMG-Ledencongres) Cholesterol: Strategie voor allen, velen of enkelen. $M C ; 41$ :pp. 1251-1252.

Evers S.M.A.A., Ament A.J.H.A., Van den Boom G., Warndorff D.K. (1992): Costs of schizophrenia in the Netherlands. Rijksuniversiteit Limburg, Vakgroep Economie van de Gezondheidszorg, Rijksuniversiteit Limburg. Maastricht, R. 92.01 .

Evers S. (1993): Kostenonderzoek binnen experimenteel gezondheidszorgonderzoek. Meta-analyse naar de methode van kostenmeting in gerandomiseerde en gecontroleerde economische evaluatiestudies; een eerste pilot. Rijksuniversiteit Limburg, Vakgroep Economie van de Gezondheidszorg, Rijksuniversiteit Limburg. Maastricht. (niet gepubliceerd).

Farmacotherapeutisch kompas (1989): Centrale Medisch Pharmaceutische Commissie van de Ziekenfondsraad. Medisch Farmaceutische Voorlichting. Farmacotherapeutisch kompas.

Finci L., Segesser von L., Meier B., Bruyne De B., Anastassiou I., Steffenino G.D., Velebit V., Righetti A., Moret P., Faidutti B., Rutishauer W. (1987): Comparison of multivessel coronary angioplasty with surgical revascularization with both internal mammary arteries. Circulation; 76, (Suppl V) :pp. 1-5. 
FOZ (Financieel Overzicht Zorg) (1990): Tweede Kamer der Staten-Generaal. Sdu. Den Haag.

FOZ (Financieel Overzicht Zorg) (1992): Tweede Kamer, vergaderjaar 19911992, 22 311, nrs. 1-2. Sdu. Den Haag.

Fracheboud J. (1987): Hartinfarct; Hartbewaking of thuisblijven? NIVEL.

Franciosa J.A. (1986): Epidemiologic Patterns, Clinical Evaluation, and LongTern Prognosis in Chronic Congestive Heart Failure. Am J Med; (suppl. 2B), 80.

Fries J.F (1980): Aging, Natural Death, and the Compression of Morbidity. $N$ Engl J Med.

Fries J.F (1988): Aging, Illness, and health policy: implications of the compression of morbidity. Perspectives in Biology and Medicine; 31, 3.

Gafni A., Birch S. (1993): Guidelines for the adoption of new technologies: a prescription for uncontrolled growth in expenditures and how to avoid the problem. Can Med Assoc J; 148, (6) :pp. 913-917.

Garber A.M. (1989/1): Annual Meeting Program and Abstracts. Competing risks and the cost-effectiveness of health interventions. Med Decis Making; no. 4.

Gardner T.J., Stuart R.S., Greene P.S., Baumgartner W.A. (1989): The risk of coronary bypass surgery for patients with postinfarction angina. Circulation; 79, (Suppl I) :pp. 79-80.

Gerard K., Mooney G. (1993): QALY league tables: handle with care. Health Econ; vol.2.

Gersh B.J., Califf R.M., Loop F.D., Akins C.W., Pryor D.B., Takaro T.C. (1989): Coronary bypass surgery in chronic stable angina. Circulation; 79 , (Suppl I) : pp. 46-59.

Gezondheidsraad (1983/2): Advies inzake hypertensie, uitgebracht door een commissie van de Gezondheidsraad. Rapportnummer 1983/2. Den Haag.

Gezondheidsraad (1984/16): Advies inzake epidemiologie en preventie van ischaemische hartziekten. Rapportnummer 1984/16. Den Haag. 
Gezondheidsraad (1984/18): Advies inzake hartchirurgie, bevattende een raming van de behoefte aan hartchirurgische ingrepen in Nederland omstreeks 1990. Rapportnummer 1984/18. Den Haag.

Gezondheidsraad (1986/29): Advies inzake grenzen van de gezondheidszorg. Rapportnummer 1986/29. Den Haag.

Gezondheidsraad (1990): Advies inzake Cholesterol. Rapportnummer 1990/l. Den Haag.

Gezondheidsraad (1992): Ontwikkelingen in cardiovasculaire technologie. De moderne hulpmiddelen van cardioloog en chirurg. Rapportnummer 1992/3. Den Haag.

Goldman L. (1981): Comparative Reproducibility and Validity of Systems for Assessing Cardiovascular Functional Class: Advantages of a New Specific Activity Scale. Circulation; 64 :pp. 1227-1234.

Goldnan L., Francis Cook E. (1984): The Decline in Ischemic Heart Disease Mortality Rates. An Analysis of the Comparative Effects of Medical Interventions and Changes in Lifestyle. Ann. of Int Med; 101.

Goldman L., Sia S.T.B., Cook E.F., Rutherford J.D., Weinstein M.C. (1988): Costs and effectiveness of routine therapy with long-term beta-adrenergic antagonists after acute myocardial infarction. $N$ Engl J Med; 319, nr. 3 :pp. 152-157.

Gore J.M., Dalen J.E. (1989): Cardiovascular disease. JAMA; 261, nr. 19 :pp. 2829-2831.

Gosselink K.J.M. (1989): Hartrevalidatie een kostenstudie. Rijksuniversiteit Limburg. Maastricht.

Grenzen van de Zorg (1987): Tweede Kamer, vergaderjaar 1987-1988. WVC, no. 20620 , nrs. 1-2.

Grimm R.H., Hunninghake D.B. (1986): Lipids and Hypertension. Implications of New Guidelines for Cholesterol Management in the Treatment of Hypertension. Am J Med; (suppl. 2A), 80. 
Grondin C.M., Campeau L., Thornton J.C., Engle J.C., Cross F.S., Schreiber H. (1989): Coronary artery bypass grafting with saphenous vein. Circulation; 79, (Suppl I) :pp. 24-29.

Groot T.L.C.M., Van de Poel J.H.R. (1993): Financieel Management van Nonprofit Organisaties. Wolters-Noordhoff. Groningen.

Grobbee D.E., Hofman A. (1989): Epidemiologie van ziekten in Nederland. Wetenschappelijke uitgeverij Bunge. Utrecht.

Gunning-Schepers L.J. (1989): The Health Benefits of Prevention: a Simulation Approach. Health Policy. Elsevier Science Publishers BV; vol. 12, no. 1-2. Amsterdam.

Hagen H. (1985): Inleiding in de Gezondheidseconomie. De Tijdstroom. Lochem/Gent.

Harris J. (1987): QALYfying the value of life. J of Medical Ethics; 13.

Hart Bulletin (1988): Editorial. De Grote Drie. Hart Bulletin ; Vol. 19.

Hartunian N.S., Smart C.N., Thompson M.S. (1981): The incidence and economic costs of major health impairments. A comparative analysis of cancer, motor vehicel injuries, coronary heart disease and stroke. Lexington Mass (Toronto). Lexington Books.

Hartz A.J., Kuhn E.M., Pryor D.B., Krakauer H., Young M., Heudebert G., Rimm A.A. (1992): Mortality after Coronary Angioplasty and Coronary Artery Bypass Surgery (The National Medicare Experience). Am J Cardiol; 70 :pp. 179 . 185.

Hasman A., Van Merode G.G. (1990): Management informatiesystemen in instellingen. In: Maarse J.A.M., Mur-Veeman I.M.: Beleid en Beheer in de Gezondheidszorg. Van Gorcum. Assen/Maastricht.

Heald D. (1983): Public Expenditure. Its Defence and Reform. Martin Robertson \& Company Ltd.

Henderson J., Mooney G. (1984): Economic Principles of Applied Option Appraisal. Heru Series of Option Appraisal. Soap no. 1. Departments of Community Medicine and Political Economy. University of Aberdeen. 
Henderson R.A., Bucknall C.A., Timmis A.D., Karani S., Dritsas A., Sowton E. (1989): Clinical outcome of coronary angioplasty for single-vessel disease. The Lancet, September :pp. 546-550.

Hofman A., Valkenburg H.A. (1980): Een epidemiologisch onderzoek naar risicofactoren voor hart- en vaatziekten (EPOZ). II Voorkomen, opsporing en behandeling van hypertensie in een open bevolking. Ned Tijdschr Geneeskd; 124: pp. 189-195.

Holmes D.R., Reeder G.S., Vlietstra R.E. (1988): Role of percutaneous transluminal coronary angioplasty in multivessel disease. Am J Cardiol; 61: pp. 9G-14G.

Holt G.W., Gersch B.J., Holmes D.R., Vlietstra R.E., Bresnahan J.F., Reeder G.S., Smith H.C. (1988): Results of percutaneous transluminal coronary angioplasty for angine pectoris early after acute myocardial infarction. Am J Cardiol; 61: pp. 1238-1242.

Hoogendoorn D. (1987): De landelijke sterfte en de kosten van de gezondheidszorg. Ned Tijdsch Geneeskd, 131, nr. 3.

Hoogendoorn D. (1990): Daalt behalve sterfte ook de frequentie van het acute hartinfarct? Ned Tijdsch Geneeskd; 134, nr. 39 :pp. 1896-1900.

Hoogeveen R.T., Brouwer J.J.L.M. (1989): Scenario's in de Volksgezondheid. Inleiding in de methodiek van de STG. Jan van Arkel. Utrecht.

Hoogenveen R.T., Jager J.C. (1990): Overlevingsduuranalyse en concurrerende doodsoorzaken. Een inleiding. RIVM, rapportnummer 958606001.

Hulshof J.A.M. Nederland loopt voorop met studie over geneesmiddelen. In: Innovator. Nefarma (1993) jaargang 1, no. 1.

Hypertensie-consensusbijeenkomst in Nederland (1990): Oorspronkelijke stukken. Ned Tijdschr Geneeskd; 134, nr. 43 :pp. 2086-2093.

Janssen C.C.M., Ament A.J.H.A. (1991): Overgewicht... een zware last. Gezondheidszorgkosten in Nederland ten gevolge van overgewicht. Vakgroep Economie van de Gezondheidszorg, Rijksuniversiteit Limburg. Maastricht, nr. 91.4. 
Janssen R. (1989): Effecten van tijdprijzen op medische consumptie en gezundheid. Dissertatie. Rijksuniversiteit Limburg. Maastricht.

Janssen R.T.J.M. (1992): Cost containment in the Netherlands, success and failure. Vakgroep Economie van de Gezondheidszorg, Rijksuniversiteit Limburg. Maastricht, Paper prepared for WHO.

Johannesson M. (1992): On the Discounting of Gained Life-Years in CostEffectiveness Analysis. Int $J$ of Techn Ass in Health Care; 8:2: pp 359-354.

Jongkind L. (1993): Verborgen vet is ook ongezond. Intermediair, 29, nr. 23.

Jonkers A.H., Sondermeijer B., Bonjer F.H. (1977): Het COPIH-project 19711974. IV Bloeddruk; anamnetische- en meetgegevens. T Soc Gezondheidsz; 55.

Jonkers A.H., Van der Lee A.P.M., Bonjer F.H. (1981): Het COPIH-project 1971-1978. I Vergelijking van de resultaten van het eerste en het tweede onderzoek. T Soc Gezondheidsz; 59.

Jonkers A.H., Van der Lee A.P.M., Bonjer F.H. (1982): Het COPIH-project 1971-1980. I De onderzoeksgegevens van uitvallers en terugkomers en de globale trends bij de 8.562 driemaal onderzochten. T Soc Gezondheidsz; 60.

Kaiser G.C., Schaff H.V., Killip T. (1989): Myocardial revascularization for unstable angina pectoris. Circulation; 79, (Suppl I): pp. 60-67.

Kamp O., Serruys P.W., Giessen van der W.J., Suryapranata H., Brand van den M.J.B.M., Feyter de P.J. (1989): Patient behandeld met stent in aorta-coronaire bypass-graft. Een alternatief voor reoperatie? Hart Bulletin; 20: pp. 172-176.

Kannel W.B. (1976): Some lessons in cardiovascular epidemiology. Am J Card; 37 .

Kannel W.B., Sorlie P., Mcnamara P.M. (1979): (Epidemiology) Prognosis After Initial Myocardial Infarction: The Framingham Study. Am J Cardiol; 44.

Kannel W.B., Dawber T.R., McGee D.L. (1980): Perspectives on systolic hypertension: The Framingham Study. Circulation; 61. 
Kannel W.B., Abbot R.D. (1984): Incidence and prognosis of unrecognized myocardial infarction. An update on the Framingham Study. $N$ Engl J Med; 311, 18.

Kannel W.B., Woolf P.A., Garrison R.J. (Eds.) (1987): The Framingham Study. An epidemiological investigation of cardiovascular disease. DHEW Pub No (NIH) 87-2284, Public Health Service. Bethesda, Maryland.

Kannel W.B. (1987/1): Congestive heart failure: Epidemiology and prevention of cardiac failure: Framingham Study insights. Eur Heart J; 8, (Suppl F): pp. 2339.

Katan M.B. (1985): Een consensus over cholesterol? Ned Tijdschr Geneeskd; 129, nr. 52: pp. 2490-2492.

Katan M.B. (1989): Hoog cholesterolgehalte bestrijden of Niet? Voedingsmagazi$n e$; Dec; jrg 2 (6): pp. 3-5.

Keeler E.B., Cretin S. (1983): Discounting of life-saving and other nonmonetary effects. Management Science; 29, nr. 3: pp. 300-306.

Kent K.M. (1987): Coronary angioplasty. A decade of experience. $N$ Engl J Med; 316, nr. 18: pp. 1148-1149.

Kent K.M. (1988): Restenosis After Percutaneous Transluminal Coronary Angioplasty. Am J Cardiol; 61: pp. 67G-70G.

Keys A. (1980): Seven Countries. A multivariate analysis of death and coronary heart disease. A Commonwealth Fund book. Harvard University Press. Cambridge, Massachusetts, London.

Killip T., Passamani E., Davis K. (1985): Coronary artery surgery study (CASS): a randomized trial of coronary bypass surgery. Eight years follow-up and survival in patients with reduced ejection fraction. Circulation; 72, (Suppl V): pp. 102-109.

Killip T. (1988): Twenty years of coronary bypass surgery. $N$ Engl J Med; 319. nr. 6: pp. 366-368.

King III S.B., Talley J.D. (1989): Coronary arteriography and percutaneous transluminal coronary angioplasty. Changing patterns of use and results. Circulation; 79, nr. 6, (Suppl I): pp. 19-23. 
Kinosian B.P., Eisenberg J.M. (1988): Cutting into cholesterol: Cost-effective alternatives for treating hypercholesterolemia. JAMA; April; 259, (15): pp. 22492254.

KISG (KLOS Informatiesysteem Gezondheidszorg) (1990): Particuliere tarieven; Classificaties en koderingen. Samenvatting prestaties. KISG, Oktober.

Klootwijk A.P.J., Simoons M.L. (1987): Medicamenteuze behandeling van angina pectoris. Geneesmiddelen Bulletin; 21, nr. 4: pp. 17-22.

Koopmans P.P., Stuyt P.M.J. (1987): De invloed van antihypertensiva op de serumlipiden. Ned Tijdschr Geneeskd; 131, nr. 36: pp. 1560-1563.

Koopmanschap M.A., Roijen van L., Bonneux L. (1991): Kosten van ziekten in Nederland. $M G Z$, nr. 91.03. (Herziene versie).

Kouchoukos N.T., Murphy S., Philpott T., Pelate C., Marshall W.G. (1989): Coronary artery bypass grafting for postinfarction angina pectoris. Circulation; 79, (Suppl I) :pp. 68-72.

Kremers M.S., Black W.H., Wells P.J. (1989): Sudden cardiac death: etiologies, pathogenesis, and management. Year Book Medical Publishers; 35, 6.

Kromhout D., Kampen-Donker van M., Obermann-de Boer G.L., Verschuren W.M.M. (1987): Peilstationsproject Hart- en vaatziekten 1987. RIVM, Rapportnummer 528901001.

Kruyswijk H.H., Muller E.J. (1984): Hartcatheterisatie voor een zachte prijs. $M C ;$ nr. 24 :pp. 753-755.

Kulbertus H.E., Wellens H.J.J. (1983): The First Year After a Myocardial Infarction. Futura Publishing Company Inc.

Laird Meeter K., Katen ten H.J., Domburg van R., Brand van den M.J.B.M., Serruys P.W., Penn O.C.K.M., Haalebos M.M.P., Bos E., Hugenholtz P.G. (1983): Tien jaar coronariachirurgie; resultaten bij 1041 patienten, geopereerd in het Thoraxcentrum te Rotterdam. Ned Tijdschr Geneeskd; 127, nr. 23: pp. 988994. 
Laird-Meeter K, Domburg van R., Brand van den M.J.B.M., Lubsen J., Bos E., Hugenholtz P.G. (1988/1): Frequentie en resultaten van heringrepen na kransvatoperaties. Ned Tijdschr Geneeskd; 132, nr. 51: pp. 2316-2320.

Laird-Meeter K. (1988/2): Stabiele angina pectoris; waarom is de prognose zo veranderd? Ned Tijdschr Geneeskd; 132, nr. 17: pp. 755-758.

Lalonde M. (1974): A new perspective on the health of Canadians. Government of Canada, Ottawa. In: Nota 2000 (1986): Over de ontwikkeling van gezondheidsbeleid: feiten, beschouwingen en beleidsvoornemens. Tweede Kamer. WVC, vergaderjaar 1985-1986.

Laupacis A., Feeny D., Detsky A.S., Tugwell P.X. (1993): Tentative guidelines for using clinical and economic evaluations revisited. Can Med Assoc J; 148, (6): pp. 927-929.

Leaf A. (1989): Sounding Board. Treating hypercholesterolemia. How should practicing physicians interpret the published data for patients? $N$ Eng $J$ Med; 321, (10): pp 676-684.

Lenders J.W.M. (1989): Hypertensie als risicofactor voor het hartinfarct. Medifo: pp. 16-17.

Levy R.I. (1986): Changing perspectives in the prevention of coronary artery disease. Am J Cardiol; 57,: pp. 17G-26G.

Levy D., Kannel W.B. (1988): Cardiovascular risks: New insights from Framingham. Am Heart J; Vol. 116, no.1.

Loop F.D., Lytle B.W., Gill C.C., Golding L.A.R., Cosgrove D.M., Taylor P.C. (1983): Trends in selection and results of coronary artery reoperations. Ann Thorac Surg; 36, nr. 4: pp. 380-388.

Loop F.D., Lytle B.W., Cosgrove D.M., Stewart R.W., Goormastic M., Williams G.W., Golding L.A.R., Gill C.C., Taylor P.C., Sheldon W.C., Proudfit W.L. (1986): Influence of the internal-Mammary Artery graft on 10-year survival and other cardiac events. $N$ Engl J Med; 314, nr. 1: pp. 1-6.

Lovastatin Study Group III (1988): A multicenter comparison of lovastatin and cholestyramine therapy for severe primary hypercholesterolemia. JAMA; 260: pp. 359-366. 
LRCP (Lipid Research Coronary Prevention Trial) (1984/1): The lipid research clinics coronary primary prevention trial results. I. Reduction in incidence of coronary heart disease. JAMA; 251, nr. 3: pp. 351-364.

LRCP (Lipid Research Coronary Prevention Trial) (1984/2): The lipid research clinics coronary primary prevention trial results. II. The relationship of reduction in incidence of coronary heart disease to cholesterol lowering. JAMA; 251, nr. 3: pp. 365-374.

Luce B.R., Elixhauser A. (1990): Estimating costs in the economic evaluation of medical technologies. Int $J$ of Techn Ass in Health Care; 6.

Ludbrook A., Mooney G. (1984): Economic Appraisal in the NHS: problems \& challenges. Northern Health Economics. Health Economics Research Unit. University of Aberdeen.

MacMahon S.W., Cutler J.A., Furberg C.D., Payne G.H. (1986): The effects of drug treatment for hypertension on morbidity and mortality from cardiovascular disease: a review of randomised controlled trials. Progress in CVD; (suppl.), 29, 1.

Mancia G. (1988): The need to manage risk factors of coronary heart disease. Am. Heart J. (Suppl), 115: In: Hart Bulletin (1988); vol. 19, editorial.

Mancini D.M., Le Jemtel T.H., Factor S., Sonneblick E.H. (1986): Central and Periheral Components of Cardiac Failure. Am J Med; (suppl. 2B), 80.

Manger Cats V. (Abstract) (1989): Epidemiologie, behandeling en prognose van stabiele angina pectoris. Bijlage bij De Medicus; 245.

Marder V.J., Sherry S. (1988/1): Thrombolytic therapy: Current status I. $N$ Engl JMed; 318, nr. 23 :pp. 1512-1520.

Marder V.J., Sherry S. (1988/2): Thrombolytic therapy: Current status II. $N$ Engl JMed; 318, nr. 24 :pp. 1585-1595.

Martens L.L., Rutten F.F.H., Erkelens D.W., Ascoop C.A.P.L. (1989): Costeffectiveness of cholesterol-lowering therapy in the Netherlands. Simvastatin versus cholstyramine. Am J Med; (suppl. 4A), 87. 
Martens L.L. (1992): The Cost-Effectiveness of Cholesterol-Lowering Therapy with Simvastatin in the Primary Prevention of Coronary Heart Disease in the Netherlands. Dissertatie. Erasmus Universiteit Rotterdam.

McCormick J.R., Schick E.C., McCabe C.H. et. al. (1985): Determinants of operative mortality and long-term survival in patients with unstable angina. $J$ Thorac Cardiovasc Serg; 89.

McCornick.J., Schrabanck P. (1988): Coronary Heart Disease is not preventable by population interventions. The Lancet.

Meijer, A.W.M. (1990): Instellingen en strategisch beleid. In: Maarse J.A.M., Mur-Veeman I.M.: Beleid en Beheer in de Gezondheidszorg. Van Gorcum, Assen/Maastricht.

Meijler F.L., Wellens H.J.J. (1987): Toekomstscenario's gezondheidszorg. Scenario's over hart- en vaatziekten 1985-2010. MC; mr. 3, 42.

Meijler F.L. (1993): Vijfentwintig jaar cardiologie (1968-1993): van sub- naar superspecialisme. MEDIATOR; jaargang 4, no. 5 :pp. 9-13.

Mensink R.P., Katan M.B. (1989): Effect of a diet enriched with mono-unsaturated or poly-unsaturated fatty acids on levels of low-density and high-density lipoprotein cholesterol in healthy women and men. $N$ Engl J Med; 321.

MFR (Stichting Medisch-Farmaceutische Research) (1992): Hart-Discriminatie II. Nieuwsbrief; 5e jaargang, no. 1.

Mooney G.H., Russell E.M., Weir R.D. (1980): Choices for Health Care. MacMillan Press Ltd.

Mooney G., Olsen J.A. (1991): QALYs: Where Next? In: McGuire A., Fenn P., Mayheur K.: Providing health care. The economics of Alternative Systems of Finance and Delivery. Oxford University Press.

Mooney G. (1992): Economics, Medicine and Health Care. Harvester Wheatsheaf. 
Mudde A.N. (1989): Stoppen met roken. Een patiëntgerichte benadering. $M C$; 44, nr. 44 :pp. 1456-1458.

Mulder J.H. (1989): Hoofdstuk 17: Doelstellingen van medische technology assessment. Ut: Medische Technology Assessment en gezondheidsbeleid. Habbema J.D.F., Casparie A.F., Mulder J.H., Rutten F.F.H. (eds) Samsom Stafleu, Alphen aan den Rijn.

Neuhauser D., Lewicki A.M. (1975): What do we gain from the sixth stool guaiac? In: Mooney G.H., Russell E.M., Weir R.D. (1980): Choices for Health Care, MacMillan Press Ltd.

Nivra geschriften (1986): Waar voor je geld? (Value for money auditing). Kluwer, Deventer; No. 40.

Nota 2000 (1986): Over de ontwikkeling van gezondheidsbeleid: feiten, beschouwingen en beleidsvoornemens. Tweede Kamer. WVC; vergaderjaar 1985-1986, (sa).

NZi (Nationaal Ziekenhuisinstituut) (1987): Financiële statistiek 1987: Algemene ziekenhuizen, landelijke tabellen. Nationaal Ziekenhuisinstituut; 88 :p. 596.

NZi (Nationaal Ziekenhuisinstituut) (1988): Financiële statistiek 1988: Algemene ziekenhuizen, landelijke tabellen. Nationaal Ziekenhuisinstituut, 89 :p. 651.

Olsen J.A. (1993): On what basis should health be discounted? Elsevier Science Publishers BV.

Ornish d., Brown S.E., Scherwitz L.W., Billings J.H., Armstrong W.T., Ports T.A., McLanahan S.M., Kirkeeide R.L., Brand R.J., Gould K.L. (1990): Can lifestyle changes reverse coronary heart disease?. The Lifestyle Heart Trial. The Lancet; vol. 336 :pp. 129-133.

Oster G., Epstein A.M. (1986): Primary prevention and coronary heart disease: the economic benefits of lowering serumcholesterol. Am J Public Health; 76.

Otten F., Reek van J., Appels A., Mulder P., Sturmans F. (1988): De KRIS follow-up Studie. III De effecten van roken op totale mortaliteit, hartinfarct, en kanker van de luchtwegen. T Soc Gezondheidsz; 66 :pp. 154-156. 
Packer M. (1985): Sudden unexpected death in patients with congestive hear failure: a second frontier. Circulation; 72, nr. 4: pp. 681-685.

Peduzzi P., Hultgren H.N. (1979): Effects of Medical vs Surgical Treatment on Symptoms in Stable Angina Pectoris. The Veterans Administration Cooperative Study of Surgery for Coronary Arterial Occlusive Disease. Circulation; 60, 4.

Petticrew M., McKee M., Jones J. (1993): Coronary artey surgery: are women discriminated against? BMJ; volume 306: pp. 1164-1166.

Postma Th.J.B.M. (1987): Een Delphi-onderzoek op het gebied van de oncologie. T Soc Gezondheidsz; 65: pp. 122-124.

Puska P., Tuomilehto J., Nissinen A., Salonen J. (1985): Ten years of the North Karelia Project. Acta Med Scand Suppl; 701: pp. 66-71.

Rahimtoola S.H. (1982): Coronary bypass surgery for chronic angina - 1981. A perspective. Circulation; 65, nr. 2: pp. 225-241.

Regress. In: Arntzemius A.C. (1990/2): Regressie van Atherosclerose. Het reversibel zijn van de afwijkingen. Hart Bulletin; vol. 21.

Relyveld J. (1989): Screenen op hypertensie in Den Haag. Resultaten van het PreTensie-project. Epidemiologisch bulletin, kwartaalschrift voor Basisgezondheidszorg en onderzoek. Den Haag.

Registratienet Huisartspraktijken (1989): Gezondheidsproblemen en diagnosen in de huisartspraktijk. Jaargang 1, no. 2., Vakgroep Huisartsgeneeskunde, Rijksuniversiteit Limburg, Maastricht.

Repka F.J., Leighton R.F. (1987): Step management of hypercholesterolemia. Am Fam Physician; 36, 4.

Revalidatie Commissie van de Nederlandse Hartstichting (1990): Hartrevalidatie op maat nieuwe visies. Nederlandse Hartstichting.

RIVM (Rijksinstituut voor Volksgezondheid en Milieuhygiëne) (1993a): Volksgezondheid Toekomst Verkenning. De gezondheidstoestand van de Nederlandse bevolking in de periode 1950-2010. Sdu. Den Haag. 
RIVM (Rijksinstituut voor Volksgezondheid en Milieuhygiëne) (1993b): TARGETS. Sustaining Health towards an integrated global health model. Globo Report Series no. 1, RIVM.

Rogers W.J., Smith L.R., Oberman A., Kouchoukos N.T., Mantle J.A., Russell R.O., Rackley C.E. (1980): Surgical vs nonsurgical management of patients after myocardial infarction. Circulation; 62 (Suppl I) :pp. 67-74.

Rose G., Hamilton P.J.S. (1978): A randomised contolled trial of the effect on middle-agged men of advice to stop smoking. J. Epidemiol Community Health.

Rose G. (1981): Strategy of prevention: lessons from cardiovascular disease. $B r$. Med. J; 281 :pp. 1847-1851.

Rose G., Hamilton P.J.S., Colwell L., Shipley M.J. (1982): A randomised controlled trial of anti-smoking advice: 10 year results. $J$ Epidemiol Comm Health; 36.

Rosenberg L., Kaufman D.W., Helmrich S.P., Shapiro S. (1985/1): The risk of myocardial infarction after quitting smoking in men under 55 years of age. $N$ Engl J Med; 313: pp. 1511-1514.

Rosenberg L., Kaufman D.W., Helmrich S.P., Miller D.R. Stolley P.D., Shapiro S. (1985/2): Myocardial infarction and cigarette smoking in women younger than 50 years of age. JAMA; 253 :pp. 2965-2969.

Rosenberg L., Palmer J.R., Shapiro S. (1990): Decline in the risk of myocardial infarction among women who stop smoking. $N$ Engl J Med; 322, 4.

Roubenoff R.A., Roubenoff R. (letters to the editor) (1986): Lowering plasma cholesterol by diet. $N$ Engl J Med; 315, 586.

Rusnak M. (1992): Mortality and morbidity models - a review. In: Morgenstern, Chigan W.E., Prokhorskas R., Rusnak M., Schettler G.: Models of Non-communicable Diseases. Health Status and Health Service Requirements. WHO.

Russell L.B. (1985): Is Prevention better than Cure? Studies in Social Economics. The Brookings Institution, Washington D.C. 20036.

Rutten F.F.H. (1988): Medische Technology Assessment: Een uitdaging voor wetenschap en beleid. Oratie, Erasmus Universiteit Rotterdam. 
Rutten M., Vondeling H. (1992): Economische evaluatie in het kader van ontwikkelingsgeneeskunde. Een algemene inleiding voor artsen. Vakgroep Economie van de Gezondheidszorg, Rijksuniversiteit Limburg. Maastricht, nr. 92.02.

Schaapveld K., Bergsma E.W., Ginneken van J.K.S., Water van de H.P.A. (1990): Setting priorities in prevention. TNO Health Research, December.

Schatzkin A., Cupples L.A., Heeren T., Morelock S., Kannel, W.B. (1984): Sudden death in the Framingham Heart Study. Differences in incidence and risk factors by sex and coronary disease status. Am J Epidemiol; 120, 6.

Schoonenboom I.J. Maatschappelijke verkenningen en onderzoeksprioritering. Verkenningen verkend. In: Stuurgroep Toekomstscenario's Gezondheidszorg (1993): STG-Bulletin; no. 36.

Schreuder R.F. (1987): Scenario's op het terrein van de volksgezondheid. $M C$; $42, \mathrm{nr} .3$.

Schuurman F.H., Van der Veur E., Ten Berge B.S., May J.F., Havinga Tj.K., Wesseling H. (1987): Waar hypertensie de dienst uitmaakt: de hypertensiedienst Groningen. Mod Med.

Selzer A., Cohn K. (1972): Functional classification of cardiac disease: a critique. Am J Cardiol; 30 :pp. 306-308.

SIG (Stichting Informatiecentrum Gezondheidszorg) (1992): Documentatie met betrekking tot 1988. SIG-Zorginformatie. Stichting Informatiecentrum Gezondheidszorg.

SIG (Stichting Informatiecentrum Gezondheidszorg) (1994): Documentatie met betrekking tot 1990-1992. SIG-Zorginformatie. Stichting Informatiecentrum Gezondheidszorg.

Spangenberg J.F.A. (1988): Naar een economische evaluatie van intensive care units in Nederland. Haalbaarheidsstudie i.o.v. het Ministerie van WVC. D. Reis Miranda, J.H.R. van de Poel (red.). LIBER, Rapport LIB/R/88/004.

Stalenhoef A.F.H. (1989): Hypercholesterolemie als risicofactor. Medifo: pp. 2225. 
Stam van A., Robles de Medina E.O. (1986): Validiteitsclassificatie in de cardiologie. Ned Tijdschr Geneeskd; nr. 37.

STG (Stuurgroep Toekomstscenario's Gezondheidszorg) (1986): Het hart van de toekomst; de toekomst van het hart. Scenarios over hart- en vaatziekten 19852010; Stuurgroep Toekomstscenario's Gezondheidszorg Utrecht/Antwerpen. Bohn, Scheltema \& Holtema, 1 en 2.

STG (Stuurgroep Toekomstscenario's Gezondheidszorg) (1987): Structuur en opdracht. Stuurgroep Toekomstscenario's Gezondheidszorg. Rijswijk, nr. 5. (sa)

STG (Stuurgroep Toekomstscenario's Gezondheidszorg) (1989): $3^{\mathrm{e}}$ signaleringsrapport Hart- en Vaatziekten STG. Overzicht hart- en vaatziekten met bijbehorende ICD-codes $\left(9^{\circ}\right.$ revisie) volgens de 154-nummerlijst van het CBS. Stuurgroep Toekomstscenario's Gezondheidszorg.

STG (Stuurgroep Toekomstscenario's Gezondheidszorg) (1990/1): Kanker. STGSignaleringsrapport 2.

STG (Stuurgroep Toekomstscenario's Gezondheidszorg) (1990/2): Leefomstandigheden, leefwijzen en gezondheid. Een aanzet voor scenario's. Es van J.C., Kramers C.W., De Weert-van Oene G.W., Schreuder R.F., Te Velde R.A. (red.). Stuurgroep Toekomstscenario's Gezondheidszorg. Rijswijk, Februari.

STG (Stuurgroep Toekomstscenario's Gezondheidszorg) (1992): Kanker. STGSignaleringsrapport 3.

STG (Stuurgroep Toekomstscenario's Gezondheidszorg) (1993): Werkprogramma 1993-1994. Stuurgroep Toekomstscenario's Gezondheidszorg.

Stichting Volksgezondheid en Roken (1985): Roken Welbeschouwd. Stichting Volksgezondheid en Roken.

Sturmans F., Burema L., Valkenburg H.A. et. al. (1977): De Kaunas-Rotterdam Intervention Study (KRIS). IV De frequentieverdeling van enkele fysiologische risicofactoren bij de eerste screening. T Soc Gezondheidsz; 55.

Sturmans F. (1986): Epidemiologie. Theorie, methoden en toepassing. Dekker \& Van de Vegt, 3de druk. Nijmegen. 
Sturmans F.: De ontwikkeling van het gezondheidszorgonderzoek in Nederland. In: Van der Maas P.J., Hofman A., Dekker E. (1989): Epidemiologie en Gezondheidsbeleid. Samson Stafleu. Alphen aan den Rijn.

Taket A.R. (1992): Resource Allocation Models and Health Service Systems: an Exploration. In: Morgenstern, Chigan W.E., Prokhorskas R., Rusnak M., Schettler G.: Models of Non-communicable Diseases. Health Status and Health Service Requirements. WHO.

TAM (Technology Assessment Methodology): Bonneux L., Barendregt J.J.M. (1992): Towards a Comprehensive Health Policy Model. In: Morgenstern Chigan W.E., Prokhorskas R., Rusnak M., Schettler G.: Models of Non-communicable Diseases. Health Status and Health Service Requirements. WHO.

Torrance G.W. (1987): Utility Approach to Measuring Health. Related Quality of life. J Chronic Dis; 40, 6 :pp. 593-600.

Tijssen J.G.P. (1989): (Abstract) De epidemiologie van instabiele angina pectoris. Bijlage bij De Medicus; (245): 2.

Tsevat J. (1992): Impact and Cost-Effectiveness of Smoking Interventions. Am J of Med; (suppl. 1A), vol. 93.

Tunstall-Pedoe H. (1989): Who is for cholesterol testing? Test selectively those who will benefit most. Br Med J; 298 :pp. 1593-1594.

Ulvenstam G., Aberg A., Bergstrand R. et. al. (1985): Recurrent myocardial infarction 1. Natural History of fatal and non-fatal events. Eur Heart J; 6.

Valkenburg H.A., Hofman A., Klein F., Grourstra F.N. (1980): Een epidemiologisch onderzoek naar risico-indicatoren voor hart- en vaatziekten (EPOZ). I Bloeddruk, serumcholesterolgehalte, Qoetelet-index en rookgewoonten in een open bevolking van 5 jaar en ouder. Ned Tijdschr Geneeskd; 124: pp. 183-189.

Van den Berg Jeths A., Poos M.J.J.C., Hulshof J.A.M., Jager J.C. (1993): Effecten van een veranderende bevolkingsopbouw op de capaciteit en kosten van zorgvoorzieningen. $T$ Soc Gezondheidsz; 2.

Van den Boom G., Ament A.J.H.A. (1992): Cost-of-illness studies. A theoretical and methodological review. Vakgroep Economie van de Gezondheidszorg, Rijksuniversiteit Limburg. Maastricht, R. 92.05. 
Van den Bos G.A.M. (1993): Chronische ziekten, gezonde levensverwachting en vraag naar gezondheidszorgvoorzieningen. $T$ Soc Gezondheidsz; 2.

Van der Feen J.A.E., Schalekamp M.A.D.H., Westerhof P.W. (1990/1): Diagnostisch onderzoek. Hart Bulletin; 21, nr. 5: pp. 169-170.

Van der Kuy A., Koster R.W. (1987): Geneesmiddelen bij angina pectoris. (Correspondentie). Ned Tijdschr Geneeskd, December.

Van der Maas P.J. (1982): Mythen over vergrijzing en volksgezondheid. Een beschouwing over drie eigentijdse mythen: de rampzalige vergrijzing van Nederland, de stuurbaarheid van de volksgezondheid en de schadelijkheid van de gezondheidszorg. T Soc Gezondheidsz; 60, mr. 23.

Van der Maas P.J., Hofman A., Dekker E. (1989): Epidemiologie en Gezondheidsbeleid. Reeks Gezondheidsbeleid. Deel 3. Samson Stafleu. Alphen aan den Rijn.

Van der Maas (1989/1): Lang Zullen We Leven? Over volksgezondheid, vergrijzing en vervuiling. Dies-rede. Erasmusuniversiteit. Rotterdam.

Van der Werf T. (1984): Percutane transluminale coronaria-angioplastiek. Ned Tijdschr Geneeskd; 128, nr. 40 :pp. 1904-1908.

Van der Werf T. (1988): Trombolyse en PTCA; verslag ACC-meeting; Atlanta, maart 1988. Hart Bulletin; 19: pp. 94-95.

Van Doorn J., Van Vught F. (1978): Forecasting; methoden en technieken voor toekomstonderzoek. Van Gorkum. Assen-Amsterdam.

Van Doorslaer E., Rutten F.F.H., Haan G. (1988): Economische Evaluatie van de Preventieve Gezondheidszorg; "Is een ons preventie een pond therapie waard?" In: Lapré R.M., Rutten F.F.H., Hagen J.H. (red.), De Economie van de Preventieve Gezondheidszorg. De Tijdstroom. Lochem.

Van Doorslaer E.K.A., Rutten F.F.H. (1990): Hoofdstuk 12. Medical Technology Assessment. In: Maarse J.A.M., Mur-Verman I.M. (1990): Beleid en Beheer in de Gezondheidszorg. Van Gorcum. Assen/Maastricht. 
Van Doorslaer E., Bouter L. (1990/1): Assessing the economic burden of injuries due to accidents: methodological problems illustrated with some examples from the literature. Health Policy; 14: pp 253-265.

Van Ginneken J.K.S., Bannenberg A.F.I., Dissvelt A.G. (1989): Gezondheidsverlies ten gevolge van een aantal belangrijke ziektecategorieën in 1981-1985. NIPG/TNO. CBS.

Van Genugten M.L.L., Hoogenveen R.T., Jager J.C. (1992): Een methodologische handleiding voor het uitvoeren van scenario-onderzoek. Rijksinstituut voor Volksgezondheid en Milieuhygiëne. Te verschijnen publicatie in opdracht van STG.

Van Haselen H.W.J. (1987): Produktieverlies als gevolg van verkeersongevallen. NEI. In opdracht van Dienst Verkeerskunde van Rijkswaterstaat. (niet gepubliceerd).

Van Hout B.A., Ideler M.A., Carro de F.Th. (1988): De kosten en effecten van Harttransplantatie. Deelrapport 6: De kosten en Harttransplantatie. Medische Faculteit en Juridische Faculteit, Erasmus Universiteit. Rotterdam, December.

Van Hout B.A. (1990): Heart Transplantation; Costs, effects and prognosis. Proefschrift. Erasmus Universiteit. Rotterdam, Februari.

Van Hout, B.A., Huijsman R., Van Ineveld B.M., Van Ommen R., Rutten F.F.H. (1992): Uniforme uitgangspunten voor kostenberekeningen bij scenario- en evaluatiestudies binnen de gezondheidszorg. Publicatie te verschijnen in opdracht van STG.

Van Ineveld B.M., Rutten F.F.H. (1990): De mogelijkheden tot een uniforme berekening van de kosten binnen scenariostudies over de gezondheidszorg. Discussie-paper in opdracht van STG. (niet gepubliceerd).

Van Leeuwen K., Fast J.H., Aengevaeren W.R.M., Pijls N.H.J., Graaf de R., Hansen M., Hendrick J., Verkerk G., Werf van der T. (1988): Resultaten op korte en lange termijn van percutane transluminale coronair angioplastiek. Hart Bulletin; 19 :pp. 75-81.

Van Ree J.W. (1981): Systematische opsporing en behandeling van risicofactoren in de huisartsenpraktijk uitvoerbaar. Hart Bulletin; 12 :pp. 69-76. 
Van Ree J.W., Gerwen van W., Hoogen van den H. (1985/1): Interventie bij een verhoogd risico op hart- en vaatziekten. I: Resultaten op langere termijn van interventie bij hypercholesterolemie, adipositas en roken. Huisarts en wetenschap; 28: pp. 21-24.

Van Ree J.W., Gerwen van W., Hoogen van den H. (1985/2): Interventie bij een verhoogd risico op hart- en vaatziekten. II. Resultaten op langere termijn bij de behandeling van hypertensie. Huisarts en Wetenschap; 28: pp. 53-58.

Van Ree J.W., Weel van C., Arts H. (1989): De samenhang tussen 'transient ischaemic attack' en cerebrovasculair accident. Ned Tijdschr Geneeskd; 133, nr. 21: pp. 1073-1076.

Van Reek J. (1983): Rookgedrag in Nederland van 1958-1982. T Alc Drugs; 9.

Van Reek J. (1984): Veranderingen in de Nederlandse consumptie van tabakswaren sinds de Tweede Wereldoorlog. T Alc Drugs; 10.

Van Zwieten P.A. (1988): Nieuwe ontwikkelingen bij de lipidenverlagende farmaca (hypolipemica): De HMG-CoA-reductaseremmers ('statines'). Hart Bulletin; 19: pp. 150-152.

Veenbergen J.G., Hagen J.H. (1988): Preventie en welvaartsontwikkeling. In: Lapré R.M., Rutten F.F.H., Hagen J.H. (red.): De Economie van de Preventieve Gezondheidszorg. De Tijdstroom. Lochem.

Veldkamp R.F., Baartman G.J., Van Domburg R., Tijssen J.G., Bos E., Meeter $\mathrm{K}$. (1991): Overleving 11 jaar na een aorto-coronaire bypass-operatie. Ned Tijdschr Geneeskd; 135, nr. 27 :pp. 1229-1233.

Verkooijen J.M., Breevoort E.L.M.G., Ament A.J.H.A. (1989): Kosten van harten vaatziekten voor het Nederlandse bedrijfsleven; Een onderzoek in opdracht van de Nederlandse Hartstichting. Nederlandse Hartstichting, Oktober. 
Vermeer F., Simoons M.L., Zwaan de C., Es van G.A., Verheugt F.W.A., Laarse van $\operatorname{der}$ A., Hoogen huyze van D.C.A., Azar A.J., Dalen van F.J., Lubsen J., Hugenholtz P.G. (1987): Chapter 8: Cost benefit analysis of early thrombolytic therapy with intracoronary streptokinase. 12 Month follow-up report of the randomised multicentre trial conducted by the Netherlands Interuniversity Cardiology Institute. In: Vermeer F. Thrombolysis in acute myocardial infarction. Proefschrift. Van Gorcum (1987). Assen/Maastricht.

Verschuren W.M.M., Blokstra A., Boerma G.J.M., Kromhout D. (1992): Veranderingen in het serum-cholesterolgehalte bij de Nederlandse bevolking in de periode 1974-1986. Ned Tijdsch Geneeskd; 136, nr. 12.

Voedingsraad (1984): Epidemiologisch onderzoek: Voeding en atherosclerose in Zutphen. Voedingsraad.

Von Neumann, Morgenstern (1953): The theory of games and economic behavior. Princeton Univ. Press,3rd ed..

Voss G.B.W.E. (1993): Severity of illness and costs of medical care in patients with acute myocardial infarction. Dissertatie. Rijksuniversiteit Limburg. Maastricht.

Vrieze O.J., Kuipers J., Boas G.M. (1991): Scenario Analyse van de Volksgezondheid en Competitieve Risico's. In: Van Leeuwen L.Th., Cruijsen: Sterfte en Gezondheid Nu en Straks. NVD. Den Haag.

Vrieze O.J., Boas G.M., Janssen J.H.A. (1994): Een Simulatie Model voor Toekomst Analyse van Coronaire Hartziekten. Te verschijnen publicatie in opdracht van STG.

Wagstaff A. (1986): The demand for health: theory and applications. $J$ of Epid and Comm Health; 40.

Wagstaff A. (1991): QALY's and the equity-efficiency trade-off. $J$ of Health Econ; 10.

Warndorff D.K., Van den Boom G., Ament A.J.H.A., Evers S.M.A.A. (1992): The costs of disorders associated with dyspepsia. Vakgroep Economie van de Gezondheidszorg, Rijksuniversiteit Limburg. Maastricht, R. 92.02. 
Warner K.E., Luce B.R. (1982): Cost-Benefit and Cost-Effectiveness Analysis in Health Care. Principles, Practice and Potential. Health Administration Press. Ann Arbor, Michigan.

Weinstein M.C., Stason W.B. (1982): Cost-effectiveness of coronary artery bypass surgery. Circulation; 66, (Suppl III) :pp. 56-66.

Weinstein M.C., Stason W.B. (1985): Cost-effectiveness of interventions to prevent or treat coronary heart disease. Ann Rev Public Health; 6 :pp. 41-63.

Weinstein M.C., Coxson P.G., Williams L.W.,Pass T.M., Stason W.B., Goldman L. (1987): Forecasting Coronary Heart Disease Incidence, Mortality and Cost: The Coronary Heart Disease Policy Model. AJPH; 77 :pp. 1417-1425.

White H.D., Rivers J.T., Maslowski A.H., e.a. (1989): Effect of intravenous streptokinase as compared with that of tissue plasminogen activator on left ventricular function after first myocardial infarction. $N$ Engl J Med; 320, nr. 13: pp. 817-821.

WHO Technical Report Series (1978): Arterial hypertension: Report of a WHO expert committee. WHO; no. 628, Geneva.

WHO (1981): Managerial Process for National Health Development. Guiding Principles. Health for All Series. WHO; no. 5. Geneva.

WHO (1981/1): Control of health care costs in social security systems. Report on workshop. Euro reports and studies 55. WHO. Copenhagen

Williams A. (1987): Response: QALYfying the value of life. $J$ of Medical Ethics; 13.

Winter J. (1988): Kosten van Hart- en Vaatziekten in Nederland. Vakgroep Economie van de Gezondheidszorg, Rijksuniversiteit Limburg. Maastricht. (niet gepubliceerd).

Winter, J. (1993): Het instrumentarium ten behoeve van kostenonderzoek binnen medical technology assessment; een overzicht in Tussenrapportage Kostenonderzoek binnen MTA. Vakgroep Economie van de Gezondheidszorg, Rijksuniversiteit Limburg. Maastricht. (niet gepubliceerd). 
WVC (Ministerie van Welzijn, Volksgezondheid, en Cultuur) (1991): Kiezen en delen. Advies in hoofdzaken van de commissie Keuzen in de zorg. WVC; (8).

Yancy C.W., Brian G. (1988): Congestive Heart Failure. DM; 34, nr. 8 :pp. 469477.

Yusuf S., Wittes J., Friedman L. (1988/1): Overview of results of randomized clinical trials in heart disease. I: Treatments following myocardial infarction. JAMA; 260, 14.

Yusuf S., Wittes J., Friedman L. (1988/2): Overview of results of randomized clinical trials in heart disease. II: Unstable angina, heart failure, primary prevention with aspirin, and risk factor modification. JAMA; 260, nr. 15 :pp. 2259 2263.

ZFR (Ziekenfondsraad) (1987): Honorering huisartsenhulp voor de jaren 1985 en 1986. Ziekenfondsraad, November.

ZFR (Ziekenfondsraad) (1989): Verandering verzekerd. Ziekenfondsraad. Amstelveen. 


\section{Samenvatting}

In Hoofdstuk 1 hebben wij de doelstelling van het proefschrift als volgt geformuleerd: "het beschrijven van de wijze waarop scenario-analyse gebruikt kan worden als een voor het beleid geschikt economisch analyse instrument, zodanig dat daarmee inzicht verkregen kan worden in de mogelijke toekomstige ontwikkeling van de kosten en gezondheidseffecten van coronaire hartziekten (CHZ) volgens verschillende toekomsttrajecten". Er is hiertoe een CHZ-model ontwikkeld waarmee de economische analyse van toekomstige patiëntenstromen uitgevoerd kan worden.

Een patiëntenstroom geeft de ziekteprocesgang weer van patiënten De patiëntenstromen in het model zijn deels afkomstig uit de gezonde bevolking, deels afkomstig uit een zieke bevolking. Met gezond wordt hier bedoeld "niet aan coronaire hartziekten lijdend". De zieke bevolking verwijst naar dat gedeelte van de bevolking dat ooit in het verleden een vorm van CHZ heeft gehad. We zijn hierbij in het model uitgegaan van de werkelijk aanwezige bevolking in 1988 in Nederland.

De personen in ieder van deze twee deelgroepen van de bevolking hebben hun eigen risicokenmerken ten aanzien van CHZ. Voor personen in de gezonde bevolking zijn deze kenmerken leeftijd, geslacht, rookgewoonte, serumcholesterolgehalte, en diastolische bloeddruk. In de zieke bevolking zijn deze determinerende factoren met name de ejectiefractie van het hart en een door ons geintroduceerd fictief begrip, namelijk: "de globale kwaliteit van het kransslagadersysteem". Het ziekteverloop en de verschillende CHZ-manifestatievormen worden in Hoofdstuk 2 besproken.

De individualisering van de persoonskenmerken in het model hebben we opgelost door iedere deelgroep te laten representeren door gemiddelde "standaardindividuen". De lotgevallen van de standaardpersonen worden via het model gesimuleerd en geaggregeerd tot landelijke cijfers. Anderzijds is het zo dat keuzen op beleidsniveau rechtstreeks aangrijpen op het niveau van de individuele patiënt. Een voorbeeld hiervan is de begrenzing van het toegestane aantal operaties. Er bestaat dus een verbinding tussen het patiëntniveau en het landelijk niveau die in het model in beide richtingen is uitgewerkt. In de Hoofdstukken 1 en 7 wordt dit aspect verder toegelicht.

De simulatie heeft betrekking op het feit dat ieder jaar alle relevante variabelen in het model aangepast worden aan de nieuwe situatie op basis van de huidige 
gezondheidszorgprogramma's en de situatie in het voorafgaande jaar. In het model is de mogelijkheid ingebouwd het optreden van CHZ-gebeurtenissen te beinvloeden door al dan niet additionele gezondheidszorgprogramma's. De additio. nele gezondheidszorgprogramma's kunnen worden geïnterpreteerd als variaties en/of aanvullingen op het gangbare. Er worden door ons twee typen gezond. heidszorgprogramma's onderscheiden: preventieprogramma's en medische programma's. De gezondheidszorgprogramma's worden besproken in de Hoofdstukken 2 en 7. De personen die meedoen aan een gezondheidszorgprogramma verkrijgen ten gevolge van dat programma een ander risicoprofiel ten aanzien van CHZ.

Het spreekt voor zich dat de ziekteprocesgang van de patiënten enerzijds bepaald wordt door het benodigde zorgprofiel van deze patiënten, en anderzijds door het aangeboden behandelingsprofiel. De discrepantie tussen beiden is medebepalend voor de wachtlijstproblematiek, waar we in de Hoofdstukken 6 en 7 dieper op ingaan. Het is overigens niet zo dat de gemaakte therapiekeuzen alleen afhankelijk zouden zijn van de beschikbare capaciteiten. De therapiekeuze wordt bepaald aan de hand van indicatiestellingen. Deze zijn in de praktijk doorgaans gebaseerd op een combinatie van patiëntkenmerken, de kennis van de arts, de heersende opvattingen omtrent de beste behandelingswijzen, de technologische ontwikkelingen en de beschikbare capaciteiten. In Bijlage II bespreken we hoe in het model de indicatiestellingen gebaseerd zijn op de patiëntkenmerken.

In Hoofdstuk 1 motiveren we dat scenario-onderzoek de maatschappelijke relevantie van zowel de gezondheidseffecten als de kosten moet omvatten. De effecten betreffen hier de relevantie van de coronaire hartziekten ten aanzien van de volksgezondheid. Deze relevantie kan worden uitgedrukt in een aantal kengetallen met betrekking tot kwaliteit van leven en levensverwachting. De aspecten hiervan worden besproken in de Hoofdstukken 3 en 4 en in de Bijlagen II en IV. De epidemiologische onderbouwing ervan wordt voor een belangrijk deel verantwoord in Bijlage I.

Het aspect kosten heeft ons genoodzaakt de behandelingsprofielen zo gedetailleerd mogelijk uiteen te rafelen. Voor ieder van deze "basisbehandelingen" is zoveel mogelijk de kostprijs (prijs per eenheid produkt) bepaald. Wanneer de benodige gegevens met betrekking tot de kostprijsbepalingen ontbraken, moesten we (noodgedwongen) terugvallen op de gepubliceerde tarieven. De kostprijsberekeningen en de gebruikte tarieven zijn in Bijlage III weergegeven. De kostprijzen (en tarieven) zijn zoveel mogelijk uitgedrukt in het prijsniveau van het jaar 1988. 
De totale kosten worden berekend als de som over alle behandelingen, waarbij de kosten per behandelingssoort gelijk zijn aan "volume (aantal behandelingen) $\mathrm{x}$ (kost)prijs. Wij hebben het volume afgeleid via het model met behulp van de vastgelegde behandelingsgangen die patiënten langs verschillende behandelingstrajecten kunnen doorlopen. De uitwerking hiervan vindt in Bijlage II plaats. De introductie van deze behandelingstrajecten vormt een belangrijk vernieuwend aspect bij de kostenberekeningen.

Scenario's zijn gebaseerd op gezondheidszorgprogramma's. Deze gezondheidszorgprogramma's zorgen voor alternatieve toekomstige patiëntenstromen, waardoor de verschillende behandelingstrajecten met andere kansen worden doorlopen. In Hoofdstuk 5 wordt het begrip scenario's verder uitgewerkt.

Gebruikers van het model kunnen met behulp van een "userinterface" zelf scenario's formuleren. De uitkomsten van 20 'n scenario worden vergeleken met een zogenaamd basisscenario. Het basisscenario wordt gevormd door de verrassingsvrije voortzetting van de huidige trends zonder additionele gezondheidszorgprogramma's. We willen onderstrepen dat aan het basisscenario in ons model geen voorspellende betekenis kan worden toegekend. Het basisscenario is vervaardigd op basis van een uitgebreide literatuurstudie, alsmede een analyse van een aantal gegevensbestanden. Aldus is het basisscenario zoveel als mogelijk gevuld met de beschikbare kennis op het gebied van $\mathrm{CHZ}$. Wij hebben het CHZ-model hierbij geijkt op gegevens uit de jaren 1986, 1988, en 1990.

Echter op verschillende plaatsen in het proefschrift benadrukken we dat er bij toekomstverkenningen veel "bekende" en "onbekende" onzekerheden zijn. Het is dan ook riskant de absolute uitkomsten van de scenario's tot toekomst te verheffen. Wat we dan ook doen is de verschillen in uitkomsten tussen de scenario's en het basisscenario verklaren met behulp van de kennis die nu voorhanden is op medisch, epidemiologisch, economisch, en toegepast wiskundig terrein. Op deze manier kan vanuit verschillende invalshoeken een voorkeursvolgorde van de scenario's gevormd worden. Deze scenario-analyse wordt in Hoofdstuk 6 uitgevoerd.

In de Epiloog wordt de validiteit van het model en de gekozen benaderingswijze besproken alsmede de bruikbaarheid van het model en de scenariostudies voor het beleid.

Het is ons doel geweest het model zo goed mogelijk te vullen met empirische gegevens. Om de ernst van de onjuistheid van gegevens te analyseren wordt in Hoofdstuk 7 een aantal sensitiviteitsanalyses uitgevoerd. Deze sensitiviteitsanalyses zijn een belangrijk hulpmiddel om te bepalen bij welke empirische gegevens er meer betrouwbaarheid nodig is. 
In Hoofdstuk 1 omschrijven we wat een economische analyse van een scenariostudie naar onze mening moet inhouden. Er kan in het model ten behoeve van zo'n analyse een keus gemaakt worden tussen het volgen van een homogene groep van én leeftijd en geslacht (een zogenaamde cohortstudie) of de gehele Nederlandse bevolking al dan niet ingeperkt (of begrensd) door risicokenmerken (een bevolkingsstudie).

In Hoofdstuk 7 leggen we het verband tussen scenario-analyse en het doel van de dissertatie. Hierin werken we uit dat scenario-analyse eigenlijk alleen gebruikt kan worden als een voor het beleid geschikt economisch analyse instrument wanneer de scenario's worden toegepast op bevolkingsstudies. De scenario-analyse's met betrekking tot scenario's die middels een cohortstudie worden uitgevoerd zijn meer geschikt ten behoeve van de kosteneffectiviteitsbeoordeling van die scenario's, zoals bij doelgroepselectie, therapietrouw, en de uitbreiding of inkrimping van gezondheidszorgprogramma's. 


\section{Summary}

In Chapter 1 the purpose of this thesis has been formulated as: "the description of the way in which scenario analysis can be used as an instrument of economic analysis suitable for policy-making purposes, so as to provide some insight into possible future changes in the costs and health effects of coronary heart disease, given various patterns of development." For these purposes a model has been constructed for the economic analysis of future flows of patients with coronary heart disease (CHD).

A 'patient flow' reflects the progress of the disease in patients. The patient flows in the model are derived in part from the healthy population, and in part from a sick population, 'healthy' meaning "not suffering from coronary heart disease". The 'sick population' is a part of those who have at some stage in the past suffered from coronary heart disease. The base population in both cases is the actual inhabitants of the Netherlands in 1988. The people in each of these two sub-groups of the total population have their own risk characteristics as regards coronary heart disease. For those in the healthy population the relevant characteristics are age, gender, smoking behaviour, blood cholesterol level and diastolic blood pressure. In the sick population the determining factors are chiefly the ejection fraction of the heart and a fictive notion which we have introduced ourselves: "the overall quality of the coronary arteries". The course of the disease and the various forms in which coronary heart disease is manifest are discussed in Chapter 2.

The personal characteristics in the model have been 'individualized' by constructing an average 'standard person' to represent each of the groups. The vicissitudes which these standard people go through are simulated in the model and scaled up to national figures. However policy decisions, for example fixing of a maximum number of operations which will be permitted in a given year, have direct effects for individual patients. There is thus a link between the dynamics at individual and national levels, and the model takes account of these influences in both directions. Chapters 1 and 7 give more details of this procedure.

The simulation involves annual updates of all the relevant variables in the model in accordance with the new situation, given the current health care programmes and the situation in the previous year. In the model it is possible to influence the incidence of coronary heart disease with health care programmes or additional programmes. The additional programmes can be seen as variations and/or aug- 
mentations of the normal situation. Two types of health care programmes have been differentiated: preventative programmes and medical programmes. The health care programmes are discussed in Chapters 2 and 7. The risk profiles, as regards coronary heart disease, of those who participate in a health care programme are altered as a result of that programme.

Naturally the process of the disease in the patients is determined on the one hand by the pattern of care which they require, and on the other hand by the pattern of treatment which is offered to them. The discrepancy between these two is one of the determinants of the length of waiting lists, which will be examined in more detail in Chapters 6 and 7. However choices between therapies should not depend only on the facilities available. Therapy choices are made on the basis of profiles of symptoms which indicate that a particular therapy is advisable. These profiles are generally based, in practice, on a combination of patient characteristics, the knowledge of the doctor, the prevailing views as to the best treatment, technological developments and the facilities which are available. Appendix II describes how the profiles in the model are based on patient characteristics.

Chapter 1 argues that scenario research must take account of the social relevance of both health effects and costs. In this case we must examine the relevance of coronary heart disease with regard to the health of the population. This relevance can be expressed in a number of numerical indicators relating to the quality of life and life expectancy. Various aspects of this question are discussed in Chapters 3 and 4 and in appendices II and IV. The epidemiological basis of these indicators are to a large extent justified in Appendix $I$.

The cost aspect required us to unravel the treatment profiles in the greatest possible detail. The unit cost (per unit of product used) is, so far as possible, determined for each of the 'basic treatments'. If the data required to determine a unit cost was unavailable, we had perforce to resort to published prices. These prices, and the unit cost calculations, are given in Appendix III. Both are expressed in terms of the price levels of 1988 wherever possible. The total costs of coronary heart disease are calculated as the sum of the costs of all the treatments, where the costs of each sort of treatment are equal to "volume (number of treatments) $x$ unit cost (or price)." The volume is derived from the model on the basis of the sequence of treatments which patients under various patterns of therapy have been found to undergo. The calculations involved are found in Appendix II. The introduction of these patterns of therapy is an important original aspect of the cost calculations.

The scenarios are based on health care programmes. These programmes lead to alternative patient flows in the future, which mean that the probabilities of pa- 
tients going through the various patterns of therapy are altered. Chapter 5 gives a more detailed description of the concept of scenarios. A 'user interface' allows those using the model to formulate scenarios for themselves. The results of such a scenario are compared to a so-called basic scenario. The basic scenario consists of the continuation of existing trends with no surprises or additional health care programmes. We should emphasise that the basic scenario in this model cannot be used to provide forecasts. It is constructed on the basis of an extensive review of the literature, plus analyses of an number of databases. Thus the basic scenario is filled with as much as possible of the available knowledge about coronary heart disease. We have calibrated the coronary heart disease model using data from 1986, 1988, and 1990. In fact, at various points in this thesis, we emphasise that exploring the future entails many 'known' and 'unknown' uncertainties. It is therefore risky to elevate the absolute results of the scenarios to the status of predictions of the future. What we can do in Chapter 6 is explain the differences between the results from the various scenarios and the basic scenario with the help of the knowledge now available in the fields of medicine, epidemiology, economics, and applied mathematics. In this way the scenarios can be ranked in order of preference from various points of view.

The Epilogue discusses the validity of the model and of the approach which has been selected, along with the utility of the model and the scenario studies for policy-making. We have endeavoured to specify the model as well as possible with empirical data. To analyze the seriousness of inaccuracies in the data, a number of sensitivity analyses were performed. These are described in Chapter 7. These sensitivity analyses are an important aid in determining where the empirical data needs to be more reliable.

In Chapter 1 we set out what, in our opinion, the economic analysis of a scenario study should contain. To assist such a study the model allows a choice between following a homogenous group from one age group and gender (a cohort study) or of taking the whole Dutch population, which may then be narrowed down for particular risk characteristics (a population study).

In Chapter 7 we explain the relationship between scenario analysis and the purpose of the dissertation. The conclusion drawn is that scenario analysis can really only be used as an instrument of economic analysis for policy purposes if the scenarios are applied to population studies. Scenario analyses which relate to scenarios worked out using a cohort study are more suitable for use in making cost-effectiveness evaluations, for instance for selecting target groups or considering the effects of compliance or of extensions or cutbacks in health care programmes. 


\section{Curriculum vitae}

Gijs Boas is in 1952 geboren in Djakarta (Indonesië). Zijn middelbare schoolopleiding heeft hij gevolgd aan het Baarnsch Lyceum te Baarn, alwaar hij in 1971 het HBS-A diploma heeft gehaald. Het doctoraal diploma Bedrijfseconomie heeft hij in 1977 aan de Vrije Universiteit verkregen. Vrijwel direct na zijn afstuderen is hij gaan werken als Management Trainee bij Pierson, Heldring en Pierson te Amsterdam. Deze periode heeft vrij kort geduurd omdat hij de voorkeur gaf aan een werkkring in de tropen. Van 1978 tot 1986 heeft hij gewerkt bij de Overheid in Curaçao als beleidsmedewerker op het terrein van de gezondheidszorg. In opdracht van het Bestuurscollege van Curaçao heeft hij in 1986 een pilot-studie verricht naar de opzet van een Bureau Ziektekosten. Na zijn terugkeer uit Curaçao werd hij in 1986 op de Rijksuniversiteit Limburg bij de vakgroep Economie van de Gezondheidszorg aangesteld als onderzoeker. Tijdens deze periode heeft hij voornamelijk gewerkt aan het onderzoek dat in dit proefschrift beschreven wordt. Er waren twee projecten die verricht zijn onder auspiciën van de Stuurgroep Toekomstscenario's Gezondheidszorg (STG). Het eerste project betrof de "Operationalisering van een model Hart- en Vaatziekten", toegekend aan de vakgroep Wiskunde van de Rijksuniversiteit Limburg (RL). Het tweede project betrof de "Economische aspecten van het scenario Hart- en Vaatziekten, toegekend aan de Economie van de Gezondheidszorg (EGZ) van de RL. Beide projecten zijn zonder gezamenlijke verantwoordelijkheid als éen geïntegreerd project uitgevoerd onder leiding van Prof. O.J. Vrieze (vakgroep Wiskunde/RL). Door de contacten die hij heeft opgebouwd in Curaçao hebben Dr. R.T.J.M. Janssen (oud-collega EGZ/RL) en hij in september 1990 in Curaçao een contractcursus "Economie en Organisatie van de Curaçaose gezondheidszorg" voor post-hoger onderwijs gedoceerd. Deze cursus was in opdracht van het Bestuurscollege van Curaçao en werd in samenwerking met de Universiteit van de Nederlandse Antillen uitgevoerd. Sinds 1991 is hij als universitair docent werkzaam bij deze vakgroep. In juni a.s. gaat hij samen met Prof. T.L.C.M. Groot een doctoraal keuzevak "Economie van de Gezondheidszorg" en tegelijkertijd een cursus "Economie en Organisatie van de Surinaamse Gezondheidszorg" in Suriname doceren. Het onderwijsprogramma wordt uitgevoerd mede door en in gezamenlijke opdracht van de Universiteit van Suriname en het Surinaamse Ministerie van Volksgezondheid. De uitvoering geschiedt in het kader van een ontwikkelingshulpprogramma van het Directoraat Generaal Internationale Samenwerking (DGIS) te Den Haag, dat is afgesloten tussen de Universiteit van Suriname en de Universiteit van Amsterdam. 